UNIVERSIDADE FEDERAL DO RIO GRANDE DO SUL INSTITUTO DE FILOSOFIA E CIÊNCIAS HUMANAS PROGRAMA DE PÓS-GRADUAÇÃO EM SOCIOLOGIA

NILSON WEISHEIMER

\title{
A SITUAÇÃO JUVENIL NA AGRICULTURA FAMILIAR
}

Porto Alegre

2009 


\section{NILSON WEISHEIMER}

\section{A SITUAÇÃO JUVENIL NA AGRICULTURA FAMILIAR}

Tese apresentada ao Programa de PósGraduação em Sociologia da UFRGS, como um dos requisitos para a obtenção do título de Doutor em Sociologia.

Orientadora: Professora Dr. ${ }^{a}$ Anita Brumer

Porto Alegre

2009 


\section{NILSON WEISHEIMER}

\section{A SITUAÇÃO JUVENIL NA AGRICULTURA FAMILIAR}

Tese de doutorado apresentada ao Programa de Pós-Graduação em Sociologia como requisito parcial para obtenção do grau de Doutor em Sociologia na Universidade Federal do Rio Grande do Sul.

Aprovado em _ de ___ de 2009.

\section{COMISSÃO EXAMINADORA}

Prof. ${ }^{\mathrm{a}}$ Dr. ${ }^{\mathrm{a}}$ Maria de Nazareth Baudel Wanderley (UFPE)

Dr. Wiliam Hector Gomez Soto (UFPEL)

Prof. Dr. Sergio Schneider (UFRGS)

Prof ${ }^{\mathrm{a}}$. Dr. ${ }^{\mathrm{a}}$ Clarissa Baeta Neves (UFRGS)

Porto Alegre

2009 
Dedico este trabalho aos jovens agricultores familiares e à sua luta por reconhecimento e autonomia. 


\section{AGRADECIMENTOS}

A conclusão de um trabalho acadêmico da dimensão de uma tese de doutorado em Sociologia só é possível através de grande empenho e responsabilidade pessoal de seu autor, porém o conhecimento que este sistematiza é socialmente construído. Assim, para sua objetivação, foi necessário o apoio de diferentes pessoas e instituições às quais dirijo meus sinceros agradecimentos.

À Coordenação de Aperfeiçoamento de Pessoal de Nível Superior (CAPES) que me concedeu bolsa de estudo.

Ao Programa de Pós-Graduação pela excelência de seu corpo docente e dedicação de seus funcionários técnicos administrativos que proporcionaram um ambiente acadêmico fecundo para o desenvolvimento deste trabalho.

À minha estimada orientadora $\operatorname{Prof}^{a}$ Dr. $^{\text {a }}$ Anita Brumer que acompanha minha trajetória acadêmica desde os tempos de graduação.

Aos Professores que participaram da banca de qualificação para este trabalho, Prof. Dr. Antônio David Cattani, Prof ${ }^{\text {a }}$. Dra. Clarissa Eckert Baeta Neves e Prof. Dr. Sergio Schneider, os quais aportaram valiosas contribuições.

Ao Ministério do Desenvolvimento Agrário por intermédio da Secretária do Reordenamento Agrário, em especial aos então Coordenadores das Políticas de Juventude, Fabiano Kempfer e Marcelo Siqueira Pickersgril, que tornaram possível a celebração do convênio MDA/FAURGS N. 109/2006, viabilizando a realização da pesquisa de campo que originou este estudo.

Aos membros da equipe de pesquisa de campo Alexandre Peres Lima, Analisa Zorzi, Bruna Cruz de Anhaia, Flávio Saideles, Lucas Coradini, Jaqueline Russesczyk, Maira Gabriela Daniel e Mariana Zanata pela dedicação e qualidade empenhada neste projeto.

Aos jovens agricultores familiares do Rio Grande do Sul que, generosamente, nos receberam, falaram de suas vidas e de seus projetos, proporcionando-nos um grande aprendizado pessoal e acadêmico.

À minha família, em especial aos meus pais Elio Pedro Weisheimer e Maria Rosária Weisheimer, que me incentivaram em minha trajetória e de quem incorporei a ética do trabalho e a consciência de classe.

À minha amada esposa Ana Paula Comin de Carvalho, cuja importância na minha vida e para a conclusão deste trabalho é incomensurável. 
Às minhas filhas amadas Camila e Isadora, pelo carinho e amor revigorante, mesmo diante de minhas ausências e de minhas presenças ausentes. 


\section{RESUMO}

O objetivo geral do estudo foi identificar os traços distintivos da situação juvenil na agricultura familiar e explicar a construção de seus projetos profissionais. Para isto, realizouse uma pesquisa representativa do universo de jovens ocupados na agricultura familiar no estado do Rio Grande do Sul. Realizaram-se entrevistas estruturadas com base em questionário padronizado junto a 681 jovens de 15 a 29 anos de ambos os sexos. Como contribuição metodológica, foi proposto um modelo descritivo da situação juvenil com quatro dimensões analíticas: dos recursos materiais, dos processos de socialização, das representações sociais e dos projetos juvenis. Os jovens agricultores familiares são uma categoria social que surge da socialização no processo de trabalho familiar agrícola, sendo a situação juvenil na agricultura familiar caracterizada por uma baixa autonomia material; por uma intensa socialização no processo de trabalho familiar agrícola e pelo predomínio de representações positivas sobre esta atividade. As evidências permitem concluir que os seus projetos profissionais derivam da própria situação juvenil na agricultura familiar, com suas diferenciações sexuais e etárias, que estão presentes na estrutura das práticas do trabalho e na incorporação das disposições necessárias a sua reprodução. Com base nisto, explicam-se porque mesmo em condições de baixa autonomia material predominam entre a maioria dos entrevistados projetos profissionais agrícolas e a recusa por parte das mulheres jovens adolescentes de permanecer nesta atividade.

PALAVRAS CHAVES: situação juvenil, agricultura familiar, projetos. 


\begin{abstract}
The main goal of this work is to identify the distinctive characteristics of young people in family farming and their professional projects. For this, we carried out a research representative of the world of the young who work in family farming in Rio Grande do Sul. We carried out interviews based on a standardized questionnaire with 681 people from 15 to 29 years old, of both genders. As a methodological contribution, we proposed a descriptive model of the juvenile situation with four analytics dimensions: resources, socialization processes, social representations, and juvenile projects. The young family farmers are a social category that is rising from the socialization of family farm work, characterized by a low material autonomy and the supremacy of positive representations of the activity. The evidences allow us to conclude that their professional projects derive from their situation in family farming, with its gender and age-based differentiations, which are present in the work practices structure and in the incorporation of the dispositions needed for its replication. Based on this, we can explain why, even with restricted material conditions, amongst most of the interviewed subjects agricultural professional projects and the refuse of staying in this activity are predominant.
\end{abstract}

KEYWORDS: Juvenile situation, family farming, projects. 


\section{RÉSUMÉ}

Le but général de cette étude est celui d'identifier les traits distinctifs de la situation juvénile dans l'agrictulture familiale et dans ses projets professionnels. Pour l'accomplir, nous avons réalisé une recherche représentative de l'univers de jeunes occupés dans l'agriculture familiale à l'état du Rio Grande do Sul. Nous avons réalisé des entrevues structurées ayant comme base un questionnaire standardisé auprès de 681 jeunes de 15 à 29 ans des deux sexes. Comme contribution méthodologique, nous avons proposé un modèle descriptif de la situation

juvénile à quatre dimensions analytiques: les ressources matérielles, les processus de socialisation, les représentations sociales et les projets juvéniles. Les jeunes agriculteurs familiaux sont une catégorie sociale qui surgit de la socialisation dans le processus de travail familial agricole, la situation juvénile dans l'agriculture familiale étant caractérisée par une basse autonomie matérielle; par une intense socialisation dans le processus de travail familial agricole et par la prédominance de représentations positives sur cette activité. Les évidences permettent de conclure que leurs projets professionnels découlent de la propre situation juvénile dans l'agriculture familiale, avec ses différenciations par rapport au sexe et à l'âge, qui sont présentes dans la structure des pratiques de travail et dans l'incorporation des dispositions nécessaires à sa reproduction. À partir de cela, nous expliquons porquoi, même dans des conditions matérielles restreintes, prédominent, pour la plupart des interviewés, des projets professionnels agricoles et le refus des jeunes femmes adolescentes de demeurer dans cette activité.

MOTS CLÉS: situation juvénile, agriculture familiale, projets. 


\section{LISTA DE FIGURAS}

FIGURA 1: MAPA DAS MESORREGIÕES DO RS..................................................39 FIGURA 2: MAPA COM A LOCALIZAÇÃO DOS MUNICÍPIOS IDENTIFICADOS POR MESORREGIÃO....................................................................................... 41 


\section{LISTA DE GRÁFICOS}

GRÁFICO 1: DISTRIBUIÇÃO ETÁRIA DOS ENTREVISTADOS (\%) ....................... 43

GRÁFICO 2: ESTADO CIVIL DOS JOVENS POR SEXO E FAIXA ETÁRIA (\%).... 45

GRÁFICO 3: JOVENS COM FILHOS POR SEXO E FAIXA ETÁRIA (\%)................ 46

GRÁFICO 4: NÚMERO DE INTEGRANTES POR FAMÍLIA (\%).............................47

GRÁFICO 5: POPULAÇÃO RURAL FEMININA NO BRASIL E REGIÕES (\%) .... 122

GRÁFICO 6: DISTRIBUIÇÃO DE HOMENS E MULHERES OCUPADOS NA AGRICULTURA NO RS POR FAIXA ETÁRIA $(F)$ 126

GRÁFICO 7: ESTIMATIVA DO PERCENTUAL DA POPULAÇÃO JOVEM OCUPADA NA AGRICULTURA FAMILIAR NO RS POR SEXO E FÄIXA ETÁRIA

GRÁFICO 8: CONDIÇÃO DE PROPRIEDADE DA TERRA (\%) .............................. 132

GRÁFICO 9: ORIGEM DA PROPRIEDADE FAMILIAR (\%) ................................. 133

GRÁFICO 10: FORMA DE USO DA TERRA ENTRE NÃO PROPRIETÁRIOS (\%)

GRÁFICO 11: PRINCIPAL DESTINAÇÃO DA PRODUÇÃO FAMILIAR (\%) ....... 136

GRÁFICO 12: FORMAS DE COMERCIALIZAÇÃO DOS PRODUTOS DAS UNIDADES DE PRODUÇÃO FAMILIAR (\%) ......................................................... 138

GRÁFICO 13: FORMA DE DISTRIBUIÇÃO DAS RENDAS AGRÍCOLAS (\%)...... 143

GRÁFICO 14: DIVISÃO DAS RENDAS AGRÍCOLAS POR SEXO E FAIXA ETÁRIA (\%) 145

GRÁFICO 15: FORMAS DE ACESSO DOS JOVENS A RENDA FAMILIAR AGRÍCOLA (\%) ....................................................................................................... 146

GRÁFICO 16: FORMAS DE ACESSO DOS JOVENS A RENDA FAMILIAR AGRÍCOLA POR SEXO E FAIXA ETÁRIA (\%) ................................................... 149

GRÁFICO 17: DISTRIBUIÇÃO DE FREQUÊNCIA DO TIPO DE GASTO DOS

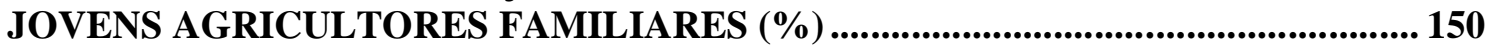

GRÁFICO 18: GASTOS DOS JOVENS AGRICULTORES FAMILIARES POR SEXO E FAIXA ETÁRIA (\%).

GRÁFICO 19: INDICADORES DE AUTONOMIA DOS JOVENS POR SEXO E TOTAL $(\%)$............................................................................................................ 155

GRÁFICO 20: PARTICIPAÇÃO NO TRABALHO AGRÍCOLA (\%)......................... 174 GRÁFICO 21: PARTICIPAÇÃO NO TRABALHO FAMILIAR AGRÍCOLA POR

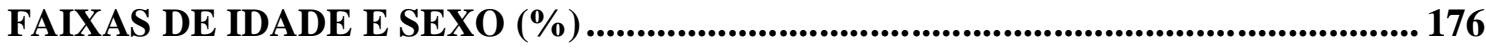
GRÁFICO 22: JORNADA DIÁRIA DE TRABALHO FAMILIAR AGRÍCOLA (\%) 177 
'GRÁFICO 23: JORNADAS DE TRABALHO FAMILIAR AGRÍCOLA POR SEXO E FAIXAS ETÁRIAS (\%). 179

GRÁFICO 24: DISTRIBUIÇÃO DAS TAREFAS ADMINISTRATIVAS DA UNIDADE DE PRODUÇÃO FAMILIAR (\%). 183

GRÁFICO 25: DISTRIBUIÇÃO DAS TAREFAS AGRÍCOLAS DA UNIDADE DE PRODUÇÃO FAMILIAR (\%) 185

GRÁFICO 26: REALIZAÇÃO DAS TAREFAS DOMÉSTICAS DA UNIDADE DE PRODUÇÃO FAMILIAR (\%) 186

GRÁFICO 27: ESCOLARIDADE DOS ENTREVISTADOS (\%) ................................193

GRÁFICO 28: ESCOLARIZAÇÃO DOS ENTREVISTADOS POR SEXO E FAIXAS ETÁRIAS (\%). 196

GRÁFICO 29: ENTREVISTADOS SEGUNDO SITUAÇÃO DE ESTUDO (\%).......... 196 GRÁFICO 30: CONDIÇÃO DE ESTUdO DOS ENTREVISTADOS POR SEXO E FAIXA ETÁRIA (\%) 198

GRÁFICO 31: CRUZAMENTO ENTRE CONDIÇÃO DE ESTUDO POR JORNADA DE TRABALHO NA UPF (\%). 201

GRÁFICO 32: OPINIÃO SOBRE A IMPORTÂNCIA DO CONHECIMENTO

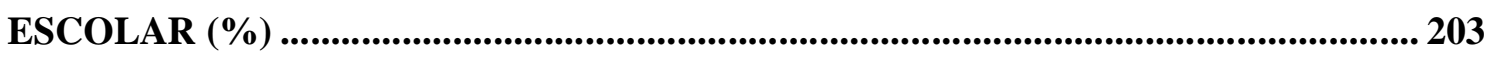

GRÁFICO 33: FREQUÊNCIA EM ATIVIDADES DE LAZER, CULTURA E PASSEIOS (\%) .............................................................................................................. 209

GRÁFICO 34: DISTRIBUIÇÃO DE FREQUÊNCIA DA QUESTÃO $O$ QUANTO VOCÊ GOSTA DO TRABALHO AGRÍCOLA? (\%) ......................................................... 223

GRÁFICO 35: CRUZAMENTO DA QUESTÃO O QUANTO VOCÊ GOSTA DO TRABALHO AGRÍCOLA? POR FAIXA ETÁRIA E SEXO (\%) ................................... 225

GRÁFICO 36: AVALIAÇÃO DA SUA PARTICIPAÇÃO NO TRABALHO FAMILIAR AGRÍCOLA (\%) ................................................................................. 226

GRÁFICO 37: CRUZAMENTO ENTRE AVALIAÇÃO DA SUA PARTICIPAÇÃO NO TRABALHO FAMILIAR AGRÍCOLA POR FAIXA ETÁRIA E SEXO (\%) ............... 228

GRÁFICO 38: DISTRIBUIÇÃO DAS REPRESENTAÇÕES SOBRE O TRABALHO FAMILIAR AGRÍCOLA (\%) 229

GRÁFICO 39: CRUZAMENTO DAS REPRESENTAÇÕES SOBRE O TRABALHO FAMILIAR AGRÍCOLA POR FAIXA ETÁRIA E SEXO (EM $F$ E \% )........................ 232 GRÁFICO 40: DISTRIBUIÇ̃̃o DAS REPRESENTAÇÕES SOBRE O TRABALHO

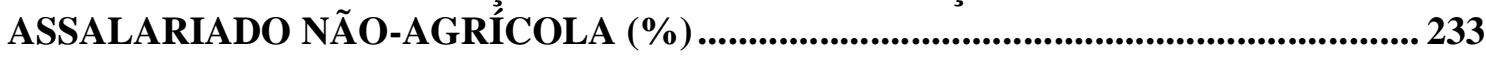

GRÁFICO 41: CRUZAMENTO DAS REPRESENTAÇÕES SOBRE O TRABALHO ASSALARIADO NÃO-AGRÍCOLA POR FAIXA ETÁRIA E SEXO $(\%)$...................... 235 GRÁFICO 42: AVALIAÇÃO DO MODO DE VIDA DOS PAIS (\%) ............................. 237 GRÁFICO 43: AVALIAÇÃO DO MODO DE VIDA DOS PAIS POR SEXO E FAIXA ETÁRIA (\%). 239 
GRÁFICO 44: DISTRIBUIÇÃO DA DISPOSIÇÃO PARA REPRODUZIR O MODO DE VIDA DOS PAIS (\%) 240

GRÁFICO 45: CRUZAMENTO DA DISPOSIÇÃO PARA REPRODUZIR O MODO DE VIDA DOS PAIS POR FAIXA ETÁRIA E SEXO (\%). 242

GRÁFICO 46: DISTRIBUIÇÃO DE PERSPECTIVA SUCESSÓRIA NA GESTÃO DA PROPRIEDADE FAMILIAR (\%). 243

GRÁFICO 47: CRUZAMENTO ENTRE PERSPECTIVA SUCESSÓRIA NA GESTÃO DA PROPRIEDADE FAMILIAR POR FAIXA ETÁRIA E SEXO (\%) 244 GRÁFICO 48: EXPECTATIVAS DE HERANÇA DA PROPRIEDADE FAMILIAR (\%) 245

GRÁFICO 49: EXPECTATIVA DE HERANÇA DA PROPRIEDADE POR SEXO E FAIXA ETÁRIA (\%) ..................................................................................................... 248

GRÁFICO 50: DISTRIBUIÇÃO DAS IDENTIDADES JUVENIS (\%) ......................... 250 GRÁFICO 51: CRUZAMENTO DAS IDENTIDADES JUVENIS POR SEXO (\%) ... 251 GRÁFICO 52: CRUZAMENTO DAS IDENTIDADES JUVENIS POR FAIXA ETÁRIA E SEXO (\%) 253

GRÁFICO 53: PROJETOS DE ESCOLARIZAÇÃO (\%) ..............................................267

GRÁFICO 54: PROJETOS DE ESCOLARIZAÇÃO POR SEXO E FAIXA ETÁRIA (\%) 269

GRÁFICO 55: DISTRIBUIÇÃO DE OCORRÊNCIA DE PROJETOS PROFISSIONAIS ENTRE JOVENS AGRICULTORES FAMILIARES (\%) .............. 271

GRÁFICO 56: DISTRIBUIÇÃO DE PROJETOS PROFISSIONAIS DOS JOVENS AGRICULTORES FAMILIARES (\%) ................................................................... 273

GRÁFICO 57: PROJETOS PROFISSIONAIS POR SEXO E FAIXA ETÁRIA (\%). 277 GRÁFICO 58: DISTRIBUIÇÃO DOS PROJETOS PROFISSIONAIS NA AGRICULTURA FAMILIAR (\%) ............................................................................ 278

GRÁFICO 59: PROJETOS DE ESTABELECIMENTO PROFISSIONAL NA AGRICULTURA FAMILIAR POR SEXO E FAIXA ETÁRIA (EM $F$ E \%)............... 280

GRÁFICO 60: DISTRIBUIÇÃO DE RESPOSTAS A QUESTÃO ONDE PRETENDE MORAR? (\%)

GRÁFICO 61: CRUZAMENTO DAS RESPOSTAS A QUESTÃO ONDE VOCÊ PRETENDE MORAR? POR FAIXA ETÁRIA E SEXO (\%)........................................... 283

GRÁFICO 62: DISTRIBUIÇÃO DAS RESPOSTAS A QUESTÃO VOCÊ PRETENDE CASAR COM UM(A) AGRICULTOR (A)? (\%). 284

GRÁFICO 63: CRUZAMENTO DAS RESPOSTAS A QUESTÃO VOCÊ PRETENDE CASAR COM UM(A) AGRICULTOR (A)? POR FAIXA ETÁRIA E SEXO (\%)........... 286 GRÁFICO 64: REPRESENTAÇÃO DAS CATEGORIAS DE SEXO, FAIXA ETÁRIA, PROPRIEDADE FUNDIÁRIA, AUTONOMIA MATERIAL E PROJETOS PROFISSIONAIS 
GRÁFICO 65: REPRESENTAÇÃO DAS CATEGORIAS DE SEXO, FAIXA ETÁRIA, JORNADA DE TRABALHO, FREQUÊNCIA À ESCOLA E EXISTÊNCIA DE

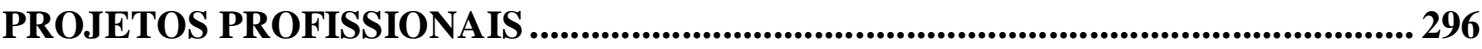

GRÁFICO 66: REPRESENTAÇÃO DAS CATEGORIAS DE SEXO, FAIXA ETÁRIA, GOSTA DO TRABALHO AGRÍCOLA, AVALIAÇÃO DO MODO DE VIDA DOS PAIS E PROJETOS PROFISSIONAIS ....................................................................... 300 
LISTA DE QUADROS

QUADRO 1: DIMENSÕES TEMÁTICAS E TÓPICOS DA PESQUISA ....................... 35

QUADRO 2: FÓRMULA DE CÁLCULO DA AMOSTRA............................................ 37

QUADRO 3: MESORREGIÕES E MUNICÍPIOS ABRANGIDOS NA PESQUISA .... 40

QUADRO 4: CARACTERÍSTICAS DO PROCESSO JUVENIL................................54

QUADRO 5: VARIÁVEIS INDEPENDENTES SELECIONADAS POR DIMENSÃO

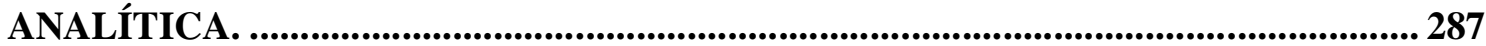

QUADRO 6: MEDIDAS DE DISCRIMINAÇÃO PARA VARIÁVEIS EM DUAS DIMENSÕES (RECURSOS MATERIAIS) ......................................................... 291

QUADRO 7: MEDIDAS DE DISCRIMINAÇÃO PARA VARIÁVEIS EM DUAS DIMENSÕES (SOCIALIZAÇÃO) ...............................................................................295

QUADRO 8: MEDIDAS DE DISCRIMINAÇÃO PARA VARIÁVEIS EM DUAS DIMENSÕES (REPRESENTAÇÕES SOCIAIS) 
LISTA DE TABELAS

TABELA 1: TAMANHO AMOSTRAL POR MESORREGIÃO, SEXO E FAIXA ETÁRIA 38

TABELA 2: ESTADO CIVIL DOS JOVENS POR SEXO (EM F E \%) ........................ 44

TABELA 3: JOVENS COM FILHOS POR SEXO (EM $F$ E \%) .................................... 46

TABELA 4: DISTRIBUIÇÃO DE FREQUÊNCIAS DA AUTODEFINIÇÃO ÉTNICA DOS ENTREVISTADOS. 48

TABELA 5: ESTIMATIVAS DO PERCENTUAL DA POPULAÇÃO DO RS POR FAIXAS ETÁRIAS (EM ANOS) E TIPO DE OCUPAÇÃO* 126

TABELA 6: ESTIMATIVAS DO PERCENTUAL DA POPULAÇÃO DO RS NA CONDIÇÃO DE OCUPAÇÃO NA AGRICULTURA FAMILIAR POR FAIXAS ETÁRIAS E SEXO

TABELA 7: DISTRIBUIÇÃO DE ESTRATOS DE ÁREA DAS PROPRIEDADES FAMILIARES. 135

TABELA 8: DISTRIBUIÇÃO DE FREQUÊNCIAS DO VALOR BRUTO DA PRODUÇÃO (R\$/ANO) 139

TABELA 9: DISTRIBUIÇÃO DE FREQUÊNCIA DA RENDA AGRÍCOLA (R\$/ANO)

TABELA 10: DISTRIBUIÇÃO DE FREQUÊNCIA DA RENDA FAMILIAR TOTAL (R\$/ANO)

TABELA 11: CRUZAMENTO DAS FORMAS DE DIVISÃO DA RENDAS AGRÍCOLAS POR SEXO (EM $F$ E \%).

TABELA 12: CRUZAMENTO ENTRE FORMA DE DIVISÃO DA RENDAS AGRÍCOLA POR FAIXA ETÁRIA (EM F E \%)

TABELA 13: CRUZAMENTO FORMAS DE RECOMPENSA POR SEXO (EM $F$ E $\%)$ 147

TABELA 14: CRUZAMENTO FORMAS DE RECOMPENSA POR FAIXA ETÁRIA (EM $F$ E \%).

TABELA 15: GASTOS DOS JOVENS AGRICULTORES FAMILIARES POR SEXO (EM F E \%)

TABELA 16: GASTOS DOS JOVENS AGRICULTORES FAMILIARES POR FAIXA ETÁRIA (EM F E \%) 152

TABELA 17: DISTRIBUIÇÃO DE FREQUÊNCIAS DO ÍNDICE DE AUTONOMIA MATERIAL DOS JOVENS 158

TABELA 18: CRUZAMENTO ENTRE GRAU DE AUTONOMIA POR SEXO (EM $F$ E \%) 158

TABELA 19: CRUZAMENTO ENTRE GRAU DE AUTONOMIA E FAIXA ETÁRIA (EM F E \%). 
TABELA 20: PARTICIPAÇÃO NO TRABALHO FAMILIAR AGRÍCOLA POR SEXO $(F \mathrm{E} \%)$

TABELA 21: PARTICIPAÇÃO NO TRABALHO FAMILIAR AGRÍCOLA POR

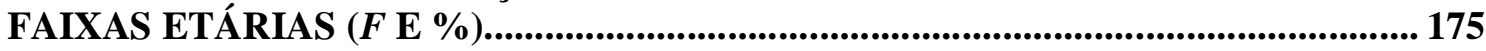

TABELA 22: JORNADA DIÁRIA DE TRABALHO POR SEXO (F E \%) ................... 178

TABELA 23: JORNADA DE TRABALHO FAMILIAR AGRÍCOLA POR FAIXA

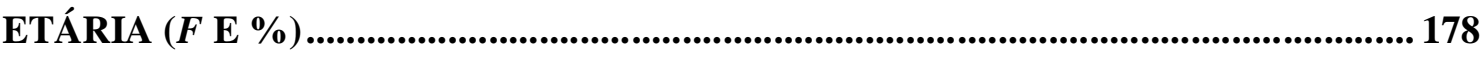

TABELA 24: DIVISÃO DO TRABALHO ENTRE OS MEMBROS DA FAMÍLIA (\%) 181

TABELA 25: ESCOLARIDADE DOS ENTREVISTADOS POR SEXO (EM F E \%) 194 TABELA 26: ESCOLARIDADE DOS ENTREVISTADOS POR FAIXA ETÁRIA (EM F E \%) 195

TABELA 27: SITUAÇÃO DE ESTUDO POR SEXO (EM F E \% ) ............................ 197

TABELA 28: CONDIÇÃO DE ESTUDO DOS ENTREVISTADOS POR FAIXA ETÁRIA (EM F E \%) ............................................................................................................. 197

TABELA 29: CRUZAMENTO ENTRE ESCOLARIDADE E CONDIÇÃO DE ESTUDO (EM F E \% )...................................................................................................... 199

TABELA 30: FREQUÊNCIA A ATIVIDADES DE LAZER, CULTURA E PASSEIOS (\%) 210

TABELA 31: CRUZAMENTO DA QUESTÃO O QUANTO VOCÊ GOSTA DO TRABALHO AGRÍCOLA? POR SEXO (EM F E \% ) ................................................... 223

TABELA 32: CRUZAMENTO DA QUESTÃO O QUANTO VOCÊ GOSTA DO TRABALHO AGRÍCOLA? POR FAIXA ETÁRIA (EM $F$ E \%)................................. 224

TABELA 33: CRUZAMENTO ENTRE AVALIAÇÃO DA SUA PARTICIPAÇÃO NO TRABALHO FAMILIAR AGRÍCOLA POR SEXO (EM F E \%) .............................. 227

TABELA 34: CRUZAMENTO ENTRE AVALIAÇÃO DA SUA PARTICIPAÇÃO NO TRABALHO FAMILIAR AGRÍCOLA POR FAIXA ETÁRIA (EM F E \%).............. 228

TABELA 35: CRUZAMENTO DAS REPRESENTAÇÕES SOBRE O TRABALHO FAMILIAR AGRÍCOLA POR SEXO (EM F E \%) .............................................. 230

TABELA 36: CRUZAMENTO DAS REPRESENTAÇÕES SOBRE O TRABALHO FAMILIAR AGRÍCOLA POR FAIXA ETÁRIA (EM F E \%) .................................... 231

TABELA 37: CRUZAMENTO DAS REPRESENTAÇÕES SOBRE O TRABALHO ASSALARIADO NÃO-AGRÍCOLA POR SEXO (EM $F$ E \%) .................................... 233

TABELA 38: CRUZAMENTO DAS REPRESENTAÇÕES SOBRE O TRABALHO ASSALARIADO NÃO-AGRÍCOLA POR FAIXA ETÁRIA (\%) ..............................234

TABELA 39: AVALIAÇÃO DO MODO DE VIDA DOS PAIS POR SEXO (EM F E \%) 237

TABELA 40: AVALIAÇÃO DO MODO DE VIDA DOS PAIS POR FAIXA ETÁRIA (EM F E \%). 
TABELA 41: CRUZAMENTO DA DISPOSIÇÃO PARA REPRODUZIR O MODO DE VIDA DOS PAIS POR SEXO (EM $F$ E \%).

TABELA 42: CRUZAMENTO DA DISPOSIÇÃO PARA REPRODUZIR O MODO DE VIDA DOS PAIS POR FAIXA ETÁRIA (EM $F$ E \%) 241

TABELA 43: CRUZAMENTO ENTRE PERSPECTIVA SUCESSÓRIA NA GESTÃO DA PROPRIEDADE FAMILIAR POR SEXO (EM $F$ E \%). 243

TABELA 44: CRUZAMENTO ENTRE PERSPECTIVA SUCESSÓRIA NA GESTÃO DA PROPRIEDADE FAMILIAR POR FAIXA ETÁRIA (EM $F$ E \%) 244

TABELA 45: EXPECTATIVAS DE HERANÇA DA PROPRIEDADE POR SEXO (EM F E \%). 246

TABELA 46: EXPECTATIVA DE HERANÇA DA PROPRIEDADE POR FAIXA ETÁRIA (EM F E \%) 247

TABELA 47: CRUZAMENTO DAS IDENTIDADES JUVENIS POR FAIXA ETÁRIA (EM F E \%) 252

TABELA 48: PROJETOS DE ESCOLARIZAÇÃO POR SEXO (EM F E \%)............ 267 TABELA 49: PROJETOS DE ESCOLARIZAÇÃO POR FAIXA ETÁRIA (EM $F$ E \%) 268

TABELA 50: CRUZAMENTO OCORRENCIA DE PROJETOS PROFISSIONAIS ENTRE JOVENS AGRICULTORES FAMILIARES POR SEXO (\%) 271

TABELA 51: CRUZAMENTO OCORRÊNCIA DE PROJETOS PROFISSIONAIS ENTRE JOVENS AGRICULTORES FAMILIARES POR FAIXA ETÁRIA (\%)...... 272

TABELA 52: CRUZAMENTO ENTRE DISTRIBUIÇÃO DE PROJETOS PROFISSIONAIS DOS JOVENS AGRICULTORES FAMILIARES POR SEXO (EM $F$ E \%) 274

TABELA 53: PROJETOS PROFISSIONAIS POR FAIXA ETÁRIA (EM F E \%).... 276 TABELA 54: CRUZAMENTO ENTRE PROJETOS PROFISSIONAIS AGRÍCOLAS E SEXO (EM F E \%) 279

TABELA 55: CRUZAMENTO ENTRE PROJETOS PROFISSIONAIS AGRÍCOLAS E FAIXA ETÁRIA (EM F E \%) 279

TABELA 56: CRUZAMENTO DAS RESPOSTAS A QUESTÃO ONDE VOC $\hat{E}$ PRETENDE MORAR? POR SEXO (EM F E \%) 282

TABELA 57: CRUZAMENTO DAS RESPOSTAS A QUESTÃO ONDE VOCÊ PRETENDE MORAR? POR FAIXA ETÁRIA (EM $F$ E \%) 283

TABELA 58: CRUZAMENTO DAS RESPOSTAS A QUESTÃO VOCÊ PRETENDE CASAR COM UM(A) AGRICULTOR (A)? POR SEXO (EM F E \%) 285

TABELA 59: CRUZAMENTO DAS RESPOSTAS A QUESTÃO VOCÊ PRETENDE CASAR COM UM(A) AGRICULTOR(A)? POR FAIXA ETÁRIA (EM F E \%) ........... 285

TABELA 60: RELAÇÃO ENTRE PROJETO PROFISSIONAL E CONDIÇÃO FUNDIÁRIA DA FAMÍLIA (EM F E \%) 289

TABELA 61: RELAÇÃO ENTRE PROJETO PROFISSIONAL E GRAU DE AUTONOMIA MATERIAL (EM $F$ E \%) 290 
TABELA 62: RELAÇÃo ENTRE PROJETO PROFISSIONAL E SITUAÇÃo DE ESTUDO (EM F E \% ) ................................................................................................. 293

TABELA 63: CRUZAMENTO ENTRE JORNADA DIÁRIA DE TRABALHO NA UPF POR PROJETO PROFISSIONAL (EM $F$ E \% )........................................................... 294

TABELA 64: CRUZAMENTO ENTRE REPRESENTAÇÃO SOBRE O TRABALHO AGRÍCOLA E PROJETO PROFISSIONAL (EM $F$ E \%) ...........................................297

TABELA 65: CRUZAMENTO ENTRE AVALIAÇÃO DO MODO DE VIDA DOS PAIS E PROJETO PROFISSIONAL (EM F E \% ) ........................................................... 298 


\section{LISTA DE SIGLAS E ABREVIATURAS}

DNTR - Departamento dos Trabalhadores Rurais

CUT - Central Única dos Trabalhadores

CONTAG - Confederação Nacional dos Trabalhadores na Agricultura

EUA - Estados Unidos da América

FAO - Food and Agriculture Organization

IBGE - Instituto Brasileiro de Geografia e Estatística

INCRA - Instituto Nacional de Colonização e Reforma Agrária

LDB - Lei de Diretrizes e Bases

OMS - Organização Mundial da Saúde

PEA - População Economicamente Ativa

$\mathrm{PhD}$ - Philosophical Doctor

PIB - Produto Interno Bruto

PNAD - Pesquisas Nacionais por Amostra de Domicílio

PRONAF - Programa Nacional de Fortalecimento da Agricultura Familiar

PROVAP - Programa de Valorização da Pequena Produção Rural

RA - Renda Agrícola

RFT - Renda Familiar Total

SPSS - Statistical Packege for Social Sciences

UEC - Unidade Econômica Camponesa

UPF - Unidade de Produção Familiar

UNESCO - United Nations Educational, Scientific and Cultural Organization

VBP - Valor Bruto da Produção 


\section{SUMÁRIO}

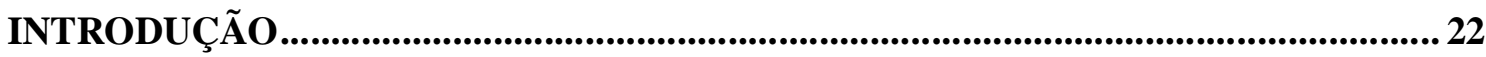

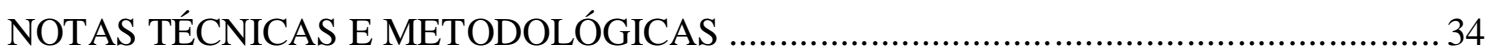

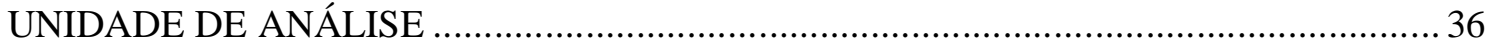

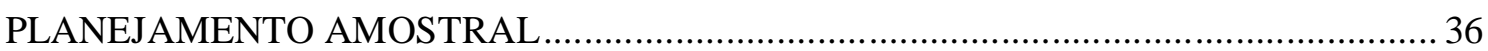

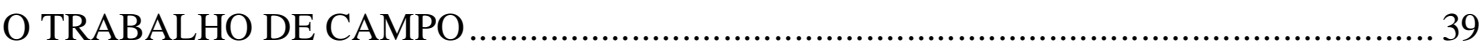

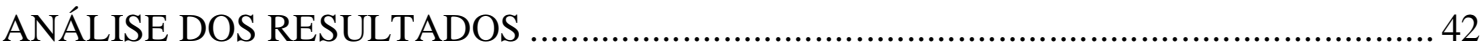

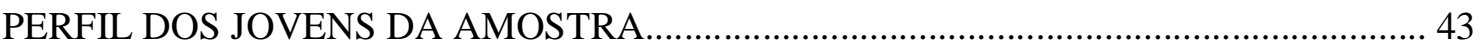

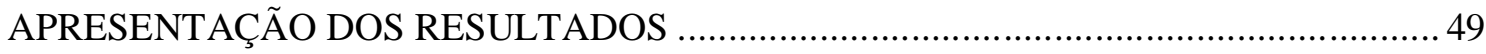

1 JUVENTUDE COMO CATEGORIA SOCIOLÓGICA .............................................51

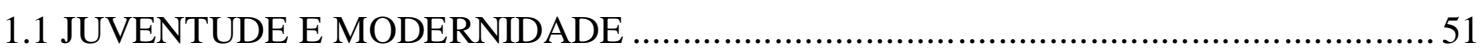

1.2 FRONTEIRAS E CARACTERÍSTICAS DO PROCESSO JUVENIL .........................53

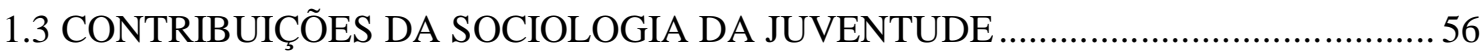

1.3.1 Os jovens nas primeiras pesquisas sociais .........................................................57

1.3.2 A constituição da Sociologia da Juventude na primeira metade do século XX...... 60

1.3.3 A Sociologia da Juventude na segunda metade do século $X X$..............................63

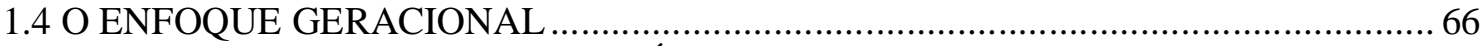

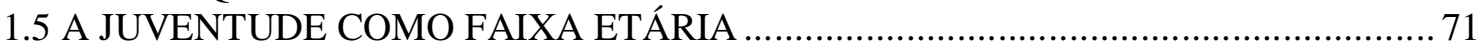

1.6 A JUVENTUDE COMO TRANSIÇÃO PARA A VIDA ADULTA............................... 75

1.7 AS CULTURAS JUVENIS: JUVENTUDE COMO ESTILO E COMO VALOR ........... 78

1.8 JUVENTUDE COMO REPRESENTAÇÃO SOCIAL E AUTORREPRESENTAÇÃO . 83

1.9 ALGUMAS CATEGORIAS TEÓRICO-OPERACIONAIS DA SOCIOLOGIA DA

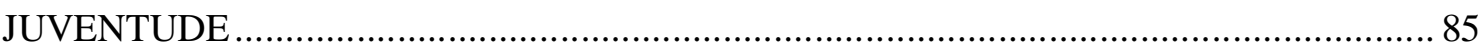

2 JUVENTUDE E AGRICULTURA FAMILIAR NO RIO GRANDE DO SUL............89

2.1 UM MARCO CONCEITUAL PARA AGRICULTURA FAMILIAR .......................... 89

2.1.1 Transformações no debate brasileiro sobre as formas familiares de agricultura... 90

2.1.2 Capitalismo e Agricultura Familiar ............................................................................... 94

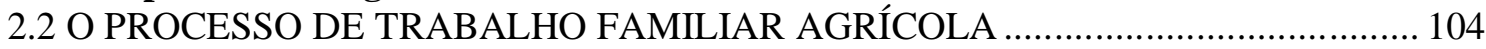

2.3 OS JOVENS AGRICULTORES FAMILIARES …................................................... 109

2.4 NOTAS SOBRE A PARTICIPAÇÃO JUVENIL NO DESENVOLVIMENTO DA

AGRICULTURA FAMILIAR NO RIO GRANDE DO SUL …...................................... 113

2.5 PARTICIPAÇÃO JUVENIL NA OCUPAÇÃO NA AGRICULTURA FAMILIAR NO

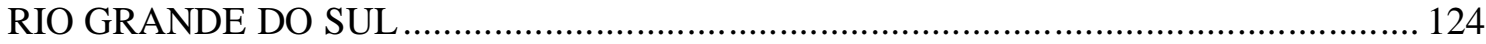

3 AS CONDIÇÕES MATERIAIS DOS JOVENS AGRICULTORES FAMILIARES 130

3.1 CARACTERÍSTICAS ECONÔMICAS DAS UNIDADES DE PRODUÇÃO FAMILIAR

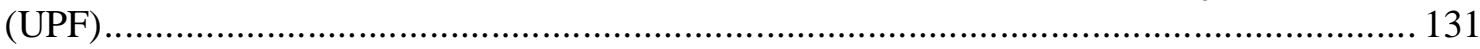

3.1.1 Condição Fundiária........................................................................................131

3.1.2 Integração Mercantil das Unidades de Produção Familiar (UPF) ........................ 135

3.1.3 Produção de valor e renda familiar ........................................................................... 138

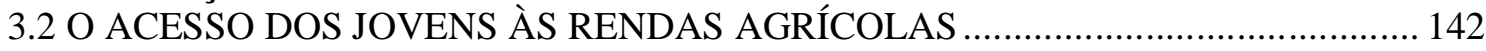

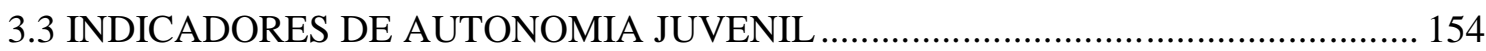

3.4 UMA SITUAÇÃO DE PRECÁRIA AUTONOMIA MATERIAL .............................. 159 
4 OS PROCESSOS DE SOCIALIZAÇÃO DOS JOVENS AGRICULTORES

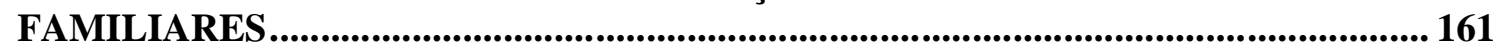

4.1 SOBRE O PROCESSO DE SOCIALIZAÇÃO.......................................................... 161

4.2 A SOCIALIZAÇÃO DOS JOVENS NO TRABALHO FAMILIAR AGRÍCOLA......... 172

4.2.1 A inserção no processo de trabalho familiar agrícola................................................. 173

4.2.2 A participação juvenil na divisão do trabalho familiar ............................................. 180

4.3 OS JOVENS AGRICULTORES FAMILIARES E O SISTEMA FORMAL DE ENSINO

4.4 ASPECTOS DA SOCIABILIDADE JUVENIL: AS PRÁTICAS DE LAZER DOS

JOVENS AGRICULTORES FAMILIARES................................................................... 205

4.5 JOVENS AGRICULTORES FAMILIARES: PREDOMÍNIO DA SOCIALIZAÇÃO NO

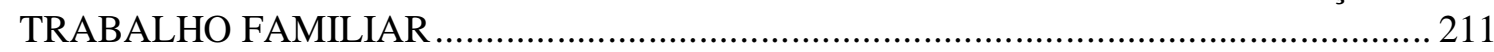

5 AS REPRESENTAÇÕES SOCIAIS DOS JOVENS AGRICULTORES FAMILIARES

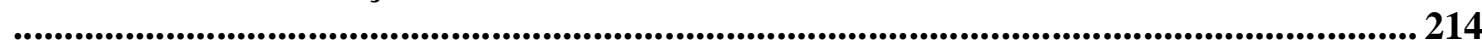

5.1 AS REPRESENTAÇÕES SOCIAIS E O PROCESSO DE IDENTIFICAÇÃO .............2214

5.2 AVALIAÇÕES DOS JOVENS SOBRE TRABALHO FAMILIAR AGRÍCOLA .........222

5.3 AVALIAÇÕES SOBRE O MODO DE VIDA DOS PAIS........................................... 236

5.4 O PROCESSO DE IDENTIFICAÇÃO SOCIAL DOS JOVENS AGRICULTORES

FAMILIARES …………................................................................................... 249

5.5 REPRESENTAÇÕES POSITIVAS E AUTOIDENTIFICAÇÃO COMO AGRICULTOR

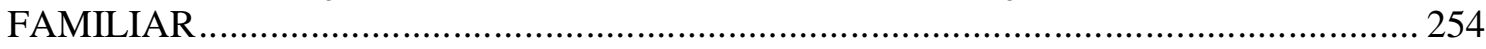

6 OS PROJETOS DA ATUAL GERAÇÃO DE JOVENS AGRICULTORES

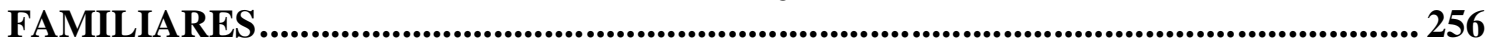

6.1 O PERCURSO TEÓRICO DO CONCEITO DE PROJETO .......................................... 256

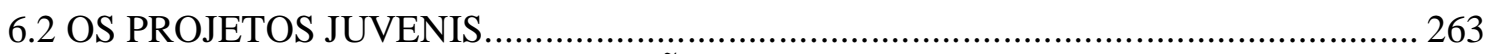

6.3 OS PROJETOS DE ESCOLARIZAÇÃO DOS JOVENS AGRICULTORES

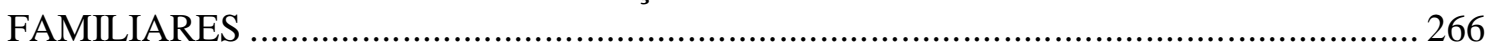

6.4 OS PROJETOS PROFISSIONAIS DOS JOVENS AGRICULTORES FAMILIARES. 270

6.5 OS PROJETOS DE VIDA DOS JOVENS AGRICULTORES FAMILIARES ………... 281

6.6 DIMENSÕES DA SITUAÇÃO JUVENIL E PROJETOS PROFISSIONAIS DOS

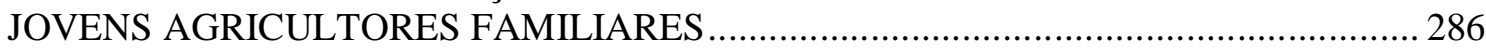

6.6.1 Condições materiais e projetos profissionais................................................................. 288

6.6.2 Processos de socialização e projetos profissionais...................................................... 293

6.6.3 Representações sociais e projetos profissionais........................................................... 297

CONSIDERAÇÕES FINAIS ............................................................................................. 303

REFERÊNCIAS BIBLIOGRÁFICAS ...................................................................311 


\section{INTRODUÇÃO}

Esta Tese de Doutorado articula as linhas temáticas de estudos sobre juventude e agricultura familiar. A tarefa sociológica proposta foi a de apontar os traços distintivos da situação juvenil na agricultura familiar, buscando, nesta, os elementos explicativos dos projetos profissionais elaborados por estes jovens. A relação estabelecida entre estas duas dimensões temporais - presente e futuro - permitem pôr em evidência a construção social desta juventude e de suas disposições em reproduzir o processo de trabalho familiar agrícola. Para isto, realizou-se uma pesquisa social empírica representativa do universo de jovens ocupados na agricultura familiar no estado do Rio Grande do Sul.

Partiu-se do entendimento de que a dinâmica do desenvolvimento capitalista vem determinando transformações nas condições de reprodução do capital e da força de trabalho na agricultura familiar, ao mesmo tempo em que torna o espaço social rural cada vez mais complexo. No caso brasileiro, de condições historicamente adversas às pequenas unidades produtivas, as novas gerações de agricultores familiares têm restringidas suas possibilidades de permanência nesta atividade (WOORTMANN, K. 1990; ABRAMOVAY, R. 1998; SILVESTRO et al., 2001; WEISHEIMER, 2004). Este processo tem implicações sociais relevantes, uma vez que, de um modo geral, a continuidade da profissão de agricultor depende da reprodução social com base familiar. Isto porque, a sucessão na agricultura familiar tende a ser endógena, com pelo menos um dos filhos sucedendo ao pai na unidade produtiva, sendo pouco frequente a adesão a essa atividade profissional por pessoas sem vivência familiar neste ramo (WEISHEIMER, 2004). Como o acesso aos recursos e as disposições dos jovens nem sempre coincidem, instaura-se um impasse na reprodução social entre agricultores familiares; o que vem, de certo modo, se desdobrando num predomínio juvenil e feminino no processo migratório recente do campo para cidade, e no decorrente envelhecimento e masculinização do campo (BAENINGER, 1998; CAMARANO \& ABRAMOVAY, R. 1999).

Considerando-se que os jovens agricultores familiares se encontram num tempo $\operatorname{liminar}^{1}$ de escolhas entre os projetos profissionais de permanência ou saída da agricultura,

\footnotetext{
${ }^{1} \mathrm{O}$ conceito de liminariedade está associado à noção de margem, termo empregado inicialmente por Van Gennep (1977) para designar a situação de transitoriedade no sentido social e ritual. Usa-se este termo para demarcar uma característica da juventude, vivenciar um tempo híbrido e transitório, tal como o "espaço liminar" em Homi Bhabha (2005) que descreve um entre-lugares. No caso, refere-se aqui a um entre-tempo no ciclo vital e social experienciado como um hibridismo que demarca a transição da "dependência" da infância à "independência" da vida adulta.
} 
podemos dizer que eles vivem o que Antony Giddens (2002) descreveu como um processo de "formação reflexiva da auto-identidade", ${ }^{2}$ em meio à crescente pluralidade e heterogeneidade das relações no "espaço social agrário" (TAVARES-DOS-SANTOS, 1991). Desta forma, parece-nos pertinente abordar as possibilidades de reprodução social do processo de trabalho familiar agrícola a partir do ponto de vista dos jovens. Tendo isto em vista, elegemos como objeto de estudo a situação juvenil na agricultura familiar, procurando explorar suas diferenciações por sexo e idades e seus reflexos sobre os projetos profissionais formulados por estes jovens.

A tese buscou dialogar com outros estudos que investigam a participação juvenil nos processos de reprodução social da agricultura familiar; diferindo-se destes, no entanto, por apontar a singularidade dos jovens neste contexto. Particularmente, entre os trabalhos brasileiros desenvolvidos sobre este tema é possível identificar ao menos quatro linhas ou abordagens de investigação diferenciadas (WEISHEIMER, 2005a) que trouxeram algumas pistas para análise do objeto proposto.

A primeira destaca o conceito de sucessão geracional na unidade de produção familiar agrícola apoiando-se na proposta de Gasson e Errington (1993), para os quais a sucessão nos estabelecimentos agropecuários familiares envolve, necessariamente, a formação de novas gerações de agricultores e inclui: a) a sucessão profissional (passagem das responsabilidades sobre o negócio, do poder e da capacidade de utilização do patrimônio para a geração seguinte, assim como a qualificação necessária para a integração dos novos agricultores num mercado competitivo); b) a transferência legal da propriedade da terra e dos ativos existentes (através do processo de sucessão patrimonial, com base na escolha de um entre os possíveis herdeiros); c) a aposentadoria da geração atual (i.e., a transferência das responsabilidades e do poder sobre os ativos que compõem a unidade produtiva para a geração seguinte) (GASSON \& ERRINGTON, 1993).

Outras variáveis consideradas são as oportunidades de trabalho independente da família; o acesso à escolarização; a perspectiva matrimonial com um(a) agricultor(a); a possibilidade de herdar terra; o envolvimento na unidade produtiva, o tamanho da propriedade e a renda familiar. Estes são apontados como fatores que incidem nas disposições dos jovens em permanecer no trabalho agrícola, assegurando que a unidade produtiva passe de geração a geração (ABRAMOVAY, R. 1998; BRUMER, 2003, 2004; BRUMER; ROSAS;

\footnotetext{
${ }^{2}$ Auto-identidade "[...] é o eu compreendido reflexivamente pela pessoa em termos de sua biografia" (GIDDENS, 2002, p. 54).
} 
WEISHEIMER, 2000; DUQUÉ \& SOUSA, 2002; HAYGERT, 2001; SILVESTRO et al., 2001).

Uma segunda abordagem agrega ao conceito anterior a noção de projetos individuais, seja na forma de "projeto profissional" ou "projeto de vida" dos jovens. Os autores destes trabalhos argumentam que as mudanças e crises recentes no meio rural fazem com que essa realidade seja reelaborada na formulação de projetos individuais e familiares. Neste contexto, os jovens são instigados a questionar os projetos familiares sustentados na reprodução de modos de vida pautados exclusivamente pela atividade agrícola e passam a reivindicar padrões de vida que incorporam valores e condições materiais tidos como "urbanos". Desta síntese, resultam novas possibilidades de permanência no campo sustentadas pela reelaboração de identidades sociais dos jovens agricultores. Estes trabalhos examinam também como variáveis independentes: a condição fundiária relativa à posse e ao tamanho da unidade produtiva; a renda agrícola obtida pela família; a socialização dos jovens no processo de trabalho da agricultura familiar, na escola e espaços de sociabilidade; as representações destes sobre o trabalho agrícola, sobre o meio rural e o urbano e as avaliações acerca do modo de vida de seus pais; para perceber a influência desses elementos na elaboração dos projetos profissionais dos jovens. Concluem afirmando que, dependendo do campo de possibilidades disponíveis aos jovens, os projetos juvenis estarão orientados em certas direções (CARNEIRO, 1998, 1999; PEREIRA, 2004; SIQUEIRA, L. 2003, 2004; WEISHEIMER, 2004, 2005b, 2007; WANDERLEY, 2006). Noção que compartilham a partir de leitura de Gilberto Velho, com referenciais à obra Projeto e Metamorfose, publicado originalmente em 1994 e que recoloca o conceito de projeto em discussão nas ciências sociais no Brasil.

Uma terceira abordagem enfatiza que a possibilidade de reprodução da agricultura familiar estaria associada às condições de acesso dos jovens à cidadania. Constatam que, na busca por direitos, os filhos(as) de agricultores familiares transitam em diferentes espaços da sociedade, construindo uma matriz valorativa diversa e, muitas vezes, contraditória. Deste modo, o movimento migratório e reivindicatório dos jovens explicita problemas estruturais da sociedade, que repercutem nas diversas dimensões do processo de desenvolvimento rural que não se explicam exclusivamente com variáveis econômicas (STRAPASOLAS, 2002, 2003; SPANEVELO, 2003). 
Podem ainda ser acrescidas as pesquisas que indicam que a intensificação dos processos de pluriatividade ${ }^{3}$ tende a favorecer a reprodução social dos agricultores familiares, argumentando que o rural não se caracteriza exclusivamente como agrícola. Tendo os resultados obtidos pela equipe do Projeto Rurbano como referência, eles defendem que a revitalização do meio rural, com uma ampliação do mercado de trabalho no meio rural e com novas alternativas de ocupação e renda geradas por atividades não-agrícolas, contribuiria para elevação da renda, das condições de vida. Por consequência, para a permanência dos jovens no campo (TEIXEIRA, 1998; RIBEIRO, 2000). Outrossim, de nossa parte, entende-se que a pluriatividade representa uma alternativa à permanência na agricultura, mesmo que não como atividade exclusiva, justamente nas regiões potencialmente mais desenvolvidas. Isto foi o que constataram Flávio Sacco dos Anjos e Nádia Velleda Caldas em pesquisa recentemente realizada no Rio Grande do Sul: Conforme estes autores:

Tudo indica que o processo sucessório na agricultura familiar é bastante mais afetado pelo grau de dinamismo das atividades econômicas na região em que esta se encontra inserida e pelo tamanho do negócio familiar do que em virtude da maior ou menor incidência da pluriatividade (SACCO DOS ANJOS; CALDAS, 2006, p. 19).

Percebe-se, nestes estudos, que há implicações materiais importantes para a viabilização deste processo, como o acesso das novas gerações aos meios de produção necessários a esta atividade, em especial à propriedade da terra; o tamanho do estabelecimento, de sua capacidade produtiva e de geração de renda. A este respeito, o sociólogo Patrick Champagne, por exemplo, numa análise sobre o processo de reprodução social dos agricultores franceses, verificou que:

[...] as famílias agrícolas que não conseguem 'reproduzir-se' no meio agrícola isto é, as que não têm sucessores - correspondem a estabelecimentos demasiadamente pequenos e insuficientemente rentáveis tendo em vista o estado atual dos mercados agrícolas (CHAMPAGNE, 1986, p. 74).

Uma pesquisa coordenada por Ricardo Abramovay na região oeste de Santa Catarina também constatou uma tendência semelhante, uma vez que entre os agricultores consolidados era mais frequente a sucessão geracional. Este autor utilizou uma tipologia dos agricultores

\footnotetext{
${ }^{3}$ Utiliza-se o termo como é empregado por Schneider (2003), que o concebe como fenômeno através do qual membros das famílias de agricultores que habitam o meio rural optam pelo exercício de diferentes atividades não-agrícolas, mantendo moradia no campo e vínculos com as atividades produtivas agrícolas (SCHNEIDER, 2003, p. 91).
} 
familiares segundo a qual os agricultores consolidados seriam capazes de garantir a reprodução da família e acumular algum excedente; os agricultores em transição seriam os que conseguiriam garantir apenas sua reprodução sem acumular excedente e os agricultores em exclusão seriam os que não conseguem garantir sua reprodução com base nas atividades agropecuárias de sua própria unidade de produção (ABRAMOVAY, R. et al., 1998, p. 57-9).

Em pesquisa realizada num município do Rio Grande do Sul, chegou-se a resultados semelhantes. Analisando-se a influência das condições materiais das famílias sobre os projetos juvenis, constatou-se que o acesso à propriedade da terra desempenha um papel central para que os jovens desenvolvam projetos de permanência na agricultura. Verificou-se também que os projetos profissionais agrícolas são mais frequentes entre os jovens cujas famílias alcançam as maiores rendas agrícolas. Entretanto, estes fatores, apesar de importantes, não se apresentavam suficientes para assegurar a reprodução geracional das unidades de produção familiar, visto que tal relação só se mostrou verdadeira entre os jovens homens. Ou seja, mesmo em condições materiais favoráveis predominou a recusa da agricultura por parte das jovens mulheres (WEISHEIMER, 2004).

Além das condições materiais que mencionamos anteriormente, o interesse dos jovens pela ocupação agrícola dependerá ainda de todo um processo de socialização profissional nesta atividade. O sociólogo francês Claude Dubar (2005) apoia-se na abordagem interacionista de Everett Hughes (1955) para falar de uma espécie de "iniciação" à cultura profissional capaz de permitir a "conversão" do indivíduo a uma concepção de si e de mundo. Em suma, de uma identidade socioprofissional. Com base nisto, aponta para três mecanismos específicos de socialização profissional: a passagem através do espelho; a instalação na dualidade e; o ajuste da concepção de Si. O primeiro, denominado "passagem através de espelho" que seria a imersão em uma cultura profissional e a identificação progressiva com a função. O segundo corresponde à "instalação na dualidade" formada pelo modelo ideal que caracteriza a dignidade da profissão, sua valorização simbólica, e o "modelo prático" que corresponde às tarefas cotidianas e aos trabalhos duros, que guardam pouca relação com o primeiro (DUBAR, 2005).

Neste contexto, a constituição de um "grupo de referência" no interior da profissão representa a antecipação de posições desejáveis e a legitimação de suas capacidades, sendo este um mecanismo essencial de gestão desta dualidade. Trata-se de um processo de projeção pessoal em uma carreira futura por identificação com os membros de um grupo de referência. Desta forma, comparando-se aos membros de seu entorno, dotados de status social mais 
elevado, eles forjam para si uma identidade, não a partir de seu grupo de pertencimento, mas por identificação com um grupo de referência. Este processo - argumenta o autor - implica a aquisição antecipada de normas, valores e modelos de comportamento originários dessas referências.

O último mecanismo diz respeito ao "ajuste da concepção de Si", ou seja, de sua identidade em vias de construção, implicando a tomada de consciência das chances de atuação profissional que se pode esperar para o futuro. Ou seja, trata-se de identificar as possibilidades de atuação profissional em relação às possibilidades e as referências que se tem. Isto é o que Everett Hughes descreve como "projeções de Si no futuro" (DUBAR, 2005, p. 186) e pressupõe a capacidade do sujeito de se orientar a partir de avaliações mais ou menos realistas de suas próprias possibilidades. Assim, a socialização profissional implicará uma construção social de identidades profissionais.

Esta socialização profissional entre agricultores familiares se realiza na própria unidade familiar, como se busca demonstrar neste estudo. Esta, não raramente, entra em contradição com a socialização obtida através da escolarização formal. Neste sentido, é necessário considerar que as possibilidades profissionais, ou ao menos de trabalho, encontram-se fortemente relacionadas às oportunidades de escolarização, visto que, esta é uma agência que tem a função social de capacitar os jovens para trajetórias profissionais. Por conta disto, Patrick Champagne (1986, p. 53) relaciona a própria "crise da identidade camponesa" com a imposição da escolarização formal no meio rural e a desqualificação do modo de vida "camponês" daí advinda.

Pela importância da escolarização como processo socializador, é preciso resgatar a contribuição dos estudos sobre a educação no meio rural para o tema da reprodução social do trabalho familiar agrícola. Assim, considerou-se necessário contemplar, nesta pesquisa, as condições diferenciadas de acesso aos estudos e prosseguimento desses entre os jovens agricultores, para produzir uma caracterização destes sujeitos e comparar as relações destas condições com as disposições de continuar na agricultura por categorias de sexo e faixa etária.

A relação entre as condições materiais e a disposição de reprodução social por jovens agricultores não é tão simples como uma relação de causa-efeito. Na verdade, esta relação é apenas indireta, pois, como salienta Champagne, no fundo, "a recusa dos filhos de suceder aos pais é, em primeiro lugar, recusa do modo de vida dos pais, a crise de reprodução sendo aqui uma crise de identidade social" (CHAMPAGNE, 1986, p. 77). Desta maneira, além das condições materiais e os processos de socialização que caracterizam a atividade produtiva na 
qual os jovens se inserem, nesta pesquisa buscar-se-á analisar a diversidade das representações sociais dos jovens agricultores, sobre si mesmos; sobre o trabalho agrícola e não-agrícola e sobre o modo de vida dos pais para verificar quais projetos profissionais prevalecem em cada uma das situações.

Entende-se que as representações dos jovens sobre suas possibilidades de permanência na agricultura, assim como as avaliações que fazem do trabalho agrícola e o modo de vida dos pais, são extremamente relevantes para o estudo das dinâmicas de reprodução social da agricultura familiar por serem os jovens que efetivamente encarnam as possibilidades de reprodução geracional deste setor produtivo. Seus projetos e suas opiniões resultam da sua participação direta no processo de trabalho familiar agrícola. Como membros de uma nova geração, suas representações guardam as peculiaridades próprias da sua posição singular no contexto histórico, revelando percepções das quais só os jovens contemporâneos são portadores e podem fazer emergir. Isto porque "a nossa cultura é desenvolvida por indivíduos que entram de maneira diferente em contato com a herança cultural" (MANNHEIN, 1982, p. 74), fazendo com que a atitude com relação à herança transmitida por seus predecessores seja completamente nova. ${ }^{4}$ Com efeito, a chave para a compreensão das possibilidades atuais de reprodução do processo de trabalho familiar agrícola encontra-se nas disposições dos jovens agricultores familiares, e não nas dinâmicas sucessórias vividas por seus pais e avós em outros contextos históricos, marcados por outras dinâmicas sociais, culturais e econômicas.

Nesta linha, analisando as representações juvenis, Patrick Champagne (1986) verificou que, quando comparada com outras atividades, a agricultura é vista pelos jovens, mas, principalmente pelas moças, de forma mais negativa do que positiva. Entre os aspectos negativos, são destacados: ausência de férias, de fins-de-semana livres e de horários regulares de trabalho; atividades agrícolas penosas, duras e difíceis, submetendo os trabalhadores ao calor e ao frio e a posições de trabalho pouco confortáveis; rendimentos baixos, irregulares e aleatórios. Entre os aspectos negativos da atividade agrícola apresentados pelos jovens entrevistados, "as moças tendem a insistir um pouco mais sobre as condições de vida, enquanto que os rapazes enfatizam os aspectos econômicos" (CHAMPAGNE, 1986, p. 80).

A situação de "crise da identidade camponesa", apontada por Champagne (1986) aproxima-se de indicações feitas anteriormente por Jerzy Tepicht (1973), quando

\footnotetext{
${ }^{4}$ Este processo é descrito por Mannheim (1982) como "contato original" com a herança social e cultural que resulta das mudanças da situação histórica e social.
} 
argumentava que o "declínio da economia camponesa" poderia ser verificado pelo esfacelamento de seu "coletivismo interno" e o acirramento de conflitos entre os "menores de trinta anos". Já para Tepicht (1973), a família camponesa encontra-se no interior de uma cápsula do coletivismo interno e individualismo externo. Este autor demonstra que este "encapsulamento" deve-se de um forte individualismo em relação ao exterior e de um coletivismo interno rigoroso, subordinando o destino pessoal de cada um ao interesse da pequena empresa familiar. Este autor argumenta que o desenvolvimento do capitalismo tenderia a ter um efeito desagregador à economia camponesa. Entende-se que com o avanço da economia de mercado e sua dinâmica concentracionista, se restringe cada vez mais o patrimônio familiar de tal maneira que os processos de modernização tecnológica da agricultura acabam por acentuar essa crise. Casamentos, migrações e mudanças de profissão seriam vistos sob esta ótica:

\begin{abstract}
A subordinação severa do destino pessoal de cada um ao interesse da pequena empresa familiar - no plano da economia, do prestígio etc. Um casamento, a partida de alguém, uma mudança de profissão, tudo é considerado sob este angulo. Enfim, uma das manifestações mais características desse estado de coisas é o caráter impessoal do trabalho e, sobretudo, da renda de todos, à exceção do chefe da família (TEPICHT, 1973, p. 23).
\end{abstract}

A subordinação de cada um dos membros da família a este coletivismo interno seria um dos principais fatores responsáveis pela permanência do trabalho familiar na agricultura através da história. Isto pressupõe a subordinação do destino pessoal ao interesse coletivo da família agricultora. Dentro desta perspectiva, os jovens agricultores devem conciliar os objetivos coletivos da comunidade de interesses da qual fazem parte - que são suas famílias com os seus próprios projetos de emancipação individual (WANDERLEY, 2003). Além disso:

\footnotetext{
Os projetos de individualização dos jovens estão incorporados ao próprio movimento natural de evolução da família. Com efeito, uma unidade familiar de produção tende, pela sua própria natureza, a propiciar a saída de um certo número de filhos que não podem ser mantidos no interior do estabelecimento familiar (WANDERLEY, 2003, p. 10).
}

As disposições dos filhos que ficarão na agricultura, assim como as daqueles que devem sair da unidade produtiva, são construídas socialmente. O que chama a atenção é que entre os últimos predominam as filhas mulheres. Isto ocorre porque o processo de transmissão do patrimônio familiar tem como fundamento a continuidade de linhagem na gestão dos 
negócios, o que exclui as mulheres não só de parte da herança, mas da condição de herdeira (BOURDIEU, 2004). Este aspecto impõe investigar a influência das relações sociais de gênero na definição dos projetos dos jovens agricultores familiares. Entende-se esta é uma categoria relacional que emerge na interação entre homens e mulheres, o que está na origem de "esquemas classificatórios que fundamentam toda a ordem social e que colocam o homem e a mulher como opostos hierarquizados" (BOURDIEU, 1999, p. 16-8). Ou ainda, como propôs Joan Scott (1990, p. 14): “O gênero é um elemento constitutivo de relações sociais fundadas sobre as diferenças percebidas entre os sexos, e o gênero é um primeiro modo de dar significado às relações de poder". Neste caso, a prevalência dos interesses coletivos da família sobre os projetos individuais passa a configurar um aspecto crítico das relações familiares e de sua organização patriarcal, onde a única possibilidade de autonomia para as mulheres encontra-se fora da atividade familiar.

É precisamente este coletivismo interno rigoroso que se torna uma das fontes de sua crise. O conflito entre os "menores de trinta anos" e seus pais [...]; a impossibilidade de se afirmar no trabalho e de dispor materialmente de si mesmo, estimulam a partida dos mais dinâmicos, engendrando o envelhecimento do "pessoal" dos estabelecimentos camponeses. O abandono daqueles que ficam, afinal, sem herdeiros. Os esforços para adaptar-se às novas exigências do tempo [...] agravam sua situação financeira, sem resolver, contudo, seus conflitos internos. O que foi um dos traços mais antigos e mais duráveis da economia camponesa torna-se um dos fatores de sua inevitável ruptura (TEPICHT, 1973, p. 24).

Com base nas ideias de Tepicht, pode-se relacionar as dificuldades da reprodução social da agricultura familiar ao esfacelamento do coletivismo interno e acirramento do conflito entre os jovens - "os menores de trinta anos" - e seus pais devido à impossibilidade dos primeiros afirmarem-se como produtores independentes, dispondo assim do próprio trabalho. Em situações onde os projetos individuais dos filhos se chocam com os projetos formulados pelos pais, pode estar em risco justamente a própria reprodução geracional da unidade de produção familiar. Esta crise se faria refletir tanto na contestação da partilha e intensificação das disputas pela herança entre os "não-herdeiros", quanto na recusa da herança e migração dos escolhidos como "herdeiros", ou seja, quando o herdeiro recusa-se a herdar.

Klass Woortmann (1990) chama a atenção para o fato de que, com a emergência de projetos individuais, fica cada vez mais difícil construir o herdeiro. Segundo este autor: "O coletivismo interno da família tem sido um dos fatores de permanência do campesinato através da história, mas hoje ele parece se chocar com os projetos individuais" 
(WOORTMANN, 1990, p. 73). Isso, segundo Tepicht (1973, p. 24), "torna-se um dos fatores de sua inevitável ruptura".

Isto ocorre porque os projetos coletivos formulados no núcleo familiar não são vividos de modo totalmente homogêneo pelos indivíduos que o compartilham. Existem diferenças na interpretação devido às particularidades de diversas ordens, no caso de uma família, de gênero e geração. Por sua vez, os projetos individuais, que podem se distinguir do projeto familiar, emergem também em função de interações e experiências fora do âmbito das relações familiares como, por exemplo, na escola, no mercado de trabalho e nos espaços de lazer (VELHO, 2003). Logo, investigar a construção social dos projetos profissionais dos jovens agricultores familiares, comparando-os segundo sexo e idade, implicará a análise dos recursos materiais e simbólicos disponibilizados ao longo dos seus processos de socialização.

Percebe-se através dos diferentes fatores vistos até aqui que a escolha de um futuro profissional por parte dos jovens agricultores familiares coloca-os frente a diversas opções que serão determinadas por um conjunto de fatores que ultrapassam a perspectiva individual dos atores e sua capacidade de escolha racional. Tal posicionamento permite superar o senso comum, que percebe os projetos profissionais como resultado de uma escolha individual ou os colocam no plano de uma vocação pessoal. De maneira distinta, este trabalho buscou identificar nas dimensões sociais da própria condição juvenil os fatores que permitem explicar a construção dos projetos profissionais de jovens agricultores familiares. Consideramos que eles resultam da combinação entre condições materiais, processos de socialização e representações sociais.

Os projeto profissionais expressam a unidade dialética entre indivíduo e sociedade. Individual na medida que implica a avaliação e o posicionamento do sujeito diante de um plano de realização pessoal e estratégias particulares. Social devido ao fato de que esta tomada de posição se realiza num contexto social e cultural específico, influenciado por fatores que independem da vontade individual, e na interação com outros atores sociais e seus projetos individuais e coletivos (VELHO, 2003; BOUTINET, 2005).

Inicialmente o "projeto" pode ser entendido como uma representação de objetivos futuros que, partindo das experiências passadas, confere sentido às ações presentes e às interações na vida cotidiana. Ou ainda, como argumenta o antropólogo Jean-Pierre Boutinet (2005, p. 279): “O projeto traduz, de certo modo a recusa da presença atual e sua preocupação com uma presença nova que dá um sentido a nossa interação momentânea”. Contudo, como alertou o sociólogo Alfred Schütz, “o projeto como qualquer outra antecipação de eventos 
futuros traz consigo horizontes em aberto, que somente serão preenchidos através da materialização do evento antecipado" (SCHÜTZ, 1979, p. 139). Deste modo, não são as possibilidades de efetivação ou não dos projetos juvenis que estão em jogo neste estudo, mas a compreensão interpretativa das avaliações dos jovens de suas possibilidades de permanência ou saída da agricultura familiar como atividade produtiva.

Lembrando que palavras são atos, cuja enunciação já constitui uma realização, como destaca a antropóloga Mariza Peirano (2001, p. 11): "não é possível separar o dito e o feito, porque o dito é também feito". Entende-se assim que a consciência discursiva (GIDDENS, 2003) do projeto não apenas exprime algo no futuro, mas possui uma força intrínseca de um evento comunicativo sobre algo do presente. Ou seja, o projeto expressa a maneira como os jovens lidam com sua condição atual, e nisto reside sua pertinência para esse trabalho. Entendemos que os projetos profissionais dos jovens traduzem, provavelmente, melhor do que qualquer outro indicador, a avaliação que fazem da agricultura familiar, assim como a sua visão das possibilidades de reprodução das unidades de produção familiar, revelando simultaneamente como eles lidam com esta condição juvenil presente e suas disposições para permanência futura nesta atividade.

O objetivo geral do estudo foi analisar as características da situação juvenil na agricultura familiar para explicar os projetos profissionais de jovens agricultores familiares no estado do Rio Grande do Sul. Para tanto, o trabalho foi desenvolvido perseguindo-se os seguintes objetivos específicos:

1) Conhecer as dimensões da participação dos jovens (de 15 a 29 anos de idade) na população ocupada na agricultura familiar no Rio Grande do Sul, segundo o Censo Demográfico do IBGE 2000;

2) Avaliar as condições materiais dos jovens agricultores familiares considerando a estrutura fundiária e a renda agrícola da unidade de produção familiar, seu acesso a esta renda e seu grau de autonomia material;

3) Analisar os processos de socialização dos jovens no trabalho familiar agrícola, na educação formal e nas práticas de lazer; 
4) Interpretar suas representações sociais referentes ao trabalho agrícola e nãoagrícola, ao modo de vida dos pais e sua auto-identificação.

5) Identificar os projetos juvenis (projeto de escolarização, de profissão e de vida);

6) Relacionar os aspectos da condição juvenil (condições materiais, processos de socialização e representações sociais) com os projetos profissionais elaborados por jovens agricultores familiares;

7) Estabelecer comparações por sexo e faixas etárias dos entrevistados ao longo da análise.

Este estudo associa-se a uma trajetória investigativa que parte das condições objetivas, suas determinações materiais e estruturais, para tentar explicar, relacionalmente, as possibilidades de subjetivação e de ação social. Parte-se do pressuposto segundo o qual a complexidade dos significados e das representações sociais são melhor compreendidas na medida em que se revelarem às relações objetivas que permitem as construções simbólicas. Estas, tendo uma origem exterior ao indivíduo, impõem-lhe constrangimento independente de sua vontade, configurando as possíveis relações de sentido com as quais os seres humanos tentam orientar suas ações. Ao mesmo tempo, percebe-se que as construções simbólicas são objetivadas na ação social, adquirindo força material por serem compartilhadas na vida social. Este duplo processo de objetivação e subjetivação está presente em todo e qualquer fato social, inclusive no trabalho de investigação sociológica e na construção de projetos juvenis.

Com efeito, as hipóteses que orientaram o desenvolvimento da pesquisa podem ser apresentadas nos seguintes termos:

1) Os jovens agricultores familiares são uma categoria social que surge da socialização no processo de trabalho familiar agrícola, sendo a situação juvenil na agricultura familiar caracterizada por uma baixa autonomia material; por uma intensa socialização no processo de trabalho familiar agrícola e pelo predomínio de representações positivas sobre esta atividade. Em decorrência disto, esperasse que: 
a) em situações nas quais os jovens contam com maior autonomia material, eles elaborem projetos profissionais agrícolas;

b) quanto maior a participação do jovem no processo de trabalho familiar agrícola mais se constatará disposições em reproduzir este processo de trabalho;

c) as avaliações positivas sobre o trabalho agrícola e do modo de vida dos pais colaboram para a elaboração de projetos profissionais agrícolas por jovens agricultores familiares.

2) A situação juvenil na agricultura familiar também se diferencia segundo o sexo e a faixa etária dos entrevistados, influenciando os projetos profissionais dos jovens, de tal modo que:

a) os jovens adultos do sexo masculino tendem a elaborar projetos de permanência na agricultura familiar;

b) as mulheres jovens adolescentes tendem a construir projetos profissionais nãoagrícolas.

\section{NOTAS TÉCNICAS E METODOLÓGICAS}

O método em pesquisa social refere-se à escolha de procedimentos sistemáticos para a reconstrução, descrição, compreensão e explicação de fenômenos sociais. Como na analogia de Marx, o método serve de fio condutor que orienta o cientista na construção do conhecimento na abordagem da realidade social. Deste modo, a objetividade pôde ser conquistada através de um processo metódico de objetivação do fenômeno social pesquisado.

$\mathrm{Na}$ construção do conhecimento científico, segue-se a orientação de Durkheim (1973) de buscar estabelecer sistematicamente rupturas com as pré-noções, a fim de assegurar uma abordagem objetivante da realidade social. Esta ruptura consciente se faz necessária também contra as explicações estabelecidas no campo científico, de modo que se possa 
superar a tendência à reprodução de uma sociologia espontânea (BOURDIEU, 1999), habitualmente encoberta pelo manto cientificista (MAY, 2000) de conceitos fortemente estabelecidos, mas que apenas refletem preconceitos e estereótipos profundamente enraizados.

Estas questões metodológicas colaboram com a crítica da representação sobre juventude rural, propondo-se, para a situação juvenil em estudo, a classificação como jovens agricultores familiares, como processo de produção do desvelamento da especificidade sociológica desta categoria social. Para enfrentar esta questão, dirigimos esforços coletivos que viabilizassem a reconstrução da situação juvenil na agricultura familiar enquanto construto teórico no duplo aspecto de sua generalidade e de sua profundidade. Neste sentido, se está propondo um modelos descritivo da situação juvenil que, neste estudo, é aplicado ao contexto da agricultura familiar, mas que pode ser aplicado a outras situações, que considera as seguintes dimensões: as condições materiais; os processos de socialização; as representações socais e os projetos juvenis. Cada um destes tópicos de análise foi submetido a uma perspectiva comparativa por sexo e faixa etária, uma vez que estes são fatores que produzem situações juvenis diferenciadas dentro deste mesmo segmento social.

Quadro 1: Dimensões temáticas e tópicos da pesquisa

\begin{tabular}{|ll|}
\hline \multicolumn{1}{|c|}{ Dimensões temáticas } & \multicolumn{1}{c|}{ Tópicos } \\
\hline Condições Materiais & Estrutura Fundiária da UPF \\
\cline { 2 - 2 } & Renda familiar \\
\cline { 2 - 2 } Processo de Socialização & Condição de autonomia material \\
& $\begin{array}{l}\text { No processo de trabalho familiar } \\
\text { agrícola }\end{array}$ \\
\cline { 2 - 2 } & No sistema formal de ensino \\
\cline { 2 - 2 } Representações Sociais & $\begin{array}{l}\text { Sobre o trabalho agrícola e não } \\
\text { agrícola. }\end{array}$ \\
\cline { 2 - 2 } & Sobre o modo de vida dos pais. \\
\cline { 2 - 2 } & Auto-indentificação \\
\hline Projetos Juvenis & Projeto de escolarização \\
\cline { 2 - 2 } & Projeto profissional \\
\cline { 2 - 2 } & Projeto de vida \\
\hline
\end{tabular}

Fonte: Elaboração do Autor.

Considera-se que a construção do conhecimento não parte nem do sujeito nem do objeto, mas da interação indissociável entre eles, para avançar daí na dupla direção de uma exteriorização objetivante e de uma interiorização reflexiva (PIAGET, 1973). Busca-se, com este modelo descritivo, realizar uma interpretação dialética que torna visível as relações entre condições objetivas e subjetivas, entre estruturas e processos de ação, contribuindo, 
simultaneamente, para construir e transformar o objeto. Neste sentido, os métodos e as técnicas de coleta de dados delineados aqui se apresentam como uma proposta de objetivação e de reconstrução analítica da situação juvenil na agricultura familiar do Rio Grande do Sul.

Os procedimentos adotados na condução desta pesquisa correspondem aos propósitos de uma abordagem extensiva que visa assegurar condições de ampla representatividade e de capacidade inferencial dos dados. A partir de uma metodologia indutiva, típica das survey, recorreu-se ao exame de dados secundários e a aplicação de questionário padronizado.

\section{UNIDADE DE ANÁLISE}

A unidade de análise correspondente à categoria dos jovens agricultores familiares foi estabelecida, com base no Censo Demográfico 2000 do IBGE, ${ }^{5}$ considerando-se os indivíduos na faixa de idade de 15 a 29 anos, por condição de ocupação na agricultura familiar. Esta última foi obtida selecionando-se entre os ocupados na agricultura os que se enquadram na situação de ocupação como: conta própria; não-remunerado em ajuda a membro do próprio domicílio; trabalhador na produção para o próprio consumo.

Posteriormente, estabeleceu-se uma diferenciação interna a este universo por sexo, faixas etárias e Mesorregiões do estado. ${ }^{6}$ As faixas etárias foram organizadas formando-se os seguintes grupos de idade: até 14 anos, de 15 a 29 anos [com subgrupos de 15 a 19; 20 a 24; 25 a 29], 30 a 44 anos, de 45 a 59 anos, de 60 a 74 anos e mais de 75 anos.

\section{PLANEJAMENTO AMOSTRAL}

O cálculo para a definição do tamanho da amostra foi realizado inicialmente para todo o estado do Rio Grande do Sul. Ela foi dimensionada tendo por base $162.760^{7}$ jovens de 15 a 29 anos ocupados na agricultura familiar no estado. Sobre este universo, aplicou-se a

\footnotetext{
${ }^{5}$ IBGE (2000), CD Microdados, v. 15, RS.

${ }^{6}$ Mesorregião é uma subdivisão dos estados brasileiros que congrega diversos municípios de uma área geográfica com similaridades econômicas e sociais. Foi criada pelo IBGE e é utilizada para fins estatísticos e não constitui uma entidade política ou administrativa.

${ }^{7}$ Fonte: IBGE. Censo Demográfico (2000).
} 
fórmula para cálculo de amostras infinitas (GIL, 1987, p. 100) definindo-se um intervalo de confiança de 95\%; com admissão de erro amostral de até 3,2\% pontos percentuais para mais ou para menos. Desta maneira, pode ser estabelecida uma amostra formada por 681 casos. Este procedimento encontra-se detalhado no Quadro 2.

Quadro 2: Fórmula de cálculo da amostra.

\begin{tabular}{|l|}
$\qquad n=\frac{\boldsymbol{o}^{2} \boldsymbol{p} . \boldsymbol{q}}{\boldsymbol{e}^{2}}$ \\
\hline Onde: \\
$\mathrm{n}=$ Tamanho da amostra \\
$\mathrm{o}^{2}=$ Nível de confiança escolhido, expresso em número de desvio padrão \\
$\mathrm{p}=$ Percentagem com a qual o fenômeno se verifica \\
q= Percentagem complementar $(100-\mathrm{p})$ \\
e= erro máximo permitido \\
Sendo: \\
721.425 o total de pessoas ocupadas na Agricultura Familiar \\
162.760 jovens de 15 a 29 anos ocupados na Agricultura Familiar \\
\hline Tamanho da amostra: 681 casos \\
\hline
\end{tabular}

O planejamento amostral seguiu o método de amostragem polietápica (BISQUERA et al., 2004), ou seja, a combinação mista da amostra estratificada e por conglomerados sequencialmente realizadas em dois estágios.

$1^{\circ}$ Estágio: amostragem estratificada com controle de cotas por sexo e faixa etária. Levando em conta a subdivisão do Rio Grande do Sul em sete mesorregiões, consideradas distintas entre si e apresentando homogeneidade interna, estabeleceu-se uma amostragem representativa de cada uma das sete mesorregiões. Foram mantidas as proporções do estado, possibilitando a inferência representativa para todo ele. Posteriormente, este tamanho de amostra foi subdividido de acordo com as categorias que influenciam na resposta a ser mensurada; ou seja, ele passou por um controle de cotas por sexo e faixa etária. Deste modo, dividiu-se o tamanho de amostra por mesorregiões de acordo com a disposição da ocupação na agricultura familiar com variáveis estabelecidas para o controle de cotas. A Tabela 1 apresenta a estratificação e o controle de cotas da amostra resultante do método proporcional.

$2^{\circ}$ Estágio: Amostragem por Conglomerados. Após a determinação das cotas de entrevistados por mesorregião (por sexo e faixa de idade), sob hipótese de homogeneidade interna, sorteou-se um município para cada uma das sete mesorregiões, com exceção da Noroeste Rio-grandense, que devido ao tamanho de sua amostra (354 casos) foi dividida em duas áreas. Os municípios sorteados tiveram sua população-alvo pré-determinada 
entrevistada, até que se completasse o tamanho de amostra requerido. Nos casos em que isso não foi possível, continuou-se a realização da pesquisa nos municípios vizinhos contidos em sua microrregião. A figura 1 apresenta o mapa de localização das mesorregiões do Rio Grande do Sul.

Tabela 1: Tamanho Amostral por Mesorregião, Sexo e Faixa Etária

\begin{tabular}{|c|c|c|c|c|c|}
\hline \multirow{2}{*}{ Mesorregião } & \multirow{2}{*}{ Sexo } & \multicolumn{3}{|c|}{ Faixa Etária } & \multirow{2}{*}{ Tota } \\
\hline & & 15 a 19 & 20 a 24 & 25 a 29 & \\
\hline \multirow[t]{3}{*}{ Total } & Masculino & 164 & 126 & 136 & 426 \\
\hline & Feminino & 85 & 78 & 92 & 255 \\
\hline & Total & 249 & 204 & 228 & 681 \\
\hline \multirow[t]{3}{*}{ Noroeste Rio-grandense } & Masculino & 91 & 65 & 66 & 222 \\
\hline & Feminino & 47 & 38 & 47 & 132 \\
\hline & Total & 138 & 103 & 113 & 354 \\
\hline \multirow[t]{3}{*}{ Nordeste Rio-grandense } & Masculino & 12 & 10 & 10 & 32 \\
\hline & Feminino & 6 & 5 & 7 & 18 \\
\hline & Total & 18 & 15 & 17 & 50 \\
\hline \multirow[t]{3}{*}{ Centro Ocidental Rio-grandense } & Masculino & 7 & 7 & 8 & 22 \\
\hline & Feminino & 3 & 3 & 4 & 10 \\
\hline & Total & 10 & 10 & 12 & 32 \\
\hline \multirow[t]{3}{*}{ Centro Oriental Rio-grandense } & Masculino & 24 & 19 & 21 & 64 \\
\hline & Feminino & 16 & 16 & 16 & 48 \\
\hline & Total & 40 & 35 & 37 & 112 \\
\hline \multirow{3}{*}{ Metropolitana de Porto Alegre } & Masculino & 18 & 14 & 17 & 49 \\
\hline & Feminino & 8 & 9 & 10 & 27 \\
\hline & Total & 26 & 23 & 27 & 76 \\
\hline \multirow[t]{3}{*}{ Sudoeste Rio-grandense } & Masculino & 2 & 3 & 4 & 9 \\
\hline & Feminino & 1 & 1 & 1 & 3 \\
\hline & Total & 3 & 4 & 5 & 12 \\
\hline \multirow[t]{3}{*}{ Sudeste Rio-grandense } & Masculino & 9 & 9 & 11 & 29 \\
\hline & Feminino & 6 & 4 & 6 & 16 \\
\hline & Total & 15 & 13 & 17 & 45 \\
\hline
\end{tabular}

Fonte: Elaboração do Autor. 


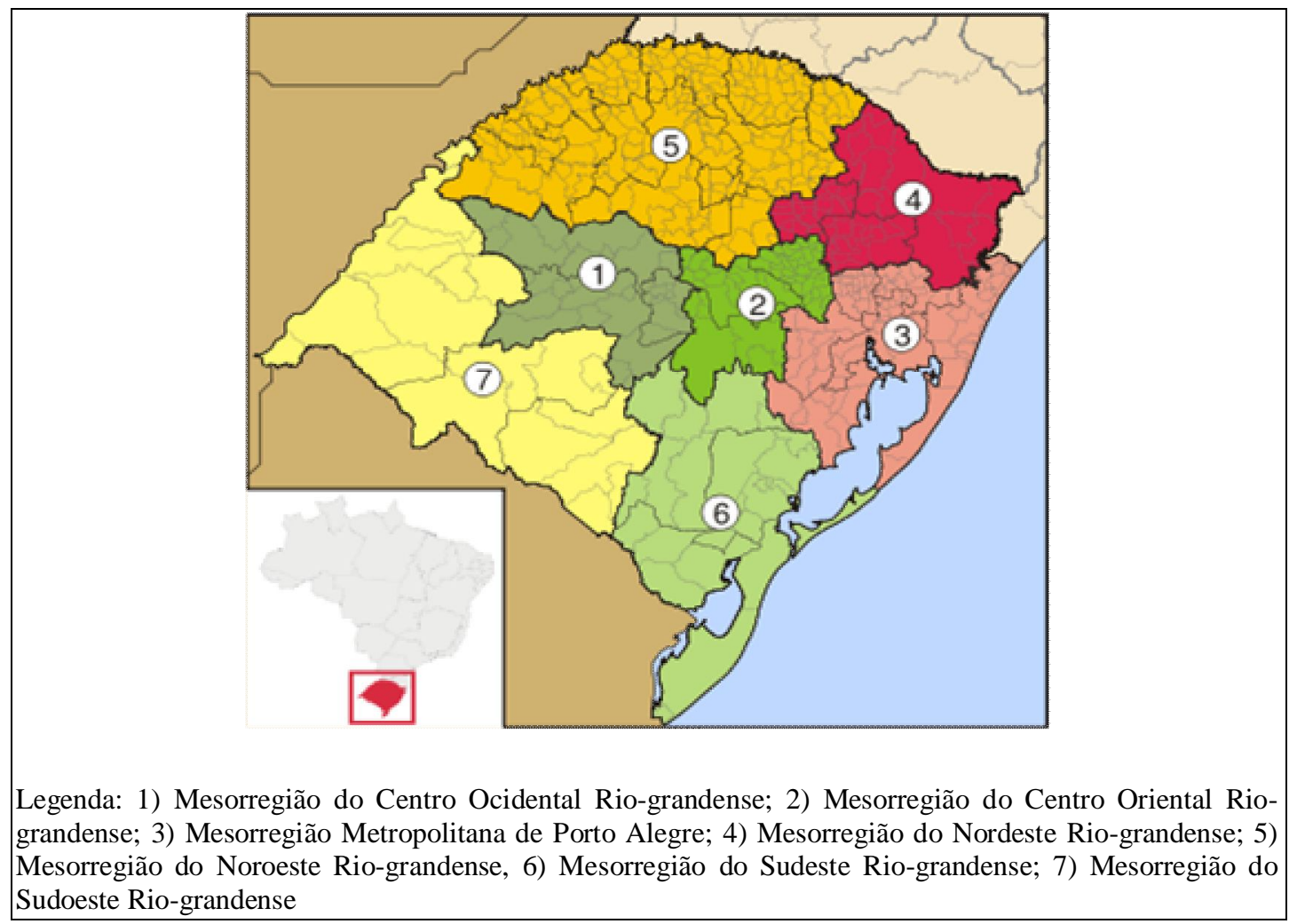
Sudoeste Rio-grandense

Figura 1: Mapa das mesorregiões do RS

Fonte: http://wikipedia.org/wiki/imagem:riograndedosul_messoregiões.svg.

\section{O TRABALHO DE CAMPO}

A realização do trabalho de campo de uma estodo extensivo representativo dos jovens ocupados na agricultura familiar do Rio Grande do Sul só foi possivel mediante a celebração de um convênio entre o Ministério do Desenvolvimento Agrário (MDA) e a Fundação de Apoio da Universidade Federal do Rio Grande do Sul (FAURGS). Este convênio teve como objeto a realização de uma pesquisa social empírica de caracterização dos jovens na agricultura familiar do Rio Grande do Sul. Deste modo, foram obtidos os recursos necessários à formação de uma equipe de pesquisa composta por oito bolsistas estudandes de graduação em Ciências Sociais e de Mestrado em Sociologia da Universidade Federal do Rio 
Grande do Sul e um Coordenador Geral, ${ }^{8}$ e todos os demais dispêndios necessários ao trabalho de campo nas sete messoregiões do estado.

Primeiramente, estes bolsistas passaram por uma capacitação realizada pelo coordenador geral da pesquisa que apresentou o referencial teórico e metodológico do estudo, o cronograma de execução, o instrumento de coleta de dados, o questionário estruturado e a plataforma digital que receberia os dados levantados. Após o treinamento e antes do campo definitivo, em dez de janeiro de dois mil e sete, foi realizado um pré-teste do instrumento de coleta de dados no município de São Sebastião do Caí. Nesta ocasião, foram entrevistados 32 jovens para verificar a inteligibilidade das questões, a coerência e a consistência das respostas fornecidas. Este teste serviu também para construirmos categorias de respostas a partir de questões que se apresentaram abertas na ocasião do teste, como as referentes à variável de auto-identificação. Após essa experiência, procedemos à avaliação e reestruturação do questionário.

Quadro 3: Mesorregiões e municípios abrangidos na pesquisa

\begin{tabular}{ll}
\hline \multicolumn{1}{c}{ Mesorregião } & \multicolumn{1}{c}{ Municípios } \\
\hline $\begin{array}{l}\text { 1. Mesorregião do Centro Ocidental Rio- } \\
\text { grandense. }\end{array}$ & Agudo*. \\
\hline $\begin{array}{l}\text { 2. Mesorregião do Centro Oriental Rio- } \\
\text { grandense. }\end{array}$ & $\begin{array}{l}\text { Candelária, Rio Pardinho, Santa Cruz do Sul, } \\
\text { Sinimbu*, Vale do Sol, Venâncio Aires. }\end{array}$ \\
\hline $\begin{array}{l}\text { 3. Mesorregião Metropolitana de Porto } \\
\text { Alegre. }\end{array}$ & $\begin{array}{l}\text { Bom Princípio, Feliz, Montenegro*, Nova Santa } \\
\text { Rita, Pareci Novo, Portão, São Sebastião do Caí, } \\
\text { São José do Hortêncio. }\end{array}$ \\
\hline $\begin{array}{l}\text { 4. Mesorregião do Nordeste Rio-grandense. } \\
\text { Cotiporã, Nova Pádua*. }\end{array}$ \\
\hline Mesorregião do Noroeste Rio-grandense. \\
$\begin{array}{l}\text { Ajuricaba, Aratiba*, Barra do Rio Azul, } \\
\text { Catuípe, Chiapeta, Erechim, Gaurama, Ijuí*, } \\
\text { Panambi, Rondinha, Severiano de Almeida, } \\
\text { Três Arroios. }\end{array}$ \\
\hline 6. Mesorregião do Sudeste Rio-grandense. & São Lourenço do Sul*. \\
\hline 7. Mesorregião do Sudoeste Rio-grandense. & São Borja*. \\
\hline
\end{tabular}

* Municípios sorteados.

Fonte: Elaboração do Autor.

\footnotetext{
${ }^{8}$ A equipe de campo foi formada por: Nilson Weisheimer (Coordenador); Analisa Zorzi, Jaqueline Russesczyk, Maira Gabriela Daniel, Mariana Zanata (Bolsistas de Mestrado); Alexandre Peres Lima, Bruna Cruz de Anhaia, Lucas Coradini (Bolsistas de Iniciação científica).
} 
O trabalho de campo ocorreu de 5 de janeiro a 3 de março de 2007. Neste período, a equipe de pesquisa esteve num total de trinta e um municípios (Quadro 3), nas sete mesorregiões do RS (Figura 2). Para facilitar a localização dos entrevistados, contatamos diversas instituições locais em momento prévio às nossas visitas. Outrossim, para evitar que essas informações influenciassem o perfil da amostra, recorremos aos próprios inquiridos para obter indicações de outros entrevistados. A aplicação do questionário ocorreu geralmente nas casas ou nos ambientes de trabalho dos jovens.

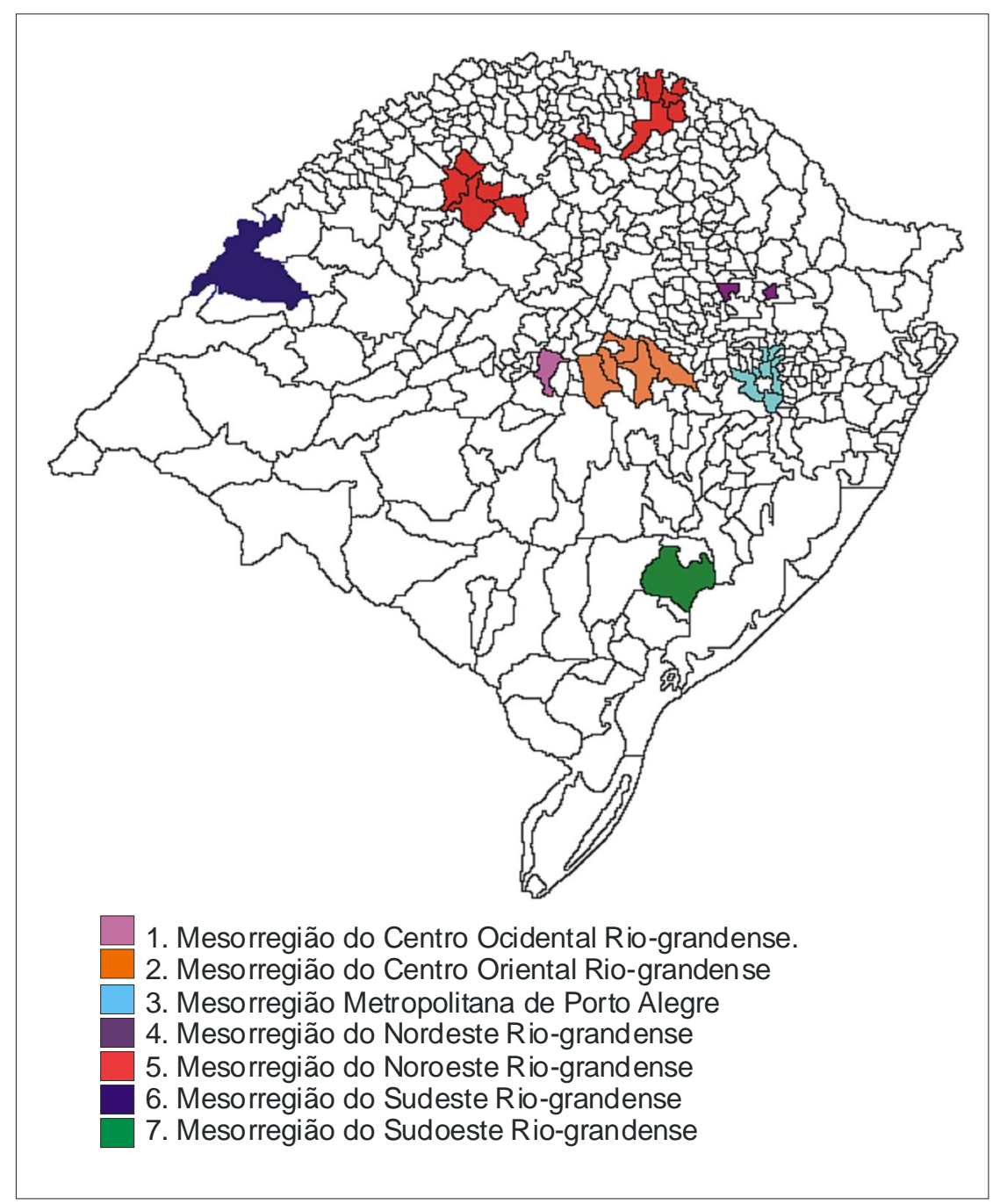

Figura 2: Mapa com a localização dos municípios identificados por mesorregião Fonte: Elaboração do Autor.

Outra questão que merece destaque diz respeito ao fato de entrevistadores e entrevistados serem jovens. Quais as implicações de um contado de jovens entrevistando jovens? No casos desta pesquisa, essa situação possibilitou uma maior identificação entre os 
sujeitos pesquisador e pesquisado, resultando em um maior engajamento dos entrevistados no processo de entrevista e dos pesquisadores na construção dos dados. Por compartilharem a mesma situação de geração ${ }^{9} \mathrm{e}$, em muitos casos, a condição de gênero, isto facilitou o entendimento mútuo, o que contribuiu para a obtenção de informações mais precisas e consistentes.

\section{ANÁLISE DOS RESULTADOS}

As informações obtidas com o questionário padronizado foram digitadas em planilha do software SPSS (Statistical Packege for Social Sciences) pela mesma equipe que realizou sua aplicação em campo. Isto reduziu, em parte, a possibilidade de ocorrência de erros, já que os digitadores tinham familiaridade com os dados que estavam sendo processados. Por outro lado, a adoção de uma tabulação e codificação dos questionários que preservou uma numeração simples facilitou a digitação. A checagem e correção da digitação, assim como a montagem final do Banco de Dados Jovens Agricultores Familiares do RS MDA/FAURGS 2007 ficaram a cargo do coordenador da pesquisa.

Em cada uma dos tópicos do modelo descritivo da situação juvenil (Quadro 4), foram realizados procedimentos típicos da estatística descritiva através de distribuição de frequências e cruzamento com as variáveis: sexo (homens e mulheres) e faixa etária (de 15 a 19 anos; 20 a 24 anos; 25 a 29 anos).

Além disto, foi realizada analise de homogeneidade por meio de um método algébrico do tipo Alternating Leaste Squares conhecido por HOMALS, que pode ser realizado com auxílio do SPSS 11.5. Este procedimento permitiu identificar as variáveis com maior poder de diferenciar os entrevistados segundo suas categorias de resposta e identificar as relações entre estas através de uma representação gráfica.

\footnotetext{
${ }^{9}$ Usado aqui no sentido que lhe é dada por Mannheim (1982), ou seja, como uma situação comum perante as dimensões históricas do processo social.
} 


\section{PERFIL DOS JOVENS DA AMOSTRA}

A composição da amostra de jovens teve como referência os percentuais de participação juvenil na agricultura familiar. Deste modo, a distribuição etária da população entrevistada é composta em 36,7\% de 15 a 19 anos, em 33,5\% de 25 a 29 anos e por 29,8\% com idades entre 20 e 24 anos. Entre os homens, esta divisão se estabelece em 38,2\% entre 15 e 19 anos, $29,7 \%$ na faixa etária de 20 a 24 anos e 32,1\% entre os de 25 a 29 anos de idade. Para as mulheres, temos a distribuição em 34,3\% de adolescentes, 29,9\% na faixa de 20 a 24 anos e 35,8\% de 25 aos 29 anos (Gráfico 1).

Conforme as respostas dos entrevistados, eles residem, predominantemente, no meio rural $(98,1 \%)$. Este percentual está acima do registrado pelo Censo Demográfico 2000 do IBGE, segundo o qual $11,7 \%$ da população ocupada na agricultura familiar no RS vive em áreas urbanas. Isto pode ser explicado, em parte, pelo fato de a condição de domicílio não ter sido considerada para o controle de cotas. Além disto, muitos ambientes classificados como urbanos pelas instituições não o são na perspectiva de suas populações. ${ }^{10}$

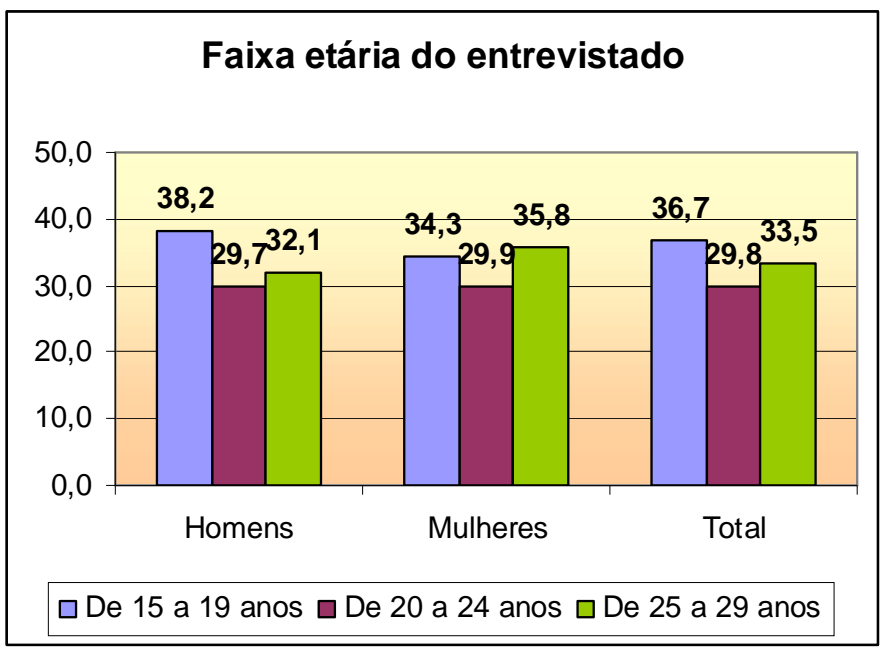

Gráfico 1: Distribuição etária dos entrevistados (\%)

Fonte: Banco de dados Jovens Agricultores Familiares RS - MDA/FAURGS, 2007.

${ }^{10}$ A este respeito José Eli da Veiga (2004, p. 77) aponta que "de um total de 5.507 sedes de municípios existentes em 2000, havia 1.176 com menos de 2 mil habitantes, 3.887 com menos de 10 mil e 4.642 com menos de 20 mil, todas com estatuto legal de cidade idêntico ao que é atribuído aos inconfundíveis núcleos que formam as regiões metropolitanas ou que constituem evidentes centros urbanos regionais" 
Analisado a composição da amostra por estado civil, constata-se que 70,9\% dos jovens entrevistados são solteiros; $28,6 \%$ são casados. Mesmo que a maior parte dos entrevistados seja composta de solteiros, o índice é bem diverso entre homens $(82,2 \%)$ e mulheres (52\%). Percebe-se que, praticamente, a metade das mulheres entrevistadas é casada (Tabela 2).

Tabela 2: Estado civil dos jovens por sexo $(\operatorname{em} f$ e \%)

\begin{tabular}{|c|c|c|c|c|c|c|c|}
\hline & & & \multicolumn{4}{|c|}{ QUAL SEU ESTADO CIVIL? } & \multirow[b]{2}{*}{ Total } \\
\hline & & & Solteiro & Casado & Divorciado & Viúvo & \\
\hline \multirow[t]{4}{*}{ SEXO } & Homens & $f$ & 351 & 75 & 1 & & 427 \\
\hline & & $\%$ & $82,2 \%$ & $17,6 \%$ & , 2\% & & $100,0 \%$ \\
\hline & Mulheres & $f$ & 132 & 120 & 1 & 1 & 254 \\
\hline & & $\%$ & $52,0 \%$ & $47,2 \%$ & , 4\% & ,4\% & $100,0 \%$ \\
\hline \multirow[t]{2}{*}{ Total } & & $f$ & 483 & 195 & 2 & 1 & 681 \\
\hline & & $\%$ & $70,9 \%$ & $28,6 \%$ & ,3\% &, $1 \%$ & $100,0 \%$ \\
\hline
\end{tabular}

Fonte: Banco de dados Jovens Agricultores Familiares RS - MDA/FAURGS, 2007.

O estado civil dos entrevistados, considerado por faixa etária e sexo, permite-nos afirmar que predomina a condição de solteiro entre os homens de todas as idades. Para as mulheres, isso ocorre apenas entre as jovens adolescentes, onde imperam as solteiras. Entre as jovens de 20 a 24 anos de idade, 53,9\% são casadas, enquanto 82,7\% dos homens desta faixa etária são solteiros. Entre os jovens adultos, as mulheres casadas chegam a 75,8\%, enquanto que apenas $35 \%$ dos homens já contraíram matrimônio (Gráfico 2). É possível afirmar, com base nestes dados que, a partir dos 20 anos de idade as mulheres que se ocupam da agricultura familiar tendem a estar casadas, enquanto que a maioria dos homens permanece solteira. 


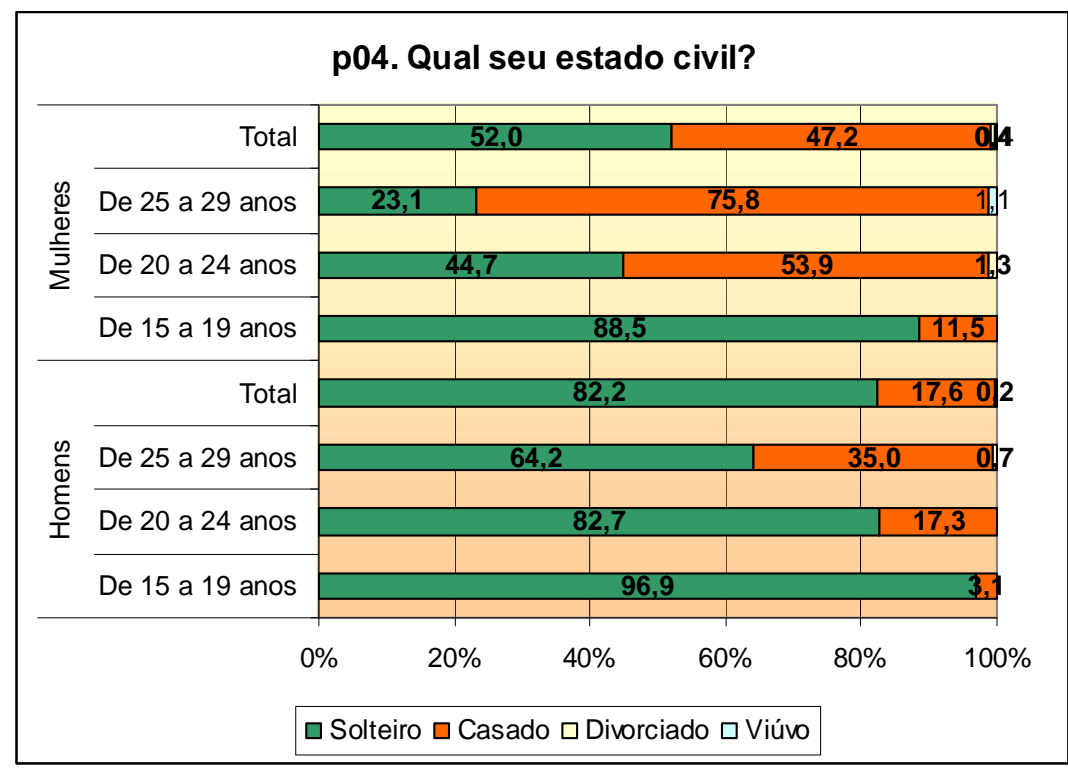

Gráfico 2: Estado civil dos jovens por sexo e faixa etária (\%)

Fonte: Banco de dados Jovens Agricultores Familiares RS - MDA/FAURGS, 2007.

O predomínio de homens solteiros em proporções tão elevadas revela um obstáculo à reprodução social dos agricultores familiares: a tendência de ampliação do celibato masculino. Isto ocorre, entre outras razões, por haver menos mulheres do que homens na agricultura e no meio rural como um todo. Além disto, elas tendem a se casar mais cedo do que os homens. O maior percentual de mulheres casadas se reflete em um maior percentual de entrevistadas que já se tornaram mães. Como podemos observar na Tabela 3, a maioria dos jovens não possui filhos. Comparando-se homem e mulheres verifica-se que o percentual de mulheres com filhos é de $35 \%$, enquanto que entre os homens este índice fica em 13,3\%. Entre todas as faixas etárias, encontramos entrevistados com filhos, sendo que isto é mais frequente entre as mulheres de 25 aos 29 anos, entre as quais 65,9\% das jovens são mães (Gráfico 3). 
Tabela 3: Jovens com filhos por sexo (em $f$ e \%)

\begin{tabular}{lllrrr}
\hline \hline & & \multicolumn{3}{c}{ VOCÊ TEM FILHOS? } & \\
\cline { 3 - 5 } & & \multicolumn{2}{c}{ Sim } & \multicolumn{1}{c}{ Não } & Total \\
\hline SEXO & Homens & $f$ & 57 & 370 & 427 \\
& & $\%$ & $13,3 \%$ & $86,7 \%$ & $100,0 \%$ \\
\cline { 2 - 5 } & Mulheres & $f$ & 89 & 165 & 254 \\
& & $\%$ & $35,0 \%$ & $65,0 \%$ & $100,0 \%$ \\
\hline Total & $\mathrm{f}$ & 146 & 535 & 681 \\
& $\%$ & $21,4 \%$ & $78,6 \%$ & $100,0 \%$ \\
\hline \hline
\end{tabular}

Fonte: Banco de dados Jovens Agricultores Familiares RS - MDA/FAURGS, 2007.

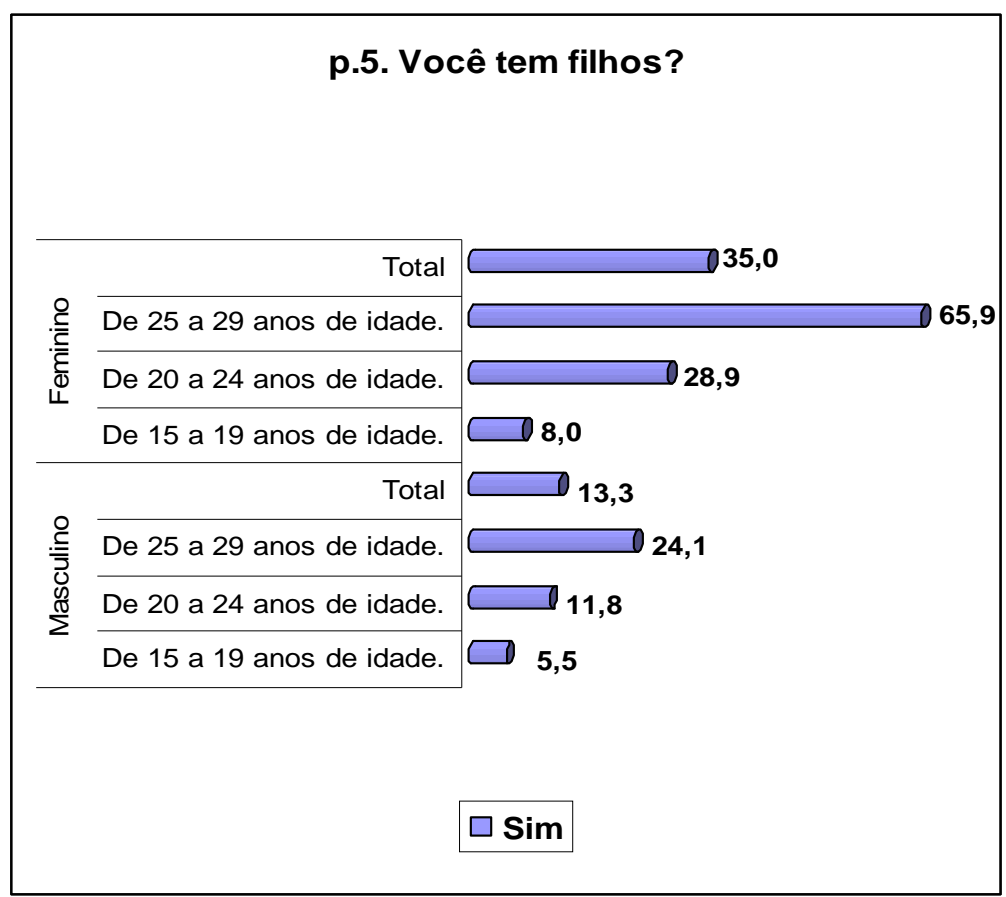

Gráfico 3: Jovens com filhos por sexo e faixa etária (\%)

Fonte: Banco de dados Jovens Agricultores Familiares RS - MDA/FAURGS, 2007.

Os jovens agricultores familiares fazem parte de famílias nucleares formadas em média por quaro pessoas. Como se observa no Gráfico 4, aqueles que têm famílias formadas por esta quantidade de membros representam 29,5\% da amostra, outros 22,6\% estão em famílias com três pessoas e 19,5\% em famílias formadas por cinco integrantes. 


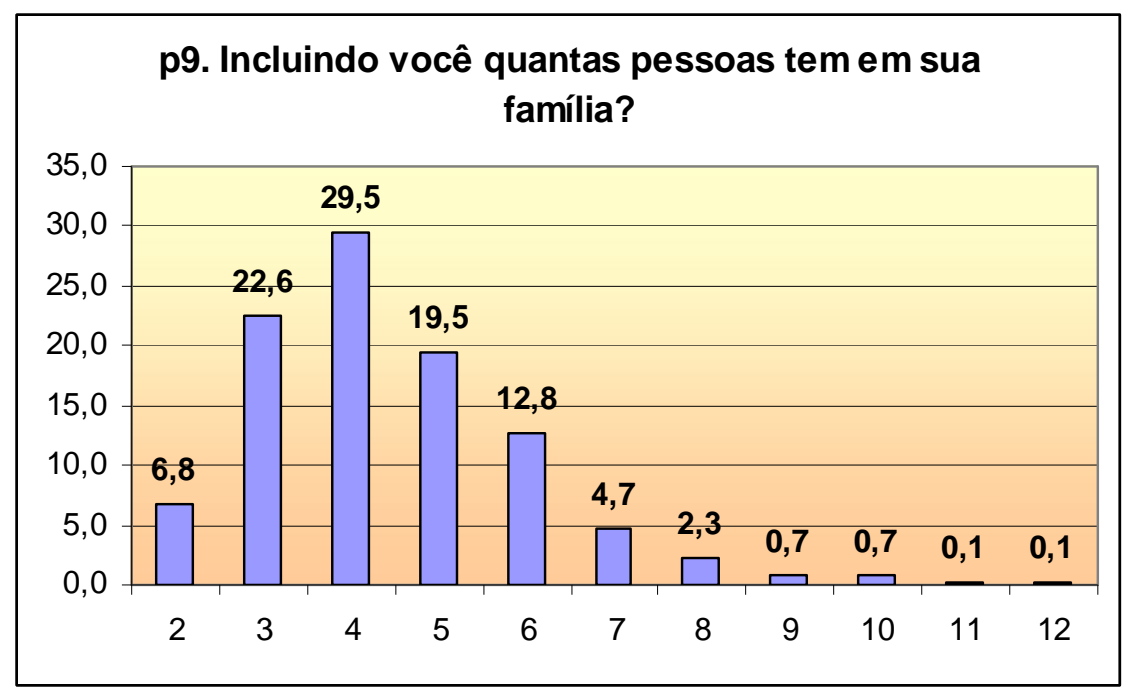

Gráfico 4: Número de integrantes por família (\%)

Fonte: Banco de dados Jovens Agricultores Familiares RS - MDA/FAURGS, 2007.

A Tabela 4 apresenta a autodefinição étnica dos jovens agricultores familiares. Destacam-se, entre as categorias singulares de resposta fornecidas pelos entrevistados, a italiana $(39,1 \%)$ e a alemã (36\%). A seguir, aparecem as classificações: brasileira (6\%), africana $(2,8 \%)$, polonesa $(2,5 \%)$ e mestiça $(1,2 \%)$. Entre as categorias combinadas predominam: a alemã e italiana $(2,5 \%)$ e italiana e alemã $(1,2 \%)$.

As identidades étnicas acionadas por eles têm raízes no processo de colonização do estado e que estão na matriz do desenvolvimento da agricultura familiar no Rio Grande do Sul. Na atualidade, os jovens agricultores familiares se autodefinem como italianos, alemães e poloneses como forma de afirmar a sua descendência em relação a estes imigrantes. Os negros entrevistados elaboram as suas identidades étnicas nos termos de uma procedência continental quando se declaram africanos. Isso ocorre, em grande parte, em decorrência da ampliação de pleitos coletivos por reconhecimento territorial e cultural junto ao estado brasileiro, mas também, por compartilharem um idioma de descendência com os grupos com os quais interagem.

As classificações brasileira e mestiça se referem aos jovens que não se reconhecem nas identidades "de origem" europeia como a reinvidicada por descendentes dos antigos “colonos alemães" ou "italianos". Em localidades constituídas a partir da colonização por imigrantes, os brasileiros são todos aqueles que descendem dos habitantes mais antigos dessas regiões, ou seja, de índios, negros e em alguns casos de portugueses. Trata-se de uma definição imputada nas relações interétnicas que acabou sendo acolhida pelos que assim eram 
referidos. A autodefinição como mestiço resulta das alianças matrimoniais entre os diferentes tipos de brasileiros.

Tabela 4: Distribuição de frequências da autodefinição étnica dos entrevistados

\begin{tabular}{|c|c|c|c|c|c|}
\hline & & Frequency & Percent & Valid Percent & $\begin{array}{c}\text { Cumulative } \\
\text { Percent }\end{array}$ \\
\hline \multirow[t]{30}{*}{ Valid } & Africana & 19 & 2,8 & 2,8 & 2,8 \\
\hline & Alemã & 245 & 36,0 & 36,0 & 38,8 \\
\hline & Branca & 6 & ,9 & ,9 & 39,6 \\
\hline & Brasileira & 41 & 6,0 & 6,0 & 45,7 \\
\hline & Espanhola & 2 & , 3 & 3 & 46,0 \\
\hline & Indígena & 4 & ,6 & ,6 & 46,5 \\
\hline & Italiana & 266 & 39,1 & 39,1 & 85,6 \\
\hline & Mestiça & 8 & 1,2 & 1,2 & 86,8 \\
\hline & Polonesa & 17 & 2,5 & 2,5 & 89,3 \\
\hline & Portuguesa & 4 & ,6 & ,6 & 89,9 \\
\hline & Africana e Alemã & 2 & ,3 & ,3 & 90,2 \\
\hline & Africana e Italiana & 1 & ,1 & ,1 & 90,3 \\
\hline & Alemã e Africana & 1 & ,1 & , 1 & 90,5 \\
\hline & Alemã e Brasileira & 7 & 1,0 & 1,0 & 91,5 \\
\hline & Alemã e Indigena & 4 & ,6 & ,6 & 92,1 \\
\hline & Alemã e Italiana & 17 & 2,5 & 2,5 & 94,6 \\
\hline & Alemã e Polonesa & 3 &, 4 & ,4 & 95,0 \\
\hline & Branca e Italiana & 2 & ,3 & ,3 & 95,3 \\
\hline & Brasileira e Italiana & 1 & , 1 & , 1 & 95,4 \\
\hline & Espanhola e Indigena & 1 & ,1 & , 1 & 95,6 \\
\hline & Indígena e Alemã & 1 & ,1 & ,1 & 95,7 \\
\hline & Italiana e Alemã & 8 & 1,2 & 1,2 & 96,9 \\
\hline & Italiana e Brasieira & 3 & ,4 & ,4 & 97,4 \\
\hline & Italiana e Indígena & 1 & , 1 & , 1 & 97,5 \\
\hline & Italiana e Polonesa & 5 & ,7 & ,7 & 98,2 \\
\hline & Polonesa e Alemã & 4 & ,6 & ,6 & 98,8 \\
\hline & Polonesa e Italiana & 1 & , 1 & , 1 & 99,0 \\
\hline & NS/NR & 6 & ,9 & ,9 & 99,9 \\
\hline & Italiana e Portuguesa & 1 & , 1 & , 1 & 100,0 \\
\hline & Total & 681 & 100,0 & 100,0 & \\
\hline
\end{tabular}

Fonte: Banco de dados Jovens Agricultores Familiares RS - MDA/FAURGS, 2007.

As demais interações étnicas são definidas através de 17 categorias combinadas que foram preservadas da maneira como foram descritas pelos jovens para salientar a importância da ordem apresentada na forma como eles se classificam. Nesse sentido, ser alemão e italiano 
não é a mesma coisa que ser italiano e alemão. A antecedência de uma categoria em detrimento da outra expressa a forma como uma linhagem engloba a outra no contexto de aliança matrimonial e outras interações sociais. De forma geral, o que esta gama de autodefinições permite aferir é a diversidade étnica dos jovens agricultores familiares no Rio Grande do Sul.

\section{APRESENTAÇÃO DOS RESULTADOS}

A organização deste trabalho acompanha a estruturação do modelo analítico descritivo proposto para o estudo da situação juvenil na agricultura familiar e se constitui, ao todo, em seis capítulos.

O primeiro deles ocupa-se do debate teórico sobre a juventude visando dotar esta categoria de maior precisão conceitual e analítica. Busca também caracterizar o processo juvenil, problematizando a trajetória deste construto no âmbito da Sociologia da Juventude e revisando suas principais abordagens. Ao final, indica-se algumas categorias teóricooperacionais para sua interpretação.

O segundo capítulo objetiva apresentar a participação juvenil na agricultura familiar no estado do Rio Grande do Sul. Para isto, é apresentado o marco teórico do debate sobre agricultura familiar, defini-se conceitualmente o processo de trabalho familiar agrícola e a categoria dos jovens agricultores familiares. Discute-se ainda a participação juvenil no desenvolvimento da agricultura familiar e os efeitos da modernização agrícola sobre este segmento. Ao final, descreve-se a participação dos jovens na ocupação na agricultura familiar no estado.

O capítulo terceiro aborda as condições materiais dos jovens na agricultura familiar, apontando as características econômicas da unidade de produção familiar, o acesso dos jovens à renda agrícola e as condições de autonomia material desta juventude. O quarto capítulo é dedicado à analise dos processos de socialização dos jovens agricultores familiares, onde se destaca sua participação no processo de trabalho familiar agrícola, sua inserção no sistema formal de ensino e as práticas de lazer destes jovens.

No quinto capítulo, são analisadas as representações sociais dos jovens sobre o trabalho agrícola, as suas avaliações sobre o modo de vida dos pais e suas disposições em 
reproduzi-lo. Discute-se também o processo de identificação social e profissional destes jovens.

Finalmente, no capítulo sexto são analisados os projetos juvenis. Para tanto, é reconstruído o percurso teórico do conceito de projeto e estabelecida a especificidade dos projetos juvenis, abordando-se os projetos de escolarização, de profissão e de vida elaborados por jovens agricultores familiares. Este capítulo fecha o estudo buscando identificar nas condições materiais, na socialização e nas representações juvenis as situações que tornam mais favoráveis a elaboração de projetos profissionais agrícolas. 


\section{JUVENTUDE COMO CATEGORIA SOCIOLÓGICA}

Um dos principais desafios colocados a quem estuda processos sociais protagonizados por jovens é dotar sua categoria central - a juventude - de maior precisão conceitual e analítica. Este trabalho pretende atribuir-lhe valor heurístico adequado ao estudo das dinâmicas da produção, reprodução e transformação da agricultura familiar. Para tanto, neste capítulo discute-se a sua emergência histórica, assim como, são descritas as características do processo juvenil como um conjunto de mudanças em diferentes âmbitos da existência humana. Recorre-se, principalmente, às contribuições da Sociologia da Juventude, destacando sua trajetória e os diferentes enfoques analíticos que conformam o debate contemporâneo, os quais contribuem para o entendimento desta como uma categoria multidimensional. Esta revisão torna possível estabelecer distinções entre os termos que frequentam o debate: juventude, jovens, condição juvenil e situação juvenil e apontar o processo de socialização como critério capaz de demarcar os traços distintivos entre as juventudes respondendo ao desafio proposto inicialmente.

\subsection{JUVENTUDE E MODERNIDADE}

A juventude é uma categoria social que passa a se constituir e adquire o sentido atual a partir do advento da modernidade. Deste modo, cabe salientar que as percepções correntes sobre ela são, necessariamente, sociais, culturais e historicamente determinadas. Isto implica reconhecer que, mesmo que já existissem jovens nos períodos históricos anteriores, seus significados, características e papeis sociais eram bastante diversos do que se atribuem recentemente.

A modernidade corresponde ao período histórico inaugurado pelo desenvolvimento do capitalismo e a ascensão política da burguesia, que rompeu, definitivamente, com os laços do tradicionalismo. Entre as principais características da modernidade, destacam-se as contínuas, rápidas e intensas transformações sociais, culturais e econômicas; a ampliação da diferenciação social; da especialização e da relativa autonomia das instituições; assim como a crescente racionalização, burocratização e secularização da vida. Estas características encontram-se relacionadas com o surgimento da juventude. Nota-se que não é sem 
justificativas que os jovens são frequentemente adjetivados como modernos, como diferentes ou inovadores.

Partindo de uma abordagem histórica, o francês Philippe Ariès (1981) relacionou a emergência da categoria juventude com o desenvolvimento do capitalismo e as novas relações sociais daí resultantes. Em sua obra, demonstrou que as noções de infância e juventude foram longamente construídas social e historicamente. Para este autor, a juventude é uma noção que emerge na modernidade com base em dois processos fundamentais, distintos, simultâneos e inter-relacionados. Vejamos cada um deles.

Conforme Ariès (1981), o primeiro corresponde às mudanças ocorridas nas formas da organização familiar a partir do século XII. Neste período, processa-se uma diferenciação entre as esferas pública e privada que se institucionalizariam com a tomada do poder político pela burguesia. Remonta a esta época uma mudança de orientação no âmbito do grupo doméstico. A família passa a voltar-se cada vez mais para si mesma, passando a organizar-se em torno da criança e erguendo entre ela mesma e a sociedade o muro da sociedade privada. Isto se reflete, também, na composição do grupo doméstico que vai deixando de ser caracterizado por laços amplos e voltando-se ao convívio mais estreito e intimo. Passa a ser processada uma importante transformação na forma de organização do grupo parental da família extensa à família nuclear - esta última formada pelo casal e seus fillhos. "A família tornou-se um lugar de uma afeição necessária entre cônjuges e entre pais e filhos, algo que não era antes” (ARIÈS, 1989, p. 11). A juventude assume então, no interior de uma família nuclear, um novo e diferenciado papel social, uma vez que passa a ser responsabilidade dos pais a preparação das condições de existência e sobrevivência futura dos filhos.

O segundo processo, não menos importante, apontado por Ariès (1989), consiste no surgimento da juventude como um fenômeno social moderno basicamente entre os setores da burguesia e da aristocracia. Estas classes sociais podiam manter seus filhos longe da vida produtiva e social enviando-os para escolas e liceus para prepará-los para funções futuras. Foi justamente esta segregação das novas gerações nas instituições educacionais que substituiu a aprendizagem privada da família por um sistema de educação via escolarização que acaba por conferir visibilidade ao fenômeno juvenil. Posteriormente, com a institucionalização e universalização do processo educacional, como etapa preparatória para a inserção das novas gerações no mundo do trabalho, tornou-se cada vez mais visível a especificidade da etapa intermediaria entre a infância e a fase adulta, configurada pela adolescência e a juventude (ARIÈS, 1981). Este é um processo típico da modernização que cria instituições de novo tipo, 
a instituição burocrática, como expressão dos processos de racionalização das práticas sociais. Tal como a industrialização do processo de trabalho tem em vista os objetivos da atividade econômica capitalista, a escolarização como forma de educação das novas gerações orienta-se pelo mesmo princípio. Por meio da institucionalização burocrática do ensino, é possibilitada a reprodução das hierarquias socais formando os gestores da indústria capitalista e do Estado burguês.

Em síntese, pode-se dizer que o aparecimento da noção de juventude - como a conhecemos hoje - resulta de processos iniciados pela modernidade e que implicaram uma crescente racionalização e individualização das práticas sociais, promovendo a distinção entre a esfera privada (família) da pública (escola). A modernidade ocidental que corresponde ao período de ascensão do modo de produção capitalista resultou numa crescente institucionalização das fases da vida humana promovida sob a perspectiva dos interesses da classe burguesa e de sua direção sobre o Estado, a escolarização e a industrialização capitalista. Deste modo, a juventude, que se diferencia dos demais grupos etários, inicialmente no âmbito das elites entre os séculos XVII e XVIII, expandiu-se como fenômeno social via nuclearização das famílias e universalização do ensino para todas as classes sociais.

\subsection{FRONTEIRAS E CARACTERÍSTICAS DO PROCESSO JUVENIL}

A juventude representa uma fase da vida situada entre a infância e vida adulta. Seu marco inicial coincide com a conclusão do desenvolvimento cognitivo da criança. Conforme a psicologia genética de Jean Piaget (1977), isto corresponde à capacidade de realizar operações formais cujo processo de estruturação se conclui por volta dos 15 anos de idade e confere ao indivíduo uma nova capacidade, a execução de operações mentais próprias do pensamento abstrato e hipotético-dedutivo. ${ }^{11}$

Como apresentamos em um trabalho anterior (WEISHEIMER, 2004), do ponto de vista das práticas sociais o início da juventude é representado pelo surgimento da puberdade.

\footnotetext{
${ }^{11}$ Segundo o modelo do equilíbrio proposto por Piaget (1977), o desenvolvimento cognitivo humano é marcado por um processo contínuo de equilibração (passagem da gênese à estrutura) que dá origem a estados de equilíbrios sucessivos e essencialmente descontínuos, ou seja, de sistemas de ações organizadas que marcam os diferentes estágios do desenvolvimento cognitivo: sensório-motor; pré-operatório; operatório concreto; operatório formal que marcam as etapas cada vez superiores de adaptação via interação entre sujeito e mundo exterior.
} 
Esta é marcada pelo desenvolvimento de um novo porte físico e por novas exigências de disciplinamento dos corpos. Estas mudanças biológicas são acompanhadas pela incorporação de novos papeis sociais que acentuam, entre outras coisas, as distinções entre os sexos. De modo geral, podemos dizer que a entrada na fase juvenil da vida é marcada por múltiplos critérios que expressam as transformações vividas pelos indivíduos no plano biológico, psicológico, cognitivo, cultural e social (WEISHEIMER, 2004).

Por sua vez, o término da juventude é definido por critérios eminentemente sociológicos. O fim da juventude aparece relacionado à progressiva autonomia nos planos cívico (maioridade civil) e ligado à conjugação de responsabilidades produtivas (um status profissional estável); conjugais (um parceiro sexual estável assumido como cônjuge); domésticas (sustento de um domicílio autônomo); e paternal (designação de uma prole dependente) (SANCHIS, 1995; DURSTON, 1997; GALAND, 1997). Desta forma, as fronteiras que demarcam o início e o término do período do ciclo de vida caracterizado como "juventude" envolve um conjunto de fenômenos objetivos e subjetivos, sociais e individuais que tendem a variar de sociedade para sociedade.

Podemos compreender o processo juvenil enquanto um conjunto de mudanças em diferentes âmbitos da existência humana. Estas diferentes alterações foram descritas pelo antropólogo chileno John Durston (1997) e sistematizadas no Quadro 4.

Quadro 4: Características do Processo Juvenil.

\begin{tabular}{|c|l|}
\hline Âmbito & \multicolumn{1}{c|}{ Processo } \\
\hline $\begin{array}{c}\text { Biológico - } \\
\text { Fisiológico }\end{array}$ & $\begin{array}{l}\text { Inicia-se e desenvolvem-se mudanças fisiológicas da puberdade e se } \\
\text { adquire capacidade reprodutiva. }\end{array}$ \\
\hline Psicossexual & $\begin{array}{l}\text { Há o desenvolvimento da aprendizagem do cortejo e do descobrimento } \\
\text { sexual. }\end{array}$ \\
\hline Cognitivo & O processo de aprendizagem formal e informal chega a seu auge. \\
\hline Interpessoal & $\begin{array}{l}\text { As pessoas definem sua identidade juvenil diante de seus pares de } \\
\text { idade. Alcançam certo grau de autonomia em relação às figuras } \\
\text { paternas, tão importantes na infância. }\end{array}$ \\
\hline Social & $\begin{array}{l}\text { Aumenta progressivamente a presença do trabalho produtivo em sua } \\
\text { vida cotidiana. A pessoa desenvolve gradualmente sua subjetividade } \\
\text { social como um novo adulto, assumindo uma maior responsabilidade } \\
\text { econômica e autoridade de voz na sociedade. }\end{array}$ \\
\hline
\end{tabular}

Fonte: WEISHEIMER, 2004, adaptado de DURSTON, 1997.

No âmbito biológico-fisiológico, são produzidos processos descritos como puberdade que marca o início da capacidade reprodutiva. Dá-se o nome de puberdade às modificações biológicas e à maturação sexual. Conforme os estudos no campo da endocrinologia pediátrica, 
este processo ocorre entre as meninas cerca de dois anos antes do que entre os meninos (SETIAN, 2002).

No âmbito psicossexual, surgem as primeiras descobertas dos jogos sexuais, as práticas do cortejo, a atração e o desejo sexual. Este processo não é vivido sem angústia e inquietação por jovens adolescentes, gerando sentimentos ambíguos e comportamentos pendulares manifestados hora pelo desejo de voltar à pureza das relações infantis, hora pelo desejo da experimentação sexual diante da dúvida se este é o momento adequado, ou ainda, se está com o parceiro(a) certo(a) para viver esta experiência.

No âmbito do desenvolvimento cognitivo, como mencionamos anteriormente, o processo de aprendizagem formal e informal chega a seu auge. Isto se deve ao amadurecimento do córtex pré-frontal e de outras regiões corticais. Possibilita tanto a evolução da memória quanto o aprofundamento do raciocínio abstrato, a maior capacidade de atenção e gerenciamento das emoções (IZQUIERDO, 2002).

No âmbito interpessoal, os sujeitos passam a construir suas identidades na interação com seus pares de idade, produzindo e incorporando uma identidade tipicamente juvenil. Esta construção social das identidades (DUBAR, 2005) sintetiza atos de pertencimento a novas esferas de ação social ao mesmo tempo em que expressa certo grau de autonomia em relação às figuras paternas, tão importantes na infância.

No âmbito social, o processo juvenil vai ser caracterizado por uma progressiva inserção nas esferas produtivas que passam a compor parte significativa do tempo cotidiano dos jovens. Simultaneamente, eles buscam construir, via ingresso no mercado de trabalho, as condições necessárias para a conquista de autonomia em relação aos pais, principalmente no quesito financeiro, mesmo que de modo parcial. Esta inserção no mercado de trabalho parece ser a chave para o reconhecimento social de que o jovem está incorporando uma nova subjetividade, tida como típica dos adultos, que é frequentemente atribuída à maior responsabilidade econômica e completada com maior direito de opinião e voz na família e na sociedade.

Novamente chamamos a atenção para a complexidade do processo juvenil no qual as maturidades físicas, sexuais, intelectuais, civis e profissionais não necessariamente coincidem. Destaca-se que, nesta fase, as potencialidades humanas encontram-se plenamente desenvolvidas. O indivíduo, como um ser social, passa a ser mais reflexivo do que em etapas anteriores, sua concepção de mundo e sua própria identidade vão se consolidando, e suas projeções em direção ao futuro tornam-se mais realistas. Neste processo, a afirmação social de 
sua individualidade é vivenciada na busca de autonomia por meio da progressiva inserção no trabalho, passando a incorporar novas responsabilidades no âmbito jurídico, familiar e social.

\subsection{CONTRIBUIÇÕES DA SOCIOLOGIA DA JUVENTUDE}

Qualquer disciplina científica tem sua especificidade definida por seu objeto de estudo. No caso da Sociologia da Juventude, podemos dizer que este objeto é constituindo por diversos processos sociais protagonizados por sujeitos jovens. Em outras palavras, por Sociologia da Juventude entende-se uma área especializada da Sociologia que se dedica ao estudo da juventude como um fenômeno social cultural e histórico.

Este tema de pesquisa surge com os primeiros estudos empíricos precursores da Sociologia; desde então, uma pauta recorrente do interesse sociológico. Entretanto, nunca se constituiu em assunto central que contasse com grande número de pesquisadores e nem logrou forjar conceitos consensualmente compartilhados entre os que se dedicaram a este campo disciplinar. Estes dois aspectos dificultam a institucionalização desta disciplina em larga escala. Esta situação vem se alterado nas últimas décadas, podendo-se dizer que a Sociologia da Juventude como disciplina acadêmica e linha de pesquisa está experimentando um novo impulso no início deste século XXI.

Não obstante, as dificuldades de uma Sociologia "diferencial", que toma como objeto a juventude, suas relações sociais, seus processos de estruturação e suas ações sociais, não foram superadas e, em grande parte, derivam justamente da dificuldade de conceituação deste objeto. Pode-se dizer, sem medo de errar, que no percurso teórico que marca o desenvolvimento deste campo disciplinar, a categoria sociológica que se denomina indistintamente de "juventude" vem recebendo diferentes tratamentos analíticos que refletem as transformações ocorridas no próprio debate sociológico. Além disto, é possível notar que, nesta trajetória teórica, processou-se uma ressemantização da categoria, acompanhando a temporalidade dos conflitos sociais e teóricos mais amplos que acabaram deslocando as identidades mais abrangentes para identidades específicas e diferenciadas que se impõem numa luta pelo reconhecimento. ${ }^{12}$ Como resultado deste debate discensual, a constituição de

\footnotetext{
${ }^{12}$ Pertilhe (2000) afirma que a luta pelo reconhecimento implica conceber as relações sociais de dominação a partir de uma dinâmica de grupos que buscam a afirmação de sua identidade e autonomia, ou seja, seu reconhecimento.
} 
uma Sociologia da Juventude tem sido bem mais lenta do que se poderia esperar (BRITTO, 1968). Quaisquer que sejam as orientações teóricas e os conceitos daí oriundos, torna-se necessário revisar os fundamentos históricos de sua proposição.

\subsubsection{Os jovens nas primeiras pesquisas sociais}

Como já referido, a juventude surge como tema de pesquisa social no alvorecer da Sociologia. Antes mesmo desta se constituir como ciência autônoma e institucionalizada no sistema de ensino universitário, a juventude é objeto de investigação nos estudos de levantamento social que marcam a pré-história das Ciências Sociais no século XVIII. Estes estudos precursores da Sociologia da Juventude são, em grande medida, impulsionados pelas transformações sociais provocadas pela emergência do capitalismo como modo de produção dominante. Esta traz como efeitos o abandono, o aumento da criminalidade juvenil e toda uma série de violências contra jovens como, por exemplo, a doméstica e o abuso sexual praticado por pessoas em situações de vantagem em relação a suas vítimas. Estes temas passaram a ser objeto de investigação racionalista e objetivista típicos do cientificismo da época.

Neste período, surgem diversos escritos de Filosofia especulativa que buscavam atribuir sentidos metafísicos à condição juvenil. São populares ainda os manuais de etiqueta que versavam sobre o modelo de bom comportamento de infantes, direcionados a rapazes e moças. Remonta também a esta época os estudos de Biologia que faziam comparações da morfologia dos corpos de diferentes idades e de ambos os sexos. Estes estudos naturalistas eram complementados por outros de Psicologia que buscavam interpretar os impulsos sexuais ou as práticas delinquentes dos jovens, também em perspectiva comparada por sexos e, em alguns casos, consideravam em suas análises as situações sociais, geralmente referentes às características da origem familiar e da situação domiciliar.

São desta fase os primeiros tratados de natureza pedagógica, cuja obra, intitula Émile ou da Educação de Jean-Jacques Rousseau (1712-1778) é tido como um exemplo paradigmático. Neste romance, que versa sobre a trajetória de um jovem que dá o nome ao livro, Rousseau desenvolve um tratado de educação laica, isto é, desvinculada de valores religiosos, apresentando o que considerava serem os fundamentos de uma Pedagogia para o exercício da cidadania. Neste texto, o período de maturação que vai da infância à idade adulta 
não é tratado como fase isolada, mas considerado através de minuciosa descrição ao longo de toda escrita. Conforme o sociólogo alemão Andréas Flitner:

\begin{abstract}
A partir de Rousseau, não só se torna necessário compreender a revalorização do período infanto-juvenil na literatura romântica, no romance referente ao desenvolvimento e nas numerosas estórias educativas, mas também a abundancia de literatura científica descritiva e observadora, característica do último terço do século XVIII (FLITNER, 1968, p. 39).
\end{abstract}

Em um texto de referência intitulado "Os problemas sociológicos nas primeiras pesquisas sobre juventude", Andréas Flitner (1968), tendo como fonte a pesquisa social alemã, demonstra como a categoria juventude foi se constituindo em um tema de interesse sociológico. Nesse trabalho, ele aborda o surgimento da temática ligada às idades infantil e juvenil nos estudos científicos e relaciona as transformações sociais e os problemas daí decorrentes que, segundo ele, acabam contribuindo para delimitar a categoria juventude. Deste modo, Flitner (1968) buscou demonstrar como os primeiros sociólogos vão paulatinamente - fazendo da juventude um campo autônomo de pesquisa social. Conforme ele argumenta, os estudos pioneiros tinham como objeto de suas investigações as formas de vida dos jovens segundo os meios em que viviam.

Contudo, neste momento de gênese da Sociologia da Juventude, quando os precursores buscavam apontar os traços distintivos do processo de maturação social, predomina a imprecisão nas categorias utilizadas. Ainda segundo Flitner: "Não é possível ignorar a falta de precisão com que são aplicados os conceitos 'juventude', 'rapazes e moças', 'os jovens' que são utilizados como contraste para ‘criança'” (FLITNER, 1968, p. 40).

Entre os precursores das pesquisas sobre juventude encontra-se o educador e pedagogo suíço Johann Heinrich Pestalozzi (1746-1827). Este, influenciado pela leitura de Émile, de Rousseau, desenvolveu uma intensa agenda de pesquisa social empírica e de debate teórico sobre a educação. Conforme indica Flitner (1968), a particularidade dos escritos de Pestalozzi reside no entrelaçamento entre argumentação social e exame empírico do caso. Deste modo, este autor produz uma análise pioneira que parte da situação social de grupos subalternos que, segundo a tese de Pestalozzi, não lhes permite o reconhecimento dos direitos mais simples e naturais e sobre os quais se faz necessário uma ação educativa. Pestalozzi desenvolveu ainda algumas experiências sociológicas no estudo das condições juvenis camponesa, de jornaleiros e artesões têxteis do campo. Ele analisa a adoção de novos métodos 
de trabalho e estilos econômicos com base em moeda corrente e novos bens de consumo e seus efeitos sobre o mundo rural.

Para Flitner (1968), justamente no que refere à educação e à estabilização social, Pestalozzi superou os que se ocupavam do problema juvenil de seu tempo por considerar, de forma rigorosa, a nova situação social provocada pela industrialização. Ou seja, Pestalozzi apontou de forma pioneira as vinculações entre formas econômicas, hierarquia social, moral, trabalho e novas exigências sociais geradas pela industrialização por meio de uma minuciosa descrição e análise dos impactos destas transformações sobre os comportamentos dos jovens.

Aproximadamente um século após Pestalozzi, o psicólogo norte-americano Granville Stanley Hall (1844-1924) se destacaria como o primeiro estudioso a receber o título de PhD em Psicologia na América, sendo iniciador do movimento de estudos da criança e da adolescência e fundador da American Psychological Associatton (Associação Americana de Psicologia) (GRINDER; STRICKLAND, 1968). Este autor foi influenciado pela psicanálise de Sigmund Freud, pelo evolucionismo de Charles Darwin e pelos filósofos idealistas alemães Johann Fichte e Friedrich Nietzsche, construindo uma teoria sobre os aspectos essenciais da condição adolescente em sua grande obra intitulada Adolescente publicada em 1904. De um lado, Stanley Hall defendia a tese de que as dificuldades psíquicas perceptíveis apresentadas neste período pertencem-lhe naturalmente, estando em ligação causal com o processo de amadurecimento biológico. De outro, ele seguiu estratégias metodológicas baseadas em levantamento de dados quantitativos por meio de aplicação de questionários e materiais estatísticos. Com base em tais procedimentos, este autor analisou as condições sociais da vida dos jovens e os problemas de seu enquadramento no mundo adulto (FLITNER, 1968). Para ele, a juventude se constituía no elemento-chave da renovação social e via nas novas gerações o advento de um novo gênero humano (BRITTO, 1968).

Esta primeira fase de surgimento dos estudos sobre juventude, que vai de Rousseau a Stanley Hall, compreende um longo período em que a Sociologia estava se constituindo e ensaiava seus primeiros passos. Deste modo, estas pesquisas iniciais são fortemente marcadas por perspectivas educacionais, normativas e psicológicas sobre a condição juvenil. Este situação só seria alterada em meados do século XX. 


\subsubsection{A constituição da Sociologia da Juventude na primeira metade do século XX}

$\mathrm{Na}$ época que corresponde ao início do século XX e se estende ao período entre as Guerras Mundiais, o campo de estudo da juventude ainda permanece, em grande medida, dominado pela Educação e Pedagogia. A constituição de uma Sociologia da Juventude se realizaria lentamente como resultado direto da maior visibilidade social adquirida pela juventude que passa a ser considerada um segmento diferenciado e grupo socialmente distinto. Para isto, foi decisivo o surgimento de um "movimento juvenil" e da "cultura juvenil" que aparece, principalmente, nos primeiros anos do século XX. Estas manifestações dos traços culturais e políticos juvenis se fazem sentir em movimentos culturais modernistas e nas vanguardas políticas. Com efeito, ainda na primeira década, iniciam-se as primeiras experiências de institucionalização das pesquisas sociais de juventude na Alemanha. No período entre as duas grandes guerras, a produção de pesquisas social desloca-se para o outro lado do Oceano Atlântico encontrando na Escola de Chicago sua expressão mais avançada.

Sobre o debate na Europa, Flitner (1968) faz referência ao processo de consolidação de estudos sobre juventude e suas primeiras formas institucionais na Alemanha do início do século XX. Estas experiências articulam pesquisas psicológicas e sociológicas como a tentativa de criação de um instituto de Psicologia e Sociologia da Juventude, promovido por Bernfeld em 1916 (FLITNER, 1968). Flitner também faz referência ao cientista social Willlian Stern que incentivou, em Hamburgo, uma série de trabalhos empíricos sobre jovens. Para Stern, a juventude existia como produto da cultura. Este pesquisador estabelece o que entendia ser uma agenda de pesquisa de uma "Sociologia própria da Juventude", considerando como tarefas inevitáveis desta especialidade sociológica a investigação das manifestações dos "talentos juvenis" e o "estudo das associações do movimento juvenil” (FLITNER, 1968, p. 47). Também o sociólogo alemão Aloys Fischer se ocupou do estudo da juventude na época em análise. Este autor defendia a coordenação de diversos órgãos e institutos dedicados à pesquisa da juventude. Os temas desenvolvidos por ele, e que passaram a ser organizados nas instituições de pesquisa, tinham um caráter sociológico e pedagógico, com especial destaque às investigações referentes ao comportamento na escola e fora dela; o centro de interesse e a iniciativa dos estudantes; o problema do controle e seus efeitos no ambiente escolar; as práticas político-culturais dos estudantes. 
Outro autor alemão que marca esta etapa dos estudos da juventude é Eduard Spranger que elabora uma sociologia diferencial da juventude cujo propósito era compreender as "formas de vida" dos jovens em relação com a realidade social. Com base em Wilhelm Dilthey, este pesquisador desenvolve um método que objetiva compreender a psique do jovem com relação às formas e as realidades da sociedade, onde as perspectivas sociológicas e psicológicas se fundem inseparavelmente (FLITNER, 1968). Neste sentido, o fundamento teórico deste Spranger é o de que o mundo cultural, como portador de sentido, fornece - para os jovens - categorias de compreensão e orientação.

Uma das características mais evidentes dessa idade é a de que o jovem se torna consciente de que não pode permanecer na dependência espiritual e no aconchego familiar, mas que necessita ingressar na ordem social e continuidade cultural, que é necessário compreendê-las e absorvê-las mantendo uma atitude mental e espiritual independente a seu respeito. O jovem se vê extraído de sua existência fechada e indiferenciada, para ser colocado no mundo incongruente de múltiplos relacionamentos mentais e de valores; vê-se envolvido em questões profissionais, sociais e políticas racionais, de gosto e religiosas, sendo intimado a tomar posição; chamado, mas, ao mesmo tempo, ainda não bem admitido às ambições e divergências do mundo adulto. (SPRANGER apud FLITNER, 1968, p. 52-3).

Percebe-se que a abordagem compreensiva de Spranger sobre a forma de vida dos jovens visava captar os sentidos presentes na integração destes à sociedade. Os resultados mais importantes dessas considerações podem ser esboçados assim:

a) Todas as declarações referentes às juventudes se não tiveram por base material empírico extensivo, só podem fornecer descrições de um recorte historicamente situado, cultural e socialmente restrito da juventude.

b) É significativo para estes jovens de um círculo social e cultural determinado que sejam levados a perceber a sociedade como algo que não se desejou e para a qual tenham que ser capacitados para colaborar individualmente, como membro produtivo e auxiliar para sua sustentação.

c) O jovem, conforme apontado por Spranger, no entanto, busca relações comunitárias intensivas, liberdade de movimento, plenitude de vida e naturalidade 
espontânea. De acordo com isto, ele é estranho a esta configuração racional, que invade sua vida com sua exigência e intervenções.

d) Do ponto de vista sociológico, o estilo próprio da juventude é de um “individualismo liberal”. São os jovens, segundo Spranger, dificilmente organizáveis em grupos maiores, porque estes tenderiam a se voltar para pequenos grupos sociais de identificação recíproca.

Com a implantação dos regimes fascistas, e depois da eclosão da II Guerra Mundial, vão ser suspensas por décadas as pesquisas sociológicas sobre juventude no continente Europeu. Só o sociólogo húngaro Karl Mannheim (1893 - 1947), em seu exílio na Inglaterra, desenvolveria de modo sistemático uma teoria sociologia das gerações. ${ }^{13}$ Este autor via nos jovens os recursos latentes de que as sociedades dispõem para sua revitalização.

Foi nos Estados Unidos da América que se desenvolveram os estudos sociológicos sistemáticos sobre juventude, durante a estagnação do debate europeu. Neste novo ambiente, a Sociologia da Juventude se constituiria definitivamente, abandonando a tendência anterior em generalizar para toda população juvenil o que era verificado entre apenas uma amostra dos jovens. Ou seja, neste novo espaço social, a juventude seria estudada em vínculo estreito com a sua comunidade.

Já na década de trinta, ganham destaque na Universidade de Chicago os estudos sobre a delinquência juvenil por meio do fenômeno das gangues urbanas. Nestas análises, a tensão racial e a demarcação da territorialidade provocada por filhos de imigrantes italianos, judeus e irlandeses aparecem como aspectos fundamentais da constituição da problemática de pesquisa sobre juventude. Nesta linha temática, destaca-se o trabalho de Frederic M. Thraster que Publica The Gang em 1936 e que se constitui em uma referência para os estudos posteriores sobre o assunto. Sob o mesmo tema, William Foote Whyte investiga entre os anos de 1936 e 1940 as gangues de jovens filhos de imigrantes italianos em uma região segregada de Boston que resulta em uma tese de doutorado e livro sob o título "Sociedade de esquina". Conforme destaca Breitner Tavares (2006), Foote Whyte se refere a algumas regularidades encontradas no cotidiano dos jovens.

\footnotetext{
${ }^{13}$ A teoria das Gerações formulada por Karl Mannheim é o tema do próximo tópico do capítulo.
} 
Para ele, as gangues são resultado de relações habituais já presentes na vida de seus integrantes, desde os primeiros contatos sociais na infância, quando viviam próximos uns dos outros. Esses grupos relativamente duradouros surgiram espontaneamente na esquina, e seus integrantes têm entre 20 e 30 anos de idade. A falta de segurança social e a semelhança entre os indivíduos propiciam uma maior interação, já que compartilham dos mesmos problemas e expectativas. Esse é o fator gerador da estrutura grupal (TAVARES, 2006, p. 789).

Ambos pesquisadores, Frederic Thraster e Foote Whyte, tratam do fenômeno social da violência e da criminalidade juvenil num contexto de desestruturação social provocada pela depressão econômica da época. Em resumo é na tradição dos estudos sobre gangues que a Sociologia da juventude se desenvolve na Universidade de Chicago a partir da perspectiva analítica que seria, posteriormente, conhecida como interacionismo simbólico. Conforme indicam as antropólogas Ruth Cardoso e Helena Sampaio (1995), nestes estudos a delinquência juvenil é tratada como uma subcultura das "classes baixas" que rejeitam os valores das "classes médias". A ideia de subcultura delinquente é central nos estudos da Escola de Chicago e junto com as noções de papeis sociais e da função mediadora exercida pelos símbolos; ao atribuir sentidos às interações sociais constitui-se num dos principais aportes desta geração à Sociologia Geral e à Sociologia da Juventude em particular.

\subsubsection{A Sociologia da Juventude na segunda metade do século XX}

Conforme argumenta a socióloga Helena Wandel Abramo, a juventude foi tematizada ao longo da segunda metade do século XX a partir da uma ótica reativa e, conforme suas palavras, "depositária de um certo medo" (ABRAMO, 1997, p. 30), ou seja, como problema social.

Nos anos de 1950, os estudos sociológicos enfatizam uma predisposição dos jovens à transgressão e à delinquência; neste sentido, apresentam-se em grande parte como continuidade dos estudos iniciados nos anos trinta pela Escola de Chicago. Nesta década, o sociólogo norte-americano Talcoltt Parsons publica "A Classe como Sistema Social" em que opera uma análise dos grupos juvenis a partir de sua perspectiva teórica: o estruturalfuncionalismo. Neste artigo, Parsons (1968) discute o desenvolvimento de uma "cultura juvenil" como decorrência do processo de expansão do sistema educacional a toda a população infanto-juvenil norte-americana. Para este autor, a "cultura juvenil" é 
necessariamente ambígua, uma vez que, na escola, os grupos de pares surgem como meio de proteção à aculturação para os jovens das classes baixas, preservando seus vínculos identitários de origem familiar e étnico. Parsons identifica neste comportamento uma postura "anti-intelectualista", enquanto que no ensino médio os pares de idade exerceriam outra função, estando agora vinculados à diversificação dos papeis sociais. Deste modo, a ambiguidade reside no duplo caráter da cultura juvenil que pode assumir funções tanto progressivas quanto regressivas, no que diz respeito à incorporação dos valores da sociedade envolvente, via os processos de socialização no ambiente escolar (PARSONS, 1968).

Torna-se importante situar o leitor que é neste período que se consolida, a partir do estrutural-funcionalismo parsoniano, a noção predominante de juventude no século XX. Ou seja, conforme sintetiza Helena Abramo (1997), a juventude passa a ser pensada como um processo de desenvolvimento social e pessoal de capacidades e ajustes aos papeis de adulto. Ou ainda, como um período de transição da infância a fase adulta, marcado pela intensificação do processo de socialização e entendido como a incorporação das normas e dos valores sociais necessários à sua integração como membro da sociedade.

Ainda nos anos cinquenta, a Organização das Nações Unidas para a Educação, a Ciência e a Cultura (UNESCO) passa a promover investigações que visavam a caracterizar a juventude de países inteiros. Desta forma, esta instituição encarregou o pesquisador francês Jean Stoetzel de realizar esta tarefa para o caso do Japão do período do pós-guerra. Para isto, o primeiro desafio foi definir com precisão a população do estudo, o que foi feito estabelecendo-se de modo arbitrário os limites de 15 a 25 anos. Em seu relatório de pesquisa, publicado pela UNESCO em Paris no ano de 1953, o autor identificou que os jovens se encontravam em relação de extrema dependência econômica de seus pais, chegando à conclusão de que "a condição de jovem é uma condição muito inferior" a dos adultos (STOETZEL, 1968, p. 131).

A UNESCO realizou no ano de 1964, em Grenoble na França, a Primeira Conferência Mundial sobre a Juventude, encarregando o professor de história da Sociologia da Juventude em Viena, o austríaco Léopold Rosenmayer, a apresentação de um relatório sobre a situação socioeconômica da juventude. Neste relatório, encontram-se as tendências mais recentes à época sobre os estudos e a situação juvenil na Europa e nos EUA. O trabalho de Rosenmayer tem grande significado por apresentar a definição de juventude que será a mais usada pelos pesquisadores desde então e por destacar um processo de universalização da 
identidade juvenil, como impacto da expansão dos meios de comunicação de massa, à generalização da educação compulsória e o surgimento de um mercado de consumo juvenil.

Nas décadas de 1960 e 1970, o enfoque dos estudos recai no papel contestador da ordem social. Nesta época, por meio do Rock'n Roll, da liberação sexual, da contracultura, do movimento estudantil, da luta por direitos civis e pela paz, a juventude produzia uma crítica à ordem social estabelecida. As pesquisas buscam explicar estas novas manifestações culturais e políticas da juventude e todas suas formas de "comportamento desviante", atribuindo a esta categoria a possibilidade de transformação social. Partes destes estudos afirmam que, naquele contexto de transformações sociais e culturais e de modernização produtiva acelerada, a juventude aparecia como uma categoria portadora de possibilidades de transformações sociais em diferentes graus e propósitos. Isto não significa o abandono do enfoque da juventude problema. No conjunto, predominam pesquisas com base teórica no funcionalismo. Estas identificavam na geração jovem uma ameaça à ordem social; nos planos político, cultural e moral, atribuindo este comportamento contestador às novas dinâmicas de socialização que permitiriam o afrouxamento dos vínculos estruturais.

No Brasil, é particularmente neste período que o tema da juventude ganha visibilidade. Os estudos voltam-se, principalmente, para as formas de engajamento político da juventude. Neste âmbito, o texto do sociólogo brasileiro Otávio Ianni (1968), intitulado $O$ Jovem Radical, juntamente com os estudos realizados pela socióloga Maria Alice Foracchi: $O$ estudante e a transformação da sociedade brasileira (1965) e A juventude na sociedade moderna (1972) podem ser vistos como exemplos paradigmáticos desta produção teórica que se iniciava.

Em contraste a este período, nos anos de 1980, a problemática da juventude passa por um deslocamento, enfatizando-se a ascensão do individualismo, do consumismo e da apatia política. Conforme resume Abramo (1995) sobre os estudos desta década, o problema da juventude passa ser sua incapacidade de resistir ao individualismo, ao conservadorismo moral, ao pragmatismo e à falta de manifestações de desejo de mudar ou mesmo corrigir as deficiências do sistema social.

Nos anos de 1990, os estudos mudam um pouco em relação à década anterior, mas o enfoque na juventude-problema persiste. Não são mais a apatia e a desmobilização que chamam a atenção; pelo contrario, "é a presença de inúmeras figuras juvenis nas ruas, envolvidas em diversos tipos de ações individuais e coletivas" (ABRAMO, 1995, p. 31). A ênfase recai sobre o envolvimento de jovens na violência urbana, na gravidez precoce, no 
desemprego e, em menor medida, nos processos migratórios do campo para as cidades. Notadamente sobre os jovens das regiões metropolitanas, uma série de estudos patrocinados pela UNESCO em Curitiba, Fortaleza, Rio de Janeiro e Brasília, deram a tônica ao debate mais recente e pautaram a institucionalização de políticas públicas para a juventude na primeira década deste século XXI no Brasil.

Observa-se que, neste percurso, duas tendências se alteram ao longo do tempo. De um lado, predominou uma noção mais generalista e abstrata da juventude; de outro, a ênfase recaiu sobre a especificidade dos jovens vinculados a experiências concretas (CARDOSO; SAMPAIO, 1995). Com efeito, recentemente vem-se consolidando o entendimento sobre a necessidade de se compreender a juventude enquanto uma construção social, cultural e histórica dinâmica sobre a qual se impõem diferentes mecanismos de interação social. Ao invés de um grupo homogêneo, ela é cada vez mais percebida como uma realidade múltipla. Entretanto, não há consenso quanto ao que configuram as juventudes e suas variações. Empiricamente, é um fenômeno que apresenta uma crescente diversidade. No campo da pesquisa social, vai constituindo-se como uma categoria multidimensional compreendida como um conceito polissêmico que resiste a ser reduzido a uma única definição. Em um trabalho anterior, ${ }^{14}$ apresentaram-se cinco diferentes aspectos que envolvem sua construção analítica: o enfoque geracional; a juventude como faixa etária; como transição para a vida adulta; a ênfase nas culturas juvenis e as representações sociais. A seguir, são discutidas estas diferentes abordagens da categoria juventude.

\subsection{O ENFOQUE GERACIONAL}

A questão das gerações figura como um dos dilemas centrais da vida social ganhando força nas pesquisas e nos debates das Ciências Sociais. Como enfoque teórico constituiu-se, principalmente, a partir das formulações do sociólogo Karl Mannheim $(1968,1982)$. Ele parte das características fundamentais da sociedade que são: a) o surgimento contínuo de novos participantes no processo cultural, enquanto; b) antigos participantes daquele processo estão continuamente desaparecendo; c) os membros de quaisquer gerações podem participar de uma sessão temporalmente limitada do processo histórico; d) é necessário, portanto, transmitir

${ }^{14}$ Ver Weisheimer, 2005a. 
continuamente a herança cultural acumulada; e) a transição de uma para outra geração é um processo contínuo através da série ininterrupta das gerações (MANNHEIM, 1982, p. 74). Tais aspectos impõem-se como condições estruturantes das relações entre indivíduo e sociedade assim como a transmissão e adaptação da herança cultural nas sociedades. Como a criação e a acumulação cultural nunca são realizadas pelos mesmos indivíduos, cada geração tem, a seu tempo, um contato original com a herança cultural acumulada (MANNHEIM, 1982). Este aspecto é absolutamente central para a compreensão do conceito de geração e de sua relevância à compreensão dos impasses atuais na reprodução social da agricultura familiar.

O conceito sociológico de geração busca romper com resquícios naturalistas da explicação do fenômeno, definindo-o como uma condição situacional frente ao processo histórico e social. Assim, uma geração é constituída por aqueles que vivem uma "situação" comum perante as dimensões históricas do processo social, o que caracteriza uma "situação de geração". De acordo com Mannheim, "para se participar da mesma situação de geração, isto é, para que seja possível a submissão passiva ou o uso ativo das vantagens e dos privilégios inerentes a uma situação de geração, é preciso nascer dentro da mesma região histórica e cultural” (MANNHEIM, 1982, p. 85). A situação de geração corresponderia a certos locais geracionais que estruturam posições sociais compartilhadas por indivíduos de um mesmo grupo etário, mas que não se reduz à idade dos mesmos. Deste modo, compreende-se que geração é um conceito situacional.

Sucedendo-se no tempo, as gerações se apresentam como a não-simultaneidade do simultâneo, o que significa que cada ponto do tempo é um espaço de tempo que não se reduz a uma única e homogênea relação com o tempo histórico. Ou seja, indivíduos de gerações diferentes experienciam de modos diferenciados os processos históricos simultâneos. Os membros de uma mesma geração também podem atribuir significados distintos ao mesmo contexto histórico. Com efeito, a geração, assim como a classe social, apresenta-se mais como uma potencialidade do que um grupo concreto que resultaria da transformação dialética do grupo em si em um grupo para si. Mannheim (1982) produz então uma importante distinção entre geração enquanto realidade e unidade de geração.

Pode-se dizer que os jovens que experienciam os mesmos problemas históricos concretos fazem parte da mesma geração real; enquanto aqueles grupos dentro da mesma geração real, que elaboram o material de suas experiências comuns através de diferentes modos específicos, constituem unidades de geração separadas (MANNHEIM, 1968, p. 87). 
A geração enquanto realidade implica algo mais que co-presença em uma tal região histórica e social, implica a criação de um vínculo concreto entre os membros de uma geração, através da exposição deles aos mesmos sintomas sociais e intelectuais de um processo de desestabilização dinâmica. Por sua vez, a unidade de geração implica um vínculo ainda mais concreto do que o verificado na geração enquanto realidade, ela se refere a um compartilhar de experiências comuns que lhe confere unidade. Esta unidade de geração ocorre quando os jovens compartilham conteúdos mais concretos e específicos formados por uma socialização similar e desenvolvem, em função disso, laços mais estreitos, levando à identificação e ao reconhecimento mútuo devido às similaridades das situações e das experiências constituindo uma comunidade de destino (MANNHEIM, 1968).

Uma unidade de geração não é um grupo concreto, embora possa ser acompanhada de grupos concretos nos quais a similaridade de situação possibilita atividades integradoras que provocam a participação e capacita-os a expressarem exigências desta situação comum. Os grupos concretos das novas gerações encontrariam no movimento juvenil a expressão de sua localização na configuração histórica prevalecente (MANNHEIM, 1968).

Percebe-se que esta abordagem confere importância central às experiências dos jovens, apontadas como fator propulsor da dinâmica da sociedade e identificadas como importantes veios de mudanças e transformações culturais e de relações sociais. Isto porque uma nova geração "não esta completamente enredada no status quo da sociedade", (MANNHEIM, 1968, p. 73). Sob este aspecto, os jovens de uma época estão sujeitos a contradições próprias frente ao estágio referente do desenvolvimento capitalista. Emergem conflitos dos jovens com a ordem social já estabelecida; estes revelam as contradições mais agudas da própria organização social, uma vez que, do ponto de vista sociológico, a juventude e a sociedade encontram-se em reciprocidade total (MANNHEIM, 1968). Conforme o autor:

\footnotetext{
O fato relevante é que a juventude chega aos conflitos de nossa sociedade moderna vinda de fora. É esse fato que faz da juventude o pioneiro predestinado de qualquer mudança da sociedade. [...] Na linguagem sociológica, ser jovem significa, sobretudo, ser um homem marginal, em muitos aspectos um estranho ao grupo (MANNHEIM, 1968, p. 74-5).
}

Este estranhamento, possibilitado pelo contato original das sucessivas gerações com a cultura criada e acumulada socialmente permite que novos valores e comportamentos sejam facilmente incorporados pela juventude. Deste fato, podem ser obtidas duas possibilidades de equação das relações intergeracionais. 
A primeira tenderá a enfatizar o potencial conflito entre as gerações, entre os jovens e a ordem social estabelecida ou mesmo entre os próprios jovens. A partir desta perspectiva, podem ser extraídos dois tipos de posicionamentos sobre a juventude: um, de caráter voluntarista, baseia-se na ideia ingênua de que os jovens são inerentemente contestadores; outro, num pólo mais conservador, apresenta uma postura cética de que esta "rebeldia" é necessariamente transitória como a juventude.

Na segunda, a juventude passa a ser vista a partir de seu potencial de mudança, enfatizando-se sua capacidade criadora e inventiva. Ela passa a ser percebida como parte dos recursos latentes de que a sociedade dispõe e de seu engajamento depende a vitalidade da própria sociedade. Como destaca Mannheim a este respeito, “a juventude não é progressista nem conservadora por índole, porém é uma potencialidade pronta para qualquer nova oportunidade" (MANNHEIM, 1968, p. 74-5). Nesta última abordagem, o maior ou o menor grau deste potencial de mudança é atribuído às sociedades dinâmicas, enquanto as que buscam conter a juventude podem ser entendidas como sociedades estáticas (MANNHEIM, 1968).

Os jovens, como parte dos "recursos latentes" de que dispõem as sociedades, aparecem como grupo estratégico não apenas na reprodução das relações sociais como também para a sua transformação. Como mencionado, as gerações são ainda "uma potencialidade", sem que a elas corresponda uma consciência, tal qual às classes que não se tornam para si. O potencial transformador da juventude, para ser exercido em toda sua potencialidade, necessita que ela se constitua em "geração para si", com alto nível de identidade e capacidade de organização. Isto só ocorre quando a juventude se encontra ciente de si mesma, percebendo sua unidade de geração e avançando na direção da construção de grupos concretos. Mannheim (1982, p. 71), em uma nota de rodapé, sugere que uma questão para a pesquisa social possa ser identificar em quais condições os membros individuais de uma geração se tornam conscientes de sua situação comum e fazem desta consciência a base da solidariedade grupal. ${ }^{15}$

A abordagem das gerações, por sua dimensão dialética, permite perceber que, sociologicamente, a juventude é um veículo de ligação entre o passado e o futuro; por meio dela, a sociedade se renova permanentemente. O instigante é que este processo de transição ininterrupto das gerações estabelece-se por meio das interações constantes entre jovens e

\footnotetext{
${ }^{15}$ No Brasil, o principal esforço para responder à questão proposta por Mannheim foi desenvolvido por Maria Alice Foracchi (1965, 1972 e 1982).
} 
adultos. Por conta dessas interações intergeracionais, os mais velhos se tornam cada vez mais receptivos às influências dos mais novos, resultante da dialética entre as gerações a partir do caráter dinâmico da própria sociedade. ${ }^{16}$ Além disso, o caráter experimental do "contato original" dos jovens permite a atribuição de novos sentidos às práticas sociais e o surgimento de um novo quadro de antecipações. Devido a isto, as juventudes não são suscetíveis de comparação, pois, ao viverem épocas históricas diferentes, têm definidos seus conflitos e sua vivência social de maneiras também diferentes (SOUSA, 2006). Logo, não é de estranhar-se a tendência ao distanciamento de projetos entre as gerações.

Entende-se que o enfoque geracional aporta questões importantes à análise dos processos de reprodução e transformação do processo de trabalho familiar agrícola por chamar atenção às alterações na situação dos padrões históricos e culturais que diferem pais e filhos neste contexto. Para compreender em profundidade o impasse atual da reprodução social da agricultura familiar, é necessário analisá-la no quadro das transformações de referências históricas, sociais, culturais e econômicas a partir das quais recebem sua forma e informam seu conteúdo. As formas socialmente estabelecidas para interpretar tais conteúdos serão sempre e necessariamente reapropriadadas e resiginificadas pelo contato original da nova geração. Entende-se que os impasses na reprodução social da agricultura familiar apresentam-se como objeto de estudo que requer esta abordagem por serem justamente as relações familiares e de parentesco os elementos decisivos para se pensar a conformação e sucessão das gerações. Estas só se configuram através das vivências individuais e coletivas dos agentes e dos processos reflexivos associados a essas vivências, às experiências que constituem a própria vida social (DOMINGUES, 2004).

Antecipando um pouco a discussão sobre a categoria que será objeto do próximo capítulo, do debate feito até o momento é possível deduzir que os atuais jovens agricultores familiares se encontram em uma situação geracional diferente daquela de seus pais e avós. Estes jovens configuram ainda uma geração enquanto realidade já que estão expostos à mesma historicidade dos processos sociais agrários que transformam o meio rural e o trabalho agrícola. Além disso, configuram uma unidade de geração quando, ao compartilharem as mesmas experiências resultantes da socialização no processo de trabalho familiar agrícola,

\footnotetext{
${ }^{16}$ Isto se evidencia através da mudança de paradigma que coloca a centralidade do conhecimento como motor do crescimento o que faz dos jovens agentes de propagação de novos saberes uma vez que possuem maior facilidade para o aprendizado e disposição para inovação. Como exemplo, atualmente os mais jovens passam a ensinar os mais velhos como fazerem uso das novas tecnologias e dos recursos informacionais, como no uso de caixas eletrônicos, da telefonia móvel e da Internet, que estão cada vez mais presentes na vida cotidianos dos agricultores familiares.
} 
produzem laços mais estreitos levando à identificação e ao reconhecimento mútuo e projetam para si destinos comuns. Esta unidade de geração assume formas de grupos concretos quando, por exemplo, estes jovens participam das instâncias juvenis dos sindicatos de trabalhadores na agricultura ou organizam suas próprias associações com pautas especificas como, por exemplo, para acessarem ao credito fundiário no Programa Nossa Primeira Terra do governo federal.

\subsection{A JUVENTUDE COMO FAIXA ETÁRIA}

A noção de juventude está intimamente ligada a um critério de medição cronológica da existência individual, o que permite o estabelecimento de diferentes faixas etárias. Esta abordagem frequentemente recorre a indicadores demográficos, critérios normativos ou padrões estabelecidos pelos organismos internacionais para definir os limites de quem é ou não considerado jovem.

Conforme a Organização Mundial da Saúde (OMS), a adolescência é definida como um processo fundamentalmente biológico, abrange as etapas da pré-adolescência (10-14 anos) e a adolescência (15-19 anos); a juventude se iniciaria nessa faixa etária como uma categoria essencialmente sociológica e "indicaria o processo de preparação para os indivíduos assumirem o papel adulto na sociedade, tanto no plano familiar quanto no profissional, estendendo-se dos 15 aos 24 anos”. (WAISELFISZ, 2002, p. 18). Por sua vez, a Organização Ibero-americana de Juventude trabalha com a faixa entre os 14 e os 30 anos de idade. Na pesquisa espanhola Informe Juventude em Espanha e na pesquisa realizada pelo Instituto Mexicano de La Juventud intitulada Encuesta nacional de Juventud 2000, foi utilizado o intervalo entre 15 a 29 anos de idade (UNESCO, 2006). Alguns países, como o Japão, classificam como jovens os indivíduos com idades até 35 anos (WAISELFISZ, 2002). No Brasil, a abordagem demográfica do IBGE classifica o "grupo jovem" entre 15 a 24 anos, em três recortes etários: 15-17 anos como jovens adolescentes, ${ }^{17}$ 18-20 anos como jovens; e 21-24 anos como jovens adultos (BAENINGER, 1998, p. 26). Estes exemplos demonstram que há vários critérios para se definir a faixa etária que compreende a juventude, sendo esta uma construção social.

17 De acordo com o Estatuto da Criança e do Adolescente, considera-se adolescente a pessoa na faixa de 12 a 18 anos (Lei 8.069 de 13 de julho de 1990). 
A definiç̧ão de faixas etárias é, obviamente, arbitrária e não dá conta das diferenças entre idade biológica e idade social. ${ }^{18}$ Seguindo a proposta de Emile Durkheim, considera-se indispensável ao método sociológico estabelecer, de modo sistemático, rupturas com as prénoções, não apenas as originadas no senso comum, mas também, aquelas presentes nas instituições oficiais. Desta maneira, a juventude não pode ser tratada como uma unidade social relacionada apenas com estes critérios de enquadramento. É neste sentido que Pierre Bourdieu enfatiza que a juventude é apenas uma palavra, lembrando que "[...] a juventude e a velhice não são dados, mas construídos socialmente na luta entre os jovens e os velhos. As relações entre a idade social e a idade biológica são muito complexas" (BOURDIEU, 1983, p. 113). O autor chama a atenção para o fato de que esta demarcação etária corresponde, necessariamente, a um jogo de lutas pela imposição de sentido que demarca quem é incluído e quem é excluído da categoria. Com efeito, deve-se estar atento ao jogo de manipulações destas construções normativas, visto que as divisões entre idades são arbitrárias e a fronteira que separa a juventude e a velhice é um objeto de disputa que envolve a dimensão das relações de poder (BOURDIEU, 1983). Logo, buscam-se evidenciar as associações cronológicas simplistas como manipulações de linguagem que encobrem, sob uma mesma categoria, realidades sociais que conservam pouca similaridade.

Para o processo de pesquisa, é mais instigante à imaginação sociológica ir além da aparência do fenômeno e buscar compreender como as faixas etárias são socialmente constituídas; como estas podem constituir-se em parâmetros para posicionar os sujeitos num espaço de relações sociais. O que está em jogo aqui é a noção de estratificação etária associada à atribuição de papeis sociais específicos, implicando certa escala de posição na hierarquia social. Tendo isto em conta, poder-se-á identificar que esses padrões etários, tal como propõe o sociólogo José Mauricio Domingues (2004), são sempre mediados pela dimensão hermenêutica da vida social, o que se torna importante à definiçãa geral do universo simbólico, assim como, à mediação entre as diversas perspectivas que constituem os diversos grupos etários e suas diferentes situações de geração. Este posicionamento apresenta a vantagem de superar a imprecisão dos limites que demarcam as gerações.

A abordagem cronológica que estabelece as faixas etárias torna-se importante para a pesquisa social empírica, principalmente para a definição precisa dos critérios de inclusão e exclusão de indivíduos na categoria juventude. Isto exige do pesquisador, como qualquer

\footnotetext{
${ }^{18}$ Van Gennep (1977), em seu texto clássico sobre os ritos de passagem, demonstra que a puberdade social não coincide, necessariamente, com a identidade biológica.
} 
outra forma de classificação, a explicitação dos parâmetros teóricos que definem a construção operacional da categoria analítica. Levando-se em consideração os diferentes processos de maturação social que envolve o processo juvenil, assume-se, neste estudo, a faixa etária dos 15 aos 29 anos de idade para demarcar, operacionalmente, a juventude, estabelecendo-se ainda, com base na análise psico-social desenvolvida pela cubana Laura Domingues Garcia (2003), a seguinte estratificação etária interna:

a) Jovens adolescentes (de 15 a 19 anos): Nesta etapa, juventude e adolescência se interpõem na superação progressiva da primeira pela segunda, uma vez que as mudanças fisiológicas se completam, suas capacidades cognitivas encontram-se plenamente desenvolvidas. O processo de socialização os leva a uma constante interação social possibilitando a incorporação de atividades diversas. Estabelecem-se condutas mais autônomas, assumem-se novos papeis e novas responsabilidades desenvolvendo-se habilidades produtivas e o futuro passa a ocupar um lugar mais importante. O presente passa a ser cada vez mais influenciado por objetivos conscientemente planejados. Neste sentido, o começar a pensar sobre o que se deseja ser no futuro, a escolha da profissão e a projeção geral da vida tomam o centro dos interesses e das ações fundamentais que se realizam nesta etapa, informando a construção reflexiva da autoidentificação dos sujeitos.

b) Jovens (de 20 a 24 anos): Este grupo se caracteriza pela maturidade biológica, que geralmente não está acompanhada ainda da maturidade social. Desenvolvem e adquirem categorias que lhes permite refletir sobre realidades sociais mais amplas e seus juízos de valor tornam-se mais críticos e objetivos. Em geral, gozam de mais liberdade e menor dependência em relação aos pais. Ao mesmo tempo, a imposição social de assumir novos papeis de adulto muitas vezes torna-se conflitiva, porque os jovens nesta fase tendem a não se identificar com eles. A definição de um projeto profissional mais do que uma possibilidade passa a ser uma exigência social. Nesta fase, a personalidade já se encontra consolidada e as decisões sobre a carreira profissional impõem-se com todo o peso da coerção social. Trata-se de um período em que a inserção profissional se generaliza, a partir das experiências acumuladas, da sua concepção de mundo e da consolidação que vai adquirindo sua auto-avaliação.

c) Jovens adultos (de 25 a 29 anos): Nesta fase, os jovens já alcançaram seu nível de plena maturidade psicológica. Consolida-se a formação profissional. Amplia-se o 
desempenho social e os papeis na sociedade passam a serem mais diversificados. O âmbito profissional adquire importância central na vida social, servindo de suporte à consolidação identitária. Verifica-se um distanciamento dos grupos de idade e a tendência para estabelecimento de uma relação conjugal mais estável e uma nova família passa a ser construída. Nesta idade, a maioria já assumiu responsabilidades familiares, e os que se encontram na condição de pai ou mãe passam a desempenhar papeis mais complexos. Nesta etapa, os jovens tendem a refletir mais intensamente sobre seus sucessos e avanços pessoais. A auto-avaliação é mais profunda e efetiva. Busca-se corrigir os rumos com a tendência de procura de alternativas que favoreçam a reorientação dos planos futuros que se tornam mais objetivos e complexos e em relação mais estreita com as esferas profissionais e familiares.

Estas características gerais das faixas etárias juvenis não são homogêneas a toda a juventude nem mesmo ocorrem simultaneamente dentro da mesma faixa etária. Teoricamente, é possível suscitar a hipótese de que os jovens agricultores familiares, em certos aspectos, amadureçam socialmente mais cedo do que outros jovens que se inserem em atividades produtivas mais tardiamente, devido à incorporação de certas responsabilidades vinculadas ao processo de trabalho que realizam. Porém, por outro lado, tendem a ter postergado suas condições de autonomia social, por conta do caráter patriarcal que marca esta atividade. Estes aspectos inscrevem-se como pistas para explicar as diferenças em relação à construção dos projetos entre as faixas etárias, ou mesmo, à ampliação temporal da transição da dependência à autonomia.

Assume-se a posição de que a abordagem da juventude como um recorte etário deve ser utilizada com cautela, evitando-se a naturalização de um fenômeno eminentemente sociológico. Além disto, esta abordagem marcadamente empírica não é suficiente para forjar uma categoria teórica; entretanto, esta posição não implica negligenciar a importância desta variável pra a compreensão do fenômeno juvenil e para a delimitação do universo de pesquisa. 


\title{
1.6 A JUVENTUDE COMO TRANSIÇÃO PARA A VIDA ADULTA
}

A noção de juventude como um período de transição para a vida adulta adquire importância na medida em que foi assumida pela UNESCO a partir da Conferência Internacional sobre Juventude, realizada em Grenoble na França, no ano de 1964, sendo uma das mais utilizadas por pesquisadores desde então. Conforme o relatório apresentado pelo sociólogo Léopold Rosenmayer ${ }^{19}$ para conferência:

\begin{abstract}
O termo "juventude" designa um estado transitório, uma fase da vida humana de começo bem definido pelo aparecimento da puberdade; quanto ao fim da juventude, varia segundo critérios e os pontos de vista que se adotam para determinar se os indivíduos são "jovens". Por "juventude" compreendemos não somente uma fase da vida, mas também os indivíduos concretos que pertencem aos grupos de idade definidos como jovens (ROSENMAYR, 1968, p. 133).
\end{abstract}

Esta definição buscou responder à necessidade de uma definição operacional que desse conta de diferentes aspectos envolvidos no fenômeno juventude, estando presentes a ideia de transição; a noção de fronteiras demarcadas por critérios biológicos (início) e culturais (término); a representação sobre indivíduos concretos que pertencem a uma mesma faixa etária. Como se demonstrou anteriormente, o problema da caracterização etária traz suas vantagens e desvantagens; cabe refletir como este estado transitório vai se constituindo em um atributo substantivado com valor permanente.

Destaca-se que a idéia de transição é inerente à vida e, por si só, não permite a definição de uma categoria analítica singular. Até porque, todas as etapas do ciclo vital são, necessariamente, transitórias; logo, as categorias neste campo devem refletir as dinâmicas dessa transição. Por isto, pensa-se que a marca da transição juvenil encontra-se fortemente relacionada aos percursos que caracterizam os processos de socialização. A este respeito, Ana Amélia Camarano e Juliana Leitão de Mello (2006) destacam que os modelos tradicionais de transição para a vida adulta constituídos após a Segunda Guerra consideravam esta passagem de forma linear. "No processo de transição, essa trajetória é composta pela saída da escola, ingresso no mercado de trabalho, saída da casa dos pais, formação de um novo domicílio pelo casamento e nascimento do primeiro filho" (CAMARANO; MELLO, 2006, p. 17).

\footnotetext{
${ }^{19}$ Traduzido de "Conditions sociales et économiques influençant l avie dês jeunes", exposé d'intruduction à la Conference internationale sur la juenesse, grenoble, 1964. Apêndice V do Rapport Final, UNESCO, Paris, 1964, doc ED/211, 24 páginas (BRITTO, 1968).
} 
Esta transição implicaria a mudança da família de orientação para a de procriação; do aprendizado para a produtividade; da crescente ascensão da autonomia, entre outras que carregam o sentido de passagem da condição de dependência da infância à independência na vida adulta. Nesta perspectiva, a idéia central é a de que a juventude é um estágio quando acontece a entrada na vida social plena e que, como situação de passagem, compõe uma "condição de relatividade: de direitos e deveres, de responsabilidade e independência mais amplas do que as das crianças e não tão completas quanto à dos adultos" (ABRAMO, 1994, p. 11). Até que esta transição se complete, estes indivíduos concretos encontram-se subordinados à autoridade dos adultos dos quais dependem, situando-se aí um dos fundamentos de sua condição subalterna. Deste modo, percebe-se que esta transitoriedade social implica uma relativa fragilidade social, subalternidade e ambivalência que caracteriza a liminariedade da juventude.

Percebe-se que esta perspectiva da transição enfatiza a fase juvenil como maturação biográfica de preparação para a vida adulta (LACCARDI, 2005). O processo de individualização ocorre, sobretudo, neste período transitório sendo sucedido por certa estabilização nos padrões de vida mais convencionais que marcariam a fase posterior. Assim, a instabilidade da juventude aparecia em oposição à estabilidade da fase adulta (GEREIRO; ABRANTES, 2005). Percebe-se o viés ideológico desta perspectiva que atribui uma estabilidade social à condição de adulto que não encontra lastro na realidade concreta dos dias atuais marcado pelo risco (BECK; GIDDENS; LACH, 1997) e pela incerteza (BAUMAN, 1997).

O ingresso no trabalho permanece como elemento central desta transição, já que, através dele, os jovens começam a adquirir uma relativa autonomia perante a família de origem. Porém, é preciso lembrar que esta inserção profissional é precária entre eles, devido à fragilidade de sua posição social e, principalmente, por causa das relações de trabalho típicas do atual regime de acumulação flexível. Fatores estes que contribuem para agravar a situação ambígua da juventude. Além disto, numa conjuntura de crescente flexibilização das relações de trabalho e precarização do emprego, a entrada dos jovens no mercado de trabalho passa a ser mais dificultada.

Estes aspectos tornam a transição bem mais complexa e menos linear. Ou seja, pensar a autonomia da vida adulta como estando vinculada a autonomia financeira passa a ser cada vez mais problemático na medida em que se ampliam as transformações no mundo do trabalho e a crise da formalização do contrato de trabalho assalariado. Como o desemprego é 
uma condição estrutural da subordinação do trabalho ao capital, reduzir a condição de adulto à autonomia financeira implicaria considerarmos que esta poderá nunca se realizar para parcelas cada vez maiores da humanidade, que não conseguirem se inserir no mercado de trabalho, ou no mínimo que esta seria feita de muitas idas e vindas. Com efeito, constata-se uma flexibilização da linearidade na sequência de eventos, resultando numa despadronização do processo de transição. ${ }^{20}$

A este respeito, o sociólogo português José Machado Pais $(2001,2005)$ tem chamado a atenção para um efeito que denomina de "geração yo-yo", como uma metáfora para ilustrar os processos experimentados por parcelas significativas da atual geração jovem de idas e vindas entre o sistema educativo e o mercado de trabalho; entre saída e retorno da casa dos pais; entre conjugalidade e vida de solteiro. Seus estudos permitem a conclusão de que a construção da autonomia entre os jovens contemporâneos como fator de reconhecimento social como adultos não obedece necessariamente a uma sincronia nem uma linearidade, ou seja, esta transição é marcada por idas e vindas. Conforme suas palavras: "Este fato teria pressionado os jovens a fazerem um uso 'ativo' de sua agência individual para inventar novos caminhos, criar novos estilos de vida, compor novas identidades, numa multiplicidade de opções disponíveis ou inventadas”. (PAIS, 2005, p. 113). Este autor adverte que a análise desta agência individual não deveria negligenciar o peso que as estruturas econômicas, sociais e culturais têm nas trajetórias juvenis, entendendo-as como um processo temporal de ação social em que os hábitos e as rotinas passados são contextualizados, e as possibilidades futuras são emolduradas nos quadros das contingências do presente.

Compreende-se, assim, porque - na sociedade contemporânea - há certa inclinação à ampliação do período da juventude; devido à dificuldade de inserção de parcelas significativas desse grupo no mercado de trabalho é que há um alongamento do período de escolarização. A dificuldade de acesso a uma condição profissional estável tem ainda impactos no adiamento dos matrimônios e, logo, na constituição de uma nova família. Deste modo, pode-se deduzir que o processo de transição para a vida adulta é cada vez mais complexo e heterogêneo, refletindo a diversidade das condições de inserção social das novas gerações marcada por antinomias que configuram a própria sociedade.

Na consideração desta abordagem, torna-se necessário ainda estar vigilante quanto à tendência de incorrer-se em certo viés etnocêntrico, e também adultocêntrico Conforme as etnografias de Bronislaw Malinowski (2003) e Margaret Mead (1979) demonstraram, as

${ }^{20}$ Ver, sobre o assunto, Camarano (2006). 
variações sociológicas e culturais produzem significados distintos aos processos transitórios que distinguem a infância da vida adulta. Na mesma direção, Ruth Benedict argumentou que “o crescimento é um processo gradual e contínuo e o padrão de independência obtida pela criança varia de cultura para cultura" (BENEDICT, 1973 apud FERREIRA, 1978, p. 88). Ou seja, o modo de se tornar adulto não é um fato natural e tão pouco universal, constroi-se historicamente, tendo como fundamento uma ampla diversidade sociocultural. Além disto, esta abordagem reflete um paradigma que coloca a idade adulta como a centralidade do ciclo vital humano. Desta maneira, as gerações adultas, ao se debruçarem sobre o universo juvenil, geralmente não indagam pelo presente da sua condição, seus ritmos, suas características particulares a diversidade e heterogeneidade objetiva de seu universo material e simbólico. Procedendo desta forma, deixam de contribuir para a vivência plena dessa fase com qualidade de vida e garantia de direitos específicos, reforçando a posição de subcidadania a qual estariam submetidos os jovens. A partir de sua posição de adulto e das experiências de sua própria juventude, corre-se o risco de produzir uma visão distorcida da juventude e seus dilemas nas sociedades em mudança (ALMEIDA, 2000). Deste modo, a noção de juventude como período de transição para a vida adulta, apesar de constituir-se em tema socialmente relevante, tem pouca precisão analítica se desconsiderar as diversidades históricas, sociais e culturais sob as quais as transições se realizam.

\subsection{AS CULTURAS JUVENIS: JUVENTUDE COMO ESTILO E COMO VALOR}

A juventude não é apenas um produto da cultura, ${ }^{21}$ é ela mesma produtora desta. A conceituação de juventude incorpora assim critérios culturais, dando destaque à configuração

\footnotetext{
${ }^{21}$ Entre as múltiplas abordagens da cultura no âmbito da Antropologia destacam-se três que tiveram mais influência neste ramo das Ciências Sociais. A primeira proposição encontra-se na obra de Edward B. Tylor que definiu cultura como todo complexo que inclui conhecimento, crença, arte, moral, lei, costumes e todas as outras capacidades e outros hábitos adquiridos pelo homem como membro da sociedade. Outra se encontra em Robert Redfield que considera a cultura como entendimentos convencionais manifestos em atos e artefatos que caracterizam as sociedades. Já Clifford Geertz a define como sistema simbólico de significados que operam como um conjunto de mecanismos de controle por onde trafegam símbolos significantes, como as palavras, mas também, gestos, desenhos, sons e qualquer coisa usada para impor um significado à experiência (FERRARI, 1983). Geertz (2001) recorre a Vygotsky, para quem a criação pessoal do sentido pela criança depende de seu domínio dos meios sociais de pensar, afirma que "o uso de signos leva os seres humanos a uma estrutura específica de comportamento, que rompe com o desenvolvimento biológico e cria novas formas do um processo psicológico baseado na cultura" (GEERTZ, 2001, p.186-7).
} 
de culturas juvenis. De certa maneira, esta abordagem desenvolveu-se mais no âmbito da Antropologia do que no da Sociologia.

Os cientistas sociais de inspiração estrutural funcionalista viam no comportamento juvenil a expressão de uma subcultura, ou seja, uma variação de algum tema central da cultura propriamente dita. A subcultura juvenil instituía suas próprias normas em diferenciação à sociedade mais ampla afirmando seus traços singulares e expressando sua rejeição às normas sociais. Sua expressão principal seria o modismo.

A partir dos meados dos anos de 1960, com o desmoronamento da grande teoria e da guinada simbólica $^{22}$ nas Ciências Sociais, processou-se uma emergência dos estudos culturais $^{23}$ com o qual a noção de culturas juvenis adquire uma nova roupagem teórica. Conforme o antropólogo José Guilherme Cantor Magnani, este termo "aponta mais para as formas em que as experiências juvenis se expressam de maneira coletiva, mediante estilos de vida distintos, tendo como referência principalmente o tempo livre" (MAGNANNI, 2005, p. 176).

Nesta perspectiva, a juventude é vista como uma expressão da cultura de massas. A mídia aparece então como o principal componente na construção do entendimento do que seja a juventude. Neste contexto, as culturas juvenis emergem como um produto da abundância, intimamente ligada à sociedade de consumo. Suas características incluem certo tipo de vestimentas, acessórios, linguagem, gostos musicais e práticas esportivas e de lazer.

Os jovens aparecem como um mercado consumidor importante; a indústria cultural estandardiza seus produtos que transcende os limites de idade através da propagação da moda jovem. Esta se constitui no padrão estético da vida cotidiana. Como resultado, ser jovem

\footnotetext{
${ }^{22}$ Neste contexto, ocorreu também a ascensão das abordagens pós-modernas que, nos estudos sobre juventude, forjou a expressão de tribos juvenis. Embora o termo pós-moderno tenha ocupado um lugar de destaque no debate acadêmico recente, permanece como uma noção imprecisa e de duvidosa comprovação empírica, sendo considerado aqui um movimento cultural, não uma época histórica. De qualquer modo, esta perspectiva não se propõe a ser uma verdade científica visto que, conforme seus expoentes - seja Lyotard, Baudrillard ou Rorty este movimento caracteriza-se pela incredulidade diante das metanarrativas, descrevendo um mundo desprovido de significado e onde o conhecimento e a legitimidade encontram-se sem conexão. No bojo deste movimento cultural, a expressão tribos juvenis obteve projeção midiática. Esta foi elaborada pelo sociólogo francês Michel Maffesoli (1987), em um livro intitulado O tempo das tribos, onde analisa o comportamento de jovens urbanos destacando o nomadismo, a fragmentação e o consumo como marcas de uma geração. Sua ênfase recai sobre a constituição de pequenos grupos, altamente voláteis e diferenciados que afirmam suas identidades em trajes e práticas culturas. Os jovens vistos por este prisma refletiriam o novo cenário do neoliberalismo "caracterizado pela fluidez, pelos ajustamentos pontuais e pela dispersão" (MAFFESOLI, 1987, p.107). Entende-se que a expressão tribo juvenil é mais metafórica do que conceitual, sendo, por isto, de pouca valia para os propósitos deste estudo.

${ }^{23} \mathrm{O}$ núcleo irradiador desta perspectiva pode ser atribuído ao Centro de Estudos de Cultura Contemporânea da Universidade de Birmingham que, desde sua fundação em 1964, vem ocupando um lugar de destaque na pesquisa das questões relativas à cultura e à identidade.
} 
torna-se um estilo de vida que não mais se restringe a uma faixa etária, produzindo o que o antropólogo Hermano Viana (1997) definiu como "promiscuidade intergeracional". Isto porque os jovens aparecem como um mercado consumidor, cujos bens de consumo transcendem ao público-alvo original. Enfatizam-se os aspectos de construção da imagem de juventude como um valor simbólico cujas referências culturais associadas às mercadorias rompem todas as fronteiras e constituem-se num padrão ideal de indivíduo moderno, no sentido de atualizado, conectado as novidades e tendências em constante transformação. Assim, não só a juventude tornou-se produto cultural, mas a própria cultura torna-se jovem. Uma vez que ela mesma se organiza em tornos de temas e problemas da juventude, não apenas como uma fase da vida, mas como um conjunto de valores. Assim, a juventude tornase um estilo que todos têm oportunidade de usufruir, independente da localidade onde moram, da sua condição de classe e mesmo da idade que possuem.

Como hoje em dia, até nas regiões mais isoladas, os meios de comunicação promovem a difusão da cultura jovem, ocorrem no seu bojo processos de hibridização que os jovens sentem de forma bastante intensa. Os pesquisadores que desenvolvem estudos sobre os jovens no meio rural identificam, com certa surpresa, neles, a utilização de signos juvenis tidos como urbanos. ${ }^{24}$ Deste modo, redundam interpretar este comportamento através da operação das categorias dicotômicas como cidade e campo ou urbano e rural. Neste sentido, a emergência da identidade juvenil no meio rural é pensada como resultado do processo de modernização do campo. Sob esta ótica, se isto não pôs fim às profundas diferenças entre os jovens rurais e urbanos, permitiu ao menos a convivência em um mesmo espaço social de práticas e valores que articulam seus elementos.

Isto leva a antropóloga Maria José Carneiro $(1998,1999)$ a sugerir que as identidades locais não sejam mais sustentadas na homogeneidade de padrões culturais, mas na diversidade; principalmente na maneira específica de combinar práticas e valores originários de universos culturais distintos, o que denomina de rurbanização. Ainda segundo essa autora, nesse contexto, os jovens filhos de agricultores reelaboram suas identidades sociais e passam a questionar os projetos de reprodução de modos de vida pautados exclusivamente na atividade agrícola, reivindicando padrões de vida, valores e condições materiais tidos como "urbanos" que se expressariam num "ideal rurbano" (CARNEIRO, 1998, 1999). Este

${ }^{24}$ Um exemplo disto pode ser encontrado na seguinte passagem de Mônica Aparecida Benevuto. "O distanciamento da Imagem de "roceiro" e "caipira" por meio de comportamento e usos de roupas, especialmente entre membros mais jovens de comunidades rurais, chamou-me a atenção durante a realização do trabalho de campo para minha dissertação de mestrado. Na comunidade investigada, havia interesse em mostrar que os jovens não tinham “cara nem jeito de roceiros” (BENEVUTO, 2000, p. 150). 
processo pode ser entendido como um, entre outros, fenômeno de hibridização cultural. Isto é, como resultado do contato entre grupos culturais distintos, que produzem misturas interculturais (CANCLINE, 2006).

O fenômeno descrito por Carneiro $(1998,1999)$ é relevante para entendermos as juventudes nos espaços sociais agrários, porém requer alguns cuidados. Pode-se pressupor que os signos da juventude estejam vinculados a um ideal urbano, que se instituiriam como uma "nova mentalidade rural" (CARNEIRO, 2007) incorporada e manifesta por estes jovens. O limite residiria em não superar a dicotomia rural-urbana, trazendo ela para a compreensão da própria juventude. Ou seja, o "urbano" permanece como noção subjacente do entendimento sobre a manifestação do fenômeno juvenil no campo. Deste modo, ser jovem implicaria, necessariamente, negar o modo de vida da agricultura familiar, obstruindo a possibilidade do reconhecimento da especificidade da condição juvenil neste contexto.

De modo alternativo, entende-se que o que está em jogo não são ideais urbanos, mas os ideais juvenis propriamente ditos. Ou seja, o que é reinvidicado por estes jovens não é um ideal urbano, mas sim um ideal juvenil. Inverte-se a lógica do problema, substituindo-se na interpretação deste processo de hibridização a pauta da urbanidade pela da juvenilidade, colocando-se, deste modo, a produção e apropriação dos sentidos sobre a juventude no centro da análise.

Os sentidos atribuídos por estes atores ao consumo ostensivo de símbolos juvenis, marcadamente através do vestuário e acessórios, são símbolos de status e reconhecimento enquanto jovens. Tal como demonstrou o antropólogo Lívio Sansone (2007), ao estudar os jovens negros de classe baixa em Salvador e Amsterdã, trata-se da apropriação ou reapropriação de emblemas de uma cultura jovem, típicas das classes médias. Isso nos remete a uma maneira de expressar o desejo por mobilidade social ascendente, principalmente para os jovens das classes trabalhadoras como é o caso dos agricultores familiares. Neste sentido, usar roupas da moda, bonés ou tênis de marca são - na perspectiva dos jovens - elementos de atribuição de status social. Em outras palavras, estes produtos não são valorizados por seus usuários em razão de serem "tipicamente urbanos", mas, sim por serem signos da cultura juvenil, própria das classes médias, neste aspecto representam mais um ideal juvenil e de status do que de urbanidade.

Além disso, deve-se evitar vincular as referências culturais a uma dimensão geográfica, ao invés de considerá-la como fluxos de sentidos que emergem nos diversos processos de interação social. Alternativamente, pode-se pensar que tais padrões culturais não 
deixaram de ser homogêneos, porque, na verdade nunca foram plenamente unificados (HALL, 1999, p. 13). Reconhece-se que a cultura juvenil entre os agricultores familiares e outros "jovens rurais" tenha sua própria complexidade enigmática. Desvendá-la requer considerar a cultura em termos de geração de significados partilhados, o que nos conduz ao menos três tipos de questões. Como na estrutura do espaço social agrário isto acontece? Em que momento os jovens the conferem significado e sentido? Quais são os significados por eles atribuídos a estes elementos simbólicos?

Encontram-se algumas pistas instigantes para enfrentar estas questões na obra do antropólogo Fredrik Barth (2000). A primeira delas é que a geração de significados se dá em lócus específicos. Ou seja, "significar é uma relação entre uma configuração ou signo e um observador, e não algo sacramentado em uma expressão cultural particular" (BARTH, 2000, p. 128). Deste modo, pode-se buscar ligar os códigos da cultura juvenil, manifestada por jovens agricultores familiares, com suas experiências particulares, seus conhecimentos e suas orientações. Estes sujeitos reconstroem os signos da cultura, fazendo com que esta seja reelaborada a partir de um novo universo de interações e significação.

Além disto, "a cultura é distributiva" (BARTH, 2000), o que implica reconhecer que estes códigos são compartilhados por uns e não por outros. Sendo assim, para se obter uma compreensão complexa dos seus efeitos e as consequências sistemáticas da criação de uma cultura juvenil entre agricultores familiares, não devemos nos debruçar sobre o que há de comum e compartilhado. Deve-se atentar, pelo contrário, para o que se encontra encoberto pelas aparências da similitude, ou seja, o que há de traços singulares desta cultura, na sua “distribuição multiforme de padrões de não-compartilhamento" (BARTH, 2000, p. 128).

Pode-se mencionar ainda que os jovens encontram-se sempre posicionados num espaço de relações sociais. A partir destas posições é que eles interpretam e compartilham suas próprias vidas e a dos outros grupos e gerações. Como o meio rural é um espaço não exclusivamente agrícola, os jovens agricultores entram em interações com jovens nãoagrícolas, produzindo um diálogo entre jovens em posições diferenciadas. Com isto, impõe-se à pesquisa social a necessidade de tentar compreender os processos sociais a partir do ponto de vista dos próprios jovens agricultores familiares, reconhecendo-se que isto é sempre uma aproximação parcial. Uma vez que, tanto sujeito pesquisador como sujeito pesquisado acessam o mundo por meio de um horizonte limitado (BARTH, 2000). A tarefa que se impõe, então, é mapear estes sentidos fazendo emergir, por meio da análise, suas conexões, suas determinações e implicações recíprocas. Isto ocorre no trabalho de reconstrução sociológica 
da realidade, conferindo-lhe uma unidade coerente que extrapola a percepção dos sujeitos investigados.

Finalmente, entende-se que a construção das culturas juvenis revela traços diferenciados que vão para além da padronização aparente. O espaço privilegiado para os jovens se apropriarem destes códigos geracionais e construírem sua autorrepresentação são os locais de vivência com seus pares de idade.

Os espaços de sociabilidade juvenil são importantes para produção de processos de identificação e auto-identificação dos jovens. O encontro dos jovens com seus pares de idade regula a veiculação das aspirações, propicia o compartilhamento e exercício das regras sociais. Nestes espaços de interação social juvenil, eles buscam - e encontram - sustentação objetiva a elementos simbólicos relativos a gostos, disposições e visões de mundo que contribuem para moldar suas identidades. Deste modo, pode-se perceber nos espaços de sociabilidade juvenil uma dualidade própria, ou seja, cumprem uma dupla função constitutiva da juventude. Eles funcionam tanto como dispositivos geradores de processos de identificação assegurando a adesão subjetiva dos atores a identidades compartilhadas, quanto se inscrevem como ambientes nos quais os jovens exercem sua capacidade de agência e constroem suas auto-identidades.

\subsection{JUVENTUDE COMO REPRESENTAÇÃO SOCIAL E AUTORREPRESENTAÇÃO}

O enfoque centrado nas representações enfatiza que a noção de "juventude" aparece como uma expressão discursiva de uma realidade objetiva. O termo designa um conjunto de relações sociais específicas, vividas por elementos classificados como jovens em uma dada sociedade. Deste modo, a categorização desloca-se da faixa etária para enfatizar as relações sociais de poder e dominação que configuram a condição juvenil, ou seja, esta posição na hierarquia social que dá sentido às representações sociais. Busca-se apreender os significados que são acionados na definição de quem é e quem não é considerado jovem em um dado contexto sócio cultural, abrindo-se, assim, a possibilidade de relativização entre os diversos sentidos atribuídos a esta categoria. Estes critérios de inclusão e exclusão são socialmente construídos, tornando-se móveis suas fronteiras. Um exemplo deste enfoque encontra-se na 
publicação intitulada História Social dos Jovens, organizada por Levi e Schmitt (1996). Conforme salientam estes autores:

\begin{abstract}
Na juventude encontra-se ainda um conjunto de imagens fortes, de modos de pensar, de representações de si própria e também da sociedade como um todo. Estas imagens constituem um dos grandes campos de batalha do simbólico. A sociedade plasma uma imagem dos jovens, atribui-lhes caracteres e papeis, trata de impor-lhes regras e valores e constata com angústia os elementos de desagregação associados a esse período de mudança, os elementos de conflito e as resistências inseridas nos processos de integração e reprodução social. Portanto, para além das taxinomias mais consolidadas (as referentes à época da vida, da maioridade do ponto de vista dos direitos civis ou políticos, ou da responsabilidade penal), vamos então interrogar-nos sobre as representações mais vagas, e quem sabe mais esclarecedoras, dos papeis sociais da juventude (LEVI; SCHMITT, 1996, p. 12).
\end{abstract}

Percebe-se que esta abordagem retém a ideia de que os jovens estariam sujeitos à incorporação de uma série de papeis sociais, ou funções socialmente atribuídas através dos processos de socialização. A alternância de papeis sociais e de processos de socialização que marcam a condição juvenil está voltada a assegurar a reprodução ou a continuidade social. Esta abordagem permite entender a constituição de diferentes culturas juvenis, uma vez que percebe a juventude enquanto realidades múltiplas, fundadas em representações sociais diferenciadas.

Entre as diferentes representações acerca da juventude, aparecem aquelas elaboradas pelos próprios jovens. Nas sociedades contemporâneas, há uma crescente diferenciação e diversificação das experiências dos jovens, o que resulta em suas múltiplas filiações identitárias e que corresponde à necessidade de dar sentidos às vivências numa multiplicidade de mundos sociais. A singularização das experiências colabora para a emergência de representações, próprias dos contextos de interação social e oportunidades de individualização. Assim, os jovens tendem a perceber a juventude como um tempo de relativa liberdade de escolhas e experimentação, de vivência do presente mais plenamente possível, e com importância em si mesmo. Percebe-se que esta forma de categorizar torna-se importante por dar ênfase às experiências dos próprios jovens, para os quais a experimentação é o elemento definidor da sua condição social e formadora de suas identidades, sejam elas coletivas ou individuais.

Com efeito, a juventude como uma representação científica, não poderia ser construída a partir de uma substantividade inerente aos atores; ao contrário, propõem-se compreendê-la relacionalmente, ou seja, por meio da análise dos processos interacionais nos 
quais os sentidos atribuídos à juventude são construídos e suas fronteiras são demarcadas. Dito de outro modo, a abordagem das representações enfatiza a determinação sociocultural da juventude, superando-se as abordagens pautadas por uma natureza biológica. Ou seja, o significado da juventude e do que é ser jovem é relacional a outras categorias e não se restringe a uma faixa etária ou período de transição.

\subsection{ALGUMAS CATEGORIAS TEÓRICO-OPERACIONAIS DA SOCIOLOGIA DA JUVENTUDE}

É possível perceber neste debate que a juventude como categoria social é uma construção social, cultural e histórica bastante complexa. Em termos sociológicos, podemos dizer que ela reflete os processos de individualização e racionalização crescentes iniciados na modernidade. O fundamental para sua construção como categoria sociológica é ter presente que a juventude não se constitui, e nem se explica, simplesmente por meio de princípios naturais ou determinações biológicas.

Como expressão da vida social, a juventude aparece como uma categoria complexa que não pode ser definida em função de um único aspecto ou característica. Podemos recorrer às observações de François Dubet (1996) que considera a própria categoria juventude como portadora de uma ambiguidade intrínseca, pois seria, ao mesmo tempo, um momento no ciclo de vida, experimentando as características socioculturais de uma determinada historicidade; simultaneamente, um processo de inserção social ou ainda uma experiência delimitada pela estrutura social.

Reconhecer a complexidade de um fenômeno sociológico não equivale a negar sua possibilidade de compreensão e sistematização por meio de conceitos gerais e válidos para múltiplas realidades. Deste modo, não podemos nos furtar de sistematizar as categorias de análise necessárias ao estudo dos fenômenos juvenis. Para tanto, um primeiro procedimento necessário é considerar que a juventude é uma categoria sociológica; por isto mesmo, seu significado é necessariamente relacional, de tal modo que, assim como afirmou o sociólogo Pierre Bourdieu (1988), sempre somos jovens ou velhos em relação a alguém. Neste sentido, devemos pensar os sentidos da juventude como algo que é produzido em determinados contextos de interação social. Ou seja, tal como propõe Bourdieu, (1998 a, p. 28) para conceber a juventude como categoria sociológica é importante "pensá-la como forma de um 
espaço de relações sociais". Busca-se imprimir contornos nítidos no campo teóricooperacional a esta tomada de posição epistemológica com o estabelecimento de definições sintéticas para as categorias: Juventude, Jovens, Condição Juvenil; Situação Juvenil.

Entende-se por juventude uma categoria relacional fundada em representações sociais, tais como as que conferem sentidos ao pertencimento a uma faixa etária, que posiciona os sujeitos na hierarquia social a fim de promover a incorporação de papeis sociais através dos diferentes processos de socialização que configuram as transições da infância à vida adulta. Parafraseando Mannheim (1982), podemos dizer que a juventude é antes de tudo um signo das relações que a sociedade estabelece, simultaneamente, com seu passado e seu futuro. Entre as características dessa categoria, destaca-se a ambivalência típica de sua situação liminar e transitória; a posição subalterna aos adultos na hierarquia social; a conflitividade originada pelo processo de individualização nesta situação liminar e subalterna; a criatividade e capacidade de inovação própria do contato original das novas gerações com a cultura pré-estabelecida.

Por jovens são designados os indivíduos concretos que vivem os processos de socialização específicos. Constituem-se em sujeitos históricos cujas trajetórias implicam a transição da condição social de criança à vida adulta. Em outras palavras, os jovens constituem a unidade de analise por excelência dos estudos da sociologia da juventude. Estes podem ser definidos como "agentes", isto é, como indivíduos socialmente constituídos na totalidade de suas determinações e dotados de poder de produzir impactos significativos na ordem social, quanto como "atores", ou seja, aqueles que desempenham papeis específicos e pré-estabelecidos. ${ }^{25}$

Além das categorias já citadas, outras duas se impõem. Seguindo a trilha de Miguel Abad (2002) e Marília Sposito (2003), buscamos explicitar as diferenças entre condição e situação juvenil.

A condição juvenil corresponde ao modo como a sociedade constitui e atribui significados às juventudes em determinadas estruturas sociais, históricas e culturais, implicado um modo de ser jovem determinado por estruturas sociais mais amplas. Desta maneira, busca-se destacar que, mais do que uma faixa etária, a condição juvenil é uma posição na hierarquia social. No caso dos jovens, corresponde a uma posição subordinada aos

${ }^{25}$ Tal como propõe o sociólogo português Rui Pena Pires (2007), os dois conceitos - agente e ator social - estão relacionados, já que os agentes são indivíduos socialmente constituídos pelo desempenho de múltiplos papeis, o desempenho dos papeis é condicionado não só pelos sistemas de regras que os especificam como também pelas intersecções presentes e passadas, num mesmo agente, de diferentes tipos de papeis, bem como pelas posições sociais ocupadas pelos agentes, as quais condicionam as possibilidades diferenciais de exercício daqueles papeis. 
adultos. Lembrando que esta é, por definição, uma condição transitória que se perde com a passagem dos anos, os pesquisadores da UNESCO (2004) argumentam que a superação da subordinação e a conquista de autonomia constituem o eixo central da trajetória que os jovens deverão percorrer.

Por sua vez, "a situação juvenil" diz respeito aos diversos percursos experimentados pela condição juvenil, ou seja, traduz as suas diversas configurações. Esta última categoria é utilizada então para referir-se aos variados processos empíricos, condições conjunturais e particularizadas das múltiplas juventudes.

Estes dois últimos conceitos nos remetem ao fato de que estas primeiras definições seriam incompletas se não incorporassem a multiplicidade destas representações sociais. Isto é, implicam a necessidade de pensarmos mais em termos de juventudes no plural do que no singular, uma vez que estas vivem realidades sociais diversas, construindo experiências e identidades juvenis distintas (WEISHEIMER, 2005). "Ou seja, a juventude só pode ser entendida em sua especificidade, em termos de segmentos de grupos sociais mais amplos" (CARDOSO; SAMPAIO, 1995, p. 18). Esta postura conduz à necessidade de qualificá-la, percebendo-a como uma categoria social complexa e heterogênea, na tentativa de evitar simplificações e esquematismos (VELHO, 2006).

Para efeito de análise, entende-se que a especificidade das juventudes pode ser estabelecida através do exame dos processos de socialização nos quais os jovens estão inseridos (WEISHEIMER, 2004, 2005a, 2005b, 2007). Ao serem consideradas, por exemplo, as diferenças de classe social, etnia e gênero, percebem-se distinções relativas às posições ocupadas nos espaços sociais por estes jovens e consequentemente distinções relativas aos respectivos processos de socialização. Ou seja, para conferir maior precisão analítica à juventude como categoria sociológica é necessário relacioná-la aos processos de socialização predominantes entre os jovens estudados.

Este posicionamento rompe com as definições de caráter substancialista sobre a juventude, possibilitando construir a categoria analítica de modo relacional, isto é, em termos de sua posição num espaço de relações (BOURDIEU, 1989) sociais. Com efeito, a reconstrução sociológica da condição juvenil, com base no processo de socialização confere maior coerência à proposta de privilegiar as noções de juventudes (representações) e jovens (sujeitos/atores/agentes) no plural.

Assumindo-se as consequências do debate teórico proposto neste capítulo, torna-se necessário buscar estabelecer com precisão o que marca diferencialmente a socialização dos 
jovens agricultores familiares. Para isto, é necessário enfrentar o debate conceitual sobre a agricultura familiar e identificar a participação juvenil nesta ocupação. Este é o tema do próximo capítulo. 


\section{JUVENTUDE E AGRICULTURA FAMILIAR NO RIO GRANDE DO SUL}

O objetivo deste capítulo é discutir a inserção juvenil na agricultura familiar no Rio Grande do Sul. Para isto, inicia-se buscando apresentar um marco teórico para agricultura familiar. Nesta parte, são apresentadas de modo sintético as trasnformações no debate brasileiro a fim de demonstrar como esta categoria vai ganhando legitimidade. Na sequência, discutem-se as articulações entre o modo de produção capitalista e as formas familiares de produção agrícola a fim de apontar a pertinência teórica da categoria agricultura familiar. $\mathrm{O}$ argumento defendido é que a expansão das relações mercantis e da subordinação do trabalho ao capital implicam o fim das sociedades camponesas e a emergência da agricultura familiar.

Em seguida, discute-se como este segmento realiza um processo de trabalho sui generis no capitalismo, que se realiza a partir de relações familiares. Isto implica a caracterização do processo de trabalho familiar agrícola e sua articulação indissociável com as dinâmicas de reprodução social da agricultura familiar. Este aspectos formam a infraestrutura sorbe a qual se configura a situação juvenil na agricultura familiar, de tal modo que os jovens agricultores familiares podem ser percebidos como uma categoria social específica devido às peculiariades da socialização no processo de trabalho familiar agrícola.

Uma vez comprovada a especificidade sociológica desta juventude, busca-se resgatar sua participação no desenvolvimento da agricultura familiar no estado e os efeitos da modernização agrícola sobre ela. No último tópico, discute-se a participação juvenil na composição da força de trabalho ocupada na agricultura familiar no Rio Grande do Sul, estabelecendo-se comparações com outras faixas etárias e entre os sexos.

\subsection{UM MARCO CONCEITUAL PARA AGRICULTURA FAMILIAR}

O propósito deste tópico é discutir os marcos conceituais que sustentam a noção de agricultura familiar. Isto permitirá posicionar os jovens agricultores familiares no espaço de relações sociais de produção, o que lhes confere sentido e especificidade como categoria social e analítica. A agricultura familiar é uma denominação que emerge com força entre os estudiosos brasileiros a partir da década de 1990. Busca-se demostrar como esta categoria é adequada para interpretar a produção familiar no contexto de domínio do modo de produção 
capitalista na agricultura. Este tópico encontra-se organizado em duas partes: a primeira se propõe a apresentar as transformações ocorridas no debate brasileiro sobre o tema; a segunda, a discutir as implicações das relações capitalistas sobre as formas familiares de produção agrícola.

\subsubsection{Transformações no debate brasileiro sobre as formas familiares de agricultura}

De meados dos anos de 1950 até o final da década de 1960, os debates realizados sobre "a questão agrária brasileira" buscavam explicar, do ponto de vista da economia política e da história, o caráter do desenvolvimento capitalista no Brasil, tendo como base principal o referencial marxista clássico. Nesses estudos, o termo "campesinato" abrangeria um conjunto de diferentes tipos de produtores minifundiários caracterizados pela produção de subsistência, que apareciam em oposição ao latifúndio. Minifúndio e latifúndio correspondiam às categorias que conformavam a estrutura agrária brasileira. As relações que se estabeleciam entre elas levaram a interpretações que as caracterizavam como "resquícios feudais" no campo brasileiro. Esta opinião alicerçava-se em duas ideias. A primeira apontava para o fato de que o trabalho agrícola encontrava-se imobilizado, não se constituindo em mercadoria, devido aos vínculos personalistas e clientelistas que se estabeleciam entre grandes proprietários fundiários e lavradores dependentes, situação que ficou conhecida como coronelismo. A segunda correspondia ao entendimento de que, sob estas condições de monocultura para exportação, não se desenvolvia internamente a integração ao mercado capitalista, de consumo, de crédito e de produtos. Deste modo, a ênfase destes estudos recaía na ideia de que a agricultura, tal como estava organizada no país, representava um obstáculo ao desenvolvimento capitalista no Brasil.

A voz discordante das tese feudal foi de Caio Prado Jr. que, desde o final da década de 1940, se opusera à interpretação feudal do campo brasileiro, o que ficaria explícito em $A$ Revolução Brasileira. Para esse autor, o dualismo agrário no Brasil era resultado do tipo de capitalismo dependente aqui desenvolvido. De um lado, o latifúndio se constituía como uma "exploração agromercantil" que explorava a mão de obra dos trabalhadores sem acesso a terra para "o fornecimento em larga escala de produtos primários aos mercados europeus" (PRADO JÚNIOR, 1969, p. 11). De outro, o campesinato, descrito como "pequenos 
produtores que trabalham por conta própria em terras suas ou arrendadas" (PRADO JÚNIOR, 1969, p. 15), estava "voltado para a produção de gêneros de subsistência da população" (PRADO JÚNIOR, 1969, p. 13) e convertia-se, aceleradamente, em uma forma de "assalariamento disfarçado"; portanto, constituía-se como proletariado rural. (PRADO JÚNIOR, 1978).

Apesar dos diferentes enfoques nos debates realizados entre os marxistas sobre a questão agrária brasileira, conforme destacam Maria Estela Grossi Porto e Deis Elucy Siqueira (1994), o importante é reter que, nesse período, a categoria analítica de campesinato está carregada de conteúdo político e ideológico, visto que a preocupação era identificar seu papel no desenvolvimento capitalista e na revolução socialista.

Os anos de 1960 e 1970 foram marcados pela intensificação das políticas de "modernização da agricultura", o que significou a implementação de inovações tecnológicas promovidas através do apoio do Estado. Além de aumentos nos índices de produtividade agrícola, esse processo resultou em novas formas de organização da produção e relações sociais no campo. Seu modelo de desenvolvimento apontava para a sociedade urbano/industrial, sendo o rural sinônimo de arcaico. Enfatizava também a necesidade de libertar o camponês das antigas relações pré-capitalistas de trabalho no campo, mas o fez às custas de um enorme êxodo rural. Isto porque esta modernização foi incapaz de resolver o problema da concentração da propriedade da terra; à qual permanecem subordinados os trabalhadores rurais, limitando a qualidade de vida das populações do campo e da cidade.

Na década de 1970, houve um deslocamento neste debate, com a emergência da noção de pequeno produtor. Sua crescente utilização, segundo Porto e Deis Siqueira, deve-se a dois tipos de processos:

[...] por um lado as transformações políticas no Estado brasileiro, implicando, entre outras coisas, na desarticulação de vários grupos e de movimentos organizados, entre os quais destacava-se, no contexto dessa reflexão, o das Ligas Camponesas. Por outro, a conformação de um modelo de desenvolvimento assentado em políticas de cunho modernizante e que, em termos da agropecuária, traduziu-se no que convencionou-se identificar como modernização conservadora (PORTO \& SIQUEIRA, D. 1994, p. 79).

O termo pequena produção contribuiu para demarcar uma conotação menos politizada do que a noção de campesinato. A utilização desta denominação apresentou-se enquanto categoria operacional, associada, mais diretamente, à caracterização de realidades imediatamente empíricas dos grupos estudados. Este termo receberia, ao longo da década de 
1980, o acréscimo de outras duas noções: "integração" e "exclusão", que demarcavam a forma de relação estabelecida com o capital, notadamente o industrial (complexo agroindustrial). Contudo, a noção de camponês não deixou de ser utilizada. Sólidas pesquisas foram realizadas na segunda metade dos anos 1970, buscando articular ambas as categorias, principalmente fazendo uso da formulação chayanoviana de modo de produção camponês, visto como processo de trabalho indiretamente subordinado ao capital. ${ }^{26}$

Na década de 1980, o debate prosseguiu incorporando as transformações econômicas e tecnológicas presentes na agricultura brasileira. Predominaram assim as discussões em torno do grau de "integração" e "exclusão" das pequenas propriedades em relação aos complexos agroindustriais. Consideravam-se como integrados os agricultores que tinham sua produção agrícola voltada às demandas da agroindústria e do mercado consumidor. Por sua vez, os agricultores excluídos eram aqueles cuja produção não estava voltada aos complexos agroindustriais e que não haviam incorporado os processos de modernização agrícola (PORTO \& SIQUEIRA, D. 1994). Outra novidade deste período é a emergência de novos atores e movimentos sociais no campo. Destacam-se as questões trazidas pela retomada das lutas pela reforma agrária e pelo reconheciemento dos direitos sociais e trabalhistas para as mulheres, como produtoras rurais.

Foi apenas no final dos anos 1980, num trabalho realizado por Ângela Kageyama e Sônia Bergamasco, que pesquisadores brasileiros fizeram uso do volume do trabalho assalariado por estabelecimentos agropecuários como critério de classificação. As autoras constataram que a agricultura com base no trabalho familiar representava mais de $70 \%$ dos estabelecimentos agrícolas no Brasil (KAGEYAMA; BERGAMASCO, 1989). O termo "agricultura familiar" ganharia legitimidade a partir dos anos 1990, através de um processo que envolve questões acadêmicas e políticas.

No âmbito acadêmico, foram pioneiros nos estudos da agricultura familiar os trabalhos de José Eli da Veiga (1991) e Ricardo Abramovay (1998) ${ }^{27}$, , assim como o estudo internacional realizado pela equipe liderada por Hughes Lamarche (1993, 1998), que contou com a participação dos sociólogos brasileiros Anita Brumer, Guislaine Duque, Fernado Antonio Lourenço e Maria Nazaré Baudel Wnderley. Estes estudos conferiram um estatuto teórico à categoria de agricultura familiar, dando visibilidade a esta forma social de

\footnotetext{
${ }^{26}$ Destacam-se como principais referências no âmbito destes estudos os trabalhos de Garcia Jr. (1983) Heredia (1983); e Tavares dos Santos (1984).

${ }^{27}$ Cuja a tese entitulda "De camponeses a agricultores - paradigmas do capitalismo agrário em questão" foi defendida em 1990 e publicada pela primeira vez em 1992.
} 
agricultura. Segundo Sérgio Schneider (2003), o grande mérito destes trabalhos foi o de terem revelado que a agricultura familiar correspondia a uma forma social reconhecida e legitimada na maioria dos países desenvolvidos, onde a estrutura agrária é majoritariamente composta por explorações nas quais o trabalho da família assume uma importância decisiva. Ainda conforme Schneider (2003), a distinção entre campesinato e agricultura familiar presente particularmente no trabalho de Ricardo Abramovay vem exercendo grande influência nos estudos nacionais por conferir maior valor heurístico e conceitual à agricultura familiar como objeto sociológico, superando a falsa dicotomia em torno do caráter tradicional versus moderno ou capitalista versus camponês que caracterizou o debate precedente.

No campo político, primeiramente, o termo emerge como categoria-síntese utilizada pelos movimentos sociais do campo, especialmente o sindicalismo rural ligado à Central Única dos Trabalhadores (CUT) e à Confederação Nacional dos Trabalhadores na Agricultura (CONTAG). Estas organizações, no início da década de noventa, usam o termo para fazer a defesa de seus interesses frente à constituição do Mercosul. Depois, ao longo da década, ele é utilizado nas mobilizações anuais do "Grito da Terra", ${ }^{28}$ para agrupar um amplo leque de movimentos que reinvidicam políticas de preços e de crédito diferenciadas para os agricultores familiares (SCHNEIDER, 2003).

Merece destaque ainda o convênio FAO/INCRA, em 1994, coordenado por Carlos Guanziroli que compara o desempenho econômico entre a agricultura familiar e a agricultura patronal, mostrando a superioridade econômica da primeira, apesar de esse modelo dispor de menor acesso a terra e a crédito. Este estudo identificou três categorias de agricultores familiares: a) familiar consolidada, integrada ao mercado; b) familiar de transição e c) familiar de subsistência ou periférica, mostrando principalmente que esta não era formada por um público homogêneo. Este relatório embasou a proposição de instrumentos de apoio à agricultura familiar, servindo de base para a elaboração do PRONAF. Assim, o termo adquire legitimação institucional, sendo incorporado pelo Estado ao criar o Programa Nacional de

\footnotetext{
${ }^{28}$ Com a intensificação das lutas sindicais dos agricultores, aproximação e definição de estratégias de mobilização conjuntas por parte da CONTAG e do Departamento dos Trabalhadores Rurais da CUT (DNTR/CUT), ganham destaque as Jornadas Nacionais de Lutas que, a partir de 1995, passariam a ser conhecidas como "Grito da Terra". Ainda em 1993, estas organizações apresentaram ao governo presidido por Itamar Franco uma proposta de crédito de investimento subsidiado para os agricultores familiares que destacava a necessidade de um programa que contemplasse a diversidade existente no interior da agricultura brasileira. Atendendo a esta reivindicação, foi criado o Programa de Valorização da Pequena Produção Rural (PROVAP) no âmbito do Ministério da Agricultura e do Abastecimento. O PROVAP era fundamentalmente uma linha de crédito voltada a atender os agricultores familiares com juros baixos (de $4 \%$ a.a., sem correção monetária).
} 
Fortalecimento da Agricultura Familiar (PRONAF), em 1996. ${ }^{29}$ Esse processo de consolidação da agricultura familiar como categoria política atinge um novo grau de institucionalização em 2006, com a sanção presidencial da Lei 11.322/06, que estabelece a Política Nacional de Agricultura Familiar e Empreendimentos Familiares Rurais. Com ela, a agricultura familiar passa a ser reconhecida como um segmento produtivo e adquire estatuto legal..$^{30}$

É possível constatar neste debate que há uma relação entre as transformações por que passa o objeto de estudo e os confrontos e as reorientações teóricas que o subsidiaram, cujo resultado, até o presente, é a consolidação da categoria agricultura familiar. Contudo, considerando a diversidade das formas empíricas em que se manifesta, esta permanece como uma categoria bastante genérica. Isto porque, como indicou Lamarche, "a exploração familiar não é um elemento da diversidade, mas contém nela mesma toda a diversidade" (LAMARCHE, 1993, p. 18). Ainda é tarefa o aprimoramento desta construção analítica, uma vez que a combinação entre terra, trabalho e família assume uma grande diversidade de formas sociais. A seguir, examina-se como esta categoria se forja a partir das articulações entre agricultura e capitalismo.

\subsubsection{Capitalismo e Agricultura Familiar}

Discute-se agora como as dimânicas promovidas pelo modo de produção capitalista envolevem a agricultura, transformando as relações de produção camponesas sem disolver o processo de trabalho familiar na agricultura. Neste sentido, a primeira questão que se impõe é estabelecer o cárater deste modo de produção.

\footnotetext{
${ }^{29}$ Em 1995, sob o governo de Fernando Henrique Cardoso, o PROVAP passa a ser reformulado. Essas modificações resultariam no Decreto Presidencial n. 1.946 de 28 de junho de 1996, que institui o PRONAF no âmbito do Ministério da Agricultura. Conforme este decreto, o PRONAF surge tendo como objetivo geral "propiciar condições para o aumento da capacidade produtiva, a geração de empregos e a melhoria da renda, contribuindo para a melhoria da qualidade de vida e a ampliação do exercício da cidadania por parte dos agricultores familiares".

${ }^{30}$ Conhecida como Lei da Agricultura Familiar, foi aprovada pelo Congresso Nacional em 4 de julho de 2006. A lei define os conceitos da agricultura familiar e do agricultor familiar e prevê a descentralização - com a participação de Municípios, Estados, Governo Federal e produtores rurais - no desenvolvimento e na gestão dos programas agrários. Disponível em: http://www.incra.gov.br. Acesso em: 29 jul. 2006.
} 
Conforme Karl Marx (1968, 1985, 2004), o que define o caráter de um modo de produção $^{31}$ é a articulação existente entre as forças produtivas e as relações sociais de produção. Essa articulação visa a assegurar a própria reprodução do modo de produção. Com isso, podemos dizer que os modos de produção até hoje existentes se definem pela presença de classes sociais complementares e antagônicas que resultam da articulação entre determinado estágio de desenvolvimento das forças produtivas e suas correspondentes relações sociais de produção.

No capitalismo, este processo implica o fato de que: a) todo produto social toma a forma de mercadorias (e não apenas uma fração exedente); b) a própria força de trabalho é uma mercadoria; c) o capital, que é uma relação social, cristaliza-se em meios de produção que são também mercadorias. Este processo possibilita a extração da mais-valia como aproporiação privada do valor gerado pelo trabalho social e potencializa a circulação do capital em base ampliada. Ou seja, conforme expõe Karl Marx, o que define o capitalismo não é simplesmente a produção de mercadorias, mas, precisamente, o fato de que: "1) As mercadorias são produto do capital; 2) a produção capitalista é a produção de mais-valia 3) é, no fim de contas, produção e reprodução do conjunto da relação, e é através disso que este processo imediato de produção se caracteriza como especialmente capitalista" (MARX, 2004, p. 37).

Com base nesta definição geral, os camponeses aparecem na teoria marxista como uma "exploração parcelar" ${ }^{32}$, ou seja, que produz em uma parcela restrita de terra e que estão integrados parcialmente ao processo de divisão social do trabalho. A maior parte de sua produção é utilizada como meio de subsistência, logo, possui apenas valor de uso e não valor de troca, ao contrário do agricultor, que depende totalmente da venda de seu produto, que é mercadoria.

Os camponeses, como trabalhadores e proprietários dos meios de produção, configuravam uma situação atípica no capitalismo, sendo percebidos como resquícios de um

\footnotetext{
${ }^{31} \mathrm{O}$ conceito de modo de produção em Marx aparece qualificado por algum termo como, escravista, feudal ou capitalista. Isso ocorre porque, em sua análise, Marx não aborda a produção em geral, mas se refere sempre à produção em um determinado estágio de desenvolvimento das forças produtivas da humanidade. Além disso, é importante considerar que este conceito não se reduz a uma interpretação econômica da sociedade, ou seja, ao processo de produção de bens materiais. Outrossim, trata-se de uma ferramenta teórica que inclui outros níveis de realidade social, como o jurídico, o político e o ideológico, que figuram no plano da superestrutura da sociedade. Ou seja, o modo de produção é um conceito que permite pensar a totalidade social.

32، A exploração parcelar não tem como barreira o lucro médio do capital, ainda que o camponês seja um pequeno capitalista, nem a necessidade de renda, ainda que ele seja um proprietário de terra. Sendo ele um pequeno capitalista, o único limite absoluto é constituído pelo salário que ele atribui a si mesmo, feita a dedução de suas despesas propriamente ditas" (MARX, 1985, p.185).
} 
modo de produção pré-capitalista. Assim, são descritos como uma forma de "produção simples de mercadorias", ${ }^{33}$ uma vez que eles não correspondem propriamente a nenhuma das três classes fundamentais do capitalismo na agricultura: o capitalista industrial, o proprietário fundiário e o trabalhador agrícola assalariado. A cada uma delas corresponderia, respectivamente, uma das três formas de divisão do valor: o lucro, a renda da terra e o

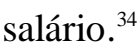

Percebe-se que, apesar da aliança entre capitalista e proprietário fundiário, o segundo possui, na propriedade do solo (condição para a renda absoluta), na diversidade natural dos tipos de solo (condição para a renda diferencial), um título que lhe permite embolsar uma parte dessa mais-valia, para a qual ele não contribui nem para dirigir nem para criar. Por isto, acrescenta Marx, o capitalista considera o latifundiário como uma mera excrescência, um parasita e mesmo um entrave para a produção capitalista. (MARX, 1985; AMIN, 1977; ROSDOLSKY, 2001). Esse processo é geral e dominante no capitalismo, mas não pode ser considerado como homogêneo. Há toda uma série de arranjos específicos, estruturais e conjunturais, na expansão e dominação das relações capitalistas na agricultura que Marx não considerou. $^{35}$

Para os propósitos deste estudo, encontra-se na obra do economista russo Alexander Chayanov $(1974,1981)$ uma análise apurada da interação entre capitalismo e agricultura que se realiza com base no trabalho familiar. Sua perspectiva teórica buscou integrar as vertentes

\footnotetext{
33 Este conceito está presente na perspectiva neomarxista de Harriet Friedmann (1978) para a análise da reprodução das formas familiares na agricultura que estariam organizadas com base em relações sociais específicas segundo a qual "a condição básica para a reprodução da produção simples é a contínua recriação da integridade da unidade familiar como unidade de produção e consumo pessoal" (FRIEDMANN apud SCHNEIDER, 2003, p. 56).

${ }^{34}$ Marx tomou como parâmetro para sua análise do capitalismo na agricultura o caso inglês. No Capítulo XXIV do volume. 1 de $O$ Capital, ele descreve "A chamada acumulação primitiva", ponto de partida do regime capitalista de produção. No item 2, analisa "Como foi expropriada a terra da população rural": Os antigos senhores feudais valeram-se de seu poder e iniciaram o processo de cercamento dos campos, com vista à criação de ovelhas para a nascente indústria de lã, expulsando os camponeses que as utilizavam para seus cultivos. Também a reforma religiosa impulsionou um violento processo de expropriação da maioria do povo que vivia em posses feudais da Igreja. A revolução gloriosa declarou a nova era de saque dos terrenos de domínio público e bens comunais. Com a lei do cercamento das terras comunais, transformando-as em propriedade privada sem conceder nenhuma indenização aos camponeses expropriados. A terra, que era um bem, coletivo transforma-se em propriedade privada: "Com estos métodos se abrió paso a la agricultura capitalista, se incorporo el capital a la tierra y se crearon los contingentes de proletários libres y privados de medios de vida que necessitaba la industria de las cidades." (MARX, 1973, p. 624)

35 Aqui é interessante estabelecer uma distinção entre modo de produção e formação social. O conceito de formação social é utilizado para designar uma totalidade social concreta e historicamente determinada, com suas diferenciações internas, ou seja, refere-se ao conjunto da sociedade, a qual possui uma dupla dimensão: a da infra-estrutura e a da superestrutura. Esse conceito é concernente às realidades complexas e impuras (diferentemente do conceito de modo de produção). Uma formação social corresponde a uma totalidade social que guarda em seu interior diferentes estágios de desenvolvimento das forças produtivas e distintas relações sociais de produção, bem como diferentes processos de trabalho (WEISHEIMER, 2008, p. 163).
} 
da economia política de Marx com as diretrizes da escola marginalista (econômica neoclássica) produzindo uma teoria econômica do campesinato com ênfase na microeconomia. Este autor parte do que chamou de modo de produção camponês (não-capitalista) cujas unidades elementares são formadas por famílias simultaneamente proprietárias dos meios de produção, realizadoras do trabalho e gestoras do empreendimeto produtivo. Tais unidades estariam, principalmente, voltadas a suprirem suas demandas internas e comercializariam apenas a fração excedente dos produtos.

Para Chayanov, a unidade de análise fundamental era a família camponesa, considerada como uma totalidade cujo trabalho ele percebeu como indivisível. Ou seja, a família camponesa correspondia a uma unidade de força de trabalho e de consumo centrada em um casal e seus filhos, aos quais podem ser agregados outros membros e cujo esforço se dirige ao que ele descreveu como balanço entre a capacidade de trabalho e a necessidade de consumo buscando alcançar o grau ótimo de exploração. Conforme propunha este autor:

\begin{abstract}
Uma análise mais profunda indica o seguinte: o produto do trabalho indivisível de uma família, e, por conseguinte, a prosperidade da exploração familiar, não aumenta de maneira tão marcante quanto o rendimento de uma unidade econômica capitalista influenciada pelos mesmos fatores, porque o camponês trabalhador, ao perceber o aumento da produtividade do trabalho, inevitavelmente equilibrará os fatores econômicos internos de sua granja, ou seja, com menor auto-exploração de sua capacidade de trabalho. Ele satisfaz melhor as necessidades de sua família, com menor dispêndio de trabalho, e reduz assim a intensidade técnica do conjunto de sua atividade econômica (CHAYANOV, 1981, p. 141).
\end{abstract}

Depreende-se dessa passagem que o caráter indivisível do resultado do trabalho familiar constitui-se na dimensão fundamental para a compreensão da família camponesa. A produção é o retorno da atividade de toda a família, fator este que pode liberar força de trabalho para fora da unidade familiar quando parte dela for excedente, ou introduzir mudanças no padrão tecnológico como estratégia para compensar a escassez de força de trabalho. Chayanov (1974) parte da premissa de que a família tem o controle sobre o próprio trabalho e sobre o processo produtivo que realiza, sendo capaz de definir as melhores estratégias visando à satisfação de suas necessidades com o menor grau de auto-exploração do trabalho. É deste pressuposto que emerge a ideia de que há uma dimensão subjetiva que molda o perfil camponês de seu tempo. De tal modo que:

A familia campesina trata de cubrir sus necesidades de la manera más fácil y, por lo tanto, pondera los medios efectivos de producción y cualquier otro objeto al cual puede aplicarse su fuerza de trabajo, y la distribuye dé manera que brida una 
remuneración elevada. De esta manera, es frecuente que, al buscar la retribución más alta por unidad doméstica de trabajo, la familia campesina deje sin utilizar la tierra y los medios de producción de que dispone si otras formas de trabajo le proporcionan condiciones más ventajosas (CHAYANOV, 1974, p. 120).

Nota-se que, da centralidade da família como promotora do esforço de trabalho e detentora da propriedade e definidora das necessidades de consumo, decorre a importância da evolução de sua composição demográfica, como um elemento chave do próprio processo de transformação interno da unidade família/estabelecimento, o que Chayanov (1981) denominou "diferenciação demográfica". Ou seja, no ciclo de desenvolvimento da família ocorre uma alteração entre o número de consumidores e o de produtores, promovendo uma diferenciação relativa na composição interna do grupo doméstico. Ao longo de sua existência, a família atravessa diferentes ciclos demográficos que determinam tanto a oferta de trabalho quanto o nível de consumo. Há uma história (econômica) da família, em que o apogeu de sua capacidade produtiva é alcançado quando esta consegue um equilíbrio entre os membros trabalhadores e consumidores. Conclui-se, assim, que:

Cada familia, entonces, segun su edad, constitui en sus diferentes fases un aparato de trabajo completamente distinto de acuerdo com su fuerza de trabajo, la intensidad de la demanda de sus necessidades, la relación consumidor-trabahador, y la possibilidad de aplicar los princípios de la cooperacion compleja (CHAYANOV, 1974, p. 55-6).

Em síntese, segundo sua teoria a Unidade Econômica Camponesa (UEC), com plena capacidade de se autodeterminar no processo produtivo, funcionaria com base em quatro aspectos gerais:

a) Ser ao mesmo tempo uma unidade de produtores e de consumidores;

b) Ter a capacidade de estabelecer os objetivos e as estratégias para o equilíbrio entre consumo e penalidade do trabalho, ou seja, buscando atingir o grau ótimo de exploração do trabalho;

c) As UECs não são historicamente homogêneas porque, no seu interior, ocorre uma permanente diferenciação demográfica (da infância à velhice, passando pela juventude e vida adulta), assim, a evolução econômica da família é dada pelo avanço do ciclo etário; 
d) A família sempre realiza um cálculo para decidir entre intensificar a exploração do trabalho ou introduzir mudanças tecnológicas, ou ainda procurar trabalho fora da UEC.

Percebe-se que o eixo central de sua abordagem consiste na afirmação de que essa unidade econômica - a família camponesa - exerce a gestão de sua unidade produtiva, pautando sua orientação por princípios provenientes de seu funcionamento interno, buscando equilibrar a capacidade de trabalho da família com suas necessidades de consumo. Assim, o trabalho familiar se opõe ao trabalho assalariado. Segundo Chayanov (1974, 1981), essa forma de trabalho caracterizado pelo emprego da mão-de-obra familiar confere-lhe uma especificidade, sendo um dos fatores centrais que a diferem das unidades de produção capitalista.

Decorrente desta posição, Chayanov (1974) constata que o preço da terra não é, sob estas condições, equivalente à capitalização da renda, visto que esta não existe, mas ao trabalho necessário para satisfazer as necessidades da família. Ou seja, a terra não é vista como um ativo econômico do qual se extrai uma renda, mas é uma terra de trabalho do qual se produz um sustento, sendo por este balizado seu valor. A segunda conclusão é a de que o chamado modo de produção camponês, quando integrado a uma formação capitalista dominante, perde seu conteúdo de autonomia. O autor constata, então, que a capacidade de resistência da economia familiar camponesa decore da aceitação de baixa remuneração de seu trabalho que faz a agricultura capitalista perder todo o seu poder de concorrência.

Quais as implicações destas constatações? O economista egípcio Samir Amin sugere que a redução da remuneração do trabalho realizado nestas condições é tal que: "1) a renda do solo (renda imputada à propriedade) é anulada; 2) a remuneração do trabalho - a que se reduz o preço dos produtos - equipare-se ao valor da força de trabalho proletária" (AMIN, 1977, p. 29).

Entende-se que a subsunção real $^{36}$ dos agricultores ao capital possibilita aos capitalistas apropriarem-se do valor produzido pelo trabalho familiar sem necessitar repassá-

\footnotetext{
${ }^{36}$ Subsunção, traduzido do alemão subsumtion, que quer dizer subordinação, mas também inclusão (conforme nota de Klaus Von Puchem, tradutor de Capítulo VI Inédito de O capital de Karl Marx. Editora Centauro, 2004). Este conceito é forjado por Marx para diferenciar a subsunção formal - "subordinação direta do processo de trabalho ao capital" (MARX, 2004, p. 104), que ocorre através do contrato de trabalho assalariado, da subordinação real (indireta) do trabalho ao capital, tal como ocorre entre os agricultores familiares que se encontram integrados ao complexo agroindustrial. Conforme Marx, esta - a subsunção real - só ocorre quando o modo de produção capitalista se generaliza transformando o processo de trabalho e as suas condições de realização. Segundo Marx isto ocorre quando "a agricultura de subsistência, transformada em agricultura para o comércio [...] o cultivo do território nacional [...] ajusta-se a esta mudança” (MARX, 2004, p. 104).
} 
lo ao proprietário fundiário na forma de renda da terra. $\mathrm{O}$ trabalho familiar na agricultura permite, deste modo, que uma parte maior do valor seja apropriada pelo empresário capitalista desfazendo a necessidade do latifundiário. Uma nova aliança de classe se produz entre capitalista e proprietário minifundiário. Os produtores familiares (produtores simples de mercadorias) continuam proprietários formais de seus meios de produção, mas, convertem-se em trabalhadores para a agroindústria, produtores de valores de troca (produtos e serviços) ao custo da sua reprodução de simples. ${ }^{37}$ Como resultado, a alteridade camponesa apontada por Chayanov vai sendo solapada pelas condições estruturais e estruturantes das relações plenamente mercantis típicas do capitalismo.

Sobre este último aspecto, Henri Mendras (1978) contribui para o entendimento dos efeitos sociológicos da relação entre capitalismo e agricultura. Ele re-elaborou o termo sociedades camponesas formulado originalmente no âmbito do funcionalismo ${ }^{38}$ para aplicá-lo em termos de tipos ideais à experiência francesa. Segundo este autor, as sociedades camponesas podem ser identificadas pela presença de cinco características:

a) A autonomia relativa das coletividades camponesas frente a uma sociedade envolvente que as domina, mas tolera as suas originalidades;

b) A importância estrutural do grupo doméstico, organização da vida econômica e da vida social da coletividade;

c) Um sistema econômico de autarquia relativa, que não distingue consumo e produção e que tem relações com a economia envolvente;

d) Uma coletividade local caracterizada por relações internas de interconhecimento e de relações débeis com as coletividades circunvizinhas;

\footnotetext{
${ }^{37}$ É este processo que José Vicente Tavares dos Santos descreve com precisão em "Colonos do Vinho - estudo sobre a subordinação do trabalho camponês ao capital" (TAVARES DOS SANTOS, 1984).

38 O termo "Sociedades Camponesas" ganha estatuto científico a partir dos estudos do antropólogo norteamericano Robert Redfield já nos fins de 1940. Este segue as orientações da tradição antropológica de Malinowski e Radcliffe-Brown, transpondo o método utilizado no estudo de "sociedades primitivas" para o campesinato. O termo sociedade é de maior importância, uma vez que para os funcionalistas o objeto de estudo é tomado como uma totalidade autodeterminada (WEISHEIMER, 2004).
} 
e) A função decisiva do papel de mediação dos notáveis entre coletividades camponesas e sociedades envolventes (MENDRAS, 1978, p. 14-5).

Percebe-se que os princípios que estruturavam as sociedades camponesas eram a racionalidade econômica incompleta e os vínculos sociais dados pela tradição e pelas relações personificadas. Neste caso, a vida em comum implicava relações personificadas que operavam com base na reciprocidade - o direito à subsistência e à reciprocidade aparecia como princípios morais que norteavam a "vida da aldeia". A reciprocidade era um dos princípios estruturadores da vida social e material das formações econômicas anteriores ao capitalismo. Assim, a especificidade do campesinato residiria na existência de um código de conduta partilhado comunitariamente até por setores sociais antagônicos, que funcionaria como princípio estruturador da vida social.

Mendras constatou que este padrão de relacionamento social estaria em plena dissolução. Segundo ele, as antigas sociedades camponesas estariam em desaparecimento frente à expansão das relações econômicas capitalistas. Conforme suas palavras: “o 'camponês' transforma-se em agricultor, produtor agrícola que é ao mesmo tempo, ‘empreiteiro' e 'trabalhador', proprietário de seus meios de produção, mas que não utiliza ou só em pequena escala - mão-de-obra assalariada" (MENDRAS, 1978, p. 13). Neste caso, a produção agrícola comandada pelo mercado realiza-se em empresas familiares onde já não mais existe o autoconsumo, e a produção é inteiramente comercializada. Este autor apontava o fim do campesinato no território francês e sua substituição pelo agricultor moderno, visto que: “[...] o camponês não saberá sobreviver ao desaparecimento da coletividade aldeã e da autocracia familiar" (MENDRAS, 1978, p. 15).

Mendras atualiza a posição expressa por Max Weber (1982) no texto "Capitalismo e sociedade rural na Alemanha" que, ao comparar a agricultura nos Estados Unidos da América com a praticada no sul da Alemanha, constatou a incompatibilidade dos últimos em relação às práticas típicas do capitalismo. Desta maneira, ele definiu os camponeses europeus como representantes de uma estrutura social arcaica e em descompasso com o "espírito do capitalismo". Para Weber:

O poder da tradição predomina, inevitavelmente na agricultura, cria e mantém tipos de produção rural no continente europeu que já não existem num pais novo, como nos Estados Unidos; a esses tipos pertence, em primeiro lugar, o camponês europeu. [...] $\mathrm{Na}$ América, o agricultor produz para o mercado. O mercado é mais antigo do que ele na América. $\mathrm{O}$ camponês europeu do tipo antigo era um homem 
que, na maioria dos casos, herdou a terra e produzia principalmente para atender às suas próprias necessidades. Na Europa, o mercado é mais novo do que o produtor. É claro que durante muitos anos o camponês vendeu seus produtos excedentes e, embora tecesse e fiasse, não podia satisfazer suas necessidades com seu próprio trabalho. Os últimos dois mil anos não treinaram o camponês para produzir visando o lucro (WEBER, 1982, p. 124).

Percebe-se, nesta passagem, que Weber opõe a racionalidade camponesa à racionalidade capitalista. Deste modo, ele chamou atenção para o fato de que a expansão do capitalismo implicaria necessariamente a dissolução do campesinato, ou, ao menos, grandes dificuldades para que estes acompanhassem o desenvolvimento capitalista e sua mentalidade plenamente mercantil.

Estas teorias contribuíram para a compreensão atual sobre a agricultura familiar, descrevendo as dinâmicas internas das unidades familiares, ou mostrando a dissolução das relações não-mercantis em comunidades de agricultores. Deste modo, o campesinato pode ser entendido como uma forma particular da agricultura familiar, mas os agricultores familiares já não podem mais ser caracterizados exclusivamente como camponeses. Isto porque ambas as categorias compartilham o caráter familiar das relações de trabalho que se fundamenta nos princípios da reciprocidade interna à família e não por relações formalmente mercantilizadas.

O processo de expansão capitalista impôs profundas mudanças à lógica tradicional camponesa. A autonomia perante o mercado, que era a base objetiva da alteridade camponesa, hoje persiste apenas como expressão de precariedade social e inadequação frente ao mercado de produtos agrícolas. $\mathrm{O}$ modo de produção camponês e a racionalidade típica de atores parcialmente inseridos nas trocas mercantis - sucumbem frente à dinâmica da acumulação do capital. O capitalismo como modo de produção dominante impõe sua racionalidade mercantil como racionalidade dominante. $\mathrm{O}$ que se realiza, principalmente, pela subsunção dos agricultores ao complexo agroindustrial resultando na imposição de novos padrões tecnológicos; consequentemente na crescente dependência destes em relação ao sistema financeiro. Com efeito, a noção de agricultura familiar visa a enfatizar as mudanças que ocorrem com o desenvolvimento do capitalismo na agricultura.

Ricardo Abramovay (1998) sustenta que integração da agricultura de base familiar ao mercado capitalista implicou mudanças na vida social, na racionalidade econômica e nos processos produtivos que caracterizavam o campesinato. Segundo demonstrou este autor, uma agricultura familiar altamente integrada no mercado, capaz de incorporar os avanços técnicos e a responder às políticas governamentais, não pode ser pensada como camponesa. Neste sentido, menciona que: 
As sociedades camponesas são incompatíveis com o ambiente econômico onde imperam relações claramente mercantis. Tão logo os mecanismos de preços adquiram função de arbitrar as decisões referentes à produção, de funcionar como princípio alocativo do trabalho social, a reciprocidade e a personalização dos laços sociais perderão inteiramente o lugar, levando consigo o próprio caráter camponês da organização social (ABRAMOVAY, R. 1998, p. 117).

Segundo esta proposta, no capitalismo, o trabalho agrícola realizado com base em relações familiares e não-salariais denomina-se agricultura familiar. Ainda conforme Ricardo Abramovay (1998), nas circunstâncias de um mercado capitalista plenamente desenvolvido, é mais adequado pensar as formas de configuração e reprodução da agricultura familiar, correspondendo a situações em que a propriedade dos meios de produção e a organização do processo de trabalho encontram-se assentadas em bases de relações familiares. $\mathrm{O}$ autor destaca que no capitalismo "não há atividade econômica em que o trabalho e a gestão se estruturam tão fortemente em torno de vínculos de parentesco e onde a participação de mãode-obra não-contratada seja tão importante" (ABRAMOVAY, R. 1998, p. 209) como na agricultura familiar. Estas características fazem da agricultura familiar um setor único na economia.

Entende-se que os agricultores familiares contemporâneos são agentes dos processos de transformação pelos quais têm passado a agricultura e os espaços sociais agrários. Além disso, esta categoria social vem transformando sua própria existência ao longo da história, adaptando-se ao modo de produção dominante e buscando, ao mesmo tempo, preservar o caráter familiar do processo de trabalho. Tal compreensão torna relevante considerar os elementos endógenos no funcionamento destas unidades produtivas. Este aspecto também está presente na definição esboçada por Ricardo Abramovay (1997):

\footnotetext{
A agricultura familiar é aquela em que a gestão, a propriedade e a maior parte do trabalho vêm de indivíduos que mantém entre si laços de sangue ou casamento. Que esta definição não seja unânime e muitas vezes tão pouco operacional é perfeitamente compreensível, já que os diferentes setores sociais e suas representações constroem categorias científicas que servirão a certas finalidades práticas: a definição de agricultura familiar, para fins de atribuição de crédito, pode não ser exatamente a mesma daquela estabelecida com finalidades de quantificação estatística em um estudo acadêmico. O importante é que estes três atributos básicos (gestão, propriedade e trabalho familiares) estão presentes em todas elas (ABRAMOVAY, R. 1997, p. 3).
}

Em síntese, as características centrais da agricultura familiar residem no fato de que a gestão do trabalho e da propriedade dos meios de produção - mesmo que não, necessariamente, da terra - encontram-se sob a responsabilidade da família, entendida como 
grupo doméstico de trabalho e de consumo, que realiza a reprodução geracional do processo de trabalho e a transmissão do patrimônio familiar.

Diferentemente das unidades camponesas, a causalidade estrutural da agricultura familiar deve-se à expansão do capitalismo na agricultura. Neste sentido, é preciso considerar as diferenças existentes entre os agricultores familiares, que podem envolver desde empresas familiares altamente capitalizadas, que incorporam inovações tecnológicas e de produtividade elevada; estabelecimentos com baixo rendimento produtivo e financeiro, mesmo estando altamente integrados ao mercado através de sistemas agroindustriais; e outros com características próximas do modelo camponês voltado para a produção de subsistência. Apesar do volume e da intensidade das mudanças que marcam as distinções entre camponeses e agricultores familiares, este processo conservou o caráter fundamental da agricultura familiar como uma unidade de produção e de consumo parental, ou seja, manteve-se o caráter familiar do trabalho agrícola. Examinam-se, a seguir, a natureza e características deste processo de trabalho.

\subsection{O PROCESSO DE TRABALHO FAMILIAR AGRÍCOLA}

A agricultura familiar se caracteriza pela realização de um processo de trabalho singular no interior do modo de produção capitalista, o qual se denomina no presente estudo como processo de trabalho familiar agrícola. Processo de trabalho é aquele segundo o qual os seres humanos atuam sobre as forças da natureza, submetendo-as a seu controle e transformando-as em certos valores de uso, ou seja, dando forma útil à sua vida. Segundo Marx (1985), os elementos componentes do processo de trabalho são: a) a atividade adequada a um fim, isto é, o próprio trabalho; b) a matéria a que se aplica o trabalho, o objeto de trabalho; c) os meios de trabalho, o instrumental de trabalho.

O processo de trabalho ocorre pela articulação entre as forças produtivas e as relações sociais de produção. A noção de forças produtivas corresponde aos fatores necessários à produção, como os trabalhadores, os instrumentos de trabalho e os meios de produção. As relações sociais de produção referem-se às diferentes funções executadas por indivíduos ou grupos no processo de produção e no controle dos meios de produção. Trata-se de uma intervenção racional do homem sobre a natureza, detendo uma dimensão subjetiva 
que confere uma lógica ao próprio trabalho. Nessa atividade, os homens criam e recriam a si próprios, uma vez que este processo não produz apenas os meios de vida dos quais depende sua reprodução física imediata, mas, ao fazê-lo, produzem sua própria existência:

\begin{abstract}
O modo como os homens produzem seus meios de vida depende, antes de tudo, da própria natureza dos meios de vida com que se encontram e que se trata de reproduzir. Este modo de produção não deve ser considerado somente enquanto a reprodução da existência física dos indivíduos. Já é, além disso, determinado modo da atividade desses indivíduos, determinado modo de manifestar sua vida, determinado modo de vida dos mesmos. Tal e como os indivíduos manifestam sua vida, assim são. O que são coincide, por conseguinte, com sua produção, tanto com o que produzem como com o modo como produzem. O que os indivíduos são depende, portanto, das condições materiais de sua produção (MARX; ENGELS, 1968, p. 6).
\end{abstract}

Dois aspectos chamam a atenção nesta passagem de Marx e Engels. O primeiro diz respeito ao fato de que, em sua análise, o homem é a personificação do processo de trabalho que realiza; em termos sociológicos, implica reconhecer que o modo de vida produz o sujeito social. O segundo aspecto é que, para Marx, o processo de produção contém em si o seu mecanismo de reprodução. Esta reprodução depende antes de tudo da maneira como os homens produzem: a maneira de produzir satisfaz não apenas suas necessidades imediatas, mas possibilita sua própria existência social, ou seja, possibilita sua reprodução social e não apenas sua reprodução biológica. Sendo assim, as condições de produção são simultaneamente as de reprodução.

Qualquer que seja a forma social do processo de produção, tem este de ser contínuo ou de percorrer, periódica e ininterruptamente, as mesmas fases. Uma sociedade não pode parar de consumir nem de produzir. Por isso, todo processo social de produção, encerrado em suas conexões constantes e no fluxo de sua renovação, é ao mesmo tempo processo de reprodução (MARX, 1985, p. 659).

Este mecanismo de reprodução, no livro segundo de $O$ Capital, aparece com uma distinção entre reprodução simples e reprodução ampliada, resultado da própria relação capital - trabalho, que é a base da relação social que permite a acumulação no capitalismo. No primeiro caso, a produção renova-se de ano a ano em quantidades iguais. Trata-se de uma reprodução simples, porque, na relação capital-trabalho, toda mais-valia é consumida pela classe capitalista sem que haja nenhuma acumulação. No segundo caso, a reprodução tende a ser cada vez maior quando, ao longo do processo de circulação do capital, possibilita uma maior acumulação por parte de quem o possui. Nestas circunstâncias, a extração contínua da mais-valia, proporcionada pela repetição do processo de produção capitalista, permite alterar a 
composição orgânica do capital (isto é, a relação entre capital constante e variável), reiniciando em novo patamar a reprodução do capital, da força de trabalho e, por conseguinte, do processo de produção capitalista.

O processo de trabalho capitalista é, essencialmente, um mecanismo de produção de mais-valia e não de produção simples de mercadorias. Destaca-se que, em Marx, a ideia de reprodução está articulada aos fatores econômicos de produção da vida material, condicionados pela forma de propriedade dos meios de produção e de troca de mercadorias, engendrando sua reprodução.

Embora os conceitos de processo de trabalho e de reprodução simples e ampliada tenham sido forjados por Marx para analisar as dinâmicas de concentração do capital e as transformações sociais produzidas pelo modo de produção capitalista, pode-se adaptá-los ao estudo das práticas produtivas da agricultura familiar. Isto implicará a transposição de seu sentido original preservando sua lógica dialética. Com isto, busca-se interpretar o processo de trabalho familiar agrícola como um processo de transformação da natureza para obtenção de produtos agrícolas realizados por pessoas que mantém entre si ligações de parentesco, sendo este o caráter fundamental das relações sociais internas a estas unidades de produção. Além disto, é possível perceber que este processo de trabalho já é ele um mecanismo de reprodução destas relações sociais de produção sendo, portanto, simultaneamente, um processo de produção e reprodução do trabalho familiar na agricultura.

Ainda, em analogia aos conceitos de reprodução simples e ampliada do capital, os processos de reprodução social dos agricultores familiares podem ser pensados em termos de reprodução da família no ciclo curto (como reprodução biológica) e no ciclo longo (como reprodução geracional) do processo de trabalho familiar agrícola. A proposta teórica assumida neste trabalho é que a reprodução social do trabalho familiar agrícola se realizaria de um lado como reprodução no ciclo curto, cujo foco é a unidade de consumo/residência e de outro a reprodução no ciclo longo, que se realiza por meio da sucessão geracional e cuja ênfase está na unidade do casal mais filhos(as).

Conforme Henri Lefebvre (1994), a reprodução social consiste no processo de manter, repor e transmitir os mecanismos sociais de geração para geração, no interior do processo de produção constituído. Para que isto se viabilize, é necessária à eficácia de um "núcleo gerador", o que, no caso dos agricultores familiares, é o próprio grupo doméstico seu mecanismo central. Isto impõe a necessidade de especificar as características do processo de 
trabalho familiar agrícola para se obter a chave da compreensão de seus mecanismos de reprodução social.

Uma vez definido o conceito de processo de trabalho e sua relação com a reprodução social, é possível apresentar as características que fazem do processo de trabalho familiar agrícola algo singular. O primeiro traço distintivo deste processo reside no fato de estabelecer relações produtivas com base na reciprocidade das obrigações familiares e não em relações salariais, não havendo, assim, retenção interna de mais-valia. Em consequência disto, este processo de trabalho só pode ter como objetivo a reprodução social da família e da unidade produtiva, tanto no ciclo curto (reprodução biológica) quanto no ciclo longo (reprodução geracional), e não a acumulação de capital. Isto confere a este processo de trabalho um caráter não-capitalista, embora os agricultores estejam integrados de maneira subordinada ao modo de produção capitalista como "produtores simples de mercadorias" (MARX, 1985). Considera-se ainda que o processo de trabalho familiar agrícola se caracteriza por atravessar fases distintas conforme a evolução do ciclo demográfico da família, alterando ao longo do tempo a relação entre trabalho e consumo (CHAYANOV, 1974).

A composição familiar determina, por sua vez, a forma que assumirá a divisão sexual do trabalho, culturalmente estabelecida, onde a condição de gênero funciona como dispositivo mediador entre o material e o simbólico, a exemplo da oposição que se estabelece entre trabalho e ajuda. Com efeito, este processo de trabalho constroi não só o espaço agrícola, mas também espaços de relações sociais de gênero e de geração. Neste sentido, o processo de trabalho familiar agrícola como atividade consciente é coordenado pelo homem adulto (marido, pai), que assume o papel de chefe do processo produtivo por ser o detentor de um saber agrícola específico. Este processo de trabalho constitui-se ainda em um espaço de inserção das novas gerações na atividade produtiva, o que envolve a construção de saberes necessários à reprodução do processo de trabalho. Logo, este se realiza com base em saberes e práticas que serão construídos e transmitidos através do próprio trabalho, o que confere um caráter socializador, de ensino e aprendizado, ao processo de trabalho familiar agrícola. ${ }^{39}$

\footnotetext{
39 Articulando os conceitos de processo de trabalho de Marx com a teoria do modo de produção camponês de Chayanov, Tavares dos Santos (1984) propôs a noção de processo de trabalho camponês. "A especificidade deste processo de trabalho provém, inicialmente, da presença da força de trabalho familiar configurada como trabalhador coletivo. Por isso, é o ciclo de existência da família que provoca a possibilidade do trabalho acessório camponês, bem como a eventual utilização de força de trabalho assalariada na unidade produtiva camponesa" (TAVARES DOS SANTOS, 1984, p. 171). Considerando as mudanças históricas e sociais que justificam a passagem do termo camponês a agricultor familiar, buscou-se atualizar a objetividade e a complexidade deste conceito para que possa incorporar os feixes de relações sociais de produção, de gênero e de geração que lhe são peculiares e que não se faziam presentes nas propostas anteriores.
} 
Este processo de trabalho familiar agrícola pode ser mais bem compreendido quando se estabelece uma distinção entre unidade de produção e formação social. A formação social proporciona o contexto para a reprodução das unidades de produção e em combinação com a estrutura interna desta unidade determina suas condições de reprodução, transformação ou decomposição. Deste modo, se estabelece uma diferença importante entre as relações de produção que se realizam no plano da unidade produtiva, que estão baseadas nas relações familiares, daquelas que predominam no plano social mais amplo, estabelecidas com base na circulação das mercadorias, das quais se destaca a própria força de trabalho por meio do assalariamento. É possível explicar, assim, a presença de processos de trabalhos singulares não-capitalistas - inseridos no modo de produção capitalista, diferenciando a forma direta da indireta com que se realiza a subordinação do trabalho ao capital.

Compreende-se que as condições de reprodução social destas unidades de produção familiares que não realizam a reprodução ampliada do capital estão condicionadas por um duplo movimento de natureza endógena e exógena. Deter-nos-emos, por um instante, nestes aspectos.

Devido às determinações externas, as unidades de produção familiar tendem a ser restringidas pelo padrão de acumulação capitalista. $\mathrm{O}$ avanço das relações de produção capitalistas e a consequente integração dos agricultores ao mercado - do qual dois aspectos são a constante: subida de preços dos insumos de que necessitam e a quase estagnação dos preços dos produtos comercializados - leva amplas parcelas a ter inviabilizadas suas condições de reprodução social. Como resultado, conforme já apontado anteriormente, as novas gerações, principalmente a composta por mulheres, têm deixado a agricultura para trabalhar como assalariadas não-agrícolas, ou buscam combinar trabalho assalariado com a atividade agrícola em tempo parcial, configurando situações de pluriatividade. ${ }^{40}$ Outros agricultores encontram nas possibilidades abertas pelas relações mercantis os meios para profissionalizar a produção familiar e aumentar a produtividade e a rentabilidade de suas atividades produtivas. Frente a esse cenário, confirma-se uma tendência à diferenciação social entre os agricultores familiares em seu conjunto.

Por outro lado, eles estão sujeitos a fatores internos da própria unidade produtiva e à sua lógica familiar que, entre seus condicionantes, incluem a estrutura fundiária, sua condição

\footnotetext{
${ }^{40}$ Utiliza-se o termo como vem sendo empregado por Schneider (2003), que o concebe como um fenômeno através do qual membros das famílias de agricultores optam pelo exercício de diferentes atividades não agrícolas, mantendo moradia no campo e vínculos com as atividades produtivas com a agricultura (SCHNEIDER, 2003, p. 91).
} 
econômica e a composição familiar. Neste sentido, a presença dos jovens agricultores e suas disposições de sucederem aos pais na atividade agrícola assumem importância crucial no processo de reprodução social dos agricultores familiares. A este respeito, os antropólogos Klass e Ellen Woortmann esclarecem que a exploração familiar não produz apenas mercadorias: "mas a produção de mercadorias é antecipada logicamente pela produção de bens, e esta, por sua vez, é antecipada pela produção-reprodução de bens simbólicos que constituem o campo do saber" (WOORTMANN; WOORTMANN, 1997, p. 13). Neste caso, “a transmissão do saber é mais do que transmissão de técnicas: ela envolve valores e construção de papeis" (WOORTMANN; WOORTMANN, 1997, p. 11).

Percebe-se que a transmissão deste saber-fazer específico - que permite o reconhecimento dos sujeitos como agricultores - realiza-se, principalmente, através das interações intergeracionais que se estabelecem no próprio processo de trabalho. Este fator é uma das condições necessárias à formação das novas gerações de agricultores, possibilitando a reprodução social desta categoria. Esta é a base para a identificação dos jovens agricultores familiares como sujeitos históricos singulares, o que é abordado no tópico seguinte.

\subsection{OS JOVENS AGRICULTORES FAMILIARES}

Já foi defendido anteriormente que a especificidade de cada situação juvenil pode ser verificada através do exame dos processos de socialização nos quais os jovens encontram-se inseridos. Ao se considerarem as diferenças de classe social, assim como de etnia e gênero, percebem-se distinções relativas às posições ocupadas nos espaços sociais e consequentemente de processos de socialização respectivos. Tal posicionamento permite superar a invisibilidade social a que diversas categorias juvenis se encontram submetidas. Para que isto possa ser realizado de modo consciente, é necessário reconhecer o papel da teoria na reconstrução do objeto sociológico (BOURDIEU; CHAMBOREDON; PASSERON, 1999). Deste modo, acredita-se que se faz necessário construir rupturas com o senso comum e promover a polêmica com as categorias analíticas pré-estabelecidas.

Para superar o atual estado de incompreensão que predomina do debate sociológico sobre os jovens nos contexto da agricultura familiar, fazem-se necessários não apenas uma teoria sobre a juventude e outra sobre os processos sociais agrários, mas também um construto 
teórico que sintetize a complexidade da suas mútuas implicações. Conforme sugere Bourdieu (1998, p. 28), "a primeira urgência em todos estes casos seria tomar como objeto o trabalho social de construção do objeto pré-construído: é aí que está o verdadeiro ponto de ruptura". Deste modo, a exigência de reflexividade da sociologia impõe a reconstrução laboriosa do objeto para além de sua aparência fenomênica, fazendo emergir todo um feixe de relações de força que as categorias pré-definidas tendem a encobrir.

Esta reconstrução sociológica das categorias não se efetiva por meio da reprodução dos recortes demográficos ou critérios normativos que demarcam os limites etários, nem pela aplicação sem por à prova das categorias pré-estabelecidas a partir da dicotomia rural-urbano, mesmo que oriundas do campo científico. Este é o caso da categoria "juventude rural”, que é forjada a partir de uma ótica urbana que percebe o rural como um espaço da precariedade social, reforçando, mesmo que involuntariamente, o estigma sobre este segmento. Desta maneira, a homogeneização das diferenças no interior de uma categoria mais ampla, como a de "juventude rural", acaba contribuindo para perpetuar a invisibilidade dos jovens agricultores familiares e de outras juventudes, na medida em que não reconhece as especificidades das diversas situações juvenis ${ }^{41}$.

Apesar de contar com legitimidade social, a definição de rural é frágil no Brasil, uma vez que se baseia em critérios normativos (definido pelas Câmaras Municipais) ou em oposição ao urbano. A este respeito, busca-se apoio na crítica ao dualismo rural - urbano, uma vez que este referencial geográfico é insuficiente para caracterizar uma categoria sociológica (TAVARES DOS SANTOS, 1991). Reivindica-se uma visão complexa da realidade social, resgatando um pensamento relacional, que "percebe os processos sociais agrários como expressões do processo histórico de divisão social do trabalho" (TAVARES DOS SANTOS, 1991, p. 15).

Somam-se a este argumento as próprias transformações pelas quais passa o "meio rural brasileiro", como as relacionadas com a evolução do emprego não-agrícola, a ponto de este não poder mais ser pensado como exclusivamente agrícola (GRAZIANO DA SILVA, 1999). Como nem todos os jovens rurais ocupam-se de atividades agrícolas, julga-se necessário demarcar a singularidade daqueles que estão inseridos no processo de trabalho familiar agrícola. Buscando uma maior precisão analítica se faz uso da categoria jovem

\footnotetext{
${ }^{41}$ Em trabalho anterior (WEISHEIMER, 2005) identificamos a existência de múltiplas categorias mobilizadas nos estudos sobre juventudes rurais no Brasil, as quais foram relacionadas a duas matrizes: as que operam com referencial geográfico e residencial na definição das categorias de jovens (ex. juventude rural, jovens do sertão, jovens do campo) as que se baseiam em processos de socialização ou tipos de ocupações (ex. jovens agricultores, jovens sem-terra, jovens assentados).
} 
agricultor familiar ${ }^{42}$ para enfatizar a singularidade dos jovens no contexto da agricultura familiar.

No caso dos jovens pesquisados, considerou-se que as relações sociais, que lhes conferiam sentido e especificidade, resultam da posição ocupada por eles na divisão social do trabalho, ou seja, por sua ocupação na agricultura familiar (WEISHEIMER, 2004, 2005b, 2007a, 2007b). Assim, tornou-se parte central da análise a dimensão do trabalho enquanto locus da produção de bens materiais (produtos e serviços) e simbólicos (valores, representações e identidades sociais) (GUIMARÃES, 2005). Deste modo, entendeu-se possível tomar os jovens agricultores familiares como uma categoria sociológica, possibilitando a análise das condições sociais que balizam suas existências e a construção de seus projetos profissionais.

Os jovens agricultores familiares constituem uma categoria social específica devido à sua socialização no processo de trabalho familiar agrícola. Como eles são membros de uma unidade doméstica que também atua como unidade de produção agrícola, predomina a instituição de saberes, normas e valores do universo da família e do processo de trabalho que esta realiza. Com efeito, a socialização realizada neste contexto produz a incorporação de saberes específicos associada à configuração de identidades sociais e profissionais ligadas à agricultura. Diferentemente de outros jovens, sua identidade social se constroi em relação ao trabalho familiar agrícola, o que produz os dilemas e as características diferenciados de sua situação juvenil.

Como apontou Galeski (1979), ao analisar a família camponesa, os filhos são ao mesmo tempo herdeiros e trabalhadores da fazenda. Essa condição impõe uma ambivalência em relação ao trabalho agrícola e à herança do patrimônio familiar que caracterizará a condição juvenil na agricultura familiar. Estes jovens são protagonistas dos impasses e dilemas das dinâmicas de produção, de reprodução, de transformação e de decomposição da unidade de produção familiar, uma vez que a eles cabe a tarefa de realizar a sucessão geracional desta unidade produtiva.

Destaca-se que num período ainda recente a inserção no universo produtivo conduzia ao questionamento da própria existência da juventude na agricultura, uma vez que, conforme argumentava Tavares dos Santos (1984, p. 46), “os processos de socialização primária e secundária se confundiam num único momento, visto que ocorrem no âmbito das relações

\footnotetext{
${ }^{42}$ Neste estudo, por abordar exclusivamente o universo empírico da agricultura familiar, também fazemos uso no texto da expressão jovem agricultor para se referir aos investigados, abstraindo-se a diferenciação entre as categorias de agricultores (empresariais, familiares e assalariados).
} 
familiares". Com base nisto, acreditava-se que não haveria um período de transição "pois de crianças passam diretamente à condição de adultos". (TAVARES DOS SANTOS, 1984, p. 46). Entende-se que essa percepção não corresponde aos processos sociais que configuram a situação juvenil na agricultura familiar; embora os jovens exerçam um papel produtivo importante no âmbito do trabalho isto não chega a configurar a superação da condição juvenil, uma vez que eles permanecem subordinados à autoridade dos pais: não foi superada a sua posição subalterna na hierarquia familiar.

É necessário distinguir a capacidade plena de trabalho da condição social de adulto. A capacidade para trabalho confere ao jovem um novo papel social no interior da unidade produtiva distinto daquele da infância, agora marcado pela inserção como "força plena" (TEPICHT, 1973) no processo de trabalho da família. Contudo, isto não significa que seja socialmente reconhecido como adulto. Socialmente, ele não é considerado "adulto", pois não se concluiu o processo de individualização, que só será efetivado com a constituição de uma unidade produtiva autônoma, após o casamento ou após a passagem sucessória do estabelecimento familiar de pai para filho(a). Com efeito, os jovens agricultores, como todos os outros jovens, estão apenas parcialmente integrados no "mundo adulto", mas não contam com o reconhecimento de um agricultor pleno. Como indicado anteriormente, isto envolve ainda o domínio de um saber agrícola que será transmitido no próprio trabalho. Neste sentido, a inserção no processo de trabalho da agricultura familiar não é suficiente para superar sua condição juvenil, isto é, como sujeito subalterno nas hierarquias do grupo doméstico. É justamente este processo que configura a situação juvenil na agricultura familiar.

O fundamental deste debate é reconhecer que - através das práticas cotidianas do trabalho familiar - se realizam a formação e a capacitação dos jovens para se tornarem agricultores. Do pondo de vista da análise sociológica, é necessário perceber que é o domínio sobre esse saber fazer da agricultura e na agricultura, e não apenas a idade do sujeito, que constitui a base para seu reconhecimento como agricultor pleno, capaz de construir uma nova família e dirigir uma unidade produtiva independente. Deste modo, o processo de trabalho constitui-se no espaço privilegiado de socialização das novas gerações na lógica do trabalho e da produção agrícola. Este se configura no meio objetivo no qual se inserem os jovens e que possibilita a sua representação social como jovem agricultor familiar. 


\subsection{NOTAS SOBRE A PARTICIPAÇÃO JUVENIL NO DESENVOLVIMENTO DA AGRICULTURA FAMILIAR NO RIO GRANDE DO SUL}

A história social da juventude na agricultura familiar no Rio Grande do Sul ainda está para ser pesquisada e escrita. Até o momento, os jovens não figuram na historiografia regional, assim, como são raras as referências a este segmento em estudos sociológicos e econômicos. Isto é parte do processo de invisibilidade social que afeta os jovens na agricultura familiar. Contudo, os poucos registros existentes permitem argumentar que a participação juvenil no desenvolvimento do processo de trabalho familiar e na policultura no estado se destaca ao menos por quatro razões: a) por sua participação no contingente populacional de migrantes; b) na ocupação da fronteira agrícola; c) como agentes dos processos de modernização agrícola; d) mais recentemente no processo migratório do meio rural para o urbano. Neste tópico, nos deteremos sobre estes quatros aspectos.

A historiografia ${ }^{43}$ indica que o desenvolvimento da agricultura em bases familiares e da policultura no Rio Grande do Sul iniciou-se com a colonização por imigrantes europeus a partir de 1824, cujo marco é a fundação de São Leopoldo. Este processo se deu, inicialmente, entre as margens do Rio dos Sinos e Rio Caí, indo em direção à encosta dos morros, estendendo-se em lotes com dimensões de $220 \mathrm{~m}$ de largura por $3.200 \mathrm{~m}$ de profundidade e ocupando uma área constituída, basicamente, por uma grande floresta extremamente densa (LISBOA, 2000). O sistema de produção desenvolvido na primeira fase das colônias caracterizou-se pela derrubada das matas, queimadas e rotação das áreas cultivadas. Devido às dificuldades do meio físico e ao isolamento das cidades, era comum que os agricultores se reunissem na hora de derrubar as florestas e fazer as plantações, o que provocou a emergência, na organização local, de um forte laço de solidariedade, indispensável à sobrevivência deles nas novas colônias (SCHNEIDER, 1999).

Em um estudo clássico acerca da colonização alemã no Rio Grande do Sul, Jean Roche (1969) aponta quatro fases da expansão da agricultura colonial. A primeira refere-se ao período que vai de 1824 a 1840, quando se inicia a "colonização" propriamente dita, com a distribuição e o arroteamento das terras; fase marcada pela agricultura de subsistência. A segunda fase vai de 1840 a 1860, quando ocorre a expansão da zona pioneira em direção à encosta da serra, com predomínio de atividades voltadas à subsistência com venda de

\footnotetext{
${ }^{43}$ Cf. Filho (1960), Roche (1969), Pesavento (1985), Lando \& Barros (1992).
} 
excedentes. A terceira fase vai de 1860 a 1890, quando a colonização atinge o auge de sua produtividade agrícola, passando a ser marcada pela especialização da produção tendo em vista o mercado. A quarta e última fase ocorre a partir de 1890 e inaugura o declínio da agricultura nas colônias alemãs antigas, atribuído às técnicas rudimentares e associado à excessiva subdivisão das propriedades (ROCHE, 1969).

No que diz respeito aos italianos, que ingressaram no estado do Rio Grande do Sul a partir de 1875, eles chegam em situação de desvantagem, se comparada com a dos primeiros imigrantes alemães, visto que já se estabelecem sobre a vigência da Lei de Terras de $1850 .{ }^{44}$ As melhores áreas já haviam sido ocupadas, e os imigrantes italianos passam a ser assentados em lotes menores, com 25 ha, na encosta da Serra. A saída encontrada por estes agricultores foi a da especialização no cultivo de parreirais para produção de vinho e, em menor escala, o cultivo de milho e criação de suínos (PESAVENTO, 1985).

Ainda Roche (1969) indica que entre o primeiro contingente migrante predominavam jovens, que segundo suas palavras: "Foram os artífices de seus primeiros sucessos, sem dúvida porque eram jovens e prolíficos [...]. Esta mesma característica encontra-se no transcurso do segundo período, que se estende entre 1844 e 1874" (ROCHE, 1968, p. 159). Conforme este autor, de 1874 a 1888 entrou um número pequeno de imigrantes alemães, sendo este aproximadamente a metade da média do período anterior. Foi neste período que o estado recebeu a maior parte de imigrantes italianos; apesar de os casais terem uma faixa etária maior do que a registrada entre os alemães, aqueles traziam consigo uma maior quantidade de filhos. De 1888 a 1914, é retomada com força a imigração alemã vindo desta vez 9.944 solteiros. Deste modo, Roche destaca que:

O elemento imigrante aparecia, portanto, um pouco mais jovem ainda que o anterior a 1874, e sua estrutura, que é a de grupos alijados por nova separação social, contribuiu para conservar a endogamia, visto que os jovens solteiros procuravam, a seu redor, mulher entre os teuto-brasileiras, nas colônias onde se instalaram (ROCHE, 1968, p. 160).

Este processo de colonização resultou no crescimento da população do estado e, particularmente, o perfil dos imigrantes resultou na expansão da população ocupada na agricultura no mesmo ritmo em que cresceu o número de descendentes por casal. A cada nova

\footnotetext{
${ }^{44}$ A Lei n. 601 de 1850 foi promulgada em 18 de setembro daquele ano pelo imperador Dom Pedro II e estabeleceu pela primeira vez a terra como um ativo econômico no Brasil. Em seus artigos 17 e 18, faz referência aos estrangeiros estabelecidos em colônias como a de São Leopoldo.
} 
geração esta passou de 6,0 para 12,8 filhos por casal no intervalo de três gerações (ROCHE, 1968).

A redução das áreas produtivas, em virtude da subdivisão das propriedades familiares, e o esgotamento dos solos promoveram, de maneira acelerada, a constituição de uma população excedente que crescia conforme o aumento da fecundidade das famílias de agricultores. A alternativa encontrada pelos colonos, até meados do século $\mathrm{XX}$, foi o deslocamento das novas gerações de agricultores para outras áreas de fronteira agrícola.

Analisando a trajetória do sistema agrícola colonial, Schneider (1999) aponta que os momentos de crise indicavam a fraqueza e os limites do sistema, além da capacidade de reconversão e adaptação do modo de vida colonial a novos desafios. Registraram-se, então, duas estratégias de resistência que foram fundamentais à sobrevivência do processo de produção familiar. A primeira foi a substituição da policultura comercial pela criação de suínos, destinados à produção da banha, ocorrida entre 1890 e 1930, como estratégia produtiva do sistema produtivo colonial da região de colonização antiga para buscar uma alternativa à entrada das colônias novas na produção agrícola. A segunda estratégia de resistência, que, de certo modo ocorre em consequência da anterior, refere-se às migrações das colônias velhas às colônias novas. As dificuldades de reprodução do sistema produtivo levaram um grande número de jovens agricultores, filhos dos colonos, a emigrarem. É neste período que se conclui o processo de ocupação da fronteira agrícola das regiões norte e noroeste do Rio Grande do Sul (SCHNEIDER, 1999).

A historiadora Sandra Pesavento (1985) constatou que, em 1930, a fronteira agrícola do Rio Grande do Sul já se encontrava totalmente esgotada. Restava para os filhos de agricultores que não herdariam as propriedades dos pais, além da migração urbana e a entrada em seminários e conventos católicos, a migração para novas fronteiras. Graças a este deslocamento populacional cada vez mais ao norte a cada nova geração, ocupou-se o oeste de Santa Catarina e do Paraná até meados dos anos de 1950. Na geração seguinte, os agricultores põem-se novamente em marcha para o centro-oeste e norte do país, ocupando desta vez áreas que se estendem dos estados de Mato Grosso ao Tocantins, já em meados de $1970 .{ }^{45}$

A partir da segunda metade do século XX, principalmente após os anos sessenta, verifica-se um novo movimento do capital, objetivando reduzir os custos de produção, quando as antigas áreas coloniais passam a ser percebidas como "viveiros de força de trabalho",

\footnotetext{
${ }^{45}$ Sobre processo de colonização das fronteiras agrícolas do norte do Brasil, suas implicações políticas e sociais, destacam-se os trabalhos de Martins (1975, 1997), Martine (1987) e Tavares dos Santos (1993).
} 
segundo a expressão forjada por Martins (1975). Esse período é marcado pelo processo de modernização da agricultura; embora voltado para as grandes propriedades e produtos para exportação, também se refletiu entre os agricultores familiares da região, que passaram a adotar novas tecnologias, principalmente voltadas à correção do solo e introdução de maquinarias. Com efeito, parte do trabalho que era realizado manualmente passou a ser feito com equipamentos mecânicos, liberando parcelas significativas da mão de obra ocupada na agricultura.

Durante as décadas de 1960 e 1970, o governo brasileiro injetou grandes volumes de subsídios à agricultura através do crédito rural, privilegiando os produtos destinados à exportação e beneficiando, predominantemente, os grandes produtores e a região Sul do Brasil. Juntamente com o programa de crédito rural subsidiado, o governo interveio no sistema de preços relativos, com políticas de estoques reguladores e medidas protecionistas tanto nos mercados de produtos como no de insumos (MARTINE, 1987). A concessão de valores de crédito maiores de acordo com o tamanho da propriedade encorajou a concentração de terra. No Rio Grande do Sul, o setor que mais se beneficiou desta política foi o do cultivo de soja, transformada em principal ativo de exportação. A política de modernização também provocou uma mudança nas relações de trabalho no campo, com a força de trabalho dos arrendatários residentes nas fazendas sendo substituída pela força de trabalho assalariada temporária (DEERE, 2003).

Este conjunto de medidas que resultaram na adoção de novas tecnologias voltadas à ampliação da produtividade de produtos agrícolas ficou conhecida como "Revolução Verde" que se iniciara já na década de 1950. Esta se constituiu sob um novo padrão tecnológico para a agricultura, rompendo com os processos produtivos do passado e impondo aos agricultores uma nova racionalidade técnica e econômica. Além disso, conforme Navarro (2001), este novo padrão tecnológico levou à mercantilização da vida social, restringindo a relativa autonomia setorial que, em outros tempos, a agricultura havia experimentado.

De um modo geral, a "Revolução Verde" que chegou ao campo gaúcho, como no restante do Brasil e dos "países em desenvolvimento", serviu para elevar a produtividade agrícola dos estabelecimentos e das regiões em que as rendas já eram altas; nada pôde, no entanto, fazer para melhorar a situação dos pobres do campo. Por isso, tornou ainda mais profundo o fosso entre as classes rurais de altas e baixas rendas, contribuindo para agravar ainda mais as contradições da agricultura capitalista (GUIMARÃES, 1979). Isto porque, para 
promover a industrialização da agricultura com a importação do pacote tecnológico ${ }^{46}$ da "Revolução Verde", foi necessário um pesado investimento monetário que, entre os países latino-americanos, só pode ser realizado por meio do Estado, sob a forma de subsídios agrícolas dirigidos, como já foi referido, aos grandes proprietários fundiários desde então denominados "empresários rurais".

Além disto, o novo padrão tecnológico exigiu uma apropriada atividade de pesquisa e assistência técnica a fim de se atingir rendimentos compatíveis para a inserção no mercado internacional. Enquanto isso, para os agricultores menos capitalizados, a concentração de terras direcionou-os para áreas menos férteis, restringindo-se a produção a práticas tradicionais, visto que o novo pacote tecnológico fora pensado para as grandes propriedades rurais (MARTINE; GARCIA, 1987).

Conforme destaca o economista José Graziano da Silva, remonta a este período "a identificação espúria de rural com atrasado para justificar as propostas intervencionistas 'de fora', entre as quais os programas de assistência técnica e extensão rural" (SILVA, 1999, p. 2) Como parte da estratégia de desenvolvimento, surge a necessidade de promover uma qualificação da força de trabalho ocupada na agricultura, o que chamaria a atenção especial para a juventude que passa a ser vista como um importante mediador geracional na adoção das novas técnicas de produção de uma contabilidade mercantil. Ou seja, é neste contexto que surge um discurso sobre a "juventude rural" como público alvo a ser abordado por extensionistas com vistas à difusão das práticas produtivistas e da racionalidade econômica.

O exemplo emblemático deste processo pode se verificado nos Clubes 4S, construídos a partir do modelo norte-americano. A intervenção desta organização junto à juventude visava à divulgação de novos métodos e técnicas entre os agricultores gaúchos. Para tanto, ofereciam treinamento para o desempenho das novas técnicas agrícolas para os rapazes e noções de economia doméstica para as moças. Ronaldo Dieterich (1983), em sua dissertação de mestrado mostra a grande expansão organizativa destes clubes no RS, que inicialmente eram 25, com 530 sócios, em 1960, e chegaram a somar 471 clubes em funcionamento envolvendo 10.744 jovens associados em 1971. Também a historiadora Sirlei de Fátima Souza (2003), em outra dissertação, descreve como a passagem de jovens por estes

\footnotetext{
${ }^{46} \mathrm{O}$ pacote tecnológico consiste num conjunto de práticas e procedimentos técnicos que se articulam entre si e que são utilizados indivisivelmente numa lavoura, segundo padrões estabelecidos pela pesquisa. Desta forma, $o$ pacote tecnológico passa a corresponder, na verdade, a uma linha de montagem, onde o uso de uma dada inovação técnica (ou insumo de origem industrial) exige o emprego de uma dada inovação técnica anterior e a utilização de uma certa inovação técnica posterior. Essa combinação de uso de insumos (e máquinas) não pode ser rompida, sob o risco de invalidar totalmente os resultados da exploração agrícola (AGUIAR, 1984).
} 
clubes influenciou a adoção de práticas da modernização agrícola para o caso da região central do estado do Rio Grande do Sul. ${ }^{47}$ Pode-se assim estabelecer que - por sua capilaridade - em todas as regiões agrícolas do estado, os jovens desempenharam, em todo o RS, um papel similar ao descrito por Souza ao analisar o caso de Passo Fundo. Neste sentido, os jovens agricultores cumpriam a função de agentes do desenvolvimento deste novo padrão na agricultura, desde então chamado de moderno.

Como resultado deste padrão produtivista, o mundo rural (e as atividades agrícolas, em particular) passou a se subordinar como mera peça dependente aos novos interesses, classes e formas de vida e de consumo, majoritariamente urbanas, que a expansão econômica desta época ensejou. Este período, que coincide com a impressionante expansão capitalista dos anos dourados (1950-1975), torna-se um divisor de águas para as atividades agrícolas, transformando o mundo rural tão logo os efeitos desta época de mudanças se completaram (NAVARRO, 2001).

O balanço desses quase 50 anos de intervenções mostra que as transformações na agricultura não modificaram o estado de pobreza e a dinâmica da subordinação dos trabalhadores nas zonas rurais, tão pouco se estabeleceu à democracia nas relações sociais agrárias. Este padrão de desenvolvimento pode ser caracterizado, assim, como uma "modernização conservadora", ${ }^{48}$ porque não alterou a estrutura fundiária nem as relações de poder. A exemplo dos Junkers alemães ${ }^{49}$ - que representam um paralelo com o caso do Brasil - verificou-se que os grandes proprietários fundiários mantiveram sua posição de poder, com a subordinação dos trabalhadores rurais, até mesmo dirigindo a modernização sob seus interesses.

Esta comparação é ainda mais pertinente se considerarmos que a situação da agricultura no Brasil e na Alemanha difere, substancialmente, dos processos de modernização pelos quais passaram, por exemplo, a França e o México, onde os conflitos agrários levaram ao enfraquecimento da grande propriedade rural por meio de reformas agrárias. Ou seja, o modelo de modernização conservadora conseguiu transformar o aparato produtivo e alcançar expressivos níveis de crescimento econômico sem alterar os níveis de pobreza absoluta, mantendo grande parte da população em condições miseráveis e acentuando ainda mais a concentração de rendas e de terras no Brasil.

${ }^{47}$ Sobre a atuação dos Clubes 4 S no Rio Grande do Sul, podem ser consultados: DIETERICH, Ronald, 1983, e SOUZA, Sirlei de Fátima, 2009.

${ }^{48}$ Expressão originalmente forjada por Barrington Moore Jr. (1966).

${ }^{49}$ Cf. Max Weber (1979) em "O caráter Nacional e os 'Junkers'”. 
Esta política agrícola esgotou-se na passagem dos anos de 1970 a 1980 devido à impossibilidade de os Estados nacionais continuarem arcando com seu elevado custo de investimento, frente à crise econômica mundial que se deflagrou após 1973. Somam-se a isto os insatisfatórios resultados, particularmente em relação à redução da pobreza rural e da fome, as quais pouco se modificaram

Durante a primeira metade da década de 1980, a política agrícola caracterizou-se pela falta de crédito e pela retirada dos subsídios agrícolas, com efeitos, principalmente, sobre os médios e grandes produtores e sobre os cultivos destinados à exportação. Os produtores menos afetados foram os que produziam cultivos para o mercado interno, devido à existência de uma política de preços mínimos. Na segunda metade da década, novas políticas agrícolas levaram à desregulamentação do setor, o que foi agravado pela abertura comercial com o exterior, com o favorecimento das importações de produtos agrícolas, muitos dos quais recebem subsídios em seus países. O governo brasileiro começou a implantar um conjunto de reformas estruturais liberalizantes, promovendo a retirada, às vezes gradual (café, cana de açúcar); noutras, repentina (trigo), das atividades de regulação dos mercados agrícolas (SILVA, J.; BALSADI; DEL GROSSI, 1997).

Conforme mostraram Dias e Amaral (2000), o corte dos gastos e as políticas monetárias restritivas recomendadas pelo FMI atingiram, severamente, os setores agrícolas, imprimindo sérias limitações na política de preços mínimos e reduzindo, de modo acentuado, os montantes de crédito rural oriundos das fontes oficiais. Além disso, os agricultores passaram a usar as fontes privadas de crédito com taxas de juros muito mais altas, acumulando endividamentos e reduzindo as margens de lucro. As únicas forças favoráveis ao setor agrícola eram dadas pela política cambial que, para possibilitar o incremento das exportações, mantinha o câmbio desvalorizado. Apesar das dificuldades da economia, a agricultura conseguiu altas taxas de crescimento através de mecanismos específicos de exportação de produtos agrícolas e políticas de crédito e de preços mínimos. Alguns setores conseguiram taxas de crescimento elevadas, como citricultura, açúcar, álcool e a produção de grãos (PAULILLO, 2000).

A partir da década de 1990, predomina um novo contexto mundial marcado por mudanças econômicas, políticas, sociais e culturais que caracterizam o que David Harvey (1994) descreve como uma transição no regime de acumulação e no modo de regulamentação social a ele associado. Estas transformações estruturais ensejam novas maneiras dominantes 
da experiência sobre o espaço e o tempo e conferem novos papeis à informação e à centralidade do conhecimento com reflexos sobre as populações rurais e a agricultura.

Como se indicou em outro trabalho (BRUMER; WEISHEIMER, 2006), no exame do impacto destas transformações nas relações de produção sobre o meio social rural, Diego Piñeiro (2003) destaca que os programas de ajuste estrutural, desregulamentação estatal, privatização, abertura da economia a inversões estrangeiras e abertura das fronteiras comerciais, seguidas com disciplina pelos governos latino-americanos, não aumentaram o bem estar da população. Ao contrário, produziram mais pobreza e desigualdades sociais (PIÑEIRO, 2003). Além disso, "la deuda externa del continente creció a niveles asfixiantes impedindo la capacitalización y el desarrollo económico" (PIÑEIRO, 2003, p. 27).

Na mesma direção, Schneider (2005) sistematiza as múltiplas dimensões da reestruturação econômica, produtiva e institucional, apresentando cinco efeitos sobre a agricultura familiar e o mundo rural. Conforme o autor, primeiro são abertos os mercados, quando se aceleram as trocas comerciais e intensifica-se a competitividade, agora tendo por base poderosas cadeias agroalimentares que monopolizam a produção e o comércio atacadista em escala global, restringindo a participação nestas relações de troca de imensas regiões produtoras. Isso vale inclusive para alguns países e mesmo parcelas continentais (REARDON; BERDEGUÉ, 2003 apud SCHNEIDER, 2005). Segundo, paralelamente ao processo contínuo de aprofundamento do progresso tecnológico (agora via biotecnologias, engenharia genética, etc.) destaca-se o aparecimento de iniciativas, das mais variadas matizes, que contestam e criticam o padrão técnico dominante (GOODMAN; WATTS, 1997, apud SCHNEIDER, 2005). Terceiro, as modificações nos processos de produção pós-fordistas (mais flexíveis e descentralizados) levam à diluição das diferenças setoriais (o agribusiness é visto como o encadeamento de vários setores) e espaciais. O rural deixa de ser o locus específico das atividades agrícolas, e as variadas formas de complementação de renda e ocupação em atividades não-agrícolas permitem que a renda de muitas famílias que residem no meio rural se estabilize ao longo do ano e que os filhos não precisem mais deixar o meio rural para achar emprego (OCDE, 1996; ECHEVERRÍA, 2001; SILVA, J. 1999; SCHNEIDER, 2003, SCHNEIDER, 2005). Quarto, o papel do poder público e das instituições que atuam nos espaços rurais se modificam. O centralismo cede espaço à parceria e à participação da sociedade (BOISIER, 1999; CAMPANHOLA \& GRAZIANO DA SILVA, 2000 apud SCHNEIDER, 2005). Quinto, a dimensão ambiental e a sustentabilidade do uso dos recursos naturais deixam de ser vistas como um aspecto secundário e um 
argumento de minorias e passa a ser um fator de competitividade, um elemento de estímulo à ampliação do consumo, uma vantagem econômica comparativa e um pré-requisito para obtenção de créditos e acesso a fundos de investimento, especialmente os de fontes públicas (PLOEG; RENTING, 2000 apud SCHNEIDER, 2005).

Com a implementação de maiores restrições à agricultura, nos anos 1990, em decorrência do processo de globalização e das políticas das agências internacionais, os agriculturas dos países latino-americanos promoveram ajustes para compensar as novas restrições. Também as mudanças ocorridas nas décadas anteriores os levaram a empregar formas alternativas de capitalização interna aos estabelecimentos produtivos, ligados principalmente ao forte aumento da produtividade, à redução de custos e à desmobilização de ativos. Como consequência, o processo de desemprego de mão de obra foi ainda mais acentuado, não somente de trabalhadores contratados, mas também de membros das famílias dos produtores. Houve também redução no número de estabelecimentos e queda nos preços das terras, principalmente após a estabilização registrada nos países que vivenciavam altos índices de inflação. No Brasil, como indicam Dias e Amaral, este processo agrava uma situação anterior, com fortes raízes históricas, que caracteriza o setor agrícola brasileiro como registrando uma das distribuições de renda mais desiguais na América Latina (DIAS; AMARAL, 2000).

Como resultado, houve uma maior subordinação do trabalho ao grande capital, e o êxodo rural provocou uma urbanização acelerada. A população rural no Brasil, que correspondia a 54,6\% em 1960, foi reduzida para 24,5\% em 1990 e chegou a 18,8\% em 2000, o que representa um deslocamento para as zonas urbanas de mais de 40 milhões de pessoas em 40 anos (SCHNEIDER, 2003). Já em 2003, a população rural atingiu seu patamar mais baixo registrando apenas $16 \%$ da população brasileira. ${ }^{50}$ Percebe-se que, em todo o Brasil, com a modernização da agricultura, ocorreu uma migração massiva em direção às cidades, decorrente, principalmente, da falta de empregos e das condições de trabalho na agricultura (MARTINE; GARCIA, 1987). Somente durante a década de 1970, quase 16 milhões de pessoas deixaram o campo, e o êxodo rural, entre 1960 e 1980, contabilizou cerca de 28 milhões de indivíduos (MARTINE; ARIAS, 1987, p. 41). Particularmente na Região Sul, a população rural diminuiu continuamente em referência à população total. Nesta região, a população rural passou de 9.193.066 habitantes (55,7\% do total), em 1970, para 4.785.617 habitantes (19,1\% do total), em 2000 (IBGE, 2001), com uma redução populacional tanto em

\footnotetext{
${ }^{50}$ Disponível em: http://www.ibge.gov.br. Acesso em: 22 set. 2008.
} 
termos relativos como em números absolutos. No Rio Grande do Sul, considerada a população em idade ativa (com 10 anos ou mais) registrou-se uma redução absoluta de 459 mil pessoas no meio rural no período de 1981 e 1999 (SCHNEIDER, 2003).

Todo este conjunto de mudanças estruturais afetou a juventude do campo, como é possível perceber ao se analisar o perfil da população migrante. É importante destacar que, na década de 1950, o contingente que mais emigrou das áreas rurais correspondia à faixa dos 30 a 39 anos de idade. Já nos anos 1990, ocorreu um deslocamento populacional, principalmente na faixa etária de 20 a 24 anos (CAMARANO \& ABRAMOVAY, R. 1998). Com isto, verificamos que os processos de mobilidade social horizontal, marcados pelo fluxo populacional dos campos para as cidades, vêm sendo protagonizados por indivíduos jovens.

Outra característica marcante do processo migratório recente é a participação feminina. O Gráfico 5 mostra que, nos últimos trinta anos, a participação de mulheres residentes no meio rural vem diminuindo, progressivamente, em todas as regiões do Brasil, com curvas mais acentuadas para as regiões Sul, que apresentava $26,7 \%$ da população total em 1970, passando a 9,1\% em 2000, e no Centro-Oeste, que detinha 24,2\%, em 1970, e passou a $6 \%$ em 2000. A região Nordeste mantém o maior índice de população rural feminina $(14,9 \%)$, enquanto a Sudeste apresenta a menor porcentagem $(4,5 \%)$.

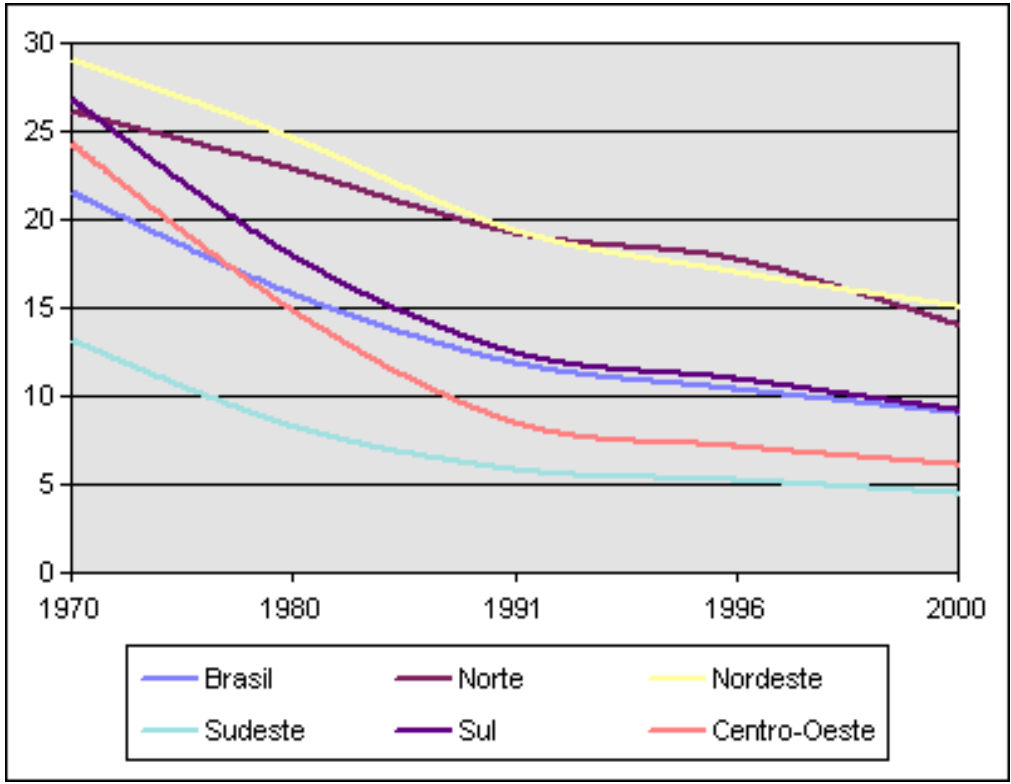

Gráfico 5: População rural feminina no Brasil e regiões (\%)

Fonte: IBGE, Censo Demográfico 1980, 1991 e 2000 e Contagem da População 1996. 
A mudança populacional produzida pela dinâmica da modernização conservadora tem efeitos na divisão sexual do trabalho na agricultura familiar. Diferentes estudos sobre os efeitos da modernização da agricultura consideram que, com o aumento das atividades mecanizadas e poupadoras de mão de obra, as mulheres são excluídas das atividades produtivas e voltam-se principalmente para as atividades domésticas (WANDERLEY, 1988; MAUREL, 1990).

No que diz respeito estritamente à participação da juventude neste processo, verificase que as mulheres jovens migram mais que os homens da mesma faixa etária, representando $52 \%$ do total da migração juvenil. De acordo com o censo de 1991, para o total do Brasil, enquanto $20,8 \%$ dos jovens do sexo masculino entre 15 a 24 anos de idade eram migrantes, para as moças desta mesma faixa etária a proporção de migrantes era de $24,2 \%$. Na região Sul do país, de um total de 2.181.868 migrantes do sexo masculino, 21,5\% tinham idades entre 15 a 24 anos, enquanto que a migração feminina na mesma faixa etária foi de 24,6\% (BAENINGER, 1998, tab. 14, p. 46). Devido ao predomínio juvenil e feminino no processo migratório campo-cidade, temos como resultado um acentuado processo de envelhecimento e masculinização da população rural.

Este processo migratório e a consequente retração da população ocupada na agricultura familiar têm sido explicados ora por fatores de atração, ora por fatores de expulsão. Conforme indicam os dados do Projeto Rurbano (CAMPANHOLA; GRAZIANO DA SILVA, 2000), o emprego doméstico desempenha hoje, para as mulheres, o papel que a construção civil teve nas décadas passadas para os homens. Especialmente para as mulheres mais jovens, esta atividade aparece como uma das poucas formas de inserção no mercado de trabalho nos anos 1990, dadas as restrições crescentes à sua inserção na força de trabalho da agricultura. $^{51}$

Reconhece-se a importância dos fatores de atração, mas estes, de um modo geral, apresentam-se como alternativa para a juventude em contraponto à falta de perspectivas de continuar como agricultor(a) ou de ocupar-se em atividades não-agrícolas em suas comunidades de origem. O êxodo rural - enquanto mobilidade horizontal das populações resulta da conjunção de ambos os fatores, visto que um deles é componente inseparável do outro. Grande parte dos migrantes muda-se, ao menos provisoriamente, para as periferias de

\footnotetext{
${ }^{51}$ Monteiro (1996), por exemplo, em sua Dissertação de Mestrado em Sociologia, argumenta que a inserção das moças e meninas adolescentes provenientes do meio rural no trabalho doméstico urbano como empregadas das classes médias configura um processo de re-socialização e subordinação no qual encontram-se inseridas, faltando-lhes um encaminhamento adequado à vida adulta e profissional.
} 
cidades, sem perder contato com sua localidade e com sua família de origem, e coloca em circulação mão-de-obra, dinheiro, bens e alimentos de uma residência a outra. Por fim, podemos concluir que a intensidade da migração juvenil e feminina reflete tanto o processo de modernização que vem ocorrendo nos espaço social agrário quanto as diferentes oportunidades de ocupação existentes no meio rural dela resultantes.

\subsection{PARTICIPAÇÃO JUVENIL NA OCUPAÇÃO NA AGRICULTURA FAMILIAR NO RIO GRANDE DO SUL}

O processo migratório rural-urbano (êxodo rural) - visto na seção anterior significou a diminuição relativa da população ocupada na agricultura. Assim, apesar de, entre 1950 e 1980, a população com atividade agrícola no Brasil ter aumentado em números absolutos (de 10 milhões de pessoas, em 1950, para mais de 21 milhões, em 1980), na verdade ocorreu uma distribuição da força de trabalho entre os setores da economia. Em 1950, trabalhavam na agricultura 57,8\% da população economicamente ativa (PEA), enquanto que, em 1983, a população economicamente ativa na agricultura representava $25,8 \%$ da PEA total (SILVA, M. 1990, p. 21). De maneira semelhante, Silva et al. (1997), com base em dados das pesquisas nacionais por amostra de domicílio (PNAD), registram a queda do emprego agrícola durante os anos 1990 (26\% da PEA total, em 1990) e o aumento da PEA não-agrícola residente no meio rural, que cresceu a uma taxa de 3,5\% ao ano (SILVA et al., 1997, p. 51). Também no Rio Grande do Sul, esta redução da PEA apresentou-se mais acentuada entre os ocupados na agricultura. Schneider (2003) indica que em 1981 a PEA agrícola no estado somava 1.160.800 pessoas, passando a 789.379 em 1999. O autor destaca que esta redução está ligada à diminuição do número de agricultores familiares, uma vez que os índices negativos ocorrem principalmente entre os que trabalham por conta própria $(-1,65 \%$ a.a.) e entre os não remunerados (-3,1\% a.a) no período 1992-1999. Estima-se que, entre os nãoremunerados, predominem os jovens e as mulheres.

Por outro lado, o incremento das ocupações não-agrícolas tem crescido em toda a América Latina. Schneider (2003) menciona que os empregos rurais não-agrícolas representam $40 \%$ das rendas dos habitantes do meio rural latino americano. Para o Brasil, José Graziano da Silva mostra que a população economicamente ativa rural, entre 1985 e 1995, cresceu a uma taxa de $0,4 \%$ ao ano, muito menor que a taxa de crescimento urbano, de 
2,5\% ao ano. Paralelamente, considerando os empregados em atividades agrícolas entre 1992 e 1995, a população rural diminuiu $0,5 \%$ ao ano, enquanto que a atividade não-agrícola no meio rural teve um crescimento de $3,5 \%$ ao ano, compensando as perdas de postos de trabalho que ocorriam no setor produtivo agrícola (SILVA, 1996). Schneider (2003) descreve como vem ocorrendo este processo no Rio Grande dos Sul, demonstrando que a PEA ocupada em atividades não-agrícolas aumentou de 297 mil em 1992 para 352 mil em 1999 (um aumento de 55,24\% das ocupações). Ele conclui afirmando que "esse aumento não foi suficiente para compensar a perda dos ocupados em atividades agrícolas" (SCHNEIDER, 2003, p. 155).

Estas informações dão conta de um processo de diversificação das formas de ocupação e renda no meio rural que resultam das novas dinâmicas espaciais possibilitadas por processos técnicos e organizacionais que caracterizam a nova estratégia de acumulação. Nesse sentido, a busca das empresas por relações de trabalho mais flexíveis é a principal indutora dos processos de industrialização difusa que estão alterando as características espaciais da divisão social do trabalho, transformando o meio rural num espaço não exclusivamente agrícola. Outrossim, ainda há setores importantes do meio rural que são agrícolas, enquanto que outros incluem uma dupla atividade: agrícola e não-agrícola. Havia, no Brasil, em 1997, 350 mil pessoas que combinavam atividades agrícolas e não-agrícolas (CAMPANHOLA; SILVA, 2000, p. 52).

No que concerne ao volume da ocupação agrícola no Rio Grande do Sul, apesar de haver apresentado uma retração nas últimas décadas, continua sendo bastante expressivo. Como pode ser verificado na Tabela 5 , cerca de $11,4 \%$ de toda a população gaúcha encontrase ocupada no setor da produção primária, como trabalhadores agropecuários, florestais e de caça e pesca. Considerando os percentuais cumulativos das faixas etárias percebe-se que os jovens neste tipo de ocupação representam $2,8 \%$ da população total para a população do estado, o que equivale a 285.259 de pessoas da faixa etária de 15 a 29 anos.

Considerando-se a distribuição da população ocupada na agricultura por faixa etária e por sexo, obtém-se o Gráfico 6, no qual se observa um predomínio de homens em todas as faixas etárias. Entre os ocupados na agricultura no RS, encontram-se, principalmente, homens de 30 a 44 anos que somam 178.702 trabalhadores agrícolas. Os jovens do sexo masculino com idades de 15 a 29 anos formam o segundo maior contingente ocupado no setor, representando um universo de 150.940 pessoas, sendo superior à participação de homens entre 45 a 59 anos. Entre as mulheres, ocorre uma inversão entre estas faixas etárias, com 
mais delas com idades entre 45 a 59 (83.081) ocupadas na agricultura do que entre as jovens de 15 a 29 anos (64.341).

Tabela 5: Estimativas do Percentual da População do RS por Faixas Etárias (em anos) e Tipo de Ocupação*

\begin{tabular}{|c|c|c|c|c|c|c|}
\hline & \multicolumn{4}{|c|}{ Idade (anos) } & \multirow[t]{2}{*}{ Total } \\
\hline & & De 15 a 19 & De 20 a 24 & De 25 a 29 & Outra & \\
\hline \multirow{11}{*}{$\begin{array}{l}\text { Tipo de } \\
\text { Ocupação** }\end{array}$} & 0 & 0,09 & 0,10 & 0,07 & 0,22 & 0,48 \\
\hline & 1 & 0,02 & 0,11 & 0,19 & 1,58 & 1,90 \\
\hline & 2 & 0,07 & 0,22 & 0,35 & 1,88 & 2,52 \\
\hline & 3 & 0,19 & 0,48 & 0,46 & 2,03 & 3,16 \\
\hline & 4 & 0,46 & 0,73 & 0,51 & 1,51 & 3,21 \\
\hline & 5 & 0,96 & 1,35 & 1,33 & 7,13 & 10,77 \\
\hline & 6 & 0,98 & 0,88 & 0,94 & 8,62 & 11,42 \\
\hline & 7 & 0,84 & 1,22 & 1,24 & 6,05 & 9,35 \\
\hline & 8 & 0,16 & 0,26 & 0,22 & 0,77 & 1,41 \\
\hline & 9 & 0,09 & 0,12 & 0,13 & 0,65 & 0,99 \\
\hline & 10 & 5,58 & 2,72 & 1,97 & 44,52 & 54,79 \\
\hline Total & & 9,44 & 8,19 & 7,41 & 74,96 & 100,00 \\
\hline
\end{tabular}

*Considera toda a população do RS. Não considera pessoas de menos de 10 anos de idade ou pessoas de 10 ou mais anos de idade que não tinham trabalho na semana de referência.

**Tipo de Ocupação: 0 - membros das forças armadas, policiais e bombeiros militares, 1 - membros superiores do poder público, dirigentes de organizações de interesse público e de empresas, gerentes; 2 profissionais das ciências e das artes, 3 - técnicos de nível médio; 4 - trabalhadores de serviços administrativos; 5 - trabalhadores dos serviços, vendedores do comércio em lojas e mercados; 6 trabalhadores agropecuários, florestais, caça e pesca; 7 - trabalhadores da produção de bens e serviços industriais; 8 - trabalhadores da produção de bens e serviços industriais; 9 - trabalhadores de reparação e manutenção; 10 - Outras ocupações mal especificadas.

Fonte: Censo Demográfico 2000. Microdados da Amostra.

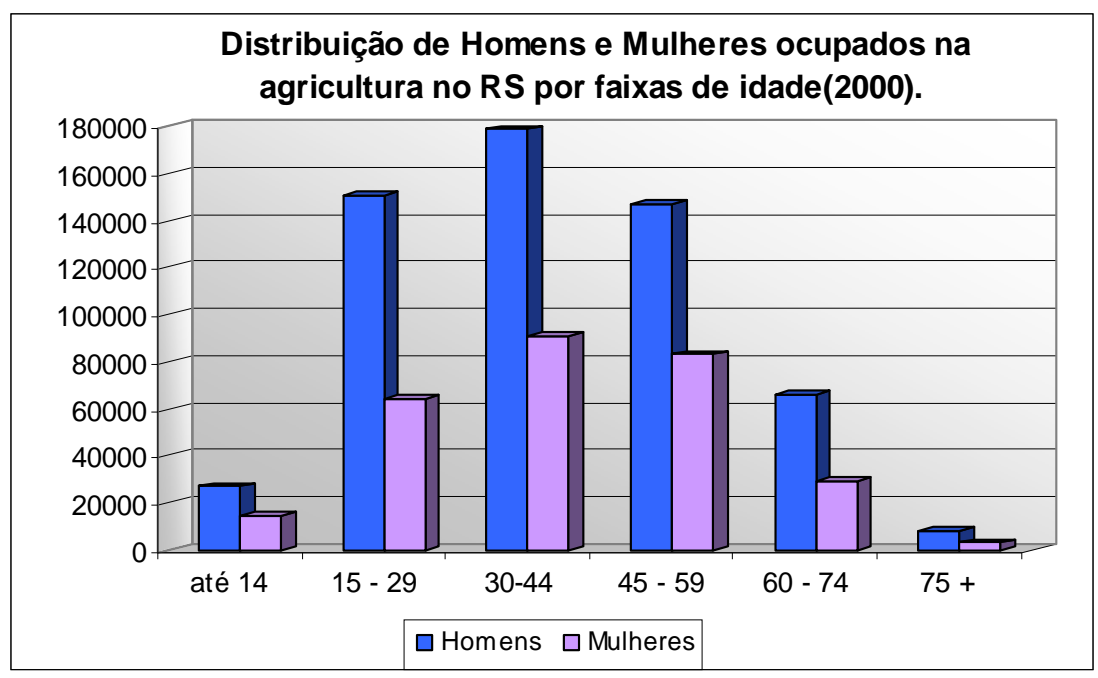

Gráfico 6: Distribuição de Homens e Mulheres ocupados na agricultura no RS por faixa etária $(f)$ Fonte: Censo Demográfico 2000. 
Considerando estritamente a agricultura familiar, constata-se uma tendência de queda no volume de ocupação. Em 1991, registravam-se 734.608 ocupados na agricultura familiar no Rio Grande do Sul, ou seja, $81 \%$ das ocupações na agricultura. ${ }^{52}$ Já conforme o Censo Demográfico de 2000, a população ocupada na agricultura familiar passou a 721.425 pessoas, o que equivale a $83,4 \%$ do total das ocupações na agricultura no RS. Esta comparação permite identificar uma diminuição em termos absolutos do número de ocupações na agricultura familiar, ao mesmo tempo em que registra uma ampliação em termos relativos da sua participação no total da ocupação na agricultura do estado.

Analisando a ocupação juvenil na agricultora familiar do estado, verifica-se que, no início da década de 1990, os jovens de 15 a 29 anos de idade somavam 234.466 ocupados nesta atividade, dentre os quais $69,7 \%$ eram homens e $30,3 \%$ eram mulheres. A população jovem formava $31,9 \%$ do total da mão de obra ocupada na agricultura familiar no Rio Grande do Sul. ${ }^{53}$

Conforme os Microdados da Amostra do Censo Demográfico 2000 para o RS, estima-se que os homens ocupados na agricultura familiar representam $61,31 \%$ do total dos ocupados, predomínio que ocorre em todas as faixas etárias. Ao compararmos a participação nesta ocupação por faixas etárias, verifica-se que os jovens de 15 a 29 anos de idade representam 22,77\% do total dos ocupados na agricultura familiar no estado. Eles formam o terceiro principal grupo de idade entre os agricultores familiares, registrando uma participação inferior às pessoas de 30 a 44 anos de idade $(30,265)$ e do contingente de 45 a 59 anos de idade (27,68\%). Destaca-se que os jovens do sexo masculino representam 14,25\% de todos os ocupados, enquanto que as jovens mulheres representam $8,52 \%$ do total da ocupação na agricultura família gaúcha (Tabela 6).

Tabela 6: Estimativas do Percentual da População do RS na Condição de Ocupação na Agricultura Familiar por Faixas Etárias e Sexo

\begin{tabular}{l|l|l|l|l|l|l|l}
\hline Sexo & Até 14 & 15 a 29 & 30 a 44 & 45 a 59 & 60 a 74 & 75 ou mais & Total \\
\hline Homens & 3,61 & 14,25 & 17,96 & 16,37 & 8,09 & 1,03 & 61,31 \\
\hline Mulheres & 2,11 & 8,52 & 12,30 & 11,31 & 4,03 & 0,42 & 38,69 \\
\hline Total & 5,72 & 22,77 & 30,26 & 27,68 & 12,12 & 1,45 & 100,00 \\
\hline
\end{tabular}

*Considera toda a amostra disponível de agricultores familiares (117.145).

Fonte: Censo Demográfico 2000. Microdados da Amostra.

\footnotetext{
${ }^{52}$ Fonte: Censo Demográfico do IBGE, 1991.

${ }^{53}$ Fonte: Censo Demográfico do IBGE, 1991.
} 
Considerando a estimativa do percentual da população jovem ocupada na agricultura familiar no RS por faixa etária e sexo, verifica-se uma participação um pouco maior dos jovens de 15 a 19 anos $(8,34 \%)$ do que das outras faixas etárias no total da ocupação nesta atividade. Isto se deve principalmente a participação de adolescentes homens $(5,47 \%)$. Percebe-se que esta é a maior registrada segundo os critérios propostos. Já entre as mulheres ocorre uma participação maior das jovens adultas com idades de 25 a 29 anos (3,06\%) do que a verificada entra as de outras faixas de mulheres jovens (Gráfico 7).

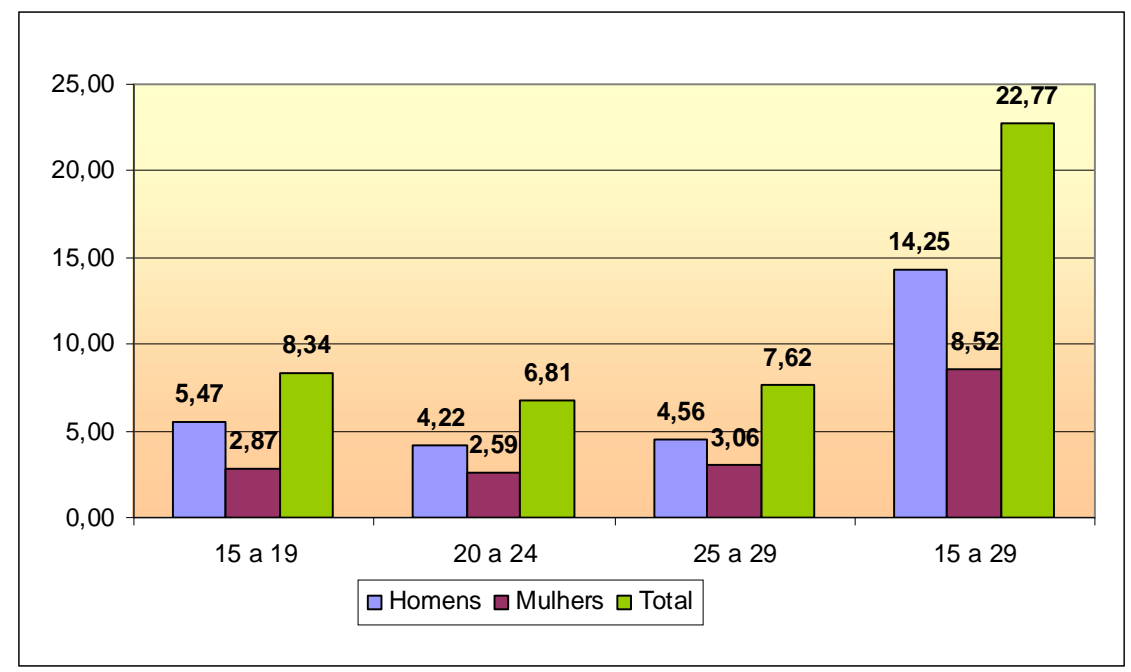

Gráfico 7: Estimativa do percentual da população jovem ocupada na agricultura familiar no RS por sexo e faixa etária*

*Considera toda a amostra disponível de agricultores familiares (117.145). Fonte: Censo Demográfico 2000. Microdados da Amostra.

A diferença no volume de homens e mulheres ocupados na agricultura familiar do Rio Grande do Sul não chega a ser surpresa. Ela está em conformidade com uma maior restrição à participação feminina na agricultura e com a tendência de masculinização do meio rural. Outrossim, conforme Brumer e Spanavelo (2008, p. 29) o que marca essas diferenças (entre homens e mulheres) na agricultura familiar "é que, apesar das atividades produtivas serem realizadas como somatório da força de trabalho, elas são consideradas como atividades masculinas". Como resultado deste viés de gênero, que não reconhece a importância da participação feminina na produção agrícola, as próprias fontes estatísticas oficiais contribuem para reforçar a invisibilidade da participação feminina no trabalho agrícola, como sugere o relatório sobre a situação das mulheres trabalhadoras rurais no Brasil (BRASIL/MDA, 2006). Assumindo-se, contudo, as estatísticas oficiais, registra-se um predomínio masculino entre os 
jovens ocupados na agricultura familiar no estado, na proporção de dois rapazes para uma moça.

Em outro capítulo será detalhada a participação dos jovens no trabalho familiar agrícola, porém, antes serão analisadas as condições matérias sobre as quais se estrutura a situação juvenil na agricultura familiar gaúcha. 


\section{AS CONDIÇÕES MATERIAIS DOS JOVENS AGRICULTORES FAMILIARES}

Neste capítulo, busca-se analisar as condições de acesso dos jovens aos recursos materiais como uma das dimensões que caracterizam a situação juvenil na agricultura familiar no Rio Grande do Sul. Como entre os agricultores familiares os meios de produção e o trabalho são familiares e a condição juvenil implica dependência em relação à família, buscou-se - primeiramente - levantar informações referentes à unidade de produção familiar (UPF) da qual os jovens participam. Esta é percebida como o espaço social que estrutura a existência dos jovens agricultores familiares. Assim, as condições materiais dos jovens são analisadas através da identificação das características econômicas da unidade produtivas no que diz respeito à sua condição fundiária, às formas de integração mercantil e às rendas familiares. Num segundo momento, são analisados o acesso dos jovens às rendas agrícolas e o uso que fazem destes recursos, recorrendo-se à análise comparativa segundo o sexo e a faixa etária dos entrevistados. No tópico final, a mesma abordagem comparativa é realizada com um conjunto de variáveis independentes que permitem avaliar o grau de autonomia material dos jovens agricultores familiares.

Estas condições materiais, objetivadas em um conjunto de indicadores, formam um complexo estruturado e articulado que condiciona, objetivamente, as possibilidades de reprodução geracional do processo de trabalho familiar agrícola. A inclusão desta dimensão analítica no presente estudo se deve ao pressuposto teórico de que as implicações de ordem material situam os jovens em posições determinadas nas relações sociais de produção e configuram o seu campo de possibilidades futuro. Ou seja, esta estrutura sobre a qual se desenvolve a agricultura familiar é vista como formando os recursos alocativos (GIDDENS, 2003) que procedem do controle de produtos materiais, ou aspectos do mundo material que tendem a exercer influência sobre as disposições dos jovens agricultores à reprodução do trabalho familiar, produzindo efeitos no campo das representações e do simbólico. Enfim, neste capítulo, demonstra-se que há significativa diferenciação entre os jovens agricultores familiares quanto ao acesso aos recursos materiais e, portanto, em suas condições de autonomia. 


\subsection{CARACTERÍSTICAS ECONÔMICAS DAS UNIDADES DE PRODUÇÃO FAMILIAR (UPF)}

No capítulo precedente, demonstra-se que a agricultura familiar, apesar de ser uma categoria de análise recente, conta com ampla legitimidade, social, política e acadêmica. Por definição, esta se caracteriza pelo fato de atributos como a gestão, a propriedade dos meios de produção e o trabalho possuírem um caráter familiar. Isto aponta para a relevância dos aspectos endógenos destas unidades produtivas tais como sua condição fundiária e sua capacidade de geração de valor e renda. Porém, sobre ela também incidem aspectos exógenos como aqueles que se estabelecem a partir de relações mercantis. Considerando a combinação destes aspectos, pode-se identificar, por vias puramente empíricas, que se trata de uma categoria internamente diferenciada. Busca-se, neste tópico, identificar esta diversidade econômica da agricultura familiar analisando-se a condição fundiária, as formas de interação mercantil e a produção de valor e renda nas unidades de produção familiar a partir das informações fornecidas pelos jovens agricultores entrevistados.

\subsubsection{Condição Fundiária}

Os agricultores familiares considerados neste trabalho são proprietários - parcial ou total - dos meios de produção que usam em seu processo de trabalho. Destes, a terra é o principal meio sobre o qual atuam. Ocorre que nem todos os agricultores familiares são proprietários das terras em que trabalham; além disto, entre os proprietários, predominam pequenas áreas. Para realizarmos um exame das condições fundiárias das unidades de produção familiar, apoiamo-nos em informações referentes: a) à condição de propriedade da terra; b) às formas como foram adquiridas as propriedades; c) às condições de uso da terra entre agricultores não proprietários; d) ao tamanho da área da unidade de produção familiar.

Considerando a condição de dependência e subordinação aos adultos, que caracteriza a juventude, principalmente desse meio, a situação dos entrevistados, segundo a condição de uso da terra, foi aferida através da pergunta: "Sua família é proprietária da terra em que trabalha?". As respostas demonstram que a ampla maioria dos jovens agricultores entrevistados $(88,4 \%)$ são membros de famílias proprietárias da terra (Gráfico 8). Este índice 
confirma o predomínio de proprietários entre os agricultores familiares identificados em outros estudos, como o Censo Agropecuário 1995/96, analisado pela equipe do convênio FAO/INCRA, que informava ser de $80,8 \%$ e percentual de agricultores familiares na condição de proprietários da terra em que trabalham.

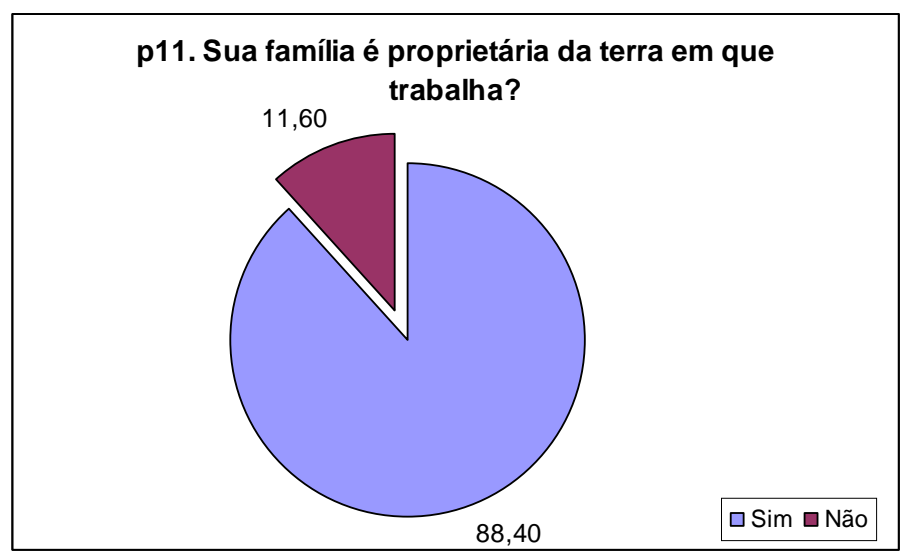

Gráfico 8: Condição de propriedade da terra (\%)

Fonte: Banco de dados Jovens Agricultores Familiares RS - MDA/FAURGS, 2007.

Buscou-se saber também qual era a origem destas propriedades. O Gráfico 9 apresenta a distribuição de respostas à questão: “Como foram obtidas as terras?". Verifica-se que o principal meio de acesso à propriedade fundiária pelas famílias dos entrevistados tem sido a transmissão de patrimônio por herança, que obteve $37,3 \%$ de respostas válidas. Outros $27,3 \%$ afirmaram que as propriedades foram obtidas através da compra de terceiros; $21 \%$ dos entrevistados disseram que a atual área da propriedade familiar atual resulta da combinação entre herança e compra de terceiros. Os menores índices de respostas a esta pergunta ficaram entre os jovens que informam que as terras foram adquiridas através da compras de parentes (8\%); 3,8\% dos entrevistados disseram que as terras da família resultaram de assentamento agrícola. 


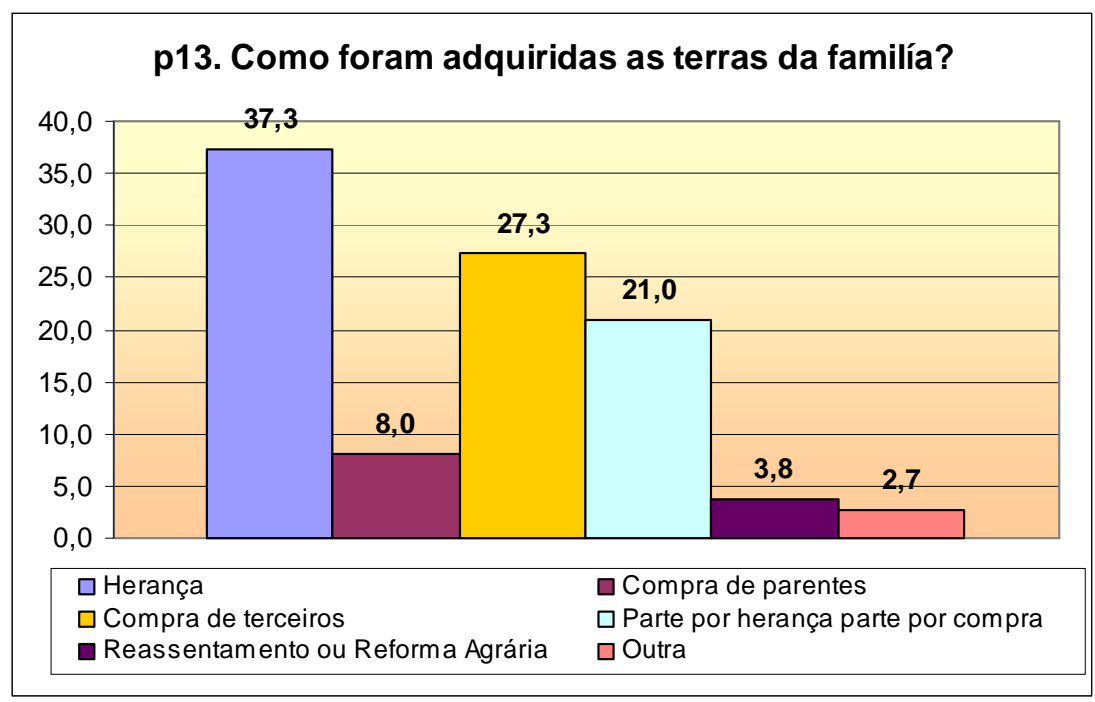

Gráfico 9: Origem da propriedade familiar (\%)

Fonte: Banco de dados Jovens Agricultores Familiares RS - MDA/FAURGS, 2007.

Entre os jovens membros de famílias não-proprietárias de terra (11,6\% do total), a principal forma de ter acesso a ela é a parceria. Como é possível verificar no Gráfico 10, a situação de parceria corresponde a 75,4\% destes casos. Conforme ocorre no espaço agrário do Rio Grande do Sul, a figura do parceiro é assumida por agricultores que trabalham com suas famílias arrendando a terra por meio de um "contrato de parceria". Nesta situação, eles entram com a força de trabalho familiar, com as ferramentas e com os custos dos insumos enquanto que os proprietários fundiários participam da parceria com as áreas de terra; por vezes, com insumos, dividindo o resultado da produção em porcentagem previamente estabelecida entre as partes..$^{54}$

Outros $9,3 \%$ dos entrevistados afirmaram que o uso da terra ocorre por meio de arrendamento. Nestes casos, suas famílias alugam áreas de terra por um preço fixo, combinando, previamente, o pagamento em dinheiro ou em produto. Ainda há 5,4\% de casos em que o uso da terra se dá na condição de meeiro. Como se pode observar, este tipo de relação fundiária assemelha-se em tudo ao da parceria, com exceção de que o pagamento da terra se fará em $50 \%$ do valor gerado pela produção. Geralmente estes "contratos" estabelecidos por prazos de duração média de três anos, com acertos anuais ou por safras.

\footnotetext{
${ }^{54}$ As diversas definições sobre parceria e as formas que se apresentam no Brasil podem ser encontradas em Loureiro (1977).

${ }^{55}$ Nestes casos, predominam acordos verbais sem formalização de contratos registrados em cartório.
} 


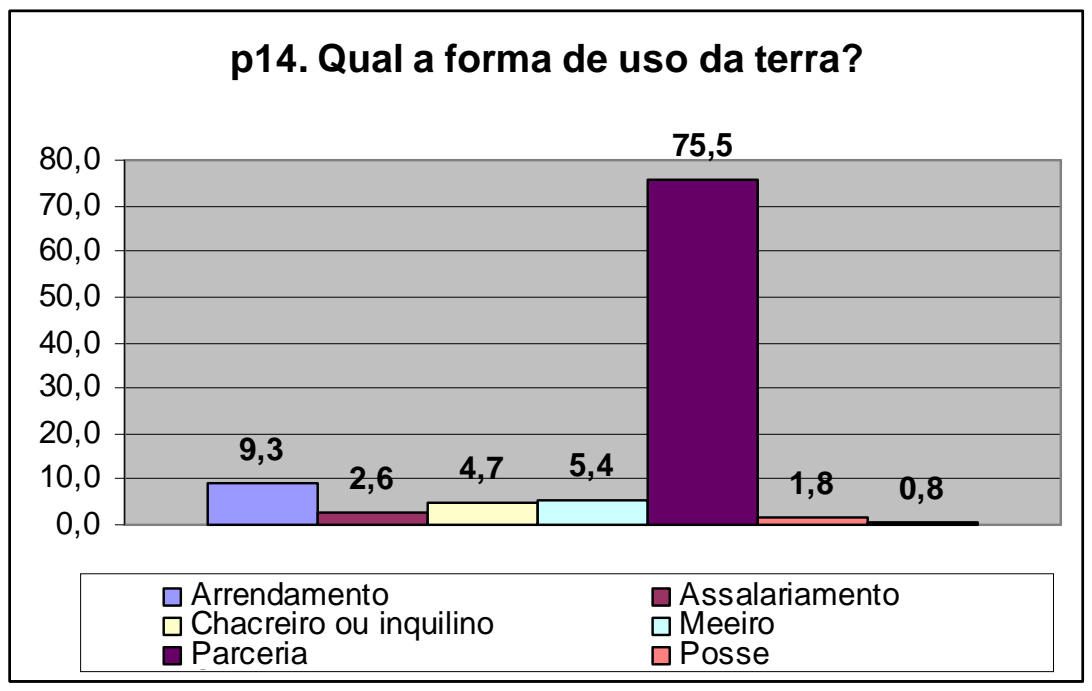

Gráfico 10: Forma de uso da terra entre não proprietários (\%)

Fonte: Banco de dados Jovens Agricultores Familiares RS - MDA/FAURGS, 2007.

Quanto ao tamanho das propriedades, os dados levantados revelam que os jovens agricultores se encontram em unidades produtivas com áreas cujo tamanho médio é de 31,4 hectares. ${ }^{56}$ Contudo, é importante mencionar que pode ser observada uma grande diferenciação quanto ao tamanho das propriedades da agricultura familiar gaúcha. Entre os casos estudados, são encontradas tanto unidades produtivas com áreas de um hectare cada, quanto outras, cuja extensão chega a 300 hectares.

Considerando para análise as repostas válidas quanto ao tamanho das unidades produtivas, estabelecemos uma estratificação social com cinco escalas, conforme o tamanho das propriedades. A Tabela 7 mostra que $13,7 \%$ dos entrevistados se encontram em propriedades menores do que 5 hectares. Por sua vez, o maior percentual (46\%) de jovens encontra-se em propriedades com áreas entre 05 a 20 hectares. Outros 36\% afirmaram que as propriedades possuem tamanhos entre 20 a 50 hectares. As maiores áreas registram as menores ocorrências, uma vez que $3,1 \%$ dos inquiridos encontram-se em propriedades com 50 a 100 hectares, enquanto que as propriedades com extensões superiores a 100 hectares e inferior a 15 Módulos Regionais ${ }^{57}$ constituem apenas 1,2\% do universo investigado. Considerando o percentual acumulativo, percebe-se que $95,7 \%$ dos jovens agricultores vivem em unidades produtivas com áreas menores que 50 hectares.

\footnotetext{
${ }^{56}$ Este dado é superior ao da média registrada para o Brasil que é de 26 ha e para a região Sul do Brasil que é de 21 ha (FAO/INCRA, 2000). Esta diferença pode ser explicada pelo fato de que o tamanho das propriedades não foi considerado como critério de estratificação para definição da amostra.

${ }^{57}$ O Módulo Regional do Sul do Brasil equivale em média a 25 hectares.
} 
Tabela 7: Distribuição de Estratos de Área das Propriedades Familiares

\begin{tabular}{llrrrr}
\hline \hline & & & & & Cumulative \\
& & Frequency & Percent & Valid Percent & Percent \\
\hline GRUPOS DE ÁREA & Até 5 ha & 80 & 11,7 & 13,7 & 13,7 \\
DAS PROPRIEDADES & +5 ha a 20 ha & 268 & 39,4 & 46,0 & 59,7 \\
(em ha) & +20 ha a 50 ha & 210 & 30,8 & 36,0 & 95,7 \\
& +50 ha a 100 ha & 18 & 2,6 & 3,1 & 98,8 \\
& +100 ha a 15 MR & 7 & 1,0 & 1,2 & 100,0 \\
& Total & 583 & 85,6 & 100,0 & \\
Missing & NA & 79 & 11,6 & & \\
& NS/NR & 19 & 2,8 & & \\
Total & Total & 98 & 14,4 & & \\
\hline \hline
\end{tabular}

Fonte: Banco de dados Jovens Agricultores Familiares RS - MDA/FAURGS, 2007.

Os dados apresentados neste tópico demonstram que, naquilo que diz respeito ao acesso a terra, a maioria dos jovens fazem parte de famílias que possuem a propriedade da terra na qual trabalham. Revelam ainda que a principal forma de acesso à propriedade continua sendo a herança, seguida das transações no mercado de terras. Entre os nãoproprietários predomina o acesso a terra através do estabelecimento de parceria. Por fim, pode-se perceber que as unidades produtivas possuem tamanhos restritos, visto que a maior parte dos jovens agricultores reside e trabalha em áreas com tamanho inferior a 50 hectares (sendo que 60\% encontram-se em estabelecimentos com área inferior a 20 hectares).

\subsubsection{Integração Mercantil das Unidades de Produção Familiar (UPF)}

Conforme os dados divulgados pelo Censo Agropecuário de 1995-1996, do IBGE, havia no Rio Grande do Sul 429.958 propriedades rurais, das quais 395.584 (92\%) eram de agricultura familiar. Guilhoto et al. (2005) demonstram que a participação do chamado "agronegócio familiar" no estado atingiu o patamar de $23,5 \%$ do seu Produto Interno Bruto (PIB) no período de 1995 a 2003, o que representa uma participação 2,5 vezes superior ao da média nacional $(9,3 \%)$. Considerando-se os mesmos índices para o "agronegócio patronal”, a participação deste setor no Rio Grande do Sul (19,4\% do PIB) é semelhante aos da média nacional (19,1\% do PIB). Estes dados são ainda mais significativos tendo em vista as grandes 
diferenças entre estes dois segmentos, no que concerne às áreas de terras, ao volume de crédito, ao aporte tecnológico e ao acesso à assistência técnica; bastante inferiores para o segmento familiar se comparado ao patronal.

Percebe-se, assim, que a agricultura familiar no Rio Grande do Sul encontra-se, em grande parte, integrada ao complexo agroindustrial e de capital, o que pode ser constatado ao considerar-se: a) o destino da produção; b) as formas de comercialização dos produtos; c) o acesso ao crédito agrícola pelas famílias dos jovens.

Como pode ser observado no Gráfico 11, isto se traduz no expressivo volume de entrevistados $(82,8 \%)$ que afirmam que as atividades produtivas da unidade de produção familiar destinam-se, principalmente, à comercialização. Já os jovens que responderam que elas estão voltadas prioritariamente para o autoconsumo da família, representam $8,5 \%$ da amostra, percentual similar ao dos que afirmam que a produção destina-se igualmente para a comercialização e para o autoconsumo $(8,4 \%)$.

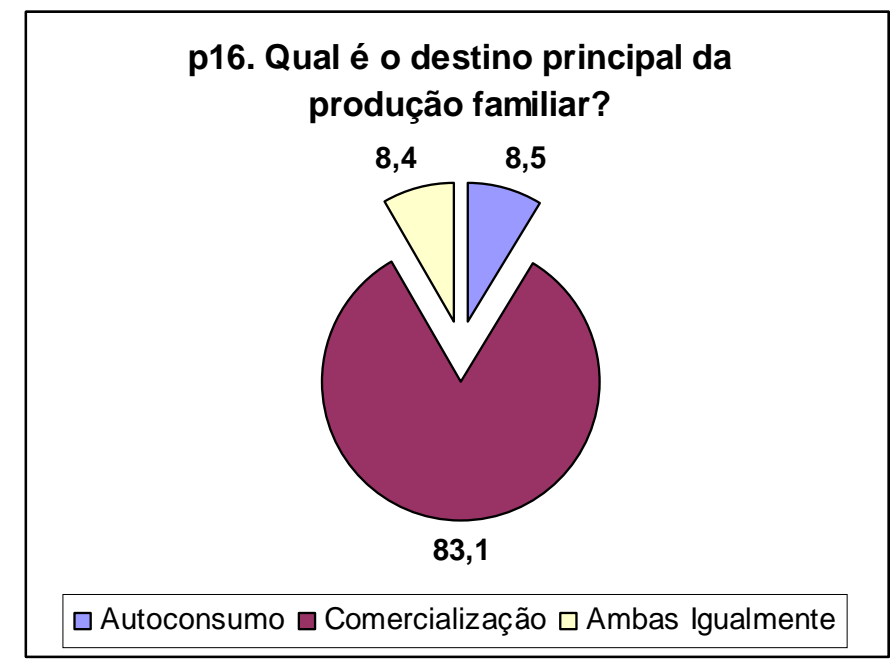

Gráfico 11: Principal destinação da produção familiar (\%) Fonte: Banco de dados Jovens Agricultores Familiares RS - MDA/FAURGS, 2007.

Entre aqueles jovens que relataram que as atividades produtivas dos estabelecimentos familiares em que estão inseridos são direcionadas para o autoconsumo (43 casos em um universo de 681), 32,6\% se encontram em propriedades com áreas inferiores a cinco hectares. Enquanto outros 39,5\% fazem parte de unidades familiares com tamanhos entre 5 a 20 hectares e 25,6\% estão em propriedades com extensão de 20 a 50 hectares. Particularmente, este último contingente diz respeito a situações em que a terra se encontra parcialmente arrendada, ou é usada para outros fins comercias que não o da produção 
agromercantil. De qualquer modo, as informações obtidas revelam que a produção para o autoconsumo predomina entre as propriedades menores, porém não é exclusiva das pequenas áreas.

Conforme relatam os jovens, a produção para autoconsumo não significa que estas unidades produtivas estejam fora das relações mercantis, mas sim que apresentam sistemas de produção diferenciados. Os exemplos disto ficam por conta dos casos em que são cultivados produtos como milho, mandioca, cana e feijão, e estes alimentos são consumidos pela família e por animais de criação. Desta forma, os produtores familiares valem-se do valor de uso destes produtos como insumo da produção mercantil de leite, queijo, ovos, aves e suínos. Outra característica destes casos é que, pelo menos, um dos membros da unidade produtiva obtém alguma fonte de rendimento externo, tais como o assalariamento agrícola sazonal, aposentadoria e assalariamento não-agrícola. Contudo, estas situações são minoritárias na produção familiar gaúcha.

No Rio Grande do Sul, a agricultura familiar se realiza como uma atividade agromercantil, na qual o produto do trabalho familiar entra no processo de circulação e acumulação de capital, transferindo valor para outros ramos da atividade econômica. Isto ocorre através de relações comerciais estabelecidas pelos agricultores com agentes econômicos do complexo agroindustrial. Como se apresenta no Gráfico 12, as formas de comercialização da produção familiar são realizadas, principalmente, por meio da integração dos agricultores com cooperativas $(38,4 \%)$ ou com grandes agroindústrias $(37,8 \%)$, enquanto que a comercialização através de agroindústrias familiares e de associações de produtores são as formas menos utilizadas. 


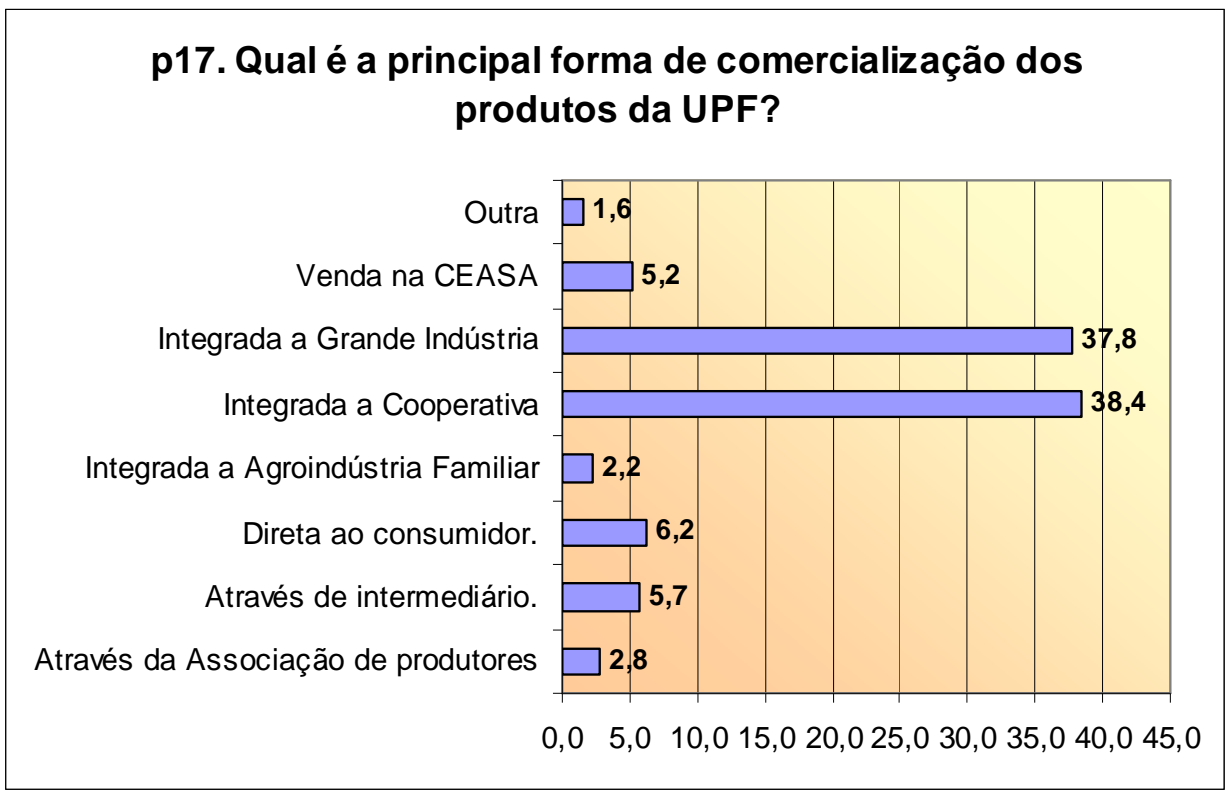

Gráfico 12: Formas de comercialização dos produtos das Unidades de Produção Familiar (\%) Fonte: Banco de dados Jovens Agricultores Familiares RS - MDA/FAURGS, 2007.

Estes dados colaboram com o que referimos no capítulo anterior, quanto à inserção do trabalho familiar nas relações mercantis capitalistas. Sob tais condições, o trabalho familiar e seu produto são canalizados para grandes indústrias e cooperativas agrícolas. Na relação com a agroindústria, encontram-se os produtores de fumo, aves e suínos, enquanto que através das grandes cooperativas são comercializados, principalmente, a soja e o milho. A produção de uva e leite também se destina, principalmente, a estas duas formas de comercialização. As vendas diretas ao consumidor, agroindústria familiar e associações de produtores, apesar de minoritárias, apresentam uma grande diversificação de produtos, com predomínio da fruticultura e da horticultura, voltadas, principalmente, ao consumo das populações circunvizinhas.

\subsubsection{Produção de valor e renda familiar}

As diferenças de renda entre os jovens agricultores podem ser verificadas recorrendo-se a três variáveis: a) Valor Bruto da Produção (VBP); b) Renda Agrícola (RA); c) Renda Familiar Total (RFT). Estes indicadores de renda foram obtidos junto aos entrevistados e seus pais e se referem aos valores obtidos no ano de 2006, apresentados aqui sem correção 
monetária. Obteve-se o Valor Bruto da Produção somando-se todo o valor da produção anual dos produtos (animais e vegetais) comercializados pela unidade familiar ao longo do ano. A Renda Agrícola foi obtida subtraindo-se do VBP o Custo de Produção para o mesmo período. Por sua vez, a Renda Familiar Total foi obtida somando-se a RA com outras fontes de rendimento como salários; transferências e benefícios sociais; beneficiamento de produtos na UPF; rendas eventuais ou sazonais, e outras fontes de renda obtidas por todos os membros das famílias dos entrevistados no ano de referência.

A tabela abaixo apresenta a distribuição de frequência da variável Valor Bruto da Produção. Primeiramente, é necessário destacar o fato de que 26,6\% deles não souberam responder a esta pergunta. Isto ocorreu, principalmente, entre os jovens adolescentes e as jovens mulheres. A ausência de respostas revela que estes sujeitos se encontram distantes da gestão financeira da UPF. Entre eles, temos ainda situações que nem mesmo os pais dos entrevistados souberam nos informar o valor produzido na propriedade porque não realizavam qualquer tipo de contabilidade em sua unidade produtiva.

Tabela 8: Distribuição de frequências do Valor Bruto da Produção (R \$/ano)

\begin{tabular}{llrrrr}
\hline \hline & & & & \multicolumn{2}{c}{ Cumulative } \\
& & Frequency & Percent & Valid Percent & Percent \\
\hline Valid & + +0 a 10.000 & 148 & 21,7 & 29,6 & 29,6 \\
& +10.000 a 20.000 & 146 & 21,4 & 29,2 & 58,8 \\
& +20.000 a 30.000 & 82 & 12,0 & 16,4 & 75,2 \\
& +30.000 a 40.000 & 48 & 7,0 & 9,6 & 84,8 \\
& +40.000 & 76 & 11,2 & 15,2 & 100,0 \\
& Total & 500 & 73,4 & 100,0 & \\
Missing & NS/NR & 181 & 26,6 & & \\
Total & & 681 & 100,0 & & \\
\hline \hline
\end{tabular}

Fonte: Banco de dados Jovens Agricultores Familiares RS - MDA/FAURGS, 2007.

Considerando os casos válidos, na mesma Tabela 8 , verifica-se que $29,6 \%$ dos inquiridos declararam que as famílias obtêm rendas positivas de até $\mathrm{R} \$ 10.000,00$ e outros $29,2 \%$ que as suas rendas ficam entre $\mathrm{R} \$ 10.000,00$ a $\mathrm{R} \$ 20.000,00$. Ainda 16,4\% deles informaram renda bruta anual de $\mathrm{R} \$ 20.000,00$ a $\mathrm{R} \$ 30.000,00$. Deste modo, observa-se que $75,2 \%$ dos jovens agricultores fazem parte de uma unidade de produção familiar cujo VBP não ultrapassa $R \$ 30.000,00$ ao ano. A frequência de casos de valores entre $R \$ 30.000 .00$ a $\mathrm{R} \$ 40.000 .00$ é de $9,6 \%$, enquanto um percentual um pouco maior que este $(15,2 \%)$ é registrado para aqueles que alcançam valores superiores a $\mathrm{R} \$ 40.000,00$. 
Na Tabela 9, observamos a distribuição de frequência da variável de Renda Agrícola. Para esta questão, também, não obtivemos respostas de praticamente $1 / 4$ dos entrevistados, pelos mesmos motivos referidos anteriormente. No que diz respeito aos casos válidos, verifica-se que 5,1\% dos entrevistados estão em famílias com Renda Agrícola negativa ${ }^{58}$ (até $\mathrm{R} \$ 0,0$ ao ano). Já a maioria dos jovens agricultores familiares $(60,2 \%)$ encontra-se no grupo que obtém RA de até $\mathrm{R} \$ 10.000,00$ líquidos anuais. Os que possuem RA entre $\mathrm{R} \$ 10.000,00 \mathrm{a}$ $\mathrm{R} \$ 20.000,00$ correspondem a 21,2\% dos casos. Por sua vez, para 8,8\% dos entrevistados esta é de $\mathrm{R} \$ 20.000,00$ até $\mathrm{R} \$ 30.000,00$, sendo de 1,9\% dos jovens declararam rendas superiores a R\$ 30.000,00 até R\$ 40.000,00. Os jovens cujas famílias possuem Renda Agrícola superiores a $\mathrm{R} \$ 40.000,00$ representam $2,7 \%$ dos casos.

Tabela 9: Distribuição de frequência da Renda Agrícola (R \$/ano)

\begin{tabular}{llrrrr}
\hline \hline & & & & & Cumulative \\
Valid & Até 0 & Frequency & Percent & Valid Percent & Percent \\
& + +0 a 10.000 & 26 & 3,8 & 5,1 & 5,1 \\
& + 10.000 a 20.000 & 109 & 45,4 & 60,2 & 65,3 \\
& + 20.000 a 30.000 & 45 & 16,0 & 21,2 & 86,5 \\
& +30.000 a 40.000 & 10 & 1,5 & 1,9 & 97,3 \\
& +40.000 & 14 & 2,1 & 2,7 & 100,0 \\
& Total & 513 & 75,3 & 100,0 & \\
Missing & NS/NR & 168 & 24,7 & & \\
Total & & 681 & 100,0 & & \\
\hline \hline
\end{tabular}

Fonte: Banco de dados Jovens Agricultores Familiares RS - DA/FAURGS, 2007.

Quando o enfoque passa a ser a Renda Familiar Total, percebe-se um aumento no valor gerado pela família. Conforme o percentual válido, a ocorrência de rendas negativas é de $7,9 \%$, mais frequente do que a registrada para RA. Isto pode ser atribuído ao fato de que pode haver um volume maior de respostas válidas para esta pergunta. Os jovens que afirmam contar com RFT de até R \$ 10.000,00 representam 41,1\% do total de casos válidos. Aqueles cujas famílias possuem rendas totais entre $\mathrm{R} \$ 10.000,00$ a $\mathrm{R} \$ 20.000,00$ são 27,4\% e os que possuem entre $\mathrm{R} \$ 20.000,00$ e $\mathrm{R} \$ 30.000,00$ formam $10,5 \%$ dos casos. O percentual com

\footnotetext{
${ }^{58}$ De modo semelhante ao identificado por Buanin, Romero e Guaziroli (2003), os estabelecimentos com Rendas Agrícolas negativas correspondem a três tipos de situações: a) aquelas em que os investimentos em novas atividades demandam gastos que ainda não estão dando retorno; b) agricultores que tiveram prejuízos na safra considerada pela pesquisa, seja por problemas de mercado referente ao descompasso entre custos dos insumos e cotação de seus produtos seja por problemas climáticos principalmente relacionados com estiagem; c) agricultores que produzem em pequena escala, e que os gastos gerais da propriedade ultrapassam a Renda Agrícola gerada.
} 
rendas anuais de $\mathrm{R} \$ 30.000,00$ a $\mathrm{R} \$ 40.000,00$ é apenas 4,9\% dos casos válidos, enquanto os que afirmam ter RFT superior a $\mathrm{R} \$ 40.000,00$ corresponde a 5,3\% destes casos (Tabela 10).

Tabela 10: Distribuição de frequência da Renda Familiar Total (R\$/ano)

\begin{tabular}{llrrrr}
\hline \hline & & & & & \multicolumn{2}{c}{$\begin{array}{c}\text { Cumulative } \\
\text { Percent }\end{array}$} \\
\hline Valid & Até 0 & 50 & 7,3 & 7,9 & 7,9 \\
& +0 a 10.000 & 280 & 41,1 & 44,0 & 51,9 \\
& +10.000 a 20.000 & 174 & 25,6 & 27,4 & 79,2 \\
& +20.000 a 30.000 & 67 & 9,8 & 10,5 & 89,8 \\
& +30.000 a 40.000 & 31 & 4,6 & 4,9 & 94,7 \\
& +40.000 & 34 & 5,0 & 5,3 & 100,0 \\
& Total & 636 & 93,4 & 100,0 & \\
Missing & NS/NR & 45 & 6,6 & & \\
Total & & 681 & 100,0 & & \\
\hline \hline
\end{tabular}

Fonte: Banco de dados Jovens Agricultores Familiares RS - MDA/FAURGS, 2007.

A análise das variáveis Valor Bruto da Produção (VBP), Renda Agrícola (RA) e Renda Familiar Total (RFT) demonstram que predomina entre os jovens os menores estratos de renda. Ao serem comparadas, percebe-se que 41,2\% dos entrevistados estão em unidades produtivas que geram VBP superior a RS 20.000,00, enquanto apenas 13,5\% obtêm RA superior a $\mathrm{R} \$ 20.000,00$. Este resultado mostra que o valor gerado no interior da unidade de produção familiar - e que é taxado de fora - acaba sendo em sua maior parte consumido pelo custo de produção, condenando a atividade agrícola ao baixo retorno financeiro. Nestas condições, outras fontes de rendimento permitem a elevação da renda familiar, uma vez que a RFT superior a $\mathrm{R} \$ 20.000,00$ obtém $20,8 \%$ de respostas. Por sua vez, as menores faixas de renda apresentam percentuais maiores na RA do que na RFT. 


\subsection{O ACESSO DOS JOVENS ÀS RENDAS AGRÍCOLAS}

Neste tópico, são analisadas as formas de acesso dos jovens às rendas agrícolas geradas na unidade de produção familiar e quais usos eles fazem destes recursos. A construção das inferências a este respeito valeu-se das questões: Como é feita a divisão da renda agrícola? O que você recebe por sua participação no trabalho familiar agrícola? Em que você gasta o dinheiro recebido pelo trabalho agrícola? Com o propósito de produzir uma análise mais detalhada da situação juvenil na agricultura familiar, são feitos cruzamentos das respostas a estas questões com as variáveis sexo e faixa etária.

Quando perguntado aos jovens agricultores como é feita a divisão das rendas agrícolas, 39,3\% deles informaram que elas são divididas entre todos os que trabalham na agricultura sendo esta categoria de resposta a mais frequente. O segundo maior percentual de respostas é registrado para categoria o pai e a mãe juntos centralizam os rendimentos $(22,4 \%)$. A terceira resposta mais frequente corresponde a situações em que apenas $o$ pai centraliza os rendimentos (20,2\%). Aparecem, ainda, 11,4\% referentes a outras formas de divisão das rendas. Este percentual corresponde às situações em que os entrevistados já estão casados e passam a administrar os recursos provenientes de sua atividade. Registra-se, ainda, que apenas 3,3\% afirmaram que cada um fica com o que ganha, o que representa uma forma de maior individualização das rendas agrícolas. Considerando-se as respostas que apontam para uma concentração dos rendimentos pelos pais dos entrevistados, obtém-se um percentual acumulado de $44 \%$ das respostas (Gráfico 13).

Na tabela subsequente, encontra-se o cruzamento da questão em pauta com a variável sexo. Constatam-se poucas diferenças nas respostas sobre a forma como são divididas as rendas agrícolas, uma vez que para as principais categoriais figuram os mesmo percentuais entre homens e mulheres. Destaca-se o percentual um pouco maior - composto de homens $(22 \%)$ que afirma ser o pai quem centraliza o destino dos rendimentos do que o verificado entre as mulheres (17\%). Por sua vez, elas apresentam índice maior do que o deles para a resposta outra forma, o que corresponde a situações de jovens casadas em que os recursos são centralizados pelos cônjuges, ou, então, são administrados pelo jovem casal (Tabela 11). 


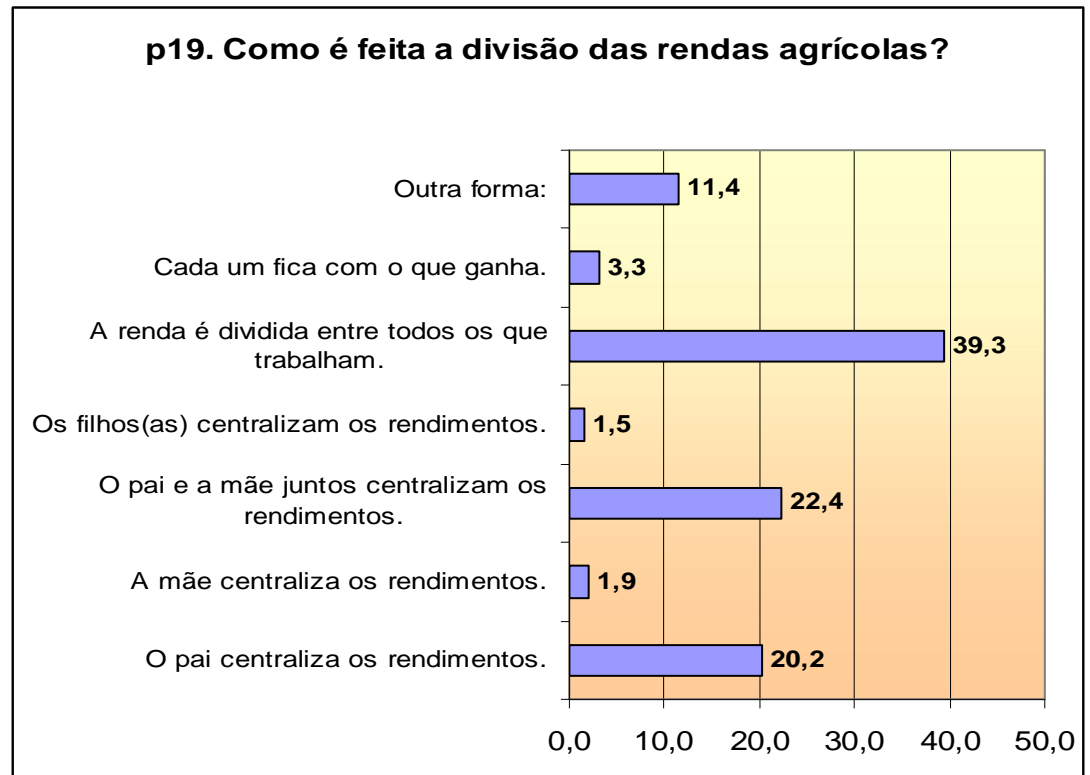

Gráfico 13: Forma de distribuição das rendas agrícolas (\%)

Fonte: Banco de dados Jovens Agricultores Familiares RS - MDA/FAURGS, 2007.

Tabela 11: Cruzamento das formas de divisão da Rendas Agrícolas por sexo (em $f$ e \%)

\begin{tabular}{|c|c|c|c|c|c|}
\hline & & & \multicolumn{2}{|c|}{ SEXO } & \multirow[b]{2}{*}{ Total } \\
\hline & & & Homens & Mulheres & \\
\hline \multirow{14}{*}{$\begin{array}{l}\text { COMO É FEITA A } \\
\text { DIVISÃO DAS } \\
\text { RENDAS } \\
\text { PROVENIENTES } \\
\text { DA ATIVIDADE } \\
\text { AGRÍCOLA? }\end{array}$} & \multirow{2}{*}{ O pai centraliza os rendimentos. } & $f$ & 93 & 43 & 136 \\
\hline & & $\%$ & $22,0 \%$ & $17,1 \%$ & $20,2 \%$ \\
\hline & \multirow[t]{2}{*}{ A mãe centraliza os rendimentos. } & $f$ & 8 & 5 & 13 \\
\hline & & $\%$ & $1,9 \%$ & $2,0 \%$ & $1,9 \%$ \\
\hline & \multirow{2}{*}{$\begin{array}{l}\text { O pai e a mãe juntos centralizam } \\
\text { os rendimentos. }\end{array}$} & $f$ & 95 & 56 & 151 \\
\hline & & $\%$ & $22,5 \%$ & $22,3 \%$ & $22,4 \%$ \\
\hline & \multirow{2}{*}{$\begin{array}{l}\text { Os filhos(as) centralizam os } \\
\text { rendimentos. }\end{array}$} & $f$ & 7 & 3 & 10 \\
\hline & & $\%$ & $1,7 \%$ & $1,2 \%$ & $1,5 \%$ \\
\hline & \multirow{2}{*}{$\begin{array}{l}\text { A renda é dividida entre todos os } \\
\text { que trabalham. }\end{array}$} & $f$ & 167 & 98 & 265 \\
\hline & & $\%$ & $39,5 \%$ & $39,0 \%$ & $39,3 \%$ \\
\hline & \multirow[t]{2}{*}{ Cada um fica com o que ganha. } & $f$ & 16 & 6 & 22 \\
\hline & & $\%$ & $3,8 \%$ & $2,4 \%$ & $3,3 \%$ \\
\hline & \multirow[t]{2}{*}{ Outra forma: } & $f$ & 37 & 40 & 77 \\
\hline & & $\%$ & $8,7 \%$ & $15,9 \%$ & $11,4 \%$ \\
\hline \multirow{2}{*}{\multicolumn{2}{|c|}{ Total }} & $f$ & 423 & 251 & 674 \\
\hline & & $\%$ & $100,0 \%$ & $100,0 \%$ & $100,0 \%$ \\
\hline
\end{tabular}

Fonte: Banco de dados Jovens Agricultores Familiares RS - MDA/FAURGS, 2007.

Na Tabela 12, apresenta-se o cruzamento entre a questão Como é feita a divisão da renda agrícola? com a variável faixa etária. Verifica-se que, entre os jovens adolescentes (de 15 a 19 anos), são mais frequentes os casos em que o pai e a mãe $(35,2 \%)$ ou apenas o pai 
(29,6\%) centralizam os rendimentos do trabalho da família. Entre os jovens de 20 a 24 anos, predomina a partilha entre todos os que trabalham (44,3\% dos casos). Depois aparecem, com percentuais idênticos, as situações em que apenas os pais ou o pai e a mãe centralizam os rendimentos. Esta tendência se intensifica entre os jovens adultos (de 25 a 29 anos), visto que $50,2 \%$ deles informaram que a renda é dividida entre todos. Ainda entre os jovens adultos $21,1 \%$ respondem que a renda é dividida de outra forma, confirmando que entre estes há um percentual maior que obtêm recursos próprios, uma vez que estão em um estágio da transição mais próximo da condição de autonomia. Destaca-se que o acesso dos jovens às rendas provenientes da atividade agrícola apresenta um gradual aumento conforme avança a faixa etária dos entrevistados, visto que o percentual de jovens adultos que afirma que a renda é dividida entre todos é o dobro da verificada entre os jovens adolescentes.

Tabela 12: Cruzamento entre forma de divisão da Rendas Agrícola por faixa etária (em $f$ e \%)

\begin{tabular}{|c|c|c|c|c|c|c|}
\hline & & & \multicolumn{3}{|c|}{ FAIXA ETÁRIA: } & \multirow[b]{2}{*}{ Total } \\
\hline & & & $\begin{array}{l}\text { De } 15 \text { a } \\
19 \text { anos }\end{array}$ & $\begin{array}{l}\text { De } 20 \text { a } \\
24 \text { anos }\end{array}$ & $\begin{array}{l}\text { De } 25 \text { a } \\
29 \text { anos }\end{array}$ & \\
\hline \multirow{14}{*}{$\begin{array}{l}\text { COMO É FEITA A } \\
\text { DIVISÃO DAS } \\
\text { RENDAS } \\
\text { PROVENIENTES } \\
\text { DA ATIVIDADE } \\
\text { AGRÍCOLA? }\end{array}$} & \multirow{2}{*}{ O pai centraliza os rendimentos. } & $f$ & 74 & 40 & 22 & 136 \\
\hline & & $\%$ & $29,6 \%$ & $19,9 \%$ & $9,9 \%$ & $20,2 \%$ \\
\hline & \multirow[t]{2}{*}{ A mãe centraliza os rendimentos. } & $f$ & 6 & 2 & 5 & 13 \\
\hline & & $\%$ & $2,4 \%$ & $1,0 \%$ & $2,2 \%$ & $1,9 \%$ \\
\hline & \multirow{2}{*}{$\begin{array}{l}\text { O pai e a mãe juntos centralizam os } \\
\text { rendimentos. }\end{array}$} & $f$ & 88 & 40 & 23 & 151 \\
\hline & & $\%$ & $35,2 \%$ & $19,9 \%$ & $10,3 \%$ & $22,4 \%$ \\
\hline & \multirow{2}{*}{$\begin{array}{l}\text { Os filhos(as) centralizam os } \\
\text { rendimentos. }\end{array}$} & $f$ & 1 & 2 & 7 & 10 \\
\hline & & $\%$ &, $4 \%$ & $1,0 \%$ & $3,1 \%$ & $1,5 \%$ \\
\hline & \multirow{2}{*}{$\begin{array}{l}\text { A renda é dividida entre todos os } \\
\text { que trabalham. }\end{array}$} & $f$ & 64 & 89 & 112 & 265 \\
\hline & & $\%$ & $25,6 \%$ & $44,3 \%$ & $50,2 \%$ & $39,3 \%$ \\
\hline & \multirow[t]{2}{*}{ Cada um fica com o que ganha. } & $f$ & 8 & 7 & 7 & 22 \\
\hline & & $\%$ & $3,2 \%$ & $3,5 \%$ & $3,1 \%$ & $3,3 \%$ \\
\hline & \multirow[t]{2}{*}{ Outra forma: } & $f$ & 9 & 21 & 47 & 77 \\
\hline & & $\%$ & $3,6 \%$ & $10,4 \%$ & $21,1 \%$ & $11,4 \%$ \\
\hline \multirow{2}{*}{\multicolumn{2}{|c|}{ Total }} & $f$ & 250 & 201 & 223 & 674 \\
\hline & & $\%$ & $100,0 \%$ & $100,0 \%$ & $100,0 \%$ & $100,0 \%$ \\
\hline
\end{tabular}

Fonte: Banco de dados Jovens Agricultores Familiares RS - MDA/FAURGS, 2007.

As diferenças no acesso às rendas agrícolas por faixa etária tendo sexo como variável interveniente pode ser verificada no Gráfico 14. Nele percebe-se que o percentual referente à divisão delas entre todos os que trabalham aumenta com a faixa etária dos entrevistados, tanto para os homens como para as mulheres. No sentido inverso, diminuem as respostas que apontam a centralização das rendas pelo pai ou, pelo pai e mãe em conjunto. 
Destaca-se ainda a categoria outra forma, que é mais expressiva entre as mulheres de 25 a 29 anos de idade, representando $27 \%$ dos casos. Na perspectiva dos jovens adultos, a renda é, predominantemente, partilhada entre todos os que trabalham $(53,7 \%)$. Com efeito, pode-se dizer que as mulheres jovens têm menor acesso às rendas provenientes das atividades agrícolas do que os homens, uma vez que, quando elas são solteiras, as rendas são centralizadas pelo pai; quando elas são casadas, as rendas tendem a ser centralizadas pelo marido.

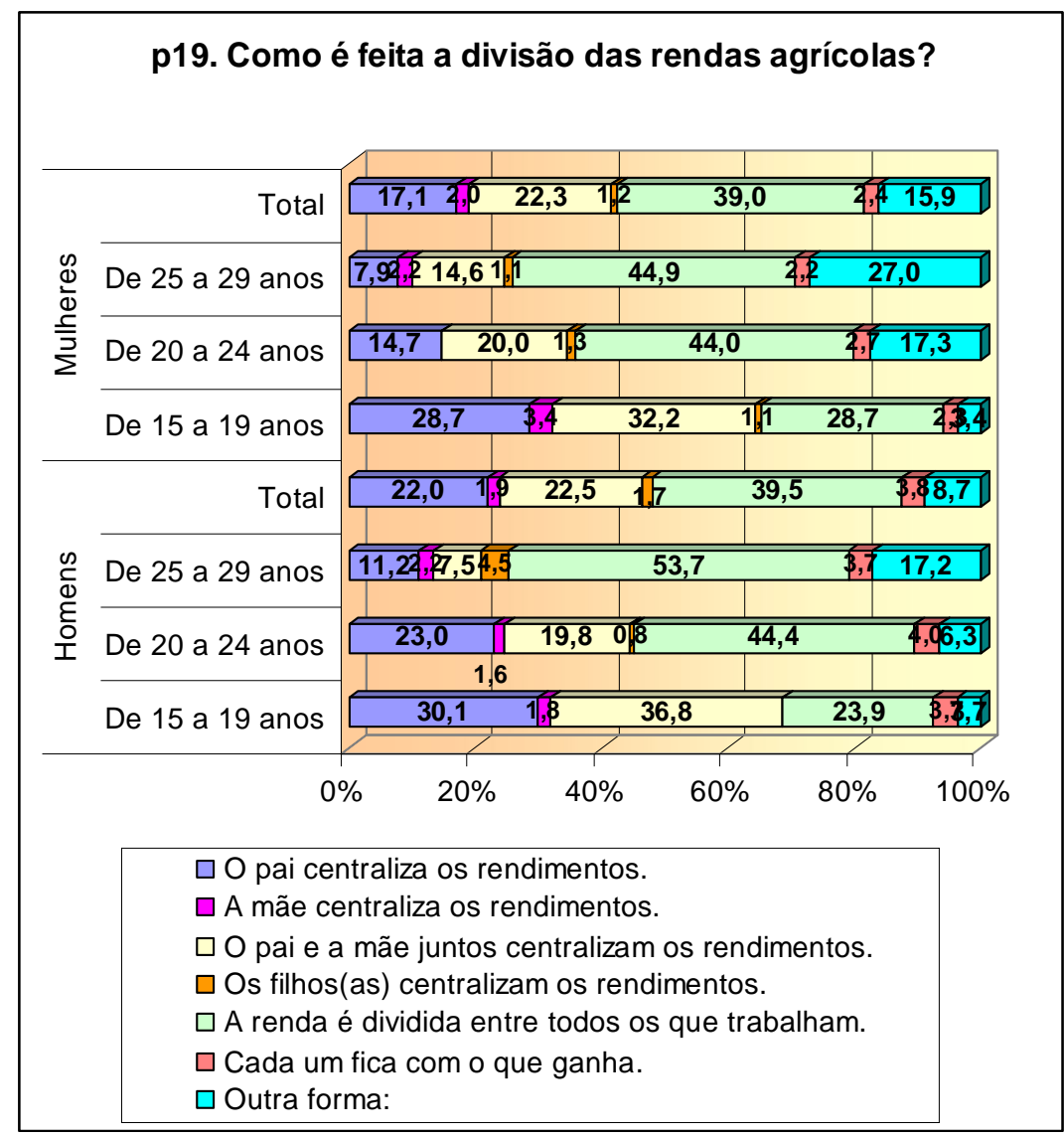

Gráfico 14: Divisão das rendas agrícolas por sexo e faixa etária (\%) Fonte: Banco de dados Jovens Agricultores Familiares RS - MDA/FAURGS, 2007.

A ideia predominante de que as rendas agrícolas são divididas entre todos os que trabalham não pode ser interpretada como um indicador de autonomia dos jovens. Na verdade, estas respostas encobrem os diferentes arranjos familiares que tendem a manter as rendas agrícolas o mais indivisíveis possível. Ou seja, centralizada pelo chefe da família com os recursos apenas "pingando" na mão dos jovens, como nos relatou um entrevistado, de tal 
modo que eles permanecem na dependência dos pais para usufruírem do resultado do trabalho que realizaram.

Isto pode ser percebido na medida em que mudamos a abordagem sobre o acesso dos jovens à renda agrícola perguntado $O$ que você recebe por sua participação no trabalho familiar agrícola? Para esta questão, predomina a resposta Quando preciso de alguma coisa ou dinheiro peço aos meus pais $(54,4 \%)$. Isto mostra que o fato de todos receberem pelo seu trabalho não implica uma remuneração periódica, estando os jovens em condição de dependência de ter de pedir dinheiro aos pais toda vez de que necessitam de algo.

Conforme as informações levantadas, apenas 13,7\% dos inquiridos trabalham em parceria com seus pais, recebendo uma parte pré-definida dos resultados da produção familiar. Aqueles que afirmaram receber, periodicamente, uma quantia em dinheiro para seus gastos pessoais correspondem a $12,4 \%$ dos casos. Outros $10,4 \%$ ficam com parte dos recursos provenientes daquilo que comercializam; apenas $4,3 \%$ deles ficam com recursos provenientes de atividades autônomas. Estas informações apresentadas no Gráfico 15 revelam que os jovens agricultores familiares são, financeiramente, dependentes de seus pais e que não acessam com regularidade os recursos provenientes da produção familiar.

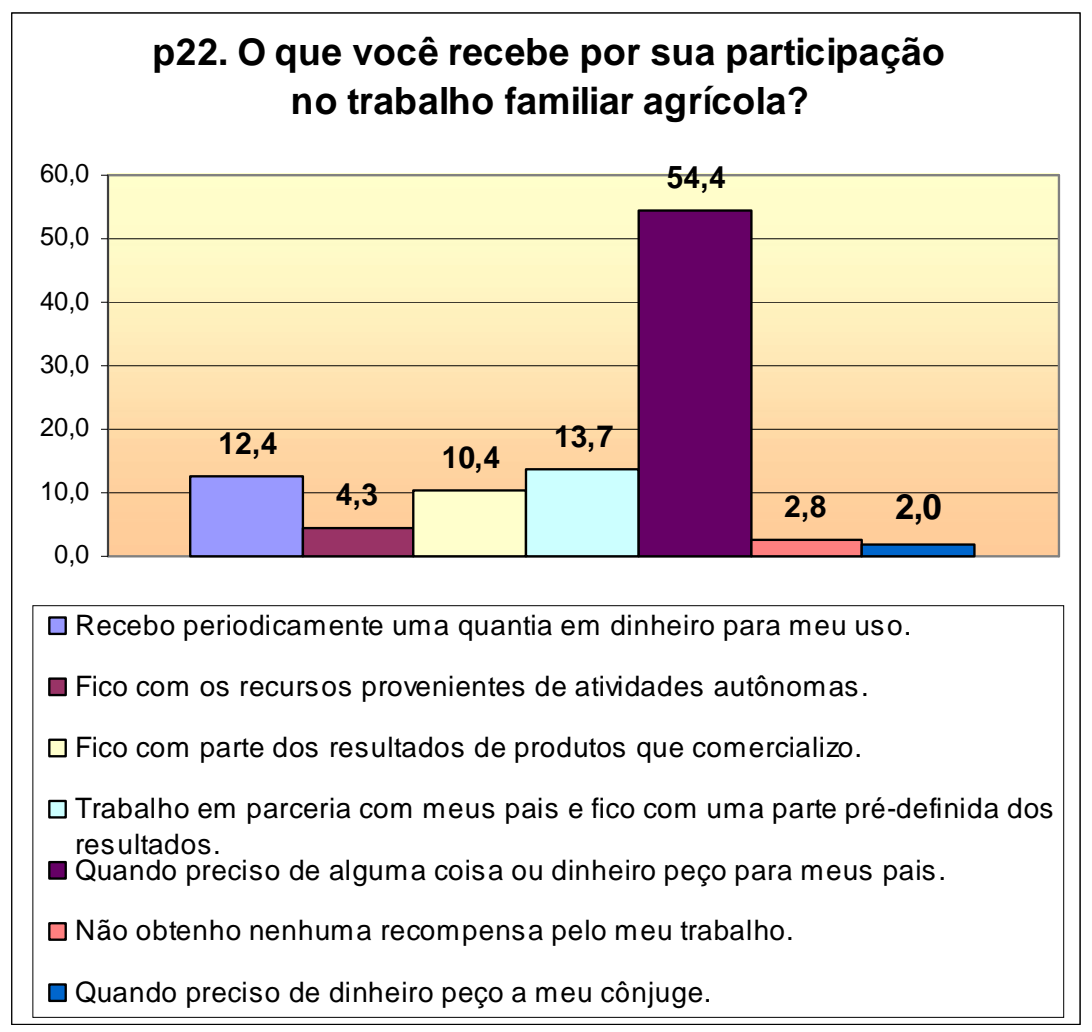

Gráfico 15: Formas de acesso dos jovens a renda familiar agrícola (\%)

Fonte: Banco de dados Jovens Agricultores Familiares RS - MDA/FAURGS, 2007 
A baixa autonomia financeira é uma realidade que afeta os jovens de ambos os sexos. Como pode ser constatado na Tabela 13, predomina com o mesmo percentual para homens e mulheres a alternativa que revela a dependência destes em relação aos pais. Apesar da diferenciação por sexo ser pouco representativa do ponto de vista estatístico para as respostas à questão em análise, chama atenção que as mulheres apresentam percentuais menores em categorias de respostas que apontam para alguma forma de reconhecimento do trabalho através de remuneração ou estabelecimento de parceria. Confirmando a desigualdade entre homens e mulheres no acesso aos recursos financeiros gerados na produção familiar agrícola, as jovens entrevistadas apresentam percentuais maiores do que os homens quando as respostas são: "não obtenho nenhuma remuneração pelo meu trabalho" e "quando preciso de dinheiro peço ao meu cônjuge”.

Tabela 13: Cruzamento formas de recompensa por sexo (em $f$ e \%)

\begin{tabular}{|c|c|c|c|c|c|}
\hline & & & \multicolumn{2}{|c|}{ SEXO } & \multirow[b]{2}{*}{ Total } \\
\hline & & & Homens & Mulheres & \\
\hline \multirow{14}{*}{$\begin{array}{l}\text { O QUE VOCÊ } \\
\text { RECEBE POR } \\
\text { SUA } \\
\text { PARTICIPAÇÃO } \\
\text { NO TRABALHO } \\
\text { FAMILIAR } \\
\text { AGRÍCOLA? }\end{array}$} & \multirow{2}{*}{$\begin{array}{l}\text { Recebo periodicamente uma quantia } \\
\text { em dinheiro para meu dispo }\end{array}$} & $f$ & 55 & 26 & 81 \\
\hline & & $\%$ & $13,3 \%$ & $10,9 \%$ & $12,4 \%$ \\
\hline & \multirow{2}{*}{$\begin{array}{l}\text { Fico com os recursos provenientes de } \\
\text { atividades autônomas. }\end{array}$} & $f$ & 18 & 10 & 28 \\
\hline & & $\%$ & $4,4 \%$ & $4,2 \%$ & $4,3 \%$ \\
\hline & \multirow{2}{*}{$\begin{array}{l}\text { Fico com parte dos resultados de } \\
\text { produtos que comercializo. }\end{array}$} & $f$ & 46 & 22 & 68 \\
\hline & & $\%$ & $11,2 \%$ & $9,2 \%$ & $10,4 \%$ \\
\hline & \multirow{2}{*}{$\begin{array}{l}\text { Trabalho em parceria com meus pais } \\
\text { e fico com uma parte pré- }\end{array}$} & $f$ & 61 & 28 & 89 \\
\hline & & $\%$ & $14,8 \%$ & $11,7 \%$ & $13,7 \%$ \\
\hline & \multirow{2}{*}{$\begin{array}{l}\text { Quando preciso de alguma coisa ou } \\
\text { dinheiro peço para meus pa }\end{array}$} & $f$ & 225 & 129 & 354 \\
\hline & & $\%$ & $54,6 \%$ & $54,0 \%$ & $54,4 \%$ \\
\hline & \multirow{2}{*}{$\begin{array}{l}\text { Não obtenho nenhuma recompensa } \\
\text { pelo meu trabalho. }\end{array}$} & $f$ & 5 & 13 & 18 \\
\hline & & $\%$ & $1,2 \%$ & $5,4 \%$ & $2,8 \%$ \\
\hline & \multirow{2}{*}{$\begin{array}{l}\text { Quando preciso de dinheiro peço a } \\
\text { meu cônjuge. }\end{array}$} & $f$ & 2 & 11 & 13 \\
\hline & & $\%$ &, $5 \%$ & $4,6 \%$ & $2,0 \%$ \\
\hline \multirow[t]{2}{*}{ Total } & & $f$ & 412 & 239 & 651 \\
\hline & & $\%$ & $100,0 \%$ & $100,0 \%$ & $100,0 \%$ \\
\hline
\end{tabular}

Fonte: Banco de dados Jovens Agricultores Familiares RS - MDA/FAURGS, 2007.

$\mathrm{Na}$ Tabela 14, apresenta-se o cruzamento das respostas à pergunta Que recompensa você ganha por sua participação no trabalho familiar agrícola? pela variável faixa etária. Em todas as faixas etárias, a resposta a Quando preciso de alguma coisa ou dinheiro peço aos 
meus pais aparece como a mais frequente. Contudo, sua frequência é bem diferente entre as faixas etárias. Esta é a resposta de 75,2\% dos jovens adolescentes, mas passa a 51,3\% entre a faixa etária de 20 a 24, e a 32,\% entre os jovens adultos. Entre os jovens da faixa etária intermediária, refere-se ao estabelecimento de parceria entre pais e filhos, enquanto que entre os jovens adultos $20,9 \%$ responderam que ficam com parte dos resultados dos produtos que comercializam. Estas informações comprovam que, na medida em que aumenta a idade dos jovens, eles vão tendo mais acesso aos rendimentos da agricultura. Enquanto são adolescentes, passam a receber, periodicamente, quantias em dinheiro. Quando são um pouco mais velhos, predomina a parceria como meio de acessar recursos próprios. Já na situação de jovem adulto, aumenta a presença da comercialização autônoma de produtos agrícolas. Ou seja, com o avançar da idade eles vão obtendo maior acesso aos recursos provenientes da agricultura de forma cada vez mais autônoma.

Tabela 14: Cruzamento formas de recompensa por faixa etária (em $f$ e \%)

\begin{tabular}{|c|c|c|c|c|c|c|}
\hline & & & \multicolumn{3}{|c|}{ FAIXA ETÁRIA: } & \multirow[b]{2}{*}{ Total } \\
\hline & & & $\begin{array}{l}\text { De } 15 \text { a } \\
19 \text { anos }\end{array}$ & $\begin{array}{l}\text { De } 20 \text { a } \\
24 \text { anos }\end{array}$ & $\begin{array}{l}\text { De } 25 \text { a } \\
29 \text { anos }\end{array}$ & \\
\hline \multirow{14}{*}{$\begin{array}{l}\text { O QUE VOCÊ } \\
\text { RECEBE POR } \\
\text { SUA } \\
\text { PARTICIPAÇÃO } \\
\text { NO TRABALHO } \\
\text { FAMILIAR } \\
\text { AGRÍCOLA? }\end{array}$} & \multirow{2}{*}{$\begin{array}{l}\text { Recebo periodicamente uma } \\
\text { quantia em dinheiro para meu dispo }\end{array}$} & $f$ & 32 & 23 & 26 & 81 \\
\hline & & $\%:$ & $12,8 \%$ & $11,8 \%$ & $12,6 \%$ & $12,4 \%$ \\
\hline & \multirow{2}{*}{$\begin{array}{l}\text { Fico com os recursos provenientes } \\
\text { de atividades autônomas. }\end{array}$} & $f$ & 2 & 9 & 17 & 28 \\
\hline & & $\%:$ &, $8 \%$ & $4,6 \%$ & $8,3 \%$ & $4,3 \%$ \\
\hline & \multirow{2}{*}{$\begin{array}{l}\text { Fico com parte dos resultados de } \\
\text { produtos que comercializo. }\end{array}$} & $f$ & 6 & 19 & 43 & 68 \\
\hline & & $\%:$ & $2,4 \%$ & $9,7 \%$ & $20,9 \%$ & $10,4 \%$ \\
\hline & \multirow{2}{*}{$\begin{array}{l}\text { Trabalho em parceria com meus } \\
\text { pais e fico com uma parte pré- }\end{array}$} & $f$ & 15 & 38 & 36 & 89 \\
\hline & & $\%:$ & $6,0 \%$ & $19,5 \%$ & $17,5 \%$ & $13,7 \%$ \\
\hline & \multirow{2}{*}{$\begin{array}{l}\text { Quando preciso de alguma coisa ou } \\
\text { dinheiro peço para meus pa }\end{array}$} & $f$ & 188 & 100 & 66 & 354 \\
\hline & & $\%:$ & $75,2 \%$ & $51,3 \%$ & $32,0 \%$ & $54,4 \%$ \\
\hline & \multirow{2}{*}{$\begin{array}{l}\text { Não obtenho nenhuma recompensa } \\
\text { pelo meu trabalho. }\end{array}$} & $f$ & 5 & 4 & 9 & 18 \\
\hline & & $\%:$ & $2,0 \%$ & $2,1 \%$ & $4,4 \%$ & $2,8 \%$ \\
\hline & \multirow{2}{*}{$\begin{array}{l}\text { Quando preciso de dinheiro peço a } \\
\text { meu cônjuge. }\end{array}$} & $f$ & 2 & 2 & 9 & 13 \\
\hline & & $\%:$ &, $8 \%$ & $1,0 \%$ & $4,4 \%$ & $2,0 \%$ \\
\hline \multirow[t]{2}{*}{ Total } & & $f$ & 250 & 195 & 206 & 651 \\
\hline & & $\%:$ & $100,0 \%$ & $100,0 \%$ & $100,0 \%$ & $100,0 \%$ \\
\hline
\end{tabular}

Fonte: Banco de dados Jovens Agricultores Familiares RS - MDA/FAURGS, 2007.

No Gráfico 16, verifica-se que a maior dependência dos pais ocorre entre as jovens adolescentes, já que $86,2 \%$ delas quando precisa de alguma coisa ou dinheiro, pedem para os pais, enquanto esta é uma realidade para $69,3 \%$ dos homens desta mesma faixa etária. Chama 
a atenção, também, a situação das mulheres de 25 a 29 anos, entre as quais $10 \%$ afirmaram que não recebem nenhuma remuneração pelo trabalho; outras $10 \%$ responderam que quando precisam de dinheiro pedem para o cônjuge. Percebe-se assim que, praticamente, metade das jovens adultas não dispõe de recursos próprios, reproduzindo a posição de subordinação financeira dos pais agora com o marido.

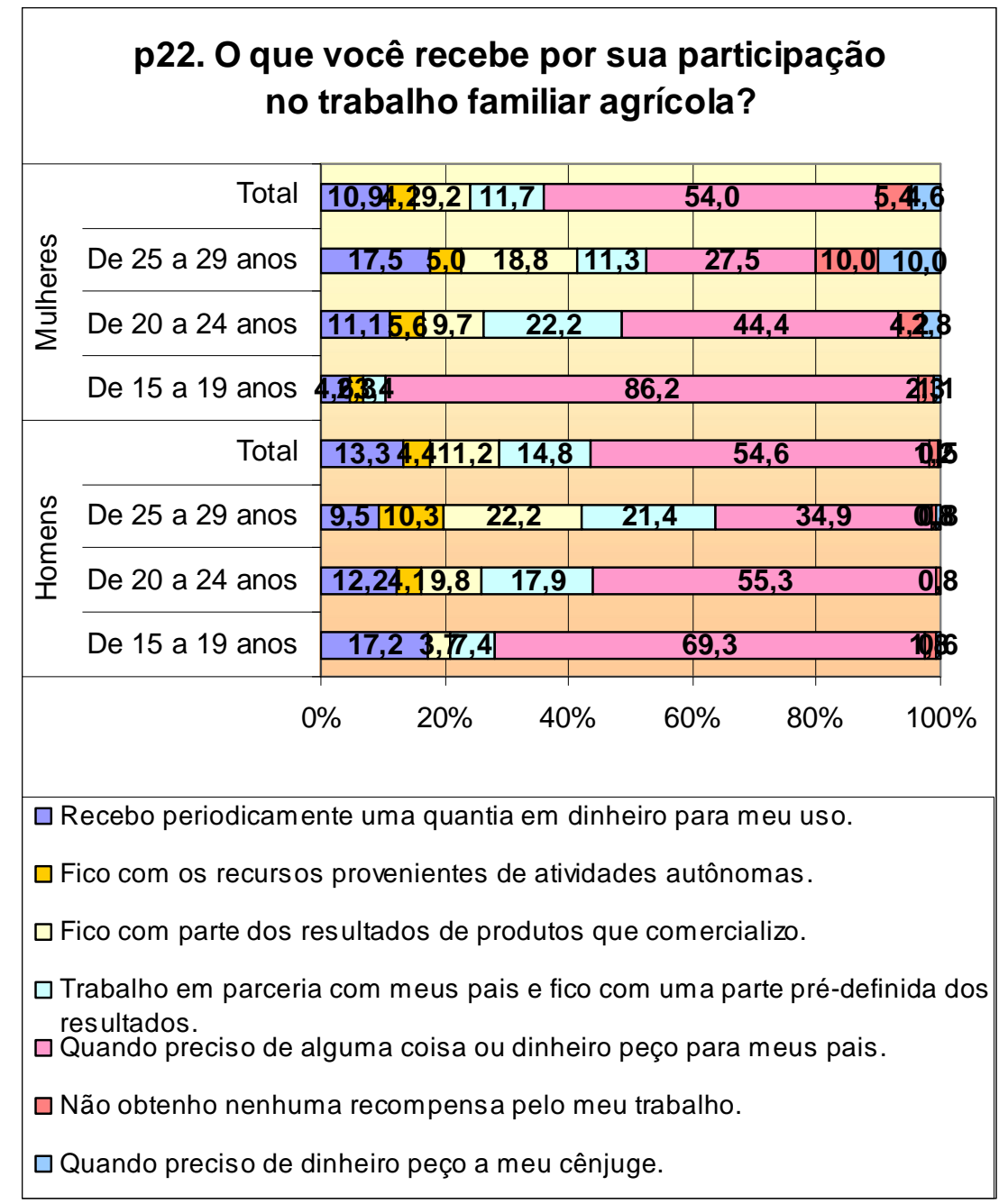

Gráfico 16: Formas de acesso dos jovens a renda familiar agrícola por sexo e faixa etária (\%) Fonte: Banco de dados Jovens Agricultores Familiares RS - MDA/FAURGS, 2007.

Além do acesso às rendas, buscou-se identificar o destino dado aos rendimentos obtidos pelos jovens agricultores. Assim foi perguntado Em que você gasta o dinheiro recebido pelo trabalho agrícola? A distribuição de frequências das respostas a esta questão encontra-se no Gráfico 17. Predominam, entre as respostas, com 46\%, os gastos com bens de uso pessoal. O segundo maior percentual $(17,1 \%)$ refere-se a investimento em atividades 
agrícolas ou de criação de animais. $\mathrm{O}$ terceiro gasto mais recorrente corresponde a atividades de lazer e diversão, com 9,1\%. Os entrevistados que afirmam estar pagando bens de consumo durável representam $7,9 \%$ da amostra, enquanto outros $7 \%$ responderam que estão guardando seus recursos financeiros.

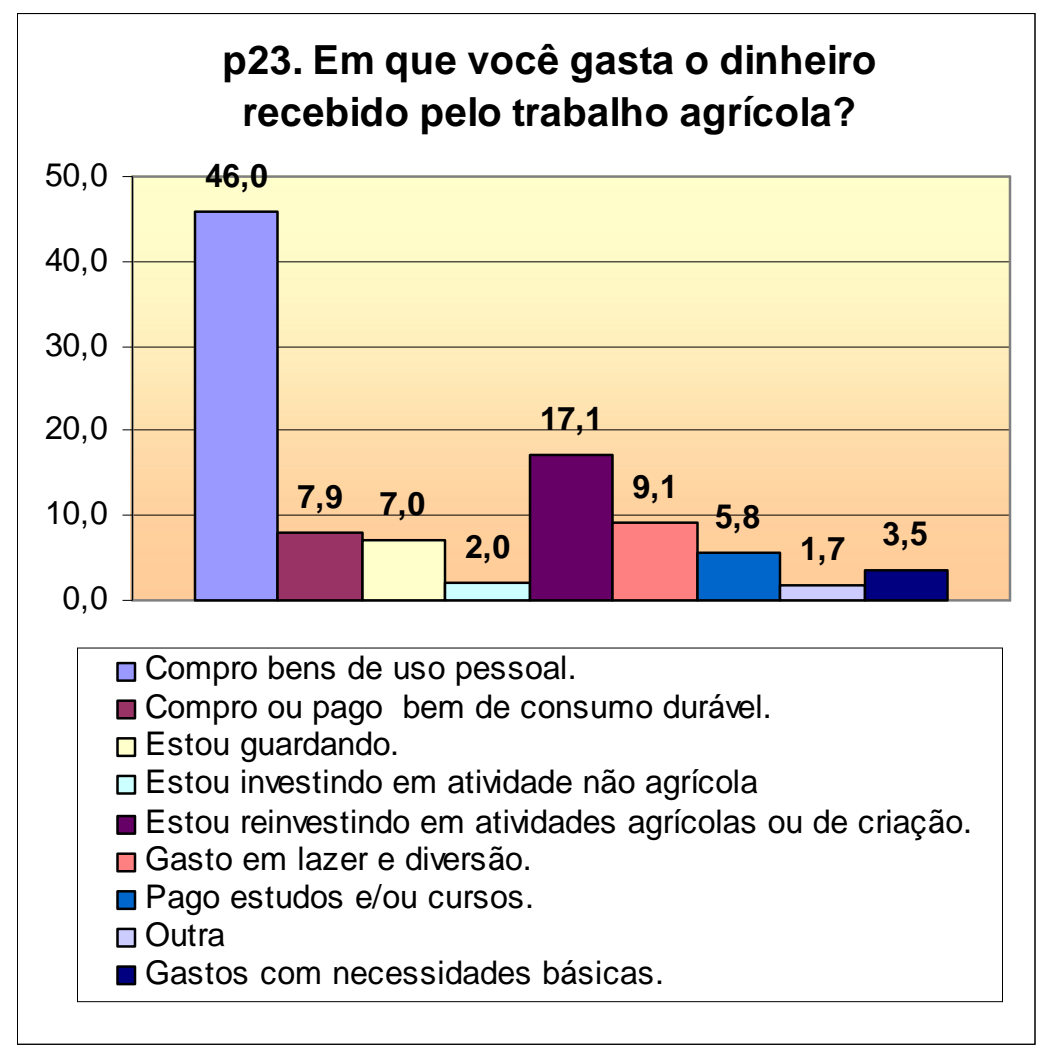

Gráfico 17: Distribuição de frequência do tipo de gasto dos jovens agricultores familiares (\%) Fonte: Banco de dados Jovens Agricultores Familiares RS - MDA/FAURGS, 2007.

Submetendo-se esta mesma questão a uma comparação por sexo do entrevistado, constata-se que os homens gastam, principalmente, nesta ordem: bens de uso pessoal (40,35\%), investimento na produção $(19,3 \%)$ e lazer e diversão (12,6\%). As mulheres também usam seu dinheiro, principalmente, em gastos pessoais, como roupas, calçados e revistas $(55,8 \%)$ em percentual maior do que o deles. Elas também investem na atividade agrícola $(13,3 \%)$, em menor percentual do que os homens. Aqui também, apesar de não ser representativo do ponto de vista estatístico, não o deixa ser para a análise sociológica o fato de que as mulheres apresentam percentuais maiores do que os dos homens nas categorias de respostas: estou guardando e pago estudos e cursos. (Tabela 15). 
Tabela 15: Gastos dos jovens agricultores familiares por sexo (em $f$ e \%)

\begin{tabular}{|c|c|c|c|c|c|}
\hline & & & \multicolumn{2}{|c|}{ SEXO } & \multirow[b]{2}{*}{ Total } \\
\hline & & & Homens & Mulheres & \\
\hline \multirow{18}{*}{$\begin{array}{l}\text { EM QUE } \\
\text { VOCÊ GASTA } \\
\text { O DINHEIRO } \\
\text { RECEBIDO } \\
\text { PELA } \\
\text { ATIVIDADE } \\
\text { AGRÍCOLA? }\end{array}$} & \multirow{2}{*}{$\begin{array}{l}\text { Compro bens de uso pessoal (roupa, } \\
\text { calçados,revistas, etc.) }\end{array}$} & $f$ & 169 & 134 & 303 \\
\hline & & $\%$ & $40,3 \%$ & $55,8 \%$ & $46,0 \%$ \\
\hline & \multirow{2}{*}{$\begin{array}{l}\text { Compro ou pago bem de consumo } \\
\text { durável (carro, moto, computa }\end{array}$} & $f$ & 44 & 8 & 52 \\
\hline & & $\%$ & $10,5 \%$ & $3,3 \%$ & $7,9 \%$ \\
\hline & \multirow[t]{2}{*}{ Estou guardando. } & $f$ & 26 & 20 & 46 \\
\hline & & $\%$ & $6,2 \%$ & $8,3 \%$ & $7,0 \%$ \\
\hline & \multirow{2}{*}{$\begin{array}{l}\text { Estou investindo em atividade não } \\
\text { agrícola }\end{array}$} & $f$ & 12 & 1 & 13 \\
\hline & & $\%$ & $2,9 \%$ &, $4 \%$ & $2,0 \%$ \\
\hline & \multirow{2}{*}{$\begin{array}{l}\text { Estou reinvestindo em atividades } \\
\text { agrícola ou de criação. }\end{array}$} & $f$ & 81 & 32 & 113 \\
\hline & & $\%$ & $19,3 \%$ & $13,3 \%$ & $17,1 \%$ \\
\hline & \multirow[t]{2}{*}{ Gasto em lazer e diversão. } & $f$ & 53 & 7 & 60 \\
\hline & & $\%$ & $12,6 \%$ & $2,9 \%$ & $9,1 \%$ \\
\hline & \multirow[t]{2}{*}{ Pago estudos e/ou cursos. } & $f$ & 19 & 19 & 38 \\
\hline & & $\%$ & $4,5 \%$ & $7,9 \%$ & $5,8 \%$ \\
\hline & \multirow[t]{2}{*}{ Outra } & $f$ & 7 & 4 & 11 \\
\hline & & $\%$ & $1,7 \%$ & $1,7 \%$ & $1,7 \%$ \\
\hline & \multirow[t]{2}{*}{ Gastos com necessidades básicas. } & $f$ & 8 & 15 & 23 \\
\hline & & $\%$ & $1,9 \%$ & $6,3 \%$ & $3,5 \%$ \\
\hline \multirow{2}{*}{\multicolumn{2}{|c|}{ Total }} & $f$ & 419 & 240 & 659 \\
\hline & & $\%$ & $100,0 \%$ & $100,0 \%$ & $100,0 \%$ \\
\hline
\end{tabular}

Fonte: Banco de dados Jovens Agricultores Familiares RS - MDA/FAURGS, 2007.

A Tabela 16 apresenta o cruzamento dos gastos por faixa etária. Verifica-se que em todas as idades predominam gastos com bens de uso pessoal. O segundo principal gasto dos jovens adolescentes está relacionado ao lazer e à diversão; nas outras faixas, os inquiridos reinvestem em atividades agrícolas e de criação. Além do lazer, os mais jovens gastam com estudos e cursos $(16,2 \%)$ o que vai diminuindo com a idade. A mesma tendência decrescente é observada em relação aos gastos com roupas, calçados e revistas.

Chama atenção, ainda, o fato de que apenas $2 \%$ dos jovens adolescentes afirmam que realizam investimentos em atividades produtivas, índice que sobe para 30,8\% entre os jovens adultos. Ou seja, na medida em que a idade aumenta, caem os gastos em bens pessoais e aumenta o investimento produtivo. Os gastos com necessidades básicas também apresentam um aumento com avanço da idade. 
Tabela 16: Gastos dos jovens agricultores familiares por faixa etária (em $f$ e $\%$ )

\begin{tabular}{|c|c|c|c|c|c|c|}
\hline & & & \multicolumn{3}{|c|}{ FAIXA ETÁRIA: } & \multirow[b]{2}{*}{ Total } \\
\hline & & & $\begin{array}{l}\text { De } 15 \text { a } \\
19 \text { anos }\end{array}$ & $\begin{array}{l}\text { De } 20 \text { a } \\
24 \text { anos }\end{array}$ & $\begin{array}{l}\text { De } 25 \text { a } \\
29 \text { anos }\end{array}$ & \\
\hline \multirow{18}{*}{$\begin{array}{l}\text { EM QUE } \\
\text { VOCÊ GASTA } \\
\text { O DINHEIRO } \\
\text { RECEBIDO } \\
\text { PELA } \\
\text { ATIVIDADE } \\
\text { AGRÍCOLA? }\end{array}$} & \multirow{2}{*}{$\begin{array}{l}\text { Compro bens de uso pessoal (roupa, } \\
\text { calçados,revistas, etc.) }\end{array}$} & $f$ & 146 & 84 & 73 & 303 \\
\hline & & $\%$ & $59,1 \%$ & $42,4 \%$ & $34,1 \%$ & $46,0 \%$ \\
\hline & \multirow{2}{*}{$\begin{array}{l}\text { Compro ou pago bem de consumo } \\
\text { durável (carro, moto, computa }\end{array}$} & $f$ & 9 & 24 & 19 & 52 \\
\hline & & $\%$ & $3,6 \%$ & $12,1 \%$ & $8,9 \%$ & $7,9 \%$ \\
\hline & \multirow[t]{2}{*}{ Estou guardando. } & $f$ & 19 & 11 & 16 & 46 \\
\hline & & $\%$ & $7,7 \%$ & $5,6 \%$ & $7,5 \%$ & $7,0 \%$ \\
\hline & \multirow{2}{*}{$\begin{array}{l}\text { Estou investindo em atividade não } \\
\text { agrícola }\end{array}$} & $f$ & 2 & 5 & 6 & 13 \\
\hline & & $\%$ & ,8\% & $2,5 \%$ & $2,8 \%$ & $2,0 \%$ \\
\hline & \multirow{2}{*}{$\begin{array}{l}\text { Estou reinvestindo em atividades agrícola } \\
\text { ou de criação. }\end{array}$} & $f$ & 5 & 42 & 66 & 113 \\
\hline & & $\%$ & $2,0 \%$ & $21,2 \%$ & $30,8 \%$ & $17,1 \%$ \\
\hline & \multirow[t]{2}{*}{ Gasto em lazer e diversão. } & $f$ & 40 & 12 & 8 & 60 \\
\hline & & $\%$ & $16,2 \%$ & $6,1 \%$ & $3,7 \%$ & $9,1 \%$ \\
\hline & \multirow[t]{2}{*}{ Pago estudos e/ou cursos. } & $f$ & 24 & 9 & 5 & 38 \\
\hline & & $\%$ & $9,7 \%$ & $4,5 \%$ & $2,3 \%$ & $5,8 \%$ \\
\hline & \multirow[t]{2}{*}{ Outra } & $f$ & 1 & 3 & 7 & 11 \\
\hline & & $\%$ & , 4\% & $1,5 \%$ & $3,3 \%$ & $1,7 \%$ \\
\hline & \multirow[t]{2}{*}{ Gastos com necessidades básicas. } & $f$ & 1 & 8 & 14 & 23 \\
\hline & & $\%$ & , 4\% & $4,0 \%$ & $6,5 \%$ & $3,5 \%$ \\
\hline \multirow{2}{*}{\multicolumn{2}{|c|}{ Total }} & $f$ & 247 & 198 & 214 & 659 \\
\hline & & $\%$ & $100,0 \%$ & $100,0 \%$ & $100,0 \%$ & $100,0 \%$ \\
\hline
\end{tabular}

Fonte: Banco de dados Jovens Agricultores Familiares RS - MDA/FAURGS, 2007.

As respostas dos entrevistados indicam que seus gastos são diferentes segundo o sexo e a faixa etária. No Gráfico 18, verifica-se que predomina a resposta compro bens de uso pessoal, exceto entre os homens de 25 a 29 anos de idade que, em 34,6\% dos casos, gastam com investimentos na atividade agrícola. Destaca-se a grande concentração de respostas entre as adolescentes $(78,2 \%)$ de gastos com bens de uso pessoal. Isto ocorre, basicamente, porque elas não acessam, periodicamente, as rendas agrícolas, de modo que, quando precisam, pedem para os pais apenas o extremamente necessário para seu uso, como roupas e calçados

Entre as mulheres da faixa etária seguinte, esta categoria de resposta baixa para $48,6 \%$ e entre as de 25 a 29 anos de idade representa 38,3\%. Os homens apresentam percentuais menores do que o das mulheres da sua mesma faixa etária para este gasto. Os jovens de 15 a 19 anos são os que mais gastam em lazer e diversão $(23,1 \%)$. Percebe-se que o gasto com compras de bens de consumo durável ocorre mais entre os homens de 20 a 24 anos de idade. Os que mais gastam com estudos são os adolescentes de ambos os sexos. As 
mulheres jovens adultas são as que apresentam o maior percentual para as respostas estou guardando e gasto meu dinheiro com necessidades básicas.

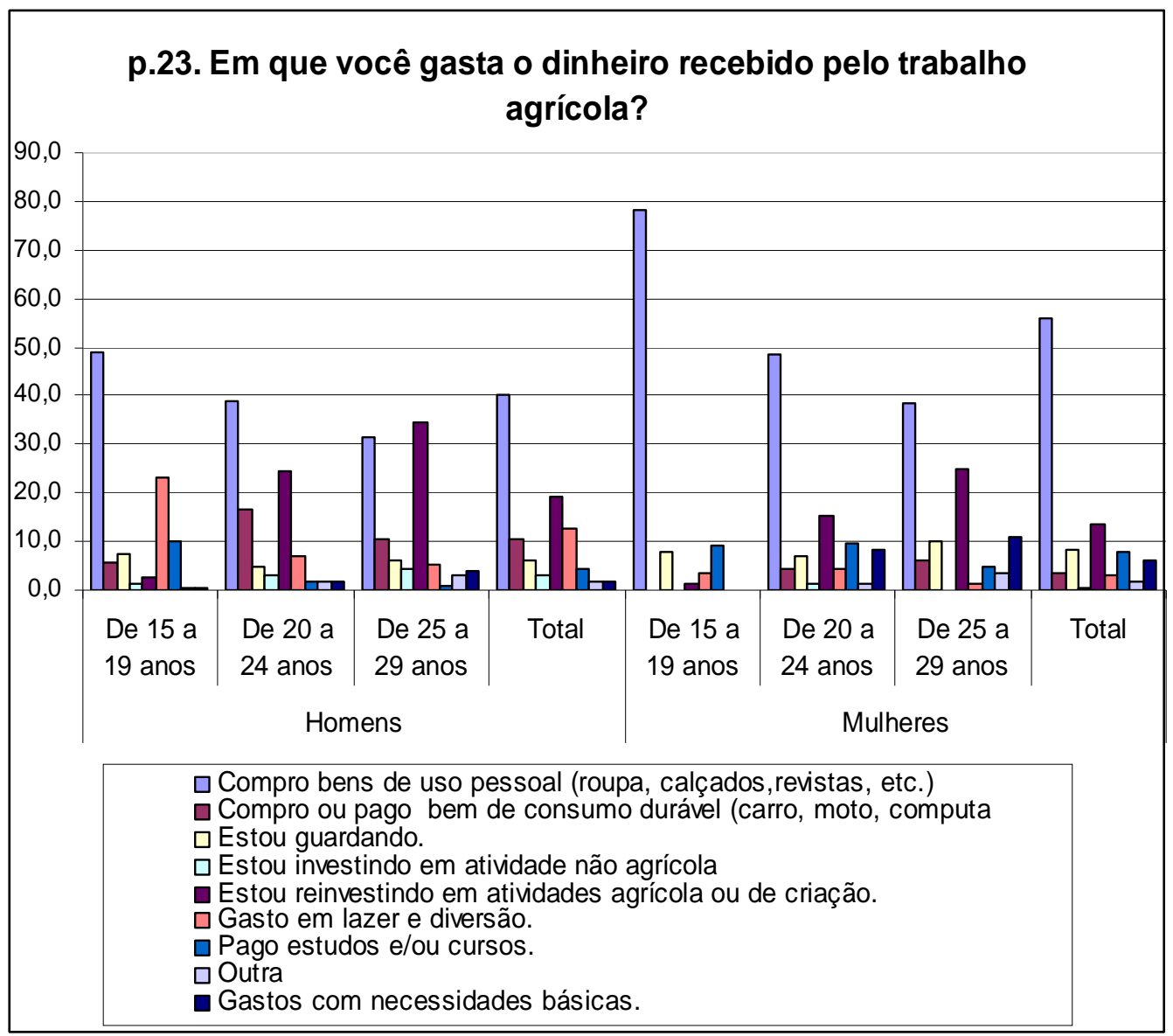

Gráfico 18: Gastos dos jovens agricultores familiares por sexo e faixa etária (\%) Fonte: Banco de dados Jovens Agricultores Familiares RS - MDA/FAURGS, 2007.

A situação juvenil na agricultura familiar é marcada por um restrito acesso a uma renda monetária própria. As informações apresentadas neste tópico demonstram que os jovens dificilmente obtêm alguma renda da atividade agrícola que realizam. Além disso, existe uma acentuada diferença entre homens e mulheres e entre jovens adultos e jovens adolescentes. Os dados revelam, ainda, que os gastos dos jovens são, principalmente, com bens de uso pessoal. Esses, no entanto, vão decrescendo e dão lugar a outros gastos na medida em que as idades avançam. 


\subsection{INDICADORES DE AUTONOMIA JUVENIL}

Uma das características do ser humano é sua possibilidade de autonomia. Por este motivo, esta noção vem sendo utilizada para diferentes propósitos analíticos, figurando na explicação de processos psíquicos, sociais, políticos e econômicos. Esses diferentes usos revelam que esta propriedade humana se realiza em diferentes âmbitos de maneira articulada. O sentido de autonomia adotado neste trabalho corresponde "à condição de uma pessoa ou de uma coletividade cultural de determinar ela mesma a lei à qual se submete" (LALANDE, 1999, p. 115). Ou seja, aqui, o termo autonomia é utilizado para descrever situações onde o sujeito é capaz de especificar as suas próprias regras, ou orientar-se pelo que é adequado para ele. Destaca-se que a autonomia é uma "condição", visto que esta é uma propriedade que se inscreve nas relações sociais, assim “[...] se dá no mundo e não apenas na consciência dos sujeitos, sua construção envolve dois aspectos: o poder de determinar a própria lei e também o poder ou capacidade de realizar" (ZATTI, 2007). Para que haja autonomia, os dois aspectos devem estar presentes, e o pensar autônomo precisa ser também fazer autônomo. Este fazer encontra-se determinado socialmente de tal maneira que a autonomia é limitada por condicionamentos; não é absoluta. Dessa forma, autonomia jamais pode ser confundida com autossuficiência (ZATTI, 2007). Ao acrescentarmos o termo material - autonomia material pretende-se especificar o processo pelo qual a propriedade de recursos alocativos de ordem material permite a operação de ações auto-orientadas.

Entre os jovens agricultores familiares, a autonomia material refere-se as condições que possibilitam aos jovens construir um espaço próprio no processo de trabalho familiar agrícola e obter uma renda própria. Logo, as condições materiais que possibilitam ao jovem construir sua autonomia podem ser estudadas através de indicadores empíricos referentes à estrutura fundiária, à integração mercantil e ao acesso a rendas agrícolas entre os jovens. Estas informações foram obtidas solicitando-se aos entrevistados que respondessem sim ou não conforme a sua situação por ocasião da entrevista para um conjunto de sete assertivas. 1) Desenvolvo atividade produtiva autônoma na unidade de produção familiar;. 2) Possuo bloco de produtor rural em meu nome; 3) Recebo remuneração em dinheiro por minha participação no trabalho familiar agrícola; 4) Tenho área de terra em meu nome; 5) Tenho conta corrente em meu nome; 6) Tenho conta poupança em meu nome; 7) Tenho financiamento em meu nome. 
Segue-se a exposição de cada uma destas variáveis para, após, reduzi-las a três índices sintéticos do grau de autonomia material dos jovens agricultores familiares. As respostas positivas por sexo e totais dão origem ao Gráfico 19.

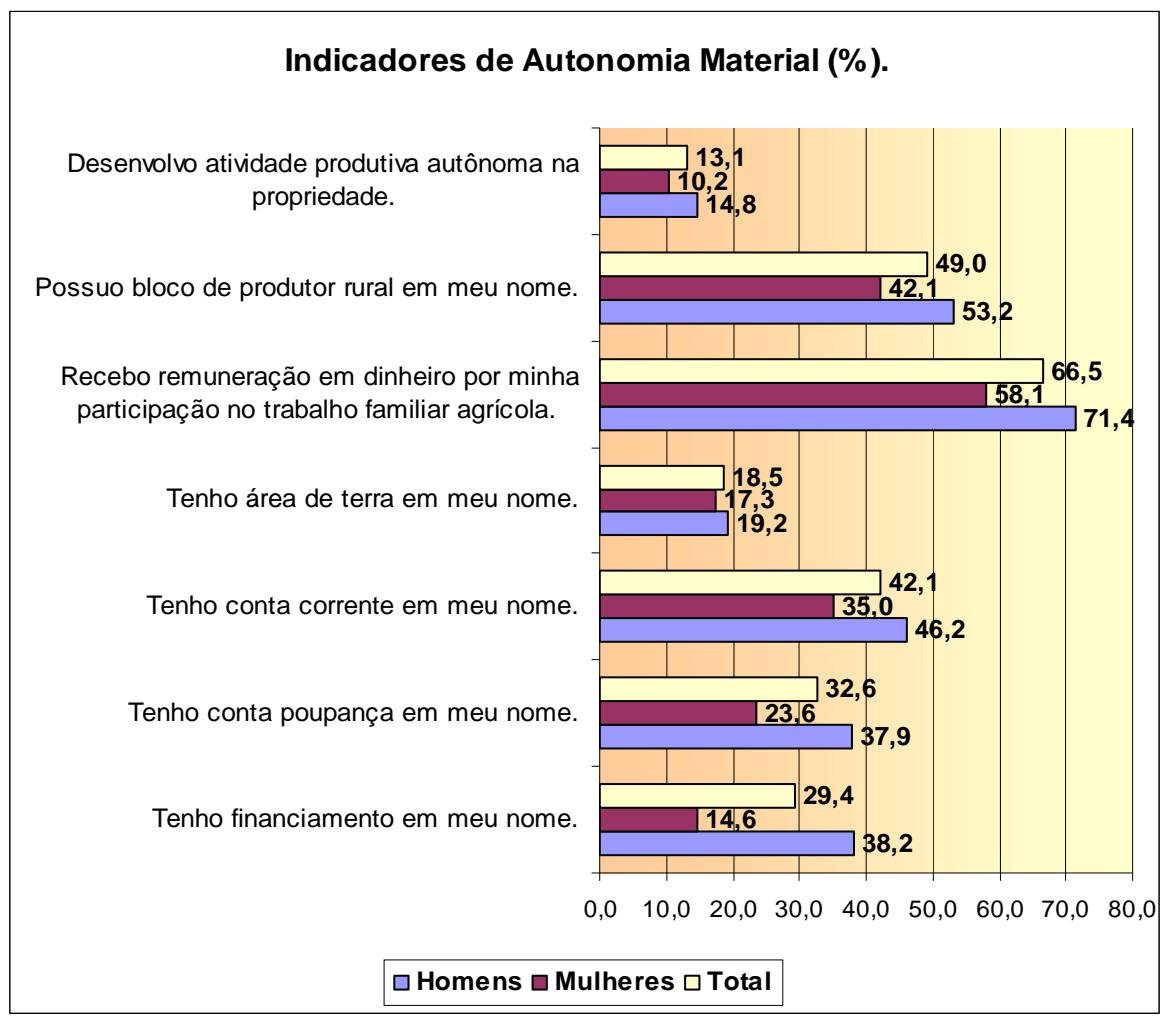

Gráfico 19: Indicadores de autonomia dos jovens por sexo e total (\%)

Fonte: Banco de dados Jovens Agricultores Familiares RS - MDA/FAURGS, 2007.

Inicialmente, podemos observar que poucos jovens $(13,1 \%)$ desenvolvem alguma atividade produtiva de maneira autônoma nas propriedades familiares, sendo esta prática mais presente entre os homens do que entre as mulheres. No caso deles, o mais frequente é a criação de animais, destacando-se os aviários, suínos e gado. Existem casos em que o pai cede um espaço da propriedade para o filho, geralmente uma pequena área, onde ele procura introduzir novas culturas, promovendo a diversificação produtiva e gerando inovações na unidade de produção familiar, ou mesmo "tocando sozinho" uma parte do principal produto da unidade familiar. Entre as jovens, esta atividade autônoma também aparece, frequentemente, relacionada à criação de pequenos animais de abate como aves, coelho e chinchila, ou ainda de animais de grande porte como vacas leiteiras. Entre elas, incluem-se ainda a transformação de alimentos e beneficiamento de produtos, como a produção de embutidos, queijo, compotas, schmier, pães, bolos e bolachas. 
A realização de atividades autônomas por jovens na propriedade familiar possibilitalhes desenvolver habilidades produtivas e comerciais sob a orientação dos pais, constituindose num importante componente de treinamento profissional que os capacita para a realização de empreendimentos maiores no futuro. Além disto, propicia a geração de uma renda extra, que poderá ser administrada pelo próprio jovem. Isto provoca mudanças na posição ocupada por eles na hierarquia familiar, uma vez que passam a ficar menos dependentes dos recursos dos pais para suas pequenas despesas, permitindo-lhes adquirir maior autoconfiança e reconhecimento de outros como um agricultor. De modo geral, estas práticas são adotadas por iniciativas dos jovens e aceitas pelos pais após muita negociação e convencimento, mas estes últimos acabam vendo nisto uma demonstração de interesse dos filhos e uma oportunidade de fortalecer os vínculos dos jovens com a agricultura ou ainda uma forma de incentivá-los a permanecer neste ramo de atividade.

$\mathrm{O}$ reconhecimento formal dos jovens como agricultores pode ser identificado por meio da sua inscrição no Bloco do Produtor ${ }^{59}$ Constata-se que, praticamente, a metade dos entrevistados é titular do bloco de produtor. Nesta situação, os homens são maioria, com $53,2 \%$, enquanto que $42,1 \%$ das mulheres são titulares. $\mathrm{O}$ fato de serem titulares do bloco de produtor rural é relevante porque se trata de um documento que comprova a atuação profissional do jovem agricultor familiar.

No que tange à obtenção de uma remuneração pelo trabalho desempenhado na agricultura, verifica-se uma posição de desvantagem das mulheres na comparação com os homens. Nota-se que 66,5\% dos jovens responderam que recebem remuneração em dinheiro por sua participação no trabalho familiar. Entre os homens, isto corresponde a $71,4 \%$ dos casos enquanto esta situação só se verifica para 58,1\% das mulheres. Contudo, esta informação deve ser relativizada, tendo em vista as formas como os jovens acessam às rendas agrícolas. Ou seja, muitas vezes a remuneração não tem uma periodicidade regular e em diferentes contextos pode encobrir formas de dependência financeira. Por outro lado, estes arranjos podem assegurar aos jovens o atendimento de suas demandas por bens e produtos de maior valor monetário, geralmente obtidos a partir do retorno financeiro com uma "boa safra".

\footnotetext{
${ }^{59}$ O Bloco do Produtor em Família foi instituído através da Lei n. 11.571/01 do Estado do Rio Grande do Sul, de autoria do Deputado Estadual Elvino Bohn Gass (PT). Esta possibilita a inclusão dos nomes de dois titulares e até cinco produtores-participantes no talão de notas fiscais da unidade produtiva. Desta forma, mulheres e jovens - com idade a partir de 16 anos - têm um documento comprovando seu trabalho na unidade de produção familiar que garante seu reconhecimento como segurados junto à Previdência Social e asseguram outros direitos como o reconhecimento da atividade nos pleitos de obtenção de crédito agrícola e fundiário.
} 
$\mathrm{O}$ acesso dos jovens à propriedade fundiária aparece como uma das questões mais difíceis para a maioria dos jovens, uma vez que esta tende a vir por meio de herança. O que implica um longo tempo de espera até que se conclua o ciclo da gestão dos pais. Deste modo, apenas uma pequena parte dos entrevistados (18,5\% dos casos) já possuem área de terra no próprio nome. Entre eles, os homens novamente apresentam percentual maior do que o identificado para as mulheres. Destaca-se que estas áreas de terra foram adquiridas pelos jovens, principalmente, através da compra, apontando para a necessidade da ampliação das políticas de financiamento fundiário para a instalação de novas unidades produtivas para a atual geração de jovens agricultores familiares.

A maior autonomia masculina também se verifica na titularidade de conta corrente em instituições bancárias, visto que $46,2 \%$ dos jovens afirmam ser titulares enquanto que $35 \%$ delas estão na mesma condição. Destaca-se que entre estas entrevistadas, quase a metade tem conta conjunta com o marido; outra parte tem conta conjunta com os pais, sendo menor o percentual de mulheres com titularidade exclusiva de conta corrente. Ainda são $32,6 \%$ os homens titulares de contas de poupança, percentual maior entre homens $(37,9)$ do que entre mulheres $(23,6 \%)$. Esses dados refletem um maior acesso dos homens às rendas das atividades do que uma opção por guardar dinheiro.

Por fim, conforme o Gráfico 19, 29,4\% dos entrevistados realizaram operações de crédito em seu nome. Aqui também são bem marcadas as diferenças entre jovens homens e mulheres. Enquanto 38,2\% deles dizem ter financiamento, elas não chegam à metade deste percentual. A grande maioria dos jovens que acessam o crédito está na faixa etária de 25 a 29 anos de idade; entre estes, a maior parte já está casada e trabalhando em uma unidade de produção familiar autônoma, isto é, independente dos pais. Uma pequena parte destes jovens, dentre as quais se destacam as mulheres, relatou que os recursos foram apenas financiados em seu nome, mas que eles foram destinadas à atividade produtiva dirigida pelo pai, ou pelo cônjuge, que apresentavam algum tipo de impedimento para contratar o financiamento.

Para construir o índice sintético capaz de informar o grau de autonomia material dos jovens agricultores familiares, os sete indicadores foram agrupados sem ponderação, considerando as respostas positivas dos indivíduos, de tal modo que estes puderam ser distribuídos em três categorias: (1) com respostas positivas para até dois indicadores (de 0 a 2) foram classificados como baixa autonomia; (2) com resposta positivas para três a quatro indicadores foram classificados como média autonomia; (3) com resposta positivas para cinco ou mais indicadores (de 5 a 7 ) foram classificados como alta autonomia. 
A Tabela 17 apresenta a distribuição de frequência do índice de autonomia material dos jovens agricultores familiares. Percebe-se que predomina uma condição de baixa autonomia material entre estes entrevistados $(54,2 \%)$. Os jovens com índice de alta autonomia apresentam o menor percentual, apenas $17,3 \%$ do total dos entrevistados.

Tabela 17: Distribuição de frequências do índice de autonomia material dos jovens

\begin{tabular}{llrrrr}
\hline \hline & & & & Cumulative \\
& & Frequency & Percent & Valid Percent & \multicolumn{1}{c}{ Percent } \\
\hline Valid & baixa autonomia & 369 & 54,2 & 54,2 & 54,2 \\
& média autonomia & 194 & 28,5 & 28,5 & 82,7 \\
& alta autonomia & 118 & 17,3 & 17,3 & 100,0 \\
& Total & 681 & 100,0 & 100,0 & \\
\hline \hline
\end{tabular}

Fonte: Banco de dados Jovens Agricultores Familiares RS - MDA/FAURGS, 2007.

Ao proceder ao cruzamento do índice de autonomia material dos jovens agricultores familiares pela variável sexo, confirma-se a tendência já verificada em outras variáveis independentes de uma acentuada desvantagem da situação das mulheres em relação aos homens. Entre as jovens mulheres, 66,9\% contam com baixa autonomia e apenas 9,8\% possuem alta autonomia. Entre os homens, registram-se 46,6\% de casos de baixa autonomia e $21,8 \%$ de alta autonomia; este último, duas vezes maior do que o verificado entre as mulheres. (Tabela 18).

Tabela 18: Cruzamento entre grau de autonomia por sexo (em $f$ e \%)

\begin{tabular}{llrrrr}
\hline \hline & & \multicolumn{2}{c}{ SEXO } & \\
\cline { 3 - 5 } & & Homens & Mulheres & Total \\
\hline Grau de & butonomia & & 199 & 170 & 369 \\
Material & & $\%$ & $46,6 \%$ & $66,9 \%$ & $54,2 \%$ \\
\cline { 2 - 5 } & média autonomia & $\mathrm{f}$ & 135 & 59 & 194 \\
& & $\%$ & $31,6 \%$ & $23,2 \%$ & $28,5 \%$ \\
\cline { 2 - 5 } & alta autonomia & $\mathrm{f}$ & 93 & 25 & 118 \\
& & $\%$ & $21,8 \%$ & $9,8 \%$ & $17,3 \%$ \\
\hline Total & & $\mathrm{f}$ & 427 & 254 & 681 \\
& & $\%$ & $100,0 \%$ & $100,0 \%$ & $100,0 \%$ \\
\hline \hline
\end{tabular}

Fonte: Banco de dados Jovens Agricultores Familiares RS - MDA/FAURGS, 2007.

Quando se realiza o cruzamento do índice de autonomia material dos jovens agricultores familiares pela variável faixa etária também se revelam acentuadas diferenças das condições de autonomia material entre os entrevistados. Isto é bem marcado entre as extremidades do 
período juvenil. Enquanto $82 \%$ dos jovens adolescentes dispõem de baixa autonomia material, a mesma condição ocorre entre 33,3\% dos jovens adultos. Entre os jovens de 20 a 24 anos, registra-se o maior percentual de média autonomia (38,4\%). Entre estes jovens de 25 a 29 anos registra-se o maior percentual de alta autonomia da amostra (30,3\%). Isto confirma um processo de progressiva autonomia material dos jovens agricultores com o avançar da idade.

Tabela 19: Cruzamento entre grau de autonomia e faixa etária (em $f$ e \%)

\begin{tabular}{|c|c|c|c|c|c|c|}
\hline & & & \multicolumn{3}{|c|}{ FAIXA ETÁRIA: } & \multirow[b]{2}{*}{ Total } \\
\hline & & & $\begin{array}{l}\text { De } 15 \text { a } \\
19 \text { anos }\end{array}$ & $\begin{array}{l}\text { De } 20 \text { a } \\
24 \text { anos }\end{array}$ & $\begin{array}{l}\text { De } 25 \text { a } \\
29 \text { anos }\end{array}$ & \\
\hline \multirow{6}{*}{$\begin{array}{l}\text { Grau de } \\
\text { Autonomia } \\
\text { Material }\end{array}$} & baixa autonomia & $f$ & 205 & 88 & 76 & 369 \\
\hline & & $\%$ & $82,0 \%$ & $43,3 \%$ & $33,3 \%$ & $54,2 \%$ \\
\hline & média autonomia & $f$ & 33 & 78 & 83 & 194 \\
\hline & & $\%$ & $13,2 \%$ & $38,4 \%$ & $36,4 \%$ & $28,5 \%$ \\
\hline & alta autonomia & $f$ & 12 & 37 & 69 & 118 \\
\hline & & $\%$ & $4,8 \%$ & $18,2 \%$ & $30,3 \%$ & $17,3 \%$ \\
\hline \multirow[t]{2}{*}{ Total } & & $f$ & 250 & 203 & 228 & 681 \\
\hline & & $\%$ & $100,0 \%$ & $100,0 \%$ & $100,0 \%$ & $100,0 \%$ \\
\hline
\end{tabular}

Fonte: Banco de dados Jovens Agricultores Familiares RS - MDA/FAURGS, 2007.

Este conjunto de informações demonstra que predomina, entre os jovens agricultores familiares, a condição de baixa autonomia material. Esta situação é ainda mais severa entre as mulheres e os jovens adolescentes. Isto revela que estes se encontram em uma situação relativamente subalterna que restringe suas possibilidades de satisfação de suas demandas materiais.

\subsection{UMA SITUAÇÃO DE PRECÁRIA AUTONOMIA MATERIAL}

Neste capitulo, abordaram-se as condições de acesso dos jovens agricultores familiares aos recursos materiais relacionados com a atividade agrícola. Foi possível identificar que o universo de estudo se caracteriza pela presença de famílias proprietárias de pequenos lotes de terra que foram, em grande medida, obtidos por herança e pela combinação desta forma de aquisição com a compra de terceiros. Além disto, verifica-se que o estabelecimento de parceria é o mecanismo principal para a utilização de terra por agricultores não proprietários no Rio Grande do Sul. Também foi possível comprovar que a agricultura 
familiar gaúcha esta prioritariamente voltada à comercialização, principalmente ligada à grande indústria ou a cooperativas. Chamam a atenção os baixos rendimentos obtidos por estes agricultores: as Rendas Agrícolas das famílias dos entrevistados em sua maior parte não ultrapassam os $\mathrm{R} \$ 20.000,00$ ao ano, havendo casos em que a renda líquida é negativa.

Ao buscar-se identificar como os jovens percebem o seu acesso à renda agrícola, verificou-se que eles afirmam principalmente que esta é dividida entre todos que trabalham. Entretanto, quando questionados sobre o que efetivamente recebem por sua participação no trabalho familiar agrícola, percebe-se que as rendas agrícolas encontram-se na maioria dos casos concentrados pelos pais. Destaca-se que a maioria dos jovens só acessa os resultados de seu trabalho na medida em que pede para os pais aquilo que necessita. Situação em que se encontram, principalmente, os jovens adolescentes. Dentre estes, a possibilidade de obter renda é ainda mais restrita para as mulheres. Verificou-se ainda que quando os jovens contam com algum recurso financeiro este costuma ser empregado na compra de bens de uso pessoal, havendo também significativa parcela deles que usam os recursos para reinvestir em atividades agrícolas ou de criação.

Ao serem detalhadas as condições de autonomia material, pode-se verificar que a situação juvenil na agricultura familiar é marcada por uma baixa autonomia. Esta é ainda mais precária para as jovens mulheres e para os jovens adolescentes. Não obstante, confirma-se que, com a progressão das idades dos entrevistados, vai sendo ampliado o acesso aos recursos materiais que possibilitam o desenvolvimento da atividade agrícola, porém, mesmo entre os jovens adultos do sexo masculino, este acesso é parcial e limitado. Com efeito, pode-se concluir que a situação juvenil na agricultura familiar é caracterizada por uma precária autonomia material. Isto ocorre porque, um alto grau de autonomia material é incompatível com a condição subalterna dos jovens dentro da família. Neste sentido, a autonomia é conquistada com o fim da juventude, que não será marcada pela idade, mas, pelo acesso a uma renda própria, pela saída da casa dos pais e formação de uma nova família e principalmente quando forma sua própria unidade produtiva.

Busca-se, adiante, identificar como estes fatores influenciam as disposições dos jovens em reproduzir este processo de trabalho. Entende-se, contudo, que entre as dimensões de ordem material e as representações sociais não ocorre uma simples relação de causa e efeito, mas que suas implicações são, necessariamente, mediadas de modo objetivo pelas dinâmicas dos processos de socialização vividos pelos jovens. Este será o objeto do próximo capítulo. 


\section{OS PROCESSOS DE SOCIALIZAÇÃO DOS JOVENS AGRICULTORES FAMILIARES}

Neste capítulo, são analisados os processos de socialização e de sociabilidade dos jovens agricultores familiares no Rio Grande do Sul. Deste modo, inicia-se avaliando a intensidade da inserção juvenil e sua participação na divisão do trabalho familiar. A esta agência socializadora, seguem-se outras, complementares e concorrentes, dentre as quais se destaca o sistema formal de ensino, em relação ao qual se analisa o grau de escolaridade, a frequência escolar e a percepção dos jovens sobre a escola. No que tange às formas de sociabilidade juvenil, apresentam-se as atividades de lazer e a frequência com que eles as realizam. Aponta-se as diferenciações com base em atributos como sexo e a idade, para demonstrar que a socialização destes jovens se estrutura a partir de critérios originados das relações sociais de gênero e geração. Busca-se, deste modo, confirmar que entre os jovens agricultores predomina a socialização no trabalho familiar agrícola, sendo esta a principal característica da situação juvenil na agricultura familiar. Porém, antes de expor os resultados da pesquisa, apresenta-se a uma breve revisão teórico-conceitual do debate sobre os processos de socialização.

\subsection{SOBRE O PROCESSO DE SOCIALIZAÇÃO}

O processo de socialização é um objeto sociológico por excelência. Trata-se de um processo socialmente estruturado de internalização dos valores e normas coletivas pelo indivíduo; simultaneamente, de integração do indivíduo a sociedade ou a um setor desta. Devido à importância central deste conceito para esta tese retoma-se de forma breve o debate que embasa a noção de socialização que utilizamos.

A principal referência clássica desse debate encontra-se em Émile Durkheim, principalmente na obra Educação e Sociologia, publicada, postumamente, em 1922, onde se encontra a afirmação de que e "a educação consiste numa socialização metódica das novas gerações" (DURKHEIM, 1978, p. 41). Conforme este autor, ao ser individual - ligado às experiências de cada um - soma-se, progressivamente, o ser social. É a própria sociedade enquanto estrutura - que funda suas forças morais diante das quais os homens sentem a inferioridade. A cada nova geração, essas forças devem ser totalmente retrabalhadas para que se 
agregue o mais rápido possível ao ser egoísta e a-social um novo ser, uma natureza apta a viver em sociedade. Assim - argumenta - a educação não desenvolve uma natureza aprisionada, mas produz um novo ser em cada indivíduo. Esta, portanto é a função da educação, que apenas seria apreensível identificar após a análise estrutural (DURKHEIM, 1978).

Seguindo a trilha de Durkheim sobre o processo de socialização, Samuel Noah Eisenstadt (1976) fornece uma explicação teórica a partir do ponto de vista funcionalista, para o surgimento, a estrutura e as funções das diferentes gerações nas sociedades e de suas relações como processos de socialização. Ele buscou entender em que condições a idade é decisiva à alocação de papeis e fronteiras entre os grupos, verificando se as graduações etárias traduzir-seiam em interações concretas, produzindo efeitos integrativos. Segundo tal autor, uma das tarefas principais com que se defronta toda a sociedade e todo o sistema social é estabelecer as condições para a perpetuação de sua própria estrutura, normas e valores.

Por esse motivo, a passagem de um indivíduo pelos diferentes estágios que não só a ele dizem respeito, mas uma questão de importância crucial para todo o sistema social, enfatizando os perigos em potencial da descontinuidade e da ruptura e a necessidade de superá-los. É por esta razão que o indivíduo, em todos os momentos de sua vida, não só desempenha determinados papeis e interage com outras pessoas, mas é também obrigado a garantir, por seu desempenho, um certo grau de continuidade do sistema (EISENSTADT, 1976, p. 4-5).

Os papeis desempenhados pelos indivíduos em qualquer etapa de sua vida, na interação com indivíduos de outras gerações, devem "aguçar" e reforçar seu papel como transmissor e receptor da herança cultural e social (EISENSTADT, 1976). Consequentemente, as relações entre gerações e a ênfase dada às diferenças etárias decorrem das características básicas do processo de socialização. Portanto: “A função das definições de idade é tornar o indivíduo capaz de aprender e adquirir novos papeis para tornar-se um adulto, e desta maneira manter a continuidade social" (EISENSTADT, 1976, p. 7). Nesta perspectiva, a socialização aparece como um mecanismo de modelagem das personalidades que estruturam as condutas essenciais ao funcionamento social.

Isto nos conduz à questão de uma teoria mais geral sobre a transmissão cultural presente no conceito de habitus, tal como desenvolvido por Pierre Bourdieu. Este autor retoma esta palavra latina utilizada pela tradição escolástica e que traduz a palavra grega hexis, que fora empregada por Aristóteles para designar "as disposições adquiridas do corpo e da alma" (DUBAR, 2005). Bourdieu resgata esta noção filosófica, que já havia sido utilizada em sociologia por Durkheim e, posteriormente por Norbert Elias, buscando dar-lhe uma definição 
mais complexa, mais dialética e também mais operacional. Apesar das definições de habitus variarem ao longo de seus escritos, é possível reter-lhe o sentido de um sistema de disposições incorporadas e duradouras que funcionam como princípios geradores de práticas e de representações.

Ou seja, conforme Bourdieu (2005, p. 296), “a produção do sistema de disposição que é o habitus" realiza a "mediação entre as estruturas e as práticas". Com este conceito, ele busca dar conta, na explicação das práticas sociais previamente orientadas por disposições incorporadas, da interdependência entre a realidade objetiva (da estrutura social) e a subjetiva (da ação social), o que o leva a percebê-la em relação à divisão de classes sociais. Conforme suas palavras:

Estrutura estruturante que organiza as práticas e a percepção das práticas, o habitus é também estrutura estruturada: o princípio de divisão em classes lógicas que organiza a percepção do mundo social é, por sua vez, o produto da incorporação da divisão em classes sociais. Cada condição é definida, inseparavelmente, por suas propriedades intrínsecas e pelas propriedades relacionais inerentes à sua posição no sistema das condições que é, também, um sistema de diferenças, de posições diferenciadas, ou seja, por tudo o que a distingue de tudo o que ela não é e, em particular de tudo o que lhe é oposto: a identidade social define-se e afirma-se na diferença (BOURDIEU, 2008, p.164).

Esta dimensão relacional da socialização, que produz a incorporação das disposições de classe, através de um habitus de classes, significa o entendimento de que os indivíduos tendem a querer apenas o que têm chance de conseguir. Ou seja, este mecanismo assegura a adesão dos agentes à reprodução de sua posição social e a sua participação ativa neste processo de reprodução. Disto pode-se sustentar que a disposição de um jovem agricultor familiar será de se orientar "por suas propriedades intrínsecas e pelas propriedades relacionais inerentes à sua posição no sistema das condições" e reagirá a elas como aprendeu precocemente a fazer, contribuindo, assim, para a reprodução de seu grupo social. Isto porque o habitus, nada mais é do que a cultura do seu grupo de origem, incorporada à sua personalidade através dos processos de socialização.

Percebe-se que, nesta tradição iniciada em Durkheim e com prolongamentos até Bourdieu, a socialização que produz a incorporação duradoura de disposições de maneiras de pensar e de agir, em conformidade com os valores culturais e sociais de seu grupo de origem tende a enfatizar a incorporação de disposições necessárias à reprodução social. Deste modo, é preciso estar atento para o fato de que esta socialização se, por um lado, engendra estratégias objetivas que cumprem funções de reprodução; por outro, é orientada para a conservação ou para 
o aumento do patrimônio. Ou seja, não se pode negar que, na verdade, reproduzir as condições de produção implica querer alcançar um status superior e não manter a mesma posição da origem (BOURDIEU, 2004). Sem esta possibilidade de progressão, via adaptação a novos contextos e desenvolvimento de inovações, a própria reprodução passa a estar em risco.

É possível considerar a expressão das estruturas objetivas que produzem um habitus pela configuração de processos sociais de interiorização e exteriorizarão dos valores, das normas e práticas sociais, tais como nos processos de socialização. Bourdieu desenvolveu estes aspectos principalmente analisando o papel do sistema de ensino na reprodução da estrutura de distribuição do capital cultural e na justificação da desigualdade social. Destacam-se três temas recorrentes em sua obra. Primeiro: o desempenho acadêmico está ligado ao backgroud cultural, ou capital cultural prévio originado da família. Segundo: o sistema educacional atualiza o grau de oportunidade educacional e capital cultural herdado, o que é particularmente visível nos casos de estudantes de classes baixa academicamente bem sucedido e que dependem da escola para aquisição de seu capital cultural. Deste modo, reconhece na escola a possibilidade de mobilidade social, limitada e controlada, e por isto mesmo uma das fontes de apoio da ideologia da meritocracia. Terceiro: o processo seletivo da educação está relacionado à estrutura de classes sociais, demonstrando uma alta correlação entre classes social e desempenho escolar (BOURDIEU, 2002, 2004, 2006).

Como vimos ate aqui, os processos de socialização são responsáveis pela interiorizarão de normas, dos valores, estruturas cognitivas e conhecimentos práticos. Segundo este "esquema do condicionamento" (BOUDON; BOURRICAUD, 1993), este processo implica a assimilação precoce e inconsciente de esquemas corporais e atitudes culturais que, presumivelmente, determinam suas condutas futuras. Boudon e Bourricaud (1993) enfatizam que certas aprendizagens cognitivas ou corporais levam à aquisição de aptidões específicas; outras, ao domínio de procedimentos operatórios gerais, mais ou menos indefinidamente adaptáveis à diversidade das situações concretas.

O conteúdo destes conhecimentos transforma-se a partir do caráter dinâmico da própria sociedade que encontra sua contrapartida numa nova geração que, por seu contato original com a cultura, encontra-se mais aberta a incorporar e desenvolver as mudanças no seu sistema de comportamento. Este processo só é possível por meio de uma interação constante. Por isto, este paradigma da "socialização-condicionamento", no que pese ter lançado bases profundas para o entendimento desta questão, ainda é insuficiente porque "faz do indivíduo uma espécie de 
autômato determinado ou programado por suas experiências passadas, e não um ator livre para escolher e responsável por seus atos" (DUBAR, 2005, p. 73).

Como se indicou anteriormente, o enfoque geracional enfatiza a experiência comum a toda uma geração, de modo que os membros de um mesmo grupo etário têm uma situação comum perante as dimensões históricas do processo social (MANNHEIM, 1982). Sob este aspecto, verifica-se que os jovens de uma época estão sujeitos a contradições próprias frente ao estágio do desenvolvimento capitalista. A juventude aparece marcada por uma posição social subalterna em relação aos adultos e liminar típica dos processos de transição caracterizados pela aprendizagem, pela busca de afirmação pessoal e inserção social naquilo que pode ser compreendido como espaço social dos adultos. Destaca-se que cada nova geração tem uma função de mediar as relações entre o passado e o futuro. Assim, as gerações somente se constroem em processos de interação umas com as outras.

Com efeito, os processos de socialização também possuem esta dimensão interacional, de tal modo que não se pode considerar a socialização como um processo de mão única. O que está presente na noção mannheimiana de que "não apenas o professor educa seu aluno, mas o aluno também educa o professor" (MANNHEIM, 1982, p. 83). Compreende-se, que as gerações se constituem a partir das vivências intergeracionais que configuram as sucessões entre gerações. Estas interações assumem um caráter de processos reflexivos associados a estas vivências. Acolhe-se na interpretação deste processo a perspectiva interacionista que salienta a dinâmica das interações na aquisição de know-how e insiste no vínculo entre conhecimento de si e do outro, construção de si e construção do outro (MOLLO-BOUVIER, 2005, p. 393).

O conceito de socialização supõe uma dimensão dinâmica, tal como encontramos na perspectiva interacionista presente nos estudos de Berger e Luckman (1973). Segundo estes autores, socialização é definida como: "a ampla e consciente introdução de um indivíduo no mundo objetivo de uma sociedade ou setor dela" (BERGER; LUCKMAN, 1973, p.175). Para eles, o processo de socialização, embora contínuo, pode ser percebido em dois momentos distintos.

A socialização primária é a primeira socialização que o indivíduo experimenta na infância, e em virtude da qual se torna membro da sociedade. A socialização secundária é qualquer processo subsequente que introduz um indivíduo já socializado em novos setores do mundo objetivo de sua sociedade. (BERGER; LUCKMAN, 1973, p. 175). 
Esta abordagem, pautada pelo paradigma da interação dos autores de A Construção Social da Realidade, permite dar uma dimensão efetiva à distinção entre "socialização primária" e "socialização secundária". A socialização primária caracteriza a infância e possibilita a introdução do indivíduo na sociedade via imposição de significados que vão sendo assimilados com base na identificação com os pais. A criança absorve os papeis e as atitudes dentro da família, interiorizando-os e tornando-os seus (BERGER; LUCKMAN, 1973). A socialização secundária caracteriza-se pela incorporação de novos papeis sociais relacionados agora com uma inserção produtiva; como aquisição de conhecimentos e desempenho de papeis específicos da divisão social do trabalho (BERGER; LUCKMAN, 1973). Neste sentido, a socialização secundária caracteriza a etapa da juventude. Ainda segundo Berger e Luckman (1973), há grande variabilidade sócio-histórica nas representações implícitas na socialização secundária.

O mérito da contribuição de Berger e Luckman reside na ideia de que o processo de socialização extrapola a função de reprodução social via imposição da identificação entre sujeito e sociedade e abre espaço para a transformação e inovação. Isto está presente em suas formulações acerca da socialização secundária, quando os jovens passam a ser inseridos no âmbito da lógica do trabalho via aprendizado técnico e profissional e veem aberta a possibilidade de uma reconversão da identidade assimilada na socialização primária.

A socialização como construção social da realidade supera o pressuposto teórico do funcionalismo, segundo qual a unidade do mundo social seria essencial na formação do indivíduo. Berger e Luckman (1973) substituem esta unidade pela interação, o equilíbrio pela contradição, colocando a incerteza no cerne da realidade social, definida como um permanente confronto entre lógicas de ação heterogêneas. As bases teóricas da passagem realizada por estes autores residem de um lado na dialética do trabalho, da interação e do reconhecimento de Georg Wilhelm Friedrich Hegel, e de outro na associação constante entre interação e simbolismo de George Herbert Mead, que percebe a socialização como a construção de si-mesmo na relação com o outro (DUBAR, 2005).

É necessário estabelecer certa mediação para pensar os processos de socialização entre os jovens agricultores. Estes diferem dos de outros jovens, por ocorrerem no âmbito do trabalho familiar agrícola, o que faz desaparecer a cisão entre socialização primária e secundária, ao menos enquanto a família permaneça como agente responsável também pela socialização secundária. A alternativa proposta é tentar, primeiramente, perceber a emergência de dispositivos e agências socializadoras concorrentes e não exclusivos e muitas vezes 
contraditórios entre si. Além da família e do trabalho que se fundem em uma única agência socializadora, a escola, os grupos de pares, os veículos de comunicação e a participação na vida comunitária aparecem como agências concorrentes na socialização dos jovens e nas quais eles se inserem de modo ativo. Isso torna os processos de socialização contemporâneos bastante complexos.

Com efeito, deve-se buscar estabelecer com precisão o que marca, diferencialmente, a socialização dos jovens agricultores familiares. Esta, devido ao próprio processo de trabalho, se caracterizara como uma socialização profissional e como reprodução da diferenciação dos papeis sociais de gênero.

A socialização dos jovens agricultores se realiza, principalmente, como imersão em uma atividade profissional. Esta inserção precoce na esfera produtiva levou ao questionamento da própria existência da juventude entre os agricultores. $\mathrm{O}$ argumento utilizado por Tavares dos Santos (1984) era o de que, entre os agricultores familiares, os processos de socialização primária e secundária se confundiam num único momento, visto que ocorrem no âmbito das relações familiares ainda na infância, dando a falsa impressão de que a socialização se encerrava nesta época da vida. Assim, conforme este autor, não haveria o período de juventude "[...] de crianças passam diretamente à condição de adultos" (TAVARES DOS SANTOS, 1984, p.46).

Em nossas pesquisas (WEISHEIMER, 2001; 2004; 2007), buscamos distinguir a capacidade plena de trabalho da condição social de adulto. O argumento é o de que, embora os jovens de ambos os sexos estejam inseridos no "mundo adulto" - porque já trabalham como tal esta situação se realiza apenas parcialmente, uma vez que filhas e filhos permanecem subordinados à autoridade dos pais na atividade produtiva, não superando o que caracteriza sua condição juvenil. Por isto, a inserção no processo de trabalho familiar agrícola não é suficiente para torná-los adultos. Trata-se, na verdade, de um treinamento que tem como finalidade prepará-los para, no futuro, tornarem-se agricultores independentes. Portanto, será o domínio sobre o saber fazer da agricultura, e não a idade, que proporcionará seu reconhecimento social como agricultor adulto, isto é, apto a construir uma nova família e dirigir uma unidade produtiva independente (WEISHEIMER, 2004). Desta forma, o processo de trabalho familiar agrícola se estabelece de modo objetivo entre os jovens agricultores, impondo-lhes uma posição no mundo. A este respeito, Bourdieu constata que:

El sistema de las disposiciones inculcadas por las condiciones materiales de existência y por la educación familiar (por ejemplo, el habitus) que constituye el principio generador y unificador de lãs práticases fruto de lãs estruturas que estas práticas 
tendem a reproducir, de modo que los agentes sólo podem reproducir, es decir reinventar inconscientemente o imitar conscientemente (BOURDIEU, 2004, p. 171).

Desta maneira, a estrutura objetiva, que é o trabalho familiar, tende a produzir, como efeito do processo socializador, as disposições necessárias para que os jovens agricultores produzam ações estruturadas que tenderão a reproduzir esta estrutura objetiva que é o processo de trabalho e sua forma de organização. Nisto consiste a força do processo de socialização orientado para a reprodução geracional do trabalho agrícola. Ou seja, se está diante de um processo de socialização que não é simplesmente familiar. Ele é também profissional, no sentido de que isto implica tanto numa posição nas relações sociais de produção, quanto em juízos de valor e prestígio. Temos, portanto, uma socialização profissional como uma espécie de imersão na cultura profissional, uma identificação das funções e tarefas a serem realizadas e a identificação com o grupo de referência (DUBAR, 2005).

Esta perspectiva coloca a socialização profissional no centro da análise da reprodução social da agricultura familiar. Para tanto, estamos conferindo ao termo profissão uma definição mais ampla do que predomina na sociologia das profissões. ${ }^{60}$ Isto porque entendemos que os agricultores familiares não apenas são detentores de um saber especializado como também criam uma ética profissional cujas regras se transmitem às novas gerações no próprio trabalho. Deste modo, a socialização no trabalho familiar agrícola implica imersão profissional em um duplo significado. Como indício de integração à economia de mercado "admitindo-se que esta noção de profissão é tanto mais aceita quanto maior for esta integração" (BILLAUD, 1998 p, 175) e, principalmente, como reprodução de um "sistema de valores que organiza as condutas individuais e no qual a maneira de legitimar o trabalho é reveladora de uma ética que ultrapassa o âmbito apenas profissional" (BILLAUD, 1998 p, 175).

Além disto, é preciso destacar que a socialização dos jovens agricultores é atravessada por relações sociais de gênero. Estas implicam imposição de hierarquias sociais, relações de poder e dominação que atravessam o conjunto da sociedade e se articulam com outras relações sociais, como as intergeracionais.

\footnotetext{
${ }^{60}$ No campo da sociologia das profissões, como demonstra Claude Dubar (2005), concorrem diferentes abordagens e definições sobre profissão. Além disto, como alerta Eliot Freidson (1998), mesmo buscando-se no caráter histórico e concreto do conceito e nas muitas perspectivas sob as quais ele pode ser legitimamente observado, estes sempre frustram a esperança de uma definição amplamente aceita e de valor analítico geral para o termo profissão. Contudo, isto não nos desobriga a definir a agricultura como uma atividade profissional em que seus práticos, detentores de um saber especializado e de uma ética de trabalho, realizam atividades que lhes reserva um lugar próprio na divisão social do trabalho.
} 
Autoras como Nancy Chodorow (1979) desenvolveram uma reflexão sobre como a condição de gênero interfere na socialização, reproduzindo papeis sociais diferenciados para homens e mulheres. Essa, especificamente, argumenta que as mulheres são socializadas no ambiente doméstico em companhia das mulheres de gerações anteriores, as quais lhes transmitem desde cedo uma série de atributos objetivos. Ainda crianças, as mulheres aprendem as atividades do ambiente doméstico, se tornando "pequenas mães". Já a experiência de socialização dos homens é oposta: eles precisam aprender a ser homens longe do ambiente doméstico, procurando companhias horizontais (meninos de sua idade) e estabelecendo laços públicos. Com efeito, a partir dessa socialização diferenciada, os princípios geradores do status social também se diferenciam. (CHODOROW, 1979).

Este mesmo processo é descrito por Levi e Schmitt (1996), mostrando como, na educação das crianças, vão sendo incutidas representações sobre os papeis de gênero futuros que reproduzem as relações de dominação masculina que imperam no mundo adulto e se fazem presentes orientando o futuro.

\footnotetext{
Desde os primeiros tempos da existência, as formas educativas, os espaços de liberdade, as próprias atividades lúdicas preparam para destinos divergentes. Yonne Verdier mostrou de modo exemplar de que maneira, no campo, num período ainda recente, a aprendizagem da costura, do bordado ou do preparo da comida tendia não tanto para a efetiva formação de capacidades práticas, mas sim a inculcar o sentido de um destino percebido como inevitável: o da futura esposa e mãe (LEVI; SCHMITT, 1996, p. 14).
}

Estes autores chamam a atenção para o fato de que as mais inocentes brincadeiras infantis produzem a incorporação de papeis sociais de gênero. Conforme Pierre Bourdieu (1999), para quem a socialização é fundamentalmente a incorporação de um habitus, tanto o homem quanto a mulher são produtos da dominação masculina na medida em que ela cria expectativas sociais às quais ambos estão sujeitos. Como se trata de uma forma de dominação simbólica, esta conta, necessariamente, com um sentido de obediência dos dominados. $\mathrm{O}$ autor aponta o papel das próprias mulheres no reconhecimento dessa dominação masculina como legítima, à medida que elas também reproduzem as mesmas normas que as oprimem na socialização de seus filhos homens e mulheres.

Considerando-se o papel fundamental das mães na socialização das crianças, pode-se dizer que elas atuam na reprodução dos mecanismos de dominação em relação aos seus filhos e filhas por meio de diferenciação dos processos de socialização, da atribuição de espaços sociais, papeis sociais e expectativas diferenciadas por sexo. Assim, na agricultura familiar as diferenças 
entre sexos, diferença fundamental em qualquer ordenação social, tendem a ser usadas como justificativa da desigualdade que é reproduzida culturalmente, distinguindo posições e papeis sociais entre jovens de ambos os sexos.

$\mathrm{O}$ enfoque de gênero, conjuntamente com o geracional, permite identificar que a socialização dos jovens no trabalho familiar agrícola impõe-lhes um repertório de regras que devem ser respeitadas em suas práticas cotidianas. O predomínio do chefe masculino se transmite na socialização no trabalho, onde as mulheres se subordinam aos homens; os jovens, aos seus pais. Estas práticas reproduzem as posições ocupadas por homens e mulheres, crianças, jovens, adultos e idosos na hierarquia doméstica.

Tais aspectos se evidenciam na distinção e complementaridade entre forças de trabalho de homens e mulheres culturalmente estabelecidas na agricultura como "forças plenas e marginais" (TEPICHT, 1973). Como veremos entre os jovens homens, a capacidade para trabalho confere-lhes um novo papel social no interior da unidade produtiva, agora marcada pela inserção como "força plena". Entre as jovens mulheres, o reconhecimento como agricultoras é mais precário porque elas serão sempre consideradas como "forças marginais" apenas pelo fato de serem mulheres.

Entre os pesquisadores nacionais, Afrânio Gracia Jr (1975), Beatriz Alásia de Heredia (1977) e Marie France Garcia (1977) realizaram etnografias ao longo da década de setenta onde discutem o lugar ocupado por cada membro da família no interior do "modo de produção camponês" (CHAYANOV, 1974). Tendo como base a situação dos agricultores do nordeste brasileiro, estes antropólogos identificaram em comum que, cada membro do grupo doméstico ocupa um lugar ligado à sua posição em relação às atividades que desenvolvem na "casa" e no "roçado". A oposição e complementaridade entre "casa" e "roçado" corresponderia ao fato de que, no roçado, o grupo se materializa enquanto unidade de produção, viabilizando com que na casa este se constitua em unidade de consumo. A partir desta distinção de espaços, os papeis são atribuídos aos membros das famílias e um status à sua participação no trabalho familiar. Deste modo, identificaram que o trabalho familiar agrícola é classificado através de duas categorias: "trabalho" e "ajuda". À primeira corresponde a todas as tarefas realizadas por homens adultos (responsável pelas atividades que o conjunto da família desenvolve no roçado); à segunda corresponderia a todo o trabalho realizado por mulheres e filhos (crianças e jovens), seja na casa ou no roçado (HEREDIA; GARCIA; GARCIA JR. 1984).

$\mathrm{Na}$ mesma linha de diferenciação por sexo e idade da força de trabalho agrícola, a socióloga Maria Ignez Paulilo (1987), com base em pesquisas realizadas no sul do Brasil, 
identificou diferenças culturalmente estabelecidas entre homens e mulheres por meio das classificações: "trabalho pesado" e "trabalho leve". Tal classificação não significa, contudo, uma divisão de tarefas a fim de resguardar mulheres e crianças das insalubridades intrínsecas ao trabalho agrícola, mas é uma forma de não reconhecimento e desvalorização de parte da força de trabalho familiar. Conforme suas palavras:

\footnotetext{
Poder-se-ia pensar que mulheres e crianças desempenham certas tarefas porque, de fato, estas são leves por sua própria natureza. Mas não é bem assim. Na verdade, qualifica-se o trabalho em função de quem o realiza: são "leves" as atividades que se prestam a execução por mão-de-obra feminina e infantil (PAULILO, 1987, p. 3).
}

A antropóloga Ellen Woortmann (1995), que comparou as práticas de agricultores do sul aos do nordeste brasileiro, afirma que, por meio da divisão sexual do trabalho que é, ideologicamente, engendrado, caberá as mulheres realizarem de modo exclusivo as tarefas domésticas além de participarem conjuntamente com os homens das tarefas agrícolas não tendo reconhecido seu trabalho como produtivo. Ou seja, esta autora identificou que as tarefas realizadas por mulheres exclusivamente perdem o caráter de trabalho, ao menos em seu sentido produtivo. "Mas, se estas não são "produtivas" são, seguramente, reprodutivas, isto é, centrais para a reprodução do grupo doméstico e do próprio trabalho" (WOORTMANN, 1995, p. 35). Logo, a divisão de trabalho entre forças plenas e marginais corresponderia a um papel socialmente atribuído à mulher. Ou seja, a desvalorização do trabalho feminino na agricultura faz com que este seja percebido como "parcial" "leve" ou considerado como "ajuda". Considerar o trabalho feminino e juvenil desta maneira é uma forma de invisibilidade social das suas participações no trabalho, conferindo a estes atores uma importância secundária à realização do trabalho familiar.

Este debate nos leva a considerar que o processo de socialização dos jovens agricultores familiares reproduz as relações sociais de gênero atribuindo papeis diferenciados a homens e mulheres. No contexto da organização do trabalho familiar agrícola, isto implica a reprodução da divisão sexual e geracional do trabalho familiar hierarquizando os espaços na unidade produtiva e as tarefas que nela se realizam. Ou seja, esta socialização mediada por relações sociais de gênero vincula os filhos homens às tarefas agrícolas auxiliares a dos pais; as filhas mulheres às tarefas domésticas como ajudantes das mães. Como efeito, destas práticas a participação das jovens no trabalho agrícola será - via de regra - identificado como "parcial", "leve" ou como "ajuda"; portanto, secundário e pouco valorizado no âmbito do grupo doméstico. Assim, 
prepara-se terreno para a exclusão das filhas mulheres da sucessão hereditária na atividade agrícola e de sua participação na herança da terra onde se realiza o trabalho familiar. ${ }^{61}$

A retomada deste debate teórico busca demonstrar que os jovens agricultores familiares encontram-se, parcialmente, integrados ao mundo social dos adultos. Trabalham como força plena, mas não são reconhecidos como agricultores plenos, o que envolverá o domínio de um saber agrícola que será transmitido no próprio trabalho. "Esse saber é transmitido à 'força de trabalho', aos filhos que, ao trabalhar, estão se constituindo também como 'conhecedores plenos"” (WOORTMANN \& WOORTMANN, 1997, p.13). Isto faz da socialização no trabalho familiar agrícola, uma socialização profissional com fortes trações de desigualdades de gênero.

Em síntese, percebe-se que a socialização consiste no processo pelo qual o indivíduo aprende a ser um membro da sociedade, o que sugere uma dialética da inserção do sujeito na sociedade e da interiorização das regras de funcionamento desta pelo indivíduo. Deste modo, a participação no processo de trabalho familiar agrícola aparece como o principal dispositivo de socialização dos jovens agricultores. Isso permite a aquisição de um saber prático, a interiorização de uma ética do trabalho e todo um conjunto de disposições que servirão de referência à construção de suas identidades sociais e de seus projetos profissionais.

\subsection{A SOCIALIZAÇÃO DOS JOVENS NO TRABALHO FAMILIAR AGRÍCOLA}

O trabalho familiar é o elemento central da reprodução da agricultura familiar. Neste sentido, toda a força de trabalho da família tende a ser direcionada e organizada para a realização do trabalho agrícola. Esta organização do trabalho familiar baseia-se numa divisão sexual e etárias de tarefas, com precedência em hierarquias no interior do grupo doméstico e que prescrevem papeis sociais diferenciados por critérios de sexo e idade que caracterizam as relações sociais de gênero e geração neste meio social. Neste tópico, analisa-se como ocorre a inserção dos jovens no trabalho familiar sob um duplo aspecto: a) a intensidade de seu envolvimento no trabalho e; b) a sua participação na divisão do trabalho familiar.

\footnotetext{
${ }^{61}$ Este padrão sucessório que tende excluir a mulheres da herança encontram-se descritos nos trabalhos de Moura (1978); Seiferth, (1985); Abramovay et al. (1998); Silvestro et al. (2001); Carneiro (2001); Zorzi (2005); Spanavelo (2008).
} 


\subsubsection{A inserção no processo de trabalho familiar agrícola}

De modo geral, os jovens agricultores familiares já nascem em uma família de agricultores. Devido a unidade família-trabalho participam da realização de tarefas agrícolas desde a infância, iniciando a trabalhar em média aos onze anos de idade. Parte deles, relata haver começado a trabalhar após sete anos de idade. Predomina entre os entrevistados a opinião naturalizada de que começaram trabalhando aos poucos, num misto de "brincadeira e ajuda" aos pais, aumentando a intensidade de participação com o tempo.

Registraram-se alguns poucos casos de entrevistados com inicio após os vinte anos de idade, sendo que esta inserção, relativamente tardia, é exceção no universo analisado. Ela fica restrita às situações de jovens mulheres que passaram a trabalhar na agricultura após o casamento, pois o cônjuge já se encontrava estabelecido nesta atividade.

Os jovens foram questionados ainda sobre a sua participação no trabalho familiar agrícola, considerando quatro categorias de tempo dedicado a este trabalho: 1) tempo integral; 2) parcial (quatro a cinco dias); 3) parcial (dois a três dias); 4) parcial (um dia). A distribuição de frequência destas categorias encontra-se no Gráfico 20. Constata-se que a grande maioria deles $(79,6 \%)$ trabalha em tempo integral na propriedade, dedicando seis dias por semana à agricultura. Dentre aqueles que atuam nessa atividade em tempo parcial, predominam os que o fazem de quatro a cinco dias por semana, com $9 \%$ dos casos. Estes dados confirmam que o trabalho agrícola é um elemento central na vida cotidiana destes jovens, estabelecendo sua posição nas relações sociais de produção e incutindo-lhe uma disciplina moral. 


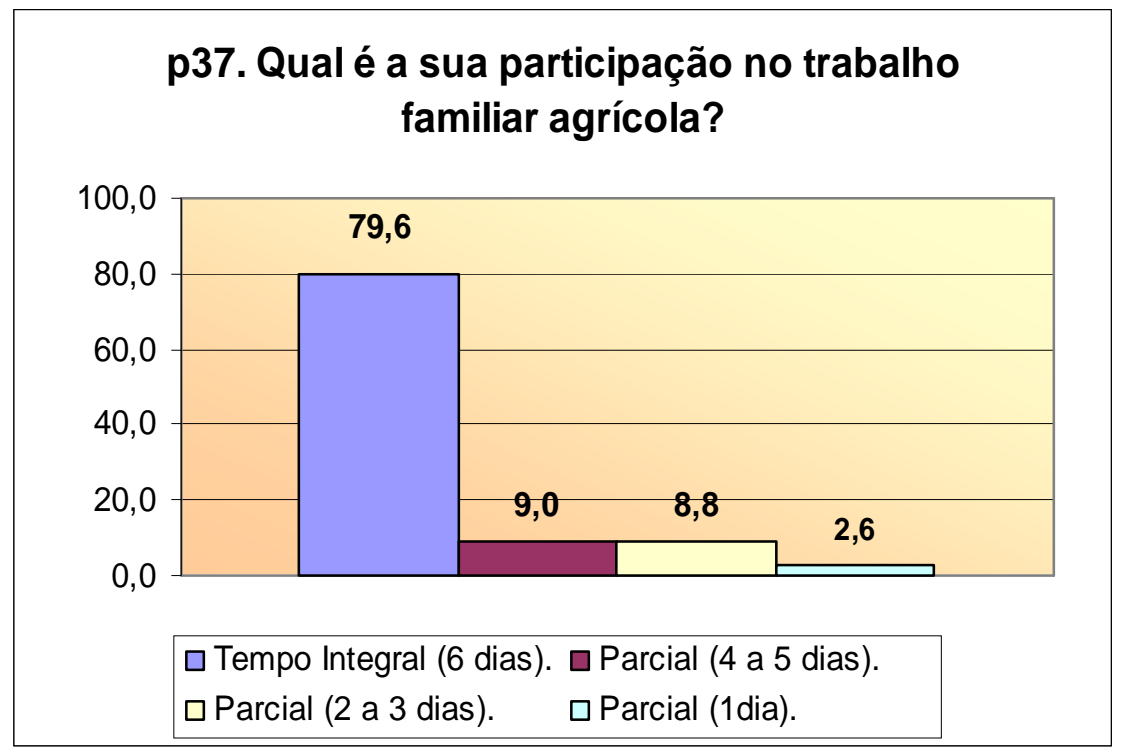

Gráfico 20: Participação no trabalho agrícola (\%)

Fonte: Banco de dados Jovens Agricultores Familiares RS - MDA/FAURGS, 2007.

Quando se realiza o cruzamento da mesma questão pela variável sexo, observa-se que os homens $(84,8 \%)$ afirmam trabalhar mais em tempo integral na agricultura do que as mulheres $(70,9 \%)$. Elas apresentam percentuais maiores quando se trata de atuação nesta atividade em tempo parcial (Tabela 20).

Tabela 20: Participação no trabalho familiar agrícola por sexo $(f$ e \%)

\begin{tabular}{|c|c|c|c|c|c|}
\hline & & & \multicolumn{2}{|c|}{ SEXO } & \multirow[b]{2}{*}{ Total } \\
\hline & & & Homens & Mulheres & \\
\hline \multirow{8}{*}{$\begin{array}{l}\text { QUAL É SUA } \\
\text { PARTICIPAÇÃO NO } \\
\text { TRABALHO FAMILIAR } \\
\text { AGRICOLA? }\end{array}$} & Tempo Integral (6 dias) & $f$ & 362 & 180 & 542 \\
\hline & & $\%$ & $84,8 \%$ & $70,9 \%$ & $79,6 \%$ \\
\hline & Parcial (4 a 5 dias) & $f$ & 28 & 33 & 61 \\
\hline & & $\%$ & $6,6 \%$ & $13,0 \%$ & $9,0 \%$ \\
\hline & Parcial (2 a 3 dias) & $f$ & 30 & 30 & 60 \\
\hline & & $\%$ & $7,0 \%$ & $11,8 \%$ & $8,8 \%$ \\
\hline & Parcial (1 dia) & $f$ & 7 & 11 & 18 \\
\hline & & $\%$ & $1,6 \%$ & $4,3 \%$ & $2,6 \%$ \\
\hline \multirow[t]{2}{*}{ Total } & & $f$ & 427 & 254 & 681 \\
\hline & & $\%$ & $100,0 \%$ & $100,0 \%$ & $100,0 \%$ \\
\hline
\end{tabular}

Fonte: Banco de Dados Jovens Agricultores Familiares RS - MDA/FAURGS, 2007. 
$\mathrm{Na}$ medida em que levamos em conta a faixa etária dos entrevistados, verificamos que a participação deles no trabalho familiar agrícola em tempo integral aumenta com a idade. Esta participação, que já é alta entre os jovens adolescentes de 15 a 19 anos (71,6\%), sobe para 86,4\% entre aqueles que têm de 25 a 29 anos. Situação inversa é observada para a dedicação em tempo parcial, de quatro a cinco dias. Ela passa de 12,4\% dos casos entre jovens adolescentes para $5,7 \%$ entre os jovens adultos (Tabela 21 ).

Tabela 21: Participação no trabalho familiar agrícola por faixas etárias $(f$ e \%)

\begin{tabular}{|c|c|c|c|c|c|c|}
\hline & & & \multicolumn{3}{|c|}{ FAIXA ETÁRIA: } & \multirow[b]{2}{*}{ Total } \\
\hline & & & $\begin{array}{l}\text { De } 15 \text { a } \\
19 \text { anos }\end{array}$ & $\begin{array}{l}\text { De } 20 \text { a } \\
24 \text { anos }\end{array}$ & $\begin{array}{l}\text { De } 25 \text { a } \\
29 \text { anos }\end{array}$ & \\
\hline \multirow{8}{*}{$\begin{array}{l}\text { QUAL É SUA } \\
\text { PARTICIPAÇÃO NO } \\
\text { TRABALHO FAMILIAR } \\
\text { AGRICOLA? }\end{array}$} & Tempo Integral (6 dias) & $f$ & 179 & 166 & 197 & 542 \\
\hline & & $\%$ & $71,6 \%$ & $81,8 \%$ & $86,4 \%$ & $79,6 \%$ \\
\hline & Parcial (4 a 5 dias) & $f$ & 31 & 17 & 13 & 61 \\
\hline & & $\%$ & $12,4 \%$ & $8,4 \%$ & $5,7 \%$ & $9,0 \%$ \\
\hline & Parcial (2 a 3 dias) & $f$ & 28 & 14 & 18 & 60 \\
\hline & & $\%$ & $11,2 \%$ & $6,9 \%$ & $7,9 \%$ & $8,8 \%$ \\
\hline & Parcial (1 dia) & $f$ & 12 & 6 & 0 & 18 \\
\hline & & $\%$ & $4,8 \%$ & $3,0 \%$ &, $0 \%$ & $2,6 \%$ \\
\hline \multirow[t]{2}{*}{ Total } & & $f$ & 250 & 203 & 228 & 681 \\
\hline & & $\%$ & $100,0 \%$ & $100,0 \%$ & $100,0 \%$ & $100,0 \%$ \\
\hline
\end{tabular}

Fonte: Banco de Dados Jovens Agricultores Familiares RS - MDA/FAURGS, 2007.

Como é possível visualizar no Gráfico 21, a participação em tempo integral na agricultura predomina entre os jovens de todas as faixas etárias, independente do sexo e aumenta com a idade de homens e mulheres. O estrato com maior participação em tempo integral é de homens de 25 a 29 anos, enquanto a maior participação em turno parcial é das mulheres de 15 a 19 anos. Contudo, o percentual de jovens que trabalha em tempo parcial na agricultura não ultrapassa a casa dos $10 \%$ entre todas as faixas de idade. 


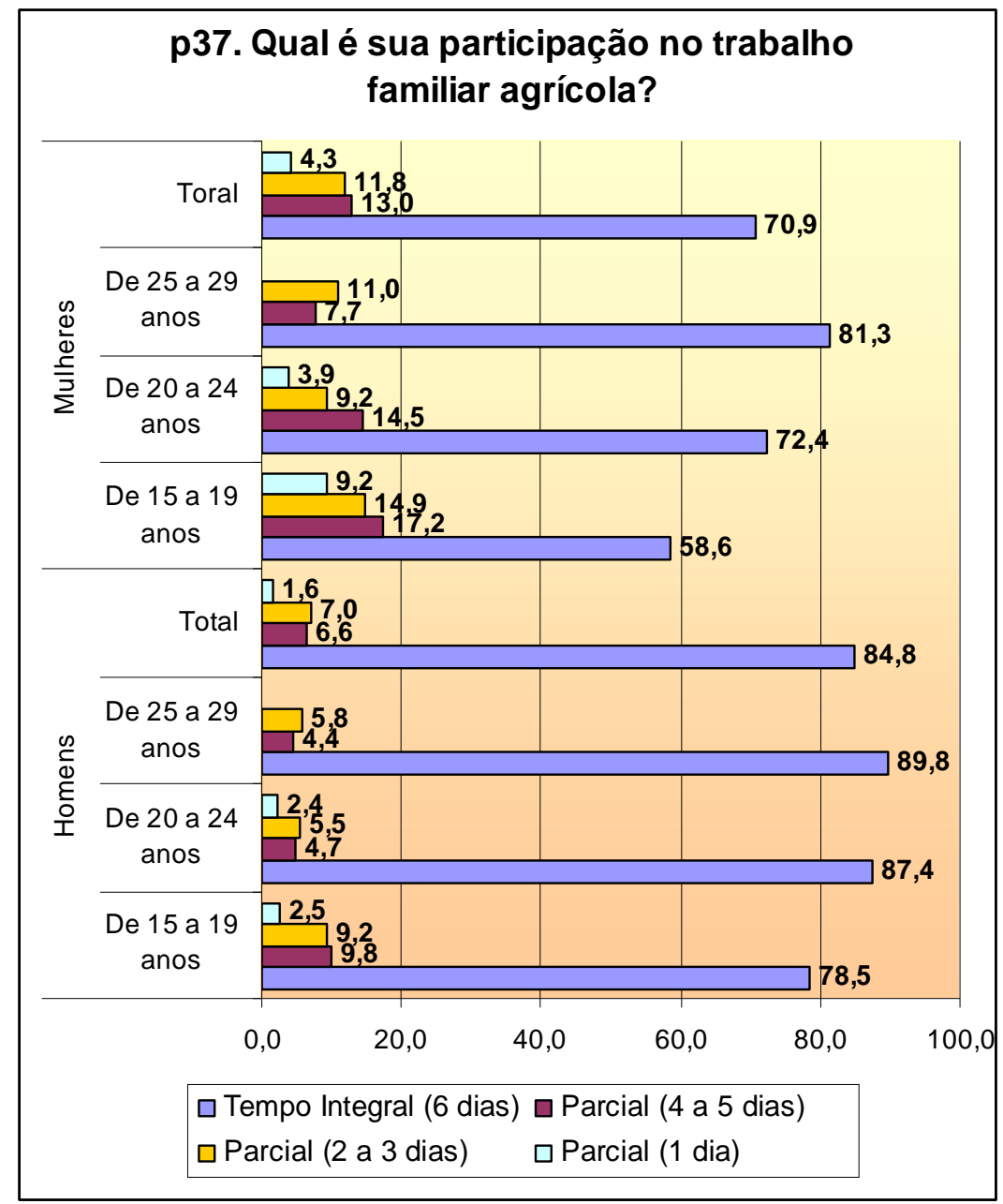

Gráfico 21: Participação no trabalho familiar agrícola por faixas de idade e sexo (\%) Fonte: Banco de dados Jovens Agricultores Familiares RS - MDA/FAURGS, 2007.

A análise dos dados revela que a jornada diária de trabalho dos entrevistados é de oito horas e meia, em média. A sua distribuição pode ser verificada no Gráfico 22. Nele observa-se que o percentual de respostas cresce conforme aumenta a jornada diária de trabalho. Enquanto $11,7 \%$ dos entrevistados afirmam trabalhar até quatro horas, $27,1 \%$ informam que trabalham de oito a dez horas por dia. e 30,4\% dos jovens enfrentam jornadas diárias superiores a dez horas. Considerados os percentuais cumulativos das maiores categorias, verifica-se que $57,5 \%$ deles exercem uma jornada diária de trabalho maior do que as registradas entre assalariados em outras ocupações, que tende a ser de até oito horas. 


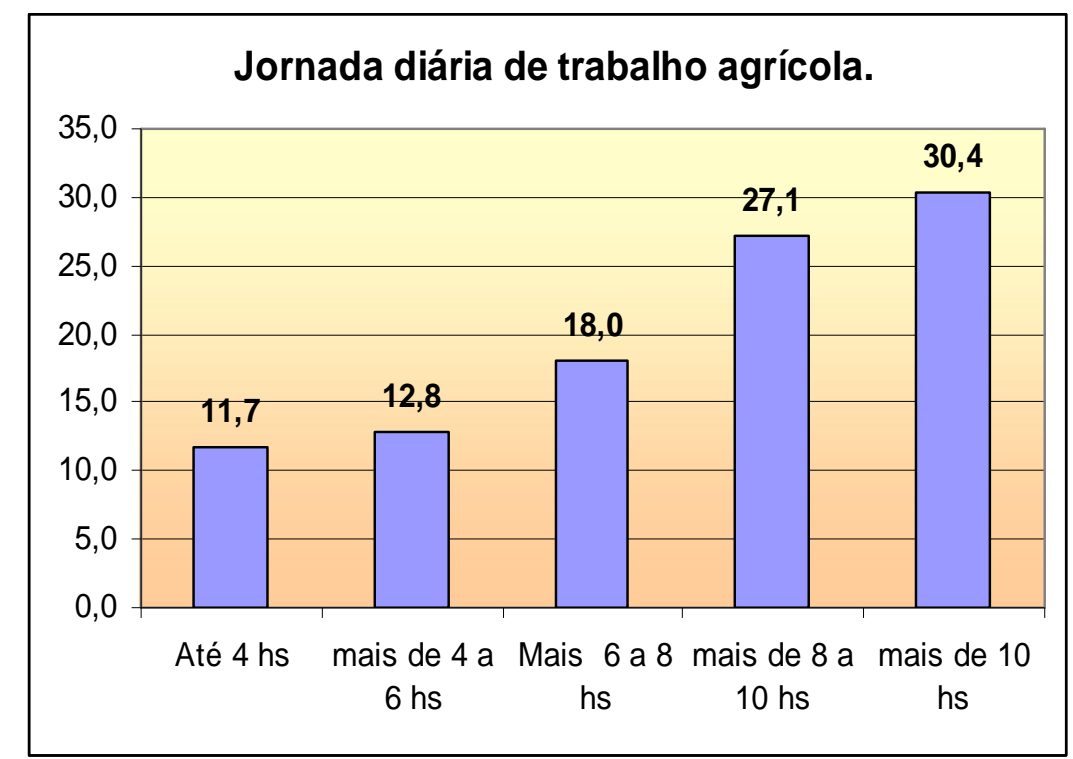

Gráfico 22: Jornada diária de trabalho familiar agrícola (\%)

Fonte: Banco de Dados Jovens Agricultores Familiares RS - MDA/FAURGS, 2007.

A Tabela 22 traz a distribuição de frequências e percentuais da jornada de trabalho familiar agrícola por sexo dos entrevistados. Constata-se que as mulheres têm maior participação do que os homens nas jornadas inferiores a seis horas diárias de trabalho, com 18,5\% delas cumprindo jornadas de até quatro horas, enquanto apenas 7,5\% deles figuram na mesma categoria de resposta. Na medida em que aumenta a jornada diária de trabalho o percentual de jovens também cresce, sendo de 29,3\% trabalhando de oito a dez horas e outros $34,2 \%$ com jornada superior a dez horas diárias. Já, entre elas, verificam-se percentuais um pouco menores de $23,2 \%$ e 23,6\%, respectivamente, para as mesmas jornadas diárias de trabalho.

Existem diferenças nas jornadas diárias de trabalho por faixas etárias dos entrevistados, como pode ser identificado na Tabela 23. Enquanto os jovens de 15 a 19 anos ocupam-se, em $24 \%$ dos casos, em jornadas diárias que ficam entre seis a oito horas, aqueles que têm entre 20 a 24 anos encontram-se em 34,5\% nas jornadas de oito a dez horas. Já entre os inquiridos com idades de 25 a 29 anos 43,4\% desenvolvem jornadas superiores a dez horas diárias. Nesta última categoria de resposta, participam 16,4\% dos jovens adolescentes. Destes últimos, 17,6\% afirmaram trabalhar até quatro horas por dia na agricultura familiar, enquanto que, entre os jovens adultos, apenas 6,6\% declararam desenvolver jornada semelhante. Percebe-se que a jornada diária de trabalho dos jovens vai crescendo conforme aumentam as suas idades. 
Tabela 22: Jornada diária de trabalho por sexo $(f$ e $\%)$

\begin{tabular}{|c|c|c|c|c|c|}
\hline & & & \multicolumn{2}{|c|}{ SEXO } & \multirow[b]{2}{*}{ Total } \\
\hline & & & Homens & Mulheres & \\
\hline \multirow{10}{*}{$\begin{array}{l}\text { JORNADA } \\
\text { DIÁRIA DE } \\
\text { TRABALHO } \\
\text { NA UPF: }\end{array}$} & Até 4 hs & $f$ & 32 & 47 & 79 \\
\hline & & $\%$ & $7,5 \%$ & $18,7 \%$ & $11,7 \%$ \\
\hline & mais de 4 a 6 hs & $f$ & 42 & 45 & 87 \\
\hline & & $\%$ & $9,9 \%$ & $17,9 \%$ & $12,8 \%$ \\
\hline & Mais 6 a $8 \mathrm{hs}$ & $f$ & 81 & 41 & 122 \\
\hline & & $\%$ & $19,0 \%$ & $16,3 \%$ & $18,0 \%$ \\
\hline & mais de 8 a $10 \mathrm{hs}$ & $f$ & 125 & 59 & 184 \\
\hline & & $\%$ & $29,3 \%$ & $23,4 \%$ & $27,1 \%$ \\
\hline & mais de $10 \mathrm{hs}$ & $f$ & 146 & 60 & 206 \\
\hline & & $\%$ & $34,3 \%$ & $23,8 \%$ & $30,4 \%$ \\
\hline \multirow[t]{2}{*}{ Total } & & $f$ & 426 & 252 & 678 \\
\hline & & $\%$ & $100,0 \%$ & $100,0 \%$ & $100,0 \%$ \\
\hline
\end{tabular}

Fonte: Banco de dados Jovens Agricultores Familiares RS - MDA/FAURGS, 2007.

Tabela 23: Jornada de trabalho familiar agrícola por faixa etária $(f$ e $\%)$

\begin{tabular}{|c|c|c|c|c|c|c|}
\hline & & & \multicolumn{3}{|c|}{ FAIXA ETÁRIA: } & \multirow[b]{2}{*}{ Total } \\
\hline & & & $\begin{array}{l}\text { De } 15 \text { a } \\
19 \text { anos }\end{array}$ & $\begin{array}{l}\text { De } 20 \text { a } \\
24 \text { anos }\end{array}$ & $\begin{array}{l}\text { De } 25 \text { a } \\
29 \text { anos }\end{array}$ & \\
\hline \multirow{10}{*}{$\begin{array}{l}\text { JORNADA } \\
\text { DIÁRIA DE } \\
\text { TRABALHO NA } \\
\text { UPF: }\end{array}$} & \multirow[t]{2}{*}{ Até 4 hs } & $f$ & 44 & 20 & 15 & 79 \\
\hline & & $\%$ & $17,6 \%$ & $9,9 \%$ & $6,7 \%$ & $11,7 \%$ \\
\hline & \multirow[t]{2}{*}{ mais de 4 a 6 hs } & $f$ & 50 & 19 & 18 & 87 \\
\hline & & $\%$ & $20,0 \%$ & $9,4 \%$ & $8,0 \%$ & $12,8 \%$ \\
\hline & \multirow[t]{2}{*}{ Mais 6 a 8 hs } & $f$ & 60 & 28 & 34 & 122 \\
\hline & & $\%$ & $24,0 \%$ & $13,8 \%$ & $15,1 \%$ & $18,0 \%$ \\
\hline & \multirow[t]{2}{*}{ mais de 8 a $10 \mathrm{hs}$} & $f$ & 55 & 70 & 59 & 184 \\
\hline & & $\%$ & $22,0 \%$ & $34,5 \%$ & $26,2 \%$ & $27,1 \%$ \\
\hline & \multirow[t]{2}{*}{ mais de $10 \mathrm{hs}$} & $f$ & 41 & 66 & 99 & 206 \\
\hline & & $\%$ & $16,4 \%$ & $32,5 \%$ & $44,0 \%$ & $30,4 \%$ \\
\hline \multirow[t]{2}{*}{ Total } & & $f$ & 250 & 203 & 225 & 678 \\
\hline & & $\%$ & $100,0 \%$ & $100,0 \%$ & $100,0 \%$ & $100,0 \%$ \\
\hline
\end{tabular}

Fonte: Banco de dados Jovens Agricultores Familiares RS - MDA/FAURGS, 2007.

As diferenças na jornada de trabalho por sexo e faixas etárias são apresentadas no Gráfico 23. Jovens de ambos os sexos cumprem jornadas mais longas na medida em que suas idades aumentam. As jovens adolescentes são as que exercem jornadas mais curtas. Entre as mulheres na faixa de idade de 15 a 19 anos registram-se o percentual de $27,6 \%$ com jornada de até quatro horas, a mais alta para esta categoria de resposta. Outras $28,7 \%$ delas trabalham entre quatro a seis horas diárias na agricultura. Em situação oposta, encontram-se os jovens homens de 
25 a 29 anos de idade que, em 53,7\% dos casos exercem jornadas superiores a dez horas enquanto em $23,5 \%$ dos jovens a jornada chega ser de oito á dez horas de trabalho.

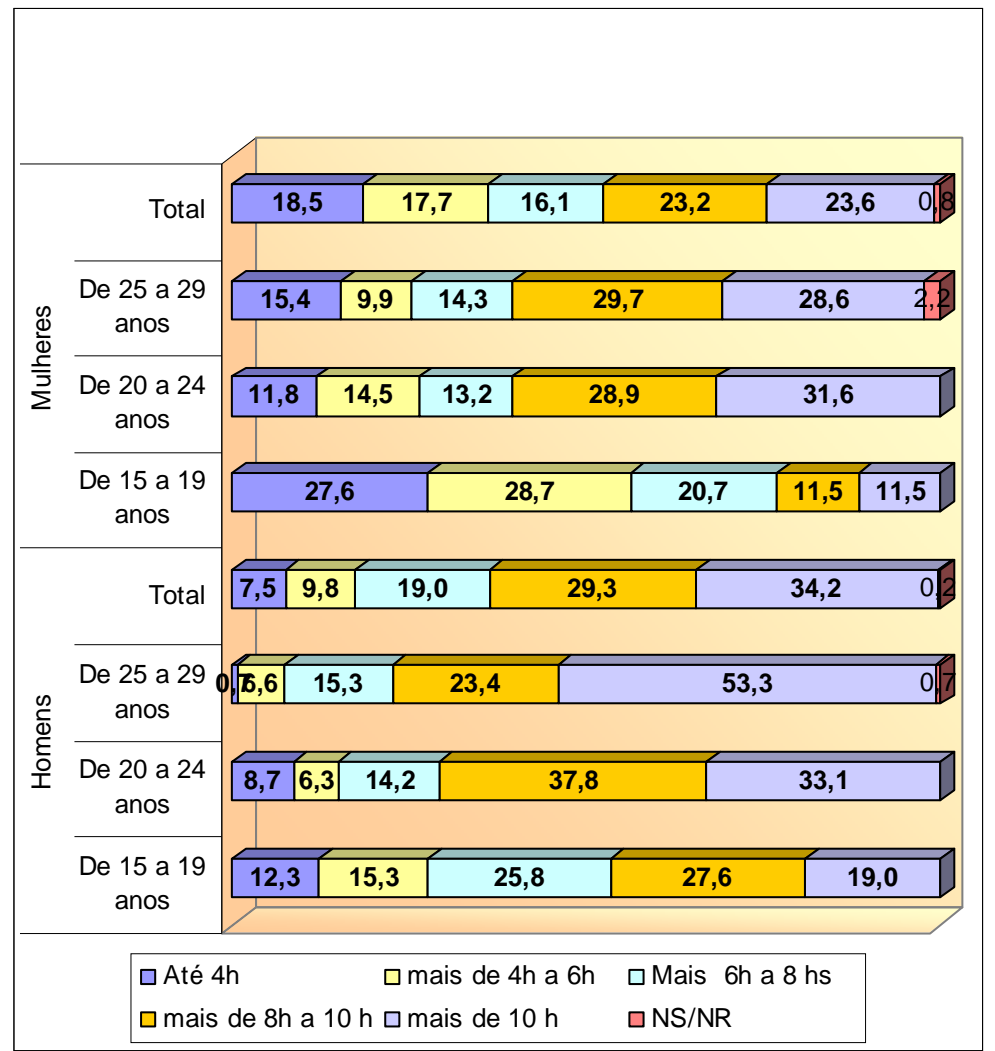

Gráfico 23: Jornadas de trabalho familiar agrícola por sexo e faixas etárias (\%) Fonte: Banco de Dados Jovens Agricultores Familiares RS - MDA/FAURGS, 2007.

Percebe-se que os jovens de ambos os sexos apresentam uma elevada participação no trabalho familiar agrícola, considerando-se tanto o tipo de participação quanto a jornada de trabalho. Estas duas variáveis analisadas permitem verificar que os jovens ocupam a maior parte de seu tempo com a execução dos trabalhos agrícolas na unidade de produção familiar. Contudo, são observadas diferenças no volume de participação que colocam os jovens adultos e as jovens adolescentes em posições assimétricas em relação à intensidade do seu envolvimento nesta atividade. As diferenças de intensidade na participação no trabalho agrícola correspondem às dinâmicas da divisão sexual e etária do trabalho no interior da unidade de produção familiar e a respectiva atribuição de papeis sociais distintos com base nestes critérios. Deste modo, as respostas dos informantes, que apontam uma participação no trabalho agrícola inferior de jovens adolescentes e mulheres em comparação a dos jovens adultos e homens podem ter duas explicações: a) entre os adolescentes o trabalho deve estar associado ao estudo formal e; b) entre as jovens mulheres as suas respostas podem não ter considerado o tempo dedicado as atividades 
domésticas. Nestes casos, isto corresponderia a uma expressão da cultura que percebe o trabalho feminino como "parcial", "leve" e "ajuda" como discutido anteriormente. Ou seja, esta assimetria na participação por sexos e idades pode ser explicada por duas alternativas. À primeira, corresponde a possibilidade de que elas tenham internalizado a desvalorização de sua participação no trabalho agrícola e não reconhecem suas atividades domésticas como parte do trabalho familiar agrícola. A segunda, possibilidade é a de que, realmente, as jovens mulheres, com destaque para as adolescentes, estejam tendo uma inserção parcial e realizando jornadas diárias de trabalho menores do que a dos jovens homens. Nestes casos, elas tendem a apresentar outras formas de ocupação do tempo excedente, o que poderá ser verificado em relação à participação no ensino formal e em atividades de lazer. Antes, porém, no próximo tópico, buscase aprofundar estas questões identificando como ocorre a divisão do trabalho e em quais atividades a participação dos jovens se destaca.

\subsubsection{A participação juvenil na divisão do trabalho familiar}

A produção familiar na agricultura implica a realização de um conjunto relativamente vasto de tarefas. Estas atividades produtivas apresentam variação conforme o sistema de produção adotado e, além das atividades da lida da roça (cultivo e criação), envolvem a gestão do empreendimento mercantil e as tarefas domésticas que viabilizam a reprodução da força de trabalho da família e criam valores diversos. Neste tópico é analisada a participação dos jovens na divisão do trabalho familiar, com isto se poderá identificar a posição ocupada pelos jovens a partir do papel desempenhado no processo de trabalho da agricultura familiar. Processo este que constitui uma relação objetiva entre os membros da família de agricultores e reforça as construções simbólicas relativas a papeis de gênero e geração na hierarquia familiar.

O exame das informações sobre quem entre os membros da família dos entrevistados assume a responsabilidade pela condução de determinadas tarefas permite identificar a forma que assume a divisão social do trabalho familiar agrícola, isto é, a divisão do trabalho no interior da unidade de produção familiar destes jovens. Estes dados foram construídos por intermédio de uma pergunta sobre quem realiza uma determinada tarefa, a partir de uma lista de 31 atividades. As respostas foram registradas a partir de uma pré-codificação originadas de respostas abertas obtidas ainda na etapa preparatória da pesquisa e que buscou contemplar a diversidade de 
membros das unidades produtivas. Assim, puderam ser inferidas as formas que assumem a divisão do trabalho entre: entrevistado; entrevistada; pai; mãe; cônjuge; pai e mãe; pai e filhos; mãe e filhas, entrevistado(a) e cônjuge; entrevistado(a) e irmãos; toda a família, outras pessoas.

Os indicadores contidos na Tabela 24 foram, posteriormente, organizados em três conjuntos com a distribuição de índices sintéticos sobre quem executa: a) as tarefas administrativas (tarefas 1 a 10); b) as tarefas agrícolas (tarefas 15 a 31) e c) as tarefas domésticas (tarefas 11 a 14). Deste modo, obtivemos os Gráficos 24, 25 e 26, respectivamente, que ilustram a forma da divisão social do trabalho na perspectiva dos jovens agricultores. Este procedimento permite demonstrar que, para além de sua aparente unidade, o processo de trabalho familiar agrícola se realiza por meio de uma divisão interna de tarefas e responsabilidades que se estruturam através das diferenças de gênero e geração, que demarcam os papeis sociais e revelam as posições hierárquicas ocupadas no interior do grupo doméstico.

Tabela 24: Divisão do trabalho entre os membros da família (\%)

\begin{tabular}{|c|c|c|c|c|c|c|c|c|c|c|c|c|c|c|c|}
\hline $\begin{array}{l}\text { Quem realiza as } \\
\text { seguintes tarefas } \\
\text { na UPF? (em \%) }\end{array}$ & 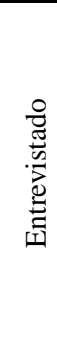 & 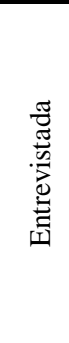 & ¿ే & $\sum_{\Sigma}^{\mathbb{\pi}}$ & 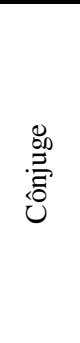 & 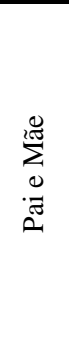 & $\begin{array}{l}\stackrel{\infty}{0} \\
\stackrel{0}{1} \\
0 \\
0 \\
0\end{array}$ & 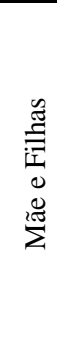 & 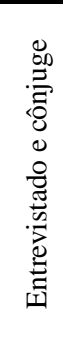 & 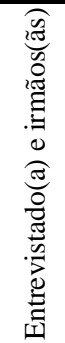 & 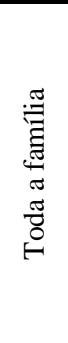 & 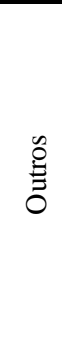 & $\mathbb{Z}$ & 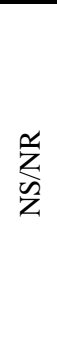 & 氶 \\
\hline $\begin{array}{l}\text { 1. Comprar } \\
\text { Insumos }\end{array}$ & 7,8 & 0,9 & 50,2 & 2,9 & 10,0 & 2,6 & 7,3 & 0,4 & 1,2 & 3,1 & 3,4 & 7,4 & 2,5 & 0,1 & 100 \\
\hline $\begin{array}{l}\text { 2. Decidir o que } \\
\text { plantar }\end{array}$ & 5,1 & 0,1 & 29,4 & 1,9 & 5,7 & 9,5 & 10,0 & 0,1 & 5,1 & 1,5 & 24,2 & 5,7 & 0,7 & 0,3 & 100 \\
\hline $\begin{array}{l}\text { 3. Decidir onde } \\
\text { plantar }\end{array}$ & 6,0 & 0,6 & 31,4 & 1,9 & 6,9 & 6,9 & 10,4 & 0,0 & 4,3 & 1,8 & 22,8 & 5,3 & 1,0 & 0,4 & 100 \\
\hline $\begin{array}{l}\text { 4. Decidir sobre } \\
\text { os investimentos }\end{array}$ & 4,1 & 0,7 & 22,8 & 2,2 & 3,8 & 12,9 & 7,0 & 0,1 & 6,8 & 1,0 & 31,7 & 5,6 & 0,9 & 0,4 & 100 \\
\hline $\begin{array}{l}\text { 5. Depositar } \\
\text { dinheiro no } \\
\text { banco } \\
\end{array}$ & 7,0 & 1,6 & 32,0 & 5,0 & 7,6 & 10,7 & 6,6 & 0,3 & 3,4 & 0,9 & 13,7 & 6,5 & 4,3 & 0,4 & 100 \\
\hline $\begin{array}{l}\text { 6. Falar com o } \\
\text { técnico } \\
\text { agrônomo }\end{array}$ & 9,7 & 1,0 & 35,5 & 2,1 & 8,7 & 4,7 & 9,7 & 0,1 & 2,9 & 1,8 & 11,2 & 6,5 & 5,7 & 0,4 & 100 \\
\hline $\begin{array}{l}\text { 7. Participar de } \\
\text { reuniões de } \\
\text { Sindicato ou } \\
\text { Cooperativa }\end{array}$ & 6,8 & 1,0 & 31,9 & 2,9 & 6,0 & 9,4 & 9,0 & 0,0 & 2,9 & 1,3 & 8,2 & 6,8 & 13,4 & 0,4 & 100 \\
\hline $\begin{array}{l}\text { 8. Sacar } \\
\text { dinheiro no } \\
\text { banco }\end{array}$ & 7,6 & 1,5 & 30,8 & 5,7 & 9,0 & 11,6 & 7,0 & 0,4 & 3,7 & 1,2 & 12,6 & 5,1 & 3,2 & 0,4 & 100 \\
\hline $\begin{array}{l}\text { 9. Tirar } \\
\text { financiamento } \\
\text { no banco }\end{array}$ & 4,0 & 1,3 & 33,9 & 2,8 & 8,1 & 6,5 & 16,2 & 0,1 & 2,8 & 1,3 & 5,0 & 6,3 & 11,6 & 0,1 & 100 \\
\hline $\begin{array}{l}10 . \text { Vender a } \\
\text { produção }\end{array}$ & 6,6 & 0,4 & 40,0 & 1,3 & 9,5 & 5,1 & 12,9 & 0,1 & 2,2 & 1,2 & 9,7 & 7,5 & 3,2 & 0,1 & 100 \\
\hline 11. Decidir o & 2,2 & 5,9 & 6,6 & 35,4 & 4,6 & 12,5 & 1,0 & 2,8 & 5,4 & 0,1 & 19,1 & 4,0 & 0,3 & 0,1 & 100 \\
\hline
\end{tabular}




\begin{tabular}{|c|c|c|c|c|c|c|c|c|c|c|c|c|c|c|c|}
\hline $\begin{array}{l}\text { que comprar } \\
\text { para a casa }\end{array}$ & & & & & & & & & & & & & & & \\
\hline $\begin{array}{l}\text { 12. Fazer } \\
\text { compras para a } \\
\text { casa }\end{array}$ & 2,3 & 6,8 & 6,2 & 35,8 & 5,1 & 14,1 & 1,5 & 2,5 & 5,3 & 0,4 & 14,8 & 4,3 & 0,3 & 0,6 & 100 \\
\hline $\begin{array}{l}\text { 13. Limpeza da } \\
\text { casa }\end{array}$ & 2,3 & 18,4 & 1,2 & 36,0 & 5,6 & 1,2 & 0,9 & 20,9 & 1,5 & 0,3 & 6,6 & 4,3 & 0,9 & 0,3 & 100 \\
\hline $\begin{array}{l}\text { 14. Preparo das } \\
\text { refeições }\end{array}$ & 1,2 & 15,0 & 1,8 & 44,2 & 6,8 & 0,9 & 0,6 & 15,4 & 0,4 & 0,1 & 4,3 & 8,5 & 0,7 & 0,3 & 100 \\
\hline $\begin{array}{l}\text { 15. Aplicação de } \\
\text { veneno } \\
\text { (defensivos) }\end{array}$ & 14,7 & 0,4 & 26,0 & 0,1 & 11,9 & 1,3 & 22,0 & 0,1 & 1,5 & 2,8 & 4,4 & 9,0 & 5,4 & 0,3 & 100 \\
\hline $\begin{array}{l}16 . \\
\text { Beneficiamento } \\
\text { de produtos }\end{array}$ & 5,1 & 1,3 & 6,6 & 4,8 & 1,9 & 1,2 & 4,8 & 0,0 & 2,9 & 0,9 & 13,4 & 4,3 & 52,4 & 0,3 & 100 \\
\hline 17. Capina & 4,4 & 1,5 & 4,1 & 3,1 & 1,2 & 5,3 & 7,6 & 1,5 & 5,6 & 0,6 & 48,9 & 3,7 & 12,3 & 0,3 & 100 \\
\hline 18. Colheita & 5,1 & 0,4 & 4,4 & 0,4 & 2,9 & 3,4 & 11,2 & 0,0 & 5,4 & 1,0 & $\overline{52,6}$ & 8,3 & 4,4 & 0,4 & 100 \\
\hline $\begin{array}{l}\text { 19. Consertos da } \\
\text { casa, galpão ou } \\
\text { estábulos. }\end{array}$ & 8,5 & 0,7 & 17,8 & 1,2 & $\overline{6,8}$ & 1,8 & 20,3 & $\overline{0,3}$ & 2,3 & 1,0 & 23,5 & 12,2 & 3,4 & 0,3 & 100 \\
\hline $\begin{array}{l}\text { 20. Embalar } \\
\text { produtos }\end{array}$ & 4,6 & 2,5 & 5,1 & 2,9 & 2,5 & 2,1 & 8,2 & 0,9 & 2,9 & 0,6 & 24,7 & 2,5 & 40,2 & 0,3 & 100 \\
\hline $\begin{array}{l}\text { 21. Limpeza de } \\
\text { chiqueiro ou } \\
\text { estábulos }\end{array}$ & 13,4 & 1,0 & 12,8 & 4,4 & 4,7 & 5,1 & 15,7 & 1,2 & 2,6 & 4,6 & 18,2 & 6,3 & 9,7 & 0,3 & 100 \\
\hline $\begin{array}{l}\text { 22. Manutenção } \\
\text { da lavoura ou } \\
\text { estufa }\end{array}$ & 8,8 & 1,2 & 18,1 & 1,3 & 7,9 & 3,4 & 18,8 & 0,1 & 3,4 & 2,1 & 26,6 & 5,1 & 2,9 & 0,3 & 100 \\
\hline 23. Plantio & 8,4 & 0,7 & 10,9 & 1,8 & 5,7 & 3,7 & 19,7 & 0,4 & 3,8 & 1,9 & 33,3 & 7,2 & 2,2 & 0,3 & 100 \\
\hline $\begin{array}{l}\text { 24. Preparo do } \\
\text { solo para plantio }\end{array}$ & 13,4 & 0,4 & 19,2 & 2,2 & 8,2 & 2,3 & 22,5 & 0,3 & 1,3 & 1,8 & 16,7 & 6,9 & 4,4 & 0,3 & 100 \\
\hline 25. Tirar leite & 5,9 & 5,1 & 2,6 & 24,4 & 2,3 & 4,1 & 2,5 & 8,8 & 4,3 & 0,7 & 18,4 & 4,4 & 16,2 & 0,3 & 100 \\
\hline $\begin{array}{l}\text { 26. Trabalho na } \\
\text { horta para } \\
\text { consumo } \\
\text { próprio }\end{array}$ & 3,2 & 6,0 & 1,6 & 37,5 & 3,1 & 3,1 & 1,3 & 10,4 & 5,3 & 0,1 & 16,9 & 6,3 & 4,7 & 0,3 & 100 \\
\hline $\begin{array}{l}\text { 27. Trabalho no } \\
\text { pomar }\end{array}$ & 5,1 & 1,5 & 8,4 & 10,4 & 1,3 & 2,9 & 4,4 & 2,5 & 5,0 & 0,7 & 30,0 & 5,1 & 22,1 & 0,3 & 100 \\
\hline $\begin{array}{l}28 . \\
\text { Transformação } \\
\text { de alimentos }\end{array}$ & 1,2 & 4,1 & 1,3 & 33,2 & 2,8 & 1,3 & 0,9 & 6,5 & 1,2 & 0,1 & 7,6 & 4,6 & 35,0 & 0,3 & 100 \\
\hline $\begin{array}{l}\text { 29. Tratar do } \\
\text { gado }\end{array}$ & 8,7 & 1,2 & 9,4 & 6,0 & 3,5 & 5,4 & 12,1 & 0,9 & 4,0 & 0,4 & 33,5 & 3,8 & 10,7 & 0,3 & 100 \\
\hline $\begin{array}{l}\text { 30. Tratar dos } \\
\text { suínos }\end{array}$ & 8,4 & 1,2 & 19,3 & 4,9 & 3,2 & 3,2 & 9,3 & 0,6 & 3,1 & 0,6 & 22,4 & 7,2 & 16,3 & 0,4 & 100 \\
\hline $\begin{array}{l}\text { 31. Tratar dos } \\
\text { pequenos } \\
\text { animais }\end{array}$ & 1,3 & 4,7 & 6,2 & 18,2 & 2,5 & 4,3 & 4,3 & 3,2 & 3,2 & 0,4 & 29,6 & 8,1 & 7,8 & 0,4 & 100 \\
\hline
\end{tabular}

Fonte: Banco de dados Jovens Agricultores Familiares RS - MDA/FAURGS, 2007.

Iniciamos verificando como são distribuídas as responsabilidades sobre a realização das tarefas administrativas na unidade de produção familiar. No Gráfico 24 , percebe-se que há um predomínio do pai no exercício das ações relacionadas com a gestão do empreendimento familiar, com índice de 33,9\%. Em 14,2\% dos casos a administração é exercida por toda a família; em 9,6\%, a gestão é compartilhada por pais e filhos. Em $8 \%$ das situações, a administração da unidade produtiva é feita por pais e mães enquanto que 7,5\% dos jovens 
responderam que era o cônjuge quem realizava estas tarefas na propriedade. Entre estes, em apenas um caso era de um entrevistado de sexo masculino. Este caso refere-se à situação onde já ocorreu a emancipação do jovem, ou seja, ele é o responsável pela unidade produtiva. Indica ainda que entre as mulheres se reproduz com o casamento a condição que tinha como filha, de não-envolvimento nas atividades administrativas da unidade produtiva. Por sua vez, $6,5 \%$ dos entrevistados realizam estas tarefas, percentual bem maior do que o registrado entre as entrevistadas $(0,9 \%)$.

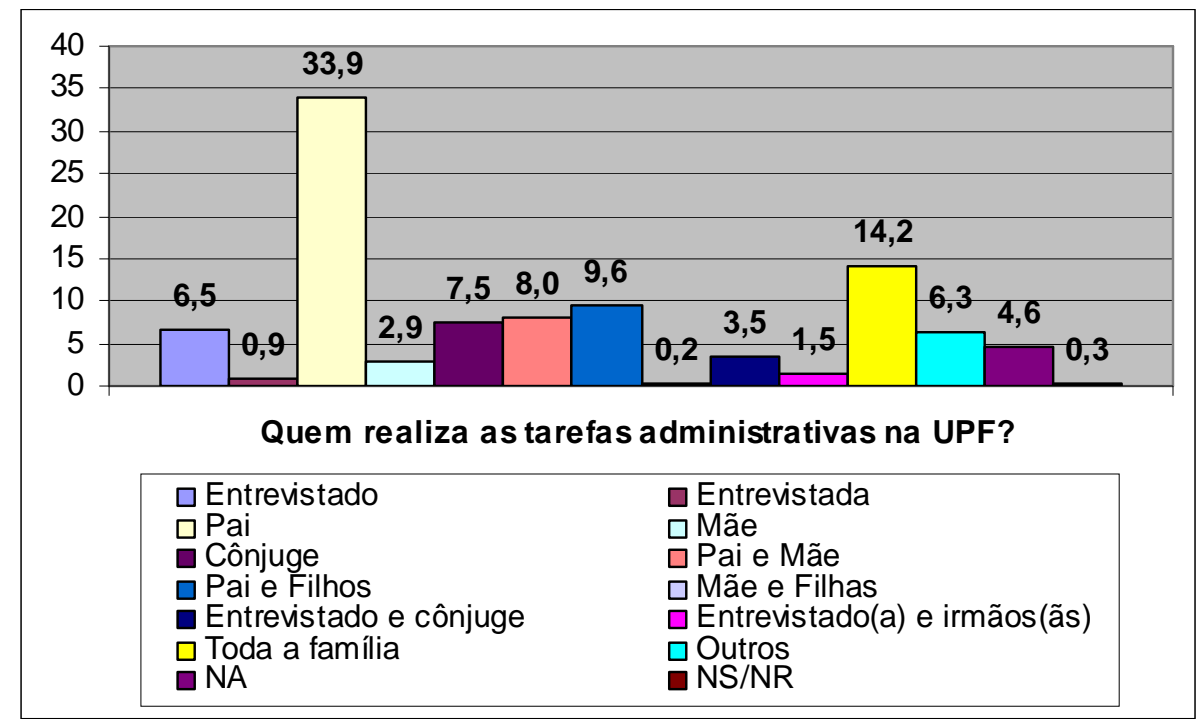

Gráfico 24: Distribuição das tarefas administrativas da Unidade de Produção Familiar (\%) Fonte: Banco de Dados Jovens Agricultores Familiares RS - MDA/FAURGS, 2007.

Recorrendo-se à Tabela 24, pode ser verificado o rol de tarefas administrativas da unidade de produção familiar (itens 1 a 10). Nela percebe-se que, praticamente, todas são, predominantemente, realizadas pelo pai. Destas tarefas, as que mais são realizadas exclusivamente pelos pais dos entrevistados são comprar insumos, vender a produção e falar com o técnico agrônomo. A exceção fica por conta da decisão sobre os investimentos, que é, em $31,7 \%$ dos casos, atribuição de toda a família. A categoria de resposta toda a família também figura com percentuais significativos quando se trata de definir o que plantar $(24,2 \%)$ e decidir onde plantar $(22,8 \%)$. O fato de a decisão sobre os investimentos e outras ações futuras serem tomadas como uma decisão coletiva da família é emblemática do tipo familiar de gestação da unidade produtiva e indica a ocorrência de estratégias comumente partilhadas no interior do grupo doméstico. Ainda entre estas atividades, a participação dos entrevistados é maior quando 
se trata de falar com o técnico agrônomo $(9,7 \%)$, enquanto que entre as jovens entrevistadas é depositar dinheiro no banco $(1,6 \%)$.

Tomando a realização de tarefas relativas à administração da atividade produtiva como um indicador das posições ocupadas na hierarquia familiar, percebe-se que o pai personifica a gestão da atividade, o que é compartilhado, em alguns casos, com a esposa, sem ameaçar o predomínio masculino na tomada de decisões: os jovens encontram-se distantes destas atividades enquanto residirem com seus pais. Neste sentido, pode-se dizer que os filhos encontram-se subordinados aos pais na gestão da unidade de produção familiar; entre eles, as jovens mulheres encontram-se ainda mais distantes das tomadas de decisão, ocupando posições mais baixas na hierarquia familiar.

Aborda-se, agora, o exame das formas que assumem a divisão das tarefas agrícolas na UPF. Estas correspondem a um conjunto de tarefas voltadas ao cultivo e à criação e para as quais é mobilizada a força de trabalho de todos os membros da família. O Gráfico 25 apresenta o índice de distribuição de quem realiza as tarefas agrícolas. Na realização destas, sobressai a participação de todos os membros da família (24,7\%). Destaca-se ainda que quase $15 \%$ das respostas indicam atividades que não são realizadas e figuram na categoria não se aplica (NA), o que resulta da diversidade dos sistemas de produção da agricultura familiar gaúcha. Mais relevante, no entanto, é que "pais e filhos" correspondem a 11\% de respostas, percentual próximo ao registrado para "pai" $(10,2 \%)$. Os jovens homens entrevistados são os responsáveis pelas atividades agrícolas em 7,1\% dos casos; as jovens mulheres entrevistadas assumem essa função, exclusivamente, em 1,9\% das respostas. Estas informações não deixam dúvidas da importância da participação da força de trabalho juvenil para a realização das tarefas agrícolas. 


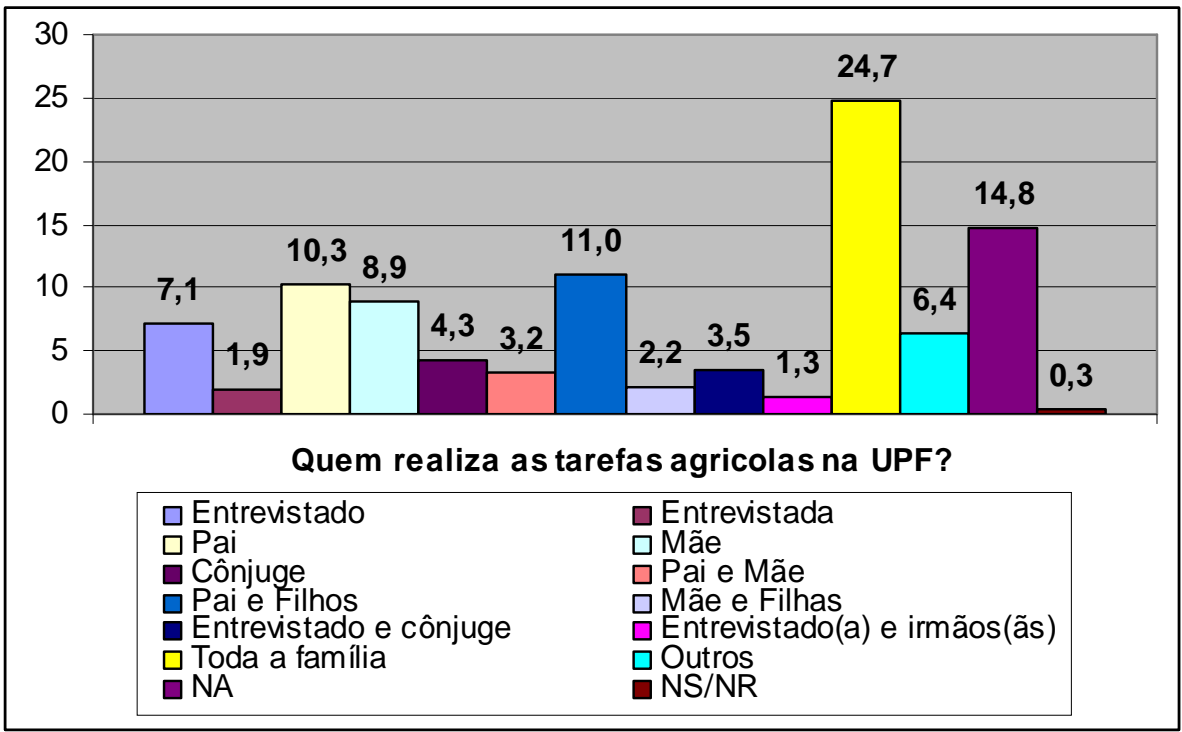

Gráfico 25: Distribuição das tarefas agrícolas da Unidade de Produção Familiar (\%) Fonte: Banco de dados Jovens Agricultores Familiares RS - MDA/FAURGS, 2007.

Conforme a Tabela 24, a aplicação de veneno ou defensivos é, principalmente, realizada pelos homens, sejam os pais $(26 \%)$, por pais e filhos $(22 \%)$ ou exclusivamente pelo entrevistado (14,7\%). As tarefas como colheita, capina e plantio são as mais realizadas por todos os membros da família. Neste contexto, a participação dos jovens no trabalho contribui para o trabalho familiar, permanecendo encoberta na alternativa "toda a família”. O preparo do solo é uma tarefa em que também se destaca a atuação conjunta de pais e filhos. Das tarefas agrícolas, a que mais é realizada, exclusivamente, pelos entrevistados corresponde à aplicação de veneno e defensivos, seguindo-se o preparo do solo para o plantio e a limpeza de chiqueiros e estábulos. Por sua vez, as jovens mulheres entrevistadas apresentam um percentual maior do que o dos homens no trabalho da horta para consumo próprio, na transformação de alimentos e no trato dos pequenos animais.

Existe um conjunto de tarefas indispensáveis ao funcionamento da unidade produtiva que se realizam no âmbito doméstico, tais como o preparo das refeições, a limpeza da casa e outras que são necessárias para a reprodução da força de trabalho da família. O Gráfico 26 descreve quem realiza as tarefas domésticas na UPF. Este é o que apresenta maior percentual de concentração da atividade, com uma média de 37,9\% para mãe dos entrevistados. A realização exclusiva do trabalho doméstico também predomina entre as entrevistadas $(11,5 \%)$. Foram registrados também 11,2\% de casos onde o trabalho doméstico é compartilhado por todos os membros da família. Todavia, este índice é inferior ao registrado por esta categoria de resposta quando se trata das tarefas administrativas ou agrícolas. Por outro lado, $10,4 \%$ dos inquiridos 
afirmam que as tarefas domésticas são realizadas por mãe e filha, índice bastante superior ao que foi constatado para esta categoria em outras atividades. Estas respostas demonstram que o trabalho doméstico é, praticamente, exclusivo das mulheres (mães, entrevistadas, mães e filhas).

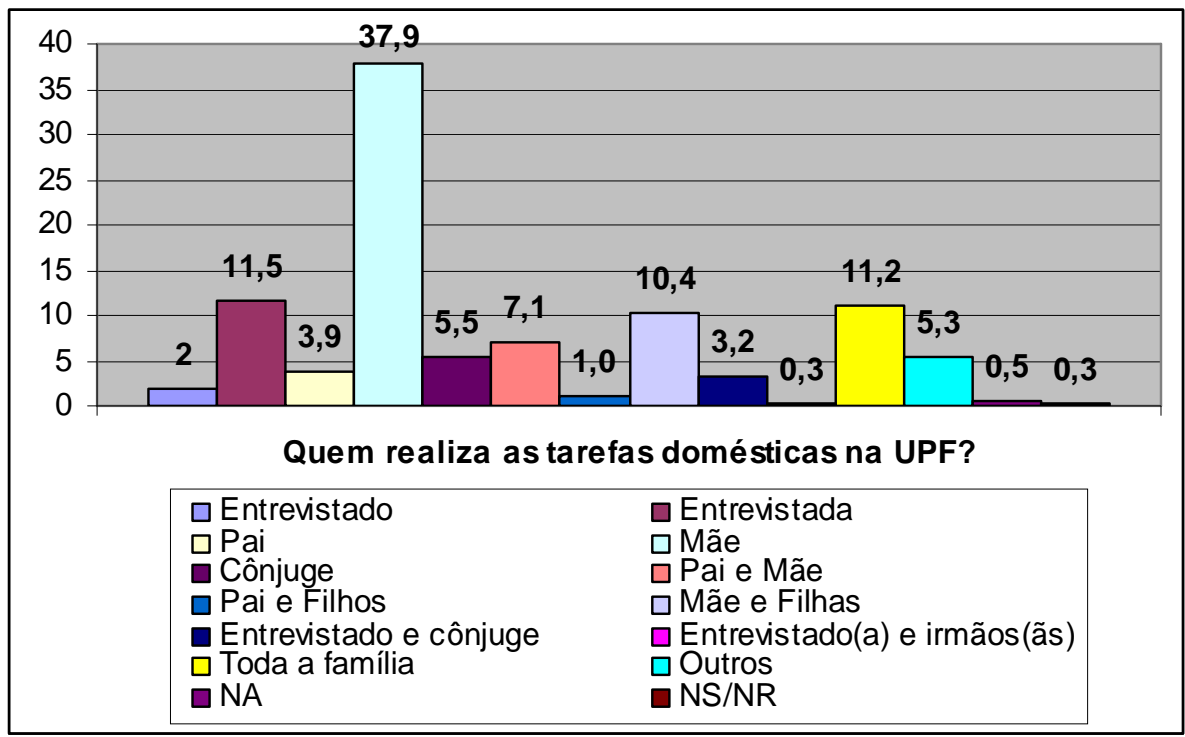

Gráfico 26: Realização das tarefas domésticas da Unidade de Produção Familiar (\%) Fonte: Banco de dados Jovens Agricultores Familiares RS - MDA/FAURGS, 2007.

Voltando à Tabela 24, verificamos que todas as tarefas domésticas são exercidas, principalmente, pela mãe. No preparo de refeições e na limpeza da casa predominam na ordem a exclusividade da mãe, de mãe e filha e entrevistada. Entre estas atividades, as entrevistadas são as principais responsáveis, principalmente na limpeza da casa $(18,4 \%)$ e no preparo de refeições (15\%), tarefas que são realizadas apenas por 2,3\% e 1,2\% dos jovens homens, respectivamente.

Estes dados confirmam que os trabalhos domésticos concentram-se, principalmente, nas mãos das mulheres, reproduzindo desta forma a divisão sexual do trabalho entre as novas gerações. A construção de um espaço de atuação diferenciado por sexo no cotidiano da agricultura familiar reflete as construções ideológicas relativas à mulher e ao papel social que se espera que ela desempenhe no interior da família. Estas se referem ao fato de que, ao atribuir às mulheres uma responsabilidade, quase exclusiva sobre as tarefas domésticas, se está impondo a elas uma posição subalterna na hierarquia familiar. O fato de os homens não participarem da realização dos trabalhos domésticos, apesar de sua aparente naturalidade, revela as relações de poder no interior do grupo doméstico, sendo uma expressão da dominação masculina. Ideologia que, compartilhada pelo grupo social estudado, impõe às mulheres múltiplas jornadas de trabalho, sem lhe assegurar o reconhecimento de seu trabalho como "produtivo". 
Considerando as tarefas relativas à administração da unidade produtiva como indicador das posições superior na hierarquia familiar, percebe-se que os pais ocupam a posição de maior autoridade na gestão do trabalho e de seus resultados no interior do grupo familiar. "Ele é o detentor de um saber que o autoriza a governar o processo de trabalho, isto é, a dirigir o trabalho da família" (WOORTMANN \& WOORTMANN, 1997, p. 13). Esta autoridade está fundamentada no fato de o pai ser o detentor do saber agrícola e que este saber transforma a terra em terra de trabalho. Deste modo, se produz um processo de legitimação do agricultor pleno que concentra em suas mãos o controle sobre a renda familiar e sobre a gestão da produção agrícola.

O pai, por assim dizer, é sempre força plena (TEPICHT, 1979) de trabalho da família, não por ter o maior vigor físico entre os membros do grupo doméstico - até porque em certo estágio do ciclo evolutivo da família, os filhos podem ter mais força do que o pai para trabalhar - mas, porque, ideologicamente, define-se como aquele que reúne plenas condições para participar de todas as etapas do processo de trabalho familiar, principalmente na gestão do negócio mercantil.

Sendo o pai quem encarna o trabalho agrícola, logo o resultado do trabalho ali realizado é trabalho dele; a esposa, os filhos e as filhas, mesmo desempenhando tarefas fundamentais à produção, como no preparo do solo, no plantio e na colheita, apenas "ajudam”. Como resultado, os mais jovens e as mulheres enfrentam resistência para obter seu reconhecimento enquanto agricultores.

Os jovens homens vão assumindo aos poucos, e sucessivamente, a responsabilidade pela realização de certas tarefas agrícolas. Entre as tarefas realizadas por eles, destacam-se: a aplicação de veneno e defensivos, a limpeza de chiqueiros e estábulos, o preparo do solo para o plantio, o trato dos pequenos animais, assim como do gado e dos suínos. As atividades mencionadas assinalam a passagem progressiva dos filhos das atividades que se realizam com a supervisão dos pais para aquelas que ele vai executar sozinho. Assim, cada nova tarefa implica uma fase do processo transitório da etapa de dependência a de individualização progressiva. Situação última que só será alcançada, plenamente, com a passagem sucessória ou o abandono da casa dos pais, constituindo uma nova família nuclear e uma nova unidade produtiva.

O trabalho das jovens mulheres, por estar inserido nas atividades realizadas por toda a família, como o plantio, a capina e a colheita, muitas vezes não é percebido, ficando sem reconhecimento e visibilidade. Elas também estão presentes nas tarefas realizadas em conjunto com a mãe, principalmente no trabalho da horta para o consumo próprio. Geralmente realizam 
tarefas que são consideradas como especificamente femininas; na medida em que são realizadas por mulheres, perdem o caráter de trabalho; passam a ser consideradas como ajuda.

Os resultados desta pesquisa confirmam a tendência verificada em outros estudos ${ }^{62}$ de que, na organização do trabalho familiar, as mulheres estão realizando tarefas para as quais lhes são atribuídas qualidades específicas como força de trabalho, justamente por serem mulheres. É preciso registrar que a realização de tarefas domésticas não se restringe ao espaço físico da casa; ela envolve principalmente o pátio próximo à residência com suas hortas e jardins, o trato dos animais que nele circulam, a limpeza e embalagem dos produtos e beneficiamentos diversos.

Conforme sugere Brumer (2004), a participação das mulheres nas atividades produtivas geralmente ocorre quando elas: a) requerem uma execução manual, durante as fases de limpeza do solo e de colheita dos produtos; b) referem-se ao processamento de produtos agrícolas (limpeza, seleção, embalagem, etc.); c) destinam-se ao cuidado de animais, incluindo a retirada de leite e a criação de animais pequenos destinados, principalmente, ao autoconsumo. Segundo a autora, essas atividades têm em comum a exigência de algumas qualidades que, supostamente, as mulheres têm por natureza, por aquisição através do processo de socialização ou devido à sua situação de trabalhadoras eventuais, decorrentes da manutenção de suas obrigações na esfera da reprodução, como a responsabilidade do cuidado de crianças pequenas. Entre as qualidades consideradas como femininas a autora destaca: a) a capacidade de executar tarefas repetitivas, tediosas e intensivas; b) a capacidade de realizar várias tarefas ao mesmo tempo (uma característica de grande parte das atividades executadas no âmbito doméstico); c) a possibilidade de associar ao trabalho suas responsabilidades na esfera da reprodução, trazendo consigo os filhos ou afastando-se de suas residências por pouco tempo; d) a disponibilidade de envolver-se em trabalhos temporários, sejam eles concentrados em determinados períodos durante o ano seja envolvendo apenas algumas horas do dia; e) sua maior habilidade para execução de algumas tarefas que requerem dedos pequenos e ágeis, assim como a permanência em posição desconfortável (como trabalhar agachada) por bastante tempo; f) a aceitação de uma remuneração relativamente inferior à paga aos homens ou a trabalhadores envolvidos em outras atividades; g) a maior conformidade (o que implica maior aceitação das exigências do trabalho e menor número de reivindicações) (BRUMER, 2004). Ou seja, confirma-se que sua condição de gênero determina sua posição no interior da classe social; neste caso, no processo de trabalho familiar agrícola.

${ }^{62}$ HEREDIA; GARCIA; GARCIA JUNIOR, 1984; DEERE; LEON, 2002; BRUMER, 2004; PAULILO, 2004; BRUMER; WEISHEIMER, 2006. 
É preciso perceber que esta naturalização é mais uma justificativa do que uma explicação da divisão sexual do trabalho familiar. Trata-se de um processo socialmente construído de imposição de papeis sociais por meio de um longo processo de socialização que determina a posição de cada indivíduo na família e em relação ao trabalho e à propriedade. Este processo não é natural, mas naturalizado e mobilizado pelos sujeitos - homens e mulheres - de todas as idades na sua ação cotidiana.

As jovens mulheres realizam as atividades menos valorizadas no trabalho; por consequência, ocupam as posições mais subalternas na hierarquia familiar, visto que, com exceção do exercício das atividades domésticas não exercem nenhuma outra sob sua responsabilidade exclusiva. A subordinação dos agricultores familiares às dinâmicas do modo de produção capitalista se viabiliza através de uma distribuição desigual de poder no interior das famílias; como se verá no próximo capítulo, das baixas expectativas das filhas em sucederem aos pais na gestão da unidade produtiva. Com efeito, as relações sociais de produção valem-se da distinção de gênero, construída social e culturalmente, para atribuir papeis sociais que são incorporados por homens e mulheres de todas as idades, o que pode ajudar a entender o fraco reconhecimento, inclusive por parte das próprias mulheres, da sua participação no trabalho familiar, percebido como trabalho doméstico, auxiliar ao dos homens e frequentemente caracterizado por elas como ajuda. ${ }^{63}$

\subsection{OS JOVENS AGRICULTORES FAMILIARES E O SISTEMA FORMAL DE ENSINO}

Busca-se agora analisar a socialização dos jovens no sistema formal de ensino. Compreende-se esta escolarização formal como o ensino regular oferecido por instituições públicas e privadas nos diferentes níveis da educação brasileira. Considera-se, com base na Lei de Diretrizes e Bases da Educação Nacional, sancionada em 25 de dezembro de 1996, que estes se compõem de Educação Infantil, Ensino Fundamental, Ensino Médio, Ensino Médio Profissionalizante, Educação Superior e Pós-graduação.

Como argumentava Durkheim (1978), a educação promovida no sistema escolar distingue-se da educação que é dada na família pelo fato de ser voluntária. Assim, ela não tem em vista apenas reproduzir uma cultura, mas é ela mesma identificada como um modelo cultural

${ }^{63}$ HEREDIA; GARCIA; GARCIA JUNIOR, 1984; DEERE; LEON, 2002; BRUMER, 2004; PAULILO, 2004; BRUMER; WEISHEIMER, 2006. 
que procura produzir um tipo de sociedade e de indivíduo. Isto é relevante uma vez que o sistema formal de ensino orienta-se por diretrizes curriculares unificado para todo território nacional ${ }^{64}$ e que visam capacitar os estudantes principalmente para o desempenho de funções sociais pautadas pela inserção no mercado de trabalho. Mas como isto se processa nas escolas que tem como público os agricultores familiares?

As Ciências Sociais vêm demonstrando que as possibilidades de reprodução do trabalho familiar, ou seja, o engajamento das novas gerações como agricultor é, em grande parte, dependente das possibilidades profissionais ou de trabalho propiciadas pela escolarização. Champagne (1986, p. 73) relaciona a própria “crise da identidade camponesa" com a imposição da escolarização no meio rural e a desqualificação do mundo camponês daí advinda. Silvestro et al. (2001), apoiando-se em estudos anteriores realizados por John Durston (1996) afirma que:

[...] a educação é um elemento decisivo no horizonte profissional de qualquer jovem: na agricultura familiar, entretanto, a regra constada em inúmeros estudos da América Latina (DURSTON, 1996) é que fica no campo o filho ao qual "La cabeza no Le da para más" (SILVESTRO et al., 2001, p. 48) [grifo do autor].

Com base nesta observação, é de se esperar como tendência que apenas ficarão na atividade agrícola aqueles jovens com o pior desempenho escolar. Sendo isto verdadeiro, deveríamos então interrogar-nos por que isto acontece. Será isto responsabilidade exclusiva dos próprios jovens agricultores? Este não parece ser o caso, porque, se fosse, seria um fenômeno restrito a este segmento. Mas não é isto que ocorre. Uma baixa inserção no sistema formal de ensino é recorrente entre os diversos jovens residentes no meio rural brasileiro. Existe uma defasagem observada entre a escolarização obtida por estes, em comparação aos do meio urbano da mesma faixa etária. Conforme os indicadores disponibilizados pelo IBGE, ao considerar-se a média de anos de estudos da população de 15 anos ou mais, verifica-se que o acesso da população rural ao sistema formal de ensino no Brasil é, praticamente, a metade do registrado para a população urbana. Entre os jovens de 15 a 24 anos de idade, a média de anos de estudo é maior na área urbana em todas as regiões do Brasil. Particularmente, na região sul, onde os índices educacionais estão entre os melhores do país, a média de anos de estudo de jovens entre 15 a 24 anos é de 6,7 para os rurais, enquanto que chega a 8,5 na área urbana. No estado do Rio

\footnotetext{
${ }^{64}$ Conforme consta no artigo 26 da LDB, "os currículos do ensino fundamental e médio devem ter uma base nacional comum, a ser complementada, em cada sistema de ensino e estabelecimento escolar, por uma parte diversificada, exigida pelas características regionais e locais da sociedade, da cultura, da economia e da clientela" (art.26.). BRASIL. Lei n. 9.394 de 20 de dezembro de 1996. Estabelece as diretrizes e bases da educação nacional. Diário Oficial [da] República Federativa do Brasil, Brasília, DF, 23 dez. 1996. Seção 1.
} 
Grande do Sul, este indicador é de 8,3 anos de estudo no meio urbano e de 6,9 no meio rural para a mesma faixa dos 15 a 24 anos de idade ${ }^{65}$ Considerando-se a taxa de frequência à escola no Brasil, os jovens do meio rural também apresentam uma menor participação ao serem comparados com os do meio urbano. Considerando-se estritamente a região sul do Brasil, esta taxa é de $77 \%$ entre os residentes do meio urbano em idade de 15 a 17 anos, enquanto para os rurais da mesma idade é de $65 \%^{66}$ Deste modo, antes de atribuirmos este fato a um suposto desinteresse dos jovens agricultores pela escolarização será necessário considerar o contexto da oferta e o próprio conteúdo do ensino que lhes é proposto nas instituições escolares.

De modo geral, as pesquisas sobre juventude e educação rural no Brasil descrevem dois modelos educacionais que produzem efeitos distintos: o sistema formal de ensino e os projetos e programas de capacitação profissional (WEISHEIMER, 2005a).

Um primeiro conjunto de pesquisas ${ }^{67}$ enfatiza que há um descompasso entre um modelo educacional predominante no ensino formal, que tem como paradigma as sociedades urbanas industriais, em relação às necessidades específicas dos jovens que vivem no campo e da agricultura em particular. Na mesma direção, Damasceno e Bezerra (2004), em uma sistematização dos estudos sobre educação rural no Brasil, concluem que a educação rural apresenta problemas graves de origem visto que é planejada a partir da escola urbana. Desta forma a escola rural parece tão alienada do seu meio quanto o são também as escolas urbanas para as classes populares (WILLIS, 1991). Segundo estas autoras, as pesquisas desta temática confirmam as "discrepâncias existentes entre as expectativas do planejamento governamental e as das populações rurais beneficiárias" (DAMASCENO; BEZERRA, 2004, p. 79). Afirmam, portanto, que, tal como se apresenta, a escola rural é inadequada ao seu meio. ${ }^{68}$

Ao mesmo tempo em que a escola aparece distanciada do trabalho agrícola, introduz na cultura local os valores e estilos de vida destoante das práticas sociais locais. Os estudos sistematizados por Weisheimer (2005a) analisam, ainda, as percepções e os significados atribuídos à educação pelos jovens. Desta forma, no que pese as deficiências do sistema escolar, os pesquisadores e as populações rurais reconhecem a importância desta para a difusão de conhecimentos necessários aos agricultores familiares e demais populações rurais. Neste sentido, os pesquisadores brasileiros enfatizam que os jovens percebem a escolarização como uma condição necessária para viabilizar uma possível futura inserção no mercado de trabalho.

\footnotetext{
${ }^{65}$ Fonte: IBGE-PNAD 2001.

${ }^{66}$ Fonte: IBGE-Censo Demográfico 2000.

${ }^{67}$ SILVA, 1992; CAMPOLIM, 2000; SILVA, 2000, 2002; FREIRE, 2002; TURQUINO, 2003.

${ }^{68}$ Neste ponto Damasceno \& Bezerra (2004) fazem referência a Leite (1999), Moreira \& Silva (1994) e McLaren, (1997).
} 
Sustentam ainda a opinião segundo a qual entre os jovens do meio rural, as mulheres viveriam mais intensamente este processo (SILVA, 1992; CAMPOLIM, 2000; SILVA, 2000, 2002; FREIRE, 2002; TURQUINO, 2003).

Ainda há um segundo conjunto de pesquisas que focaliza a participação dos jovens em diferentes projetos de capacitação e formação profissional, que envolve os filhos de agricultores familiares, principalmente fora do sistema formal. As distintas experiências são investigadas a partir dos impactos social e econômico que geram e suas consequências sobre a permanência dos jovens no campo e na agricultura. Em comum, concluem que, após participarem desses programas, os jovens demonstram maior disposição em permanecer nas atividades agrícolas ou agro-industriais, incorporam conhecimentos que são aplicados em suas unidades produtivas, geralmente com a introdução de novas técnicas de produção. Relatam que a aplicação destes conhecimentos resulta em mudanças nas condições materiais das famílias, possibilitando assim a redução da tendência de migração e da evasão escolar. Estas pesquisas demonstram que esses projetos fortalecem a identidade destes jovens tanto como agricultores quanto como empreendedores e empresários rurais; o que varia conforme as bases ideológicas que motivam estas iniciativas (MANHANI, 2000; ESTEVAM, 2001).

Nas duas abordagens desta temática, percebe-se a influência da socialização dos jovens agricultores no processo educacional em sua disposição de permanecer no meio rural e na atividade agrícola. A experiência escolar é formativa da identidade juvenil que ocorre num sistema escolar uniforme no território brasileiro. ${ }^{69}$ Isto é, com um currículo e exames idênticos para todos, pautando a experiência educacional dos jovens agricultores por uma matriz urbana e industrial. Isto possibilita a convivência entre os jovens que participam do processo de trabalho familiar agrícola e os jovens que não se inserem neste processo, propiciando novas dinâmicas às interações sociais. Com efeito, as experiências advindas da socialização escolar frequentemente entram em choque com os valores e as disposições geradas na prática cotidiana do trabalho e que são necessárias à reprodução do trabalho familiar. Impõe-se, assim, a necessidade de analisar as condições de acesso e prosseguimento nos estudos formais entre os jovens agricultores familiares.

Como vimos, os jovens não contam com as mesmas condições de acesso ao ensino formal. Esta estratificação social pela escolarização também ocorre, internamente, à categoria

\footnotetext{
${ }^{69}$ BRASIL. Lei n. 9.394 de 20 de dezembro de 1996. Estabelece as diretrizes e bases da educação nacional. Diário Oficial [da] República Federativa do Brasil, Brasília, DF, 23 dez. 1996. Seção 1.
} 
dos jovens agricultores familiares, havendo situações que variam da não-escolarizado à pósgraduação.

Considerando o grau de escolaridade dos jovens agricultores, obtemos o Gráfico 27. Observa-se que predomina entre eles o ensino médio completo $(28,9 \%)$ e o fundamental incompleto $(27,6 \%)$. Outros $20,1 \%$ contam com o ensino médio incompleto. Os informantes com ensino fundamental completo formam $15,3 \%$ dos casos. Chama atenção a presença reduzida de jovens que frequentaram o ensino técnico (completo e incompleto). Ela é menor do que o percentual de jovens com ensino superior incompleto (4,3\%). Com isto, podemos afirmar, que no que depende do ensino formal, os jovens agricultores familiares gaúchos estão acessando mais o ensino superior do que o técnico. Os jovens buscam por meio do ensino superior assegurar, segundo as suas possibilidades, a melhor inserção produtiva fora da agricultura.

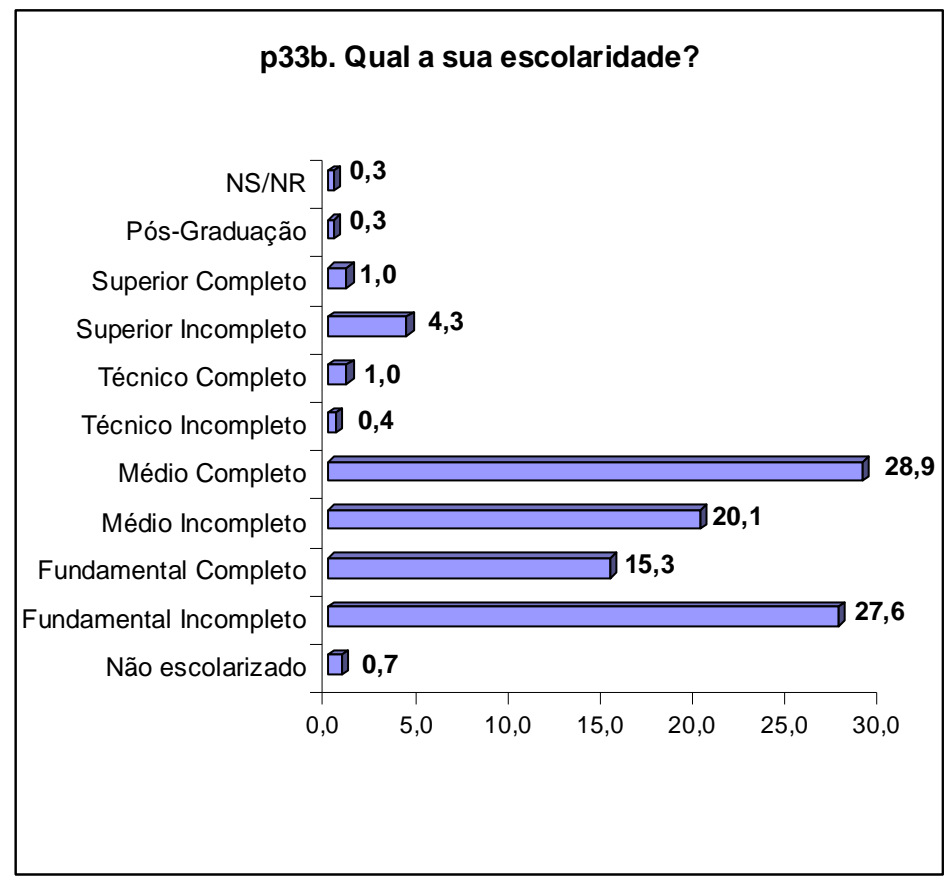

Gráfico 27: Escolaridade dos entrevistados (\%)

Fonte: Banco de dados Jovens Agricultores Familiares RS - MDA/FAURGS, 2007.

Comparando a escolaridade por sexo, obtemos a Tabela 25. Nela destaca-se que os homens cursaram, principalmente, o ensino fundamental incompleto (29\%), seguido do ensino médio completo $(28,6 \%)$. Já as mulheres apresentam percentuais maior nas categorias de respostas ensino médio completo $(29,5 \%)$, seguido por ensino médio incompleto e o fundamental incompleto, ambos com 24,4\%. É possível notar que os jovens homens mais do que as mulheres têm seus estudos restritos ao ensino fundamental, enquanto que as jovens mulheres 
apresentem percentuais maiores nos ensino superior. Com efeito, estas informações mostram que as jovens mulheres alcançam graus de escolaridade superiores aos dos jovens homens.

Tabela 25: Escolaridade dos entrevistados por sexo (em $f$ e \%)

\begin{tabular}{|c|c|c|c|c|c|}
\hline & & & \multicolumn{2}{|c|}{ SEXO } & \multirow[b]{2}{*}{ Total } \\
\hline & & & Homens & Mulheres & \\
\hline \multirow{22}{*}{$\begin{array}{l}\text { QUAL A SUA } \\
\text { ESCOLARIDADE? }\end{array}$} & Não escolarizado & $f$ & 3 & 2 & 5 \\
\hline & & $\%$ & ,7\% & , 8\% & ,7\% \\
\hline & Fundamental Incompleto & $f$ & 126 & 62 & 188 \\
\hline & & $\%$ & $29,5 \%$ & $24,4 \%$ & $27,6 \%$ \\
\hline & Fundamental Completo & $f$ & 69 & 35 & 104 \\
\hline & & $\%$ & $16,2 \%$ & $13,8 \%$ & $15,3 \%$ \\
\hline & Médio Incompleto & $f$ & 75 & 62 & 137 \\
\hline & & $\%$ & $17,6 \%$ & $24,4 \%$ & $20,1 \%$ \\
\hline & Médio Completo & $f$ & 122 & 75 & 197 \\
\hline & & $\%$ & $28,6 \%$ & $29,5 \%$ & $28,9 \%$ \\
\hline & Técnico Incompleto & $f$ & 3 & 0 & 3 \\
\hline & & $\%$ & ,7\% &, $0 \%$ &, $4 \%$ \\
\hline & Técnico Completo & $f$ & 6 & 1 & 7 \\
\hline & & $\%$ & $1,4 \%$ & , 4\% & $1,0 \%$ \\
\hline & Superior Incompleto & $f$ & 16 & 13 & 29 \\
\hline & & $\%$ & $3,7 \%$ & $5,1 \%$ & $4,3 \%$ \\
\hline & Superior Completo & $f$ & 5 & 2 & 7 \\
\hline & & $\%$ & $1,2 \%$ & ,8\% & $1,0 \%$ \\
\hline & Pós-Graduação & $f$ & 0 & 2 & 2 \\
\hline & & $\%$ &, $0 \%$ & ,8\% & ,3\% \\
\hline & NS/NR & $f$ & 2 & 0 & 2 \\
\hline & & $\%$ &, $5 \%$ & ,0\% & ,3\% \\
\hline \multirow[t]{2}{*}{ Total } & & $f$ & 427 & 254 & 681 \\
\hline & & $\%$ & $100,0 \%$ & $100,0 \%$ & $100,0 \%$ \\
\hline
\end{tabular}

Fonte: Banco de dados Jovens Agricultores Familiares RS - MDA/FAURGS, 2007.

A escolaridade apresenta diferenças significativas por faixa de idades dos entrevistados, de tal modo que, entre os jovens de 15 a 19 anos, 40,8\% possuem o ensino médio incompleto, enquanto $18 \%$ concluíram o ensino médio. Entre os entrevistados de 20 a 25 anos de idade, 4,8\% completaram o ensino médio e outros $18 \%$ o ensino fundamental. Os jovens com 25 a 29 anos de idades apresentam escolaridades menores, com 39,5\% com o ensino fundamental incompleto, enquanto que outros 29,8\% cursaram o ensino médio completo (Tabela 26). A maior escolarização dos jovens adolescentes em comparação com a dos jovens adultos sugere que está havendo uma elevação da escolaridade entre os jovens agricultores familiares no estado do Rio Grande do Sul. 
Tabela 26: Escolaridade dos entrevistados por faixa etária (em $f$ e \%)

\begin{tabular}{|c|c|c|c|c|c|c|}
\hline & & & \multicolumn{3}{|c|}{ FAIXA ETÁRIA: } & \multirow[b]{2}{*}{ Total } \\
\hline & & & $\begin{array}{l}\text { De } 15 \text { a } \\
19 \text { anos }\end{array}$ & $\begin{array}{l}\text { De } 20 \text { a } \\
24 \text { anos }\end{array}$ & $\begin{array}{l}\text { De } 25 \text { a } \\
29 \text { anos }\end{array}$ & \\
\hline \multirow{22}{*}{$\begin{array}{l}\text { QUAL A SUA } \\
\text { ESCOLARIDADE? }\end{array}$} & Não escolarizado & $f$ & 2 & 3 & 0 & 5 \\
\hline & & $\%$ &, $8 \%$ & $1,5 \%$ &, $0 \%$ &, $7 \%$ \\
\hline & Fundamental Incompleto & $f$ & 53 & 45 & 90 & 188 \\
\hline & & $\%$ & $21,2 \%$ & $22,2 \%$ & $39,5 \%$ & $27,6 \%$ \\
\hline & Fundamental Completo & $f$ & 31 & 34 & 39 & 104 \\
\hline & & $\%$ & $12,4 \%$ & $16,7 \%$ & $17,1 \%$ & $15,3 \%$ \\
\hline & Médio Incompleto & $f$ & 102 & 16 & 19 & 137 \\
\hline & & $\%$ & $40,8 \%$ & $7,9 \%$ & $8,3 \%$ & $20,1 \%$ \\
\hline & Médio Completo & $f$ & 45 & 84 & 68 & 197 \\
\hline & & $\%$ & $18,0 \%$ & $41,4 \%$ & $29,8 \%$ & $28,9 \%$ \\
\hline & Técnico Incompleto & $f$ & 2 & 0 & 1 & 3 \\
\hline & & $\%$ & ,8\% &, $0 \%$ &, $4 \%$ & ,4\% \\
\hline & Técnico Completo & $f$ & 3 & 3 & 1 & 7 \\
\hline & & $\%$ & $1,2 \%$ & $1,5 \%$ & ,4\% & $1,0 \%$ \\
\hline & Superior Incompleto & $f$ & 10 & 13 & 6 & 29 \\
\hline & & $\%$ & $4,0 \%$ & $6,4 \%$ & $2,6 \%$ & $4,3 \%$ \\
\hline & Superior Completo & $f$ & 1 & 2 & 4 & 7 \\
\hline & & $\%$ & ,4\% & $1,0 \%$ & $1,8 \%$ & $1,0 \%$ \\
\hline & Pós-Graduação & $f$ & 0 & 2 & 0 & 2 \\
\hline & & $\%$ &, $0 \%$ & $1,0 \%$ &, $0 \%$ & ,3\% \\
\hline & NS/NR & $f$ & 1 & 1 & 0 & 2 \\
\hline & & $\%$ & ,4\% &, $5 \%$ &, $0 \%$ & ,3\% \\
\hline \multirow[t]{2}{*}{ Total } & & $f$ & 250 & 203 & 228 & 681 \\
\hline & & $\%$ & $100,0 \%$ & $100,0 \%$ & $100,0 \%$ & $100,0 \%$ \\
\hline
\end{tabular}

Fonte: Banco de dados Jovens Agricultores Familiares RS - MDA/FAURGS, 2007.

Percebe-se que a faixa etária intervém na distribuição da escolaridade por sexo. É possível verificar no Gráfico 28 que, entre os jovens adolescentes de ambos os sexos, predomina a condição de ensino médio incompleto. As mulheres desta idade apresentam percentual de 47\%, enquanto os homens chegam a 37\%. Nos jovens, da faixa etária intermediaria destaca-se o nível de ensino médio completo. Sendo eles inclusive que apresentam escolaridades mais elevadas. Entre os jovens adultos, prevalece o ensino fundamental incompleto. Em todas as faixas de idade, as mulheres atingem graus de escolarização maiores do que os alcançados pelos homens. Destaca-se que cerca de 63\% das mulheres de 15 a 19 anos já romperam a barreira do ensino fundamental, enquanto que o mesmo percentual dos homens de 25 a 29 anos não ultrapassou este grau de instrução formal. 


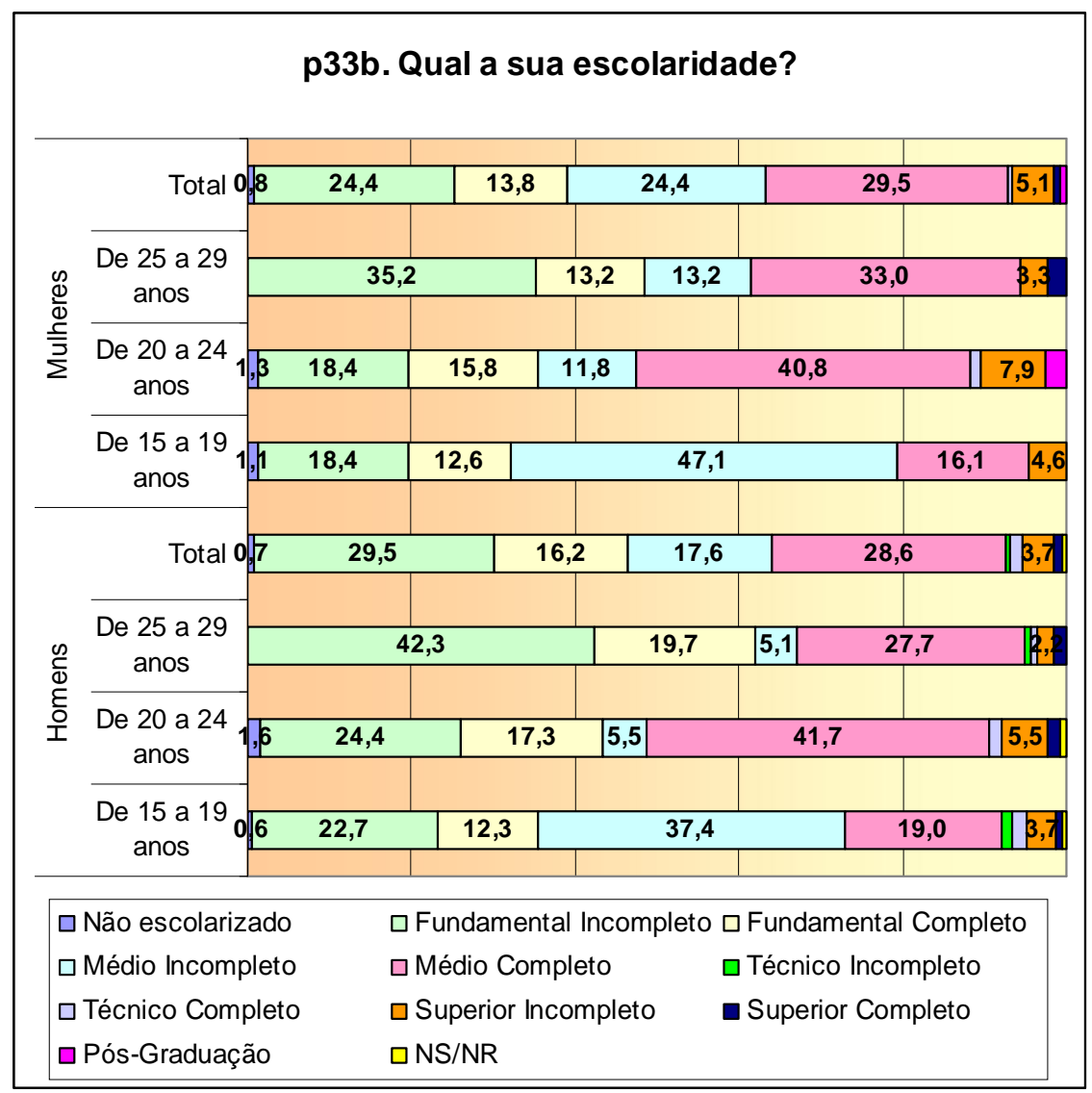

Gráfico 28: Escolarização dos entrevistados por sexo e faixas etárias (\%)

Fonte: Banco de Dados Jovens Agricultores Familiares RS - MDA/FAURGS, 2007.

Buscamos identificar a frequência ao sistema formal de ensino perguntando-lhes Você esta estudando atualmente? O resultado das informações indicam que $72 \%$ dos entrevistados estavam fora do sistema de ensino. Ou seja, para a grande maioria dos jovens agricultores familiares entrevistados a escola não fazia mais parte de seu cotidiano. (Gráfico 29).

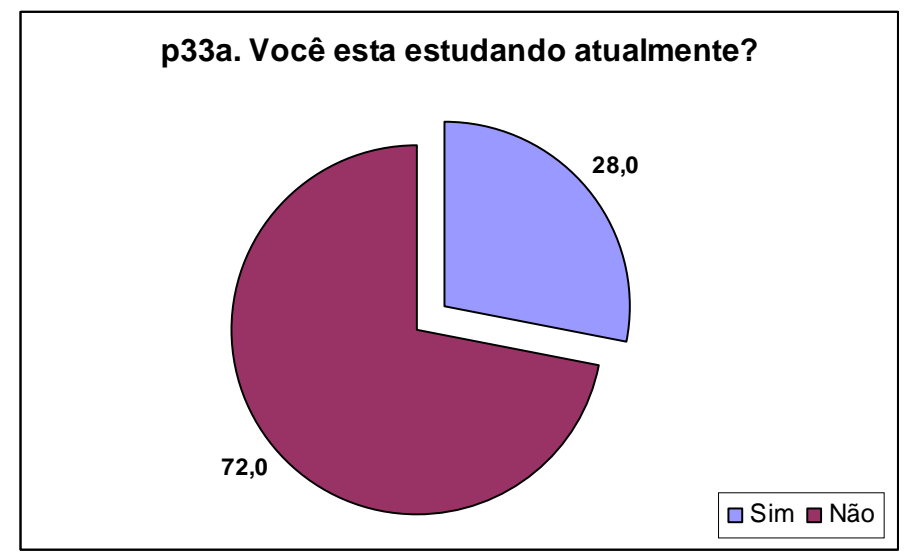

Gráfico 29: Entrevistados segundo situação de estudo (\%)

Fonte: Banco de Dados Jovens Agricultores Familiares RS - MDA/FAURGS, 2007. 
Cruzando a mesma questão pela variável sexo, observamos, na Tabela 27, um relativo equilíbrio em relação à situação de estudo. Não obstante, registra-se um percentual um pouco maior de homens fora da escola do que de mulheres.

Tabela 27: Situação de estudo por sexo (em $f$ e \%)

\begin{tabular}{|c|c|c|c|c|c|}
\hline & & & \multicolumn{2}{|c|}{ SEXO } & \multirow[b]{2}{*}{ Total } \\
\hline & & & Homens & Mulheres & \\
\hline \multirow{4}{*}{$\begin{array}{l}\text { VOCÊ ESTA ESTUDANDO } \\
\text { ATUALMENTE? }\end{array}$} & Sim & $f$ & 116 & 75 & 191 \\
\hline & & $\%$ & $27,2 \%$ & $29,5 \%$ & $28,0 \%$ \\
\hline & Não & $f$ & 311 & 179 & 490 \\
\hline & & $\%$ & $72,8 \%$ & $70,5 \%$ & $72,0 \%$ \\
\hline \multirow{2}{*}{\multicolumn{2}{|c|}{ Total }} & $f$ & 427 & 254 & 681 \\
\hline & & $\%$ & $100,0 \%$ & $100,0 \%$ & $100,0 \%$ \\
\hline $\begin{array}{l}\text { Banco de dac } \\
\text { MDA/FAURGS, }\end{array}$ & $\begin{array}{l}\text { ddos } \\
2007\end{array}$ & vens & Agricultores & Familiares & $\mathrm{RS}$ \\
\hline
\end{tabular}

Já a Tabela 28 demonstra que, na situação de estudo, vão se apresentar diferenças mais nítidas por idade dos entrevistados. Enquanto entre os jovens adolescentes predominam os que estavam estudando $(60,45)$, a frequência à escola vai diminuindo entre os jovens das idades seguintes e fica em $7 \%$ entre os jovens de 25 a 29 anos de idade.

Tabela 28: Condição de estudo dos entrevistados por faixa etária (em $f$ e \%)

\begin{tabular}{|c|c|c|c|c|c|}
\hline & & \multicolumn{3}{|c|}{ FAIXA ETÁRIA: } & \multirow[b]{2}{*}{ Total } \\
\hline & & $\begin{array}{l}\text { De } 15 \text { a } \\
19 \text { anos }\end{array}$ & $\begin{array}{l}\text { De } 20 \text { a } \\
24 \text { anos }\end{array}$ & $\begin{array}{l}\text { De } 25 \text { a } \\
29 \text { anos }\end{array}$ & \\
\hline \multirow{2}{*}{$\begin{array}{l}\text { VOCÊ ESTA ESTUDANDO Sim } \\
\text { ATUALMENTE? }\end{array}$} & $f$ & 151 & 24 & 16 & 191 \\
\hline & $\%$ & $60,4 \%$ & $11,8 \%$ & $7,0 \%$ & $28,0 \%$ \\
\hline Não & $f$ & 99 & 179 & 212 & 490 \\
\hline & $\%$ & $39,6 \%$ & $88,2 \%$ & $93,0 \%$ & $72,0 \%$ \\
\hline \multirow[t]{2}{*}{ Total } & $f$ & 250 & 203 & 228 & 681 \\
\hline & $\%$ & $100,0 \%$ & $100,0 \%$ & $100,0 \%$ & $100,0 \%$ \\
\hline
\end{tabular}

Fonte: Banco de dados Jovens Agricultores Familiares RS - MDA/FAURGS, 2007.

O Gráfico 30 ilustra a condição de estudos dos jovens por sexo e faixa etária. Primeiramente, demonstra-se que entre os jovens adolescentes, que são os que mais estavam estudando na rede de ensino formal, as mulheres apresentam uma participação de 65,5\%, superior a dos homens, que é de 57,7\%. Assim também ocorre na faixa dos jovens adultos, onde $11 \%$ delas afirmaram estar estudando, enquanto que, entre os homens da mesma faixa etária, 
apenas $4 \%$ estudam. A exceção no predomínio da participação de mulheres na escola formal fica por conta das jovens de 20 a 25 anos. Nesta faixa etária, há maior equilíbrio entre os percentuais registrados por sexo, com um percentual pouco maior para os homens. Destaca-se também que as diferenças de sexo e idade confirmam que as diferenças relativas à condição de estudo ficam mais acentuadas entre as jovens adolescentes e os jovens adultos.

Estes dados indicam uma tendência de ampliação do nível de escolaridade entre os jovens agricultores familiares no estado, uma vez que os jovens adolescentes apresentam escolaridades superiores às alcançadas por jovens adultos; o que representa um fator de mobilidade intrageracional no que diz respeito à elevação da escolaridade.

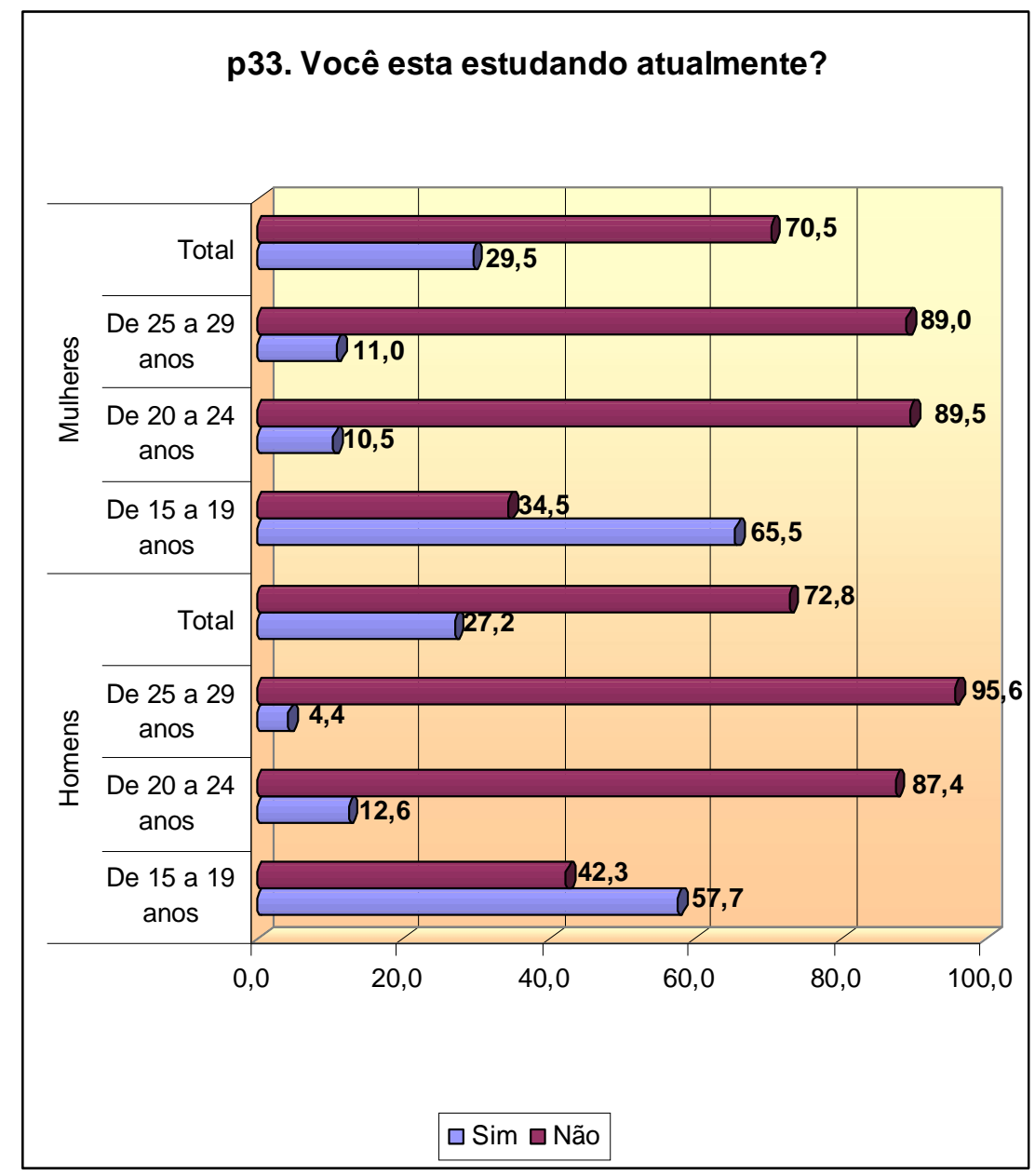

Gráfico 30: Condição de estudo dos entrevistados por sexo e faixa etária (\%) Fonte: Banco de Dados Jovens Agricultores Familiares RS - MDA/FAURGS, 2007. 
Cruzando-se as variáveis escolaridade e condição de estudo (Tabela 29), verificamos que entre os jovens que estão estudando $54,5 \%$ cursam o ensino médio; $17,8 \%$ estão no ensino fundamental e 14,1\% encontram-se no curso superior. Isto sugere a importância das relações entre escola e trabalho sob o ponto de vista dos jovens, visto que, mesmo estando inseridos em um processo produtivo que exige uma participação intensa nas tarefas realizadas na unidade de produção familiar, a maior parte dos entrevistados não deixam de dar continuidade aos seus estudos até que seja impossível conciliar estas duas atividades.

Tabela 29: Cruzamento entre escolaridade e condição de estudo (em $f$ e \%)

\begin{tabular}{|c|c|c|c|c|c|}
\hline & & & \multicolumn{2}{|c|}{$\begin{array}{c}\text { VOCÊ ESTA } \\
\text { ESTUDANDO } \\
\text { ATUALMENTE? }\end{array}$} & \multirow[b]{2}{*}{ Total } \\
\hline & & & Sim & Não & \\
\hline \multirow{22}{*}{$\begin{array}{l}\text { QUAL A SUA } \\
\text { ESCOLARIDADE? }\end{array}$} & Não escolarizado & $f$ & 0 & 5 & 5 \\
\hline & & $\%$ &, $0 \%$ & $1,0 \%$ &, $7 \%$ \\
\hline & Fundamental Incompleto & $f$ & 34 & 154 & 188 \\
\hline & & $\%$ & $17,8 \%$ & $31,4 \%$ & $27,6 \%$ \\
\hline & Fundamental Completo & $f$ & 11 & 93 & 104 \\
\hline & & $\%$ & $5,8 \%$ & $19,0 \%$ & $15,3 \%$ \\
\hline & Médio Incompleto & $f$ & 104 & 33 & 137 \\
\hline & & $\%$ & $54,5 \%$ & $6,7 \%$ & $20,1 \%$ \\
\hline & Médio Completo & $f$ & 12 & 185 & 197 \\
\hline & & $\%$ & $6,3 \%$ & $37,8 \%$ & $28,9 \%$ \\
\hline & Técnico Incompleto & $f$ & 1 & 2 & 3 \\
\hline & & $\%$ &, $5 \%$ &, $4 \%$ &, $4 \%$ \\
\hline & Técnico Completo & $f$ & 1 & 6 & 7 \\
\hline & & $\%$ &, $5 \%$ & $1,2 \%$ & $1,0 \%$ \\
\hline & Superior Incompleto & $f$ & 27 & 2 & 29 \\
\hline & & $\%$ & $14,1 \%$ &, $4 \%$ & $4,3 \%$ \\
\hline & Superior Completo & $f$ & 0 & 7 & 7 \\
\hline & & $\%$ &, $0 \%$ & $1,4 \%$ & $1,0 \%$ \\
\hline & Pós-Graduação & $f$ & 1 & 1 & 2 \\
\hline & & $\%$ &, $5 \%$ & ,2\% & ,3\% \\
\hline & NS/NR & $f$ & 0 & 2 & 2 \\
\hline & & $\%$ &, $0 \%$ &, $4 \%$ & ,3\% \\
\hline \multirow[t]{2}{*}{ Total } & & $f$ & 191 & 490 & 681 \\
\hline & & $\%$ & $100,0 \%$ & $100,0 \%$ & $100,0 \%$ \\
\hline
\end{tabular}

Fonte: Banco de dados Jovens Agricultores Familiares RS - MDA/FAURGS, 2007.

Por sua vez, entre os jovens que não estão estudando, 37,8\% concluíram o ensino médio e 31,4\% pararam os estudos antes de concluir o ensino fundamental. Este grupo de jovens que pararam de estudar sem concluir o ensino fundamental, apresentam, de certo modo, uma equivalência ao fenômeno identificado por Paul Wilis (1991) entre os jovens da classe operária 
inglesa onde ocorrera o predomínio de uma cultura antiescola e uma conversão ao trabalho manual. O estudo deste autor, embora tenha sido realizado em um contexto histórico e cultural muito deferente do que estamos analisando, guarda uma aproximação teórica por apresentar algumas pistas explicativas dos mecanismos de reprodução social entre as classes trabalhadoras. Esta aproximação está no fato de que, assim como os jovens da Escola de Hammertown, os jovens agricultores por nós entrevistados não identificam nos conteúdos escolares os recursos necessários ao trabalho que realizam ou pretendem realizar. Deste modo, em ambos os casos é possível identificar um certo comportamento desviante (WILIS, 1991) do que seria típico de um bom aluno. De modo oposto ao dos jovens ingleses que debochavam dos seus colegas, os jovens agricultores é que são frequentemente objetos de provocações e estigmas, recebendo um tratamento que desvaloriza a sua identidade social construída no universo do trabalho familiar e do grupo doméstico. Deste modo, a saída da escola e a dedicação prioritária ao trabalho podem ser compreendidas como um ato de desacato, não aos pais ou professores, mais ao que a escola representa em termos de desrespeito ao ethos de agricultor, que se assenta na austeridade e na ética do trabalho em oposição ao desfrute do lazer - neste caso um lazer escolástico (BOURDIEU, 2001). Com efeito, a recusa à socialização escolar pode nos remeter à compreensão de Weber a respeito do fenômeno da dominação que é assentada na "obediência" e não do poder de impor, ao outro, a própria vontade. É neste sentido que a recusa destes jovens à escola pode ser compreendido como uma desobediência à imposição de valores que lhes são estranhos.

As diferenças entre estas duas situações discutidas acima servem para chamar a atenção para as relações estabelecidas pelos jovens agricultores familiares entre educação escolar e trabalho familiar. A este respeito Sposito (2005, p. 106), afirma que "não se pode configurar nem uma adesão linear à escola ou um abandono ou exclusão total de aspirações de escolaridade no âmbito das orientações dos jovens que trabalham". Parafraseando esta autora, podemos dizer que, para os jovens agricultores, "escola e trabalho são projetos que se superpõem ou poderão sofrer ênfases diversas de acordo com o momento do ciclo de vida e as condições sociais que lhes permitem viver a condição juvenil" (SPOSITO, 2005, p. 106). Neste sentido, uma das questões que precisam ser analisadas diz respeito às possibilidades dos jovens agricultores equacionarem uma dupla inserção no trabalho agrícola e no estudo formal.

Conseguir conciliar trabalho e estudo é uma das principais dificuldades vividas pelos jovens agricultores. Como pode ser visto no Gráfico 31, a condição de estudo é fortemente determinada pela jornada de trabalho na agricultura. A maioria dos jovens que estudam (57\%) 
são justamente os que têm jornada de trabalho de até quatro horas, seguido dos que têm jornadas de quatro a seis horas; desses, $54 \%$ estudam. A partir deste ponto, o percentual de estudantes cai, significativamente, para 35,2\% entre os que cumprem jornadas de seis a oito horas, diminuindo até atingir $11,7 \%$ entre os jovens que cumprem jornadas de trabalho superiores a dez horas diárias. A frequência à escola diminui na medida em que aumenta o tempo dedicado ao trabalho familiar agrícola, de tal modo que as longas jornadas diárias de trabalho que caracterizam a situação destes jovens apresentam-se como um obstáculo à ampliação de sua escolarização formal.

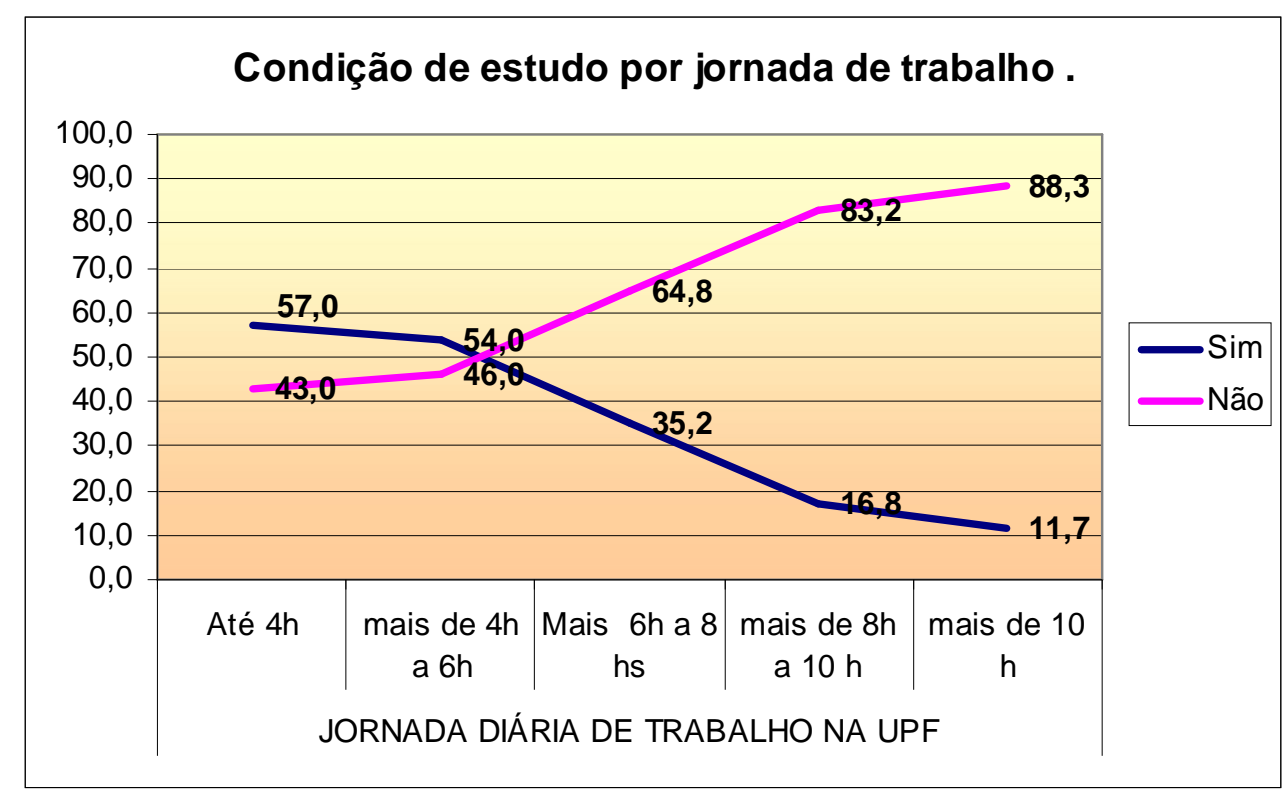

Gráfico 31: Cruzamento entre condição de estudo por jornada de trabalho na UPF (\%) Fonte: Banco de Dados Jovens Agricultores Familiares RS - MDA/FAURGS, 2007.

Diferente de outras situações juvenis, entre a atual geração de jovens agricultores familiares não predomina a socialização via sistema formal de ensino; sim a socialização profissional realizada no âmbito do trabalho familiar. Neste sentido, sob o ponto de vista da promoção da escolarização formal destes jovens, e abstraindo-se as deficiências do próprio sistema de ensino, o entrave para continuidade de seus estudos reside no fato de que, com o aumento da idade, aumentam também as responsabilidades sobre as tarefas da unidade produtiva, como comprova a expansão do número de horas de trabalho. A equação deste impasse tem sido a interrupção dos estudos, se possível logo que se completa um ciclo de formação, acontecendo muitas vezes antes. Isto ocorre porque a demanda pela força de trabalho dos jovens é imprescindível para a reprodução da família no ciclo curto e o tempo da escola formal é 
inflexível. Além disto, para muitos entrevistados o ensino formal aparece como dispensável para sua atuação como agricultor. O que nos leva a fazer referência à pluralidade de opiniões dos jovens sobre a importância do conhecimento escolar.

Os jovens agricultores manifestam opiniões frequentemente ambíguas sobre a escola. Se, de um lado, esta aparece como um espaço de aprendizado, de convivência com outros jovens e de possibilidades de interação que isto propicia; por outro, ela se coloca como um ambiente hostil à instituição de valores gerados a partir da socialização realizada nas práticas da unidade de produção familiar, produzindo estranhamento e desconforto social. Outros, ainda, atribuírem importância ao conhecimento escolar, mas considera-no insuficiente para garantir sua inserção no mercado de trabalho. Com efeito, os próprios resultados da escolarização são, frequentemente, questionados pelos entrevistados. Eles atribuem sentidos à socialização escolar que não se limitam aos pretendidos pela lógica da inserção produtiva.

No Gráfico 32, registra-se o tipo de importância atribuída pelos entrevistados ao conhecimento adquirido na escola. Nele é avaliada uma série de sete questões de interesse da pesquisa e que foram obtidas a partir da redução de respostas a questões abertas realizadas na etapa preparatória do campo. Observa-se que os jovens vão, principalmente, avaliar que este é muito importante para fazer amigos $(77,7 \%)$; para ser valorizado pelos pais $(72,8 \%)$ e para ser valorizado pela sociedade $(72,1 \%)$. Revela-se que, do ponto de vista juvenil, a escola adquire outros sentidos além do da educação. Para eles, esta aparece como um espaço social que possibilita o convívio com pares; ainda no âmbito das interações, eles percebem, neste conhecimento, um meio de obter reconhecimento social na família e na comunidade mais ampla. No que diz respeito à inserção profissional, 48,5\% deles consideram o conhecimento escolar muito importante para conseguir um emprego fora da agricultura. Enquanto que apenas 26\% avaliam que ele é muito importante para serem agricultores, outros $29,8 \%$ avaliam que este é mais ou menos importante; outros 29,2\% afirmam que é pouco importante. Isto indica que, na percepção dos jovens, os conhecimentos necessários para o trabalho agrícola não estão contemplados naquilo que é ofertado na escola. O conhecimento adquirido na escola é considerado por 48,3\% muito importante para entender a realidade econômica e social do país. Ele ainda é considerado por 39,5\% dos entrevistados como muito importante para conseguir namorado(a). Isto remete às questões anteriormente mencionadas no que se refere à importância do espaço escolar na interação juvenil. 


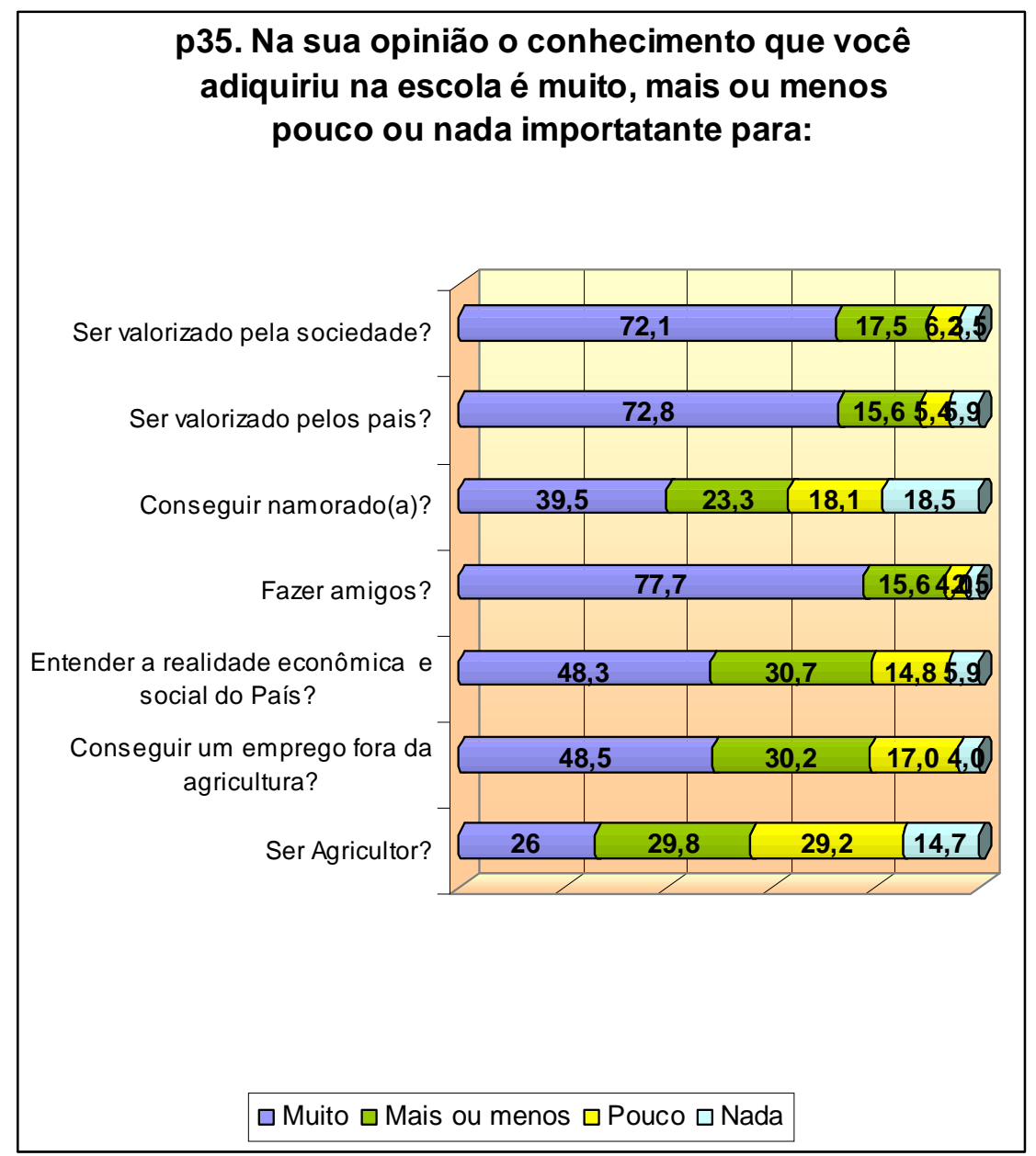

Gráfico 32: Opinião sobre a importância do conhecimento escolar (\%)

Fonte: Banco de Dados Jovens Agricultores Familiares RS - MDA/FAURGS, 2007.

$\mathrm{Na}$ perspectiva dos jovens, o conhecimento adquirido em sala de aula dota-os, prioritariamente, de prestígio social, seja no âmbito de seu grupo de pares, da família ou da sociedade com um todo. De modo geral, pode-se dizer que o conhecimento escolar opera como um capital cultural bem cotado porque permite mobilidade social ascendente. Neste sentido, um maior investimento em escolarização por parte das jovens mulheres representa um esforço de toda a família visando à sua reconversão profissional fora da agricultura familiar, como uma estratégia de ascensão social. A este respeito, Durston (1997) resume bem a situação em que se encontram as jovens agricultoras.

Para la mujer rural joven, al igual que la migración, la educación formal toma nuevo significado libertador. Pero para ser "algo más" que una ama de casa campesina, no basta com migrar, porque sin educación la migrante está condenada a una condición de ninguna manera superior: la de sirviente doméstica. Como lo expresa Madeira (1985, p.167) para el caso brasileño, opera fuertemente "la ideologia del ascenso social por la vía de la escolaridad". La escuela, por lo demás, “ofrece status y 
posibilidades de sociabilidaes inmediatas de pertencer a una cultura joven" (MADEIRA, 1985). Este último valor de la escuela es subrayado también por Valdés para Chile (1985:284): la escuela es el único medio permetido para la mujer joven de estar incluida en la sociedad, de participar en su comunidad (DURSTON, 1997, p. 25).

Conforme os entrevistados, o principal incentivo à escolarização vem dos seus pais. Isto porque, para alguns agricultores, principalmente para aqueles com maiores dificuldades financeiras, o estudo é pensado como estratégia de ressocialização dos filhos e, principalmente, das filhas, para seu futuro engajamento como força de trabalho assalariada no meio urbano (TEDESCO, 1999). Particularmente entre as jovens mulheres, estudar passa a ser uma obrigação moral tão importante, ou por vezes até maior que a participação no trabalho familiar, fazendo com que estas se restrinjam muitas vezes às tarefas domésticas. Isto se reflete na opinião dos informantes.

Este conjunto de informações revela que as diferenças na socialização dos jovens agricultores familiares - a partir das condições de estudo e na escolaridade dos jovens reforçam os papeis sociais que vão sendo assumidos segundo a condição de gênero e idades. Constata-se a tendência de uma escolarização mais elevada entre as mulheres, que conta com o incentivo entusiasmado de seus pais, visando à garantia de uma melhor colocação profissional no mercado de trabalho não-agrícola. O que se deve, como revelam outros estudos, ${ }^{70}$ às dinâmicas sucessórias que tradicionalmente excluem as mulheres da herança da terra e da sucessão hereditária do patrimônio familiar. Na medida em que as idades avançam, predominando a condição de trabalho na agricultura familiar, verifica-se uma posição de distanciamento entre os conhecimentos que os jovens consideram necessários para o desenvolvimento do trabalho, de suas práticas produtivas e o conteúdo do conhecimento escolar. Intensificado pela pouca oferta de educação técnica voltada para a agricultura familiar, o processo de educação formal revela-se distante das tarefas cotidianas dos jovens agricultores, e, não raramente, se opõe aos valores da família e da racionalidade do trabalho familiar agrícola. Assim, na perspectiva dos jovens agricultores, a socialização escolar adquire outros sentidos que não se restringem à inserção no mercado de trabalho urbano, antes é percebida como espaço de interação que permite a produção de uma identidade juvenil e também como espaço de construção de reconhecimento social, expresso em termos como ser valorizado ou ser alguém na vida como dizem.

\footnotetext{
70 MOURA 1978, SEIFERTH, 1979; CHAMPAGNE, 1986, WOORTMANN, 1995; ABRAMOVAY1998; CARNEIRO,1998, ABRAMOVAY, 1998; CARNEIRO; SILVESTRO, 2001; SPANAVELO, 2008.
} 


\subsection{ASPECTOS DA SOCIABILIDADE JUVENIL: AS PRÁTICAS DE LAZER DOS JOVENS AGRICULTORES FAMILIARES}

Neste tópico, propomo-nos uma aproximação em relação às formas de sociabilidade juvenil vividas pelos agricultores familiares entrevistados, focando-nos nos tipos de ocupação do "tempo livre" através da realização de atividades de lazer. Isto é pertinente visto que as interações nestes espaços, além de ser uma expressão da cultura juvenil, contribuem para a construção de processos de autoidentificação, sendo entendida como uma dimensão da situação juvenil que caracteriza os jovens agricultores entrevistados.

O debate sobre as formas de sociabilidade tem, na sociologia formal de Georg Simmel (2006), sua principal referência. Para este autor, a sociedade é algo que os indivíduos fazem e sofrem. "Essa interação surge sempre a partir de determinados impulsos ou da busca de certas finalidades" (SIMMEL, 2006: 59). São os laços de associação feitos, desfeitos e refeitos de maneira fluídica que compõem a sociação, esta entendida como uma forma pura de interação e não como "associação". Simmel irá definir como conteúdo e matéria da sociação:

[...] tudo o que existe nos indivíduos e nos lugares concretos de toda a realidade histórica como impulso, interesse, finalidade, tendência, condicionamento psíquico e movimento nos indivíduos - todo o que está presente nele de modo a engendrar ou mediatizar os efeitos sobre os outros ou receber esses efeitos dos outros (SIMMEL, 2006, p. 60).

Deste modo, no processo de sociação combinam-se deferentes maneiras de agir em função dos interesses que motivam os indivíduos. Complementando o conceito de sociação surge o de sociabilidade; definido como "a forma lúdica de sociação" (SIMMEL, 2006, p. 65). Deste modo, podemos entender por sociabilidade as formas de interação "livre de todos os conteúdos materiais". Com efeito, ela está além das realidades objetivas da vida real enfatizando, assim, muito mais os aspectos da forma do que dos conteúdos, visto que não está atrelada e condicionada a motivações concretas.

Como forma lúdica, a sociabilidade traduz as forças e conteúdos da sociedade concreta, dos quais nosso autor de referência destaca o fato de que os indivíduos tenham que se adequar a um contexto comum de modo que possam viver em conformidade com o interesse coletivo, assim como os valores e aspectos relevantes devem refluir para o indivíduo a partir deste contexto. A isto correspondem os processos socializadores, de modo que Simmel irá apresentar uma distinção entre os dois conceitos afirmando que: 
[...] a tarefa ética da socialização é fazer com que a junção e a separação dos indivíduos que interagem achem a expressão das relações entre estes indivíduos, embora essas relações sejam espontaneamente determinadas pela vida em sua totalidade, então na sociabilidade, a liberdade para formar relações e a adequação de outra expressão não obedecem a qualquer condicionamento concreto e de conteúdo mais profundo (SIMMEL, 2006, p. 79) [grifos nosso].

Segundo a proposta deste autor, a socialização corresponde a um processo de interação entre indivíduos com propósitos concretos: de conversão das ações a certos conteúdos previamente definidos e que balizam as relações a fim de permitir a internalização destes mesmos conteúdos tornado - os indivíduos - seres sociais, ou seja, adequados a um contexto comum e a viver para ele. $\mathrm{O}$ sentido ético da sociabilidade corresponde à produção de um efeito similar ao descrito - produzir indivíduos sociais - através das interações espontâneas em espaços de autonomia e liberdade. O que nos permite deduzir a sociabilidade como uma forma livre, autônoma e lúdica de socialização. Com efeito:

Toda sociabilidade é um símbolo da vida quando esta surge no fluxo de um jogo prazeroso e fácil. Porém, é justamente um símbolo da vida cuja imagem se modifica até o ponto em que a distância em relação à vida o exige. Da mesma maneira, para não se mostrar vazia e mentirosa, a arte mais livre, fantástica e distante da cópia de qualquer realidade se nutre de uma relação profunda e fiel com a realidade (SIMMEL, 2006, p. 80).

A sociabilidade vem a ser o espaço onde a interação sai dos meandros convencionais e entra no âmbito do jogo, da brincadeira, do prazer e da diversão, como são as atividades de lazer, mas que se nutre da própria realidade e a expressa Com efeito, o lazer pode ser considerado como tempo sociológico no qual a liberdade de escolha é elemento preponderante e que se constitui para os jovens enquanto campo potencial de construção de identidades, descoberta de potencialidades humanas e exercício de inserção efetiva nas relações sociais. Contudo, é importante lembrar que a autonomia dos sujeitos sociais nos tempos e espaços de lazer encontra a sua relatividade no modo como esses se inserem na esfera produtiva, estabelecem suas relações culturais e também na forma como experimentam a liberdade de ação em determinado contexto social comunitário. Além disto, a própria base material da existência é um dos limites mais fortes da inserção diferenciada no mundo do lazer (BRENNER; DAYRELL; CARRANO, 2005).

A investigação sobre a dinâmica da ocupação do tempo livre dos jovens como forma de sociabilidade é de extrema importância para se compreender os sentidos do próprio tempo das 
juventudes nas sociedades, conforme apontam Brenner, Dayrell e Carrano (2005). De acordo com estes autores, a realidade efetiva dos aspectos que organizam a vida dos jovens nas culturas vividas no lazer e no tempo livre se expressa, em grande medida, através da dinâmica sociocultural da vida juvenil. A pesquisa junto aos jovens agricultores familiares no Rio Grande do Sul, cujos dados serão apresentados a seguir, ao se aproximar da realidade concreta deste segmento juvenil, busca ampliar a percepção da existência de condições distintas de vivência do tempo da juventude descortinando a singularidade desta situação juvenil.

Considerando que os entrevistados estão sujeitos à confluência de vários processos socializadores que não se restringem ao âmbito da família, do trabalho e da escola, buscou-se identificar quais atividades de lazer eles realizam e com qual frequência usufruem delas. Isto se torna importante na medida em que se reconhece que estas experiências culturais coletivas, nas quais eles se inserem, se constituem em referência importante no seu processo de identificação (DUBAR, 2005). A convivência em grupos possibilita a criação de confiança recíproca, deste modo, constitui-se num aprendizado de práticas sociais que servem de referência na construção de suas identidades. Particularmente, as "atividades de lazer criam uma certa consciência de liberdade ao permitir uma fuga temporária à rotina cotidiana de trabalho e obrigações sociais" (BRENNER; DAYRELL; CARRANO, 2005, p. 177). Deste modo, o lazer aparece como um importante elemento na construção das identidades juvenis, uma vez que "no espaço-tempo de lazer os jovens consolidam relacionamentos, sentidos estéticos e processo de identificação cultural”. (BRENNER; DAYRELL; CARRANO, 2005, p. 177).

Para identificamos as atividades de lazer que os jovens realizam e a frequência com que isso ocorre, citamos um conjunto de atividades de lazer e pedimos aos entrevistados que nos informassem se a realizaram, conforme as seguintes categorias de resposta: 1) nos últimos 30 dias; 2) nos último 12 meses; 3) alguma vez na vida; ou 4) nunca fez.

As respostas a estas questões encontram-se organizadas no Gráfico 33 As quatro atividades de lazer mais praticadas por jovens agricultores nos últimos 30 dias são: ir a igreja $(72,2 \%)$, esportes coletivos $(67,7 \%)$, ir a lanchonetes e sorveteria $(55,1 \%)$ e dançar em bailes ou danceteria $(52,6 \%)$. As três mais frequentes no período dos últimos 12 meses são: festa ou quermesse na comunidade (51\%), festas em casa de amigos $(34,5 \%)$ e show musical $(32,2 \%)$.

É importante ressaltar que estas atividades envolvem pouco deslocamento dos entrevistados, no máximo até a sede dos municípios em que vivem. Dentre as que foram praticadas alguma vez na vida por eles, destacam-se ir ao shopping center (31,3\%), viajar no fim de semana $(30,7 \%)$ e ir a praia de mar $(30,1 \%)$. Quando se trata de atividades que nunca foram 
realizadas, predominam as alternativas: ir ao cinema (63\%), ao estádio de futebol $(57,9 \%)$ e à praia de mar $(50,2 \%)$. As opções de lazer raramente ou nunca realizadas implicam deslocamento dos jovens das cidades em que residem. Desta maneira, as formas de diversão dos jovens são, geralmente, aquelas que lhes são mais acessíveis em termos de distâncias e custos requeridos.

Quando considerado o sexo dos entrevistados (Tabela 30), constata-se que os homens apresentam percentuais superiores aos das mulheres nas atividades de lazer realizadas nos últimos trinta dias. A maior diferença de percentuais entre eles está na prática de esportes coletivos. Constituem exceções a este predomínio masculino ir a igreja e dançar em bailes ou danceterias, pois existem práticas de diversão nas quais os percentuais das jovens superam o dos homens (ir a lanchonetes e sorveteria; à praia de água doce; ao cinema e praticar esportes coletivos) e outros em que se verifica um equilíbrio (festa em casa de amigos e passear em parques e praças). No que tange às atividades realizadas alguma vez na vida, destacam-se os percentuais das mulheres que já foram ao shopping (39\%) e o dos homens que foram ao estádio de futebol $(31,4 \%)$. Quando se trata das que nunca foram feitas, ir ao cinema é a opção mais indicada por jovens de ambos os sexos. 


\section{p44. Vou citar algumas atividades de lazer e você responde quando realizou pela ultima vez .}

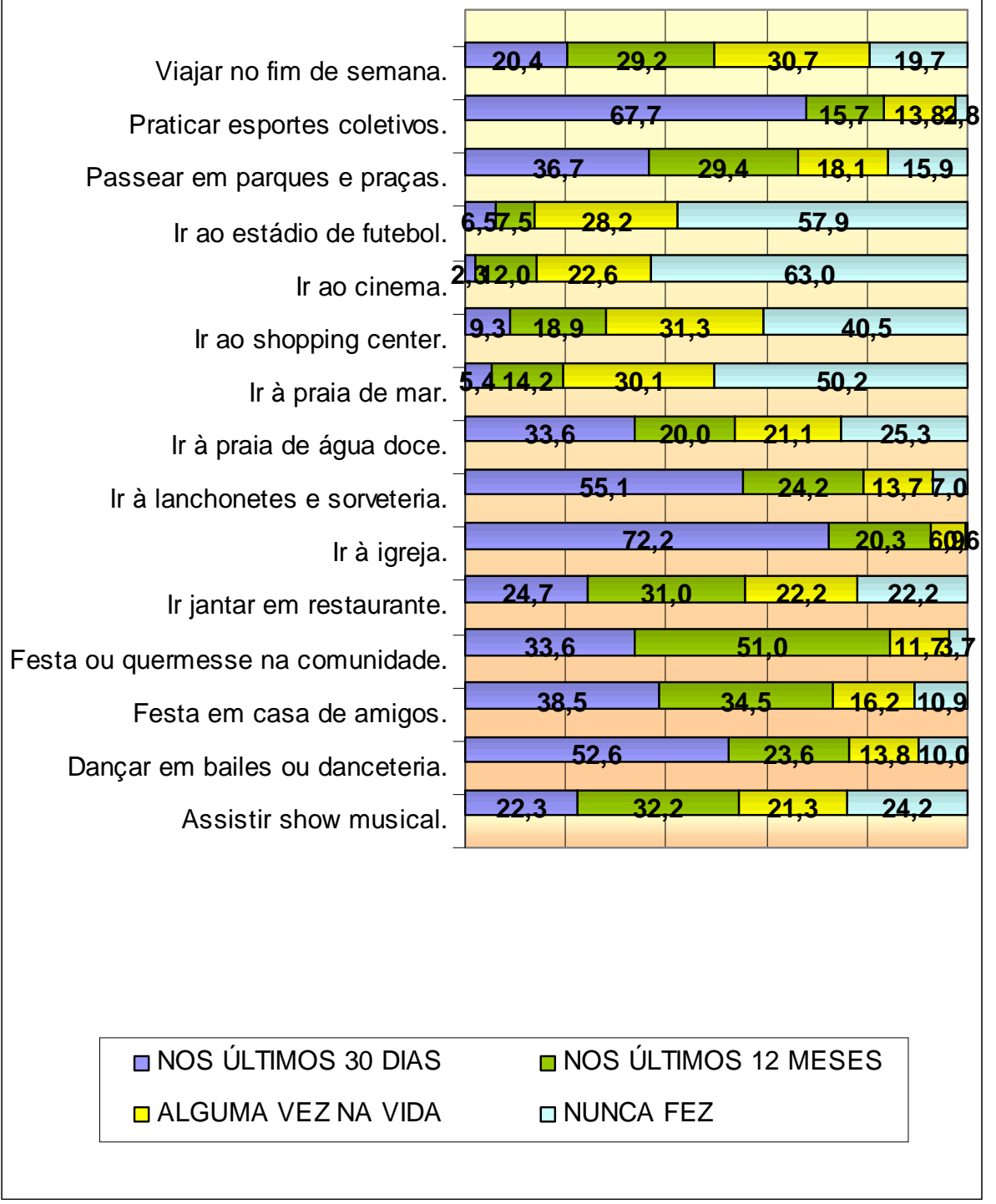

Gráfico 33: Frequência em atividades de lazer, cultura e passeios (\%)

Fonte: Banco de Dados Jovens Agricultores Familiares RS - MDA/FAURGS, 2007. 
Tabela 30: Frequência a atividades de lazer, cultura e passeios (\%)

\begin{tabular}{|c|c|c|c|c|c|c|}
\hline & & $\begin{array}{l}\text { Nos últimos } \\
30 \text { dias }\end{array}$ & $\begin{array}{l}\text { Nos últimos } \\
12 \text { meses }\end{array}$ & $\begin{array}{l}\text { Alguma vez } \\
\text { na vida }\end{array}$ & Nunca fez & Total \\
\hline \multirow{3}{*}{$\begin{array}{l}\text { Assistir show } \\
\text { musical. }\end{array}$} & Homens & 26,2 & 34,0 & 18,3 & 21,5 & 100,0 \\
\hline & Mulheres & 15,7 & 29,1 & 26,4 & 28,7 & 100,0 \\
\hline & Total & 22,3 & 32,2 & 21,3 & 24,2 & 100,0 \\
\hline \multirow{3}{*}{$\begin{array}{l}\text { Dançar em bailes ou } \\
\text { danceteria. }\end{array}$} & Homens & 51,5 & 26,0 & 11,5 & 11,0 & 100,0 \\
\hline & Mulheres & 54,3 & 19,7 & 17,7 & 8,3 & 100,0 \\
\hline & Total & 52,6 & 23,6 & 13,8 & 10,0 & 100,0 \\
\hline \multirow{3}{*}{$\begin{array}{l}\text { Festa em casa de } \\
\text { amigos. }\end{array}$} & Homens & 41,0 & 34,7 & 14,8 & 9,6 & 100,0 \\
\hline & Mulheres & 34,3 & 34,3 & 18,5 & 13,0 & 100,0 \\
\hline & Total & 38,5 & 34,5 & 16,2 & 10,9 & 100,0 \\
\hline \multirow{3}{*}{$\begin{array}{l}\text { Festa ou quermesse } \\
\text { na comunidade. }\end{array}$} & Homens & 35,4 & 49,9 & 11,9 & 2,8 & 100,0 \\
\hline & Mulheres & 30,7 & 52,8 & 11,4 & 5,1 & 100,0 \\
\hline & Total & 33,6 & 51,0 & 11,7 & 3,7 & 100,0 \\
\hline \multirow{3}{*}{$\begin{array}{l}\text { Ir jantar em } \\
\text { restaurante, pizzaria, } \\
\text { churrascaria, etc... }\end{array}$} & Homens & 26,7 & 34,0 & 20,4 & 19,0 & 100,0 \\
\hline & Mulheres & 21,3 & 26,0 & 25,2 & 27,6 & 100,0 \\
\hline & Total & 24,7 & 31,0 & 22,2 & 22,2 & 100,0 \\
\hline \multirow[t]{3}{*}{ Ir a igreja. } & Homens & 69,3 & 22,5 & 8,0 & 0,2 & 100,0 \\
\hline & Mulheres & 77,2 & 16,5 & 5,1 & 1,2 & 100,0 \\
\hline & Total & $\overline{72,2}$ & 20,3 & 6,9 & 0,6 & 100,0 \\
\hline \multirow{3}{*}{$\begin{array}{l}\text { Ir a lanchonetes e } \\
\text { sorveteria. }\end{array}$} & Homens & 57,1 & 23,2 & 12,9 & 6,8 & 100,0 \\
\hline & Mulheres & 51,6 & 26,0 & 15,0 & 7,5 & 100,0 \\
\hline & Total & 55,1 & 24,2 & 13,7 & 7,0 & 100,0 \\
\hline \multirow{3}{*}{$\begin{array}{l}\text { Ir a praia de água } \\
\text { doce. }\end{array}$} & Homens & 38,9 & 19,0 & 20,6 & 21,5 & 100,0 \\
\hline & Mulheres & 24,8 & 21,7 & 22,0 & 31,5 & 100,0 \\
\hline & Total & 33,6 & $\overline{20,0}$ & 21,1 & 25,3 & 100,0 \\
\hline \multirow[t]{3}{*}{ Ir a praia de mar. } & Homens & 6,1 & 15,5 & 28,6 & 49,9 & 100,0 \\
\hline & Mulheres & 4,3 & 12,2 & 32,7 & 50,8 & 100,0 \\
\hline & Total & 5,4 & 14,2 & 30,1 & 50,2 & 100,0 \\
\hline \multirow{3}{*}{$\begin{array}{l}\text { Ir ao } \\
\text { Shopping center. }\end{array}$} & Homens & 11,0 & 20,8 & 26,7 & 41,5 & 100,0 \\
\hline & Mulheres & 6,3 & 15,7 & 39,0 & 39,0 & 100,0 \\
\hline & Total & 9,3 & 18,9 & 31,3 & 40,5 & 100,0 \\
\hline \multirow[t]{3}{*}{ Ir ao cinema. } & Homens & 2,8 & 11,7 & 23,0 & 62,5 & 100,0 \\
\hline & Mulheres & 1,6 & 12,6 & 22,0 & 63,8 & 100,0 \\
\hline & Total & 2,3 & $\begin{array}{l}12,0 \\
\end{array}$ & 22,6 & 63,0 & 100,0 \\
\hline \multirow{3}{*}{$\begin{array}{l}\text { Ir ao estádio de } \\
\text { futebol }\end{array}$} & Homens & 8,0 & 10,1 & 31,4 & 50,6 & 100,0 \\
\hline & Mulheres & 3,9 & 3,1 & 22,8 & 70,1 & 100,0 \\
\hline & Total & 6,5 & 7,5 & 28,2 & 57,9 & 100,0 \\
\hline \multirow{3}{*}{$\begin{array}{l}\text { Passear em parques e } \\
\text { praças. }\end{array}$} & Homens & 40,0 & 29,5 & 16,9 & 13,6 & 100,0 \\
\hline & Mulheres & 31,1 & 29,1 & 20,1 & 19,7 & 100,0 \\
\hline & Total & 36,7 & 29,4 & 18,1 & 15,9 & 100,0 \\
\hline \multirow{3}{*}{$\begin{array}{l}\text { Praticar esportes } \\
\text { coletivos. }\end{array}$} & Homens & 67,7 & 15,7 & 13,8 & 2,8 & 100,0 \\
\hline & Mulheres & 29,5 & 18,5 & 35,8 & 16,1 & 100,0 \\
\hline & Total & 53,5 & 16,7 & 22,0 & 7,8 & 100,0 \\
\hline \multirow{3}{*}{$\begin{array}{l}\text { Viajar no fim de } \\
\text { semana. }\end{array}$} & Homens & 22,7 & 31,9 & 27,9 & 17,6 & 100 \\
\hline & Mulheres & 16,5 & 24,8 & 35,4 & 23,2 & 100,0 \\
\hline & Total & 20,4 & 29,2 & 30,7 & 19,7 & 100,0 \\
\hline
\end{tabular}

Fonte: Banco de Dados Jovens Agricultores Familiares RS - MDA/FAURGS, 2007. 
A baixa taxa de participação em atividades culturais como cinema está, principalmente relacionado a problemas de infra-estrutura cultural dos municípios onde residem os entrevistados. Conforme apontam Brenner, Dayrell e Carrano (2005) com base em levantamento do IBGE sobre a distribuição de equipamentos culturais, segundo o tamanho do município, constata-se que, quanto menor o município, menos frequentes são a existência de equipamentos culturais.

Os dados levantados em campo e apresentados acima revelam que são restritas as práticas de lazer dos jovens agricultores familiares. Num quadro como este, de precário acesso a equipamentos culturais e esportivos, o lazer dos jovens - que já é restrito pelo tempo dedicado ao trabalho - fica bastante limitado. Isto faz com que as formas de sociabilidade juvenil ocorram, principalmente, nos espaços de convívio da comunidade, onde se destacam a frequência à igreja, à prática esportiva limitada ao futebol, e o encontro em bares e lanchonetes, geralmente nas mediações centrais do município ou distrito. A pesquisa revela que as desigualdades no acesso a este tipo de lazer, suas formas e intensidade, são marcantes quando considerada a variável sexo do entrevistado. Ou seja, há um viés de gênero na configuração das práticas de lazer entre os jovens estudados, de modo que podemos dizer que se o lazer dos homens é restrito, o das jovens mulheres é ainda mais. Deste modo, enquanto entre as juventudes das regiões metropolitanas a preocupação é o que fazer com o tempo livre para que elas tenham práticas de "sociabilidade sadia", entre os jovens agricultores familiares a problemática assume outro contorno: como fazer com que eles tenham tempo livre para experimentar práticas de sociabilidade juvenil, ou ainda, como reverter a precariedade das práticas de lazer.

\subsection{JOVENS AGRICULTORES FAMILIARES: PREDOMÍNIO DA SOCIALIZAÇÃO NO TRABALHO FAMILIAR}

Ao analisar o processo de socialização e de sociabilidade dos jovens agricultores, mostramos sua participação no processo de trabalho familiar agrícola, sua inserção no sistema de educação formal e em atividades de lazer. Ficou evidenciada a intensa participação dos entrevistados no trabalho familiar, o que se converte na principal característica desta juventude. A este respeito, destaca-se não só o predomínio de casos em que há dedicação em tempo integral a esta atividade, como também se constatou uma elevada jornada de trabalho que, na maioria dos 
casos, ultrapassa dez horas diárias. Registramos um maior envolvimento de homens, principalmente dos jovens com mais de 20 anos de idade nas jornadas de trabalho mais extensas.

A participação no processo de trabalho familiar agrícola aparece como o principal dispositivo de socialização dos jovens agricultores, o que permitirá a interiorização de uma ética do trabalho e todo um conjunto de disposições que servirão de referência à construção de suas identidades sociais e de seus projetos profissionais. Os jovens agricultores trabalham como força plena, mas não são reconhecidos como agricultores plenos, permanecendo em uma posição de subalternos aos seus pais.

Para além de sua aparente unidade, o processo de trabalho familiar agrícola se realiza por meio de uma divisão interna de tarefas e responsabilidades que se estruturam através das diferenças de sexo e idade, que demarcam os papeis sociais e revelam as posições hierárquicas ocupadas no interior do grupo doméstico. As tarefas administrativas, relacionadas à tomada de decisões no empreendimento agrícola, são, predominantemente, efetuadas pelo pai, que detém os saberes do processo produtivo em sua totalidade, o que lhe confere uma posição superior na hierarquia familiar. As tarefas domésticas são realizadas pelas mulheres e pelas jovens agricultoras enquanto entre os homens predominam as atribuições de aplicar veneno ou defensivos, preparar o solo para o plantio, tratar os animais e limpar chiqueiros ou estábulos. Entretanto, muitas tarefas são descritas como realizadas por toda a família, o que ocorre no plantio, capina e colheita. São destas atividades agrícolas que as jovens mais participam; pelo fato de serem, geralmente, realizadas por toda a família, o envolvimento delas é percebido como ajuda, ficando sem reconhecimento e visibilidade, conferindo-lhes posição de subalternidade na hierarquia familiar.

Quanto à inserção no sistema de ensino formal, pode ser identificado que os jovens agricultores possuem escolaridade relativa ao ensino médio incompleto. Considerada a distribuição da escolaridade, o maior percentual de jovens tem o ensino médio completo; o segundo grupo é formado por jovens com ensino fundamental incompleto. A maioria dos jovens agricultores não está estudando atualmente, mas, grande parte concluiu o ensino médio. Entre os que se encontravam estudando no período da pesquisa, predominam os jovens adolescentes. A maioria encontrava-se cursando o ensino médio, seguido do fundamental e do superior. Tal situação indica um crescimento do nível de escolarização entre os jovens agricultores, uma vez que os jovens adolescentes apresentam escolaridades mais elevadas do que a dos jovens adultos. Ressalta-se ainda que os jovens tendem a deixar de estudar na medida em que aumenta sua jornada de trabalho na agricultura. Deste modo, embora reconheçam a importância da 
escolarização, eles consideram que esta é mais importante para fazer amigos, ser valorizado pelos pais, pela sociedade e para conseguir um emprego não-agrícola, do que para ser agricultor.

Verificamos ainda que são restritas as atividades de lazer, cultura e passeio dos jovens agricultores familiares. Entre as práticas mais frequentes está ir à Igreja, praticar esportes coletivos (essencialmente futebol), ou frequentar bailes: aquelas que demandam pouco deslocamento e baixo custo financeiro. Com base na análise das variáveis apresentadas neste capítulo, pode-se concluir que a situação juvenil na agricultura familiar é determinada pelo envolvimento no processo de trabalho familiar agrícola, sendo este fator o que marca, diferencialmente, a categoria dos jovens agricultores familiares. No próximo capítulo, discute-se o conjunto de representações sociais que os jovens passam a compartilhar a partir desta socialização no trabalho agrícola. 


\section{AS REPRESENTAÇÕES SOCIAIS DOS JOVENS AGRICULTORES FAMILIARES}

Neste capítulo, são analisadas as representações sociais dos jovens sobre o trabalho agrícola, o modo de vida dos seus pais e suas identidades sociais. O interesse por analisar o conjunto de ideias, avaliações e opiniões dos jovens agricultores familiares torna-se importante porque nos ajuda a conhecê-los de modo mais qualificado, permitindo que se realize uma interpretação da sua tomada de posição sobre o trabalho agrícola e suas disposições de reproduzi-lo no futuro. Com isto, busca-se mapear as referências simbólicas dos jovens sobre suas práticas cotidianas, as percepções que têm das condições de vida de seus pais e seu processo de identificação juvenil e socioprofissional.

\subsection{AS REPRESENTAÇÕES SOCIAIS E O PROCESSO DE IDENTIFICAÇÃO}

As representações sociais se constituem em um importante material para a pesquisa social, estando presentes em diferentes tradições sociológicas e recebendo diversas abordagens. Em Durkheim, a noção de representações coletivas é da maior importância para seu esquema teórico. Este autor procura demonstrar que os fatos sociais são exteriores aos indivíduos, exercendo sobre eles uma coerção externa. $O$ fato social apresenta uma existência própria, independente das manifestações individuais. Toda crença, todos os valores e comportamentos são construídos socialmente. Seguindo os postulados da tradição francesa (LEVINE, 1997), Durkheim (1973) sustenta que a sociedade é mais do que a soma dos indivíduos que a compõem: é uma síntese com qualidades específicas distintas dos indivíduos. Ou seja, os fenômenos que caracterizam a sociedade encontram suas explicações no todo e não nas partes individuais; assim, as representações coletivas não implicam, necessariamente, uma consciência individual.

Segundo Durkheim (1973), os fatos sociais são formados por representações coletivas: como a sociedade vê a si mesma e ao mundo que a rodeia. A sociedade é constituída pelos indivíduos que a compõem e também pelas ideias que estes fazem dela. As representações coletivas configuram-se a partir de um longo processo de interação de indivíduos de diferentes gerações, conformando assim elementos mais estáveis do que os preceitos individuais.

Conforme Durkheim, as representações coletivas surgem como o produto de uma intensa cooperação que se estende no espaço e no tempo e sobre as quais atuam uma 
multiplicidade de espíritos diversos que - ao interagirem - misturaram e combinam suas ideias e seus sentimentos. Isto implica reconhecer que sobre tais representações atuam longas séries de gerações que acumulam e depositam nelas suas experiências e sabedoria. Com efeito, uma compreensão mais rica e mais complexa do que a individual se constitui nessas representações.

As representações coletivas emergem da realidade social, mas adquirem existência própria, tendo como causa outras representações e não apenas as estruturas sociais. Depois de constituído um fundo inicial de representações que emergem como substrato das estruturas sociais, estas se tornam realidades, parcialmente, autônomas e dotadas de vida própria. Disso conclui Durkheim que as novas representações têm, por causa próxima, outras representações coletivas, além da própria estrutura social. Algumas destas representações acabam exercendo uma influência maior do que outras. Este é o caso da religião e da moral do grupo social destacadas por Durkheim, juntamente com as categorias de tempo e espaço, às quais poderiam ser acrescentadas as representações de gênero e geração. Esta proposição de grande envergadura teórica é amplamente conhecida a partir de um breve fragmento da obra deste autor, na qual ele se ensina que:

As representações coletivas traduzem a maneira como o grupo se pensa nas suas relações com os objetos que os afetam. Para compreender como a sociedade se representa a si própria e ao mundo que a rodeia, precisamos considerar a natureza da sociedade e não a dos indivíduos (DURKHEIM, 1973, p. 79).

Percebe-se que, para Durkheim, as "representações coletivas" emergem como um idioma cultural em estreita relação com a estrutura social, adquirindo uma existência externa aos indivíduos e podendo gerar novas representações. Com efeito, a vida social gera as representações coletivas e estas adquirem certa autonomia e não se prendem diretamente a determinadas particularidades da "morfologia social" (DURKHEIM, 1973). Deste modo, entende-se que as representações são construções sociais que envolvem uma longa série de gerações, sendo mais estáveis do que as opiniões individuais. De igual relevância é a noção de que novas representações têm por base outras representações coletivas além da influência da estrutura social.

Outro clássico da sociologia, o alemão Max Weber, que introduz a sociologia compreensiva, aborda o problema das representações sociais fazendo uso de termos como: “ideias”, "espírito”, “concepções”, “mentalidade” e "visão de mundo”. Essas noções são usadas para enfrentar o desafio da interpretação sociológica da realidade; sua sociologia propõe compreender o sentido da ação social. Por ação social, Weber entende a conduta humana (ato, 
omissão ou permissão) dotada de significado subjetivo pelo sujeito que executa a ação. Este sentido que orienta o comportamento dos agentes é atribuído a partir da conduta de outros, orientando-se por esta em seu desenvolvimento. Nesse sentido, sua sociologia propõe-se a interpretar a conexão dos sentidos definidores da ação social. As representações sociais podem ser apreendidas, em sentido weberiano, como os juízos de valor que motivam os indivíduos dotados de vontade a procederem de forma específica em suas ações.

Conforme Gerth e Mills (1982), Weber procurou incorporar os pontos de vista tanto de Marx quanto de Nietzsche em sua análise. Com Marx, ele compartilha de uma abordagem sociológica das ideias. Como Nietzsche, Weber interessa-se pela importância das ideias para as relações sociais. No entanto, Weber difere-se desses autores ao buscar identificar as possíveis tensões entre ideias e interesses. Ou seja, ele propugna a tese da recíproca influência entre fundamentos materiais e o conteúdo das ideias.

Em A Ética Protestante e o Espírito do Capitalismo, Weber procura explicar, através de forças das representações (o ascetismo calvinista, a noção luterana de profissão-vocação e a moral fundada sobre eles), a emergência do sistema capitalista (WEBER, 2004). Sua proposta pretende complexificar a teoria que, segundo ele, estabelece uma relação monocausal na determinação da base econômica sobre as representações. Conforme encontramos nas conclusões da obra citada:

\begin{abstract}
Aqui apenas procuramos tratar dos fatos e da direção de sua influência a partir apenas de um ponto de vista, ainda que importante. Contudo, será também necessário investigar como o ascetismo protestante foi por sua vez influenciado em seu desenvolvimento e caráter pela totalidade das condições sociais, especialmente pelas condições econômicas. Isto porque, se bem que o homem moderno seja incapaz de avaliar o significado de quanto às ideias religiosas influenciam a cultura e os caracteres nacionais, não se pode pensar em substituir uma interpretação materialista unilateral por uma igualmente bitolada interpretação causal da cultura e da história (WEBER, 2004, p. 136).
\end{abstract}

Weber nunca chegou a realizar a proposição de estudar o desenvolvimento da ética protestante considerando seus condicionantes econômicos. Como considera Cuvillier (1975), seu interesse não foi de refutar o marxismo, opondo-lhe uma interpretação idealista da história. "Seu pensamento essencial parece ter sido que cada estrutura social e cultural possui uma originalidade própria e forma um complexo único" (CUVILLIER, 1975, p. 43). Da contribuição de Weber à questão das representações sociais tiram-se duas lições: A primeira é de que as “ideias”, como parte da realidade social, são passíveis de interpretação sociológica. A segunda leva a perceber que as representações não podem ser tomadas como reflexos mecânicos das 
condições materiais, mas que as condições materiais e representações sociais condicionam-se mutuamente.

Em Karl Marx, a consciência social exprime e constitui ao mesmo tempo as relações sociais. Ocorre, no entanto, que nem os grupos sociais, nem suas modalidades de pensamento se expressam e relacionam-se de forma harmônica. Sua análise dialética aponta para as diferenças e contradições no interior das formações sociais. Em A Ideologia Alemã, encontra-se a mais completa abordagem das representações sociais realizada por Marx. Ele estabelece como ponto de partida que a "produção das ideias" e as "representações das consciências" estão primeiramente implicadas à atividade material dos homens.

\begin{abstract}
A produção das ideias, representações da consciência, é, em primeiro lugar, imediatamente implicada na atividade material e no comércio material dos homens, sendo a linguagem da vida real. $\mathrm{O}$ ato de representar, de pensar, o intercâmbio espiritual dos homens, ainda aqui aparecem como emanação direta de suas atitude [...] Se os homens e suas condições aparecem em toda ideologia num sentido inverso como em um quarto escuro, tal fenômeno decorre de seu processo vital histórico assim como a inversão dos objetos sobre a retina deriva de seu processo diretamente físico [...] é pelo seu verdadeiro processo vital que se representa igualmente o desenvolvimento dos reflexos ideológicos e dos ecos ideológicos desse processo vital (MARX, 1968, p. 147).
\end{abstract}

Decorrem, daí, algumas considerações. Primeiramente, que o homem - ser social - é criador de representações. Depois, que as ideias, representações e os pensamentos constituem a consciência dos homens que vivem em determinadas condições materiais de existência empiricamente constatáveis, sendo as representações emanação de suas condições materiais de existência. A noção de ideologia aparece como a consciência "invertida", isto é, como falsa consciência e como reflexo dos processos vitais dos homens.

Marx percebia que se é o meio de vida material que condiciona o processo da vida social na sua generalidade - em termos atuais, as expressões subjetivas deveriam ser explicadas a partir de determinados condicionantes objetivos - era igualmente preciso perceber entre estrutura e superestrutura uma relação dialética. Ele propunha, assim, que a atividade humana fosse percebida em seu lado ativo, enquanto atividade sensível ao conhecimento prático, o que o materialismo antes dele tinha negligenciado.

Em suas Teses sobre Feuerbach (1968) encontra-se um Marx crítico aos materialistas vulgares e aos idealistas, buscando, de certa maneira, uma superação dessa oposição. Em poucas folhas, ele pontuou um conjunto de 11 notas críticas dirigidas ao filósofo Ludwig Andreas 
Feuerbach, que consistiu numa pesada crítica ao conjunto da filosofia alemã. Conforme a primeira tese:

O principal defeito de todo o materialismo até aqui (incluído o de Feuerbach) consiste em que o objeto, a realidade, a sensibilidade, só é aprendido sob a forma de objeto ou de intuição, mas não como atividade humana sensível, como práxis, não subjetivamente. Eis porque, em oposição ao materialismo, o aspecto ativo foi desenvolvido de maneira abstrata pelo idealismo, que, naturalmente, desconhece a atividade real, sensível, como tal. Feurbach quer objetos sensíveis - realmente distintos do pensamento: mas não apreende a própria atividade humana como atividade objetiva (MARX, 1968, p. 133).

Nesta nota, Marx propõe abordar as práticas humanas como fatos concretos, como atividade objetiva, já que as relações sociais configuram a própria sociedade. Portanto, o materialismo não percebe a sociedade como sendo composta por objetos inanimados, desconexos entre si. Ao contrário, sua dimensão dialética enfatiza que as relações humanas são dotadas de uma dinâmica subjetiva que só vinha sendo trabalhada pelos filósofos idealistas. Disto decorre que as relações sociais incluem uma parte de ideal, que são matéria dotada de subjetividade e que tais processos são passíveis de uma análise científica que persiga a construção da objetividade. Tal análise constituir-se-ia como uma atividade crítico-prática, que remete à noção de praxis à atividade científica.

Feuerbach propunha que os homens são produtos das circunstâncias e da sua educação, como reação do ser à consciência, tese partilhada com os materialistas franceses. Segundo ele, o homem é um ser passivo que registra, docilmente, todas as impressões que recebe da natureza. Marx opõe a esta outra visão: a de que tudo que se realiza no homem não é apenas o resultado da ação da natureza sobre ele, mas também de sua ação sobre a natureza. Ou seja, as circunstâncias fazem os homens; dialeticamente, os homens fazem as circunstâncias. Marx contrapõe-se ao determinismo mecânico da base material sobre a consciência, chamando atenção para as contradições existentes entre as forças produtivas, o estado social e a produção das ideias.

Com Marx, aprende-se que as representações sociais estão ligadas às práticas sociais. Elas resultam de uma sociedade cindida em classes, e a ideologia dominante é a da classe dominante, sendo percebida por ele como uma falsa consciência. Neste sentido, este autor enfatiza que há uma estreita relação entre as representações sociais a as condições materiais da existência social.

As abordagens clássicas de Durkheim, Weber e Marx foram recuperados em análises recentes da Sociologia. Conforme encontramos em Pierre Bourdieu, em suas Meditações Pascalianas: 
Em outras palavras, é preciso construir uma teoria materialista capaz de recuperar no idealismo, conforme o desejo expresso por Marx nas Teses sobre Feuerbach, "o lado ativo" do conhecimento prático abandonado pela tradição materialista. Eis precisamente a função da noção de habitus que restitui ao agente um poder gerador e unificador, construtor e classificador, lembrando ainda que essa capacidade de construir a realidade social, ela mesma socialmente construída, investindo na prática dos princípios organizadores socialmente construídos e adquiridos no curso de uma experiência social situada e dada (BOURDIEU, 2001, p. 167).

Ao propor a noção de habitus como um conjunto de disposições incorporadas e duráveis que atuam como um economizador de reflexibilidade, Pierre Bourdieu inscreve-se no desafio proposto pelos autores clássicos, tentando superar a dicotomia entre preceitos objetivistas e subjetivistas e a dicotomia entre estrutura e ação através de uma dialética da interioridade e exterioridade. Ou seja, "da interiorização da exterioridade e da exteriorização da interioridade". Na proposta de Bourdieu, as estruturas do meio social podem ser apreendidas a um meio socialmente estruturado produzindo um habitus.

Essa noção corresponde a um sistema de disposições adquiridas que atuam como um princípio gerador e estruturador das práticas e das representações sociais. Atuam como "estruturas estruturadas predispostas a funcionar como estruturas estruturantes" (BOURDIEU, 2001, p. 60). Isto é, são as estruturas sociais de nossa subjetividade, correspondendo a como elas se imprimem em nossas cabeças e nossos corpos. Nessa dupla dimensão, objetiva e subjetiva da realidade social, Bourdieu propõe certa primazia às estruturas objetivas. Isso é o que leva esse autor a sugerir dois momentos na investigação; num primeiro momento, objetivista; num segundo, mais subjetivista.

\footnotetext{
A teoria mais acentuadamente objetivista tem de integrar não só a representação que os agentes têm do mundo social, mas também, de modo mais preciso, a contribuição que eles dão para a construção da visão desse mundo e, assim, para a própria construção desse mundo, por meio do trabalho de representação (em todos os sentidos do termo) que continuamente realizam para imporem a sua visão de mundo ou a visão da sua própria posição nesse mundo, a visão de sua identidade social (BOURDIEU, 1998, p. 139).
}

Bourdieu sustenta a ideia de representação como um trabalho ativo de construção de uma visão de mundo e de uma identidade. A percepção do mundo social é objeto de disputa na luta política, uma vez que esta é uma luta teórica e prática pelo poder de conservar ou transformar o mundo social através da conservação ou transformação das categorias de percepção desse mundo. 
Compreende-se que os sistemas de representações e sua lógica são externos ao sujeito; portanto, eles necessitam de um trabalho de interiorização pelos indivíduos, o que é realizado pela educação. Essas categorias do pensamento coletivo se configuram em verdadeiras instituições fixadas em nossas almas pelo processo de socialização. Elas atuam como uma teia de significação que se estende sobre o mundo, procurando classificá-lo, codificá-lo e transformar as suas dimensões sensíveis em dimensões passíveis de entendimento. Os sistemas de representações atuam como uma rede, cujas malhas conformam os domínios da experiência, estabelecendo os limites dos comportamentos dos grupos e dos indivíduos. Com efeito, ao dividir os domínios da experiência, as representações estabelecem cortes e contrastes e instituem diferenças que se refletem nos comportamentos e nas expectativas dos indivíduos sobre o mundo em que vivem.

Sinteticamente, pode-se tomar o conceito de representação social como um conjunto de elementos simbólicos, socialmente construídos e compartilhados, que contribuem para a construção da realidade social e que devem ser compreendidos a partir dos contextos objetivos específicos de sua produção e reprodução. As representações sociais diferem, assim, das opiniões individuais dos atores sociais sobre o fato analisado. Trata-se, ao contrário, de uma orientação coletiva motivada por estruturas de conhecimento que, mesmo contendo diferentes níveis de distanciamento do real, tornam-se dados objetivos para a interpretação da realidade social investigada.

Esta abordagem materialista das representações sociais fortaleceu-se por meio da crítica pós-estruturalista que se ergueu em reação à noção clássica de representação. Os representantes desta crítica percebem as representações sociais não apenas como um reflexo do real, mas como um construto objetivo. Nesta trilha, os teóricos dos estudos culturais, buscaram recuperar o conceito de representação, desenvolvendo-o em conexão com uma teorização sobre a identidade e diferença e restaurando a perspectiva crítica que percebe a realidade social e cultural como um conjunto de relações de força.

Conforme o sociólogo jamaicano Stuart Hall (2003), as representações são entendidas como um sistema de signos, constituindo-se num construto social com dimensões materiais. Esta marca deve-se à reformulação do conceito original, que passa a ser uma expressão exterior dos indivíduos ou coletividades, podendo ser apreendido objetivamente. Para o linguista indiano Homi Bhabha (2005), as representações são expressas por meio de uma pintura, de uma fotografia, de um filme, de um texto, de uma expressão oral. Deste modo, para estes autores, a representação é marca ou traço visível, exterior. As representações são a forma de atribuição de 
sentido, por isto assumem forma material. Incorporam e materializam um sistema linguístico e cultural arbitrário, indeterminado e estreitamente ligado a relações de poder. Os discursos e os sistemas de representação constroem lugares a partir dos quais os indivíduos podem se posicionar e a partir dos quais podem falar (SILVA, 2000(a)). A ênfase na representação e o papel chave da cultura na produção de significados que permeia todas as relações sociais levam a uma preocupação com a identificação.

É por meio da representação que a identidade e a diferença adquirem sentido, visto que esta inclui as práticas de significação e os sistemas simbólicos por meio dos quais os significados são produzidos, posicionando os indivíduos como sujeitos. A representação como um processo cultural estabelece identidades individuais e coletivas e os sistemas simbólicos nos quais se baseiam essas representações fornecem possíveis respostas às questões: Quem eu sou? O que eu poderia ser? Quem eu quero ser? Deste modo, é por meio dos significados produzidos pelas representações que damos sentido à nossa experiência e àquilo que somos. Os sistemas simbólicos tornam possível aquilo que somos e aquilo no qual podemos nos tornar.

O sociólogo francês Denys Cuche (1999) chama a atenção para o fato de que a identidade é uma construção social e não um dado; se ela emerge no âmbito das representações, não significa que seja uma ilusão. Ao contrário, o percurso teórico realizado até aqui permite perceber que a identidade é construída, socialmente, no interior de contextos sociais que determinam a posição dos agentes e, por isto mesmo, orientam suas escolhas. Mais isto não se dá em isolamento, como, aliás, nada o é em sociologia. Desde a obra de Frederik Barth (1969), a identidade se estabelece numa situação relacional. Percebe-se que não há identidade em si, nem mesmo unicamente para si. Ela situa-se sempre em relação a outras identidades de tal modo que identidade e alteridade estão ligadas em uma relação dialética.

A identidade social se constroi a partir das atualizações do processo de identificação - o que a situa numa dimensão histórica - e envolve a noção de pertencimento a um grupo social. A identidade social não se descarta da identidade pessoal, porque esta é em alguma medida um reflexo daquela. $\mathrm{O}$ conceito de identidade pessoal e social possui um conteúdo explicitamente reflexivo, uma vez que supõe relações sociais bem como um código de categorias destinado a orientar o desenvolvimento destas relações (OLIVEIRA, 1976).

A identidade, então, tem a função de vincular o sujeito à estrutura. No entanto, os sujeitos não podem ser pensados como tendo uma identidade unificada e estável. A diversificação dos modos de vida e das alternativas culturais que se sobrepõem na vida cotidiana estaria levando a uma fragmentação do sujeito e de sua identidade. Esta, fragmentada e por 
vezes contraditória, colocaria em crise a noção de identidade, ou ao menos de sua identidade tradicional (HALL, 1999).

Conclui-se, então, que a identidade é sempre resultante de um processo de identificação que ocorre no interior de uma situação relacional. Neste sentido, a identificação é sempre relativa e até mesmo precária, visto que pode evoluir e mesmo alterar se mudar a situação. Deste modo, adota-se o conceito de identificação por seu caráter dinâmico que o torna condizente com o processo vivenciado pelos jovens agricultores familiares.

O conceito de identificação emerge como um processo pelo qual os indivíduos identificam-se com os outros, seja pela ausência de uma consciência da diferença ou da separação, seja como resultado de supostas similaridades. Percebe-se que há um contínuo processo de identificação, no qual os sujeitos buscam criar alguma compreensão sobre si próprios, por meio de sistemas simbólicos, e se identificar com as formas pelas quais são vistos por outros. Desta maneira, o processo de identificação ocorre por meio de uma projeção em direção ao futuro que antecipa aquilo que se pretende ser. Sendo assim, tenta-se não se incorrer no erro de pensar as identidades como plenamente unificadas. Propõe-se, com base na sugestão de Hall (1999), a ideia de que, à medida que os sistemas de significação e representação se multiplicam, os jovens passam a ser confrontados com uma multiplicidade móvel de identidades alternativas, cuja identificação lhes é possível.

A identificação dos jovens com um grupo profissional de referência representa uma antecipação das posições desejáveis e uma instância de legitimação de suas capacidades, constituindo-se num espaço de construção de reconhecimento social. Isto implica a aquisição antecipada de saberes, normas, valores e comportamentos típicos de seu grupo de referência, que permite explicar representações mais positivas sobre o processo de trabalho e maior disposição ao engajamento em suas tarefas.

\subsection{AVALIAÇÕES DOS JOVENS SOBRE TRABALHO FAMILIAR AGRÍCOLA}

As avaliações dos jovens sobre o trabalho agrícola foram identificadas por meio do questionamento $O$ quanto você gosta do trabalho agrícola? A distribuição de frequência desta

questão encontra-se no Gráfico 34. Metade dos entrevistados adotou uma posição ambígua a respeito da atividade que realizam, optando pela resposta mais ou menos. Esta resposta é 
significativa dos impasses dos jovens na agricultura e reflete, simultaneamente, a disposição ao engajamento na atividade e os contratempos e desconfortos desta. Outros 45,7\% dos entrevistados respondem gosto muito. Deste modo, poucos disseram não gostar do trabalho agrícola.

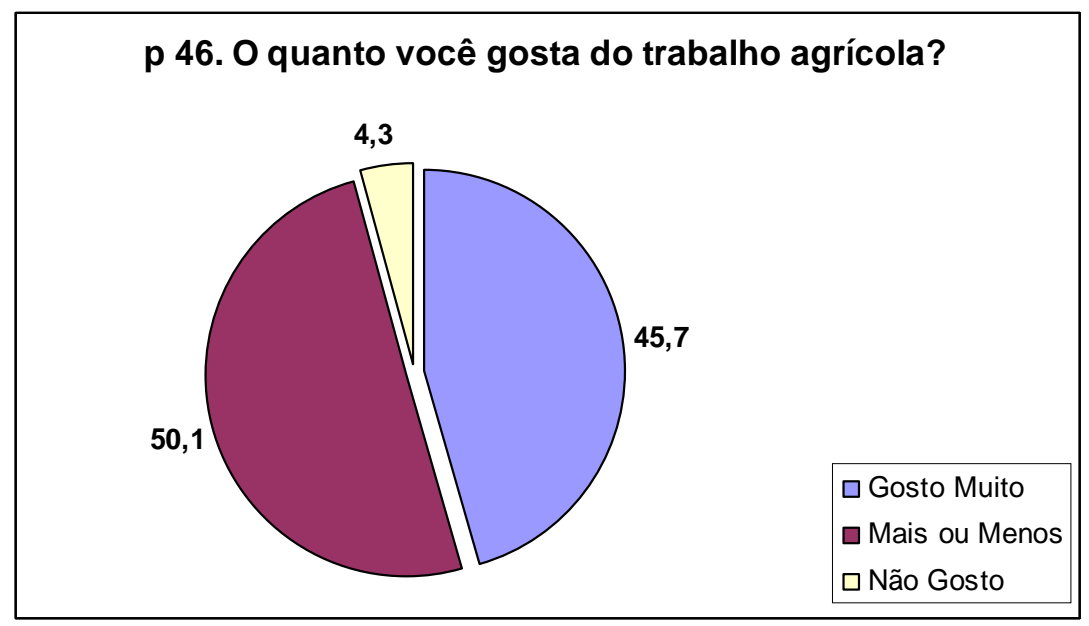

Gráfico 34: Distribuição de frequência da questão $O$ quanto você gosta do trabalho agrícola? (\%) Fonte: Banco de dados Jovens Agricultores Familiares RS - MDA/FAURGS, 2007.

Quando se realiza o cruzamento das respostas a esta questão com a variável sexo, verifica-se que os jovens homens avaliam de modo mais positivo o trabalho agrícola do que as jovens mulheres. Entre eles, predomina a categoria gosto muito com 50,6\% das respostas, enquanto entre elas $57,1 \%$ responderam mais ou menos. Elas ainda responderam em maior proporção não gosto mais do que eles (Tabela 31).

Tabela 31: Cruzamento da questão O quanto você gosta do trabalho agrícola? por sexo (em $f$ e $\%)$

\begin{tabular}{lllrrr}
\hline \hline & & \multicolumn{2}{c}{ SEXO } & \\
\cline { 3 - 5 } & & & Homens & Mulheres & \multicolumn{1}{c}{ Total } \\
\hline O QUANTO VOCÊ & Gosto Muito & $\mathrm{f}$ & 216 & 95 & 311 \\
GOSTA DE TRABALHAR & & $\%$ & $50,6 \%$ & $37,4 \%$ & $45,7 \%$ \\
\cline { 2 - 5 } NA AGRÍCULTURA? & Mais ou Menos & $\mathrm{f}$ & 196 & 145 & 341 \\
& & $\%$ & $45,9 \%$ & $57,1 \%$ & $50,1 \%$ \\
\cline { 2 - 5 } & Não Gosto & $\mathrm{f}$ & 15 & 14 & 29 \\
& & $\%$ & $3,5 \%$ & $5,5 \%$ & $4,3 \%$ \\
\hline Total & & $\mathrm{f}$ & 427 & 254 & 681 \\
& & $\%$ & $100,0 \%$ & $100,0 \%$ & $100,0 \%$ \\
\hline \hline
\end{tabular}

Fonte: Banco de dados Jovens Agricultores Familiares RS - MDA/FAURGS, 2007. 
A tabela abaixo apresenta o cruzamento da questão em análise com faixa etária. A maior parte dos jovens de 15 a 19 anos $(56,4 \%)$ gosta mais ou menos de trabalhar na agricultura. Situação semelhante é verificada entre aqueles que têm de 20 a 24 anos (51,7\%). Porém, os jovens adolescentes são os que mais declaram que não gostam do trabalho agrícola. Posição bem diferente é verificada entre os jovens adultos onde predomina a resposta gosta muito, com 56,1\% dos casos. Estas opiniões de desagrado com relação ao trabalho agrícola manifestada por jovens adolescentes podem ter suas explicação em aspectos abordados nos capítulos precedentes, notadamente no fato de que este grupo é o que possui menor acesso aos recursos materiais e, por conseguinte, tem uma baixa autonomia.

Além disto, os jovens adolescentes encontram-se menos inseridos no processo de trabalho e realizam as tarefas menos valorizadas na unidade produtiva. Ao mesmo tempo, são eles os que mais se encontram no sistema formal de ensino o qual apresenta outras possibilidades, materiais e simbólicas, pra além do trabalho agrícola. Desta maneira, podemos dizer que esta tomada de posição dos jovens adolescentes em relação ao trabalho familiar agrícola é bastante coerente com a posição que eles ocupam e os papeis que desempenham nas unidades produtivas de suas famílias.

Tabela 32: Cruzamento da questão O quanto você gosta do trabalho agrícola? por faixa etária (em $f$ e \%)

\begin{tabular}{|c|c|c|c|c|c|c|}
\hline & & & \multicolumn{3}{|c|}{ FAIXA ETÁRIA: } & \multirow[b]{2}{*}{ Total } \\
\hline & & & $\begin{array}{l}\text { De } 15 \text { a } \\
19 \text { anos }\end{array}$ & $\begin{array}{l}\text { De } 20 \text { a } \\
24 \text { anos }\end{array}$ & $\begin{array}{l}\text { De } 25 \text { a } \\
29 \text { anos }\end{array}$ & \\
\hline \multirow{6}{*}{$\begin{array}{l}\text { O QUANTO VOCÊ } \\
\text { GOSTA DE TRABALHAR } \\
\text { NA AGRÍCULTURA? }\end{array}$} & Gosto Muito & $f$ & 90 & 93 & 128 & 311 \\
\hline & & $\%$ & $36,0 \%$ & $45,8 \%$ & $56,1 \%$ & $45,7 \%$ \\
\hline & Mais ou Memos & $f$ & 141 & 105 & 95 & 341 \\
\hline & & $\%$ & $56,4 \%$ & $51,7 \%$ & $41,7 \%$ & $50,1 \%$ \\
\hline & Não Gosto & $f$ & 19 & 5 & 5 & 29 \\
\hline & & $\%$ & $7,6 \%$ & $2,5 \%$ & $2,2 \%$ & $4,3 \%$ \\
\hline \multirow[t]{2}{*}{ Total } & & $f$ & 250 & 203 & 228 & 681 \\
\hline & & $\%$ & $100,0 \%$ & $100,0 \%$ & $100,0 \%$ & $100,0 \%$ \\
\hline
\end{tabular}

Fonte: Banco de dados Jovens Agricultores Familiares RS - MDA/FAURGS, 2007.

Como pode ser observado no Gráfico 35 , jovens de ambos os sexos, com idades de 25 a 29 anos, gostam muito de trabalhar na agricultura. Todavia, os percentuais dos homens para esta categoria de resposta em todas as faixas etárias são maiores do que os apresentados pelas mulheres. Os entrevistados de 15 a 19 anos são os que possuem percentuais mais elevados da resposta não gosto, mas nesse caso são as jovens que figuram com o maior índice $(9,2 \%)$. 
Estas informações apontam para o fato de que os jovens têm posições diferentes sobre o trabalho que desenvolvem, conforme sua condição de sexo e faixa etária. Suas avaliações, apesar de não serem predominantemente de contrariedade, não são majoritariamente positivas e expressam a ambivalência de sua condição juvenil no trabalho familiar agrícola. A intensa socialização na atividade produtiva gera disposições para uma avaliação positiva da mesma. Por outro lado, as dificuldades objetivas presentes nas práticas laborais cotidianas desta juventude produzem insatisfação. A penosidade das tarefas, o baixo retorno financeiro da atividade e a percepção do não-reconhecimento do trabalho expresso, recorrentemente, por meio de sentenças como: "a agricultura não é valorizada", "aqui na roça não se é valorizado" e "ninguém valoriza o jovem na agricultura", são alguns exemplos das questões que permeiam a avaliação dos entrevistados sobre o trabalho agrícola.

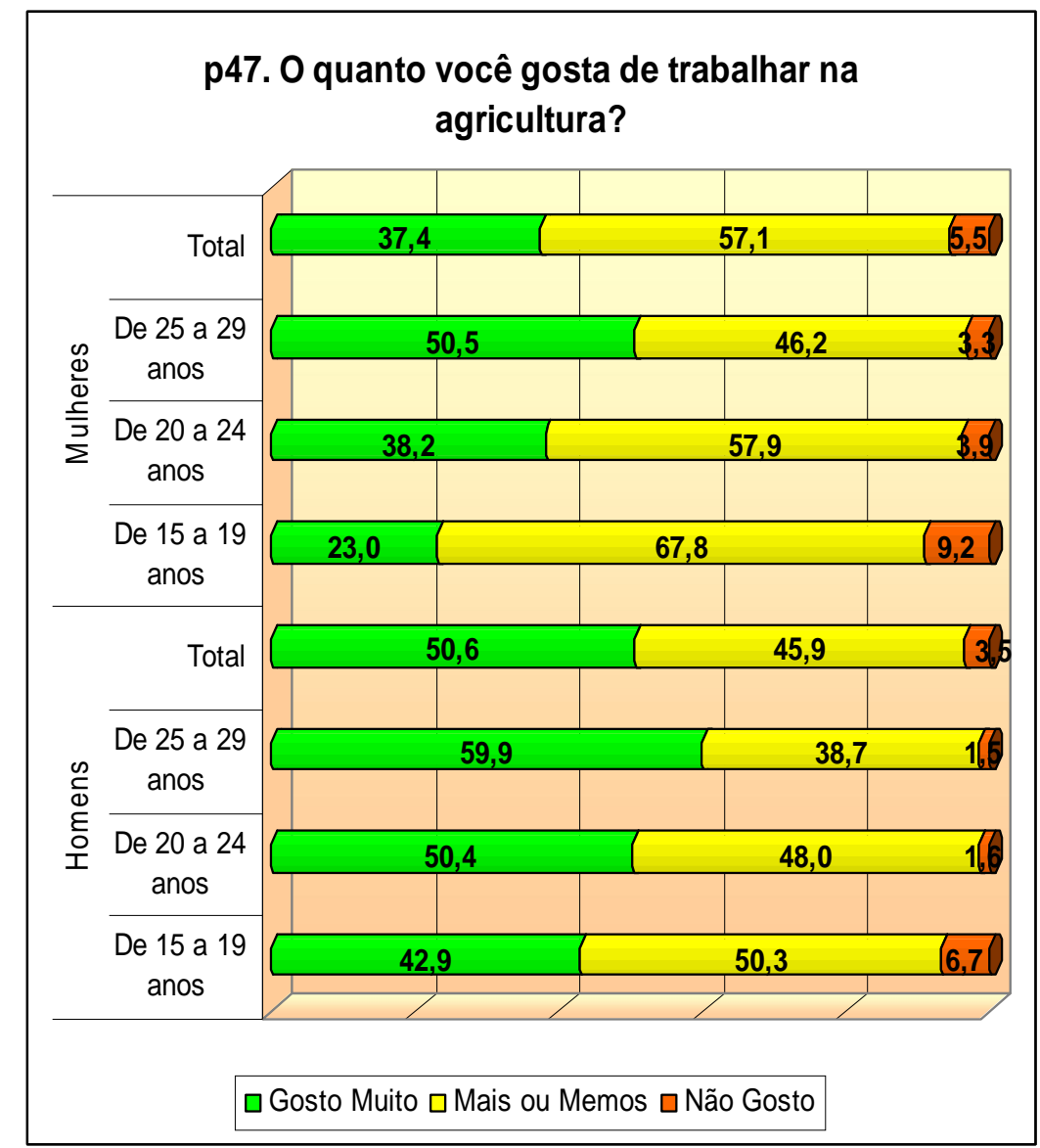

Gráfico 35: Cruzamento da questão O quanto você gosta do trabalho agrícola? por faixa etária e sexo (\%)

Fonte: Banco de dados Jovens Agricultores Familiares RS - MDA/FAURGS, 2007. 
Ainda assim, há uma parte representativa dos inquiridos que afirmaram gostar muito do trabalho agrícola, composta predominantemente por homens - e entre estes - os jovens adultos. As mulheres, com destaque para as jovens adolescentes, apresentam uma posição de maior descontentamento sobre o processo de trabalho do qual participam. Esta postura mais crítica incorpora, além das dimensões anteriormente citadas, as peculiaridades de sua condição de gênero que se revelam nas tarefas assumidas por elas na divisão do trabalho familiar.

Os entrevistados também foram levados a avaliar sua participação no trabalho agrícola. No Gráfico 36, são apresentadas as distribuições de frequência das respostas para a questão: Como você considera sua participação no trabalho familiar agrícola para os resultados obtidos por sua família? Constatou-se que os jovens percebem sua participação no trabalho como sendo importante em $47,2 \%$ e em $46,9 \%$ muito importante para os resultados obtidos pela família. Apenas 5,6\% consideram sua participação pouco importante e $0,3 \%$ consideram sua participação nada importante. Ou seja, os jovens reconhecem sua participação na atividade agrícola como sendo fundamental para a realização do trabalho familiar, o que lhes imprime um sentido de responsabilidade.

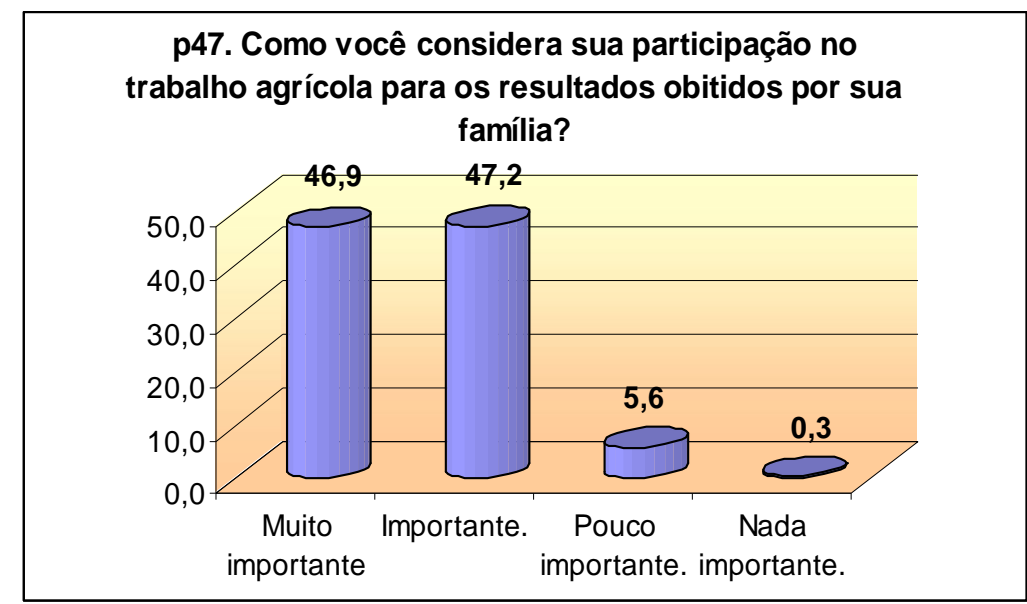

Gráfico 36: Avaliação da sua participação no trabalho familiar agrícola (\%) Fonte: Banco de dados Jovens Agricultores Familiares RS - MDA/FAURGS, 2007.

Esta questão, vista sob a perspectiva de gênero, revela diferenças tênues e que se mantém dentro da margem de erro da pesquisa. Os homens interpretam, principalmente, que sua participação é muito importante, enquanto as mulheres, em sua maioria, consideram importante. Já na resposta pouco importante, as mulheres apresentam índice maior. Além disso, há dois casos em que as jovens responderam que seu trabalho é nada importante para os resultados da família, o que não se registra entre os homens. Apesar da baixa representatividade estatística, 
esta última categoria não deixa de refletir a internalização de sua posição subalterna, e menos valorizada, no âmbito do trabalho familiar.

Tabela 33: Cruzamento entre avaliação da sua participação no trabalho familiar agrícola por sexo (em $f$ e \%)

\begin{tabular}{|c|c|c|c|c|c|}
\hline & & & \multicolumn{2}{|c|}{ SEXO } & \multirow[b]{2}{*}{ Total } \\
\hline & & & Homens & Mulheres & \\
\hline \multirow{8}{*}{$\begin{array}{l}\text { COMO VOCÊ CONSIDERA } \\
\text { SUA PARTICIPAÇÃO NO } \\
\text { TRABALHO FAMILIAR } \\
\text { AGRÍCOLA PARA OS } \\
\text { RESULTADOS OBTIDOS } \\
\text { POR SUA FAMÍLIA? }\end{array}$} & Muito importante & $f$ & 206 & 113 & 319 \\
\hline & & $\%$ & $48,4 \%$ & $44,5 \%$ & $46,9 \%$ \\
\hline & Importante. & $f$ & 202 & 119 & 321 \\
\hline & & $\%$ & $47,4 \%$ & $46,9 \%$ & $47,2 \%$ \\
\hline & Pouco importante. & $f$ & 18 & 20 & 38 \\
\hline & & $\%$ & $4,2 \%$ & $7,9 \%$ & $5,6 \%$ \\
\hline & Nada importante. & $f$ & 0 & 2 & 2 \\
\hline & & $\%$ &, $0 \%$ & ,8\% & ,3\% \\
\hline \multirow[t]{2}{*}{ Total } & & $f$ & 426 & 254 & 680 \\
\hline & & $\%$ & $100,0 \%$ & $100,0 \%$ & $100,0 \%$ \\
\hline
\end{tabular}

Fonte: Banco de dados Jovens Agricultores Familiares RS - MDA/FAURGS, 2007.

Ao realizarmos o cruzamento destas respostas com a variável faixa etária (Tabela 34), identifica-se que tende a aumentar o percentual de jovens que consideram sua participação no trabalho agrícola muito importante conforme avança as idades dos entrevistados. Esta categoria obtém $34,1 \%$ das respostas dos jovens adolescentes, passa para 48,3\% entre aqueles que têm de 20 a 24 anos e chega a 59,6\% entre os jovens adultos. Isto ocorre à medida que diminui o percentual de jovens que avaliam sua participação no trabalho como importante $(55,8 \%$ entre os de 15 a 19 anos e 36,4\% entre os de 25 a 29 anos). Entre os que consideram seu envolvimento no trabalho agrícola pouco importante para os resultados obtidos pela família, predominam os jovens adolescentes.

Os jovens agricultores são fundamentais para a realização do trabalho familiar e possuem consciência disto visto que, em todas as categorias de sexo e idade, predominam as respostas muito importante e importante. Suas avaliações apontam variações mais significativas por faixa etária do que por sexo, mesmo com os homens apresentando percentuais maiores para a resposta muito importante em todas as idades. Os índices mais próximos se encontram entre as respostas da faixa etária de 20 a 24 anos de idade de ambos os sexos. Além disto, é emblemático que as únicas respostas de que a participação no trabalho é nada importante tenham sido de mulheres na faixa de 15 a 19 anos (Gráfico 37) o que nos remete às questões anteriormente 
tratadas, principalmente no que diz respeito ao papel atribuído às jovens adolescentes entre os agricultores familiares.

Tabela 34: Cruzamento entre avaliação da sua participação no trabalho familiar agrícola por faixa etária (em $f$ e \%)

\begin{tabular}{|c|c|c|c|c|c|c|}
\hline & & & \multicolumn{3}{|c|}{ FAIXA ETÁRIA: } & \multirow[b]{2}{*}{ Total } \\
\hline & & & $\begin{array}{l}\text { De } 15 \text { a } \\
19 \text { anos }\end{array}$ & $\begin{array}{l}\text { De } 20 \text { a } \\
24 \text { anos }\end{array}$ & $\begin{array}{l}\text { De } 25 \text { a } \\
29 \text { anos }\end{array}$ & \\
\hline \multirow{8}{*}{$\begin{array}{l}\text { COMO VOCÊ } \\
\text { CONSIDERA SUA } \\
\text { PARTICIPAÇÃO NO } \\
\text { TRABALHO FAMILIAR } \\
\text { AGRÍCOLA PARA OS } \\
\text { RESULTADOS } \\
\text { OBTIDOS POR SUA } \\
\text { FAMÍLIA? }\end{array}$} & \multirow[t]{2}{*}{ Muito importante } & $f$ & 85 & 98 & 136 & 319 \\
\hline & & $\%$ & $34,1 \%$ & $48,3 \%$ & $59,6 \%$ & $46,9 \%$ \\
\hline & \multirow{2}{*}{ Importante. } & $f$ & 139 & 99 & 83 & 321 \\
\hline & & $\%$ & $55,8 \%$ & $48,8 \%$ & $36,4 \%$ & $47,2 \%$ \\
\hline & \multirow[t]{2}{*}{ Pouco importante. } & $f$ & 23 & 6 & 9 & 38 \\
\hline & & $\%$ & $9,2 \%$ & $3,0 \%$ & $3,9 \%$ & $5,6 \%$ \\
\hline & \multirow[t]{2}{*}{ Nada importante. } & $f$ & 2 & 0 & 0 & 2 \\
\hline & & $\%$ &, $8 \%$ &, $0 \%$ &, $0 \%$ & ,3\% \\
\hline \multirow[t]{2}{*}{ Total } & & $f$ & 249 & 203 & 228 & 680 \\
\hline & & $\%$ & $100,0 \%$ & $100,0 \%$ & $100,0 \%$ & $100,0 \%$ \\
\hline
\end{tabular}

Fonte: Banco de dados Jovens Agricultores Familiares RS - MDA/FAURGS, 2007.

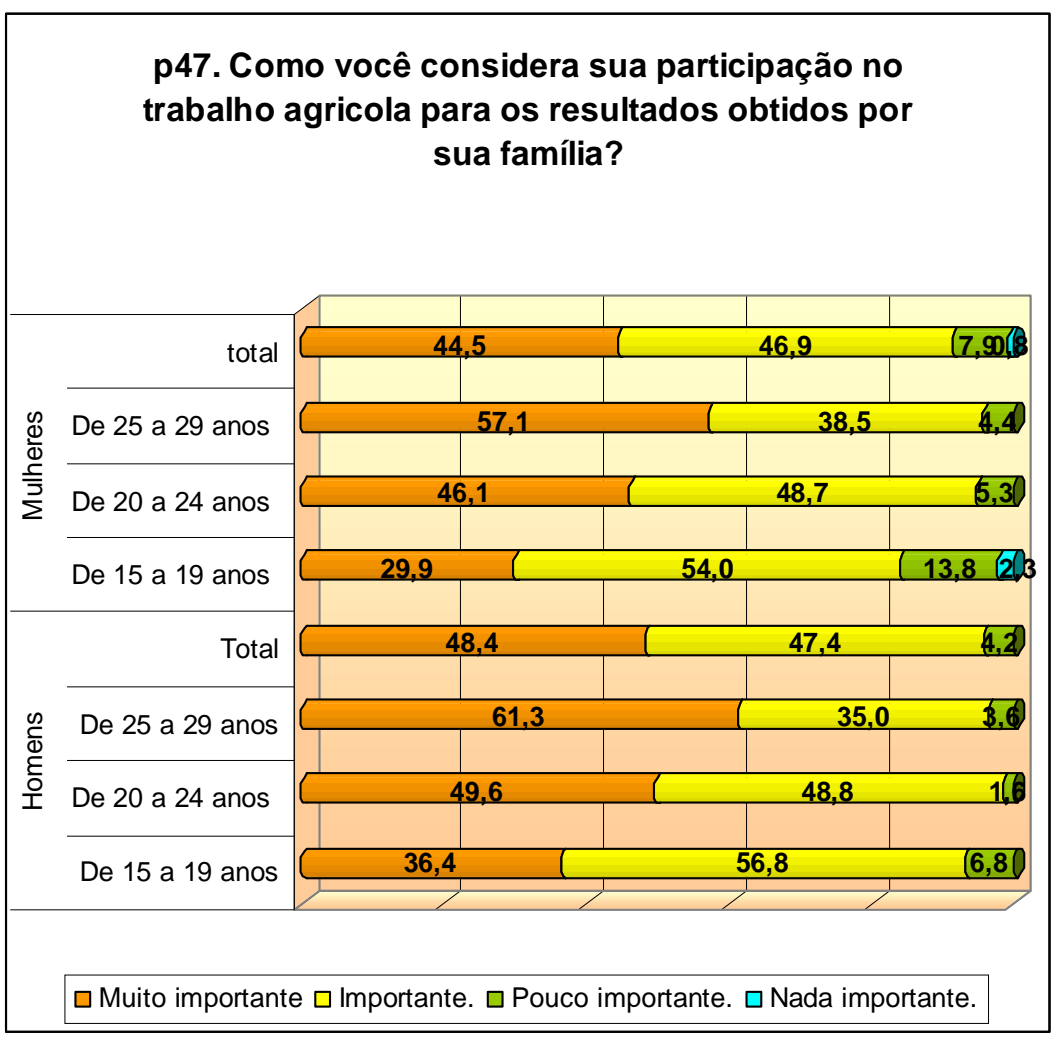

Gráfico 37: Cruzamento entre avaliação da sua participação no trabalho familiar agrícola por faixa etária e sexo (\%)

Fonte: Banco de dados Jovens Agricultores Familiares RS - MDA/FAURGS, 2007. 
Os entrevistados foram perguntados sobre Que frase mais se aproxima do que você pensa sobre o trabalho familiar agrícola? As opções de respostas apresentadas resultaram de procedimento anterior, quando esta questão foi apresentada de forma aberta, isto é, sem indução de resposta. Com base nesta pergunta, realizada na etapa preparatória do estudo, obtivemos um conjunto relativamente vasto de respostas que foram sistematizadas e reduzidas a três alternativas positivas e outras três negativas. Estas foram apresentadas aos entrevistados de modo intercalado. O resultado pode ser verificado no Gráfico 38. Verifica-se que as três respostas mais recorrentes foram: trabalho digno, importante para a sociedade com 35,3\%, seguido de permite ter independência financeira com 20,4\% e traz satisfação ver crescer o fruto do próprio trabalho com $19,5 \%$. Isto indica um predomínio de representações positivas sobre o trabalho familiar agrícola entre os jovens entrevistados.

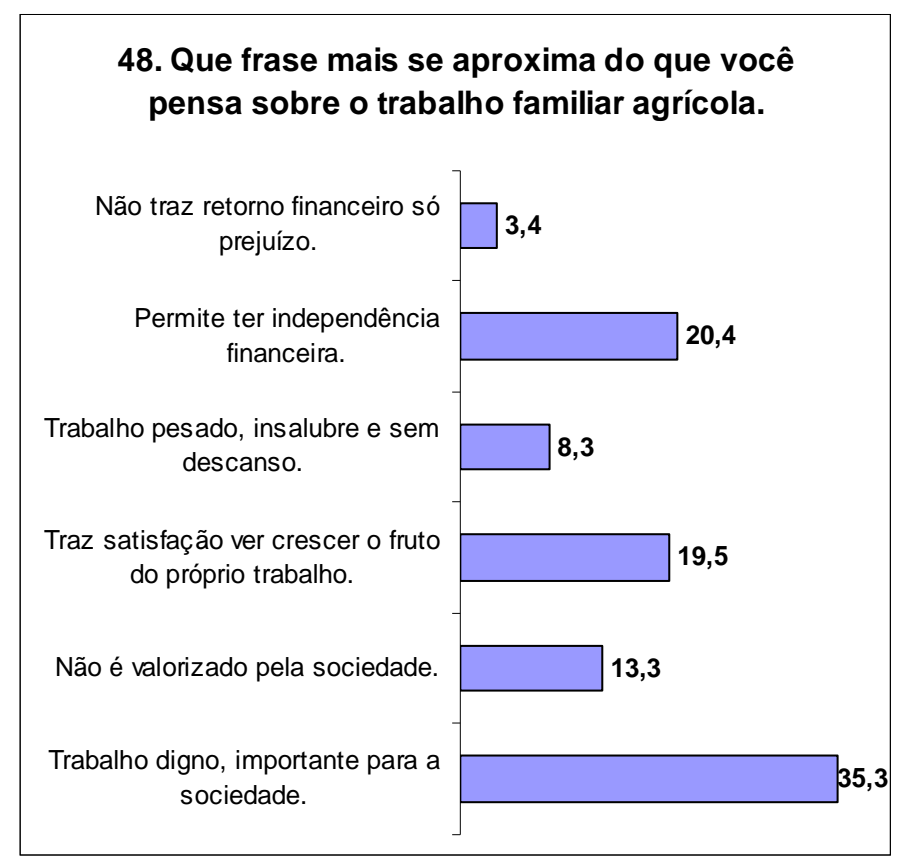

Gráfico 38: Distribuição das representações sobre o trabalho familiar agrícola (\%) Fonte: Banco de dados Jovens Agricultores Familiares RS - MDA/FAURGS, 2007.

As representações sobre o trabalho familiar agrícola foram cruzadas com a variável sexo originando a Tabela 35. Nela se evidencia que os jovens de ambos os sexos acreditam, prioritariamente, que se trata de uma atividade digna, importante para a sociedade. Chama a atenção o fato de que as mulheres apresentam um índice superior ao dos homens para esta resposta, enquanto que jovens do sexo masculino enfatizam que o trabalho familiar agrícola permite ter independência financeira mais do que elas. Isto expressa, principalmente por parte 
dos homens, a importância da ideologia da autonomia entre os agricultores familiares. Por outro lado, esta diferença de ênfase é condizente com a dificuldade das mulheres em acessar os rendimentos advindos desta atividade, o que não lhes impede de compartilhar de uma ética que valoriza o trabalho e afirma sua dignidade. Com efeito, a possibilidade de ser dono do próprio negócio é menos enfatizada pelas mulheres do que à ideia de que este trabalho traz satisfação, onde temos índices iguais para ambos os sexos. Além disto, em duas das três assertivas mais negativas, as mulheres possuem percentuais maiores do que os dos homens, indicando que elas estão mais inclinadas do que eles a assumirem posições mais críticas em relação ao trabalho familiar.

Tabela 35: Cruzamento das representações sobre o trabalho familiar agrícola por sexo $(\mathrm{em} f \mathrm{e} \%)$

\begin{tabular}{|c|c|c|c|c|c|}
\hline & & & \multicolumn{2}{|c|}{ SEXO } & \multirow[b]{2}{*}{ Total } \\
\hline & & & Homens & Mulheres & \\
\hline \multirow{12}{*}{$\begin{array}{l}\text { QUE FRASE } \\
\text { SE APROXIMA } \\
\text { MAIS DO QUE } \\
\text { VOCÊ PENSA } \\
\text { SOBRE O } \\
\text { TRABALHO } \\
\text { FAMILIAR } \\
\text { AGRÍCOLA? }\end{array}$} & \multirow{2}{*}{$\begin{array}{l}\text { Trabalho digno, importante para a } \\
\text { sociedade. }\end{array}$} & $f$ & 139 & 100 & 239 \\
\hline & & $\%$ & $32,7 \%$ & $39,5 \%$ & $35,3 \%$ \\
\hline & \multirow[t]{2}{*}{ Não é valorizado pela sociedade. } & $f$ & 61 & 29 & 90 \\
\hline & & $\%$ & $14,4 \%$ & $11,5 \%$ & $13,3 \%$ \\
\hline & \multirow{2}{*}{$\begin{array}{l}\text { Traz satisfação ver crescer o fruto do } \\
\text { próprio trabalho. }\end{array}$} & $f$ & 84 & 48 & 132 \\
\hline & & $\%$ & $19,8 \%$ & $19,0 \%$ & $19,5 \%$ \\
\hline & \multirow{2}{*}{$\begin{array}{l}\text { Trabalho pesado, insalubre e sem } \\
\text { descanso. }\end{array}$} & $f$ & 29 & 27 & 56 \\
\hline & & $\%$ & $6,8 \%$ & $10,7 \%$ & $8,3 \%$ \\
\hline & \multirow{2}{*}{$\begin{array}{l}\text { Permite ter independência financeira, } \\
\text { ser dono do próprio negócio. }\end{array}$} & $f$ & 101 & 37 & 138 \\
\hline & & $\%$ & $23,8 \%$ & $14,6 \%$ & $20,4 \%$ \\
\hline & \multirow[t]{2}{*}{ Não traz retorno financeiro só prejuízo. } & $f$ & 11 & 12 & 23 \\
\hline & & $\%$ & $2,6 \%$ & $4,7 \%$ & $3,4 \%$ \\
\hline \multirow{2}{*}{\multicolumn{2}{|c|}{ Total }} & $f$ & 425 & 253 & 678 \\
\hline & & $\%$ & $100,0 \%$ & $100,0 \%$ & $100,0 \%$ \\
\hline
\end{tabular}

Fonte: Banco de dados Jovens Agricultores Familiares RS - MDA/FAURGS, 2007.

O cruzamento desta questão por faixa etária permite destacar que a resposta trabalho digno, importante para a sociedade é a mais frequente entre jovens agricultores de todas as idades (Tabela 36). Os jovens adolescentes também apontam a satisfação em ver crescer o fruto do próprio trabalho, enquanto os demais enfatizam o aspecto da autonomia financeira (resposta que apresenta maior incidência com o aumento da faixa etária). Também a ideia de que é um trabalho pesado e insalubre cresce em função da idade dos indivíduos. 
Tabela 36: Cruzamento das representações sobre o trabalho familiar agrícola por faixa etária (em $f$ e \%)

\begin{tabular}{|c|c|c|c|c|c|}
\hline & & & \multicolumn{2}{|c|}{ SEXO } & \multirow[b]{2}{*}{ Total } \\
\hline & & & Homens & Mulheres & \\
\hline \multirow{12}{*}{$\begin{array}{l}\text { QUE FRASE } \\
\text { SE APROXIMA } \\
\text { MAIS DO QUE } \\
\text { VOCÊ PENSA } \\
\text { SOBRE O } \\
\text { TRABALHO } \\
\text { FAMILIAR } \\
\text { AGRÍCOLA? }\end{array}$} & \multirow{2}{*}{$\begin{array}{l}\text { Trabalho digno, importante para a } \\
\text { sociedade. }\end{array}$} & f & 139 & 100 & 239 \\
\hline & & $\%$ & $32,7 \%$ & $39,5 \%$ & $35,3 \%$ \\
\hline & \multirow[t]{2}{*}{ Não é valorizado pela sociedade. } & f & 61 & 29 & 90 \\
\hline & & $\%$ & $14,4 \%$ & $11,5 \%$ & $13,3 \%$ \\
\hline & \multirow{2}{*}{$\begin{array}{l}\text { Traz satisfação ver crescer o fruto do } \\
\text { próprio trabalho. }\end{array}$} & $f$ & 84 & 48 & 132 \\
\hline & & $\%$ & $19,8 \%$ & $19,0 \%$ & $19,5 \%$ \\
\hline & \multirow{2}{*}{$\begin{array}{l}\text { Trabalho pesado, insalubre e sem } \\
\text { descanso. }\end{array}$} & f & 29 & 27 & 56 \\
\hline & & $\%$ & $6,8 \%$ & $10,7 \%$ & $8,3 \%$ \\
\hline & \multirow{2}{*}{$\begin{array}{l}\text { Permite ter independência financeira, } \\
\text { ser dono do próprio negócio. }\end{array}$} & f & 101 & 37 & 138 \\
\hline & & $\%$ & $23,8 \%$ & $14,6 \%$ & $20,4 \%$ \\
\hline & \multirow[t]{2}{*}{ Não traz retorno financeiro só prejuízo. } & $f$ & 11 & 12 & 23 \\
\hline & & $\%$ & $2,6 \%$ & $4,7 \%$ & $3,4 \%$ \\
\hline \multirow{2}{*}{\multicolumn{2}{|c|}{ Total }} & $f$ & 425 & 253 & 678 \\
\hline & & $\%$ & $100,0 \%$ & $100,0 \%$ & $100,0 \%$ \\
\hline
\end{tabular}

Fonte: Banco de dados Jovens Agricultores Familiares RS - MDA/FAURGS, 2007.

No Gráfico 39, apresentamos o cruzamento das respostas à mesma pergunta com as variáveis faixa etária e sexo. Percebe-se que predomina, em todos os estratos, a noção de que o trabalho familiar agrícola é uma atividade digna e importante para a sociedade, o que pode ser interpretado como efeito do processo de socialização profissional realizada pela família. Paradoxalmente, os maiores percentuais desta resposta estão entre as mulheres. Justamente aquelas cuja participação no processo produtivo é classificada como ajuda, diluída nas categorias toda família ou mãe e filha, conforme visto no capítulo anterior. Os inquiridos do sexo masculino de 15 a 19 anos apontam em segundo lugar que traz satisfação ver o fruto do próprio trabalho. O mesmo ocorre com as jovens de todas as faixas etárias. Contudo, os homens de 20 a 24 anos e de 25 a 29 anos entendem que o trabalho permite ter independência financeira. Os percentuais relativos às avaliações negativas são mais expressivos entre as mulheres, principalmente a que considera trabalho pesado, insalubre e sem descanso. Esta questão é, sem dúvida, a principal reclamação das jovens com relação a esta atividade, enquanto que os homens apontam que este trabalho não é valorizado pela sociedade, o que tem relação com os baixos rendimentos financeiros da atividade e o desprestigio social do trabalho manual. 


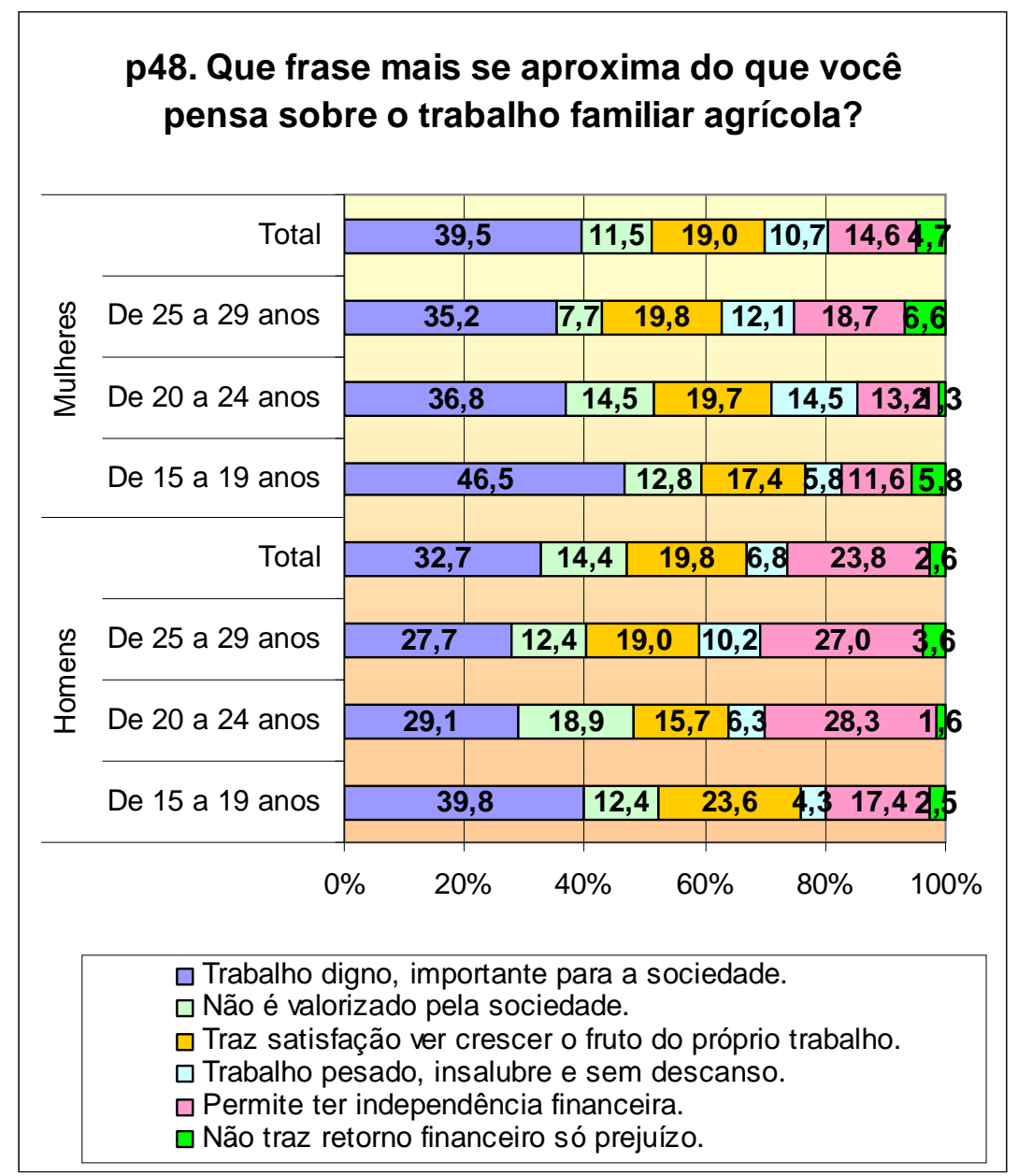

Gráfico 39: Cruzamento das representações sobre o trabalho familiar agrícola por faixa etária e sexo (\%) Fonte: Banco de dados Jovens Agricultores Familiares RS - MDA/FAURGS, 2007.

Os jovens foram instigados ainda a se posicionar em relação ao trabalho por meio do questionamento Que frase mais se aproxima do que você pensa sobre o trabalho assalariado não-agrícola? Novamente, as opções de respostas tiveram origem no teste do instrumento de pesquisa por meio de questão aberta, do qual foram obtidas alternativas de respostas com avaliações positivas e negativas na mesma quantidade e intercaladas. No Gráfico 40, observa-se que $27,6 \%$ deles pensam que é um trabalho mais leve, com direito a descanso nos fins de semana. Para outros $27,4 \%$ dos entrevistados, este é visto com ressalvas, uma vez que tem muito desemprego, é muito instável e de difícil contratação. Em terceiro lugar nas frequências de respostas, com 22,8\%, aparece a ideia de que tem a garantia de recebimento de um salário ao final do mês. Assim, existe certa valorização dos direitos relativos ao trabalho assalariado nãoagrícola. 


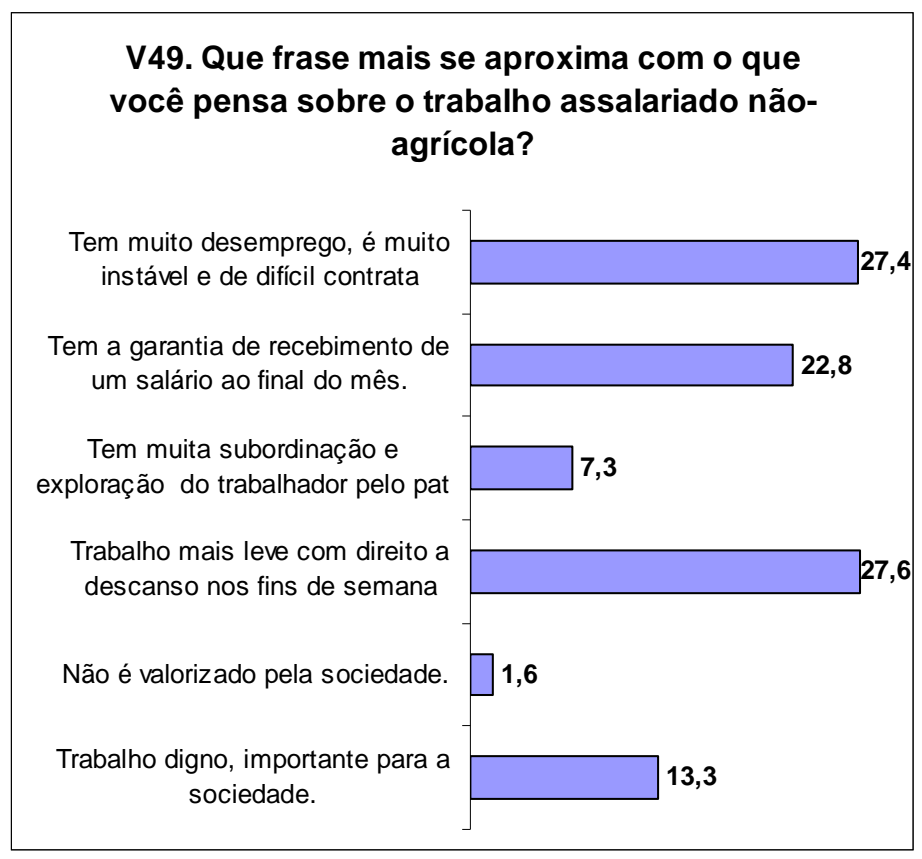

Gráfico 40: Distribuição das representações sobre o trabalho assalariado não-agrícola (\%)

Fonte: Banco de dados Jovens Agricultores Familiares RS - MDA/FAURGS, 2007.

A mesma questão analisada por sexo (Tabela 37) mostra que os homens respondem, principalmente, que o trabalho não-agrícola é mais leve $(28,8 \%)$ e que tem muito desemprego e dificuldade de inserção $(24,1 \%)$. As mulheres destacam mais as dificuldades de inserção e depois que se trata de um trabalho mais leve do que o agrícola..

Tabela 37: Cruzamento das representações sobre o trabalho assalariado não-agrícola por sexo (em $f$ e \%)

\begin{tabular}{|c|c|c|c|c|c|}
\hline & & & \multicolumn{2}{|c|}{ SEXO } & \multirow[b]{2}{*}{ Total } \\
\hline & & & Homens & Mulheres & \\
\hline \multirow{12}{*}{$\begin{array}{l}\text { QUE FRASE SE } \\
\text { APROXIMA MAIS } \\
\text { DO QUE VOCE } \\
\text { PENSA SOBRE O } \\
\text { TRABALHO } \\
\text { ASSALARIADO E } \\
\text { NÃO-AGRÍCOLA? }\end{array}$} & \multirow{2}{*}{$\begin{array}{l}\text { Trabalho digno, importante para a } \\
\text { sociedade. }\end{array}$} & $f$ & 53 & 37 & 90 \\
\hline & & $\%$ & $12,5 \%$ & $14,7 \%$ & $13,3 \%$ \\
\hline & \multirow[t]{2}{*}{ Não é valorizado pela sociedade. } & $f$ & 6 & 5 & 11 \\
\hline & & $\%$ & $1,4 \%$ & $2,0 \%$ & $1,6 \%$ \\
\hline & \multirow{2}{*}{$\begin{array}{l}\text { Trabalho mais leve com direito a descanso } \\
\text { nos fins de semana. }\end{array}$} & $f$ & 122 & 64 & 186 \\
\hline & & $\%$ & $28,8 \%$ & $25,4 \%$ & $27,6 \%$ \\
\hline & \multirow{2}{*}{$\begin{array}{l}\text { Tem muita subordinação e exploração do } \\
\text { trabalhador pelo patrão. }\end{array}$} & $f$ & 39 & 10 & 49 \\
\hline & & $\%$ & $9,2 \%$ & $4,0 \%$ & $7,3 \%$ \\
\hline & \multirow{2}{*}{$\begin{array}{l}\text { Tem a garantia de recebimento de um } \\
\text { salário ao final do mês. }\end{array}$} & $f$ & 101 & 53 & 154 \\
\hline & & $\%$ & $23,9 \%$ & $21,0 \%$ & $22,8 \%$ \\
\hline & \multirow{2}{*}{$\begin{array}{l}\text { Tem muito desemprego, é muito instável e } \\
\text { de difícil contratação. }\end{array}$} & $f$ & 102 & 83 & 185 \\
\hline & & $\%$ & $24,1 \%$ & $32,9 \%$ & $27,4 \%$ \\
\hline \multirow[t]{2}{*}{ Total } & & $f$ & 423 & 252 & 675 \\
\hline & & $\%$ & $100,0 \%$ & $100,0 \%$ & $100,0 \%$ \\
\hline
\end{tabular}

Fonte: Banco de dados Jovens Agricultores Familiares RS - MDA/FAURGS, 2007. 
Quanto à influência das diferenças etárias nas opções de resposta, podemos verificar, na Tabela 38, que os jovens adolescentes enfatizam prioritariamente a ideia de que o trabalho assalariado é mais leve do que o agrícola (31,3\%), e depois de que neste segmento tem muito desemprego (25,6\%). Entre os entrevistados de 20 a 24 anos, estas duas categorias de respostas figuram com percentuais próximos (25,6\% para a primeira e $25,1 \%$ para a segunda), mas a garantia de uma remuneração periódica antecede à percepção de instabilidade e de dificuldade de contratação, com 25,6\% dos casos. Esta última noção foi a mais indicada pelos que têm de 25 a 29 anos $(31,4 \%)$. Eles também consideram o trabalho não-agrícola menos penoso.

Tabela 38: Cruzamento das representações sobre o trabalho assalariado não-agrícola por faixa etária $(\%)$

\begin{tabular}{|c|c|c|c|c|c|c|}
\hline & & & \multicolumn{3}{|c|}{ FAIXA ETÁRIA: } & \multirow[b]{2}{*}{ Total } \\
\hline & & & $\begin{array}{l}\text { De } 15 \text { a } \\
19 \text { anos }\end{array}$ & $\begin{array}{l}\text { De } 20 \text { a } \\
24 \text { anos }\end{array}$ & $\begin{array}{l}\text { De } 25 \text { a } \\
29 \text { anos }\end{array}$ & \\
\hline \multirow{12}{*}{$\begin{array}{l}\text { QUE FRASE SE } \\
\text { APROXIMA MAIS } \\
\text { DO QUE VOCÊ } \\
\text { PENSA SOBRE O } \\
\text { TRABALHO } \\
\text { ASSALARIADO E } \\
\text { NÃO-AGRÍCOLA? }\end{array}$} & \multirow{2}{*}{$\begin{array}{l}\text { Trabalho digno, importante para a } \\
\text { sociedade. }\end{array}$} & $f$ & 37 & 31 & 22 & 90 \\
\hline & & $\%$ & $15,0 \%$ & $15,3 \%$ & $9,7 \%$ & $13,3 \%$ \\
\hline & \multirow[t]{2}{*}{ Não é valorizado pela sociedade. } & $f$ & 3 & 4 & 4 & 11 \\
\hline & & $\%$ & $1,2 \%$ & $2,0 \%$ & $1,8 \%$ & $1,6 \%$ \\
\hline & \multirow{2}{*}{$\begin{array}{l}\text { Trabalho mais leve com direito a } \\
\text { descanso nos fins de semana. }\end{array}$} & $f$ & 77 & 52 & 57 & 186 \\
\hline & & $\%$ & $31,3 \%$ & $25,6 \%$ & $25,2 \%$ & $27,6 \%$ \\
\hline & \multirow{2}{*}{$\begin{array}{l}\text { Tem muita subordinação e exploração } \\
\text { do trabalhador pelo patrão. }\end{array}$} & $f$ & 14 & 13 & 22 & 49 \\
\hline & & $\%$ & $5,7 \%$ & $6,4 \%$ & $9,7 \%$ & $7,3 \%$ \\
\hline & \multirow{2}{*}{$\begin{array}{l}\text { Tem a garantia de recebimento de um } \\
\text { salário ao final do mês. }\end{array}$} & $f$ & 52 & 52 & 50 & 154 \\
\hline & & $\%$ & $21,1 \%$ & $25,6 \%$ & $22,1 \%$ & $22,8 \%$ \\
\hline & \multirow{2}{*}{$\begin{array}{l}\text { Tem muito desemprego, é muito instável } \\
\text { e de difícil contratação. }\end{array}$} & $f$ & 63 & 51 & 71 & 185 \\
\hline & & $\%$ & $25,6 \%$ & $25,1 \%$ & $31,4 \%$ & $27,4 \%$ \\
\hline \multirow[t]{2}{*}{ Total } & & $f$ & 246 & 203 & 226 & 675 \\
\hline & & $\%$ & $100,0 \%$ & $100,0 \%$ & $100,0 \%$ & $100,0 \%$ \\
\hline
\end{tabular}

Fonte: Banco de dados Jovens Agricultores Familiares RS - MDA/FAURGS, 2007.

No Gráfico 41, temos o cruzamento das representações sobre o trabalho assalariado por faixa etária e sexo dos entrevistados. Verifica-se que os homens mais jovens percebem o trabalho assalariado não-agrícola como mais leve, com direito a descanso nos fins de semana $(34,4 \%)$. Aqueles que têm de 20 a 24 anos indicam, principalmente, que tem a garantia de recebimento de um salário ao final do mês $(27,6 \%)$ e os que têm de 25 a 29 anos destacam que tem muito desemprego, é muito instável e de difícil contratação (28,7\%). Entre as mulheres, predomina - em todas as faixas etárias - esta última categoria de resposta, seguida da menor penosidade da atividade. Este conjunto de dados indica que se de um lado os jovens agricultores 
familiares percebem vantagens no trabalho assalariado não-agrícola, em comparação com o trabalho familiar agrícola, principalmente relacionado ao menor esforço físico e a regularidade dos rendimentos, também, avaliam como restrita suas chances de inserção produtiva fora da agricultura. Sobre este aspecto, chama atenção o fato de serem as mulheres que apontam com mais frequência as dificuldades de contratação. Essa percepção parece estar vinculada a uma maior frequência na escola formal entre as adolescentes e a um maior envolvimento nas dinâmicas do trabalho familiar entre as jovens adultas. Estas últimas são, em sua grande maioria, já casadas com agricultores e, muitas vezes, com filhos pequenos, o que estaria na raiz de sua percepção das dificuldades de inserção produtiva fora da unidade de produção familiar.

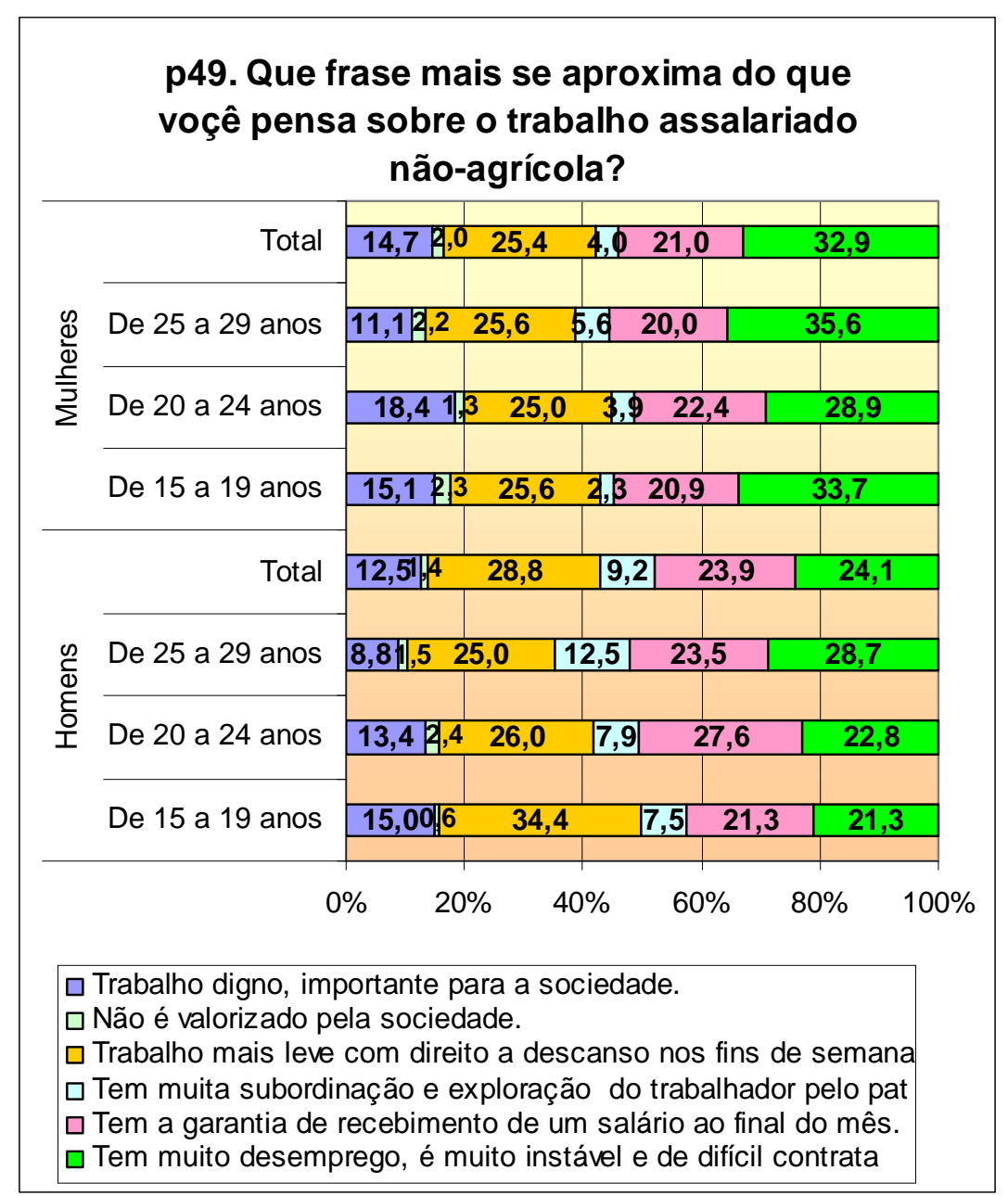

Gráfico 41: Cruzamento das representações sobre o trabalho assalariado não-agrícola por faixa etária e sexo (\%) Fonte: Banco de dados Jovens Agricultores Familiares RS - MDA/FAURGS, 2007. 
O exame das avaliações, que os entrevistados fazem do trabalho que realizam, demonstra que atual geração dos jovens agricultores compartilha uma avaliação predominantemente positiva sobre trabalho familiar agrícola. Eles percebem a importância do seu envolvimento para a realização do trabalho. Com grande frequência, atribuem a este processo de trabalho valores que enfatizam a dignidade do trabalho, a possibilidade de independência financeira e a satisfação com a realização do trabalho. Por sua vez, o trabalho não-agrícola é visto com ressalvas, se de um lado os jovens percebem que este é mais leve que o agrícola e assegura um rendimento fixo mensal, aspectos que o tornam mais atraente, por outro lado identificam as dificuldades de inserção apontando o desemprego e as dificuldades de contratação como obstáculos. Destaca-se que as diferenças por sexo e faixas etárias demonstram que as mulheres e os adolescentes apresentam opiniões um pouco mais negativas sobre o trabalho agrícola. Entre os homens de 25 a 29 anos, encontram-se as avaliações mais positivas entre todos os estratos juvenis analisados, o que se deve ao fato de que estes últimos já se encontram inseridos na agricultura familiar como força plena (TEPICHT, 1973) é não mais como quem apenas "ajuda".

\subsection{AVALIAÇÕES SOBRE O MODO DE VIDA DOS PAIS}

Neste tópico, são apresentadas as informações relativas às avaliações que os jovens agricultores fazem do modo de vida de seus pais e de sua disposição em viver da mesma maneira que eles. Foi utilizado, deliberadamente, o conceito de modo de vida para apreender as percepções dos jovens sobre as condições materiais e práticas sociais dotadas de particularidades próprias do processo de trabalho que realizam. Nas respostas obtidas, 50,9\% dos inquiridos avaliam o modo de vida dos pais como bom e outros $21,5 \%$ como ótimo, enquanto que $23,8 \%$ avaliam-na como regular. Deste modo, percebe-se que predominam avaliações positivas sobre a questão (Gráfico 42). 


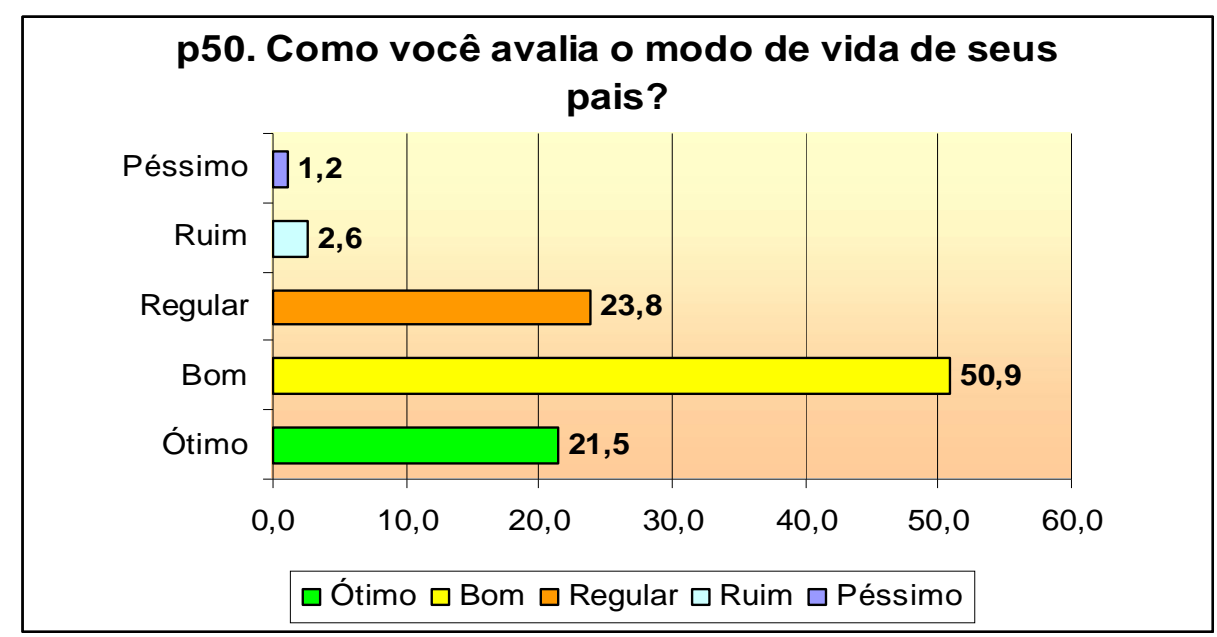

Gráfico 42: Avaliação do modo de vida dos pais (\%)

Fonte: Banco de dados Jovens Agricultores Familiares RS - MDA/FAURGS, 2007.

Estas respostas apresentam diferenças por sexo como se pode observar na Tabela 39. Verifica-se que, entre os homens, predominam avaliações como bom (52\%) e ótimo (22\%), enquanto entre as mulheres são as de bom (49\%) e regular (27,3\%). O percentual das entrevistadas que consideram o modo de vida dos pais como ótimo é de 18,9\%. O predomínio de avaliações positivas (ótimo e bom), entre ambos os sexos, não deixa de revelar que os homens estão em maior conformidade com o modo de vidas dos pais do que as jovens mulheres. Elas apresentam avaliações mais críticas do que eles sobre este assunto, visto que praticamente um terço das entrevistados respondeu regular, ruim e péssimo.

Tabela 39: Avaliação do modo de vida dos pais por sexo (em $f$ e \%)

\begin{tabular}{|c|c|c|c|c|c|}
\hline & & & \multicolumn{2}{|c|}{ SEXO } & \multirow[b]{2}{*}{ Total } \\
\hline & & & Homens & Mulheres & \\
\hline \multirow{10}{*}{$\begin{array}{l}\text { COMO VOCÊ } \\
\text { AVALIA O } \\
\text { MODO DE VIDA- } \\
\text { DE SEUS } \\
\text { PAIS? }\end{array}$} & Ótimo & $f$ & 99 & 47 & 146 \\
\hline & & $\%$ & $23,2 \%$ & $18,6 \%$ & $21,5 \%$ \\
\hline & Bom & $f$ & 222 & 124 & 346 \\
\hline & & $\%$ & $52,0 \%$ & $49,0 \%$ & $50,9 \%$ \\
\hline & Regular & $f$ & 93 & 69 & 162 \\
\hline & & $\%$ & $21,8 \%$ & $27,3 \%$ & $23,8 \%$ \\
\hline & Ruim & $f$ & 9 & 9 & 18 \\
\hline & & $\%$ & $2,1 \%$ & $3,6 \%$ & $2,6 \%$ \\
\hline & Péssimo & $f$ & 4 & 4 & 8 \\
\hline & & $\%$ & ,9\% & $1,6 \%$ & $1,2 \%$ \\
\hline \multirow[t]{2}{*}{ Total } & & $f$ & 427 & 253 & 680 \\
\hline & & $\%$ & $100,0 \%$ & $100,0 \%$ & $100,0 \%$ \\
\hline
\end{tabular}

Fonte: Banco de dados Jovens Agricultores Familiares RS - MDA/FAURGS, 2007. 
Relacionando esta questão com a variável faixa etária pode ser gerada a Tabela 40. Os inquiridos de 15 a 19 anos consideram o modo de vida dos pais bom $(53,2 \%)$ e ótimo (22\%). Nas faixas etárias seguintes, prevalecem as avaliações bom e regular, sendo que esta última categoria de resposta apresenta uma variação positiva de dez pontos percentuais da primeira faixa etária para a ultima. Registra-se que o maior percentual da categoria de resposta ruim $(5,2 \%)$ encontrase entre os jovens mais novos, enquanto péssimo aparece entre os mais velhos $(2,2 \%)$. Outrossim, de maneira geral as respostas negativas sobre o modo de vida dos pais (regular, ruim e péssimo), aumentam seus percentuais conforme avança a faixa de idade dos entrevistados. A maior parte destes jovens adultos desempenha funções mais complexas na propriedade dos pais, ou já se encontram casados e responsáveis por uma unidade produtiva própria. Deste modo, suas respostas refletem uma avaliação mais profunda e efetiva de suas principais referências que sãos os próprios pais. Além disto, esta posição crítica está relacionada com o aumento dos conflitos entre os jovens desta faixa de idade e seus pais, geralmente relacionados à busca por mais autonomia e independência financeira ou - ainda - para desenvolverem inovações nas unidades produtivas das famílias, enfrentando resistências dos responsáveis pelo estabelecimento. Com efeito, as avaliações negativas correspondem a uma afirmação por parte destes jovens das mudanças que pretendem realizar nas unidades familiares e que envolvem não apenas o sistema de produção e a intensidade do trabalho; também as formas de relacionamento entre os membros do grupo doméstico.

Tabela 40: Avaliação do modo de vida dos pais por faixa etária (em $f$ e \%)

\begin{tabular}{|c|c|c|c|c|c|c|}
\hline & & & \multicolumn{3}{|c|}{ FAIXA ETÁRIA: } & \multirow[b]{2}{*}{ Total } \\
\hline & & & $\begin{array}{l}\text { De } 15 \text { a } \\
19 \text { anos }\end{array}$ & $\begin{array}{l}\text { De } 20 \text { a } \\
24 \text { anos }\end{array}$ & $\begin{array}{l}\text { De } 25 \text { a } \\
29 \text { anos }\end{array}$ & \\
\hline \multirow{10}{*}{$\begin{array}{l}\text { COMO VOCÊ } \\
\text { AVALIA O } \\
\text { MODO DE VIDA- } \\
\text { DE SEUS } \\
\text { PAIS? }\end{array}$} & Ótimo & $f$ & 55 & 42 & 49 & 146 \\
\hline & & $\%$ & $22,0 \%$ & $20,8 \%$ & $21,5 \%$ & $21,5 \%$ \\
\hline & Bom & $f$ & 133 & 108 & 105 & 346 \\
\hline & & $\%$ & $53,2 \%$ & $53,5 \%$ & $46,1 \%$ & $50,9 \%$ \\
\hline & Regular & $f$ & 47 & 49 & 66 & 162 \\
\hline & & $\%$ & $18,8 \%$ & $24,3 \%$ & $28,9 \%$ & $23,8 \%$ \\
\hline & Ruim & $f$ & 13 & 2 & 3 & 18 \\
\hline & & $\%$ & $5,2 \%$ & $1,0 \%$ & $1,3 \%$ & $2,6 \%$ \\
\hline & Péssimo & $f$ & 2 & 1 & 5 & 8 \\
\hline & & $\%$ & ,8\% &, $5 \%$ & $2,2 \%$ & $1,2 \%$ \\
\hline \multirow[t]{2}{*}{ Total } & & $f$ & 250 & 202 & 228 & 680 \\
\hline & & $\%$ & $100,0 \%$ & $100,0 \%$ & $100,0 \%$ & $100,0 \%$ \\
\hline
\end{tabular}

Fonte: Banco de dados Jovens Agricultores Familiares RS - MDA/FAURGS, 2007. 
Os jovens agricultores familiares demonstram, em grande parte, que estão em conformidade com modo de vida dos pais. Como é possível visualizar no Gráfico 43, os entrevistados de ambos os sexos e faixas etárias avaliam, principalmente como bom, o modo de vida dos pais. As jovens adolescentes são as que mais respondem que o modo de vida de seus pais é ruim; as entrevistadas de 25 a 29 anos são as que mais avaliam tal situação como algo péssimo $(3,3 \%)$.

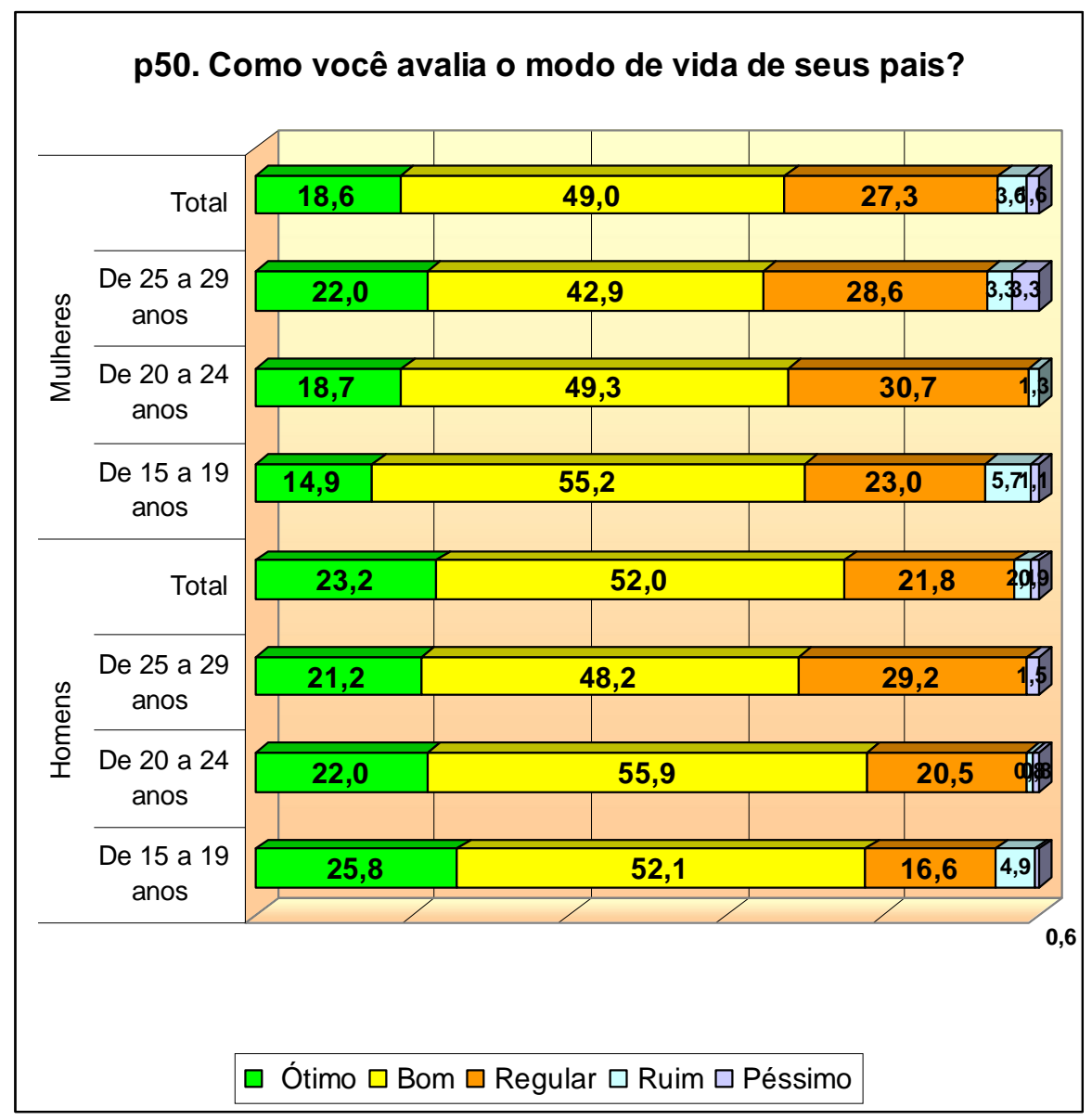

Gráfico 43: Avaliação do modo de vida dos pais por sexo e faixa etária (\%)

Fonte: Banco de dados Jovens Agricultores Familiares RS - MDA/FAURGS, 2007.

A disposição em reproduzir o modo de vida dos pais foi avaliada através das respostas à pergunta: Você gostaria de viver do mesmo modo que seus pais? Conforme o Gráfico 44, em $37,7 \%$ dos casos os entrevistados disseram que mudariam poucas coisas, enquanto que $28,1 \%$ deles responderam que modificariam muitas coisas. Há um percentual de $23,7 \%$ de jovens que responderam $\operatorname{sim}$, enquanto que apenas $10,5 \%$ afirmaram que não. Ao serem colocados diante desta questão, os jovens agricultores revelam uma disposição favorável à reprodução do modo 
de vida dos pais, ao mesmo tempo em que expressam o desejo de mudança nas suas práticas cotidianas. Por sua experiência geracional, os atuais jovens agricultores familiares são portadores de novos valores e desenvolvem comportamentos que os diferem necessariamente de seus pais, de maneira que a disposição à reprodução social do modo de vida incorpora novos elementos de adaptação e transformação.

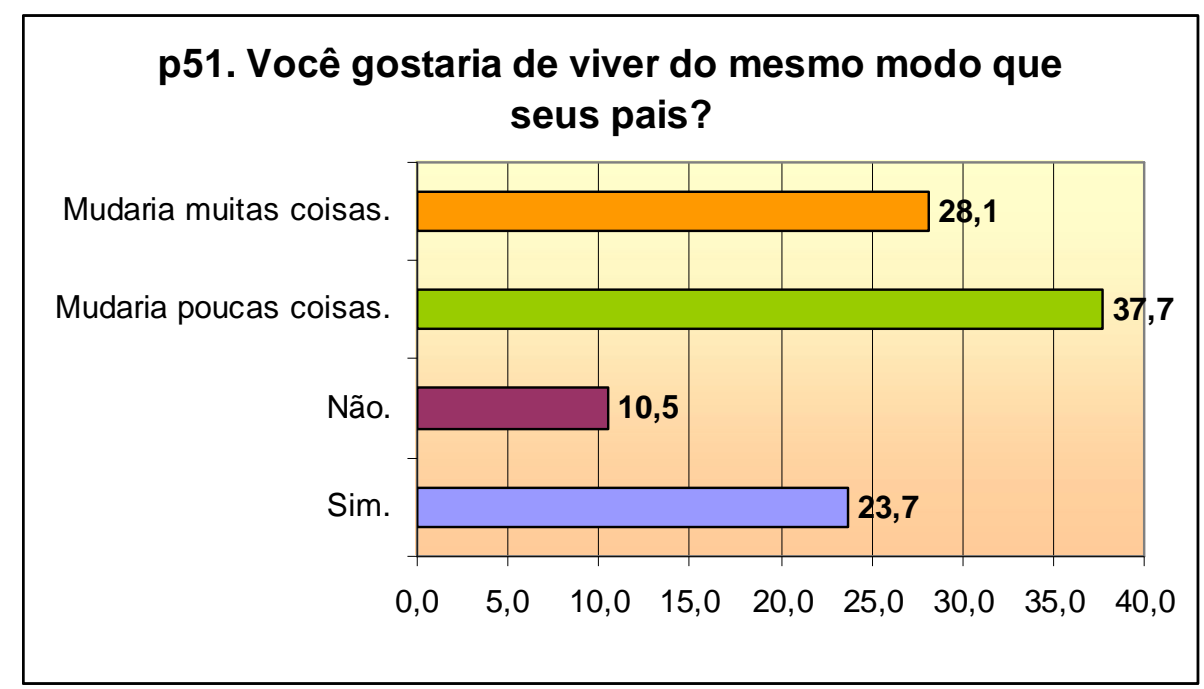

Gráfico 44: Distribuição da disposição para reproduzir o modo de vida dos pais (\%) Fonte: Banco de dados Jovens Agricultores Familiares RS - MDA/FAURGS, 2007.

O cruzamento entre Você gostaria de viver do mesmo modo que seus pais com a variável sexo pode ser verificado na Tabela 41. Os homens respondem de forma positiva mais do que as mulheres. Eles também indicam, de forma mais frequente do que elas, que mudariam poucas coisas. O índice da categoria não é maior entre as jovens, assim como são elas que dizem que mudariam muitas coisas no modo de vida dos pais. Caracteriza-se assim uma visão mais crítica delas sobre o tema. 
Tabela 41: Cruzamento da disposição para reproduzir o modo de vida dos pais por sexo $(\mathrm{em} f \mathrm{e} \%)$

\begin{tabular}{|c|c|c|c|c|c|}
\hline & & & \multicolumn{2}{|c|}{ SEXO } & \multirow[b]{2}{*}{ Total } \\
\hline & & & Homens & Mulheres & \\
\hline \multirow{8}{*}{$\begin{array}{l}\text { VOCÊ GOSTARIA } \\
\text { DE VIVER DO } \\
\text { MESMO MODO } \\
\text { QUE SEUS PAIS? }\end{array}$} & Sim. & $f$ & 111 & 50 & 161 \\
\hline & & $\%$ & $26,1 \%$ & $19,8 \%$ & $23,7 \%$ \\
\hline & Não. & $f$ & 29 & 42 & 71 \\
\hline & & $\%$ & $6,8 \%$ & $16,6 \%$ & $10,5 \%$ \\
\hline & Mudaria poucas coisas. & $f$ & 172 & 84 & 256 \\
\hline & & $\%$ & $40,4 \%$ & $33,2 \%$ & $37,7 \%$ \\
\hline & Mudaria muitas coisas. & $f$ & 114 & 77 & 191 \\
\hline & & $\%$ & $26,8 \%$ & $30,4 \%$ & $28,1 \%$ \\
\hline \multirow[t]{2}{*}{ Total } & & $f$ & 426 & 253 & 679 \\
\hline & & $\%$ & $100,0 \%$ & $100,0 \%$ & $100,0 \%$ \\
\hline
\end{tabular}

Fonte: Banco de dados Jovens Agricultores Familiares RS - MDA/FAURGS, 2007.

Respostas à mesma questão não apresentam diferenças expressivas por faixa etária. Como observado na Tabela 42, há uma pequena queda no percentual de resposta sim na medida em que as idades aumentam. Entre os entrevistados de 20 e 24 anos registra-se o maior índice da resposta mudaria poucas coisas. As diferenças etárias se fazem mais presentes na resposta mudaria muitas coisas, que passa de $25,7 \%$ entre os jovens adolescentes, para $32 \%$ entre os jovens adultos. Considerando as respostas por sexo e faixa etária, não são verificadas diferenças significativas, excetuando o posicionamento das jovens adolescentes que, em 19,5\% dos casos, dizem que não gostariam de viver como seus pais (Gráfico 45).

Tabela 42: Cruzamento da disposição para reproduzir o modo de vida dos pais por faixa etária (em $f$ e \%)

\begin{tabular}{|c|c|c|c|c|c|c|}
\hline & & & \multicolumn{3}{|c|}{ FAIXA ETÁRIA: } & \multirow[b]{2}{*}{ Total } \\
\hline & & & $\begin{array}{l}\text { De } 15 \text { a } \\
19 \text { anos }\end{array}$ & $\begin{array}{l}\text { De } 20 \text { a } \\
24 \text { anos }\end{array}$ & $\begin{array}{l}\text { De } 25 \text { a } \\
29 \text { anos }\end{array}$ & \\
\hline \multirow{8}{*}{$\begin{array}{l}\text { VOCÊ GOSTARIA } \\
\text { DE VIVER DO } \\
\text { MESMO MODO } \\
\text { QUE SEUS PAIS? }\end{array}$} & Sim. & $f$ & 63 & 50 & 48 & 161 \\
\hline & & $\%$ & $25,3 \%$ & $24,8 \%$ & $21,1 \%$ & $23,7 \%$ \\
\hline & Não. & $f$ & 30 & 17 & 24 & 71 \\
\hline & & $\%$ & $12,0 \%$ & $8,4 \%$ & $10,5 \%$ & $10,5 \%$ \\
\hline & Mudaria poucas coisas. & $f$ & 92 & 81 & 83 & 256 \\
\hline & & $\%$ & $36,9 \%$ & $40,1 \%$ & $36,4 \%$ & $37,7 \%$ \\
\hline & Mudaria muitas coisas. & $f$ & 64 & 54 & 73 & 191 \\
\hline & & $\%$ & $25,7 \%$ & $26,7 \%$ & $32,0 \%$ & $28,1 \%$ \\
\hline \multirow[t]{2}{*}{ Total } & & $f$ & 249 & 202 & 228 & 679 \\
\hline & & $\%$ & $100,0 \%$ & $100,0 \%$ & $100,0 \%$ & $100,0 \%$ \\
\hline
\end{tabular}

Fonte: Banco de Dados Jovens Agricultores Familiares RS - MDA/FAURGS, 2007. 


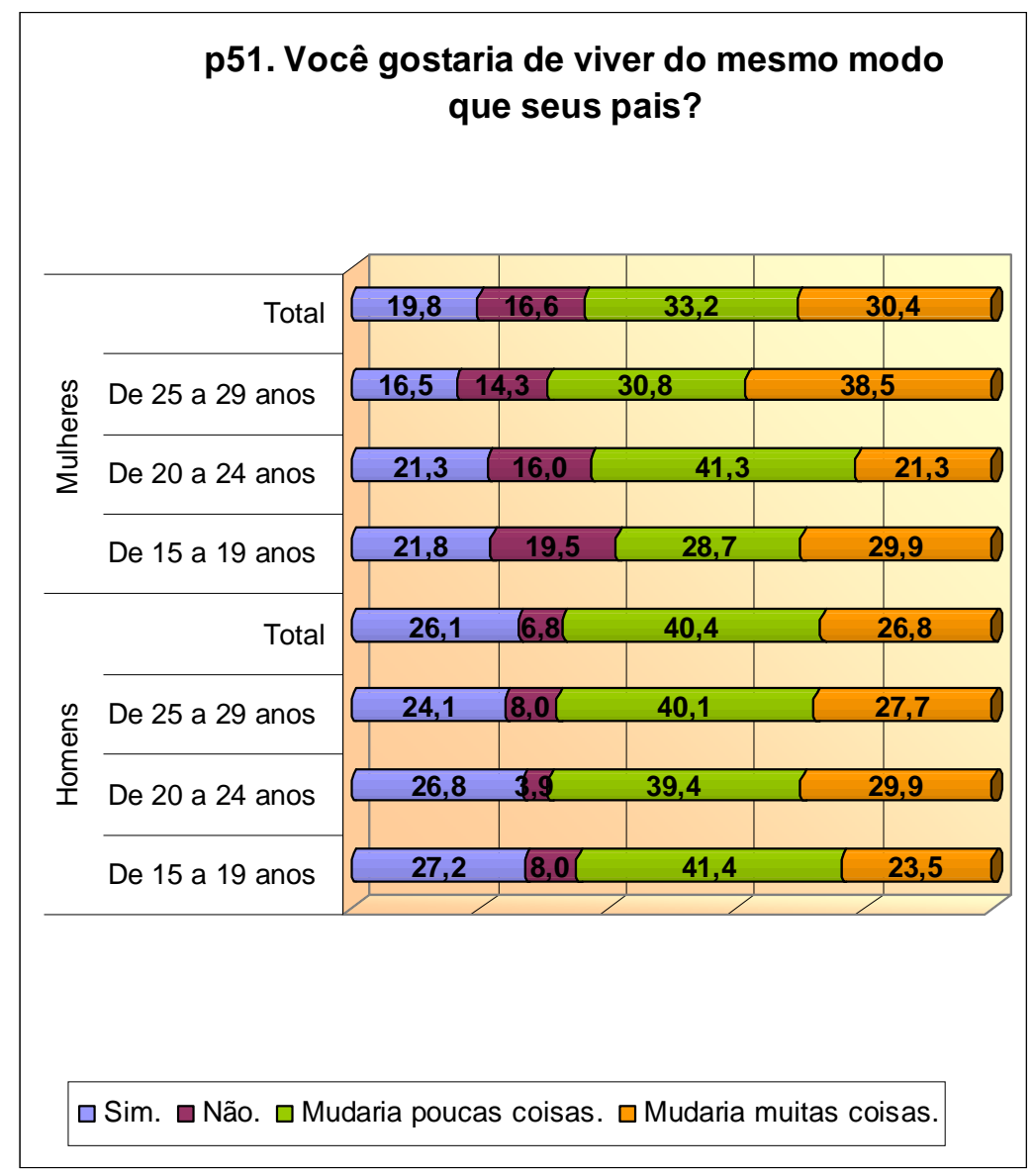

Gráfico 45: Cruzamento da disposição para reproduzir o modo de vida dos pais por faixa etária e sexo (\%) Fonte: Banco de dados Jovens Agricultores Familiares RS - MDA/FAURGS, 2007.

Ainda no tópico que versa sobre as disposições dos jovens em reproduzir o modo de vida dos pais, buscamos saber como eles se posicionam em relação às possibilidades de sucessão da unidade de produção familiar. O processo sucessório corresponde à transferência da gestão da propriedade de pais para os filhos, de uma geração à outra. Este processo vem sendo estudado a partir das expectativas dos adultos, ou seja, dos pais com relação aos filhos, assim, em relação aos atuais agricultores, que são percebidos como os com sucessores ou sem sucessores (GASSON \& ERRITON, 1993; ABRAMOVAY, R. 1998; SILVETRO et al., 2001; BRUMER et al., 2002; SPANAVELO, 2008) [grifos nossos]. Nestes estudos, a unidade de análise tem sido a família; contudo não é raro embasarem suas análises em entrevistas feitas com homens adultos, considerando apenas as opiniões dos "chefes" da unidade produtiva. Com o propósito de superar esta perspectiva adultocentrica, perguntamos aos jovens se pretendiam suceder aos pais na gestão da propriedade familiar. Neste sentido, a questão proposta aborda este tema a partir da perspectiva dos jovens, dando voz àqueles que são, efetivamente, os que realizarão os projetos 
sucessórios das famílias, perspectiva que em geral tem sido negligenciada pelos estudos anteriores.

Conforme mostra o Gráfico 46, a maioria deles $(69,3 \%)$ gostaria de ser sucessor do pai na gestão da UPF. As pretensões juvenis quanto ao processo sucessório do estabelecimento familiar são fortemente marcadas pela condição de gênero. Ocupar o lugar do pai na gestão da propriedade familiar é uma perspectiva mais frequente para os homens (77\%) que para as mulheres $(55,2 \%)$, como pode ser visto na Tabela 43 . O dado mais díspar repousa entre os que não querem suceder. O percentual feminino é o dobro do masculino.

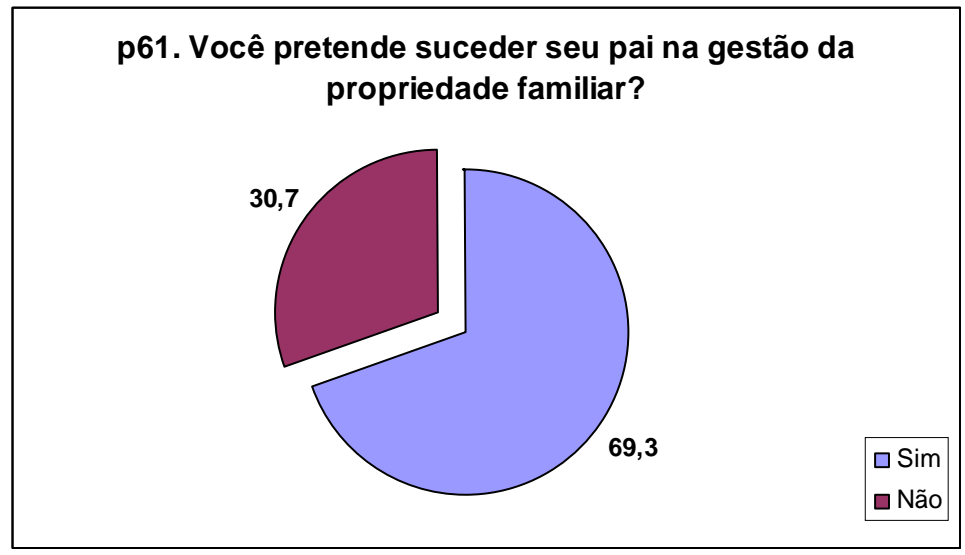

Gráfico 46: Distribuição de perspectiva sucessória na gestão da propriedade familiar (\%)

Fonte: Banco de dados Jovens Agricultores Familiares RS - MDA/FAURGS, 2007.

Tabela 43: Cruzamento entre perspectiva sucessória na gestão da propriedade familiar por sexo $(\mathrm{em} f$ e $\%)$

\begin{tabular}{lcrrrr}
\hline \hline & & \multicolumn{2}{c}{ SEXO } & \\
\cline { 3 - 5 } & & & Homens & Mulheres & \multicolumn{1}{c}{ Total } \\
\hline VOCÉ PRETENDE & Sim & $f$ & 295 & 116 & 411 \\
SUCEDER SEU PAI & & $\%$ & $77,0 \%$ & $55,2 \%$ & $69,3 \%$ \\
\cline { 2 - 5 } NA GESTÃO DA & Não & $\mathrm{f}$ & 88 & 94 & 182 \\
PROPRIEDADE & & $\%$ & $23,0 \%$ & $44,8 \%$ & $30,7 \%$ \\
FAMILIAR? & $\mathrm{f}$ & 383 & 210 & 593 \\
\hline Total & $\%$ & $100,0 \%$ & $100,0 \%$ & $100,0 \%$ \\
& & &
\end{tabular}

Fonte: Banco de dados Jovens Agricultores Familiares RS - DA/FAURGS, 2007.

Verifica-se, também, uma tendência de crescimento da pretensão de suceder aos pais à medida que aumentam as faixas etárias. Na Tabela 44 , observa-se que $61,5 \%$ dos jovens de 15 a 19 anos de idade respondem sim, percentual que aumenta para 72,3\% entre os de 20 a 24 anos e chega a $75,8 \%$ entre os entrevistados de 25 a 29 anos. 
Tabela 44: Cruzamento entre perspectiva sucessória na gestão da propriedade familiar por faixa etária $(\mathrm{em} f$ e $\%)$

\begin{tabular}{|c|c|c|c|c|c|c|}
\hline & & & \multicolumn{3}{|c|}{ FAIXA ETÁRIA: } & \multirow[b]{2}{*}{ Total } \\
\hline & & & $\begin{array}{l}\text { De } 15 \text { a } \\
19 \text { anos }\end{array}$ & $\begin{array}{l}\text { De } 20 \text { a } \\
24 \text { anos }\end{array}$ & $\begin{array}{l}\text { De } 25 \text { a } \\
29 \text { anos }\end{array}$ & \\
\hline \multirow{4}{*}{$\begin{array}{l}\text { VOCÊ PRETENDE } \\
\text { SUCEDER SEU PAI } \\
\text { NA GESTÃO DA } \\
\text { PROPRIEDADE } \\
\text { FAMILIAR? }\end{array}$} & \multirow[t]{2}{*}{ Sim } & $f$ & 139 & 128 & 144 & 411 \\
\hline & & $\%$ & $61,5 \%$ & $72,3 \%$ & $75,8 \%$ & $69,3 \%$ \\
\hline & \multirow[t]{2}{*}{ Não } & $f$ & 87 & 49 & 46 & 182 \\
\hline & & $\%$ & $38,5 \%$ & $27,7 \%$ & $24,2 \%$ & $30,7 \%$ \\
\hline \multirow[t]{2}{*}{ Total } & & $f$ & 226 & 177 & 190 & 593 \\
\hline & & $\%$ & $100,0 \%$ & $100,0 \%$ & $100,0 \%$ & $100,0 \%$ \\
\hline
\end{tabular}

Fonte: Banco de dados Jovens Agricultores Familiares RS - MDA/FAURGS, 2007.

Esta expectativa incorpora todas as posições ocupadas pelos jovens na trajetória familiar, ou seja, na evolução demográfica da família e nos novos valores incorporados por eles, que fazem com que o percentual de mulheres que pretende suceder aos pais se torne expressão daquelas que se percebem como agricultoras e querem ser reconhecidas como tal. Por outro lado, a recusa em suceder os pais na gestão da unidade produtiva evidencia que parte significativa dos entrevistados busca construir novas unidades produtivas ou outras oportunidades de trabalho. As jovens são as que mais se encontram neste grupo. Entre as inquiridas de 15 a 19 anos, 56,7\% têm presente que não serão sucessoras na gestão da propriedade. Entre os homens da mesma idade, $70,9 \%$ pretendem suceder ao pai, percentuais que sobem até $85 \%$ entre os de 25 a 29 anos (Gráfico 47).

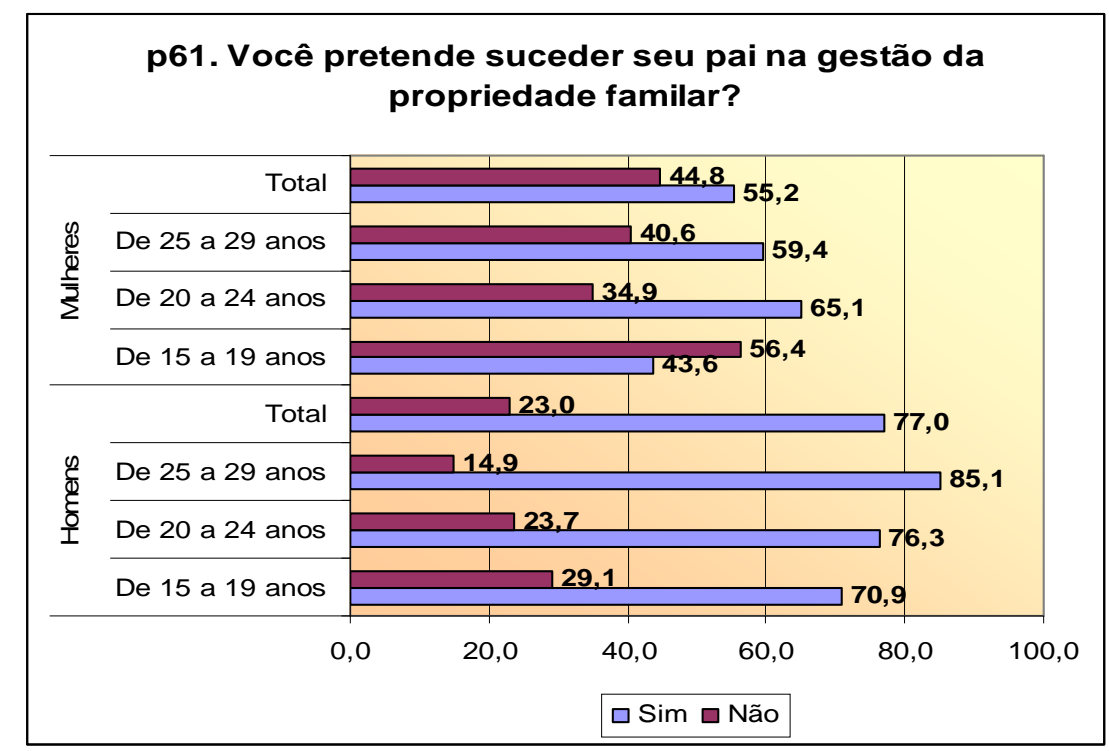

Gráfico 47: Cruzamento entre perspectiva sucessória na gestão da propriedade familiar por faixa etária e sexo (\%) Fonte: Banco de dados Jovens Agricultores Familiares RS - MDA/FAURGS, 2007. 
As possibilidades de reprodução social do modo de vida dos pais envolvem, ainda, o processo de herança do patrimônio familiar, que é a transferência legal da propriedade da terra e dos ativos produtivos da unidade familiar. Como demonstramos no capítulo três deste estudo, a herança é o principal mecanismo de acesso a terra entre os agricultores familiares. Conforme formulou Ellen Woortmann (1995, p. 195) “A herança pode ser entendida como uma retribuição deferida no tempo por um trabalho realizado nessa terra.".

Tendo isto em consideração, os entrevistados foram questionados sobre suas expectativas de herdar a propriedade da família. Suas respostas mostram que predomina a esperança da partilha igualitária, uma vez que $78,1 \%$ dos entrevistados afirmaram que todos os filhos e filhas herdarão igualmente a propriedade. Em 12,3\% dos casos os inquiridos entendem que serão os únicos herdeiros e em $6,8 \%$ não serão, mas receberão alguma compensação (Gráfico 48). O predomínio de respostas que demonstram uma expectativa de herança igualitária por parte dos jovens está em conformidade como os dispositivos legais que reconhecem todos os filhos, independente do sexo, como detentores com direitos iguais sobre a herança dos pais. Outrossim, os estudos realizados nas ultimas três décadas sobre o tema no sul do Brasil demonstra que a prática não é bem assim, como respondem os entrevistados. Neste sentido, o que prevalece é o costume que tende a excluir uma parte dos filhos da herança da terra a fim de evitar seu fracionamento e comprometer sua viabilidade como unidade produtiva. A este respeito, Miriam Nobre (1998, p. 58) menciona que "o costume é não largar a terra para a mulher", ou seja, na prática elas acabam não usufruindo o direito igualitário à herança da terra.

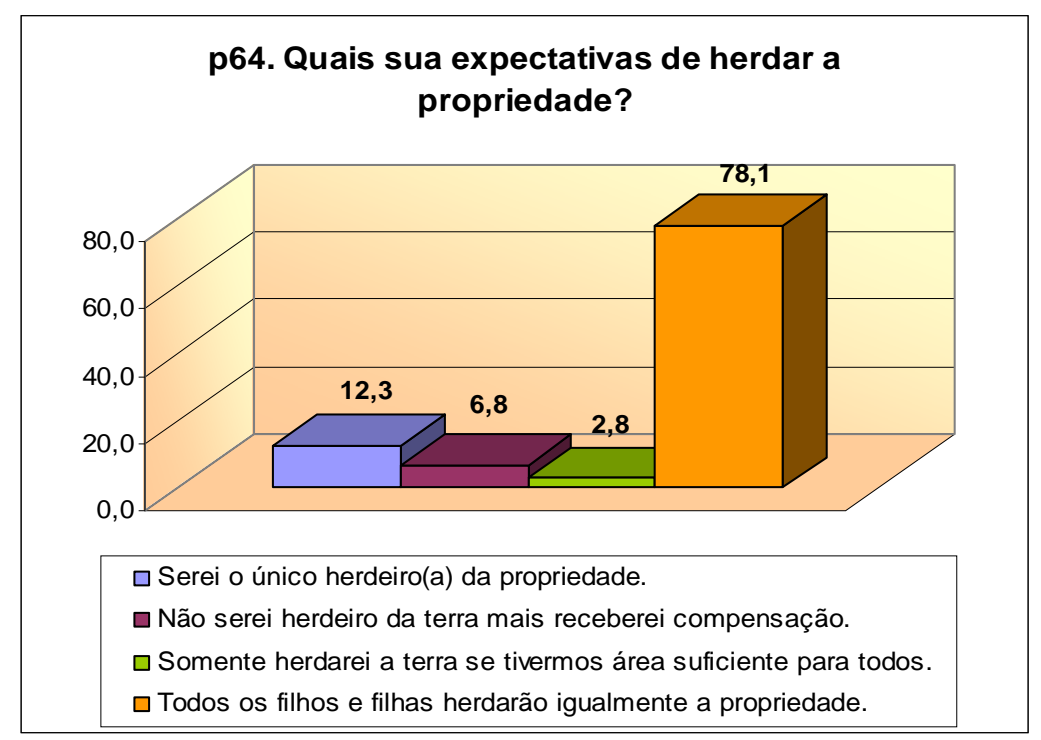

Gráfico 48: Expectativas de herança da propriedade familiar (\%)

Fonte: Banco de dados Jovens Agricultores Familiares RS - MDA/FAURGS, 2007. 
$\mathrm{Na}$ Tabela 45, vemos que os percentuais de resposta de homens e mulheres para esta questão são bastante próximos. A principal diferença aparece quando se trata da expectativa de não herdar a terra, mas receber compensação, nesta condição encontra-se 11,8\% das jovens mulheres entrevistadas; entre os homens, o percentual para esta resposta é de apenas 3,9\%. Com efeito, mesmo que a herança igualitária predomine no universo investigado, isto não representa que as mulheres tenham as mesmas chances que tem os homens de herdar o patrimônio familiar; ao contrário, os dados apontam que elas são preteridas da herança mais do que os homens. Conforme Paulilo (2000), são, principalmente, os filhos homens que herdam a terra enquanto as mulheres se tornam agricultoras por casamento.

\begin{abstract}
Elas recebem herança quando o casal não tem descendência masculina ou quando uma filha casada cuida dos pais até que eles morram. Além disso, o padrão de herança igualitária pode surgir quando a terra não tem mais importância como meio de produção para os filhos ou quando os pais têm propriedades grandes. O que importa reter aqui é que se for preciso excluir alguém, as mulheres são as primeiras a serem escolhidas. Elas são sempre consideradas como "filhas ou esposas de agricultor", termo que identifica tanto as que trabalham nos campos com as que não o fazem. Também quando a terra pertence à mulher por herança, é o marido considerado o responsável (PAULILO, 2000, p. 5).
\end{abstract}

A maior parte dos entrevistados, independente da idade, acredita que todos os filhos e filhas herdarão igualmente a propriedade. Os jovens de 15 a 19 anos indicaram mais do que os outros que serão os únicos a herdar as propriedades. Ainda se registra um aumento na expectativa de herança igualitária entre todos os filhos na medida em que aumenta a faixa de idade dos entrevistados (Tabela 46).

Tabela 45: Expectativas de herança da propriedade por sexo (em $f$ e \%)

\begin{tabular}{|c|c|c|c|c|c|}
\hline & & & \multicolumn{2}{|c|}{ SEXO } & \multirow[b]{2}{*}{ Total } \\
\hline & & & Homens & Mulheres & \\
\hline \multirow{8}{*}{$\begin{array}{l}\text { QUAIS SUAS } \\
\text { EXPECTATIVAS } \\
\text { DE HERDAR A } \\
\text { PROPRIEDADE } \\
\text { FAMILIAR? }\end{array}$} & \multirow{2}{*}{$\begin{array}{l}\text { Serei o único herdeiro(a) da } \\
\text { propriedade. }\end{array}$} & $f$ & 49 & 22 & 71 \\
\hline & & $\%$ & $13,5 \%$ & $10,4 \%$ & $12,3 \%$ \\
\hline & \multirow{2}{*}{$\begin{array}{l}\text { Não serei herdeiro da terra mais } \\
\text { receberei compensação. }\end{array}$} & $f$ & 14 & 25 & 39 \\
\hline & & $\%$ & $3,9 \%$ & $11,8 \%$ & $6,8 \%$ \\
\hline & \multirow{2}{*}{$\begin{array}{l}\text { Somente herdarei a terra se tivermos } \\
\text { área suficiente para todos. }\end{array}$} & $f$ & 11 & 5 & 16 \\
\hline & & $\%$ & $3,0 \%$ & $2,4 \%$ & $2,8 \%$ \\
\hline & \multirow{2}{*}{$\begin{array}{l}\text { Todos os filhos e filhas herdarão } \\
\text { igualmente a propriedade. }\end{array}$} & $f$ & 289 & 160 & 449 \\
\hline & & $\%$ & $79,6 \%$ & $75,5 \%$ & $78,1 \%$ \\
\hline \multirow[t]{2}{*}{ Total } & & $f$ & 363 & 212 & 575 \\
\hline & & $\%$ & $100,0 \%$ & $100,0 \%$ & $100,0 \%$ \\
\hline
\end{tabular}

Fonte: Banco de dados Jovens Agricultores Familiares RS - MDA/FAURGS, 2007. 
Tabela 46: Expectativa de herança da propriedade por faixa etária (em $f$ e \%)

\begin{tabular}{|c|c|c|c|c|c|c|}
\hline & & & \multicolumn{3}{|c|}{ FAIXA ETÁRIA: } & \multirow[b]{2}{*}{ Total } \\
\hline & & & $\begin{array}{l}\text { De } 15 \text { a } \\
19 \text { anos }\end{array}$ & $\begin{array}{l}\text { De } 20 \text { a } \\
24 \text { anos }\end{array}$ & $\begin{array}{l}\text { De } 25 \text { a } \\
29 \text { anos }\end{array}$ & \\
\hline \multirow{8}{*}{$\begin{array}{l}\text { QUAIS SUAS } \\
\text { ExPECTATIVAS } \\
\text { DE HERDAR A } \\
\text { PROPRIEDADE } \\
\text { FAMILIAR? }\end{array}$} & \multirow{2}{*}{$\begin{array}{l}\text { Serei o único herdeiro(a) da } \\
\text { propriedade. }\end{array}$} & $f$ & 32 & 18 & 21 & 71 \\
\hline & & $\%$ & $15,5 \%$ & $9,8 \%$ & $11,4 \%$ & $12,3 \%$ \\
\hline & \multirow{2}{*}{$\begin{array}{l}\text { Não serei herdeiro da terra mais } \\
\text { receberei compensação. }\end{array}$} & $f$ & 15 & 13 & 11 & 39 \\
\hline & & $\%$ & $7,2 \%$ & $7,1 \%$ & $5,9 \%$ & $6,8 \%$ \\
\hline & \multirow{2}{*}{$\begin{array}{l}\text { Somente herdarei a terra se tivermos } \\
\text { área suficiente para todos. }\end{array}$} & $f$ & 5 & 7 & 4 & 16 \\
\hline & & $\%$ & $2,4 \%$ & $3,8 \%$ & $2,2 \%$ & $2,8 \%$ \\
\hline & \multirow{2}{*}{$\begin{array}{l}\text { Todos os filhos e filhas herdarão } \\
\text { igualmente a propriedade. }\end{array}$} & $f$ & 155 & 145 & 149 & 449 \\
\hline & & $\%$ & $74,9 \%$ & $79,2 \%$ & $80,5 \%$ & $78,1 \%$ \\
\hline \multirow[t]{2}{*}{ Total } & & $f$ & 207 & 183 & 185 & 575 \\
\hline & & $\%$ & $100,0 \%$ & $100,0 \%$ & $100,0 \%$ & $100,0 \%$ \\
\hline
\end{tabular}

Fonte: Banco de dados Jovens Agricultores Familiares RS - MDA/FAURGS, 2007.

No Gráfico 49, observamos que os jovens homens de 15 a 19 anos são os que mais esperam herdar, sozinhos, a propriedade (17,2\%). Entre aqueles que têm de 25 a 29 anos, encontramos o maior percentual da perspectiva de herança igualitária $(83,5 \%)$. Entre as mulheres de 20 a 24 anos, está o maior índice da resposta não serei herdeiro da terra, mas receberei compensação $(14,5 \%)$. Esta compensação, no caso das mulheres, tende a ser o enxoval ou dote que começa a ser feito após a jovem completar seu 15 anos de idade e que lhe será entregue por ocasião do casamento.

Sobre esse tema, Carmen Derré e Margarica Leon (2002) concluem que "a medida em que se tornou mais comum as mulheres herdarem a terra, a herança de animais diminuiu e, ao mesmo tempo, as mulheres tendem a perder as bases de sua autonomia econômica relativa" (DEERÈ; LEON, 2002, p. 348). Estes aspectos permanecem e se atualizam, uma vez que, entre a atual geração de jovens agricultoras, a forma de compensação mais comum passa a ser os investimentos financeiros feitos pela família com escolarização, que visam a assegurar uma inserção em condições mais favoráveis no mercado de trabalho local. Além disto, mesmo quando estas são contempladas pela herança, pode ocorrer o que foi identificado por Ellen Woortmann, de tal modo que: "a mulher herda a terra em quantidade menor que seus irmãos que, quando herdam - pois o mais frequente é irem embora - recebem menos que o sucessor, e vendem-lhe sua parte" (WOORTMANN, E. 1995, p. 193). Em consequência, ao acessarem o patrimônio via herança e transferirem este para os irmãos quando são solteiras ou para o marido quando são casadas com agricultor, elas não têm direito a compensações. Caso tenha havido tal 
investimento em dote, enxoval ou escolarização, elas então sabem, por antecipação, que não serão herdeiras.

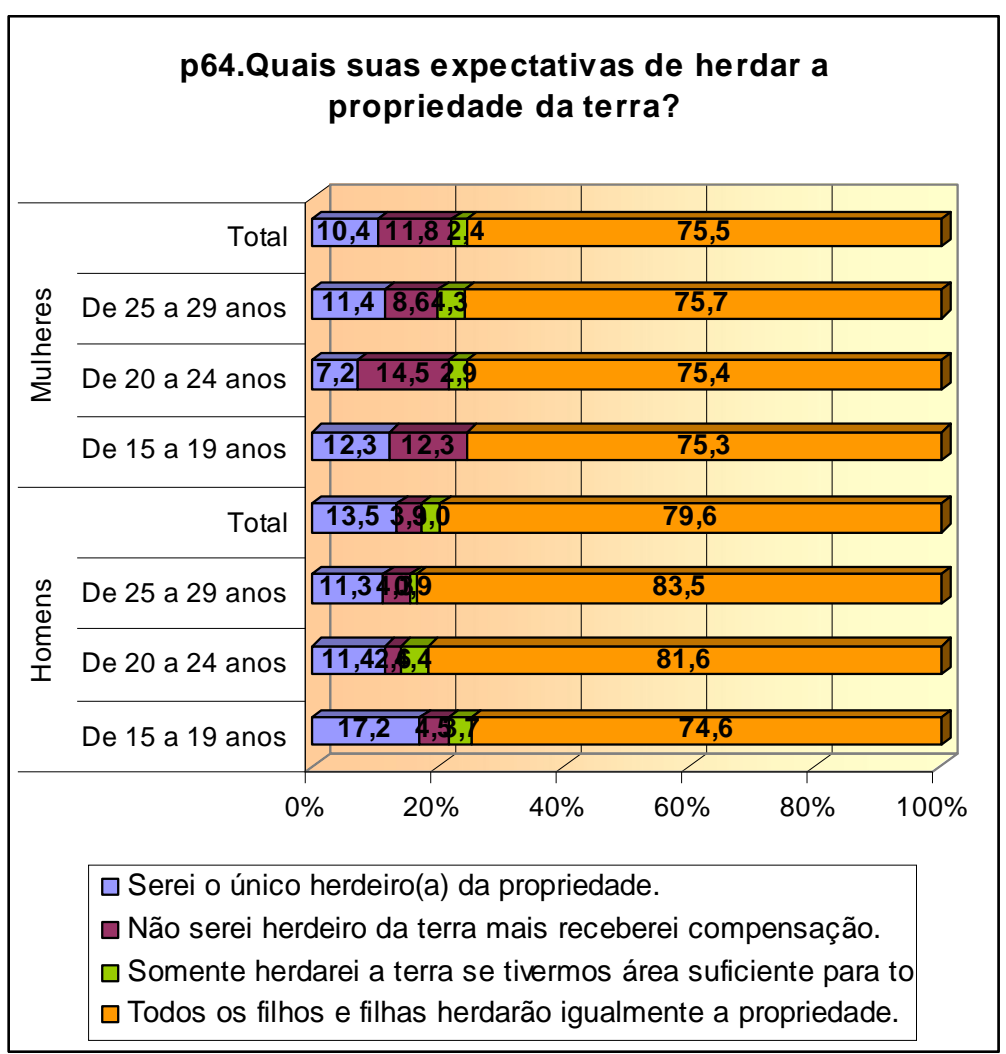

Gráfico 49: Expectativa de herança da propriedade por sexo e faixa etária (\%) Fonte: Banco de dados Jovens Agricultores Familiares RS - MDA/FAURGS, 2007.

As questões analisadas neste tópico permitem demonstrar que os jovens agricultores familiares gaúchos produzem representações predominantemente positivas sobre o modo de vida agrícola. Suas avaliações levam em conta o modo de vida dos pais, que é considerado bom pelos entrevistados. Eles manifestam ainda a disposição em reproduzir este modo de vida, mas apontam a necessidade de promover algumas mudanças. Predomina, entre os inquiridos, a disposição em suceder aos pais na gestão da unidade familiar, sendo que esta é maior entre os homens do que entre as mulheres. Verificou-se ainda as expectativas dos jovens sobre a herança da propriedade. Neste item, predominam respostas segundo as quais todos os filhos e filhas herdarão, igualmente, a propriedade. Contudo, pode ser observado que as jovens mulheres, respondem de modo muito mais frequente do que os homens que não herdarão a propriedade, esperando alguma compensação em troca. Estas expectativas estão mais próximas ao padrão de 
herança que tende a excluir as mulheres, tal como vem sendo observado em estudos realizados no sul do Brasil.

\subsection{O PROCESSO DE IDENTIFICAÇÃO SOCIAL DOS JOVENS AGRICULTORES FAMILIARES}

É recorrente em pesquisas sobre jovens, em especial sobre aqueles que vivem no meio rural, os pesquisadores atribuírem formas de identificação a este segmento social sem que haja uma problematização destas categorias, ou seja, sem que se verifique, por exemplo, se esta é a forma de identificação predominante entre os jovens estudados. $\mathrm{O}$ interesse por este aspecto é relevante na medida em que se considera que a situação juvenil envolve a construção de um conjunto de autorrepresentações que orientam os sujeitos em sua trajetória social, com vistas à sua emancipação. Em outras palavras, as formas como os jovens se identificam indicam as dimensões de sua vida que eles consideram mais relevantes no momento presente e que guardam vínculos com o que pretendem ser futuramente. Por esta razão, este tópico volta-se à análise da autoidentificação dos jovens que compõem o universo de estudo.

Esta informação foi, inicialmente, obtida no processo de teste do questionário através de uma questão aberta. As respostas fornecidas foram sistematizadas sem redução, excluindo-se apenas as formas de autodefinição a partir de critério étnicos e que já foram apresentados na apresentação do perfil da amostra na introdução deste trabalho. Desta forma, obteve-se um conjunto de onze categorias identitárias. Com base neste procedimento, foi possível se obter um conjunto de categorias de autoidentificação juvenil que não se reduz às identidades de trabalho, mas que têm nele sua principal matriz. A partir disto, os jovens foram perguntados sobre Quais destas categorias melhor descreve como você se autodefine?

Como pode ser observado no Gráfico 50, o trabalho agrícola é o elemento central na configuração das identidades sociais dos entrevistados e não o seu local de residência ou de nascimento. Deste modo, predominam entre as respostas as categorias: jovem agricultor familiar (31,9\%), jovem trabalhador rural (22,3\%) e jovem agricultor (18,6\%). Destaca-se, também, a importância da escola para a autoidentificação, uma vez que de $12,2 \%$ dos jovens se definem como estudante. Estas categorias identitárias são construídas nas relações sociais em que os jovens se inserem e revelam a aquisição de valores de seu grupo de referência, ou seja, constituem-se em códigos de categorias legitimadas por estes grupos para referirem-se a si 
próprios e que acionam nas suas relações com os outros. As formas de identificação predominantes correspondem àquelas que são utilizadas por instituições com os quais este segmento juvenil estabelece alguma relação, como os sindicatos e as escolas. Desta forma, estas categorias de autoidentificação, que são, principalmente, vinculadas ao universo do trabalho agrícola ou educacional expressam os vínculos identitários que os entrevistados estabelecem com seus grupos de referência, indicando não apenas o que são, mas, também, o que desejam ser.

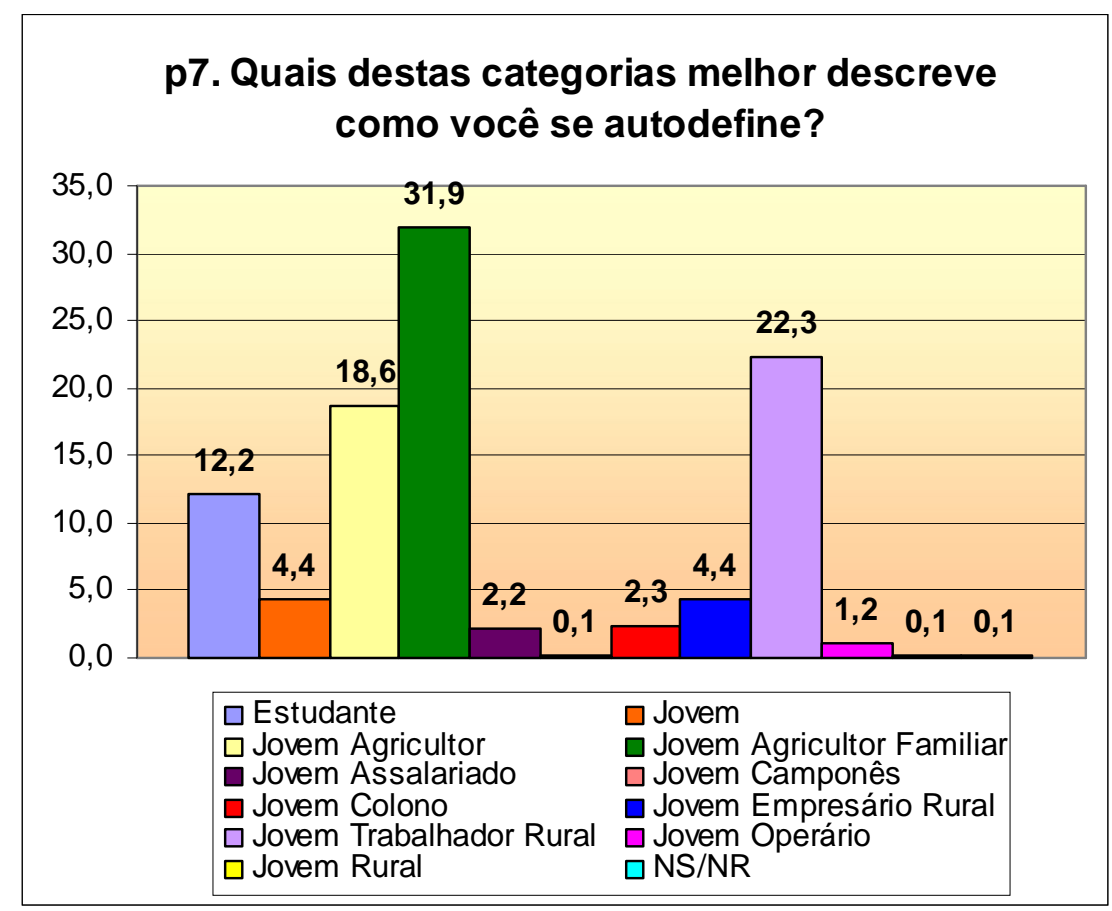

Gráfico 50: Distribuição das identidades juvenis (\%)

Fonte: Banco de dados Jovens Agricultores Familiares RS - MDA/FAURGS, 2007.

Ao considerar as respostas de jovens homens e mulheres para a mesma questão, não se constata diferenças significativas para maioria das categorias de resposta. Entre os que se definem como jovem agricultor familiar, os homens (33\%) apresentam percentual um pouco maior do que o das mulheres (30\%). Já entre os que se classificam como jovem trabalhador rural, a presença de mulheres é ligeiramente maior. As principais diferenças na definição identitária por sexo ocorrem entre aqueles que se dizem estudante. Entre elas, 16,5\% se denominam desta maneira, enquanto que entre os homens são apenas 9,6\%. Situação inversa é verificada em relação à categoria jovem empresário rural, onde eles apresentam um percentual de $6,3 \%$, enquanto entre as mulheres, apenas 1,2\% optou por esta classificação. As diferenças 
nestas respostas podem ser atribuídas a aspectos tratados no capítulo anterior, uma vez que a atribuição de papeis sociais de gênero e geração que estruturam a divisão do trabalho familiar concentra as atividades administrativas nas mãos dos homens. Em contrapartida, observa-se uma maior participação das mulheres no sistema formal de ensino, justificando-se, desta forma, porque são, principalmente, elas que se autodefinem como estudantes. Além disso, as mulheres se definem como jovem um pouca mais do que os homens, mas sem significação estatística que nos permita concluir um padrão identitário mediado por relações de gênero (Gráfico 51).

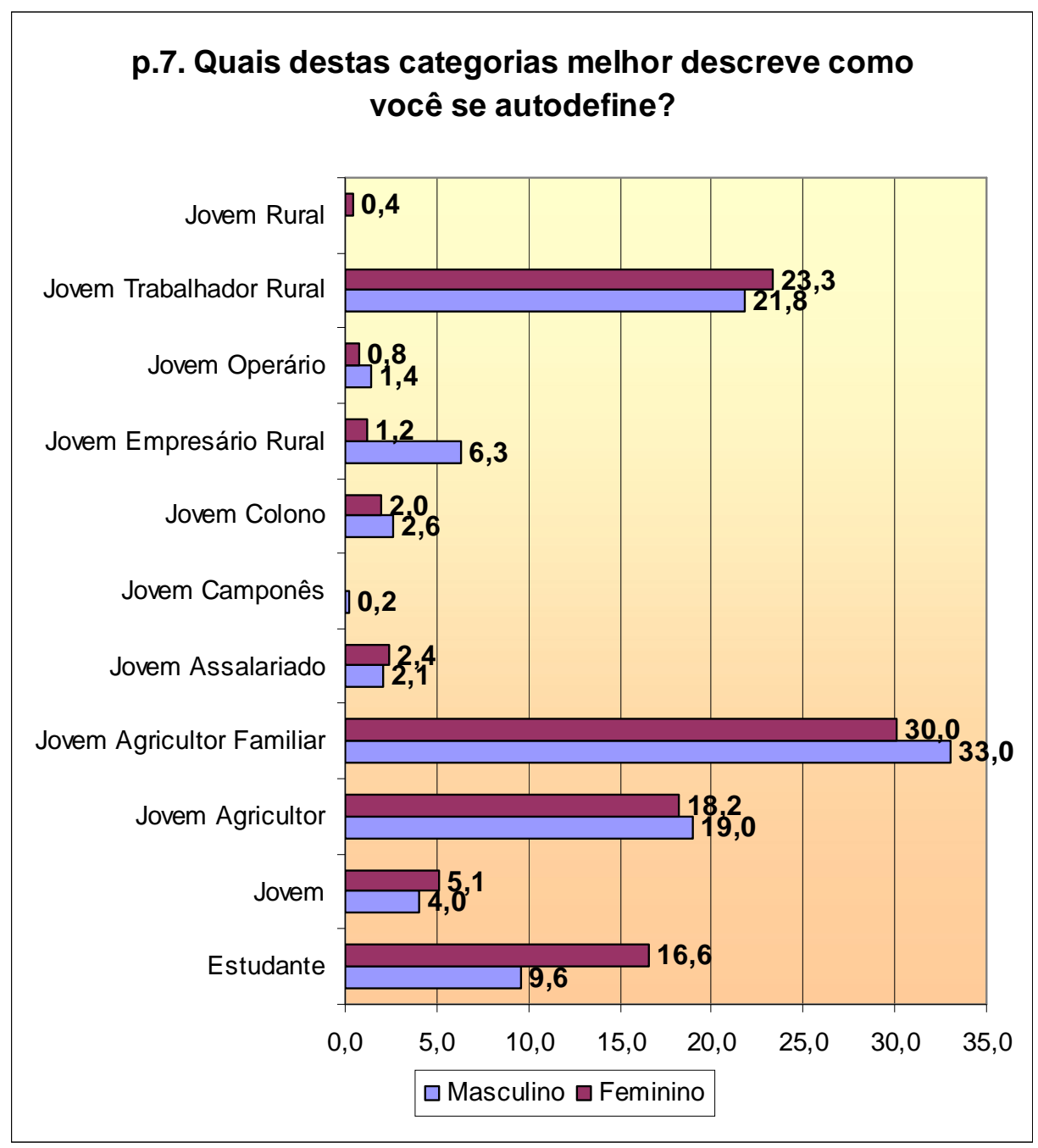

Gráfico 51: Cruzamento das identidades juvenis por sexo (\%)

Fonte: Banco de dados Jovens Agricultores Familiares RS - MDA/FAURGS, 2007.

Quando se leva em conta a faixa etária dos entrevistados (Tabela 47), identifica-se que os jovens adolescentes definem-se, primeiramente, como estudante $(28,4 \%)$; depois, como jovem agricultor familiar (23,6\%). Esta última categoria de autoidentificação apresenta percentuais 
maiores na medida em que aumenta a faixa etária dos inquiridos, uma vez que conta com $33 \%$ de respostas daqueles que têm de 20 a 24 anos e chega a 39,9\%, entre os jovens de 25 a 29 anos.

Tabela 47: Cruzamento das identidades juvenis por faixa etária (em $f$ e \%)

\begin{tabular}{|c|c|c|c|c|c|c|}
\hline & & & \multicolumn{3}{|c|}{ FAIXA ETÁRIA: } & \multirow[b]{2}{*}{ Total } \\
\hline & & & $\begin{array}{l}\text { De } 15 \text { a } \\
19 \text { anos }\end{array}$ & $\begin{array}{l}\text { De } 20 \text { a } \\
24 \text { anos }\end{array}$ & $\begin{array}{l}\text { De } 25 \text { a } \\
29 \text { anos }\end{array}$ & \\
\hline \multirow{24}{*}{$\begin{array}{l}\text { QUAL DESTAS } \\
\text { CATEGORIAS } \\
\text { MELHOR } \\
\text { DESCREVE } \\
\text { COMO VOCÊ SE } \\
\text { AUTODEFINE? }\end{array}$} & \multirow[t]{2}{*}{ Jovem } & $f$ & 15 & 10 & 5 & 30 \\
\hline & & $\%$ & $6,0 \%$ & $4,9 \%$ & $2,2 \%$ & $4,4 \%$ \\
\hline & \multirow[t]{2}{*}{ Jovem Agricultor } & $f$ & 40 & 41 & 46 & 127 \\
\hline & & $\%$ & $16,0 \%$ & $20,2 \%$ & $20,2 \%$ & $18,6 \%$ \\
\hline & \multirow[t]{2}{*}{ Jovem Agricultor Familiar } & $f$ & 59 & 67 & 91 & 217 \\
\hline & & $\%$ & $23,6 \%$ & $33,0 \%$ & $39,9 \%$ & $31,9 \%$ \\
\hline & \multirow[t]{2}{*}{ Jovem Assalariado } & $f$ & 3 & 5 & 7 & 15 \\
\hline & & $\%$ & $1,2 \%$ & $2,5 \%$ & $3,1 \%$ & $2,2 \%$ \\
\hline & \multirow[t]{2}{*}{ Jovem Camponês } & $f$ & 0 & 0 & 1 & 1 \\
\hline & & $\%$ &, $0 \%$ &, $0 \%$ & ,4\% &, $1 \%$ \\
\hline & \multirow[t]{2}{*}{ Jovem Colono } & $f$ & 6 & 4 & 6 & 16 \\
\hline & & $\%$ & $2,4 \%$ & $2,0 \%$ & $2,6 \%$ & $2,3 \%$ \\
\hline & \multirow[t]{2}{*}{ Jovem Empresário Rural } & $f$ & 10 & 7 & 13 & 30 \\
\hline & & $\%$ & $4,0 \%$ & $3,4 \%$ & $5,7 \%$ & $4,4 \%$ \\
\hline & \multirow[t]{2}{*}{ Estudante } & $f$ & 71 & 9 & 3 & 83 \\
\hline & & $\%$ & $28,4 \%$ & $4,4 \%$ & $1,3 \%$ & $12,2 \%$ \\
\hline & \multirow[t]{2}{*}{ Jovem Trabalhador Rural } & $f$ & 41 & 57 & 54 & 152 \\
\hline & & $\%$ & $16,4 \%$ & $28,1 \%$ & $23,7 \%$ & $22,3 \%$ \\
\hline & \multirow[t]{2}{*}{ Jovem Operário } & $f$ & 4 & 2 & 2 & 8 \\
\hline & & $\%$ & $1,6 \%$ & $1,0 \%$ &, $9 \%$ & $1,2 \%$ \\
\hline & \multirow[t]{2}{*}{ Jovem Rural } & $f$ & 0 & 1 & 0 & 1 \\
\hline & & $\%$ &, $0 \%$ &, $5 \%$ &, $0 \%$ &, $1 \%$ \\
\hline & \multirow[t]{2}{*}{ NS/NR } & $f$ & 1 & 0 & 0 & 1 \\
\hline & & $\%$ &, $4 \%$ &, $0 \%$ &, $0 \%$ &, $1 \%$ \\
\hline \multirow{2}{*}{\multicolumn{2}{|c|}{ Total }} & $f$ & 250 & 203 & 228 & 681 \\
\hline & & $\%$ & $100,0 \%$ & $100,0 \%$ & $100,0 \%$ & $100,0 \%$ \\
\hline
\end{tabular}

Fonte: Banco de dados Jovens Agricultores Familiares RS - MDA/FAURGS, 2007.

Considerando as categorias de identidades juvenis por faixa etária e sexo, obtemos o Gráfico 52. Nele observa-se uma distribuição identitária entre todos os grupos o que nos permite afirmar que há um padrão identitário entre os jovens entrevistados; nesse, a categoria jovem agricultor familiar predomina com percentuais próximos em ambos os sexos e crescente com o aumento das idades. A esta se segue a identificação como jovem trabalhador rural que é um pouco mais presente entre as mulheres do que entre os homens. A principal diferença na distribuição das categorias analisadas é registrada entre as jovens adolescentes, entre as quais 
41,4\% se definem como estudante e outras $10,3 \%$ como jovens: suas identidades sociais se forjam a partir do universo escolar e não do trabalho familiar. Estas formas de autoidentificação guardam uma grande coerência com os processos de socialização predominantes entre os jovens, tal como apresentado no capítulo anterior.

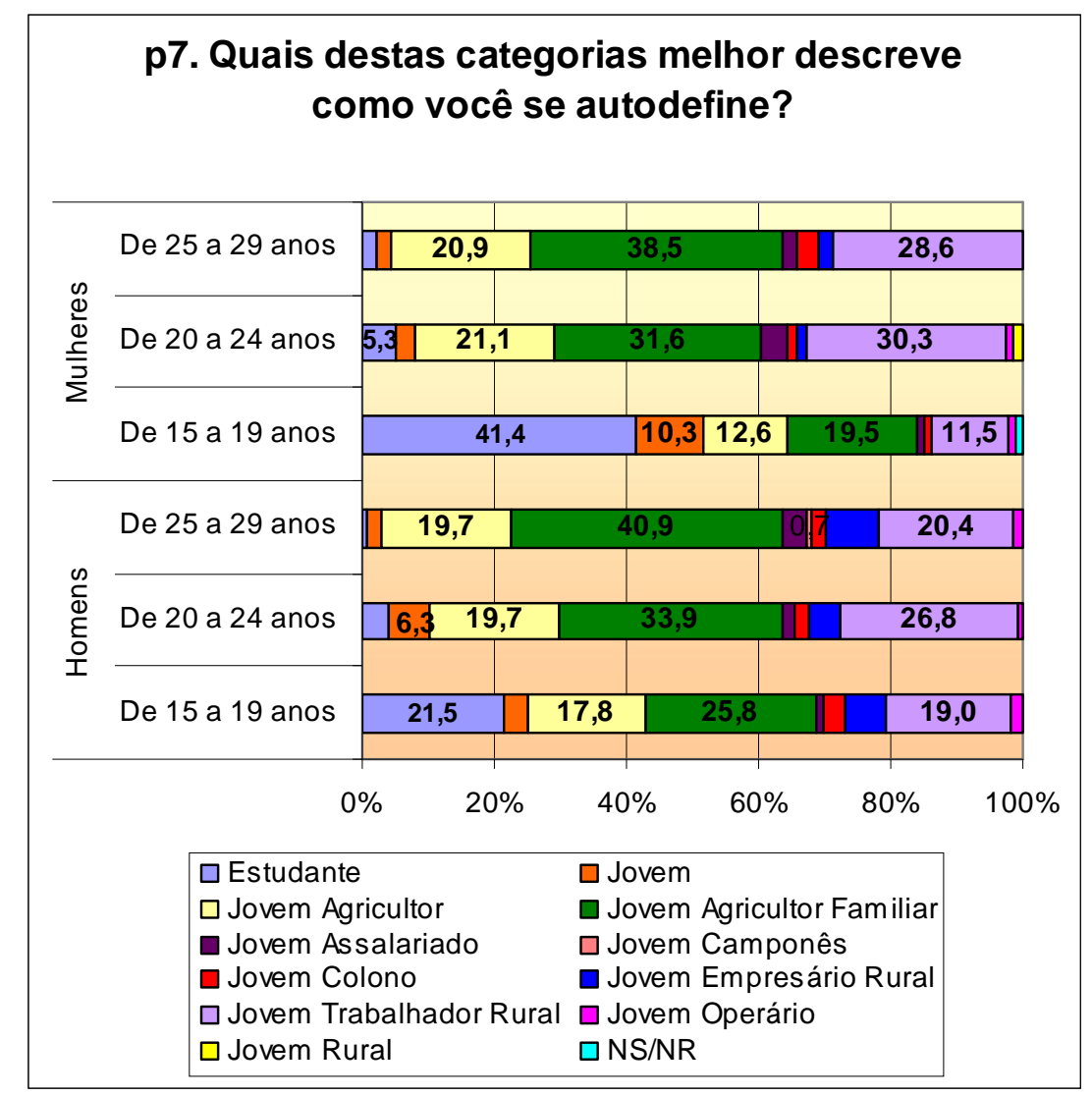

Gráfico 52: Cruzamento das identidades juvenis por faixa etária e sexo (\%) Fonte: Banco de dados Jovens Agricultores Familiares RS - MDA/FAURGS, 2007.

No seu conjunto, estas respostas podem ser interpretadas como uma transição entre a inserção objetiva dos jovens no processo de trabalho familiar agrícola e a disposição subjetiva de ser reconhecido como agricultor. Com efeito, pode-se perceber que estamos diante da construção de identidades socioprofissionais pautadas, principalmente, pelo trabalho agrícola. Isto não implica atribuirmos aos jovens identidades unificadas e estáveis, mas confirma a aquisição antecipada de saberes, normas, valores e comportamentos típicos de seu grupo de referência Estas categorias identitárias apontam para processos de identificação - o que as situam em uma dimensão histórica - e envolvem a noção de pertencimento a um grupo social: o de agricultores familiares. Esta categoria é a referência identitária entre o público estudado. 
Como já tivemos a oportunidade de afirmar, a construção de uma autoidentidade representa não apenas uma situação presente, mas uma antecipação das posições desejáveis e uma instância de legitimação de suas capacidades, constituindo-se num espaço de construção de reconhecimento social.

\subsection{REPRESENTAÇÕES POSITIVAS E AUTOIDENTIFICAÇÃO COMO AGRICULTOR FAMILIAR}

Neste capítulo, buscaram-se abordar as representações sociais dos jovens agricultores no que tange o trabalho familiar agrícola, o modo de vida dos pais e suas autoidentificações, aspectos que compõem a dimensão simbólica da situação juvenil na agricultura familiar e nos ajuda a conhecer melhor a especificidade deste segmento social.

Como pode ser demonstrado, no que se refere às representações que os jovens fazem do trabalho na agricultura familiar, a maioria deles afirma gostar do trabalho. As manifestações mais entusiasmadas são feitas por jovens adultos enquanto que as manifestações de desagrado são mais constantes entre os jovens adolescentes; principalmente, as mulheres deste grupo. Da mesma forma, a maior parte dos entrevistados considera importante, ou muito importante, sua participação no trabalho para os resultados obtidos pela família. Já entre os que respondem que sua participação familiar é pouco importante são principalmente as mulheres adolescentes. Em meio a estas representações, predominantemente positivas, os homens relacionam a agricultura a uma atividade que permite ter independência financeira; as mulheres enfatizam um pouco mais a importância deste trabalho para a sociedade.

Sobre o trabalho não-agrícola, predominam representações de um trabalho mais leve, com direito a descanso em finais de semana e férias. Este é percebido também como um trabalho onde há muito desemprego, instabilidade e que é de difícil contratação. Há ainda parcela significativa que destaca a garantia de recebimento de um salário ao final do mês como atribuição ao trabalho não-agrícola.

Constatou-se, também que entre os entrevistados predomina avaliações positivas sobre o modo de vida dos pais visto que em sua maioria avalia este como bom ou ótimo. Contudo, é possível identificar posicionamentos mais críticos, quando questionados sobre se gostariam de viver do mesmo modo que eles. Para esta questão, pode ser verificada uma disposição dos jovens em realizar mudanças. Novamente, os posicionamentos mais críticos a este respeito 
encontram-se entre as mulheres e, principalmente, junto às jovens adolescentes. Dando continuidade a estas questões, buscamos identificar as disposições dos jovens em sucederem a seus pais na gestão da unidade produtiva da família. Como resultado, constatou-se que a maioria deles pretende ser sucessor na gestão da unidade produtiva. A exceção fica por conta das mulheres da faixa etária de 15 a 19 anos. Esta questão foi complementada com outra a respeito das expectativas quanto à herança. Sobre esta questão, verificou-se que predomina, entre os jovens de ambos os sexos, a expectativa de herança igualitária entre todos os filhos homens e mulheres. Contudo, foi possível identificar que entre as entrevistadas havia um percentual significativo de resposta que indicavam uma expectativa de não herdar a propriedade, mas receber alguma compensação em troca.

No último tópico, apresentamos as formas de autoidentificação acionadas pelos jovens na ocasião das entrevistas. Entre as categorias identitárias, a mais utilizada foi de jovem agricultor familiar; depois, de jovem trabalhador rural e jovem agricultor. Isto indica que estes jovens estão construindo suas identidades sociais tendo como principal referência o trabalho agrícola. Esta informação permite-nos afirmar que o trabalho é a categoria central na construção das identidades sociais do grupo estudado. Além disto, demonstra que estes jovens não se reconhecem nas categorias a eles atribuídas, como, por exemplo, é o caso da "jovem rural", que só foi indicada por uma única entrevistada entre 681 casos. Com efeito, a noção de agricultura familiar permite-lhes a positivação de sua autoidentidade, mesmo no contexto de crescente pluralidade e heterogeneidade das relações sociais no meio rural gaúcho. Este dado confirma a proposição desta tese, segundo qual a socialização no processo de trabalho familiar agrícola produziria a identificação do jovem como agricultor familiar. Isto reforça o pleito destes jovens por reconhecimento social como categoria que se constitui a partir da posição ocupada na divisão social do trabalho como agricultores familiares. No próximo capítulo, buscar-se-á analisar as relações entre este processo de identificação com os projetos profissionais elaborados por estes jovens. 


\section{OS PROJETOS DA ATUAL GERAÇÃO DE JOVENS AGRICULTORES FAMILIARES}

Nos capítulos precedentes, cumpriu-se o objetivo de especificar, a partir dos recursos materiais, dos processos de socialização e das representações sociais, os traços distintivos dos jovens agricultores familiares. Neste, toma-se como objeto de análise os projetos juvenis. Para tanto, buscou-se respostas a questões como: O que é projeto? Os jovens agricultores elaboram projetos? Que tipos de projetos? O que estes projetos indicam sobre sua disposição em reproduzir o processo de trabalho familiar agrícola? Que diferenças são constatáveis na comparação destes por sexo e faixa etária? Inicialmente se faz necessário resgatar o percurso teórico do conceito de projeto, que emerge como categoria especulativa do iluminismo, para extrair-lhe o sentido adequado ao objeto de estudo proposto. Uma vez estabelecida sua definição sociológica, pode-se avançar para as características dos projetos juvenis. Na sequência, são analisados os projetos de escolarização, de profissionalização e de vida dos jovens agricultores familiares. No último tópico, os projetos profissionais são analisados em relação às condições materiais, ao processo de socialização e às representações sociais dos jovens. Os procedimentos adotados permitem identificar, de modo relacional, em quais situações os jovens elaboram projetos profissionais que indicam a disposição em reproduzir o trabalho familiar agrícola.

\subsection{O PERCURSO TEÓRICO DO CONCEITO DE PROJETO}

O conceito de projeto emerge no âmbito da filosofia clássica alemã, trazendo uma das marcas centrais do Iluminismo: a possibilidade da construção do futuro sob a orientação da racionalidade humana. Seu percurso encontra-se ligado aos nomes de Johann Gottlieb Fichte e Georg Wilhelm Friedrich Hegel, mesmo que o tratamento estabelecido entre eles seja distinto. A partir da reflexão sobre a temporalidade e a intencionalidade, este debate entrou no século XX através de sua influência na corrente fenomenológica de Edmund Gustav Albrecht Husserl e Martin Heidegger, que conferem ao conceito sua definição contemporânea. Sob influencia deste, o conceito foi apropriado à Sociologia por Alfred Schütz. No Brasil, o conceito de projeto vem sendo utilizado em trabalhos do antropólogo Gilberto Velho. 
Encontra-se um esboço do conceito de projeto em Fichte por meio dos seguintes elementos: a) no plano individual, o projeto é identificado com o esforço e este com uma filosofia da liberdade, de tal modo que o esforço se apoia na operação que impulsiona o Eu para fora de si; b) no plano relacional, o projeto é visto como uma interação entre sujeito e objeto, de tal sorte que o projeto realiza-se na ação recíproca do Eu e algo externo a ele; c) na passagem dos planos individual (esforço, dever-ser) e o relacional (interação Eu-Não-Eu) intervém sempre um choque entre o Não-Eu que se exerce sobre o Eu e será o gerador do projeto, provocando o esforço do Eu para sua própria superação (FICHTE, 1984). Levando-se à conscientização a alta significação dialética da oposição (Eu-Não-Eu), Fichte antecipa os trabalhos vindouros dos pensadores fenomenológicos, mesmo que estes não reconheçam esta influência (BOUTONET, 2002).

O termo fenomenologia encontra-se, primeiramente, ligado à obra de Hegel (e tem muito pouco em comum com o tratamento conferido ao termo por Husserl). A abordagem hegeliana emerge como tentativa de estabelecimento de um discurso sobre a ciência; neste caso a fenomenologia aparece como a ciência da consciência. Como primeira parte, Hegel analisa o que é o conhecimento científico e filosófico e o saber humano, não apresentando o que é, mas como ele vem a ser. Por isto, Hegel, primeiramente, refere-se à consciência, ou seja, à afirmação da subjetividade humana criadora das representações de tal modo que esta se coloque em oposição a seu outro, isto é, à realidade. $\mathrm{O}$ segundo momento é o desdobramento da consciência como consciência de si, ou seja, quando esta se define não mais na oposição a um simples objeto exterior, mas a outra consciência. Desta maneira, o sujeito, até então pura e simples negatividade, põe-se em movimento a partir da reflexão em si que conduz a um por-se-a-simesmo, como mediação consigo mesmo, de tornar-se outra coisa, ser outro (HEGEL, 1980). Hegel afirma:

O verdadeiro é unicamente essa diversidade original que se reinstaura ou a reflexão em si mesmo no ser outro. Não é uma unidade original enquanto tal, ou imediata enquanto tal. É o devir de si mesmo, o círculo que pressupõe seu fím como seu alvo, tem esse fim como princípio e é efetivo somente por meio da sua realização e do seu fim. (HEGEL, 1980, p. 13).

A fenomenologia de Hegel, como ciência da consciência, levaria ainda a um terceiro momento, quando o "espírito terá tornado seu existir igual à sua essência" (HEGEL, 1980, p. 21). Neste momento, o espírito divide-se em subjetivo, objetivo e absoluto e o espírito subjetivo em alma, consciência e espírito. Conforme Bourdieu, em Meditações Pascalianas: 
Caso se aceite a demonstração hegeliana segundo a qual o desígnio, o projeto, Vorsatz, supõe a representação, Vorstellung, e a intenção, Absicht, que supõe ela própria a abstração, a separação entre sujeito e objeto, percebe-se o quanto se está na ordem do consciente e do refletido, da ação que se pensa em sua verdade objetiva de atualização de um possível (BOURDIEU, 2001, p. 257) [Grifos do autor].

Para Hegel, a ideia se manifesta como processo histórico, mostrando que tanto as estruturas sociais, como as ideias, podem ser modificadas, transformadas pelo homem no decurso da história. Percebe-se que a transformação da consciência e do ser envolve um processo de desenvolvimento dialético, ou seja, como uma totalidade contraditória e dinâmica. Este entendimento sobre o devir de si mesmo torna a construção do projeto um empreendimento possível - que tem este fim como princípio e se conclui somente por meio da sua realização e do seu fim - devido à capacidade reflexiva dos sujeitos históricos que por meio de suas ações atualizam o campo dos possíveis.

Como pondera Boutonet (2002), identificando consciência e ser, Hegel esquiva-se do que será central à fenomenologia em Husserl, ou seja, "o fato de que a consciência só é consciência de, que o objeto é sempre um objeto para" (BOUTONET, 2002, p. 46) [Grifos do autor]. Volta-se, deste modo, à diferença existente entre o racionalismo fenomenológico de Hegel e a redução fenomenológica de Husserl. A redução da coisa aos detalhes da sua apreensão como fenômeno da consciência, visto como conhecimento objetivo dela, analítico, como simples experiência de consciência; distinta da sua visão teórica, transcendente.

No que concerne ao debate aqui proposto, Husserl parte do conceito de intencionalidade, do qual emergirá posteriormente o conceito de projeto, de tal modo que ambos os termos mantém até hoje vínculos estreitos. Em suas Meditações Cartesianas Husserl (2001) retoma o debate do cogito, não como algo isolado como em Descartes, mas como um empreendimento relacional. Deste modo, a vivência intencional aparece, necessariamente, como consciência de algo, relaciona-se com um objeto. Este objeto é percebido pelo ser cognicente, produzindo uma representação sobre um futuro. Destaca-se que Husserl utiliza o termo "representação" não como uma cópia da coisa exterior, mas como uma relação com o objeto. Isto acarreta como consequência a afirmação de que a intencionalidade é sempre um desvelamanto das coisas, rompendo-se com a certeza e abrindo a esta a possibilidade do inusitado, ou seja, como um futuro contingente. Desta maneira, Husserl (2001) estabelece $o$ projeto como uma visada consciente do futuro com possibilidades em aberto. 
Este caráter contingente do projeto, conforme proposto por Husserl, é salientado por Bourdieu (2001) ao afirmar que: De fato, Husserl estabeleceu claramente que o projeto, como visada consciente do futuro em sua verdade de futuro contingente, não deve ser confundido com a protensão, visada pré-reflexiva de um porvir que se entrega como quase presente no visível (BOURDIEU, 2001, p. 254) [Grifos do autor].

Deste modo, Husserl coloca o projeto no âmbito da contingência e da incerteza. Ampliando o pensamento de Husserl, Heidegger acoplará ao conceito de fenômeno o de existência, qualificada como "estar-no-mundo". Enquanto lançado no mundo, o ser-aí é lançado sobre o modo de ser do projeto. Enquanto ser-aí este já se projetou e permanece um projeto enquanto for. O projeto concerne sempre e de acordo com toda sua amplitude à revelação do estar no mundo (HEIDEGGER, 2004). Nesta perspectiva, o projeto traduz a capacidade de devir do homem, o que ele pode ser em razão de sua liberdade; porém, esse projeto é marcado pelo abandono, sentindo-se ameaçado pelo anonimato, pela sujeição às condições impostas pela impossibilidade de estar à altura do que se quer ser. Desta forma, a preocupação traduz justamente essa inquietação, de manter a distância projeto e queda (BOUTINET, 2002, p. 50).

Para Heidegger (2004), a preocupação traduz a inquietude do sujeito diante de sua capacidade de ser livre e levantar suas próprias questões, de - o sujeito - alcançar a totalidade das significações ligadas à sua própria existência. O papel da preocupação seria restaurar o homem em sua essência. Assim, para este autor, o projeto será o que permite desvelar o homem, o seu ser. Assim, todo o projeto do ser-aí rumo a suas responsabilidades já antecipa uma compreensão do ser. O ser está compreendido no projeto. O projeto constitui a revelação do ser (HEIDEGGER, 2004).

Este projeto de existência pode ser visto como um modo privilegiado de compreensão de si mesmo graças ao desenvolvimento do que ele torna possível, mas ele sempre aparece ameaçado por uma queda na autenticidade (BOUTINET, 2002), o que leva à imposição da preocupação.

Distanciando-se um pouco deste autor, entende-se a este respeito que a preocupação emerge como uma manifestação da vida cotidiana, uma vez que o mundo não se manifesta ao homem como realidade por ele criada, mas como um mundo já feito e impenetrável, no seio do qual a manipulação para atuação no mundo se apresenta como engajamento e atividade. Nesta trilha, estamos mais próximo da abordagem realizada pelo filosofo nascido em Praga Karel Kosik (1995) segundo o qual: 
O preocupar-se é a manipulação (de coisas e homens) na qual as ações, repetidas todos os dias, já de muito se transformaram em hábito e, portanto, são executadas mecanicamente. O caráter coisificado da práxis, expresso pelo termo preocupar-se, significa que na manipulação já não se trata mais da obra que se cria, mas do fato de que o homem é absorvido pelo mero ocupar-se e não pensa na obra (KOSIK, 1995, p. 74).

Segundo este autor, a preocupação é a práxis no seu aspecto fenomênico alienado, tornando os homens tanto manipuladores como objetos de manipulação. Com feito, a ação cotidiana impõe aos seres humanos a necessidade da antecipação operatória de sua práxis com vistas a atuar sobre o mundo e modificá-lo em razão de seu próprio projeto de existência. A preocupação é, deste modo, necessária à antecipação operatória que permite ao homem atuar sobre o mundo exterior, trazendo para si o futuro desejado.

Percebe-se que a compreensão do conceito de projeto é feita por caminhos cruzados. Sua reconstrução nos conduz a um ponto cardeal onde se defrontam as noções de projeto, preocupação, práxis e hábitos. A alternativa idealista encontrada por Heidegger foi apoiar-se na possibilidade de compreensão dos significados das coisas e sua utilização para os objetivos previamente estabelecidos. Assim, afirmava que "compreender significa exatamente projetar-se visando a uma possibilidade” (HEIDEGGER apud BOUTINET, 2002, p. 51). Apesar da relevância de sua formulação, impõe-se a questão de como ter certeza de que se está tendo uma compreensão adequada dos processos, visto que o projeto encerra um elevado grau de ambivalência?

O hábito é uma ação rotinizada e mesmo irrefletida, que expressa uma proximidade com o conceito de habitus utilizado por Bourdieu, o qual é descrito como um economizador de reflexividade e impõe a presença do passado no presente tornando possível a antecipação do porvir no presente (BOURDIEU, 2001). Deste modo, será que o habitus não se imporia no caminho da reflexividade e compreensão a fim de também influenciar o projeto de existência pensado por Heidegger? A superação para tal contradição não poderia estar justamente no conceito de práxis enquanto uma categoria epistemológica que percebe o conhecimento como uma das formas de apropriação do mundo pelo homem?

As respostas a tais questões extrapolam o propósitos deste tópico, porém o percurso realizado até este ponto permite perceber que a antecipação projetiva ocorre sobre um futuro em aberto e não pré-determinado; o que implica certo grau de preocupação derivada do censo prático que orienta a ação em meio aos desajustes entre a estrutura herdada do passado e as exigências do presente. Como práxis, constitui-se em uma forma de apropriação reflexiva do mundo. Disto isto, podemos de modo sintético compreender que o projeto constitui-se numa 
antecipação consciente do futuro contingente, que revela o ser e o transforma, orientando sua conduta em direção a um futuro pretendido.

A relação entre a fenomenologia e as Ciências Sociais foi estabelecida por Alfred Schütz, que buscou adaptar os postulados da redução fenomenológica de Husserl as discussões da sociologia da ação, tal como inaugurada por Max Weber. Para compreender sua utilidade, uma breve digressão é necessária.

Entre os contributos fundamentais de Schütz, destaca-se a incorporação dos conceitos de "mundo da vida" e de "atitude natural" na Teoria Social, com a qual dá passagem à interpretação das relações de simultaneidade, ou seja, face a face, realizadas por atores socais na vida cotidiana. Também é significativa sua abordagem crítica do conceito de significado subjetivo oriundo da Max Weber, que é a base de sua proposta compreensiva, propondo uma distinção conceitual entre os significados subjetivo e significado objetivo. Por significado objetivo entende-se o significado que emerge de um contexto-significativo que se impõe em um determinado tempo social, conformando o significado partilhado, geralmente aceito e passível de ser aprendido como um senso comum.

Outra coisa é o significado subjetivo, aquele que não é compartilhado e permanece imperceptível nos processos de interação face a face, porque se encontra na constituição dos atos subjetivos da consciência. Deste modo, a intersubjetividade que emerge nos contexto de interação social realiza-se como um contexto de significado objetivo. A intersubjetividade oferece-se como um pré-requisito para toda a experiência humana imediata no mundo da vida. Nos termos de uma sociologia fenomenológica, o lema de Husserl "de volta às próprias coisas" passa a ser "chegar ao significado subjetivo" (WOLFF, 1980). Mas como apreender o significado subjetivo uma vez que este dificilmente se revela plenamente nem mesmo ao próprio ator? Além disso, conforme Schütz (1979), as singularidades das biografias individuais produziriam estoques de conhecimentos distintos impossibilitando que se atinja plenamente o significado subjetivo. Nesse sentido, é na linguagem cotidiana que o cientista social poder buscar os sentidos atribuídos à ação social pelos agentes.

Com efeito, para Schütz (1979), toda a ação humana repousa sobre um conjunto de informações que são em sentido amplo transmitidas pelos outros nos processos de interação cotidianas. Deste modo, o sujeito pensante (projetor), capaz de antecipar sua própria ação e formulá-la subjetivamente em termos de um projeto, opera seus percursos sociais com a ajuda de um stock de conhecimento que serve de orientação no desenvolvimento da ação presente e na antecipação das coisas futuras. Em consequência, a noção de projeto trazida à Sociologia por 
Alfred Schütz ganha os contornos de uma conduta organizada para atingir finalidades específicas, sendo orientada pelo stock de conhecimentos advindos de sua experiência própria, de sua biografia, mas, não representa uma pré-determinação dos destinos pessoais ou coletivos e sim uma orientação diante um futuro contingente. Sendo assim, para este autor:

Projetar, como qualquer outra antecipação de eventos futuros, traz consigo horizontes em aberto, que somente serão preenchidos através da materialização do evento antecipado; em consequência para o ator, o significado do ato projetado tem, necessariamente, de diferir do ato projetado (SCHÜTZ, 1979, p. 139).

Ou seja, todo projeto, como o futuro em aberto, tem um grande grau de indeterminação e pode ser alterado ao longo da trajetória dos atores sociais. Com efeito, a formulação de um projeto profissional revela uma vontade de vir a ser que reflexivamente constitui-se a partir da avaliação das possibilidades futuras construídas ao longo das biografias dos atores sociais e que formam seu estoque de conhecimentos. Através da elaboração de um projeto profissional cria-se a orientação para o estabelecimento de objetivos e a organização dos meios necessários através dos quais este poderá ser atingido (SCHÜTZ, 1979).

Outrossim, para apreender o sentido sociológico do conceito de projeto é necessário superar a perspectiva filosófica que o concebeu a partir da consciência individual. Neste sentido recorremos a orientação do antropólogo Gilberto Velho (2003), que propõe fazendo uso da noção de campo de possibilidades como uma condicionalidade objetiva sobre a qual os sujeitos elaboram seus projetos. O campo de possibilidades aparece como uma dimensão sociocultural, espaço para a formulação e implementação de projetos, atuando ainda como condicionante estrutural com todos seus incentivos e constrangimentos possíveis sobre a formulação dos projetos juvenis. Segundo Velho:

\footnotetext{
Os projetos individuais sempre interagem com outros projetos dentro de um campo de possibilidades. Não operam num vácuo, mas sim a partir de premissas e paradigmas culturais compartilhados por universos específicos. Por isso mesmo são complexos e os indivíduos, em princípio, podem ser portadores de projetos diferentes, até contraditórios. Suas pertinência e relevância serão definidas contextualmente. No caso de uma jovem de quinze anos isso pode aparecer de um modo mais dramático na medida em que se caracteriza uma aparente ruptura comum à escala de valores anterior que a englobaria através da família. Mas efetivamente, esse mencionado jogo de papeis se realiza acompanhando a emergência de um projeto pessoal de alguma singularidade (VELHO, 2003, p. 46) [Grifos do autor].
}

Percebe-se que o projeto, enquanto tentativa de antecipar um ato futuro que dê sentido à experiência de viver, se constroi dentro de um campo de possibilidades que se configura na interação com outros indivíduos. Com efeito, os limites objetivos para a concretização do projeto 
são o campo de possibilidades sobre o qual atuam os sujeitos históricos, os projetos de outros com que se relaciona este sujeito e as pressões e demandas de seus pares e grupo familiar.

Gilberto Velho (2003) informa ainda que os projetos coletivos formulados no núcleo familiar não são vividos de modo totalmente homogêneo pelos indivíduos que o compartilham. Existem diferenças na interpretação devido às particularidades de diversas ordens: no caso de uma família, gênero e geração. Por sua vez, os projetos individuais, que podem se distinguir do projeto familiar, emergem, também, em função de interações e experiências fora do âmbito das relações familiares como, por exemplo, a escola, o mercado de trabalho e os espaços de lazer.

\subsection{OS PROJETOS JUVENIS}

Coloca-se o desafio de situar o projeto no âmbito da evolução do ciclo de vida com um duplo propósito: de um lado apontar a possibilidade e peculiaridade dos projetos juvenis; de outro, identificar o que estes projetos têm a nos informar da atual situação juvenil na agricultura familiar.

Conforme a psicologia genética de Jean Piaget, os jovens encontram plenamente capacitados para executar operações formais, as quais "permite ao indivíduo distanciar-se de sua visão perceptiva na qual a criança esta mais ou menos confinada, para mover-se no possível e no inatural e, consequentemente, para se tornar apto a fazer projetos" (PIAGET, 1960, p. 233). Com isto se reconhece nos jovens a capacidade de fazer projetos individuais e coletivos com o que tentam explorar as relações entre o possível e o real.

Por sua vez, Maria José Carneiro (1998), ao buscar delimitar o universo de estudo dos chamados "jovens rurais", percebeu que a possibilidade de formular um projeto de vida e a distância deste projeto em relação às atividades marca a realidade destes sujeitos, sendo o que definiria a percepção do indivíduo como jovem:

\footnotetext{
O jovem é aquele indivíduo que se encontra em uma fase caracterizada pela discrepância entre o projeto de vida vislumbrado e as atividades em realização. Ou seja, a existência de um projeto para o futuro acompanhado de estratégias com graus variados de idealização seria, em termos genéricos, o que caracterizaria um indivíduo como jovem nas comunidades pesquisadas (CARNEIRO, 1998, p. 98).
}

Percebe-se que os jovens podem distanciar-se de sua visão perceptiva presente para mover-se no possível, estando aptos a fazer projetos que servem de orientação em seus percursos 
sociais. Mais do que uma possibilidade, a construção de um projeto futuro aparece como uma exigência social feita aos jovens, impondo a diferença entre situação vivida e situação projetada como uma das marcas da condição juvenil.

Compartilhamos com Jean-Pierre Boutinet o entendimento de que o projeto juvenil resulta de uma "dupla necessidade cultural e psicológica" (BOUTINET, 2002, p. 90). Ou seja, ocorre como fenômeno coletivo que se amplia com a racionalização das experiências e; como fenômeno individual, que permite ao jovem orientar-se diante um futuro em aberto. A construção de projetos permite aos jovens antecipar a sequência seguinte da sua existência em meio às constantes atualizações e transformações da transição para a vida adulta.

O projeto segue então um paralelo com as etapas da vida. Boutinet (2002) propõe que se percebam as fases da vida como situações existenciais de projeto onde se pode identificar um conjunto de projetos possíveis que caracterizaria a fase juvenil: a) "o projeto de orientação escolar em curto prazo: trata-se do tipo de estudo almejado pelo interessado através da escolha de opções, de seções de ensino, de habilitações de formação” (BOUTINET, 2002, p. 89); b) “o projeto de orientação profissional em médio prazo: é o projeto de inserção profissional propriamente dito" (BOUTINET, 2002, p. 90) e; c) "o projeto de vida: O projeto sentimental e familiar, segundo os termos utilizados por H. Rodrigues-Tomé e F. Bariaud (1987), remete a um projeto de prazo maior que diz respeito ao estilo de vida que o jovem pretende ter dentro de alguns anos" (BOUTINET, 2002, p. 90) [Grifos nossos]. Ainda, segundo este autor: "projeto escolar, projeto profissional e projeto de vida constituem atualmente as três dimensões de qualquer projeto adolescente" (BOUTINET, 2002, p. 91).

Com base em Boutinet (2002) e voltados para descrever a situação dos jovens agricultores familiares são propostas as seguintes definições para cada um dos projetos juvenis:

- Projeto de escolarização: trata-se de um projeto em curto prazo que define o tipo de estudo almejado pelo jovem através da escolha de opções entre tipos de curso, normal ou técnico que prepare para atividade agrícola ou para uma profissão nãoagrícola, tempo de escolarização, tipos de habilitação e graus de formação e capacitações pretendidas.

- Projeto profissional: é o projeto de inserção socioprofissional em médio prazo. Reflete as imagens profissionais que os jovens agricultores reservam para si, os tipos de grupos profissionais e respectivos recursos a que aspiram. Esta projeção 
em futuros profissionais possíveis estrutura o reconhecimento de uma identidade profissional $^{71}$ construída, socialmente, por meio de interações entre trajetórias individuais e sistemas de emprego, de trabalho e de formação, logo, são construídas por meio de processos de socialização cada vez mais diversificados que ampliam o campo de possibilidades projetivas. Os projetos profissionais permitem a objetivação das representações dos jovens sobre suas possibilidades futuras de permanência ou saída da atividade agrícola.

- Projeto de Vida: este é um projeto de investimento emocional, sentimental e familiar. Remete a um projeto de prazo maior e diz respeito a certo estilo de vida que o jovem pretende adotar apontando para definições sobre a vida conjugal, como por exemplo, se querem casar com agricultor(a), onde pretende residir, o que envolve a tomada de decisão sobre estabelecimento no meio rural ou migração para os centros urbanos.

Estes projetos são parcialmente autônomos, parcialmente imbricados uns aos outros (BOUTINET, 2002). Conforme Boutinet, eles são cada vez mais presentes e valorizados como solução da continuidade entre os grupos de idades, que vem se tornando cada vez mais problemática e menos institucionalizada devido a crescente individualização dos comportamentos, obrigando, assim, os indivíduos a tomarem antecipadamente uma série de decisões quanto ao seu futuro. Isto corresponde ao que Giddens (2002) descreveu como uma tendência crescente de "colonização do futuro", que é descrito como um arrastamento de tempo futuro para o presente produzindo uma antecipação projetiva capaz de permitir o monitoramento reflexivo da ação a fim de atingir a autorrealização, entendida como um equilíbrio entre oportunidade e risco.

Neste caso, ao contrário da incerteza e do risco apresentarem-se como entraves para elaboração de projetos, restringindo os jovens ao tempo presente (LACARDI, 2005), estes fatores impõem ao jovens a necessidade da construção de projetos. Sendo esta uma das características da juventude de nossa época: a capacidade reflexiva na orientação de suas ações com vista a um futuro em aberto, mas planejável. Ou seja, esta colonização do futuro é um traço dominante da época atual, em que se vive uma "cultura do projeto", conforme a expressão de

${ }^{71}$ A construção das identidades profissionais são "sempre resultados precários ainda que muito fecundos de processos de socialização, estas identidades constituem formas sociais de construção da individualidade, a cada geração, em casa sociedade" (DUBAR, 2005, p. 330). 
Boutinet (2002), em que o sentido da existência está intimamente ligado à capacidade de projeção no futuro. É neste novo tempo operatório que as opções com que os jovens agricultores familiares são confrontados, ganham sentido e consciência. É através dos projetos que as trajetórias individuais vão se construindo (VELHO, 2003), o que faz dos mesmos um instrumento pertinente ao estudo dos impasses da situação juvenil na agricultura familiar. Nas sessões subsequentes são analisados os projetos de escolarização, profissional e de vida dos jovens agricultores familiares.

\subsection{OS PROJETOS DE ESCOLARIZAÇÃO DOS JOVENS AGRICULTORES FAMILIARES}

Colocam-se em exame, neste tópico, os projetos de escolarização dos jovens agricultores familiares. Como visto na seção anterior, trata-se de um projeto a curto prazo, referente ao interesse de dar continuidade aos estudos e tipo de escolarização almejada pelo jovem. Este projeto foi identificado por meio da questão: Se você pretende continuar ou voltar a estudar será até quando?

A totalidade das respostas a esta questão pode ser observada no Gráfico 53. Destaca-se que o maior percentual, de $31,6 \%$, é formado por aqueles que afirmaram que não pretendem continuar ou voltar a estudar. Entre os que pretendem estudar, destacam-se aqueles que querem concluir curso superior para trabalho não-agrícola. Em seguida aparecem os projetos de conclusão do ensino médio e do curso superior ligado à agricultura.

Realizando-se o cruzamento entre os projetos de escolarização por sexo, percebe-se na Tabela 48 que os projetos de escolarização de homens e mulheres são bastante diferentes entre si. Entre os homens, predominam os que não pretendem estudar (34,3\%); entre as mulheres, as que querem concluir o curso superior para trabalho não-agrícola (30\%) e o ensino médio $(14,2 \%)$. 


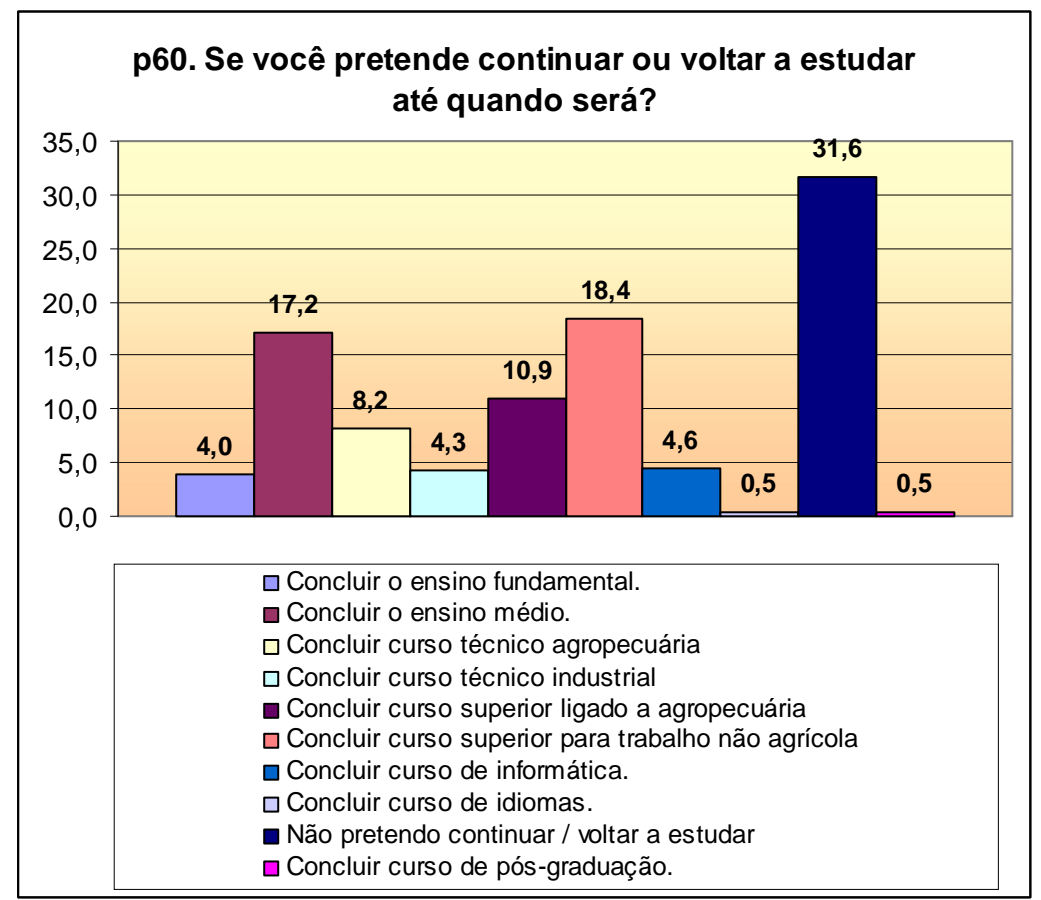

Gráfico 53: Projetos de escolarização (\%)

Fonte: Banco de dados Jovens Agricultores Familiares RS - MDA/FAURGS, 2007.

Tabela 48: Projetos de escolarização por sexo (em $f$ e \%)

\begin{tabular}{|c|c|c|c|c|c|}
\hline & & & \multicolumn{2}{|c|}{ SEXO } & \multirow[b]{2}{*}{ Total } \\
\hline & & & Homens & Mulheres & \\
\hline \multirow{20}{*}{$\begin{array}{l}\text { SE VOCÊ } \\
\text { PRETENDE } \\
\text { CONTINUAR } \\
\text { OU VOLTAR A } \\
\text { ESTUDAR ATÉ } \\
\text { QUANDO? }\end{array}$} & \multirow[t]{2}{*}{ Concluir o ensino fundamental. } & $f$ & 21 & 5 & 26 \\
\hline & & $\%$ & $5,1 \%$ & $2,0 \%$ & $4,0 \%$ \\
\hline & \multirow[t]{2}{*}{ Concluir o ensino médio. } & $f$ & 78 & 35 & 113 \\
\hline & & $\%$ & $19,0 \%$ & $14,2 \%$ & $17,2 \%$ \\
\hline & \multirow{2}{*}{$\begin{array}{l}\text { Concluir curso técnico } \\
\text { agropecuária. }\end{array}$} & $f$ & 43 & 11 & 54 \\
\hline & & $\%$ & $10,5 \%$ & $4,5 \%$ & $8,2 \%$ \\
\hline & \multirow[t]{2}{*}{ Concluir curso técnico industrial. } & $f$ & 20 & 8 & 28 \\
\hline & & $\%$ & $4,9 \%$ & $3,2 \%$ & $4,3 \%$ \\
\hline & \multirow{2}{*}{$\begin{array}{l}\text { Concluir curso superior ligado a } \\
\text { agropecuária. }\end{array}$} & $f$ & 50 & 22 & 72 \\
\hline & & $\%$ & $12,2 \%$ & $8,9 \%$ & $10,9 \%$ \\
\hline & \multirow{2}{*}{$\begin{array}{l}\text { Concluir curso superior para } \\
\text { trabalho não agrícola. }\end{array}$} & $f$ & 47 & 74 & 121 \\
\hline & & $\%$ & $11,4 \%$ & $30,0 \%$ & $18,4 \%$ \\
\hline & \multirow[t]{2}{*}{ Concluir curso de informática. } & $f$ & 10 & 20 & 30 \\
\hline & & $\%$ & $2,4 \%$ & $8,1 \%$ & $4,6 \%$ \\
\hline & \multirow[t]{2}{*}{ Concluir curso de idiomas. } & $f$ & 0 & 3 & 3 \\
\hline & & $\%$ &, $0 \%$ & $1,2 \%$ &, $5 \%$ \\
\hline & \multirow{2}{*}{$\begin{array}{l}\text { Não pretendo continuar / voltar a } \\
\text { estudar. }\end{array}$} & $f$ & 141 & 67 & 208 \\
\hline & & $\%$ & $34,3 \%$ & $27,1 \%$ & $31,6 \%$ \\
\hline & \multirow[t]{2}{*}{ Concluir curso de pós-graduação. } & $f$ & 1 & 2 & 3 \\
\hline & & $\%$ & ,2\% &, $8 \%$ &, $5 \%$ \\
\hline \multirow[t]{2}{*}{ Total } & & $f$ & 411 & 247 & 658 \\
\hline & & $\%$ & $100,0 \%$ & $100,0 \%$ & $100,0 \%$ \\
\hline
\end{tabular}

Fonte: Banco de dados Jovens Agricultores Familiares RS - MDA/FAURGS, 2007. 
Os projetos de escolarização também apresentam diferenças importantes quando se comparam os jovens por faixas etárias (Tabela 49). Entre os jovens adolescentes, predomina a intenção de concluir o ensino médio (26,2\%); depois aparecem projetos de conclusão de curso superior ligado às atividades não-agrícolas (24,6\%). Na faixa etária compreendida entre 20 e 24 anos, aumenta o número de jovens que não pretendem continuar ou voltar a estudar para 38,3\% enquanto outros $20,4 \%$ de entrevistados desta idade pretendem concluir curso superior não ligado à agricultura. Entre os jovens adultos, 45,4\% não pretendem retomar os estudos e 13,3\% gostariam de concluir o ensino médio. Deste modo, percebe-se que, conforme aumenta as idades dos entrevistados, diminuem as intenções de escolarização e aumenta o percentual de jovens que não têm pretendem estudar.

Tabela 49: Projetos de escolarização por faixa etária (em $f$ e \%)

\begin{tabular}{|c|c|c|c|c|c|c|}
\hline & & & \multicolumn{3}{|c|}{ FAIXA ETÁRIA: } & \multirow[b]{2}{*}{ Total } \\
\hline & & & $\begin{array}{l}\text { De } 15 \text { a } \\
19 \text { anos }\end{array}$ & $\begin{array}{l}\text { De } 20 \text { a } \\
24 \text { anos }\end{array}$ & $\begin{array}{l}\text { De } 25 \text { a } \\
29 \text { anos }\end{array}$ & \\
\hline \multirow{20}{*}{$\begin{array}{l}\text { SE VOCÊ } \\
\text { PRETENDE } \\
\text { CONTINUAR } \\
\text { OU VOLTAR } \\
\text { A ESTUDAR } \\
\text { ATÉ } \\
\text { QUANDO? }\end{array}$} & \multirow{2}{*}{$\begin{array}{l}\text { Concluir o ensino } \\
\text { fundamental. }\end{array}$} & $f$ & 11 & 4 & 11 & 26 \\
\hline & & $\%$ & $4,5 \%$ & $2,0 \%$ & $5,0 \%$ & $4,0 \%$ \\
\hline & \multirow[t]{2}{*}{ Concluir o ensino médio. } & $f$ & 64 & 20 & 29 & 113 \\
\hline & & $\%$ & $26,2 \%$ & $10,2 \%$ & $13,3 \%$ & $17,2 \%$ \\
\hline & \multirow{2}{*}{$\begin{array}{l}\text { Concluir curso técnico } \\
\text { agropecuária. }\end{array}$} & $f$ & 15 & 21 & 18 & 54 \\
\hline & & $\%$ & $6,1 \%$ & $10,7 \%$ & $8,3 \%$ & $8,2 \%$ \\
\hline & \multirow{2}{*}{$\begin{array}{l}\text { Concluir curso técnico } \\
\text { industrial. }\end{array}$} & $f$ & 11 & 8 & 9 & 28 \\
\hline & & $\%$ & $4,5 \%$ & $4,1 \%$ & $4,1 \%$ & $4,3 \%$ \\
\hline & \multirow{2}{*}{$\begin{array}{l}\text { Concluir curso superior } \\
\text { ligado a agropecuária. }\end{array}$} & $f$ & 38 & 18 & 16 & 72 \\
\hline & & $\%$ & $15,6 \%$ & $9,2 \%$ & $7,3 \%$ & $10,9 \%$ \\
\hline & \multirow{2}{*}{$\begin{array}{l}\text { Concluir curso superior } \\
\text { para trabalho não agrícola. }\end{array}$} & $f$ & 60 & 40 & 21 & 121 \\
\hline & & $\%$ & $24,6 \%$ & $20,4 \%$ & $9,6 \%$ & $18,4 \%$ \\
\hline & \multirow{2}{*}{$\begin{array}{l}\text { Concluir curso de } \\
\text { informática. }\end{array}$} & $f$ & 10 & 8 & 12 & 30 \\
\hline & & $\%$ & $4,1 \%$ & $4,1 \%$ & $5,5 \%$ & $4,6 \%$ \\
\hline & \multirow[t]{2}{*}{ Concluir curso de idiomas. } & $f$ & 1 & 1 & 1 & 3 \\
\hline & & $\%$ & ,4\% &, $5 \%$ &, $5 \%$ &, $5 \%$ \\
\hline & \multirow{2}{*}{$\begin{array}{l}\text { Não pretendo continuar / } \\
\text { voltar a estudar. }\end{array}$} & $f$ & 34 & 75 & 99 & 208 \\
\hline & & $\%$ & $13,9 \%$ & $38,3 \%$ & $45,4 \%$ & $31,6 \%$ \\
\hline & \multirow{2}{*}{$\begin{array}{l}\text { Concluir curso de } \\
\text { pós-graduação. }\end{array}$} & $f$ & 0 & 1 & 2 & 3 \\
\hline & & $\%$ &, $0 \%$ &, $5 \%$ &, $9 \%$ &, $5 \%$ \\
\hline \multirow[t]{2}{*}{ Total } & & $f$ & 244 & 196 & 218 & 658 \\
\hline & & $\%$ & $100,0 \%$ & $100,0 \%$ & $100,0 \%$ & $100,0 \%$ \\
\hline
\end{tabular}

Fonte: Banco de dados Jovens Agricultores Familiares RS - MDA/FAURGS, 2007. 
O cruzamento entre projetos de escolarização, faixa etária e sexo encontra-se ilustrado no Gráfico 54. Verifica-se que os jovens que não pretendem estudar são, principalmente, os homens mais velhos. Entre os que querem continuar os estudos, os jovens adolescentes se destacam. Nesta faixa etária, há marcantes diferenças nas intenções de homens e mulheres. Eles pretendem, principalmente, concluir o ensino médio $(31,45 \%)$, enquanto elas buscam concluir curso superior em áreas de conhecimentos que não são ligadas a agricultura (44,7\%). Estas mesmas distinções aparecem na faixa etária dos jovens de 20 a 24 anos. Entre os entrevistados do sexo masculino desta idade, 43,45\% afirmam que não pretendem continuar estudando, enquanto que, entre as mulheres, a resposta equivale a 29,7\%. As jovens mulheres desta idade afirmam, principalmente, que pretendem concluir o ensino superior $(32,4 \%)$. Entre as mulheres de 25 a 29 anos de idade, 40,9\% não pretende mais estudar, 13,6\% buscam concluir o ensino médio, mesmo percentual das que projetam concluir curso superior para trabalho não-agrícola.

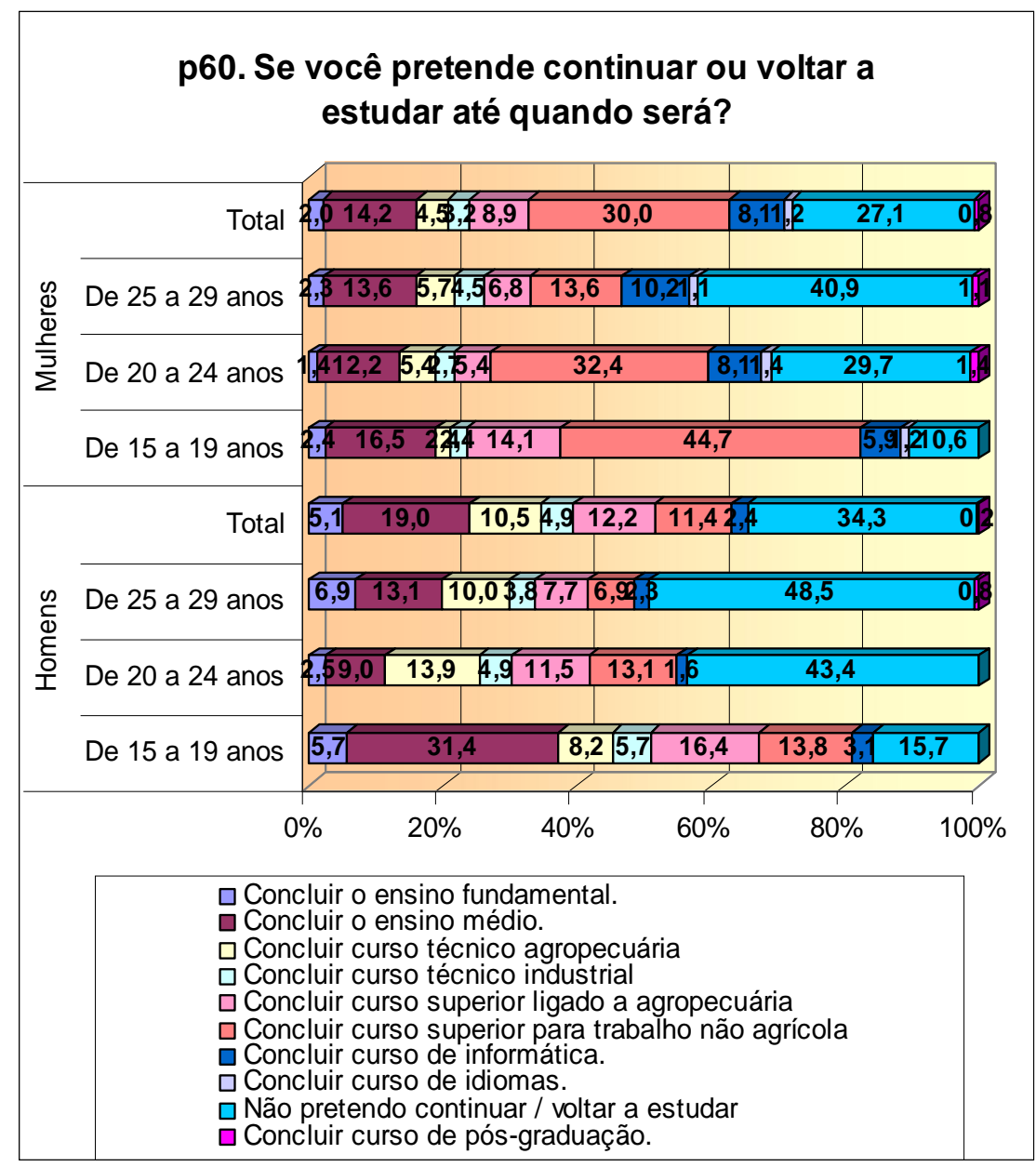

Gráfico 54: Projetos de escolarização por sexo e faixa etária (\%)

Fonte: Banco de dados Jovens Agricultores Familiares RS - MDA/FAURGS, 2007. 
Compreende-se o projeto de escolarização como uma orientação de mobilidade a curto prazo dos jovens. Este permite identificar a lógica da ação sobre a qual se estruturam suas trajetórias possíveis e que está relacionada às suas próprias motivações ou ausência delas. No caso da variável em análise, os diferentes projetos de formação escolar demonstram a busca de condições necessárias para pleitear posições futuras. Estes são elaborados a partir da experiência socializadora das práticas do grupo doméstico e do estatuto ${ }^{72}$ conferido a seus membros conforme critérios de classificação por sexo e idade. Por isto, para os homens, o ensino médio é considerado elevado o suficiente para que eles cumpram sua função de sucessores no estabelecimento familiar. Já os projetos de escolarização das jovens mulheres revelam suas intenções de adquirir capacitações, via escolarização, que lhes permitam uma boa colocação no mercado de trabalho não-agrícola. Neste sentido, os projetos de formação escolar revelam a incorporação pelos atores das regras do jogo, onde a fidelidade e a pertença ao grupo se traduzem no que homens e mulheres projetam para si e que tende a ser a confirmação do que se espera que eles façam.

\subsection{OS PROJETOS PROFISSIONAIS DOS JOVENS AGRICULTORES FAMILIARES}

Neste tópico, analisam-se os projetos profissionais elaborados por jovens agricultores familiares. Estes projetos correspondem a uma orientação com inserção socioprofissional em médio prazo, que confirma sua identificação socioprofissional. Como fora referido anteriormente, esta tomada de posição em relação à atividade futura é, socialmente, produzida por meio de processos de socialização, de tal modo que os projetos profissionais nos permitem avaliarmos as disposições dos jovens em reproduzir o processo de trabalho familiar agrícola; caso contrário, converter-se a outra profissão. Para identificar os projetos profissionais formulados por jovens agricultores no Rio Grande do Sul, foram feitas nesta sequência três questões: Você tem um projeto profissional que quer exercer no futuro? Qual é o seu projeto profissional? Você pretende se estabelecer profissionalmente como agricultor(a) familiar?

Com base na primeira questão da série, pode ser constatado que a maioria dos entrevistados $(63,7 \%)$ respondeu ter algum projeto profissional que pretendem realizar (Gráfico 55). Isto confirma que a maior parte dos jovens orienta-se por objetivos previamente

\footnotetext{
${ }^{72}$ Estatuto é usado no sentido que Weber dá a este conceito, isto é, como a posição relativa de um indivíduo, em relação a probabilidade que ele tem de influenciar os outros graças ao meios ligados a esta posição.
} 
estabelecidos que conferem sentido a suas trajetórias sociais e profissionais. A capacidade dos jovens de elaborar projetos de inserção profissional, que orientam sua conduta em médio prazo, não apresenta qualquer diferença entre homens e mulheres. Como pode ser observado na Tabela 50, ambos apresentam os mesmos percentuais de resposta para esta questão.

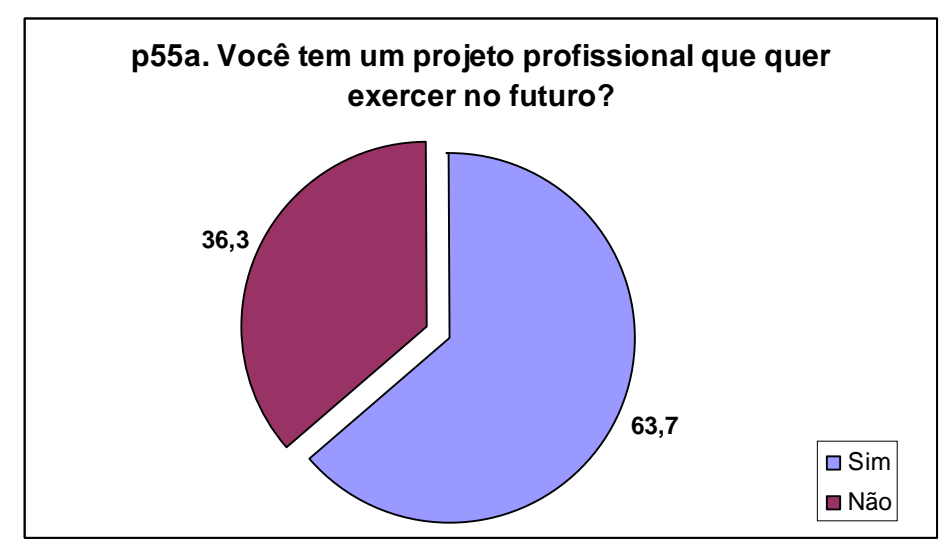

Gráfico 55: Distribuição de ocorrência de projetos profissionais entre jovens agricultores familiares (\%)

Fonte: Banco de dados Jovens Agricultores Familiares RS - MDA/FAURGS, 2007.

Tabela 50: Cruzamento ocorrência de projetos profissionais entre jovens agricultores familiares por sexo $(\%)$

\begin{tabular}{llrrrr}
\hline \hline & & \multicolumn{2}{c}{ SEXO } & \\
\cline { 2 - 4 } & & & Homens & Mulheres & Total \\
\hline VOCÊ TEM UM PROJETO Sim & $\mathrm{f}$ & 269 & 161 & 430 \\
PROFISSIONAL QUE & & $\%$ & $63,6 \%$ & $63,9 \%$ & $63,7 \%$ \\
\cline { 2 - 5 } QUER EXERCER NO & $\mathrm{Não}$ & $\mathrm{f}$ & 154 & 91 & 245 \\
FUTURO? & $\%$ & $36,4 \%$ & $36,1 \%$ & $36,3 \%$ \\
\hline Total & $\mathrm{f}$ & 423 & 252 & 675 \\
& $\%$ & $100,0 \%$ & $100,0 \%$ & $100,0 \%$ \\
\hline \hline
\end{tabular}

Fonte: Banco de dados Jovens Agricultores Familiares RS - MDA/FAURGS, 2007.

Quando é feito o cruzamento desta questão pela variável faixa etária verifica-se algumas diferenças. Conforme se demonstra na Tabela 51, os adolescentes são aqueles que apresentam o maior o percentual de formulação de projetos profissionais entre os casos estudados (69,9\%). Este índice diminui entre os inquiridos de 20 a 24 anos $(59,9 \%)$ e entre os jovens adultos $(60,4 \%)$. Esta variação decorre do estágio de vida dos jovens, onde, nas faixas etárias maiores, a inserção no trabalho agrícola já se encontra mais consolidada, fazendo com que o sentido atribuindo à noção de projeto profissional ganhe outros contornos. 
Tabela 51: Cruzamento ocorrência de projetos profissionais entre jovens agricultores familiares por faixa etária $(\%)$

\begin{tabular}{lcrrrrr}
\hline \hline & & \multicolumn{3}{c}{ FAIXA ETÁRIA: } & \\
\cline { 3 - 6 } & & & De 15 a & De 20 a & De 25 a & \\
& & & 19 anos & 24 anos & 29 anos & Total \\
\hline VOCÊ TEM UM PROJETO & Sim & $f$ & 172 & 121 & 137 & 430 \\
PROFISSIONAL QUE & & $\%$ & $69,9 \%$ & $59,9 \%$ & $60,4 \%$ & $63,7 \%$ \\
\cline { 2 - 6 } QUER EXERCER NO & Não & $f$ & 74 & 81 & 90 & 245 \\
FUTURO? & & $\%$ & $30,1 \%$ & $40,1 \%$ & $39,6 \%$ & $36,3 \%$ \\
\hline Total & $f$ & 246 & 202 & 227 & 675 \\
& & $\%$ & $100,0 \%$ & $100,0 \%$ & $100,0 \%$ & $100,0 \%$ \\
\hline \hline
\end{tabular}

Fonte: Banco de dados Jovens Agricultores Familiares RS - MDA/FAURGS, 2007.

Constatou-se que os jovens adultos respondem que não têm projeto porque já se encontram estabelecidos profissionalmente. Nestes casos, não formulam projetos profissionais, mas sim o que Boutinet (2005) define como projeto vocacional do adulto, que é a perspectiva de desenvolvimento vocacional que o indivíduo procura, progressivamente, estabelecer para si, como poderá realizar-se profissionalmente, levando em conta as possibilidades objetivas e subjetivas que estão à sua disposição.

Quando questionados sobre Qual é o seu projeto profissional, as respostas espontâneas, ou seja, obtidas sem indicação de resposta, apresentaram uma grande variação: um total de 63 categorias de respostas diferentes. Estas informações foram agrupadas por aproximação e similaridade reduzindo-se a 18 (dezoito) categorias. No Gráfico 56, encontra-se a distribuição dos percentuais de respostas válidas dos projetos profissionais sistematizados. Conforme os resultados obtidos para esta questão, pode-se perceber que predomina, no universo de estudo, a formulação de projetos profissionais não-agrícolas. Outrossim, considerando as categorias, isoladamente, ser agricultor familiar aparece como o projeto mais representativo, com 37,4\% das respostas válidas. A este seguem os projetos de inserção profissional como professor (a) $(8,6 \%$, como prestador (a) de serviços autônomo $(7,7 \%)$ e profissional superior, ligado à agricultura e à pecuária (7\%), como engenheiros agrônomos e veterinários. Primeiramente, é possível destacar que estes projetos profissionais são bastante realistas, no sentido de serem condizentes com o que se apresenta como possibilidade para esta juventude. Deste modo, pode-se concluir que os jovens agricultores familiares formulam projetos viáveis quanto à sua realização.

É importante mencionar, ainda, que na categoria de projeto agricultor familiar foram reunidos diferentes projetos que apontam para a permanência nesta atividade, e podem ser classificados em três tipos: os que buscam a manutenção do atual sistema de produção (ex. Seguir o que o pai já deixou encaminhado); os que buscam o aperfeiçoamento e ampliação de 
seu processo de trabalho sem alteração no tipo de produção (ex. Comprar mais terra, Ampliar a produção, Ampliar a atual criação de suínos); principalmente, há, entre os jovens, os que buscam promover inovações e incorporar novos elementos que permitam ampliar o valor de sua produção mercantil, visando à sua consolidação na agricultura (ex. Investir mais em gado de leite, Introduzir inovações na propriedade, Diversificar mais a produção agrícola, Beneficiar os produtos na propriedade, Mudar para produção de biodiesel, Combinar a agricultura com turismo rural, etc.).

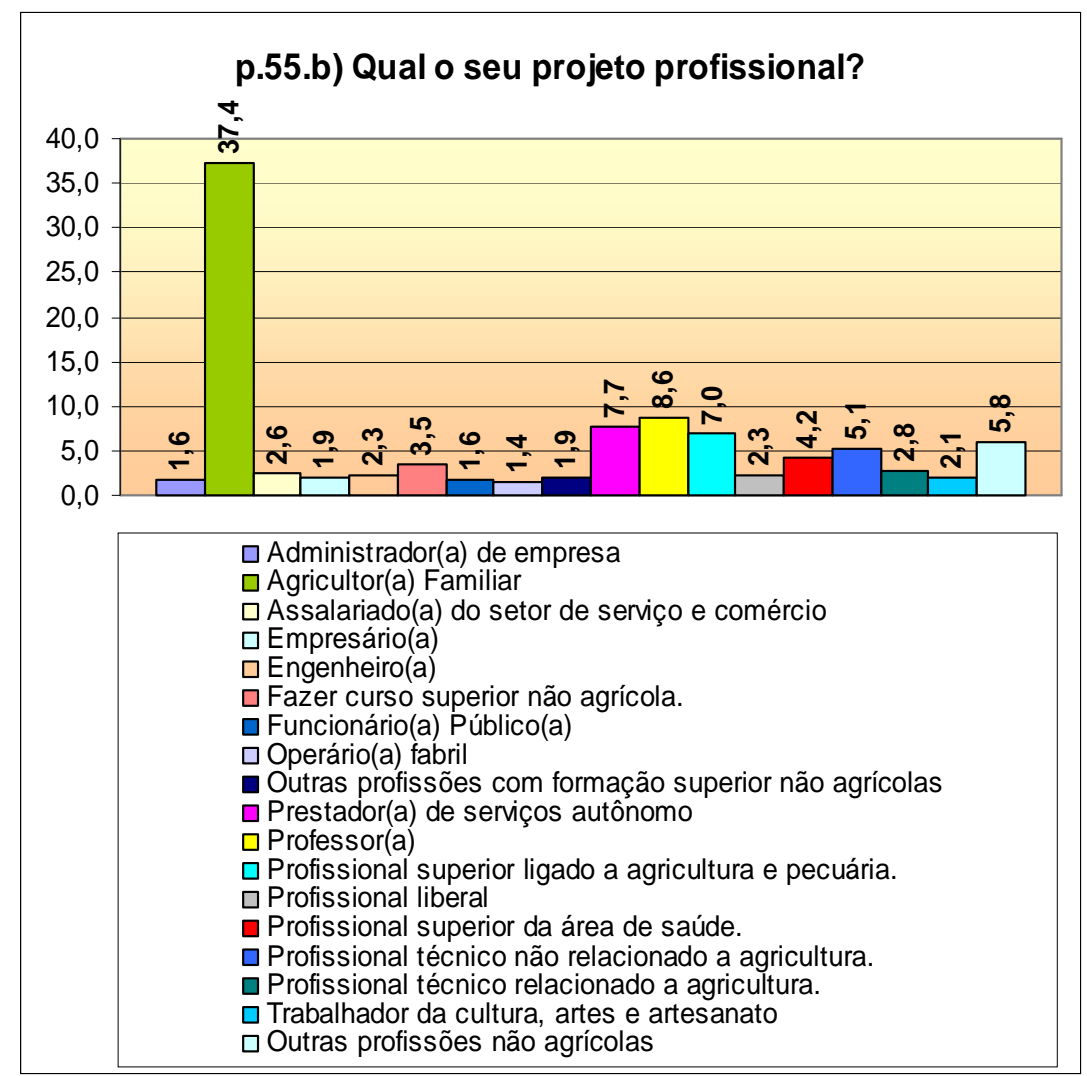

Gráfico 56: Distribuição de projetos profissionais dos jovens agricultores familiares (\%) Fonte: Banco de dados Jovens Agricultores Familiares RS - MDA/FAURGS, 2007.

As construções dos projetos profissionais revelam-se diferenciadas, conforme o sexo dos jovens. Observa-se, na Tabela 52, que os projetos profissionais que apontam para a permanência na agricultura familiar são mais recorrentes entre os homens $(43,7 \%)$ do que entre as mulheres $(26,9 \%)$. Também é indicada por eles a perspectiva de ser autônomo $(10,1 \%)$, principalmente no ramo da construção civil, mecânica e eletroeletrônicos. Entre eles, ainda 7,1\% pretendem seguir profissão com formação superior ligada à agricultura e à pecuária e 6,7\% almejam trabalhar como técnicos agrícolas, profissão não-agrícola. Já, entre as mulheres, o 
projeto profissional não-agrícola mais frequente é ser professora $(19,4 \%)$. Depois, aparecem as profissões com curso superior na área de saúde $(9,4 \%)$, com destaque para enfermagem, farmácia e pediatria.

Tabela 52: Cruzamento entre Distribuição de projetos profissionais dos jovens agricultores familiares por sexo (em $f$ e \%)

\begin{tabular}{|c|c|c|c|c|c|}
\hline & & & \multicolumn{2}{|c|}{ SEXO } & \multirow[b]{2}{*}{ Total } \\
\hline & & & Homens & Mulheres & \\
\hline \multirow{36}{*}{$\begin{array}{l}\text { Qual é seu } \\
\text { projeto } \\
\text { profissional? } \\
\text { (codificado) }\end{array}$} & \multirow[t]{2}{*}{ Administrador(a) de empresa } & $f$ & 4 & 3 & 7 \\
\hline & & $\%$ & $1,5 \%$ & $1,9 \%$ & $1,6 \%$ \\
\hline & \multirow[t]{2}{*}{ Agricultor(a) Familiar } & $f$ & 117 & 43 & 160 \\
\hline & & $\%$ & $43,7 \%$ & $26,9 \%$ & $37,4 \%$ \\
\hline & \multirow{2}{*}{$\begin{array}{l}\text { Assalariado(a) do setor de } \\
\text { serviço e comércio }\end{array}$} & $f$ & 4 & 7 & 11 \\
\hline & & $\%$ & $1,5 \%$ & $4,4 \%$ & $2,6 \%$ \\
\hline & \multirow[t]{2}{*}{ Empresário(a) } & $f$ & 5 & 3 & 8 \\
\hline & & $\%$ & $1,9 \%$ & $1,9 \%$ & $1,9 \%$ \\
\hline & \multirow[t]{2}{*}{ Engenheiro(a) } & $f$ & 9 & 1 & 10 \\
\hline & & $\%$ & $3,4 \%$ &, $6 \%$ & $2,3 \%$ \\
\hline & \multirow{2}{*}{$\begin{array}{l}\text { Fazer curso superior não } \\
\text { agrícola. }\end{array}$} & $f$ & 8 & 7 & 15 \\
\hline & & $\%$ & $3,0 \%$ & $4,4 \%$ & $3,5 \%$ \\
\hline & \multirow[t]{2}{*}{ Funcionário(a) Público(a) } & $f$ & 4 & 3 & 7 \\
\hline & & $\%$ & $1,5 \%$ & $1,9 \%$ & $1,6 \%$ \\
\hline & \multirow[t]{2}{*}{ Operário(a) fabril } & $f$ & 4 & 2 & 6 \\
\hline & & $\%$ & $1,5 \%$ & $1,3 \%$ & $1,4 \%$ \\
\hline & \multirow{2}{*}{$\begin{array}{l}\text { Outras Profissões com } \\
\text { formação superior não agricula. }\end{array}$} & $f$ & 3 & 5 & 8 \\
\hline & & $\%$ & $1,1 \%$ & $3,1 \%$ & $1,9 \%$ \\
\hline & \multirow{2}{*}{$\begin{array}{l}\text { Prestador(a) de serviços } \\
\text { autônomo }\end{array}$} & $f$ & 27 & 6 & 33 \\
\hline & & $\%$ & $10,1 \%$ & $3,8 \%$ & $7,7 \%$ \\
\hline & \multirow[t]{2}{*}{ Professor(a) } & $f$ & 6 & 31 & 37 \\
\hline & & $\%$ & $2,2 \%$ & $19,4 \%$ & $8,6 \%$ \\
\hline & \multirow{2}{*}{$\begin{array}{l}\text { Profissional superior ligado a } \\
\text { agricultura e pecuária. }\end{array}$} & $f$ & 19 & 11 & 30 \\
\hline & & $\%$ & $7,1 \%$ & $6,9 \%$ & $7,0 \%$ \\
\hline & \multirow[t]{2}{*}{ Profissional liberal } & $f$ & 5 & 5 & 10 \\
\hline & & $\%$ & $1,9 \%$ & $3,1 \%$ & $2,3 \%$ \\
\hline & \multirow{2}{*}{$\begin{array}{l}\text { Profissional superior da área de } \\
\text { saúde. }\end{array}$} & $f$ & 3 & 15 & 18 \\
\hline & & $\%$ & $1,1 \%$ & $9,4 \%$ & $4,2 \%$ \\
\hline & \multirow{2}{*}{$\begin{array}{l}\text { Profissional Técnico não } \\
\text { relacionado a agricultura. }\end{array}$} & $f$ & 18 & 4 & 22 \\
\hline & & $\%$ & $6,7 \%$ & $2,5 \%$ & $5,1 \%$ \\
\hline & \multirow{2}{*}{$\begin{array}{l}\text { Profissional Técnico relacionado } \\
\text { a agricultura. }\end{array}$} & $f$ & 10 & 2 & 12 \\
\hline & & $\%$ & $3,7 \%$ & $1,3 \%$ & $2,8 \%$ \\
\hline & \multirow{2}{*}{$\begin{array}{l}\text { Trabalhador da cultura, artes e } \\
\text { artesanato }\end{array}$} & $f$ & 3 & 6 & 9 \\
\hline & & $\%$ & $1,1 \%$ & $3,8 \%$ & $2,1 \%$ \\
\hline & \multirow[t]{2}{*}{ Outros profissões não agrícolas } & $f$ & 19 & 6 & 25 \\
\hline & & $\%$ & $7,1 \%$ & $3,8 \%$ & $5,8 \%$ \\
\hline \multirow[t]{2}{*}{ Total } & & $f$ & 268 & 160 & 428 \\
\hline & & $\%$ & $100,0 \%$ & $100,0 \%$ & $100,0 \%$ \\
\hline
\end{tabular}

Fonte: Banco de dados Jovens Agricultores Familiares RS - MDA/FAURGS, 2007. 
$\mathrm{Na}$ Tabela 53, observa-se o cruzamento entre a distribuição dos projetos profissionais por faixa etária dos entrevistados. Nela registra-se um aumento nos percentuais de projetos como agricultor familiar na medida em que aumenta a faixa etária, uma vez que esta categoria de resposta passa de $18,3 \%$ entre os jovens adolescentes, para $45,5 \%$ entre os jovens da faixa de idade intermediária e chega ao patamar 53,6\% de respostas entre os jovens adultos. Destaca-se ainda que, entre os adolescentes, o projeto profissional e de formação encontram-se profundamente imbricados, tanto que 12,45\% deles respondem a esta questão com a categoria profissional com formação superior ligada a agricultura e pecuária, enquanto outros 11,2\% projetam ser professor. Já entre as duas faixas etárias seguintes, além do trabalho agrícola, a disposição de trabalhar como autônomo e de ser professor(a) aparecem em segundo e terceira opções mais recorrentes.

Considerando a formulação dos projetos profissionais por sexo e faixa etária, o Gráfico 57 permite verificar que são os homens de 25 a 29 anos de idade os que mais projetam estabelecerem-se como agricultores familiares (60,5\%), seguidos pelos de 20 a 24 anos $(52,7 \%)$, e pelos de 15 a 19 anos, com 24,1\% dos casos. Os jovens adolescentes indicam, também, profissão técnica não relacionada com a agricultura $(11,1 \%)$, enquanto que os do recorte etário seguinte apontam o serviço autônomo como projeto profissional (12,2\%). As mulheres adolescentes pretendem, principalmente, serem professoras $(27,9 \%)$ ou ainda profissionais com formação superior na área da saúde $(13,1 \%)$. As entrevistadas de 20 a 24 anos revelam, principalmente, o desejo de ser agricultoras familiares (34\%), assim como aquelas que têm de 25 a 29 anos $(42,3 \%)$. No entanto, elas também apresentam percentuais significativos de projetos profissionais como professoras e como profissionais de setor da saúde. 
Tabela 53: Projetos profissionais por faixa etária (em $f$ e \%)

\begin{tabular}{|c|c|c|c|c|c|c|}
\hline & & & \multicolumn{3}{|c|}{ FAIXA ETÁRIA: } & \multirow[b]{2}{*}{ Total } \\
\hline & & & $\begin{array}{l}\text { De } 15 \text { a } \\
19 \text { anos }\end{array}$ & $\begin{array}{l}\text { De } 20 \text { a } \\
24 \text { anos }\end{array}$ & $\begin{array}{l}\text { De } 25 \text { a } \\
29 \text { anos }\end{array}$ & \\
\hline \multirow{36}{*}{$\begin{array}{l}\text { Qual é seu } \\
\text { projeto } \\
\text { profissional? } \\
\text { (codificado) }\end{array}$} & \multirow[t]{2}{*}{ Administrador(a) de empresa } & f & 4 & 3 & 0 & 7 \\
\hline & & $\%$ & $2,4 \%$ & $2,5 \%$ &, $0 \%$ & $1,6 \%$ \\
\hline & \multirow[t]{2}{*}{ Agricultor(a) Familiar } & $f$ & 31 & 55 & 74 & 160 \\
\hline & & $\%$ & $18,3 \%$ & $45,5 \%$ & $53,6 \%$ & $37,4 \%$ \\
\hline & \multirow{2}{*}{$\begin{array}{l}\text { Assalariado(a) do setor de } \\
\text { serviço e comércio }\end{array}$} & f & 2 & 2 & 7 & 11 \\
\hline & & $\%$ & $1,2 \%$ & $1,7 \%$ & $5,1 \%$ & $2,6 \%$ \\
\hline & \multirow[t]{2}{*}{ Empresário(a) } & $f$ & 1 & 3 & 4 & 8 \\
\hline & & $\%$ &, $6 \%$ & $2,5 \%$ & $2,9 \%$ & $1,9 \%$ \\
\hline & \multirow[t]{2}{*}{ Engenheiro(a) } & $f$ & 5 & 2 & 3 & 10 \\
\hline & & $\%$ & $3,0 \%$ & $1,7 \%$ & $2,2 \%$ & $2,3 \%$ \\
\hline & \multirow{2}{*}{$\begin{array}{l}\text { Fazer curso superior não } \\
\text { agrícola. }\end{array}$} & $f$ & 9 & 3 & 3 & 15 \\
\hline & & $\%$ & $5,3 \%$ & $2,5 \%$ & $2,2 \%$ & $3,5 \%$ \\
\hline & \multirow[t]{2}{*}{ Funcionário(a) Público(a) } & $f$ & 1 & 0 & 6 & 7 \\
\hline & & $\%$ & ,6\% &, $0 \%$ & $4,3 \%$ & $1,6 \%$ \\
\hline & \multirow[t]{2}{*}{ Operário(a) fabril } & $f$ & 4 & 2 & 0 & 6 \\
\hline & & $\%$ & $2,4 \%$ & $1,7 \%$ &, $0 \%$ & $1,4 \%$ \\
\hline & \multirow{2}{*}{$\begin{array}{l}\text { Outras Profissões com } \\
\text { formação superior não agricula. }\end{array}$} & f & 3 & 3 & 2 & 8 \\
\hline & & $\%$ & $1,8 \%$ & $2,5 \%$ & $1,4 \%$ & $1,9 \%$ \\
\hline & \multirow{2}{*}{$\begin{array}{l}\text { Prestador(a) de serviços } \\
\text { autônomo }\end{array}$} & f & 12 & 10 & 11 & 33 \\
\hline & & $\%$ & $7,1 \%$ & $8,3 \%$ & $8,0 \%$ & $7,7 \%$ \\
\hline & \multirow[t]{2}{*}{ Professor(a) } & $f$ & 19 & 9 & 9 & 37 \\
\hline & & $\%$ & $11,2 \%$ & $7,4 \%$ & $6,5 \%$ & $8,6 \%$ \\
\hline & \multirow{2}{*}{$\begin{array}{l}\text { Profissional superior ligado a } \\
\text { agricultura e pecuária. }\end{array}$} & $f$ & 21 & 7 & 2 & 30 \\
\hline & & $\%$ & $12,4 \%$ & $5,8 \%$ & $1,4 \%$ & $7,0 \%$ \\
\hline & \multirow[t]{2}{*}{ Profissional liberal } & $f$ & 3 & 6 & 1 & 10 \\
\hline & & $\%$ & $1,8 \%$ & $5,0 \%$ &, $7 \%$ & $2,3 \%$ \\
\hline & \multirow{2}{*}{$\begin{array}{l}\text { Profissional superior da área de } \\
\text { saúde }\end{array}$} & $f$ & 10 & 5 & 3 & 18 \\
\hline & & $\%$ & $5,9 \%$ & $4,1 \%$ & $2,2 \%$ & $4,2 \%$ \\
\hline & \multirow{2}{*}{$\begin{array}{l}\text { Profissional Técnico não } \\
\text { relacionado a agricultura }\end{array}$} & $f$ & 13 & 6 & 3 & 22 \\
\hline & & $\%$ & $7,7 \%$ & $5,0 \%$ & $2,2 \%$ & $5,1 \%$ \\
\hline & \multirow{2}{*}{$\begin{array}{l}\text { Profissional Técnico relacionado } \\
\text { a agricultura. }\end{array}$} & $f$ & 11 & 0 & 1 & 12 \\
\hline & & $\%$ & $6,5 \%$ &, $0 \%$ &, $7 \%$ & $2,8 \%$ \\
\hline & \multirow{2}{*}{$\begin{array}{l}\text { Trabalhador da cultura, artes e } \\
\text { artesanato }\end{array}$} & $f$ & 5 & 0 & 4 & 9 \\
\hline & & $\%$ & $3,0 \%$ &, $0 \%$ & $2,9 \%$ & $2,1 \%$ \\
\hline & \multirow[t]{2}{*}{ Outros profissões não agrícolas } & $f$ & 15 & 5 & 5 & 25 \\
\hline & & $\%$ & $8,9 \%$ & $4,1 \%$ & $3,6 \%$ & $5,8 \%$ \\
\hline \multirow[t]{2}{*}{ Total } & & $f$ & 169 & 121 & 138 & 428 \\
\hline & & $\%$ & $100,0 \%$ & $100,0 \%$ & $100,0 \%$ & $100,0 \%$ \\
\hline
\end{tabular}

Fonte: Banco de dados Jovens Agricultores Familiares RS - MDA/FAURGS, 2007. 


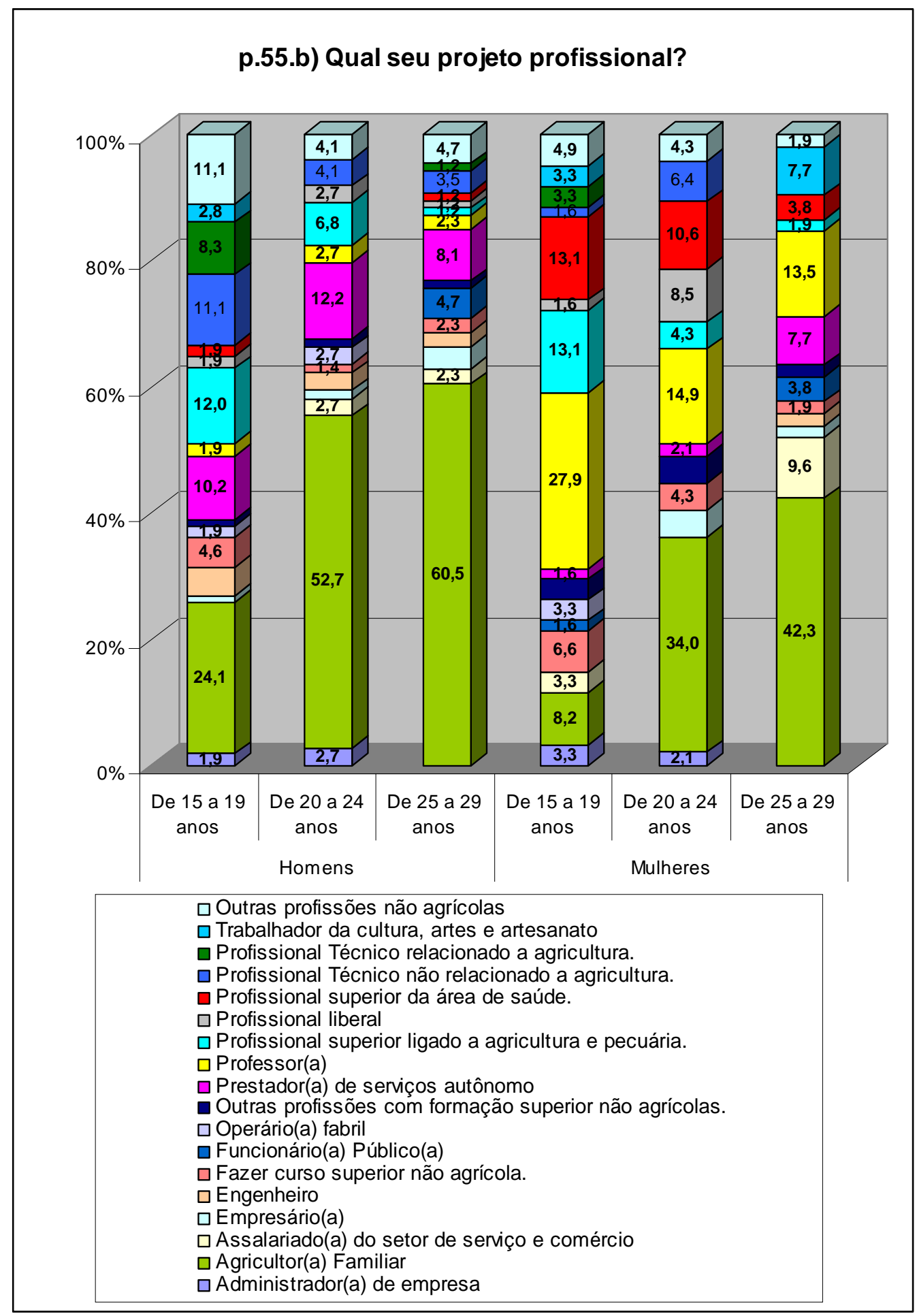

Gráfico 57: Projetos profissionais por sexo e faixa etária (\%)

Fonte: Banco de dados Jovens Agricultores Familiares RS - MDA/FAURGS, 2007.

Percebe-se que a escolha de um futuro profissional por parte dos jovens agricultores familiares coloca-os frente a diversas opções que serão determinadas por um conjunto de fatores 
que ultrapassam a perspectiva individual dos atores. Através da elaboração de um projeto profissional, cria-se a orientação para o estabelecimento de objetivos e a organização dos meios necessários através dos quais estes poderão ser atingidos (SCHÜTZ, 1979). Sua construção deve-se ao cruzamento entre biografia individual e interação social. Individual, na medida em que implica a avaliação e o posicionamento do sujeito diante de um plano de realização pessoal e estratégias particulares. Social, devido ao fato de que esta tomada de posição se realiza num contexto social e cultural específico, independente da vontade individual, e na interação com outros atores sociais e projetos coletivos e individuais. Deste modo, os projetos apresentam-se cambiantes e mesmo contraditórios. Com efeito, os projetos profissionais, como o futuro em aberto, têm um grande grau de indeterminação e podem ser alterados ao longo da trajetória dos atores sociais e em reação a processos de interação experenciados.

Quando os jovens são colocados diante deste tema de outra maneira, eles reagem de modo diferenciando, com mudanças de atitude. No Gráfico 58, verificamos as repostas obtidas para a pergunta Você pretende se estabelecer profissionalmente na agricultura? Percebe-se que a maior parte dos entrevistados $(64,4 \%)$ responde que sim.

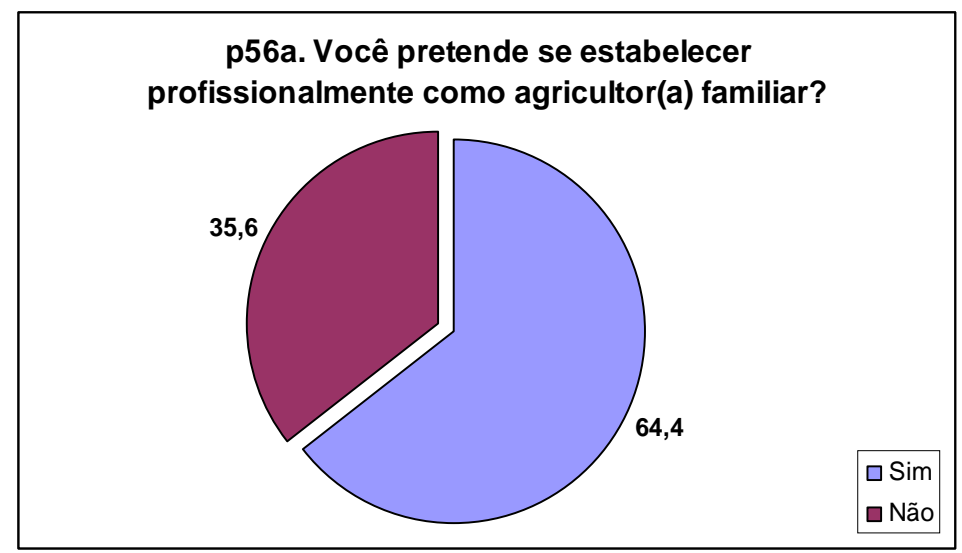

Gráfico 58: Distribuição dos projetos profissionais na agricultura familiar (\%) Fonte: Banco de dados Jovens Agricultores Familiares RS - MDA/FAURGS, 2007.

Comparando-se as respostas à mesma questão de acordo com o sexo do entrevistado, percebe-se que predomina, entre ambos, as respostas positivas. Contudo, há uma maior disposição entre os homens $(68,3 \%)$ para esta atividade do que a registrada entre as mulheres (58\%). Esta diferença de 10 pontos percentuais é significativa das posições ocupadas por homens e mulheres nas estratégias de reprodução social da agricultura familiar. 
Tabela 54: Cruzamento entre projetos profissionais agrícolas e sexo (em $f$ e \%)

\begin{tabular}{|c|c|c|c|c|c|}
\hline & & & \multicolumn{2}{|c|}{ SEXO } & \multirow[b]{2}{*}{ Total } \\
\hline & & & Homens & Mulheres & \\
\hline \multirow{4}{*}{$\begin{array}{l}\text { VOCÊ PRETENDE SE } \\
\text { ESTABELECER } \\
\text { PROFISSIONALMENTE } \\
\text { COMO AGRICULTOR(A) } \\
\text { FAMILIAR? }\end{array}$} & Sim & $f$ & 286 & 145 & 431 \\
\hline & & $\%$ & $68,3 \%$ & $58,0 \%$ & $64,4 \%$ \\
\hline & Não & $f$ & 133 & 105 & 238 \\
\hline & & $\%$ & $31,7 \%$ & $42,0 \%$ & $35,6 \%$ \\
\hline \multirow[t]{2}{*}{ Total } & & $f$ & 419 & 250 & 669 \\
\hline & & $\%$ & $100,0 \%$ & $100,0 \%$ & $100,0 \%$ \\
\hline
\end{tabular}

Fonte: Banco de dados Jovens Agricultores Familiares RS - DA/FAURGS, 2007.

A pretensão de se estabelecer, profissionalmente, na agricultura familiar é diferenciada segundo as faixas etárias dos entrevistados como pode ser verificado na Tabela 55. A metade do contingente de jovens adolescentes não pretende se estabelecer na agricultura familiar. Entre os com idades de 20 a 24, 65,3\% deles têm intenção de permanecer no trabalho agrícola. Já entre os jovens adultos, o percentual desta resposta chega a 79,9\%. Isto demonstra que há uma progressiva adesão aos projetos profissionais na agricultura familiar na medida em que as idades dos entrevistados aumentam.

Tabela 55: Cruzamento entre projetos profissionais agrícolas e faixa etária (em $f$ e \%)

\begin{tabular}{|c|c|c|c|c|c|c|}
\hline & & & \multicolumn{3}{|c|}{ FAIXA ETÁRIA: } & \multirow[b]{2}{*}{ Total } \\
\hline & & & $\begin{array}{l}\text { De } 15 \text { a } \\
19 \text { anos }\end{array}$ & $\begin{array}{l}\text { De } 20 \text { a } \\
24 \text { anos }\end{array}$ & $\begin{array}{l}\text { De } 25 \text { a } \\
29 \text { anos }\end{array}$ & \\
\hline \multirow{4}{*}{$\begin{array}{l}\text { VOCÊ PRETENDE SE } \\
\text { ESTABELECER } \\
\text { PROFISSIONALMENTE } \\
\text { COMO AGRICULTOR(A) } \\
\text { FAMILIAR? }\end{array}$} & \multirow[t]{2}{*}{ Sim } & $f$ & 120 & 132 & 179 & 431 \\
\hline & & $\%$ & $49,4 \%$ & $65,3 \%$ & $79,9 \%$ & $64,4 \%$ \\
\hline & \multirow[t]{2}{*}{ Não } & $f$ & 123 & 70 & 45 & 238 \\
\hline & & $\%$ & $50,6 \%$ & $34,7 \%$ & $20,1 \%$ & $35,6 \%$ \\
\hline \multirow[t]{2}{*}{ Total } & & $f$ & 243 & 202 & 224 & 669 \\
\hline & & $\%$ & $100,0 \%$ & $100,0 \%$ & $100,0 \%$ & $100,0 \%$ \\
\hline
\end{tabular}

Fonte: Banco de dados Jovens Agricultores Familiares RS - MDA/FAURGS, 2007.

O Gráfico 59 ilustra como os percentuais de respostas sim e não evoluem por faixa etária e sexo. Pode-se verificar que a disposição para a reprodução do trabalho familiar agrícola aumenta com as idades dos entrevistados de ambos os sexos. Contudo, é extremante significativo o fato de $60,7 \%$ das mulheres adolescentes não querer se estabelecer profissionalmente nesta atividade. Os jovens adultos são os que apresentam maiores percentuais de respostas positivas, sendo de $77,8 \%$ entre as jovens do sexo feminino e $81,3 \%$ entre os homens. 
Pode-se perceber esta informação como expressão da maneira como os jovens se posicionam nesse espaço social em transformação, indicando suas disposições de reproduzir ou romper com o processo de trabalho familiar agrícola. Com efeito, a formulação de um projeto profissional revela uma vontade de vir a ser que reflexivamente constitui-se a partir da avaliação das possibilidades futuras.

A análise dos projetos profissionais em construção por jovens agricultores familiares revela os dilemas e contradições que afetam as suas disposições em reproduzir o processo de trabalho familiar agrícola. Estes projetos traduzem a avaliação que fazem da agricultura familiar, revelando, ainda, como eles lidam com a situação em que se encontram.

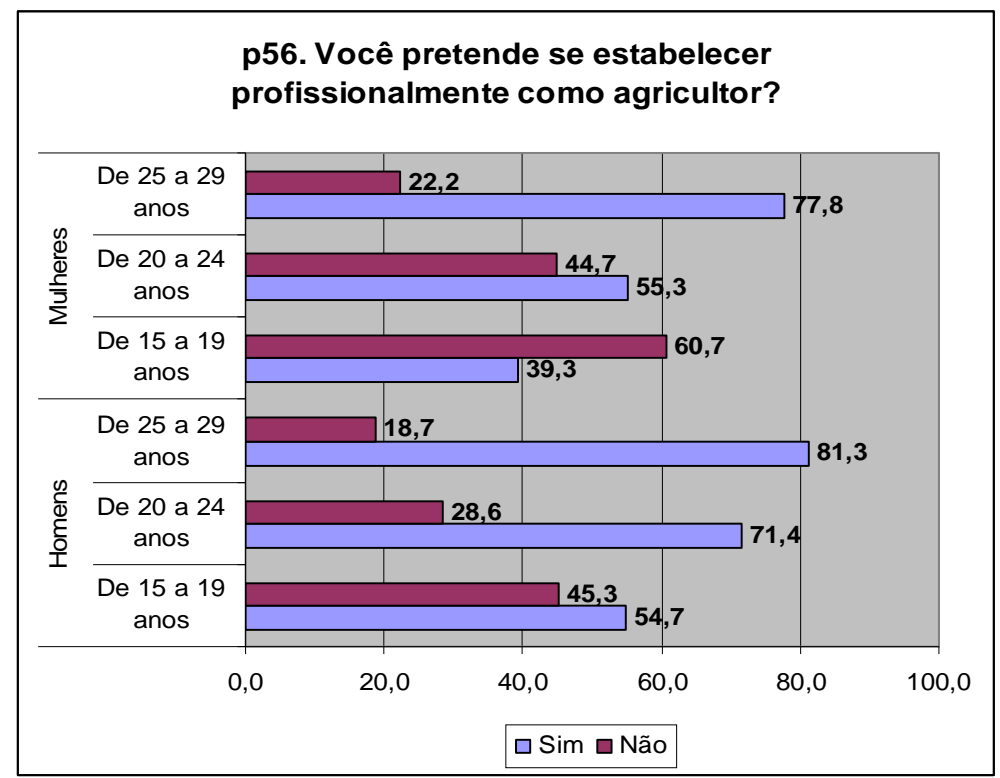

Gráfico 59: Projetos de estabelecimento profissional na agricultura familiar por sexo e faixa etária (em $f$ e \%) Fonte: Banco de dados Jovens Agricultores Familiares RS - MDA/FAURGS, 2007.

Prevalecem entre os jovens agricultores familiares gaúchos projetos profissionais agrícolas, de onde se pode concluir que, apesar de todas as dificuldades enfrentadas, os jovens encontram-se imbuídos do propósito de permanecer neste ramo de atividade, possibilitando, assim, a reprodução social desta forma de agricultura. Outrossim, os posicionamentos diferenciados por sexo e idade colocam jovens adultos do sexo masculino com uma grande disposição para a reprodução do trabalho familiar agrícola, enquanto as jovens adolescentes manifestam principalmente o desejo de romper com este processo de trabalho. Os projetos profissionais representam a recusa de seu estatuto presente e a preocupação com uma nova 
posição social. Em ambos os casos, de confirmação ou negação do trabalho agrícola, os projetos juvenis conferem sentidos a suas inserções atuais.

\subsection{OS PROJETOS DE VIDA DOS JOVENS AGRICULTORES FAMILIARES}

São analisados, agora, os projetos de vida dos jovens agricultores familiares gaúchos. Como foi definido anteriormente, o projeto de vida antecipa um tempo mais distante dos que os projetos de formação e profissional, vinculados a investimentos sentimentais e familiares, apontando para definições sobre a vida conjugal e residencial. Neste sentido, buscou-se identificar este projeto por meio das questões: Onde você pretende morar? e Você pretende casar com um(a) agricultor(a)?

No esforço de compreender a construção dos projetos de vida dos jovens agricultores familiares, inicia-se por identificar o local onde estes pretendem residir no futuro. A distribuição das respostas à primeira questão é apresentada no Gráfico 60. Este mostra que a intenção de residir no meio rural predomina entre os entrevistados $(72,1 \%)$. Entre os motivos apresentados para esta escolha, eles destacam que o meio rural é um "lugar mais calmo e tranquilo", tem uma "melhor qualidade de vida" e "maior contato com a natureza" ou ainda é mais propício para o trabalho agrícola. Entre os que pretendem residir no meio urbano, destaca-se o acesso às oportunidades de trabalho e à escolarização, além dos serviços socialmente valorizados. Estes argumentos aparecem em respostas como: "tem mais oportunidade de trabalho e emprego"; "tem mais acesso ao lazer, comércio e saúde"; "para conseguir um emprego melhor".

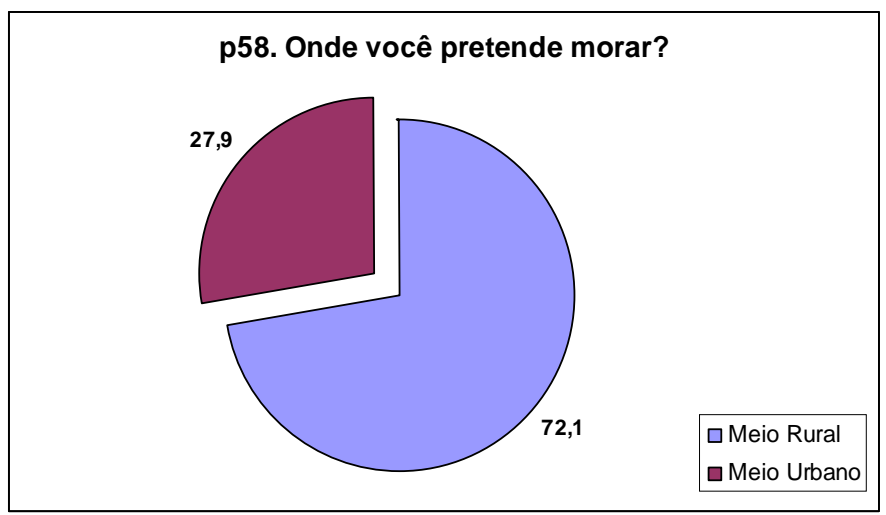

Gráfico 60: distribuição de respostas a questão Onde pretende morar? (\%) Fonte: Banco de dados Jovens Agricultores Familiares RS - MDA/FAURGS, 2007. 
O cruzamento entre a mesma questão com a variável sexo permite identificar que a disposição em residir no meio rural é maior entre os homens $(75,6 \%)$ do que entre as mulheres $(66,3 \%)$ (Tabela 56). Esta diferença confirma os projetos das jovens de buscar inserção profissional em outras atividades que não a agricultura, considerando-se as justificativas dadas pelos entrevistados referidas no parágrafo anterior. Nestes casos, a fixação de residência no meio urbano é vista como uma condição facilitadora de novas oportunidades que eles não encontram no meio rural, principalmente de continuidade na escolarização e a obtenção de emprego com remuneração mensal.

Tabela 56: Cruzamento das respostas a questão Onde você pretende morar? por sexo (em $f$ e \%)

\begin{tabular}{llrrrr}
\hline \hline & & \multicolumn{2}{c}{ SEXO } & \\
\cline { 3 - 4 } & & Homens & Mulheres & Total \\
\hline ONDE VOCÊ & Meio Rural & $\mathrm{f}$ & 316 & 167 & 483 \\
PRETENDE & & $\%$ & $75,6 \%$ & $66,3 \%$ & $72,1 \%$ \\
\cline { 2 - 5 } MORAR? & Meio Urbano & $\mathrm{f}$ & 102 & 85 & 187 \\
& & $\%$ & $24,4 \%$ & $33,7 \%$ & $27,9 \%$ \\
\hline Total & $\mathrm{f}$ & 418 & 252 & 670 \\
& $\%$ & $100,0 \%$ & $100,0 \%$ & $100,0 \%$ \\
\hline \hline
\end{tabular}

Fonte: Banco de dados Jovens Agricultores Familiares RS - MDA/FAURGS, 2007.

Considerando os percentuais de resposta à mesma questão por faixa etária, verifica-se que a intenção de residir no meio rural aumenta com as idades dos entrevistados. Entre os adolescentes ela é de 59,4\%, passa para 76,5\% entre os jovens de 20 a 24 anos de idade e chega a $81,9 \%$ entre os jovens adultos (Tabela 57). Cabe ressaltar que grande parte dos jovens com mais de 20 anos já se encontram instalados como agricultores independentes ou exercendo um importante papel na condução das tarefas produtivas na propriedade de sua família. Deste modo, a residência no meio rural é mais condizente com a efetivação de seus projetos profissionais como agricultores. 
Tabela 57: Cruzamento das respostas a questão Onde você pretende morar? por faixa etária (em $f$ e \%)

\begin{tabular}{llrrrrr}
\hline \hline & & \multicolumn{3}{c}{ FAIXA ETÁRIA: } & \\
\cline { 3 - 6 } & & De 15 a & De 20 a & De 25 a & \\
\hline ONDE VOCÊ & Meio Rural & $f$ & 19 anos & 24 anos & 29 anos & Total \\
PRETENDE & & $\%$ & $59,4 \%$ & $76,5 \%$ & $81,9 \%$ & $72,1 \%$ \\
\cline { 2 - 6 } MORAR? & Meio Urbano & $f$ & 99 & 47 & 41 & 187 \\
& & $\%$ & $40,6 \%$ & $23,5 \%$ & $18,1 \%$ & $27,9 \%$ \\
\hline Total & $f$ & 244 & 200 & 226 & 670 \\
& & $\%$ & $100,0 \%$ & $100,0 \%$ & $100,0 \%$ & $100,0 \%$ \\
\hline \hline
\end{tabular}

Fonte: Banco de dados Jovens Agricultores Familiares RS - MDA/FAURGS, 2007.

Como pode ser verificado com o cruzamento da questão em análise por faixa etária e sexo, predomina entre os entrevistados de ambos os sexos e faixas etárias a pretensão de residir no meio rural, exceto entre as mulheres adolescentes (Gráfico 61). Isto reforça a percepção de que entre os jovens adolescentes predominam projetos que apontam para ruptura com o meio rural e o modo de vida agrícola.

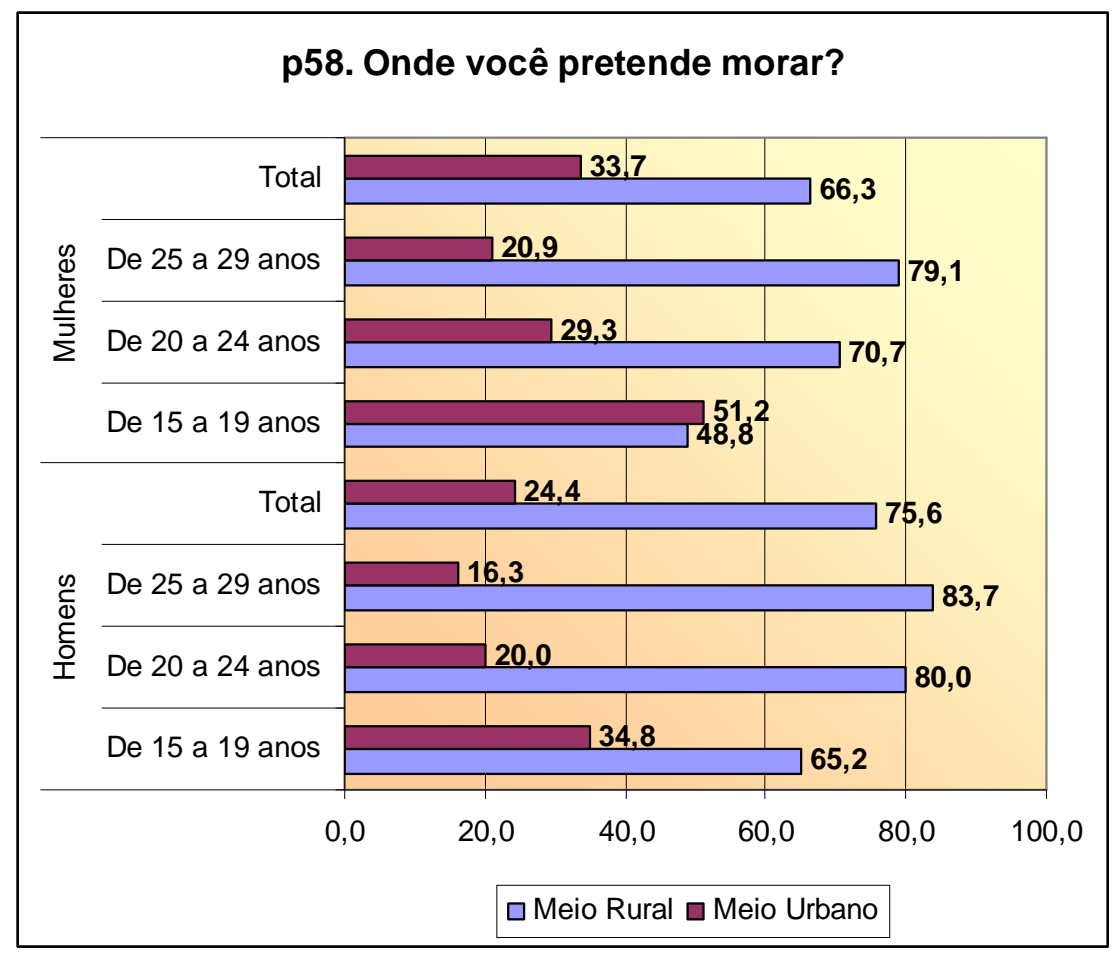

Gráfico 61: Cruzamento das respostas a questão Onde você pretende morar? por faixa etária e sexo (\%) Fonte: Banco de dados Jovens Agricultores Familiares RS - MDA/FAURGS, 2007. 
Entende-se que o estabelecimento de tipo de relacionamento conjugal faz parte do que se denomina "projeto de vida", ou seja, a vontade de encontrar um(a) companheiro(a) que compartilhe do mesmo projeto de vida, ou mesmo a opção por não tecer laços de conjugalidade. Ao mesmo tempo, entende-se que a constituição de uma nova unidade de produção familiar implica a construção de um casal de agricultores e a posterior socialização dos filhos nas atividades produtivas. De tal modo, torna-se problemático caracterizar-se como agricultor familiar, os produtores solteiros que não contam como a força de trabalho da família, mesmo que seja por meio de parceria com parentes, uma vez que em tais condições os celibatários que permanecem na agricultura terão que recorrer a força de trabalho contratada.

Com base neste raciocínio, procurou-se saber dos entrevistados se cogitavam em casarse com agricultores. Para entender como isto ocorre no universo de estudo, perguntou-se: Você pretende se casar com um(a) agricultor(a)? A distribuição das respostas a esta questão indica o predomínio, com 74,7\% de casos, dos que pretendem casar-se com agricultores (Gráfico 62).

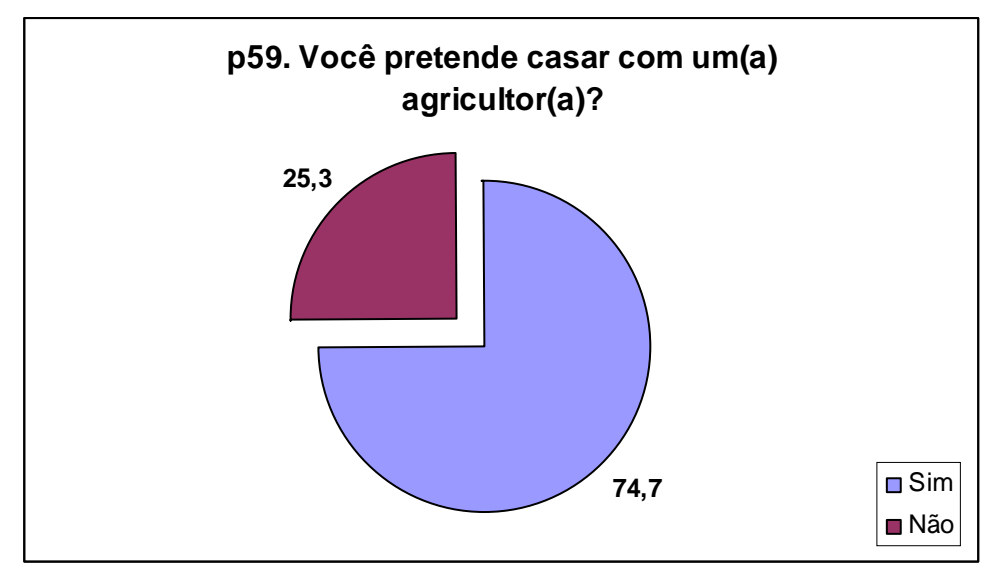

Gráfico 62: Distribuição das respostas a questão Você pretende casar com um(a) agricultor (a)? (\%) Fonte: Banco de dados Jovens Agricultores Familiares RS - MDA/FAURGS, 2007.

Realizando o cruzamento das respostas obtidas para esta mesma questão com a variável sexo, é possível identificar uma disposição um pouco maior entre os homens $(76,1 \%)$ do que entre as mulheres $(72,6 \%)$ de casar-se com agricultoras ou agricultores. Aqui temos que considerar o fato de que 47,2\% das entrevistadas já se encontram casadas; nestes casos, suas respostas confirmam uma condição já vivida e não uma projeção futura (Tabela 58). 
Tabela 58: Cruzamento das respostas a questão Você pretende casar com um(a) agricultor (a)? por sexo (em $f$ e \%)

\begin{tabular}{llrrrr}
\hline \hline & & \multicolumn{2}{c}{ SEXO } & \\
\cline { 3 - 4 } & & Homens & Mulheres & \multicolumn{1}{c}{ Total } \\
\hline VOCÊ PRETENDE & Sim & $f$ & 226 & 138 & 364 \\
CASAR COM UM(A) & $\%$ & $76,1 \%$ & $72,6 \%$ & $74,7 \%$ \\
\cline { 2 - 5 } AGRICULTOR(A)? & $\%$ & 71 & 52 & 123 \\
& Não & $f$ & $23,9 \%$ & $27,4 \%$ & $25,3 \%$ \\
\hline Total & $\%$ & 297 & 190 & 487 \\
& & $f$ & $100,0 \%$ & $100,0 \%$ & $100,0 \%$ \\
\hline \hline
\end{tabular}

Fonte: Banco de dados Jovens Agricultores Familiares RS - MDA/FAURGS, 2007.

A disposição de casar com um agricultor ou uma agricultora conforme a idade dos entrevistados pode ser visualizada na Tabela 59. Entre os jovens de 15 a 19 anos, onde predominam os solteiros, encontra-se o menor percentual de interesse por um cônjuge vinculado à agricultura. Por sua vez, com o aumento da faixa etária verifica-se um crescimento desta pretensão matrimonial que chega a $82 \%$ entre os jovens adultos.

Tabela 59: Cruzamento das respostas a questão Você pretende casar com um(a) agricultor (a)? por faixa etária (em $f$ e \%)

\begin{tabular}{lcrrrrr}
\hline \hline & & \multicolumn{3}{c}{ FAIXA ETÁRIA: } \\
\cline { 2 - 5 } & & $\begin{array}{r}\text { De 15 a } \\
19 \text { anos }\end{array}$ & $\begin{array}{c}\text { De 20 a } \\
24 \text { anos }\end{array}$ & $\begin{array}{c}\text { De 25 a 29 } \\
\text { anos }\end{array}$ & Total \\
\hline VOCÊ PRETENDE & Sim & $f$ & 103 & 115 & 146 & 364 \\
CASAR COM UM(A) & & $\%$ & $63,6 \%$ & $78,2 \%$ & $82,0 \%$ & $74,7 \%$ \\
\cline { 2 - 6 } AGRICULTOR(A)? & Não & $f$ & 59 & 32 & 32 & 123 \\
& & $\%$ & $36,4 \%$ & $21,8 \%$ & $18,0 \%$ & $25,3 \%$ \\
\hline Total & $f$ & 162 & 147 & 178 & 487 \\
& $\%$ & $100,0 \%$ & $100,0 \%$ & $100,0 \%$ & $100,0 \%$ \\
\hline \hline
\end{tabular}

Fonte: Banco de dados Jovens Agricultores Familiares RS - MDA/FAURGS, 2007.

Os projetos de vida que contemplam o matrimônio entre agricultores predominam entre os entrevistados de ambos os sexos e de todas as faixas de idade. Estes apresentam percentuais maiores entre jovens com mais idade. Os maiores índices de respostas positivas são registrados entre os jovens a partir de 20 anos de idade. Por sua vez, a rejeição a um cônjuge com esta profissão chega a $43,3 \%$ entre as jovens adolescentes, o que representa $10 \%$ a mais do que o verificado entre os homens desta mesma idade (Gráfico 63). 


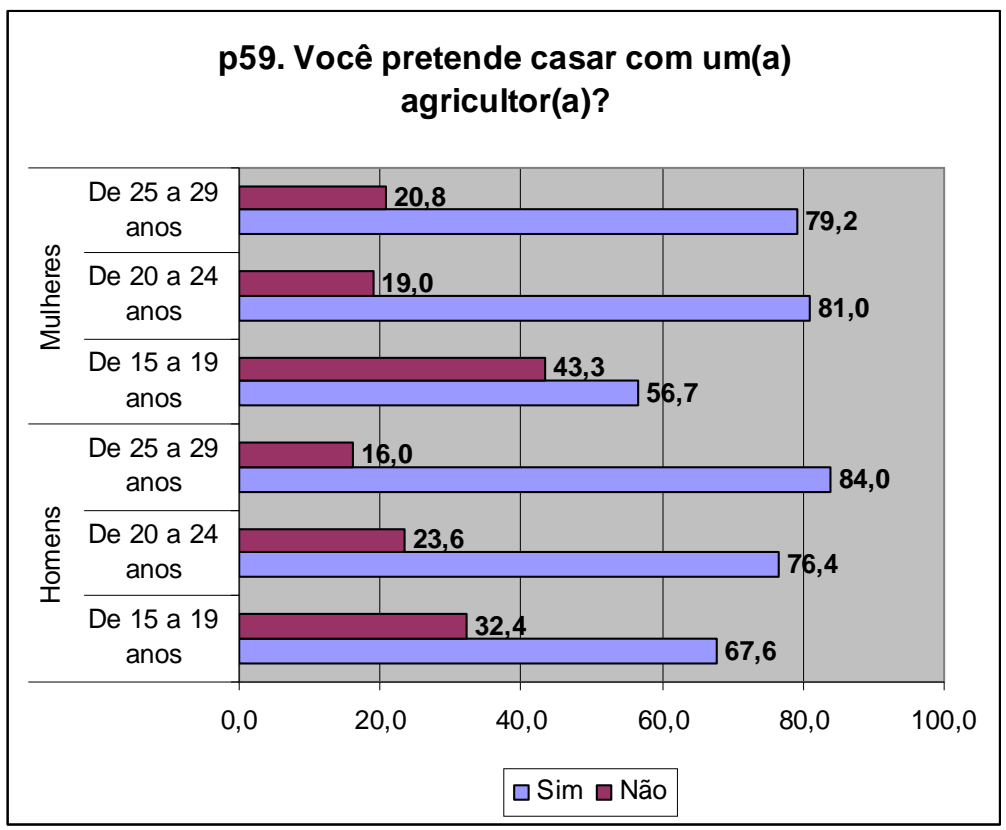

Gráfico 63: Cruzamento das respostas a questão Você pretende casar com um(a) agricultor (a)? por faixa etária e sexo $(\%)$

Fonte: Banco de dados Jovens Agricultores Familiares RS - MDA/FAURGS, 2007.

Entre as jovens adolescentes predominam as solteiras; por isto, são as mais potencialmente esposáveis. O impasse reside no fato de que são justamente elas que têm maior resistência ao matrimônio com agricultores. Isto mostra que os jovens homens que pretendem casar e se estabelecer como agricultores enfrentam dificuldades de encontrar - no mercado matrimonial - mulheres com o mesmo projeto. Além da variável em análise, as adolescentes, majoritariamente, não pretendem residir no meio rural, nem ser agricultoras e ao mesmo tempo elaboram projetos de escolarização com vistas à inserção no mercado de trabalho não-agrícola.

\subsection{DIMENSÕES DA SITUAÇÃO JUVENIL E PROJETOS PROFISSIONAIS DOS JOVENS AGRICULTORES FAMILIARES}

O projeto profissional aparece como resultado de um esforço de reflexividade dos jovens em estabelecer objetivos de inserção no mundo do trabalho. Entretanto, isto não ocorre apenas no âmbito das escolhas pessoais, resulta do balanço entre as experiências adquiridas da trajetória dos jovens e do campo de possibilidades, que atua como condicionante estrutural sobre os seus projetos (VELHO, 2003). Com base nisto, deve-se reconhecer que os projetos por eles 
formulados resultam da interação de múltiplos fatores associados às dimensões analíticas do modelo descritivo da situação juvenil proposto neste estudo. Com efeito, interessa identificar como tais dimensões da situação juvenil - condições materiais, processo de socialização e representações sociais - relacionam-se aos projetos profissionais dos entrevistados. Para dar consequência a esta perspectiva relacional na interpretação da construção dos projetos dos jovens agricultores familiares, neste tópico são analisadas as interações que se estabelecem entre cada uma das dimensões analíticas com fenômeno em questão, com base em dois procedimentos: um típico da estatística descritiva e outra referente à análise multivariada de dados qualitativos.

No que se refere ao primeiro procedimento, estaremos realizando cruzamento entre variáveis. Procurando operacionalizar esta questão, selecionou-se um conjunto de variáveis consideradas independentes (Quadro 5) que sintetizam as dimensões da situação juvenil analisadas nos capítulos anteriores para verificar como estas questões se relacionam com as respostas dicotômicas obtidas para a pergunta "Você pretende se estabelecer profissionalmente na agricultura?" que é tratada como variável dependente.

Quadro 5: Variáveis independentes selecionadas por dimensão analítica.

\begin{tabular}{|l|l|}
\hline DIMENSÃO ANALÍTICA & \multicolumn{1}{c|}{ VARIÁVEIS INDEPENDENSTES } \\
\hline Condições Materiais & $\begin{array}{l}\text { Sua família é proprietária da terra em que trabalha? } \\
\text { Grau de autonomia material. }\end{array}$ \\
\hline Processo de Socialização & $\begin{array}{l}\text { Você está estudando atualmente? } \\
\text { Jornada diária de trabalho na UPF }\end{array}$ \\
\hline Representações Sociais & $\begin{array}{l}\text { O quanto você gosta do trabalho agrícola? } \\
\text { Como você avalia o modo de vida de seus pais? }\end{array}$ \\
\hline
\end{tabular}

Fonte: Elaboração própria.

O segundo procedimento corresponde à análise de homogeneidade ${ }^{73}$ por via de um método algébrico do tipo Alternating Leaste Squares (HOMALS) que permite a identificação das associações e oposições entre variáveis a partir da representação gráfica dos espaços multidimensionais em que se distribuem os objetos e categorias em análise (Carvalho, 2004). A este, serão submetidas as mesmas variáveis que se apresentaram com maio poder de

73 "Fala-se aqui em homogeneidade no sentido em que a proximidade de um certo número de categorias (de diferentes variáveis) induz à presença de indivíduos que partilham as mesmas características. Assim aos diferentes núcleos de homogeneidade correspondem grupos de indivíduos com perfis distintos, mas que coexistem, com maior ou menor proximidade, no mesmo espaço" (CARVALHO, 2004, p. 22). 
discriminação dos indivíduos entrevistados, acrescendo sexo e faixa etária. Busca-se, agora, não mais percebê-los como fatores independentes, mas identificar o sistema de relações que se estabelecem entre eles, contemplando-se uma análise estrutural destas múltiplas relações por meio da operacionalização de indicadores categoriais.

Este procedimento analítico produz um conjunto de resultados a partir das variáveis selecionadas, dos quais se optou por utilizar dois deles: 1) A medida de discriminação que quantifica a variância de cada variável. Seus valores variam entre 0 e 1, assim, quanto mais perto de 1, mais a variável discrimina os indivíduos em uma dada dimensão. 2) A quantificação das categorias que é uma representação gráfica que distribui as categorias em quadrantes adjacentes permitindo identificar as distâncias destas entre si e a configuração da interação entre estas formando grupos cujos perfis são distintos.

Nas páginas subsequentes, desenvolve-se a análise das relações entre as dimensões analíticas e os projetos profissionais dos jovens agricultores familiares, organizados em três subitens deste tópico: o primeiro referente às condições materiais; o segundo, aos processos de socialização e; o terceiro, às representações sociais.

\subsubsection{Condições materiais e projetos profissionais}

Busca-se, agora, demonstrar como os projetos profissionais dos jovens agricultores familiares se constroem em relação às suas condições materiais. Pretende-se assim demonstrar que os recursos alocados pelos jovens estruturam suas disposições de reprodução do processo de trabalho familiar agrícola. Isso pode ser percebido, inicialmente, a partir da condição fundiária das famílias dos entrevistados e pelo grau de autonomia material desfrutado por estes na agricultura familiar.

Não deve causar estranhamento a escolha da condição fundiária como fator explicativo, visto que "o estatuto fundiário é central em toda a análise de funcionamento das unidades de produção" (LAMARCHE, 1998, p. 63). Como mencionado anteriormente, esta variável foi construída a partir da pergunta: Sua família é proprietária da terra em que trabalha? A intenção, aqui, é perceber como a propriedade da terra pela família do entrevistado relaciona-se com sua disposição em reproduzir o trabalho familiar agrícola, isto é, ser agricultor familiar no futuro. Isto é possível de ser verificado cruzando-se esta primeira questão com outra considerada como 
variável dependente: Você pretende se estabelecer profissionalmente na agricultura? Desta forma, obtemos a Tabela 60 que apresenta a relação entre condição fundiária da família e projeto profissional dos jovens. Constata-se que entre proprietários e não-proprietários predomina a vontade de ser estabelecer profissionalmente como agricultor familiar. Contudo, esta informação precisa ser considerada tendo como referência a distribuição de resposta para a totalidade do contingente analisado. Desta forma, percebe-se que os entrevistados membros de famílias proprietárias apresentam um percentual praticamente igual ao registrado para a totalidade da amostra, enquanto que os jovens de famílias não proprietárias encontram-se cerca de dez pontos percentuais abaixo do índice de referência (Total). Disto resultam duas conclusões: a primeira é que os jovens projetam a condição de agricultores mesmo quando as famílias não possuem a propriedade fundiária; a segunda, derivada desta, é que esta disposição é menor entre os não proprietários do que entre os jovens cujas famílias dispõem da propriedade da terra em que trabalham.

Tabela 60: Relação entre projeto profissional e condição fundiária da família (em $f$ e \%)

\begin{tabular}{|c|c|c|c|c|c|}
\hline & & \multicolumn{3}{|c|}{$\begin{array}{l}\text { SUA FAMÍLIA É PROPRIETÁRIA } \\
\text { DA TERRA EM QUE TRABALHA? }\end{array}$} & \multirow[b]{2}{*}{ Total } \\
\hline & & & Sim & Não & \\
\hline \multirow{4}{*}{$\begin{array}{l}\text { VOCÊ PRETENDE SE } \\
\text { ESTABELECER } \\
\text { PROFISSIONALMENTE } \\
\text { COMO AGRICULTOR(A) } \\
\text { FAMILIAR? }\end{array}$} & Sim & $f$ & 388 & 43 & 431 \\
\hline & & $\%$ & $65,5 \%$ & $55,8 \%$ & $64,4 \%$ \\
\hline & Não & $f$ & 204 & 34 & 238 \\
\hline & & $\%$ & $34,5 \%$ & $44,2 \%$ & $35,6 \%$ \\
\hline \multirow[t]{2}{*}{ Total } & & $f$ & 592 & 77 & 669 \\
\hline & & $\%$ & $100,0 \%$ & $100,0 \%$ & $100,0 \%$ \\
\hline
\end{tabular}

Fonte: Banco de dados Jovens Agricultores Familiares RS - MDA/FAURGS, 2007.

A Tabela 61 traz os resultados do cruzamento entre grau de autonomia material e projeto profissional. Considerando que a autonomia material sintetiza os recursos alocativos que permitem aos jovens projetar suas possibilidades futuras, percebe-se que, mesmo em condições de baixa autonomia material, os jovens elaboram, principalmente, projetos profissionais agrícolas $(54,3 \%)$, porém este índice fica abaixo do registrado para o total dos entrevistados $(64,4 \%)$. Ao mesmo tempo, esses projetos tendem a ser mais frequentes em situações de maior autonomia material. Observa-se que entre os jovens que contam com um grau de média autonomia material $71,6 \%$ quer ser agricultor, o que sobe para $83,9 \%$ entre aqueles com alta autonomia material. Ou seja, este cruzamento demonstra que quanto maior for a autonomia 
material dos jovens agricultores, maior será a tendência destes elaborarem projetos profissionais que permitam a reprodução do trabalho familiar agrícola.

Tabela 61: Relação entre projeto profissional e grau de autonomia material (em $f$ e \%)

\begin{tabular}{|c|c|c|c|c|c|c|}
\hline & & & \multicolumn{3}{|c|}{ Grau de Autonomia Material } & \multirow[b]{2}{*}{ Total } \\
\hline & & & $\begin{array}{c}\text { baixa } \\
\text { autonomia }\end{array}$ & $\begin{array}{c}\text { média } \\
\text { autonomia }\end{array}$ & $\begin{array}{c}\text { alta } \\
\text { autonomia }\end{array}$ & \\
\hline \multirow{4}{*}{$\begin{array}{l}\text { VOCÊ PRETENDE SE } \\
\text { ESTABELECER } \\
\text { PROFISSIONALMENTE } \\
\text { COMO AGRICULTOR(A) } \\
\text { FAMILIAR? }\end{array}$} & \multirow[t]{2}{*}{ Sim } & $f$ & 196 & 136 & 99 & 431 \\
\hline & & $\%$ & $54,3 \%$ & $71,6 \%$ & $83,9 \%$ & $64,4 \%$ \\
\hline & \multirow{2}{*}{ Não } & $f$ & 165 & 54 & 19 & 238 \\
\hline & & $\%$ & $45,7 \%$ & $28,4 \%$ & $16,1 \%$ & $35,6 \%$ \\
\hline \multirow{2}{*}{\multicolumn{2}{|c|}{ Total }} & $f$ & 361 & 190 & 118 & 669 \\
\hline & & $\%$ & $100,0 \%$ & $100,0 \%$ & $100,0 \%$ & $100,0 \%$ \\
\hline
\end{tabular}

Fonte: Banco de dados Jovens Agricultores Familiares RS - MDA/FAURGS, 2007.

Conforme aponta Bourdieu (2008), as relações singulares entre uma variável independente e outra dependente, tende a dissimular o sistema completo de relações que “constituem o verdadeiro princípio da força e da forma específicas registrados em determinada correlação particular" (BOURDIEU, 2008, p. 98). Com efeito, para além das análises dos fatores vistos acima como unidades independentes, busca-se identificar, através da análise de homogeneidade (HOMALS), o sistema de relações que se estabelecem entre elas, acrescidas ainda das variáveis sexo e faixa etária dos entrevistados.

O Quadro 06 revela os valores de discriminação e importância relativa das variáveis, obtidas a partir do emprego da técnica de análise de homogeneidade (HOMALS). Destaca-se na dimensão 1, com maior poder de discriminação a variável grau de autonomia material, seguida por faixa etária. Esta última se destaca também na dimensão 2 juntamente com a que refere à condição de propriedade da terra. É importante citar que a baixa medida de discriminação de algumas categorias e, por consequência, as proporções de variância ser pouco sugestivas, não retira o poder explicativo do instrumento. Ele revela - isso sim - uma homogeneidade dos entrevistados em relação às variáveis analisadas, assim como a ocorrência de medidas de discriminação, semelhantes entre si nas duas dimensões, indica que há uma acentuada homogeneidade entre os eixos, não permitindo sua diferenciação temática (CARVALHO, 2004). Ou seja, se estas discriminações são fracas, não são menos importantes para a interpretação de suas múltiplas relações, demonstrando que indivíduos em condições diferentes compartilham posições próximas no espaço social. Com isto é possível afirmar que os principais fatores a 
diferenciar os indivíduos são: o grau de autonomia material (dimensão 1) e; a faixa etária (dimensão 2).

Quadro 06: Medidas de discriminação para variáveis em duas dimensões (Recursos Materiais)

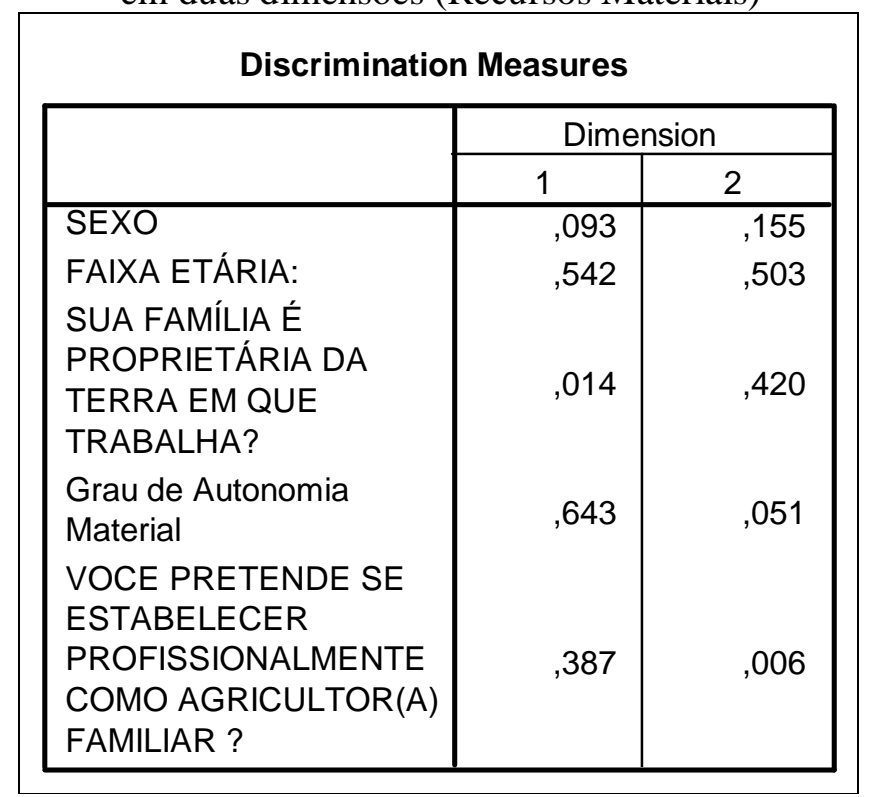

Fonte: Banco de dados Jovens Agricultores Familiares RS MDA/FAURGS, 2007.

Chega-se, desta forma, à representação gráfica dos resultados da análise multivariada das relações entre os fatores selecionados da condição material, sexo, faixa etária e projetos profissionais. Conforme pode ser observado no Gráfico 64, há uma distribuição espacial que pode ser verificada, geometricamente, entre as categorias de respostas das variáveis em consideração. A representação evidencia configurações muito bem definidas, refletindo a existência de dois grupos que se posicionam em relação aos projetos profissionais: a) os que não querem ser agricultores $\left(1^{\circ}\right.$ quadrante) e; b) os que querem ser agricultores ( ${ }^{\circ}$ quadrante). É possível observar que a negativa em ser agricultor aparece relacionada à "baixa autonomia" e à faixa de idade de "15 a 19 anos". Por sua vez, próximo à resposta "sim" para a pergunta "Você pretende se estabelecer profissionalmente na agricultura?" encontram-se as categorias: "homem", "média autonomia" e "sim" quanto à propriedade da terra. Um pouco abaixo, no $3^{\circ}$ quadrante, próximo à resposta "sim" para ser agricultor, encontra-se a categorias "alta autonomia" e a faixa etária "de 25 a 29 anos". Além destas configurações principais, é possível verificar uma relação entre autonomia material e faixa de idade. Também se destaca a posição das mulheres que se encontra em um espaço intermediário entre as respostas "sim" e "não" 
quanto a ser agricultor, estando um pouco mais próxima da segunda possibilidade. No $4^{\circ}$ quadrante, encontram-se as categorias "mulher", "não" proprietários e "baixa autonomia" material. Como resultado, conclui-se que a recusa em ser agricultor familiar está mais relacionado com a idade do entrevistado e com uma condição de baixa autonomia material, do que com outros fatores, como ser mulher, ou os seus pais não terem a propriedade da terra.

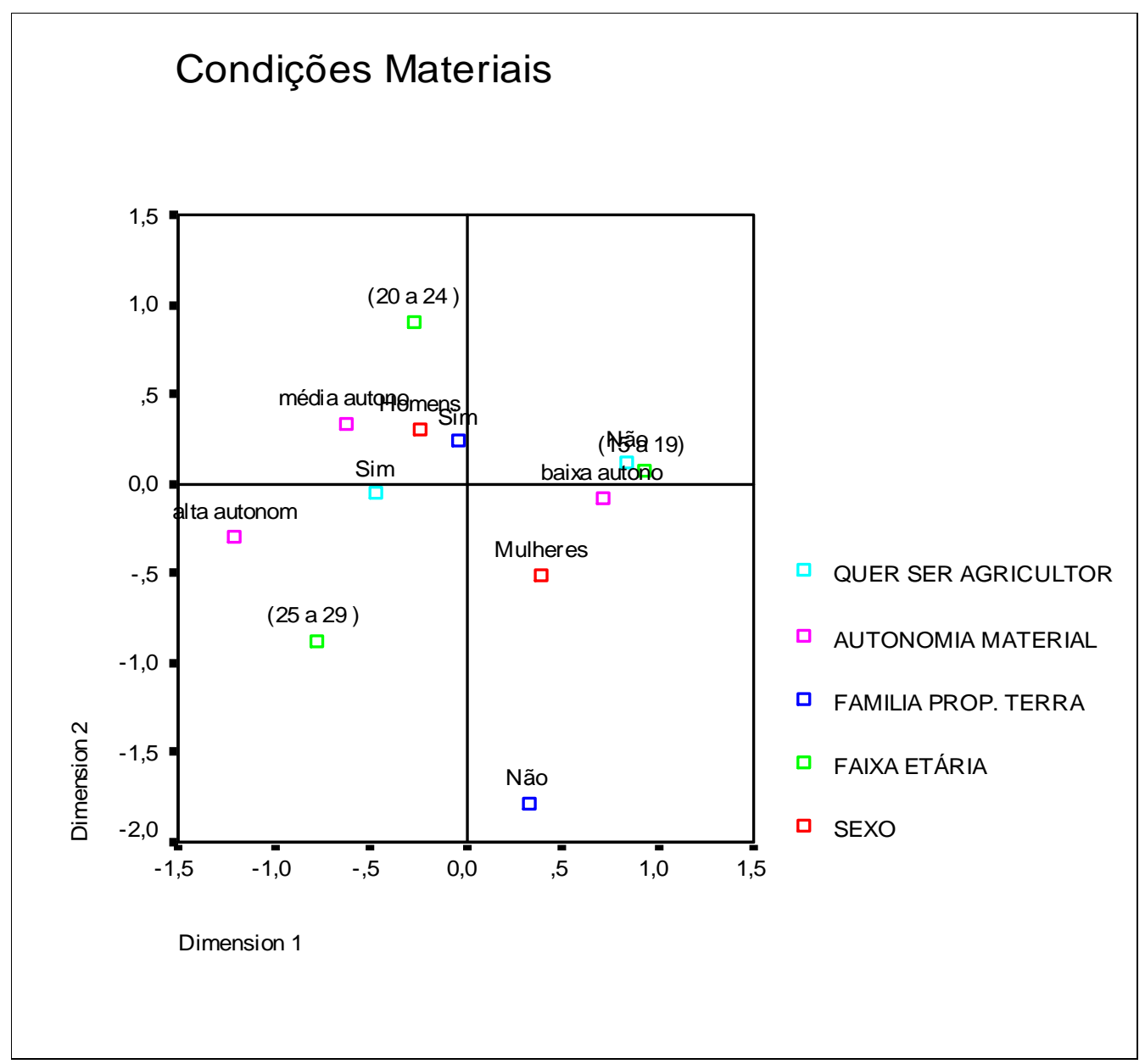

Gráfico 64: Representação das categorias de sexo, faixa etária, propriedade fundiária, autonomia material e projetos profissionais

Fonte: Banco de dados Jovens Agricultores Familiares RS - MDA/FAURGS, 2007.

As informações apresentadas nesta sessão demonstram a complexidade das relações que se estabelecem entre as condições materiais dos jovens agricultores familiares e a construção de seus projetos profissionais. Destaca-se que a propriedade fundiária por parte da família aprece com uma importância relativamente menor para a disposição de ser agricultor do que a autonomia material experimentada pelos jovens. Os dados apresentados na representação gráfica 
reforçam a informações obtidas através da análise dos cruzamentos entre variáveis. Em seu conjunto, estas evidências confirmam uma das hipóteses iniciais deste trabalho, segundo a qual se afirmava que quanto maior a autonomia material dos jovens agricultores familiares maior seria a tendência deles elaborarem projetos profissionais agrícolas.

\subsubsection{Processos de socialização e projetos profissionais}

Nesta seção, busca-se identificar as relações entre os processos de socialização que se efetivam através da participação juvenil no trabalho familiar agrícola e no ensino formal com os projetos profissionais elaborados pelos entrevistados.

Inicia-se analisando que tipo de relação se estabelece entre a socialização no sistema formal de ensino e a disposição dos jovens de serem agricultores. Conforme a Tabela 62, verifica-se uma relação negativa entre condição de estudo e projeto agrícola, uma vez que prevalece, entre os jovens que estavam estudando, a recusa de ser agricultor $(56,5 \%)$, índice que é bastante superior ao registrado para esta resposta entre o total de entrevistados. Em contrapartida, entre os que não estudavam na ocasião da entrevista, 72,5\% afirma querer se estabelecer profissionalmente na agricultura familiar. Isto confirma o que foi identificado em outros estudos: ${ }^{74}$ ficam na atividade agrícola os jovens que não estão inseridos no sistema de ensino. Isto também confirmaria a opinião corrente entre os entrevistados que colocam estudos e trabalho agrícola como possibilidades dicotômicas.

Tabela 62: Relação entre projeto profissional e situação de estudo (em $f$ e \%)

\begin{tabular}{|c|c|c|c|c|c|}
\hline & & & \multicolumn{2}{|c|}{$\begin{array}{c}\text { VOCÊ ESTA ESTUDANDO } \\
\text { ATUALMENTE? }\end{array}$} & \multirow[b]{2}{*}{ Total } \\
\hline & & & Sim & Não & \\
\hline \multirow{4}{*}{$\begin{array}{l}\text { VOCÊ PRETENDE SE } \\
\text { ESTABELECER } \\
\text { PROFISSIONALMENTE } \\
\text { COMO AGRICULTOR(A) } \\
\text { FAMILIAR? }\end{array}$} & Sim & $f$ & 81 & 350 & 431 \\
\hline & & $\%$ & $43,5 \%$ & $72,5 \%$ & $64,4 \%$ \\
\hline & Não & $f$ & 105 & 133 & 238 \\
\hline & & $\%$ & $56,5 \%$ & $27,5 \%$ & $35,6 \%$ \\
\hline \multirow{2}{*}{\multicolumn{2}{|c|}{ Total }} & $f$ & 186 & 483 & 669 \\
\hline & & $\%$ & $100,0 \%$ & $100,0 \%$ & $100,0 \%$ \\
\hline
\end{tabular}

Fonte: Banco de dados Jovens Agricultores Familiares RS - MDA/FAURGS, 2007.

\footnotetext{
${ }^{74}$ ABRAMOVAY, 1998; CARNEIRO, 1999; SILVERTRO, et al, 2001; WEISHEIMER, 2004, 2007; BRUMER; SPANAVELO, 2008.
} 
Sendo o estudo formal e o trabalho agrícola alternativas contrapostas nas praticas sociais dos entrevistados, podem ser esperados efeitos distintos de cada uma destas agências de socialização. Tudo indica que é este o caso. Conforme pode ser verificado na Tabela 63, quanto maior o a envolvimento com o trabalho familiar, maior será, também, a disposição do jovem de se estabelecer, profissionalmente, como agricultor. Isto pode ser evidenciado relacionando-se a jornada de trabalho diário na agricultura e a disposição de ser agricultor. Entre os jovens com menores jornadas diárias de trabalho, predominam projetos profissionais não-agrícolas. Entre os que desenvolvem jornadas de até quatro horas, predominam $(62,3 \%)$ os que não pretendem ser agricultores; os jovens que trabalham até seis horas diárias 52,9\% não querem permanecer nesta atividade. Na categoria com jornadas acima desta carga horária, verifica-se a ascensão de projetos profissionais agrícolas. Esses se tornam mais frequentes entre os jovens na medida em que se constata uma ampliação de sua jornada de trabalho, passando a $72,4 \%$ entre os que tem jornadas de oito a dez horas e chegando a representar $79,2 \%$ entre os jovens com a maior jornada de diária.

Isto demonstra a influência do uso do tempo na alocação de papeis-chaves - aquele aos quais se dá prioridade sobre outros papeis - estando este na base da internalização das disposições adquiridas ao longo dos processos de socialização. Desta maneira, entre os jovens com jornadas parciais com quatro horas diárias, pressupõe-se que as horas restantes sejam ocupadas por outras agências socializadoras, produzindo efeitos de incorporação de valores que embasam a busca por realizar projetos profissionais não-agrícolas. Por outro lado, o predomínio do uso do tempo em atividades agrícolas produz a internalização do habitus do trabalho familiar agrícola, fazendo com que eles só tendam a querer reproduzir este processo de trabalho (BOURDIEU, 2005).

Tabela 63: Cruzamento entre jornada diária de trabalho na UPF por projeto profissional (em $f$ e \%)

\begin{tabular}{|c|c|c|c|c|c|c|c|c|}
\hline & & & \multicolumn{5}{|c|}{ JORNADA DIÁRIA DE TRABALHO NA UPF: } & \multirow[b]{2}{*}{ Total } \\
\hline & & & Até 4 hs & $\begin{array}{c}\text { mais de } 4 \text { a } \\
6 \mathrm{hs}\end{array}$ & $\begin{array}{c}\text { Mais } 6 \text { a } \\
8 \mathrm{hs}\end{array}$ & $\begin{array}{c}\text { mais de } 8 \\
\text { a } 10 \mathrm{hs}\end{array}$ & $\begin{array}{l}\text { mais de } \\
10 \text { hs }\end{array}$ & \\
\hline \multirow{4}{*}{$\begin{array}{l}\text { VOCÊ PRETENDE SE } \\
\text { ESTABELECER } \\
\text { PROFISSIONALMENTE } \\
\text { COMO AGRICULTOR(A) } \\
\text { FAMILIAR? }\end{array}$} & \multirow[t]{2}{*}{ Sim } & $f$ & 29 & 40 & 69 & 131 & 160 & 429 \\
\hline & & $\%$ & $37,7 \%$ & $47,1 \%$ & $57,0 \%$ & $72,4 \%$ & $79,2 \%$ & $64,4 \%$ \\
\hline & \multirow[t]{2}{*}{ Não } & $f$ & 48 & 45 & 52 & 50 & 42 & 237 \\
\hline & & $\%$ & $62,3 \%$ & $52,9 \%$ & $43,0 \%$ & $27,6 \%$ & $20,8 \%$ & $35,6 \%$ \\
\hline \multirow[t]{2}{*}{ Total } & & $f$ & 77 & 85 & 121 & 181 & 202 & 666 \\
\hline & & $\%$ & $100,0 \%$ & $100,0 \%$ & $100,0 \%$ & $100,0 \%$ & $100,0 \%$ & $100,0 \%$ \\
\hline
\end{tabular}

Fonte: Banco de dados Jovens Agricultores Familiares RS - MDA/FAURGS, 2007. 
Buscando identificar a relações concomitantes entres as categorias de respostas das variáveis consideradas nesta sessão e incluindo as referentes a sexo e idade dos entrevistados, recorremos à análise de homogeneidade (HOMALS). Considerando-se a medida de discriminação das variáveis para duas dimensões, observa-se que, na dimensão 1, destaca-se em importância, primeiramente, a variável Você está estudando atualmente? seguido por "faixa etária" e "Jornada diária de trabalho na UPF". Na dimensão 2, a variável mais importante na discriminação dos indivíduos é sexo. Isto indica que o sexo define uma dimensão do processo de socialização, confirmando o que já fora apontado em capítulo anterior: o sexo constitui o fator de diferenciação nos processo de socialização de jovens agricultores familiares (Quadro 07).

Quadro 07: Medidas de discriminação para variáveis em duas dimensões (Socialização)

\begin{tabular}{|c|c|c|}
\hline \multicolumn{3}{|c|}{ Discrimination Measures } \\
\hline & \multicolumn{2}{|c|}{ Dimension } \\
\hline & 1 & 2 \\
\hline SEXO &, 033 &, 601 \\
\hline FAIXA ETÁRIA: &, 560 & 132 \\
\hline $\begin{array}{l}\text { JORNADA DIÁRIA DE } \\
\text { TRABALHO NA UPF: }\end{array}$ & ,502 & ,365 \\
\hline VOCÊ ESTA & & \\
\hline ESTUDANDO & ,634 & 034 \\
\hline ATUALMENTE? & & \\
\hline VOCE PRETENDE SE & & \\
\hline ESTABELECER & & \\
\hline PROFISSIONALMENTE & 347 & , 030 \\
\hline COMO AGRICULTOR(A) & & \\
\hline FAMILIAR ? & & \\
\hline
\end{tabular}

Fonte: Banco de dados Jovens Agricultores Familiares RS - MDA/FAURGS, 2007.

Com base na representação gráfica gerada através da HOMALS, pode-se ver que as respostas que indicam a disposição do jovem em ser agricultor familiar encontram-se em relação de proximidade com as categorias de jornada de trabalho "mais de oito a dez horas" e "mais de dez horas", das faixas de idade "de 20 a 24 anos" e "de 25 a 29 anos" e "homens". Por sua vez, a resposta "não" para questão Você pretende se estabelecer profissionalmente na agricultura? é acompanhada de perto pela categoria que se refere à jornada de trabalho "de quatro a seis horas" e "sim" para frequência à escola e à faixa etária "de 15 a 19 anos". A categoria "mulher" encontra-se no $4^{\circ}$ quadrante juntamente com as categorias "menos de quatro horas", "de quatro a seis horas" e "não" pretende ser agricultor. 


\section{Socialização}

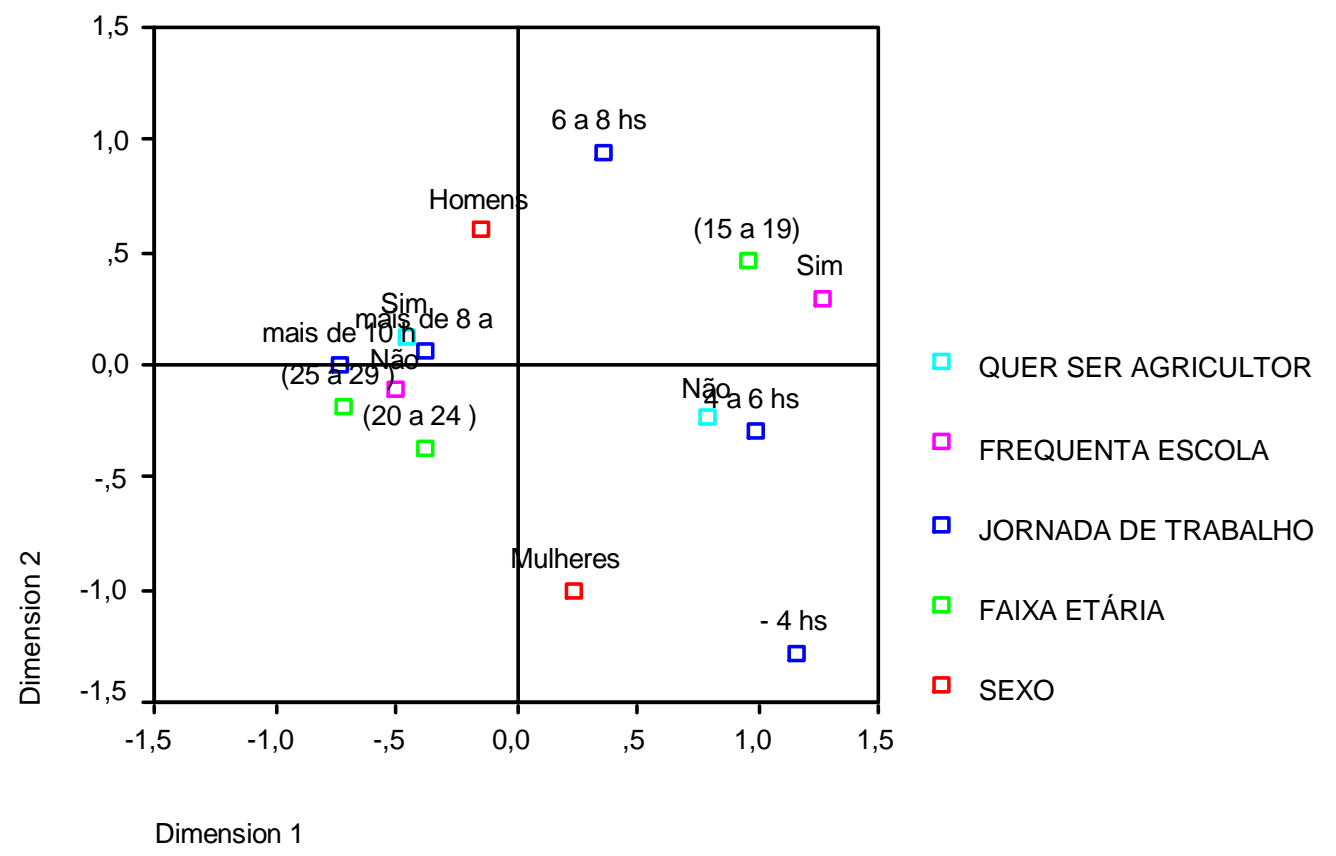

Gráfico 65: Representação das categorias de sexo, faixa etária, jornada de trabalho, frequência à escola e existência de projetos profissionais

Fonte: Banco de dados Jovens Agricultores Familiares RS - MDA/FAURGS, 2007.

Estes resultados vêm colaborar com o entendimento de que a socialização é fundamental na construção dos projetos profissionais e que esta se encontra diferenciada por critérios sexuais e etários. Com efeito, os jovens que não pretendem se estabelecer profissionalmente na agricultura são, principalmente, os com menor participação no trabalho familiar agrícola e maior frequência à escolarização formal, sendo estes, principalmente, os jovens adolescentes e do sexo feminino. Estes resultados confirmam a hipótese de trabalho segunda a qual se propunha que, quanto maior a socialização dos jovens no processo de trabalho familiar agrícola mais frequente seriam os projetos profissionais que permitiriam a reprodução deste mesmo processo de trabalho. 


\subsubsection{Representações sociais e projetos profissionais}

Nesta sessão, analisam-se as relações entre as representações dos jovens sobre o trabalho agrícola e o modo de vida de seus pais com os seus projetos profissionais. Como nas sessões anteriores deste tópico, apresentamos os cruzamentos entre variáveis e as relações entre suas categorias.

As representações dos jovens sobre o trabalho agrícola podem ser resumidas na pergunta "O quanto você gosta do trabalho familiar agrícola?. A Tabela 64 apresenta o cruzamento das respostas a esta questão por outra que expressa o projeto profissional dos jovens entrevistados. Desta forma é possível demonstrar que avaliações sobre o trabalho e a disposição de reproduzi-lo apresentam uma relação positiva, isto é, quanto mais o jovem gosta do trabalho mais quer reproduzi-lo. Assim, entre os entrevistados que respondem que gosta muito, $86 \%$ pretendem se estabelecer na agricultura familiar; os que apresentam uma posição ambígua para com a resposta "mais ou menos" 50,3\% não pretendem ser agricultores; os que respondem "não gosto" $96,6 \%$ não querem ser agricultores.

Tabela 64: Cruzamento entre representação sobre o trabalho agrícola e projeto profissional (em $f$ e \%)

\begin{tabular}{|c|c|c|c|c|c|c|}
\hline & & & \multicolumn{3}{|c|}{$\begin{array}{c}\text { O QUANTO VOCÊ GOSTA DE } \\
\text { TRABALHAR NA AGRÍCULTURA? }\end{array}$} & \multirow[b]{2}{*}{ Total } \\
\hline & & & Gosto Muito & $\begin{array}{l}\text { Mais ou } \\
\text { Memos }\end{array}$ & Não Gosto & \\
\hline \multirow{4}{*}{$\begin{array}{l}\text { VOCÊ PRETENDE SE } \\
\text { ESTABELECER } \\
\text { PROFISSIONALMENTE } \\
\text { COMO AGRICULTOR(A) } \\
\text { FAMILIAR? }\end{array}$} & \multirow[t]{2}{*}{ Sim } & $f$ & 265 & 165 & 1 & 431 \\
\hline & & $\%$ & $86,0 \%$ & $49,7 \%$ & $3,4 \%$ & $64,4 \%$ \\
\hline & \multirow[t]{2}{*}{ Não } & $f$ & 43 & 167 & 28 & 238 \\
\hline & & $\%$ & $14,0 \%$ & $50,3 \%$ & $96,6 \%$ & $35,6 \%$ \\
\hline \multirow[t]{2}{*}{ Total } & & $f$ & 308 & 332 & 29 & 669 \\
\hline & & $\%$ & $100,0 \%$ & $100,0 \%$ & $100,0 \%$ & $100,0 \%$ \\
\hline
\end{tabular}

Fonte: Banco de dados Jovens Agricultores Familiares RS - MDA/FAURGS, 2007.

A Tabela 65 apresenta a relação entre a avaliação dos jovens sobre o modo de vida dos pais e projeto profissional. De maneira geral, o cruzamento apresenta uma coerência entre esta avaliação e a disposição em reproduzir o trabalho agrícola. Entre os que avaliam como "ótimo" e "bom" o modo de vida dos pais, estão os que apresentam os maiores percentuais positivos quanto a ser agricultor respectivamente. Os demais entrevistados apresentam percentuais menores do que a média dos entrevistados para a pergunta Você pretende se estabelecer 
profissionalmente como agricultor familiar?. Destacam-se os que avaliam como "ruim" o modo de vida, dos quais $66,7 \%$ não querem permanecer na atividade dos pais.

Tabela 65: Cruzamento entre avaliação do modo de vida dos pais e projeto profissional (em $f$ e \%)

\begin{tabular}{|c|c|c|c|c|c|c|c|c|}
\hline & & & \multicolumn{5}{|c|}{ COMO VOCÊ AVALIA O MODO DE VIDA DE SEUS PAIS? } & \multirow[b]{2}{*}{ Total } \\
\hline & & & Ótimo & Bom & Regular & Ruim & Péssimo & \\
\hline \multirow{4}{*}{$\begin{array}{l}\text { VOCÊ PRETENDE SE } \\
\text { ESTABELECER } \\
\text { PROFISSIONALMENTE } \\
\text { COMO AGRICULTOR(A) } \\
\text { FAMILIAR? }\end{array}$} & Sim & $f$ & 96 & 224 & 99 & 6 & 5 & 430 \\
\hline & & $\%$ & $67,1 \%$ & $65,9 \%$ & $62,3 \%$ & $33,3 \%$ & $62,5 \%$ & $64,4 \%$ \\
\hline & Não & f & 47 & 116 & 60 & 12 & 3 & 238 \\
\hline & & $\%$ & $32,9 \%$ & $34,1 \%$ & $37,7 \%$ & $66,7 \%$ & $37,5 \%$ & $35,6 \%$ \\
\hline \multirow[t]{2}{*}{ Total } & & $f$ & 143 & 340 & 159 & 18 & 8 & 668 \\
\hline & & $\%$ & $100,0 \%$ & $100,0 \%$ & $100,0 \%$ & $100,0 \%$ & $100,0 \%$ & $100,0 \%$ \\
\hline
\end{tabular}

Fonte: Banco de dados Jovens Agricultores Familiares RS - MDA/FAURGS, 2007.

Esta coerência entre representações e projetos, que é uma forma de representação do futuro, pode ser explicada porque ela opera como uma rede de significações que se tecem nas experiências cotidianas dos jovens, no trabalho agrícola e nos demais espaços de socialização, que são produto de condições estruturais, e ao mesmo tempo, agentes da estruturação de representações que lhes permitem e justificam o funcionamento. Assim, representações e projetos são resultados de um esquema de condicionamento cuja coerência é essencial para satisfação da lógica dos indivíduos. Com efeito, podemos perceber que estas representações orientam os projetos profissionais dos jovens agricultores. Tudo ocorre de tal modo que as representações positivas do trabalho e modo de vida dos pais tendem a ser, por forma da lógica das práticas sociais, acompanhada de disposições à reprodução deste trabalho agrícola e seu modo de vida.

Considerando-se a medida de discriminação das variáveis possibilitada pela análise da HOMALS, para duas dimensões, observa-se que na dimensão que a variável com maior poder de diferenciar os entrevistados na dimensão 1 é Você pretende se estabelecer profissionalmente como agricultor familiar? e $O$ quanto você gosta de trabalhar na agricultura familiar? por sua vez na dimensão 2 destaca-se a variável Como você avalia o modo de vida de seus pais? e Sexo. Isto indica que na dimensão 1, operam de modo mais significativo, as questões relativas ao trabalho agrícola. Na dimensão 2, as relações de gênero (Quadro 08). 
Quadro 08: Medidas de discriminação para variáveis em duas dimensões (Representações Sociais)

\begin{tabular}{|l|c|c|}
\hline \multicolumn{3}{|c|}{ Discrimination Measures } \\
\hline \multicolumn{2}{|c|}{ Dimension } \\
\cline { 2 - 3 } & 1 & 2 \\
\hline SEXO &, 068 &, 308 \\
FAIXA ETÁRIA: &, 279 &, 282 \\
O QUANTO VOCÊ & & \\
GOSTA DE TRABALHAR &, 605 &, 101 \\
NA AGRÍCULTURA? & & \\
COMO VOCÊ AVALIA O & & \\
MODO DE VIDA DE &, 135 &, 480 \\
SEUS PAIS? & & \\
VOCE PRETENDE SE & & \\
ESTABELECER & &, 002 \\
PROFISSIONALMENTE &, 627 & \\
COMO AGRICULTOR(A) & & \\
FAMILIAR ? & \\
\hline
\end{tabular}

Por meio da análise de homogeneidade podem ser identificadas as formas de interação entre as categorias de resposta em analise nesta sessão, identificando alguns padrões em sua distribuição no espaço de relações. Conforme se observa no Gráfico 66, a propósito das categorias de projeção favorável ao trabalho agrícola "sim", verifica-se nitidamente três tendências. Primeiramente, a mais forte delas, por conta da proximidade entre as categorias ocorre no $2^{\circ}$ quadrante do plano gráfico, onde observa-se a proximidade das categorias "homem", das representações positivas sobre o trabalho agrícola expressa na resposta "gosto muito" e das avaliações "bom" e "ótimo" sobre o modo de vida dos pais. Próximos a estas, já no $3^{\text {o }}$ quadrante, estão idades de "20 a24 anos" e "25 a 29 anos". Estes, em seu conjunto, formam uma verdadeira "associação privilegiada de categorias" (CARVALHO, 2004) de modo que configuram um perfil de entrevistado que internalizou a disposição em reproduzir o processo de trabalho. Por sua vez, em oposição a este grupo, observa-se, no $1^{\circ}$ quadrante, a proximidade entre as categorias de idade de "15 a 19 anos" com as respostas "não gosto" do trabalho agrícola, a avaliação como "ruim" o modo de vida dos pais e "não" pretende ser estabelecer na agricultura familiar. Por sua vez, a categoria "mulher" se apresenta em uma posição intermediária entre o "sim" e o "não" quanto a ser agricultor e encontra-se no $4^{\circ}$ quadrante com as categorias ambíguas sobre o trabalho agrícola e modo de vida dos pais como "mais ou menos "e "regular" respectivamente. 


\section{Representações Sociais}

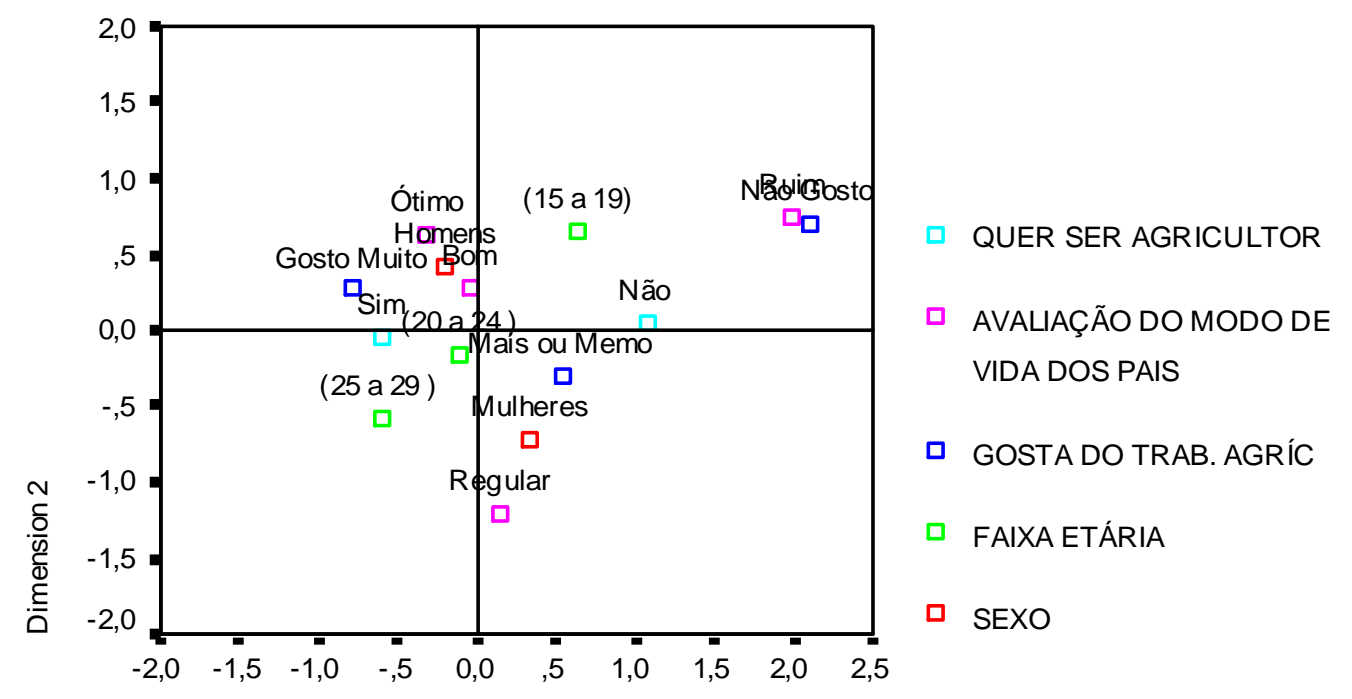

Dimension 1

Gráfico 66: Representação das categorias de sexo, faixa etária, gosta do trabalho agrícola, avaliação do modo de vida dos pais e projetos profissionais

Fonte: Banco de dados Jovens Agricultores Familiares RS - MDA/FAURGS, 2007.

Estes evidências confirmam os resultados anteriores que demonstram a relação entre projetos profissionais agrícolas e representações positivas sobre este trabalho e o modo de vida dos pais. Permitem demonstrar que estas representações se relacionam com as faixas de idade maiores de 20 anos e, principalmente, com os entrevistados do sexo masculino. Com isto confirma-se a hipótese de trabalho na afirmação que, quanto mais positivas fossem as avaliações sobre o trabalho agrícola e o modo de vida dos pais, mais os jovens agricultores familiares desenvolveriam projetos profissionais de permanência na agricultura.

O debate realizado neste capítulo permite afirmar que os projetos juvenis, entendidos como uma visada consciente do futuro em aberto, apresentam-se como um esforço de antecipar 
posições desejadas quanto à escolarização, à profissão e à vida futura (conjugal e residencial) que apresentam diferenças por sexo e idades dos entrevistados. Os projetos de escolarização são mais frequentes e amplos entre os jovens adolescentes com destaque para as mulheres. Também os projetos profissionais apresentam diferenças segundo estes critérios, com projetos de permanência na agricultura mais frequentes entre os homens e mulheres jovens com mais de 20 anos de idade, enquanto as jovens adolescentes predominantemente elaboram projetos profissionais não-agrícolas. As adolescentes diferem-se da maioria dos entrevistados também quanto ao projeto de vida, uma vez que a maior parte delas afirma que não pretende casar com agricultor, nem residir no meio rural.

Estes projetos indicam como os jovens lidam com os papeis que desempenham na atividade agrícola e as posições que ocupam na família e em suas estratégias de reprodução, ou seja, revelam como os jovens avaliam sua situação atual na agricultura familiar. Pode-se dizer que estes projetos são influenciados, em diferentes graus, pelas oportunidades objetivas de reprodução das unidades de produção familiar das quais os jovens entrevistados fazem parte. Contudo, a estrutura objetiva desta reprodução não se limita às formas de acesso à propriedade fundiária, mas ao aceso efetivo dos jovens aos recursos materiais que possibilitem a eles ter alguma autonomia material para tomarem suas próprias decisões e acessarem os resultados de seus esforços produtivos. Isto explica o fato dos projetos profissionais se diferenciarem mais com relação ao grau de autonomia material do jovem do que em relação à condição fundiária de sua família. Além disto, verificou-se que os processos de socialização atuam como um fator objetivo fundamental, visto que é por meio destes que se internalizam os conhecimentos, os valores e a ética própria do trabalho familiar agrícola, gerando as disposições necessárias à sua reprodução geracional. Neste sentido, a socialização no trabalho agrícola pode ser percebida como o principal instrumento de reprodução social na agricultura familiar, porque produz uma nova geração de agricultores familiares.

Por fim, podemos concluir que as representações dos jovens sobre o trabalho agrícola e o modo de vida dos pais revelam-se coerentes com seus projetos profissionais. A interação entre estas representações permitem-nos compreender melhor as dinâmicas desta reprodução geracional do trabalho familiar que depende da reafirmação não só de uma posição no mundo social, mas também de sua visão de mundo correspondente. Com efeito, pode-se concluir que os projetos profissionais dos jovens agricultores derivam da própria situação juvenil na agricultura familiar, com suas diferenciações sexuais e etárias, o que está presente na estrutura das práticas 
do trabalho e na incorporação das disposições necessárias a sua reprodução. Com base nisto, explicam-se a tendência das jovens adolescentes de não quererem permanecer nesta atividade. 


\section{CONSIDERAÇÕES FINAIS}

O trabalho de investigação sociológica realizado buscou contribuir para a construção do conhecimento sobre a situação juvenil na agricultura familiar, identificando as características desta juventude e a sua disposição em reproduzir o processo de trabalho de trabalho familiar agrícola. Procurou também evidenciar as diferenciações por sexo e idade presentes no fenômeno analisado.

Perseguindo este objetivo, foi realizada uma pesquisa social empírica extensiva que buscou ser representativa do universo de jovens ocupados na agricultura familiar no estado do Rio Grande do Sul. Como contribuição metodológica, foi proposto um modelo descritivo da situação juvenil que conjuga os aspectos objetivos e subjetivos da realidade social e que se encontra estruturado a partir de quatro dimensões analíticas: dos recursos materiais, dos processos de socialização, das representações sociais e dos projetos juvenis.

Inicialmente, realizou-se uma tomada de posição a favor da Sociologia da Juventude, que relaciona a juventude com os processos sociais, históricos e culturais, demonstrando que esta é uma categoria social, não um dado biológico ou psicológico. Neste sentido, indicou-se que o processo juvenil é complexo e multidimensional. Buscou-se resgatar a tradição dos estudos deste campo disciplinar sistematizando sua trajetória, das primeiras pesquisas sociais até a contemporaneidade. Discutiram-se, em seguida, os diferentes enfoques e as diferentes abordagens com que a categoria juventude vem sendo interpretada nas ciências sociais.

Assim, foram feitas considerações sobre o enfoque geracional, tal como foi inicialmente desenvolvido por Karl Mannheim, que percebe as gerações como uma situação frente ao processo histórico e social. De tal modo, que ela estrutura as posições sociais compartilhadas por indivíduos de um mesmo grupo etário, permitindo interpretar as relações entre individuo e sociedade, assim como a transmissão e adaptação da herança cultural.

Apontou-se, na sequência, que a noção de juventude está intimamente ligada a um critério de medição cronológica da existência individual, a partir do qual se propôs o estabelecimento da faixa etária dos 15 aos 29 anos de idade para demarcar operacionalmente a juventude. Foram indicadas suas subdivisões: Jovens Adolescentes (de 15 a 19 anos); Jovens (de 20 a 24 anos); Jovens Adultos (de 25 a 29 anos).

Abordou-se a noção de juventude como um período de transição para a vida adulta, problematizando que esta passagem nem sempre obedece a uma sincronia ou linearidade, e 
que a ênfase na transição pode vir permeada por um viés ideológico, etnocêntrico e adultocêntrico, que poderia resultar em uma visão distorcida da juventude. Apresentaram-se as abordagens que enfatizam a construção de culturas juvenis responsáveis pela revelação de traços diferenciados que vão para além da padronização aparente no tipo de vestimentas, acessórios, uso da linguagem, revelação de gostos musicais e tantas outras práticas sociais, vividas por jovens no contexto da agricultura familiar.

Estes processos foram interpretados como sendo de manifestação de hibridização cultural: uma maneira de produção e apropriação dos sentidos sobre a juventude feita pelos próprios jovens. Disto deriva, por sua vez, a noção de juventude como representação social e autorrepresentação. Esta implica o reconhecimento de que os sentidos das juventudes não advêm de uma substantividade inerente aos atores, mas de processos interacionais.

Com base nestas referências, podem-se especificar os termos utilizados neste estudo. Assim, a juventude pode ser entendida como uma categoria social fundada em representações sociais segundo as quais se atribui sentido ao pertencimento a uma faixa etária, posicionando os sujeitos na estrutura social. Os jovens são percebidos como indivíduos concretos que vivem processos de socialização específicos. A condição juvenil corresponde ao modo como a sociedade constitui e atribui significados às juventudes em determinadas estruturas sociais, posicionando-os como sujeitos subalternos aos adultos, enquanto, a situação juvenil traduz as diversas configurações da condição juvenil.

Este debate colabora para perceber a juventude como uma categoria multidimensional, que se constitui a partir de um amplo feixe de relações. Em decorrência disto, se propôs que a especificidade de cada categoria juvenil fosse apreendida por meio dos processos de socialização vividos pelos jovens. Assim, sustentou-se a proposta de estudar a situação juvenil na agricultura familiar.

Buscando definir a categoria social dos jovens agricultores familiares e identificar sua participação na agricultura familiar, retomou-se o debate teórico sobre as formas familiares de produção agrícola. A categoria dos agricultores familiares se caracteriza pelo fato de que a família detém a propriedade dos meios de produção e simultaneamente realiza o processo de o trabalho na unidade produtiva, efetuando no âmbito desta a transmissão do patrimônio e a reprodução geracional do processo de trabalho em condições de inserção mercantil plena.

Este segmento realiza o que se descreveu como processo de trabalho familiar agrícola, que não pode ser entendido como um processo de trabalho capitalista, mas está 
subordinado a este modo de produção. Este processo de trabalho é a principal agência de socialização das novas gerações na agricultura familiar, transmitindo saberes, valores e uma ética do trabalho dos quais depende sua própria reprodução. Os jovens agricultores familiares foram então definidos como os jovens socializados no processo de trabalho familiar agrícola.

Diferente de outras situações, este é um caso onde o trabalho produz a juventude, uma vez que é ele que posiciona os jovens no espaço das relações sociais. Ou seja, é a socialização no processo de trabalho familiar agrícola que produz a categoria dos jovens agricultores familiares. Uma vez estabelecida, teoricamente, a especificidade desta categoria juvenil, pode-se buscar empreender esforços para descortinar sua contribuição ao desenvolvimento desta forma de agricultura no estado do Rio Grande do Sul, o que se evidenciou em ao menos quatro processos: na colonização, na ocupação da fronteira agrícola, na difusão das novas técnicas da modernização agrícola e mais recentemente, no processo migratório rural-urbano.

Além disto, pode se identificar a participação juvenil na ocupação na agricultura familiar no estado. Considerando-se as informações do Censo Demográfico do IBGE dos anos de 1990 e 2000, constatou-se uma redução da participação de jovens na agricultura familiar; contudo, esta permanece relevante, representando aproximadamente um quarto de toda a ocupação na agricultura familiar no Rio Grande do Sul. Uma vez definida a categoria e mensurada sua participação neste processo de trabalho no estado, passamos a interpretar as características de sua situação social.

Aplicando-se o modelo descritivo proposto, procedeu-se à análise do acesso dos jovens aos recursos materiais relativos à atividade agrícola, buscando-se identificar o modo como estes se encontram distribuídos. Para isto, conduziu-se a investigação sobre as características econômicas da unidade de produção familiar, verificando-se a condição fundiária, os valores e a renda nela geradas. Constatou-se que os entrevistados encontram-se vinculados a unidades produtivas com extensão média de 31,4 hectares, sendo que $60 \%$ dos entrevistados estão em propriedades com tamanho inferior a 20 hectares. Sua produção encontra-se $83 \%$ voltada para a comercialização, que está integrada principalmente a grandes cooperativas e agroindústrias. $\mathrm{O}$ valor bruto da produção não ultrapassa $\mathrm{R} \$ 30.000,00$ ao ano para $75 \%$ dos casos. A renda agrícola das famílias dos entrevistados não passa de $\mathrm{R} \$ 20.000,00$ para $86,5 \%$ dos entrevistados, e a renda familiar total fica neste mesmo valor para $80 \%$ deles. Isto demonstra que estes jovens se encontram em unidades produtivas de escassos recursos econômicos. 
A partir disto, buscou-se identificar o acesso dos jovens à renda agrícola. Contatouse que eles pouco têm acesso a estes recursos, que se encontram, geralmente, controlados exclusivamente pelos pais. A este respeito, verificou-se que as entrevistadas mulheres e os jovens adolescentes acessam, em proporção menor, essa renda do que os entrevistados homens e jovens adultos. Com base em um conjunto de sete indicadores correspondentes a recursos acessados pelos jovens, pôde-se avaliar o seu grau de autonomia material. Eles apresentam uma baixa autonomia material, situação que se revelou ainda mais aguda entre os jovens adolescentes e mulheres. Com isto, pôde-se demonstrar que situação juvenil na agricultura familiar é marcada por uma baixa autonomia material e uma distribuição desigual de recursos entre os sexos e as idades. São a partir destas condições materiais que se realizam os processos de socialização dos jovens agricultores.

A socialização foi compreendida como processo socialmente estruturado de transmissão de saberes, valores e normas sociais, geralmente de uma geração à outra, permitido a inserção interativa dos indivíduos aos grupos sociais. Com base nesta perspectiva, se analisou a participação dos jovens no processo de trabalho familiar agrícola, sua inserção no sistema de educação formal e em atividades de lazer. A socialização no trabalho agrícola é a que os entrevistados vivenciam de modo mais intenso, em comparação com as demais. Devido às características do processo de trabalho familiar agrícola, que se organiza com base na divisão sexual e etárias de tarefas, a socialização neste espaço se realiza, simultaneamente, como uma socialização profissional - no sentido de uma inserção nas relações sociais de produção que implica uma emersão na cultura profissional a fim de permitir o desempenho das tarefas e a identificação com o grupo de referência - e socialização de gênero - sendo esta o modo como os indivíduos internalizam e desenvolvem os diferentes papeis sociais de gênero.

Ao considerar-se a inserção no processo de trabalho familiar agrícola, constatou-se que os jovens de ambos os sexos apresentam uma elevada participação no trabalho, tanto no tipo de participação quanto na jornada de trabalho que realizam, sendo que os jovens adolescentes e as mulheres apresentam um menor envolvimento que os demais entrevistados. No que concerne à participação juvenil na divisão do trabalho familiar, verificou-se que as tarefas administrativas, agrícolas e domésticas são distribuídas de modo diferenciado por sexos e faixas de idade. A primeira é concentrada na figura do pai que atua como chefe do estabelecimento, nas tarefas agrícolas predomina a força de trabalho de toda a família, enquanto as tarefas domésticas ficam sob a responsabilidade exclusiva das mulheres. Como 
pudemos afirmar anteriormente, as mulheres acabam tendo que realizar múltiplas jornadas de trabalho - principalmente nas tarefas agrícolas e domésticas - sem ao menos contarem com o reconhecimento de seu trabalho como "produtivo". Constatou-se uma nítida diferenciação sexual nesta socialização: os jovens homens vão assumindo, aos poucos, a responsabilidade pela realização de certas tarefas agrícolas, enquanto que o trabalho agrícola realizado por mulheres jovens é invisibilizado por meio das categorias "toda a família" e a expressão "ajuda". Elas também compartilham com suas mães a responsabilidade com as tarefas domésticas que não se limitam ao espaço da casa.

Com efeito, as funções desempenhadas na equação entre unidade doméstica e unidade produtiva revelam as posições ocupadas pelos jovens na hierarquia do grupo familiar. As jovens mulheres realizam as atividades menos valorizadas no trabalho; por consequência, ocupam as posições mais subalternas na hierarquia familiar, visto que, com exceção das tarefas domésticas, não exercem nenhuma atividade sob sua responsabilidade exclusiva. Por outro lado, elas encontram-se mais integradas ao sistema formal de ensino e alcançam graus de escolarização mais elevados do que os homens de sua mesma idade.

A socialização escolar é diferenciada por sexo e também por idades. Sob este último aspecto, é possível notar que os jovens adolescentes encontram-se em maior percentual frequentando a escola e alcançam escolaridades maiores do que a verificada para a maioria dos jovens adultos. Cabe destacar, ainda, as dificuldades dos jovens em conseguir conciliar as longas jornadas de trabalho na agricultura com o tempo destinado aos estudos. Identificaramse também as percepções dos entrevistados sobre a escola. Esta é vista por eles como um espaço de interação com seus pares de idade e fator de valorização social, dotando-os de prestígio e permitindo-lhes vislumbrar possibilidades de mobilidade social.

A situação juvenil na agricultura familiar se caracteriza ainda por um baixo acesso às atividades de lazer. Estas formas de sociabilidade, que foram entendidas como uma forma livre de socialização se restringem, basicamente, aos espaços de convívio da comunidade, onde se destacam a frequência à igreja e à prática esportiva, limitada ao futebol. Ou seja, o lazer dos jovens é restrito em decorrência do tempo que eles dedicam ao trabalho e pela escassez de uma infra-estrutura de lazer e de esporte nas comunidades onde vivem. Em resumo, entre os jovens agricultores familiares não predomina a socialização via sistema formal de ensino ou espaços de sociabilidade juvenil, como é comum em outras situações, mas sim a socialização profissional realizada no âmbito do trabalho familiar agrícola, diferenciando-se neste processo os papeis a serem desempenhados por homens e mulheres. 
A socialização, neste espaço de trabalho, possibilita a internalização de valores que são formas de representações coletivas. Com efeito, a situação juvenil também se define a partir dos sentidos atribuídos aos jovens e os que estes atribuem a suas práticas sociais, ao seu grupo de referência e às representações de si, que são as formas de autoidentidade; processo contínuo de definição de uma identidade pessoal que dá sentido a nós mesmos e a nossa relação com os grupos de referência e com o mundo social. Buscou-se, assim, abordar as representações sociais dos jovens agricultores sobre o trabalho familiar agrícola, o modo de vida dos pais e suas auto-identificações.

No que se refere às representações que os jovens fazem do trabalho na agricultura familiar, a maioria deles afirma gostar desta atividade; contudo esta opinião predomina entre os jovens adultos, enquanto os jovens adolescentes e as entrevistadas do sexo feminino revelam uma menor satisfação. Ao serem questionados sobre como consideram sua participação para os resultados obtidos pela família, a maioria respondeu que é muito importante, enquanto as mulheres adolescentes afirmam que é pouco importante. As representações sobre o trabalho mostram-se com diferenças segundo sexo e idades dos entrevistados, tanto que os homens relacionam a agricultura a uma atividade que permite ter independência financeira, enquanto as mulheres enfatizam mais a importância deste trabalho para a sociedade.

Quanto às avaliações sobre o modo de vida dos pais, predominam avaliações positivas por meio de respostas em que consta ótimo e bom. Sobre este assunto, também se verificou que os posicionamentos mais críticos partem das entrevistadas mulheres e principalmente das jovens adolescentes. Questionou-se se os jovens gostariam de viver como seus pais e se pretendiam sucedê-los na gestão da unidade produtiva. A maioria deles pretende ser sucessor dos pais, sendo os que não o querem são, novamente, as jovens adolescentes. Elas também manifestam, com maior frequência, a percepção de que não herdaram a propriedade da terra, sendo que predomina, entre os casos estudados, a expectativa de uma distribuição igualitária da herança.

Quanto às formas de auto-identidade acionada pelos jovens na ocasião das entrevistas, constatou-se que predominam, tanto entre os homens quanto entre as mulheres, identidades socioprofissionais vinculadas ao trabalho agrícola. Dentre as categorias identitárias, a mais utilizada foi de "jovem agricultor familiar", "jovem trabalhador rural" e “jovem agricultor". Mais uma vez, observou-se um comportamento diferencial entre as mulheres jovens adolescentes, que se identificam principalmente como "estudante". Esta 
categoria, juntamente com a identificação como "jovem", forma a maioria de suas respostas. Como resultado, pode-se concluir que a situação juvenil na agricultura familiar se caracteriza por representações que valorizam o trabalho familiar agrícola, sendo estas coerentes com o padrão de sua socialização. Além disto, é possível destacar que, ao assumirem a identidade social de jovem agricultor familiar, eles buscam positivar sua situação juvenil, legitimando suas capacitações e habilidades como fonte de reconhecimento social, ao mesmo tempo em que antecipam suas disposições em relação ao que pretendem ser no futuro.

Por último, empreendeu-se a análise dos projetos juvenis. Estes foram entendidos como uma visada consciente do futuro em aberto, apresentando-se como um esforço reflexivo dos jovens para antecipar posições desejadas quanto à escolarização, à profissão e à vida futura (conjugal e residencial) que mostram diferenças por sexo e idades dos entrevistados. Os projetos de escolarização são mais frequentes e amplos entre os jovens adolescentes, com destaque para as mulheres. Também os projetos profissionais apresentam diferenças segundo estes critérios, com projetos de permanência na agricultura mais frequentes entre os homens e mulheres jovens com mais de 20 anos de idade, enquanto as jovens adolescentes, predominantemente, elaboram projetos profissionais não-agrícolas.

Estas últimas diferem da maioria dos entrevistados também quanto ao projeto de vida, uma vez que a maior parte delas afirma que não pretende casar com agricultor, nem residir no meio rural. Estes projetos indicam como os jovens lidam com os papeis que desempenham na atividade agrícola e as posições que ocupam na família, assim como suas estratégias de reprodução, ou seja, revelam como eles avaliam sua situação atual na agricultura familiar.

A partir destes resultados, buscou-se identificar as relações entre os projetos profissionais formulados por jovens agricultores familiares e as dimensões da situação juvenil (recursos materiais; processo de socialização e representações sociais). Desta forma, constatou-se que estes projetos são influenciados, em diferentes graus, pelas oportunidades objetivas de reprodução das unidades de produção familiar das quais os jovens entrevistados fazem parte. Contudo, a estrutura objetiva desta reprodução não se limita às formas de acesso à propriedade fundiária, mas a efetiva alocação de recursos materiais que possibilitem aos jovens dispor de autonomia para tomarem suas próprias decisões e acessarem os resultados de seus esforços produtivos. Isto explica o fato dos projetos profissionais se diferenciarem mais com relação ao grau de autonomia material dos jovens do que em relação à condição fundiária de suas famílias. Verificou-se, também, que os processos de socialização atuam como um 
fator objetivo fundamental, visto que é por meio destes que se internalizam os conhecimentos, os valores e a ética própria do trabalho familiar agrícola, gerando as disposições necessárias à sua reprodução geracional. Neste sentido, a socialização no trabalho agrícola pode ser percebida como o principal instrumento na reprodução social na agricultura familiar, porque produz uma nova geração de agricultores familiares.

Por fim, verificou-se que as representações dos jovens sobre o trabalho agrícola e o modo de vida dos pais revelam-se coerentes com seus projetos profissionais. A interação entre estas representações permite-nos compreender melhor as dinâmicas desta reprodução geracional do trabalho familiar agrícola que depende da reafirmação não só de uma posição no mundo social, mas, também, de sua visão de mundo correspondente. Com efeito, pode-se concluir que os projetos profissionais dos jovens agricultores derivam da própria situação juvenil na agricultura familiar, com suas diferenciações sexuais e etárias, o que está presente na estrutura das práticas do trabalho e na incorporação das disposições necessárias a sua reprodução. Com base nisto, explicam-se porque, mesmo em condições matérias restritas, predominam entre os jovens os projetos profissionais agrícolas, bem como a tendência evidenciada entre as jovens adolescentes de não querer permanecer nesta atividade.

Em seu conjunto, os resultados deste trabalho confirmam as hipóteses que orientaram o estudo, já que se evidenciou que a situação juvenil na agricultura familiar é caracterizada por uma baixa autonomia material; por uma intensa socialização no processo de trabalho familiar agrícola e pelo predomínio de representações positivas sobre esta atividade. Contudo, a análise da situação juvenil empreendida neste estudo não se pretende conclusiva. Ao contrário, se reconhece que o modelo descritivo proposto pode ser complexificado, acrescentando-se outras variáveis de acordo com a situação estudada. Acredita-se que o esforço empreendido poderá contribuir para ampliar as possibilidades interpretativas das dinâmicas da reprodução social da agricultura familiar incorporando em suas considerações o ponto de vista dos jovens agricultores familiares. No entanto, os estudos sobre esta categoria social apresentam inúmeros desafios e convidam à realização de novas pesquisas.

Com efeito, este trabalho não se coloca como um ponto final deste debate, mas procura demonstrar que existe um amplo campo de possibilidades em aberto, no qual a Sociologia da Juventude poderá aportar novas chaves analíticas para os estudos agrários, ao mesmo tempo em que encontrará um terreno fértil para se desenvolver. 


\section{REFERÊNCIAS BIBLIOGRÁFICAS}

ABAD, Miguel. Laspolíticas de juventud desde la perspectiva de la relación entre conivencia, ciudadania y nueva condición juvenil. Última Década, Viña del Mar, CIDPA, mar., 2002.

ABRAMO, Helena W. Cenas juvenis; punks e darks no espetáculo urbano. São Paulo: Scrtitta, 1994.

Considerações sobre a tematização da juventude no Brasil. Revista Brasileira de Educação, São Paulo, n. 5 e n. 6, p. 25-36, 1997.

ABRAMOVAY, Miriam; CASTRO, Mary Garcia; SILVA Lorena Bernadete. Juventude e Sexualidade. Brasília: UNESCO, 2004.

; CASTRO, Mary (org.). Juventude, juventudes: o que une e o que separa? Brasília: UNESCO, 2006. Disponível em:

<http://unesdoc.unesco.org/images/0014/001468/146857PORB.pdf>. Acesso em: 15 ago.

2006.

ABRAMOVAY, Ricardo et al. Juventude e agricultura familiar: desafios dos novos padrões sucessórios. Brasília: Unesco, 1998. 101 p.

1998.

Paradigmas do capitalismo agrário em questão. Campinas: Hucitec/Unicamp,

. Uma nova extensão para a agricultura familiar. In Seminário Nacional de assistência técnica e Extensão Rural. Brasília, Anais, 1997, 29 p. (mimeo).

AGUIAR, Neuma (coord.). Mulheres na Força de Trabalho na América Latina: Análises Qualitativas. Petrópolis: Vozes, 1984.

AGULHON, Maurice. Les cercle dasn la France bourgeoise 1810-1848. Paris: Armand Colin, 1977.

ALMEIDA, Elmir de. Políticas públicas para jovens em Santo André. In: ; SOUTO Anna Luiza Salles.Joven: Política Pública e Mercado de Trabalho. São Paulo: Polis, 2000.

AMIN, Samir. O capitalismo e a renda fundiária (A dominação do capitalismo sobre a agricultura). In: , VERGOPOLUS, Kostas. A Questão agrária e o capitalismo. Rio de Janeiro: Paz e Terra, 1977. 
ANDER-EGG, Ezequiel. Técnicas de Investigación Social. Viamonte: Lumen,1988.

ARIÈS, Philip. História social da criança e da família. Rio de Janeiro: Editora Guanabara, 1981.

BAENINGER, Rosana. Juventude e movimento migratório no Brasil. In. Jovens acontecendo na trilha das políticas públicas. Brasília: CNPD, 1998.

BARTH, Fredrik. Grupos étnicos e suas fronteiras.(1969) In: PHILIPPE, Poutignat; FERNAT, Streiff. (orgs). São Paulo: Unesp, 1998.

BAUMAN, Zygmunt. O Mal Estar da Modernidade. Rio de Janeiro: Zahar, 1998.

BECK, Ulrich; GIDDENS, Anthony; LASH, Scott. Modernização reflexiva, tradição e estética na ordem moderna. São Paulo: UNESP, 1997.

BERGER, Peter L. Perspectivas Sociológicas: uma visão humanística. Petrópolis: Vozes, 1976.

; LUCKMANN, Thomas. A construção social da realidade: tratado de Sociologia do conhecimento. Petrópolis: Vozes, 1973.

BHABHA, Homi. O local da cultura. Belo Horizonte: UFMG, 2005.

BILLAUD, Jean-Paul. Inventar uma ética profissional:as regras de um jogo obrigatório. In: LAMARCHE, Hugues (coord.). A agricultura familiar: comparação internacional - do mito à realidade, v. 2. Campinas: Unicamp, 1998.

BISQUERA, Rafael et al. Introdução a estatística: enfoque informático com pacote estatístico SPSS. Porto Alegre: Artimed, 2004.

BOISIER, S. El desarrolo territorial a partir de la construccion de capital sinergético. Revista Redes, Santa Cruz do Sul, v.4, n. 01, p.61-78, jan.-abr. 1999. In: SCHNEIDER, Sergio. A abordagem territorial do desenvolvimento rural e suas articulações externas. Sociologias. [online]. jan.-jun. 2004, no.11 Acesso em: 14 nov. 2005, p. 88-125. Disponível em:

$<$ http://www.scielo.br/scielo.php?script=sci_arttext\&pid=S151745222004000100006\&lng=pt $\& n r m=i s o>$. ISSN 1517-4522.

BOTTOMORE, Tom B. Introdução à Sociologia, Rio de Janeiro: Guanabara, 1987.

BOUDON, Raymond e BOURRICAUD, François. Dicionário Crítico de Sociologia. São Paulo: Ática, 1993. 
BOURDIEU, Pierre. Questões de Sociologia. Rio de janeiro: Marco Zero,1983.

. (org.), ACCARDO, A. I et al. A Miséria do Mundo. Petrópolis: Vozes, 1997.

. O poder simbólico. Rio de Janeiro: Bertrand Brasil, 1998.

. A dominação masculina. Rio de Janeiro, Bertrand Brasil, 1999.

2001.

Meditações Pascalianas. Tradução Sérgio Miceli. Rio de Janeiro: Bertrand Brasil,

El baile de los solteros: La crisis de la sociedad campesina em el bearne. Barcelona: Anagrama, 2004.

A economia das trocas simbólicas. São Paulo: Perspectiva, 2005.

2008.

A Distinção: crítica social do julgamento. São Paulo: Edusp, Porto Alegre: Zouk:

BUANIN, Antonio Márcio., ROMEIRO, Ademar, GUAZIROLI, Carlos. Agricultura Familiar e o Novo Mundo Rural. Sociologias, ano 5, n. 10 . Porto Alegre: UFRGS/PPGSoc, 2003.

; CHAMBOREDON, Jean-Claude; PASSERON, Jean-Claude. A Profissão de Sociólogo: preliminares epistemológicas. Tradução Teixeira, Guilherme João de Freitas. Petrópolis: Vozes, 1999.

BOUTNET, Jean-Pierre. Antropologia do Projeto. Porto Alegre: Artimed, 2002.

BRASIL. Ministério do Desenvolvimento Agrário. Gênero, agricultura familiar e reforma agrária no Mercosul. (NEAD Debate; n. 9). Brasília: MDA, 2006.

BRENNER, Ana Karina, DAYREJ, Juarez; CARRANO, Paulo. Culturas do lazer e do tempo livre dos jovens brasileiros. In ABRAMO, Helena W.; BRANCO, Pedro Paulo M. Retratos da juventude brasileira: analise de uma pesquisa nacional. São Paulo: Instituto Cidadania; Fundação Perceu Abramo, 2005.

BRITTO, Sulamita (org). Sociologia da Juventude I: da Europa de Marx a América Latina de hoje. Rio de janeiro: Zahar, 1968.

BRUMER, Anita. Produção Familiar e modernização da agricultura. Porto Alegre: UFRGS, 1989.30p. (texto não publicado). 
; ROSAS, Eduardo Nunes Leite; WEISHEIMER, Nilson. Juventude rural e divisão do trabalho na unidade de produção familiar. Trabalho apresentado no Congresso Internacional da International Rural Sociological Association, 11, (IRSA), realizado no Rio de Janeiro, 30 jul.-5 ago. 2000. 30 p.

A reprodução geracional na unidade de produção familiar na agricultura: uma abordagem conceitual. In: Congresso Brasileiro de Sociologia, 11, Campinas, set. 2003.

Gênero e agricultura: a situação da mulher na agricultura do Rio Grande do Sul. Revista Estudos Feministas, Florianópolis, v. 12, n. 1, 2004. p. 205-27.

; WEISHEIMER, Nilson. Agricultura e políticas públicas para as mulheres rurais no Mercosul: documento síntese. Trabalho preparado para o Seminário Preparatório da In: BRASIL/MDA. Gênero, agricultura familiar e reforma agrária no Mercosul. Brasília: MDA, 2006. p. 189-256.

CAMARANO, A. A.; ABRAMOVAY, R. Êxodo rural, envelhecimento e masculinização no Brasil: panorama dos últimos 50 anos. Revista Brasileira de Estudos Populacionais (RBEP), v. 15, n. 2, p. 45-6, jul.-dez. 1998.

CAMPANHOLA, Clayton; GRAZIANO DA SILVA, José. O Novo Rural Brasileiro: uma análise nacional e regional. Jaguariúna: EMBRAPA, 2000.

CAMPOLIN, Adalgiza Inês. Quando alunos e alunas são rurais e a escola é urbana: o significado do ensino médio para jovens rurais. Rio de Janeiro: PUCRJ, 2000. Dissertação (Mestrado), Programa de Pós-Graduação em Educação, Pontifícia Universidade Católica do Rio de Janeiro, 2000.

CANGAS, Yanco Gonzáles. Juventud Rural: trayectorias teóricas y dilemas identitários. Revista Nueva Antropologia, v. 19, n. 63, p 153-75. México: UCM, 2003. Disponível em: http://www.iica.org.ur/redlat/index.html. Acesso em: 4 jun. 2006.

CARDOSO, Ruth C. L., e SAMPAIO,Helena M, S. (orgs). Bibliografia Sobre Juventude. São Paulo: Edusp, 1995.

CARNEIRO, MARIA JOSÉ. O Ideal Rurbano: campo e cidade no imaginário de jovens rurais. In: SILVA, Francisco C; SANTOS, Raimundo; COSTA, Flavio de C., (org) Mundo Rural e Política: ensaios interdisciplinares. Rio de Janeiro: Campus, 1999. p. 97-117.

Herança e gênero entre agricultores familiares. Rev. Estud. Fem., Florianópolis, v. 9, n. 1, 2001. Disponível em:

$<$ http://www.scielo.br/scielo.php?script=sci_arttext\&pid=S0104-

026X2001000100003\&lng=pt\&nrm=iso>. Acesso em: 11 jan. 2009. doi: 10.1590/S0104026X2001000100003. 
CARVALHO, Helena. Análise multivariada de dados qualitativos: utilização da HOMALS com SPSS. Lisboa: Sílabo, 2004.

CASTRO, Elisa Guaraná de; MACEDO, Sandra Iglesias. A migração dos jovens do campo e sua inserção no mundo do trabalho. In: Programa do Jovem Empreendedor. Rio de Janeiro: Instituto Souza Cruz, outubro de 2001.

CEBOTAREV E. A. A Organização do tempo de atividade doméstica e não-doméstica de mulheres camponesas na América latina. In: AGUIAR, Neuma (coord.) Mulheres na Força de Trabalho na América Latina: Análises Qualitativas. Petrópolis: Vozes, 1984. p. 45-78.

CORCUFF, Philippe. As Novas Sociologias: construção da realidade social. Bauru: EDUSC, 2001.

CUCHE, Denys. A noção de Cultura nas Ciências Sociais. Bauru: EDUSC, 1999.

CUVILLIER, Armand. Sociologia da Cultura. Porto Alegre: Globo, São Paulo: USP, 1975.

CHAMPAGNE, Patrick. Ampliação do espaço social e crise da identidade camponesa. (tradução do texto 'Elargissement de l'espace social et crise de l'identidade paysanne'. Cahier d'Economie et Sociologie Rurales, n. 3, déc. 1986. p.73-89.

CHAYANOV, Alexander V. La organización de la unidade económica campesina. Buenos Aires: Nueva Visón, 1974.

Sobre a teoria dos sistemas econômicos não capitalistas. In: SILVA, J Graziano da. e STOLCKE, Verena (orgs). A questão agrária. São Paulo: Brasiliense, 1981.

CHODOROW, Nancy. Estrutura Familiar e Personalidade Feminina. In: ROSALDO, M. \& LAMPHERE, L. A mulher, a cultura e a sociedade. Rio de Janeiro: Paz e Terra, 1979.

DAMASCENO, M. N.; THERRIEN, J. Educação e escola no campo. Campinas: Papirus, 1993.

DAMASCENO, Maria Nobre; BESERRA, Bernadete. Estudos sobre educação rural no Brasil: estado da arte e perspectivas. Educ. Pesqui., São Paulo, v. 30, n. 1, abr. 2004. Disponível em: <http://www.scielo.br/scielo.php?script=sci_arttext\&pid=S1517$97022004000100005 \& \operatorname{lng}=$ t\&\&m=iso>. Acesso ${ }^{\text {em. }} 30$ jan. 2009. doi: 10.1590/S151797022004000100005 .

DEERE, Carmen Diana. Women's Land rights and rural social Movements in the Brazilian Agrarian Reform. Journal of Agrarian Change, v. 3, n. 1-2, Jan.-Apr. 2003. p. 257-88. 
; LEÒN. Magdalena. O Empoderamento da Mulher: direito a terra e direitos de propriedade na América Latina. Porto Alegre: UFRGS, 2002.

DESMAREZ, P. La Sociologie industrialle aux États-Unis. Paris: Armand Colin, 1986.

DIAS, Guilherme S.; AMARAL, Cicely Amaral. Mudanças estruturais na agricultura brasileira, 1980-1998. In: Baumann, Renato (org). Brasil: uma década em transição. Rio de Janeiro: Campus (co-edição com a CEPAL), 2000.

DIETERICH, Ronaldo. Clube 4'S: descrição e análise da participação de jovens e sua permanência nas atividades agrícolas. Porto Alegre: UFRGS, 1983. Tese (Mestrado em Economia rural e Sociologia rural), Universidade Federal do Rio Grande do Sul, 1983.

DOMINGUES, José Maurício. Ensaio de Sociologia: teoria e pesquisa. Belo Horizonte: UFMG, 2004.

DOMINGUES. Lúcio. Psicologia del Desarollo: adolescencia y juventud. Selecção de Lecturas. La Havana: Felix Varela, 2003.

DUBAR, Claud. A Socialização: construção das identidades sociais e profissionais. São Paulo: Martins Fontes, 2005.

DUBET, François. Des jeunesses et des sociologies: lê cãs fançais. Sociologie et Sociétés, Montreal, v. 28, n. 1, 1996.

DUQUÉ, Ghislaine; SOUSA, Emilene Leite de. De Geração a Geração: Um Estudo Sobre a Disposição dos Jovens em Assumirem o Trabalho Agrícola. In: Congresso da Associação Latino Americana de Sociologia Rural, 6, nov. 2002, Porto Alegre.

DURKHEIM. Émile. As Regras do Método Sociológico. Tradução Esteves, Margarida Garrido. São Paulo: Abril Cultural,1973.

Educação e Sociologia. Trad. Lourenço Filho. São Paulo: Melhoramentos; Rio de Janeiro: Fundação Nacional de Material Escolar, 1978.

Educação e Sociologia. 9.ed. São Paulo: Melhoramentos, 1993.

DURSTON, John. Juventud rural excluída em America latina Reducindo la invisibilidade. Congresso Latino Americano de Sociologia, 11, 1997, São Paulo.

ECHEVERRIA, R. G. (Ed.). Desarrollo de las economías rurales. Washington: Banco Interamericano de Desarrollo, 2001. In: SCHNEIDER, Sergio. A abordagem territorial do desenvolvimento rural e suas articulações externas. Sociologias. [online]. jan.-jun. 2004, 
no.11 Acesso em: 14 nov. 2005, p. 88-125. Disponível em: http://www.scielo.br/scielo.php?script=sci_arttext\&pid=S151745222004000100006\&lng=pt \&nrm=iso>. ISSN 1517-4522.

EISENSTADT, S.N. De geração a geração. São Paulo: Perspectiva, 1976.

ESTEVAM, Dimas de Oliveira. Casa familiar rural: a formação com base na pedagogia da alternância em Santa Catarina. Florianópolis: UFSC, 2001. Dissertação (Mestrado), Programa de Pós-Graduação em Administração, Universidade Federal de Santa Catarina, 2001.

FERNANDES, Florestan. Fundamentos empíricos da explicação sociológica. São Paulo: Nacional, 1967.

FERREIRA, Berta W. Adolescência. Teoria e pesquisa. Porto Alegre: Sulina, 1978.

FICHTE, Johann Gottlieb. A doutrina-da-ciência de 1794 e outros escritos. 2.ed. São Paulo: Abril Cultural, 1984. 313 p.

FILHO, Ferreira Arthur. História Geral do Rio Grande do Sul 1503 - 1960. Porto Alegre: Globo, 1960.

FLAVELL, John H., A psicologia do desenvolvimento de Jean Piaget. Tradução Maria helena de Souza Patto. 5.ed. São Paulo: Pioneira, 1996.

FLITNER, Andreas. Os problemas sociológicos nas primeiras pesquisas sobre juventude. In: BRITTO, Sulamita de. (org). Sociologia da Juventude I. Rio de Janeiro: Zahar, 1968. p. $37-68$.

FORACCHI, Maria Alice, O estudante e a transformação da sociedade brasileira. São Paulo: Nacional, 1965.

A juventude na sociedade moderna. São Paulo: Pioneira, 1972.

A participação social dos excluídos. Parte II - A juventude: ascensão social e rebelião. São Paulo: Hucitec, 1982.

FREIDSON, Eliot. Renascimento do Profissionalismo: Teoria, Profecia e Política. São Paulo: USP, 1998.

FREIRE, Jacqueline Cunha da Serra. Retratos da Amazônia: Educação e Juventude Ribeirinha. Congresso da Associação Latino Americana de Sociologia Rural, 6, Porto Alegre, nov. 2002. 
FRIEDMANN, Heriet. Simple commodity production andwage labour in the americam plains. Journal of Peasant Studies, London, v. 6, n. 1, p 71-100, 1978. SCHNEIDER, Sergio. A abordagem territorial do desenvolvimento rural e suas articulações externas. Sociologias. [online]. jan.-jun. 2004, no.11 Acesso em: 14 nov. 2005, p. 88-125. Disponível em:

http://www.scielo.br/scielo.php?script=sci_arttext\&pid=S151745222004000100006\&lng=pt \&nrm=iso >. ISSN 1517-4522.

GALESKI, B. A Família Camponesa. Rio de Janeiro: Museu Nacional, 1979. (mimeo).

GALLAND, Oliver. Sociologie de la jeunesse. Paris: Armand Colin, 1997.

GARCIA JUNIOR. Afrânio R. Terra de Trabalho. Rio de Janeiro: UFRJ, 1977. Dissertação (Mestrado), Programa de Pós-Graduação em Antropologia Social, Universidade federal do Rio de Janeiro, 1977.

Terra de Trabalho. Rio de Janeiro: Paz e Terra, 1983.

GARCIA, Marie France. O bacurau: estudo da feira de Usina. Rio de Janeiro: UFRJ, 1975. Dissertação (Mestrado), Programa de Pós-Graduação em Antropologia Social, Universidade Federal do Rio de Janeiro, 1975.

GASSON, R.; ERRINGTON, A. The Farm Family Business. Wallingford: Cab International, 1993.

GEERTZ, Cliford. Nova luz sobre a antropologia. Rio de janeiro: Zahar, 2001.

GERTH, H.H.; MILLS, C.W. (org). Max Weber: Ensaios de Sociologia. Trad. Waltensir Dutra. Rio de Janeiro: Zahar, 1982.

GIDDENS, Antony. Modernidade e Identidade. Rio de Janeiro: Zahar, 2002.

A Construção da Sociedade. São Paulo: Martins Fontes, 2003.

GIL, Antonio Carlos. Métodos e técnicas de pesquisa social. São Paulo: Atlas, 1987.

GOODMAN, D., WATTS, M. (Eds.). Globalizing Food: agrarian questions and global restructuring. London: Routledge, 1997. In: SCHNEIDER, Sergio. A abordagem territorial do desenvolvimento rural e suas articulações externas. Sociologias. [online]. jan.-jun. 2004, n. 11 Acesso em: 14 nov. 2005, p. 88-125. Disponível em: http://www.scielo.br/scielo.php?script=sci_arttext\&pid=S151745222004000100006\&lng=pt \&nrm=iso>. ISSN 1517-4522. 
GUERREIRO, Maria das Dores; ABRANTES, Pedro. Como tornar-se adulto: processos de transição na modernidade avançada. Revista Brasileira de Ciências Sociais, São Paulo, v. 20, n. 58, 2005. Disponível em:

$<$ http://www.scielo.br/scielo.php?script=sci_arttext\&pid=S0102-

9092005000200008\&lng=pt\&nrm=iso >. Acesso em: 29 fev. 2008.

GUIGOU, Jacques. Problemas de uma sociologia da juventude rural. In: Britto Sulamita de (org). Sociologia da Juventude II. Rio de Janeiro: Zahar, 1968. p. 73-88.

GUILHOTO, Joaquim; et al. A agricultura familiar na economia: Brasil e Rio Grande do Sul. Brasília: Ministério do Desenvolvimento Agrário, 2005. 44 p.

GUimarẽes, Alberto Passos. A Crise Agrária. Rio de Janeiro: Paz e Terra, 1979.

GUIMARÃES. Nadya Araujo. Trabalho: uma categoria -chave no imaginário juvenil? In: ABRAMO, Helena W.; BRANCO, Pedro Paulo M. Retratos da juventude brasileira: analise de uma pesquisa nacional. São Paulo: Fundação Perceu Abramo, 2005.

GURVITCH, Georges. Dialética e Sociologia. São Paulo: Vértice, 1987.

HALL, Stuart. A identidade cultural na pós-modernidade. Rio de Janeiro: DP\&A, 1999.

Da diáspora: identidades e mediações culturais. Belo Horizonte: UFMG, Brasília: UNESCO, 2003.

HARVEY, David. Condição pós-moderna. 4.ed. São Paulo: Loyola, 1994.

HAYGERT, Maria Lúcia Lemos. De Pai para Filho: tecendo um novo território familiar. Florianópolis: UFSC, 2001. Dissertação (Mestrado), Programa de Pós Graduação em Antropologia Social, Universidade Federal de Santa Catarina, 2001.

HEGEL, Georg W. F. Coleção: Os Pensadores. São Paulo: Abril cultural, 1980.

HEIDEGGER, Martin. Ser e tempo. 11.ed. Petrópolis: Vozes, 2004. v. 2.

HEREDIA, Beatriz A. A Morada da vida. Rio de janeiro: Paz e Terra, 1979.

HEREDIA, Beatriz A. A Morada da vida: Trabalho Familiar de pequenos produtores no Nordeste do Brasil. Rio de Janeiro: UFRJ, 1977. Dissertação (Mestrado), Programa de PósGraduação em Antropologia Social, Universidade Federal do Rio de Janeiro, 1977. 
HEREDIA, Beatriz M. A.; GARCIA, Maria F.; GARCIA JR. Afrânio. O lugar das mulheres em unidades domésticas camponesas. (p. 29-44) In: AGUIAR, Neuma (coord.) Mulheres na Força de Trabalho na América Latina: Análises Qualitativas. Petrópolis: Vozes, 1984.

HUGHES. Everett. “Te making of a Physucan”. Human Organization, III, 1955. In: DUBAR, Claud. A Socialização: construção das identidades sociais e profissionais. São Paulo: Martins Fontes, 2005.

HUSSERL, Edmund. Meditações cartesianas: introdução à fenomenologia. Porto: Madras, 2001.

IANNI, Octávio (org). Marx. Coleção Grande Cientistas Sociais. São Paulo: Ática, 1979.

IANNI, Octavio. O jovem radical. In: BRITTO, Sulamita de (org). Sociologia da juventude I: da Europa de Marx à América Latina de hoje. Rio de Janeiro: Zahar, 1968. p. 225-42.

INCRA/FAO. Diretrizes de política agrária e desenvolvimento sustentável para a pequena produção familiar. GUAZIROLI, Carlos (coord). Brasília: FAO/INCRA, 1994. 98p.

IZQUIERDO, Iván. Memória. Porto Alegre: Artmed, 2002.

JOFFILY, Bernardo. Isto é Brasil 500 anos: Atlas histórico. São Paulo: Grupo Três, 1998.

KAGEAMA, A.; BERGAMASCO, S.M. P.P. A estrutura de produção no campo em 1980. Revista Perspectivas, São Paulo, v. 12-13, p. 55-72, 1989/1990.

KOSIK, Karel. Dialética do Concreto. São Paulo: Paz e Terra, 1995.

LACCARDI, Carmem. Por um novo significado do futuro: mudança social, jovens e tempo, Tempo Social - Revista de Sociologia da USP, São Paulo, v. 17, n. 2, nov. 2005.

LAGRAVE, Rose-Marie. Introduction. In: LAGRAVE, Rose-Marie (dir.). Celles de la terre: agricultrice, l'invention politique d'um métier. Paris: Éditions de École des Hautes Études en Sciences Sociales, 1987. p. 11-29.

LALANDE, ANDRÉ. Vocabulário Técnico e Crítico da Filosofia. 3.ed. São Paulo: Martins Fontes, 1999.

LAMARCHE, Hugues (coord). A agricultura familiar: comparação internacional. Campinas: Unicamp, 1993. v.1.

- A agricultura familiar: comparação internacional - do mito à realidade. Campinas: Unicamp, 1998. v. 2. 
LANDO, A. M., BARROS, E. C. Capitalismo e colonização - Os alemães no Rio Grande do Sul. In: DACANAL, José H. (org). Rio Grande do Sul: imigração \& colonização. 2.ed. Porto Alegre: Mercado Aberto, 1992. p. 13.

LASTRES, Helena Maria Martins, et al. Desafios e oportunidades da era do conhecimento. São Paulo em Perspectiva [online]. jul.-set. 2002, v. 16, n. 3, p. 60-6. Disponível na em: $<$ http://www.scielo.br/scielo.php?script=sci_arttext\&pid=S010288392002000300009\&lng=pt \&nrm=iso>. Acesso em: 4 jan. 2006. ISSN 0102-8839.

LEFEBVRE, Henri. Estrutura Social: a reprodução das relações sociais. In: FORACCHI, Marialice; MARTINS, José de Souza. (orgs) Sociologia e Sociedade (leituras de introdução a Sociologia) 23. tiragem. Rio de Janeiro: LTC, 1994.

LEITE, S. C. Escola rural: urbanização e políticas educacionais. São Paulo: Cortez, 1999.

LEVI, Giovani; SCHMITT, Jean-Claude. (orgs) A história dos jovens.. São Paulo: Companhia das Letras, 1996. v. 1.

LEVI, Giovani; SCHMITT, Jean-Claude. (orgs) A história dos jovens. São Paulo: Companhia das Letras, 1996. v. 2.

LEVINE, Donald N. Visões da tradição sociológica. Rio de Janeiro: Zahar, 1997.

LISBOA, J. Marques Miranda. Sistemas de cultivo de morangueiro em Feliz/RS e qualidade do produto na visão de produtores e consumidores. Porto Alegre: UFRGS, 2000 .

LOUREIRO, Maria Rita Garcia. Parceria e capitalismo. Rio de Janeiro: Zahar Editores, 1977.

MAGNANI, José Guilherme. Discurso e Representação, ou como os Baloma de Kiriwina podem reencarnar-se nas atuais pesquisas. In: CARDOSO, Ruth (org). Aventura Antropológica: teoria e pesquisa. Rio de Janeiro: Paz e Terra, 1986.

MALINOWSKI, Bronislaw. Crime e costume na sociedade selvagem. Brasília; UNB, 2003.

MANHANI, Daniela Cristina. Uma avaliação do programa de formação de jovens empresários rurais: Projovem. Piracicaba: USP, 2000. Dissertação (Mestrado em Economia Aplicada), Escola Superior de Agricultura Luiz de Queiroz, Universidade de São Paulo, 2000.

MANNHEIM, Karl. O problema da juventude na sociedade moderna. In: BRITTO Sulamita de. Sociologia da Juventude I. Rio de Janeiro: Zahar, 1968. p. 69-94. 
O problema sociológico das gerações. In. FORACHI, Maria Alice (org). Mannheim, Grandes Cientistas Sociais. n. 25. São Paulo: Ática, 1982. p. 67-95.

MARTINE, George; ARIAS, Afonso Rodrigues. Modernização e emprego no campo. In: ; GARCIA, Ronaldo Coutinho (orgs.). Impactos sociais da modernização conservadora. São Paulo: Caetés, 1987.

Êxodo rural, concentração urbana e fronteira agrícola. In: ; GARCIA,

Ronaldo Coutinho (orgs). Impactos sociais da modernização conservadora. São Paulo: Caetés, 1987.

; GARCIA, Ronaldo Coutinho (orgs). Impactos sociais da modernização conservadora. São Paulo: Caetés, 1987.

MARTINS, José de Souza. Capitalismo e tradicionalismo: estudos sobre as contradições da sociedade agrária no Brasil. São Paulo: Pioneira, 1975.

Fronteira: a degradação do outro nos confins do humano. São Paulo: Hucitec, 1997.

MARX, Karl. Economia Política e Filosofia. Rio de Janeiro: Melso, 1968.

; ENGELS, Friedrich. Desenvolvimento da teoria. In: SODRE. Nelson Werneck. Fundamento do materialismo histórico. Rio de janeiro. Civilização Brasileira, 1968.

1973. Tomo I.

El Capital: Crítica de la Economia Política. México: Fundo de Cultura Económica, . Teses sobre Feurbach. São Paulo: Grijaldo, 1977.

O Capital: crítica da economia política. São Paulo: Difel, 1985.

O Capital. Capítulo IV. São Paulo: Centauro, 2004.

MAUREL, Marie-Claude. "Etre femme sur une Causse oublié". In: Laboratoire de Géographie rurale de l'Université Paul-Valéry et Groupe d'Etudes "Dynamique de l'espace rural" du C.N.R.S., Espace Rural, 22, juin 1990. p. 89-92.

MAY, Tim. Pesquisa Social: questões métodos e processos. 3.ed. Porto Alegre: Artimed, 2004.

MCLAREN, Peter. A vida nas escolas. Porto Alegre: Artes Médicas, 1997.

MEAD, Margaret. Sexo e temperamento. São Paulo: Perspectiva, 1979. 
MENDRAS, Henry. As sociedades camponesas. Rio de Janeiro: Zahar, 1978.

MOLLO-BOUVIER, Suzanne. Transformação dos modos de socialização das crianças: uma abordagem sociológica. Educ. Soc., maio-ago. 2005, v. 26, n. 91, p.391-403. ISSN 01017330 .

MONTEIRO, Lucira Freire. Bonecas e vassouras: vida e trabalho doméstico das adolescentes do campo na cidade. Recife: UNICAP, 1996. Dissertação. (Mestrado em Sociologia), Universidade Católica de Pernambuco, 1996.

MOORE JR. Barrington. Social origins of Dictorship and democracy: Lord and Peasand in the Making of Modern Word. Hardmondsworth: Penguin, 1966.

MOREIRA, Antônio Flávio Barbosa; SILVA, Tomas Tadeu. Currículo, cultura e sociedade. São Paulo: Cortez, 1994.

MOURA, Margarida Maria. Os Herdeiros da Terra. São Paulo: Hucitec, 1978.

NAVARRO, Zander. Desenvolvimento rural no Brasil: os limites do passado e os caminhos do futuro. Estudos. Avançados, v. 15, n. 43, p. 83-100, set.-dez. 2001.

NOBRE, Miriam. Gênero e agricultura familiar a partir de muitas vozes. In: NOBRE, Miriam, (org). Gênero e agricultura familiar. São Paulo, SOF, 1998.

OLIVEIRA, Roberto Cardoso de. Identidade, Etnia e Estrutura Social. São Paulo: Pioneira, 1976.

PAIS, José Machado et al. Jovens Europeus: retrato da diversidade. Tempo social: Revista de sociologia da USP, São Paulo, v. 17, n. 2, 2005.

. Ganchos, tachos e biscates: jovens, trabalho e futuro. Lisboa: Âmbar, 2001.

PARSONS, Talcott. A classe como sistema social. In: BRITTO, Sulamita de. Sociologia da juventude III: a vida coletiva e juvenil. Rio de Janeiro: Zahar, 1968.

PAULILO, Luiz Fernando. Crisis agrícola y políticas públicas: nuevos elementos para discusión. Montecillo, México: Estado, política y recomposición institucional em el sector rural en América Latina. In: Encontro da Associação Latinoamericana de Sociologia Rural, 2000a. Anais. p. 35-53.

PAULILO, Maria Ignez S. Trabalho Familiar: uma categoria esquecida de análise. Revista Estudos Feministas, v. 12, n. 1, jan.-abr. Florianópolis: CFC/CCE/UFSC, 2004. p. 229-52. 
Movimento de Mulheres Agricultoras: Terra e Matrimônio. Cadernos de Pesquisa, Florianópolis, n. 21, p. 1-21, 2000 b. Disponível em:

<http://www.cfh.ufsc.br/ naf/doc/mma.pdf>. Acesso em: 26 dez. 2008.

O Peso do Trabalho Leve. Revista Ciência Hoje [on line]. n. 28, 1987. Disponível em: <http://www.cfh.ufsc.br/ naf/doc/OPesodoTrabalhoLeve.doc>. Acesso em: 26 dez. 2008.

PEREIRA, Jorge Luiz de Goes. Para além das fronteiras entre campo e cidade. In: Reunião Brasileira de Antropologia, 24, jun. 2004, Olinda.

PESAVENTO, Sandra Jatahy. História do Rio Grande do Sul. Porto Alegre: Mercado Aberto, 1985. $141 \mathrm{p}$.

PIAGET, Jean. Estudos Sociológicos. Rio de Janeiro: Forense, 1973.

O Desenvolvimento do Pensamento: Equilibração das estruturas cognitivas. Lisboa: Dom Quixote, 1977.

PIÑEIRO, Diego. Sustentabilidad y Democratización de las Sociedades Rurales de América Latina. Sociologias, Porto Alegre, n. 10, p. 26-33, 2003.

PIRES, Rui Pena. Árvores Conceptuais: Uma reconstrução multidimensional dos conceitos de acção e de estrutura. Sociologia. [online]. jan. 2007, n. 53, p. 11-50. Disponível em: <http://www.scielo.oces.mctes.pt/scielo.php?script=sci_arttext\&pid=S087365292007000100002\&lng=pt\&nrm=iso >. ISSN 0873-6529. Acesso em: 29 jan. 2009.

PLOEG, J.D. van der \& RENTING, H. Impact and potential: a comparative review of European rural development practices. Sociologia Ruralis, Netherlands, v. 40, n. 4, p. 529-43, 2000. In: SCHNEIDER, Sergio. A abordagem territorial do desenvolvimento rural e suas articulações externas. Sociologias [online], n. 11, jan.-jun. 2004. Acesso em: 14 nov. 2005, p. 88-125. Disponível em:

$<$ http://www.scielo.br/scielo.php?script=sci_arttext\&pid=S151745222004000100006\&lng=pt $\& n r m=i s o>$. ISSN 1517-4522.

PORTO, Maria S. Grossi; SIQUEIRA, Deis E. A Pequena Produção do Brasil: entre os conceitos teóricos e as categorias empíricas. Cadernos de Sociologia, n. 6, Porto Alegre: PPGS, UFRGS, 1994. p.76-88.

PRADO JUNIOR, Caio. A Revolução Brasileira. São Paulo: Brasiliense, 1978. . Contribuição para a Análise da Questão Agrária Brasileira. In: Agricultura Subdesenvolvida. Petrópolis: Vozes, 1969. 
REARDON, T.; BERDEGUÉ, J.A. La rápida expansión de los supermercados en América Latina: desafíos y oportunidades para el desarrollo. Banco Interamericano de Desarrollo BID (Departamento de Desarrollo Sostenible, Unidade de Desarrollo Rural), Washington, junio, 2003. In: SCHNEIDER, Sergio. A abordagem territorial do desenvolvimento rural e suas articulações externas. Sociologias [online], n. 11, jan.-jun. 2004. Acesso em: 14 nov. 2005, p. 88-125. Disponível em:

$<$ http://www.scielo.br/scielo.php?script=sci_arttext\&pid=S151745222004000100006\&lng=pt $\& n r m=$ iso $>$. ISSN $1517-4522$.

RIBEIRO, Darcy. O Povo Brasileiro: a evolução e o sentido do Brasil. São Paulo: Cia. das Letras, 1995.

RIBEIRO, Tereza Cristina Almeida. A pluriatividade: uma alternativa de reprodução social da agricultura familiar? Recife: UFP, 2000. Dissertação (Mestrado), Programa de Pós Graduação em Serviço Social, Universidade Federal de Pernambuco, 2000.

RICHARDSON, Roberto Jarry. Pesquisa Social: métodos e técnicas. São Paulo: Atlas, 1985.

ROCHE, Jean. A Colonização Alemã e o Rio Grande do Sul. Porto Alegre: Globo, 1969. v. 2 .

ROSDOLSKY, Roman. Gênese e estrutura de O Capital de Karl Marx. Rio de Janeiro: EDUERJ/Contraponto, 2001.

ROSENMAYR, Léopold. A situação sócio-econômica da juventude hoje. In: Sociologia da Juventude I. Rio de Janeiro: Zahar, 1968. p. 133-76.

RUA, Maria das Graças. Políticas Públicas e Juventude dos Anos 90. In. Jovens acontecendo na trilha das políticas públicas. v. 2. Brasília: CNPD, 1998. p. 731-52.

SACCO DOS ANJOS, Flávio; CALDAS, Nádia Velleda. Pluriatividade e Sucessão Hereditária na Agricultura Familiar. [mimeo], 2006.

SALlAS, Ana Luisa Fayte et al. Os jovens de Curitiba: desencantos e esperanças, juventude, violência e cidadania. Brasília: UNESCO, 1999.

SANCHIS, Enric. Da escola ao Desemprego. Rio de Janeiro: AGIR. 1997.

SANSONE, Lívio. Negritude sem etnicidade: o local e o global nas relações raciais e na produção cultural negra no Brasil. Salvador: EDUFBA, 2007.

SCOTT, Joan W. Gênero: uma categoria útil de análise histórica. Educação e Realidade, Porto Alegre, v. 16, n. 2, p. 5-22, 1990. 
SCHNEIDER, Sergio. Agricultura familiar e industrialização: pluriatividade e descentralização industrial no Rio Grande do Sul. Porto Alegre: UFRGS, 1999.

A pluriatividade na agricultura familiar. Porto Alegre: UFRGS, 2003.

A abordagem territorial do desenvolvimento rural e suas articulações externas.

Sociologias [online], n. 11, jan.-jun. 2004. Acesso em: 14 nov. 2005, p. 88-125. Disponível em:

$<$ http://www.scielo.br/scielo.php?script=sci_arttext\&pid=S151745222004000100006\&lng=pt \&nrm=iso >. ISSN 1517-4522.

SETIAN, Nuvarte. Endocrinologia Pediátrica. 2. ed. São Paulo: Sarvier, 2002.

SEYFERTH, G. A Colonização Alemã no Vale do Itajaí-mirim: um estudo de desenvolvimento econômico. Porto Alegre: Movimento, 1974. 160 p.

. Herança e Estrutura Familiar Camponesa. Boletim do Museu Nacional, Rio de Janeiro, v. 52, p. 1-27, 1985.

A assimilação dos imigrantes como questão nacional. Mana: estudos de antropologia social, Rio de Janeiro, v. 3, n. 1, p. 95-131, 1997.

SILVA, José. Francisco. Graziano da. Sobre a delimitação do rural e do urbano no Brasil. In: Congresso da Sociedade Brasileira de Economia e Sociologia Rural, 35, 1997, Natal (RN). Anais. Brasília (DF): SOBER, 1997. p. 114-46.

; BALSADI, Otavio Valentim; GROSSI, Mauro Eduardo Del. O emprego rural e a mercantilização do espaço agrário. Revista São Paulo em Perspectiva, São Paulo, v. 11, n. 2, p. 50-64, 1997.

O Novo Rural Brasileiro. 2.ed. Campinas (SP): Instituto de Economia da Unicamp, 1999. v. 1. 147 p.

SILVA, M. A. M. A Nova Divisão Sexual do Trabalho na Agricultura. Revista São Paulo em Perspectiva, São Paulo, v. 4, n. 3-4, p. 20-31, jul.-dez. 1990.

SILVA, Onaide Maria Fernandes da. Inovação Curricular nas Escolas Rurais de CatalaoGO e Mudança Social: Um Estudo de Caso. Viçosa: UFV, 1992. Dissertação (Mestrado), Pós Graduação em: Extensão Rural, Universidade Federal de Viçosa, 1992.

SILVA, Tomaz Tadeu. A produção social da identidade e da diferença. In: SILVA, Tomaz Tadeu da (org). Identidade e Diferença: a perspectiva dos estudos culturais. Petrópolis: Vozes, 2000 (a). 
SILVA, Vanda Aparecida da. "Eles não têm nada na cabeça..." Jovens do sertão mineiro entre a tradição e a mudança. Campinas: UNICAMP, 2000. Dissertação (Mestrado), Faculdade de Educação, Universidade Estadual de Campinas, 2000 (b).

Jovens de um Rural Brasileiro: Socialização, Educação e Assistência. Artigo. Cad. CEDES, Campinas, v. 22, n. 57, p. 97-115, ago. 2002.

SILVESTRO, Milton Luiz et al. Os Impasses sociais da sucessão hereditária na Agricultura Familiar. Florianópolis: Epagri, Brasília: Ministário do Desenvolvimento Agrário, 2001. v. 1. 120 p.

SIMMEL, George. Questões fundamentais de sociologia. Rio de Janeiro: Zahar, 2006.

SIQUEIRA, Luiza Helena Schwantz de. Juventude rural: uma identidade em construção? In: Congresso Brasileiro de Sociologia, 11, Campinas, set. 2003.

As perspectivas de inserção dos jovens rurais na unidade de produção familiar. Porto Alegre: UFRGS, 2004. Dissertação (Mestrado), Programa de Pós-Graduação em Desenvolvimento Rural, Universidade Federal do Rio Grande do Sul, 2004.

SODRÉ, Nelson Werneck. Fundamentos do Materialismo Histórico. Rio de Janeiro: Civilização Brasileira, 1968.

SOUZA, Janice Tirrelli Ponte de. Apresentação do dossiê A sociedade vista pelas gerações. Política \& Sociedade: Revista de Sociologia Política, Florianópolis, v. 5, n. 8, p. 9-30, 2006.

SOUZA, Sirlei de Fátima. Tradição x modernização no processo produtivo rural: os Clubes 4'S em Passo Fundo (1950-1980). Passo Fundo: UPF, 2003. Dissertação (Mestrado), Universidade de Passo Fundo, 2003.

SPANEVELlO, Rosani Marisa. Jovens rurais do município de Nova Palma/RS: situação atual e perspectivas. Santa Maria: UFSM, 2003. Dissertação (Mestrado), Curso de PósGraduação em Extensão Rural, Universidade Federal de Santa Maria, 2003.

A dinâmica sucessória na agricultura familiar. Porto Alegre: UFRGS, 2008. Tese (Doutorado), Programa de Pós-Graduação em Desenvolvimento Rural, Universidade Federal do Rio Grande do Sul, 2008.

SPOSITO, Maria. Algumas reflexões e muitas indagações sobre as relações entre juventude e escola no Brasil. In: ABRAMO, Helena W.; BRANCO, Pedro Paulo M. Retratos da juventude brasileira: analise de uma pesquisa nacional. São Paulo: Fundação Perceu Abramo, 2005. 
Trajetória na construção de políticas públicas de juventude no Brasil. In: Políticas

públicas: juventude em pauta. FREITAS, Maria V. et al. (org). São Paulo: CORTEZ, 2003. p. $57-74$

; CORROCHANO, Maria Carla. A face oculta da transferência de renda para jovens no Brasil. Tempo Social, Revista de Sociologia da USP, v. 17, n. 2, p.141-72, nov. 2005. São Paulo, 2005.

STOETZEL, Jean. Os jovens na sociedade japonesa: uma identificação demográfica. In: BRITTO, Sulamita de. Sociologia da Juventude VI. Rio de Janeiro: Zahar, 1968.

STROPASOLAS, Valmir Luiz. "O Mundo Rural No Horizonte Dos Jovens": O caso dos filhos (as) de agricultores familiares de Ouro/SC. Florianópolis: UFSC, 2002. Tese (Doutorado), Programa de Pós-Graduação Interdisciplinar em Ciências Humanas, Universidade Federal de Santa Catarina, 2002.

SCHÜTZ, Alfred. Fenomenologia e Relações Sociais. Rio de Janeiro: Zahar, 1979.

TAVARES, Breitner. Sociedade e Estado, Brasília, v. 21, n. 3, p. 781-91, set.-dez. 2006.

TAVARES-DOS-SANTOS, José-Vicente. Colonos do vinho: estudo sobre a subordinação do trabalho camponês ao capital. São Paulo: Hucitec, 1984.

Crítica da sociologia rural e a construção de uma outra sociologia dos processos sociais agrários. Ciências Sociais Hoje, São Paulo, p. 13-51 1991.

. Matuchos: Exclusão e Luta (Do Sul Para A Amazônia Ocidental). Tradução Lúcia Mathilde Endlich Orth. Petrópolis: Vozes, 1993. 282 p.

TEDESCO, João C. Terra, Trabalho, Família: racionalidade produtiva e ethos camponês. Passo Fundo: UPF, 1999.

TEPICHT, Jerzy. Marxisme et agriculture: Le paysan Polonais. Paris: Armand Colin, 1973.

TURQUINO, Gisele Braile. "Estilo urbano em escola rural?" Um estudo comparativo de duas realidades culturais de Londrina. Londrina: UEL, 2003. Dissertação (Mestrado), Programa de Pós em Educação, Universidade Estadual de Londrina, 2003.

VAN GENNEP, A. Os ritos de passagem. Petrópolis: Vozes, 1977.

VEIGA, José E. O desenvolvimento Agrícola: uma visão histórica. São Paulo: Hucitec, 1991. 
VELHO, Gilberto. Juventudes, projetos e trajetórias na sociedade contemporânea. In: ALMEIDA, Maria I. Mendes de; EUGENIO, Fernanda (orgs). Culturas juvenis: novos mapas do afeto. Rio de janeiro: Zahar, 2006.

Projeto e Metamorfose: antropologia das sociedades complexas. Rio de Janeiro: Zahar, 2003.

WAISELFISZ, Julio Jacobo. Mapa da violência III. Brasília: Ministério da Justiça, 2002.

Relatório de desenvolvimento juvenil 2003. Brasília: UNESCO, 2004.

WANDERLEY, Maria de Nazareth Baudel. Trajetória Social e Projeto de Autonomia: os produtores familiares de Leme, na região de Campinas, Cadernos do IFCH, 19. Campinas, UNICAMP, 1988. 166p.

Raízes históricas do campesinato brasileiro. In: TEDESCO, João Carlos (org). Agricultura familiar Realidade e Perspectivas. Passo Fundo: UPF, 1999.

Projeto de Pesquisa; Juventude Rural: vida no campo e Projetos para o futuro. Recife; (mimeo) 2003. 44 p.

Relatório de Pesquisa; Juventude Rural:Vida no Campo e Projetos para o Futuro..Recife: Universidade Federal de Pernambuco, 2006.

WEBER, Max. Capitalismo e Sociedade Rural na Alemanha. In: GERT, H. \& WRIGHT MILLS, C. (orgs). Ensaios de Sociologia. Rio de Janeiro: Zahar, 1982.

WEBER, Max. A ética protestante e o espírito do capitalismo. São Paulo: Martim Claret, 2004.

WEISHEIMER, Nilson. Os jovens agricultores: trabalho e reprodução social na agricultura familiar. Porto Alegre: UFRGS, 2001. Monografia (Graduação em Ciências Sociais), Instituto de Filosofia e Ciências Humanas, Universidade Federal do Rio Grande do Sul, 2001.

Os jovens agricultores no processo de trabalho da agricultura familiar. In: Congresso Latino Americano de Sociologia Rural, 6, Porto Alegre, 25-9 nov. 2002. 28 p.

Os Jovens Agricultores e seus projetos profissionais: Um estudo de caso no bairro de Escadinhas, Feliz (RS). Porto Alegre: UFRGS, 2004. Dissertação (Mestrado em Sociologia), Instituto de Filosofia e Ciências Humanas, Universidade Federal do Rio Grande do Sul, 2004. 
Juventudes rurais: mapas de estudos recentes. Brasília: MDA, 2005a.

Jovens Agricultores: gênero, trabalho e projetos profissionais In: Encontro Anual da Associação Nacional de Pós-Graduação e Pesquisa em Ciências Sociais, 29, 2005b, Caxambu.

Jovens Agricultores Familiares no Rio Grande do Sul: Relatório técnico de caracterização dos jovens na agricultura familiar no Rio Grande do Sul. (Convênio MDA/FAURGS N. 109 /2006). Porto Alegre: IFCH/UFRGS/FAURGS 2007.

Marx: categorias sociológicas fundamentais. In: Universidade Luterana do Brasil (org.). Sociologia Clássica. Curitiba: IBEPX, 2008. p. 141-55.

WILLIS, Paul. Aprendendo a ser trabalhador. Porto Alegre: Artes Médicas, 1991.

WOLFF, Kurt H., Fenomenologia e Sociologia. In.: BOTTOMORE, Tom e NIBEST, Robert (orgs.). História da Análise Sociologia. Rio de Janeiro; Zahar, 1980. 936 p.

WOODWARD, Katryn. Identidade e diferença: uma introdução teórica e conceitual. In: Tomaz Tadeu da Silva (org.). Identidade e Diferença: a perspectiva dos estudos culturais. Petrópolis: Vozes, 2000.

WOORTMANN, Ellen F. Herdeiros, parentes e Compadres: Colonos do Sul e Sitiantes do Nordeste. São Paulo: Hucitec, 1995.

; WOORTMANN, Klass. O trabalho da terra. Brasília: UNB, 1997.

WOORTMANN, Klass. "Com parente não se neguceia": o campesinato como ordem moral. Anuário Antropológico, Brasília, n. 87, 1990.

ZATTI, Vicente. Autonomia e educação em Immanuel Kant e Paulo Freire. Porto Alegre: EDIPUCRS, 2007. Disponível em:

http://www.pucrs.br/edipucrs/online/autonomia/autonomia/creditos.html. Acesso em: 25 set. 2008.

ZORZI, A. Transmissão da propriedade: uma etapa da reprodução social na agricultura familiar. Porto Alegre: UFRGS, 2005. Monografia (Graduação em Ciências Sociais), Instituto de Filosofia e Ciências Humanas, Universidade Federal do Rio Grande do Sul, Porto Alegre, 2005 . 